


\section{Hutan pasca pemanenan Melindungi satwa liar dalam kegiatan hutan produksi di Kalimantan}





\title{
Hutan pasca pemanenan Melindungi satwa liar dalam kegiatan hutan produksi di Kalimantan
}

\author{
Erik Meijaard \\ Douglas Sheil \\ Robert Nasi \\ David Augeri \\ Barry Rosenbaum \\ Djoko Iskandar \\ Titiek Setyawati \\ Martjan Lammertink \\ Ike Rachmatika \\ Anna Wong \\ Tonny Soehartono \\ Scott Stanley \\ Tiene Gunawan \\ Timothy O'Brien
}

Dengan kontribusi dari Robert Inger, Muchamad Indrawan,

Kuswata Kartawinata, Baas van Balen, Gabriella Fredriksson, Rona Dennis,

Stephan Wulffraat, Will Duckworth, dan Tigga Kingston 
Hak cipta dimiliki oleh CIFOR, UNESCO dan ITTO

Hak cipta dilindungi Undang-undang. Diterbitkan tahun 2006

Dicetak oleh SUBUR Printing, Jakarta

Design sampul oleh Donald Bason

Tata letak oleh Catur Wahyu dan Gideon Suharyanto

Foto sampul:

Owa Kalawat yang tidak berinduk (Hylobates muelleri) adalah korban buruknya kegiatan penebangan dan perburuan liar (Foto oleh Kimabajo) dan

Pembangunan jalan memicu timbulnya berbagai dampak negatif seperti fragmentasi tutupan hutan dan peningkatan endapan sedimen (siltasi) sungai - dampak lain yang timbul terkait dengan meningkatnya aksesibilitas manusia terhadap hutan. (Foto oleh Erik Meijaard).

Buku ini diterbitkan dengan dukungan dana dari UNESCO, ITTO, dan SwedBio. Penulis bertanggung jawab atas penyampaian fakta yang ada dalam buku ini. Opini yang tercantum di dalam buku ini tidak mencerminkan pendapat CIFOR, UNESCO, ITTO, dan SwedBio dan tidak bersifat mengikat. Kajian dan sintesa mencerminkan masukan dari berbagai organisasi, antara lain Departemen Kehutanan, LIPI, WCS, TNC, WWF, dan CIRAD. Kajian ini didukung pula oleh hasil penelitian dan kegiatan yang terkait yang didukung oleh dana hibah dari ITTO Komisi Eropa (European Commission), Bank Dunia, dan Yayasan MacArthur (MacArthur Foundation). Organisasi-organisasi ini tidak bertanggung jawab atas isi buku ini.

Center for International Forestry Research (CIFOR) adalah lembaga penelitian kehutanan internasional terdepan, yang didirikan pada tahun 1993 sebagai tanggapan atas keprihatinan dunia akan konsekuensi sosial, lingkungan dan ekonomi yang disebabkan oleh kerusakan dan kehilangan hutan. Penelitian CIFOR ditujukan untuk menghasilkan kebijakan dan teknologi untuk pemanfaatan dan pengelolaan hutan yang berkelanjutan, dan untuk meningkatkan kesejahteraan masyarakat di negara-negara berkembang yang bergantung kepada hutan tropis untuk kehidupannya. CIFOR adalah salah satu di antara 15 pusat yang didukung oleh Consultative Group on International Agricultural Research (CGIAR). Berpusat di Bogor, Indonesia, CIFOR mempunyai kantor regional di Brazil, Burkina Faso, Kamerun dan Zimbabwe, dan bekerja di lebih dari 30 negara di seluruh dunia.

\section{Perpustakaan Nasional Indonesia, Penerbitan dalam Katalog (KDT)}

Hutan pasca pemanenan: Melindungi satwa liar dalam kegiatan hutan produksi di Kalimantan = Life after logging: Reconciling wildlife conservation and production forestry in Indonesian Borneo/ Meijaard, E., Sheil, D., Nasi, R., Augeri, D., Rosenbaum, B., Iskandar, D., Setyawati, T., Lammertink, M., Rachmatika, I., Wong, A., Soehartono, T., Stanley, S., Gunawan, T. dan O’Brien, T.

Bogor, Indonesia: CIFOR, 2006.

384p.

ISBN 979-24-4657-5

1. Pengelolaan hutan 2. Konservasi Alam 3. Ilmu sosial 4. Hidupan liar 5. Penelitian

6. Kalimantan Timur 7. Indonesia

Diterbitkan oleh

Center for International Forestry Research

Alamat surat: P.O. Box 6596 JKPWB, Jakarta 10065, Indonesia

Alamat kantor: Jl. CIFOR, Situ Gede, Sindang Barang, Bogor Barat 16680, Indonesia

Tel.: +62 (251) 622622; Fax: +62 (251) 622100

Email: cifor@cgiar.org

Situs web: http://www.cifor.cgiar.org 


\section{Daftar isi}

Prakata xii

Biodata para kontributor xiv

Ucapan terimakasih xviii

Pengantar oleh Menteri Kehutanan $\quad$ Xx

Pengantar oleh Jeffrey A. Sayer xxii

$\begin{array}{ll}\text { Ringkasan eksekutif } & \text { Xxv }\end{array}$

Daftar singkatan $\quad$ xxix

Pendahuluan 1

Justifikasi 1

Tujuan 2

Lingkup kajian dan kaitannya $\quad 3$

$\begin{array}{ll}\text { Pentingnya hidupan liar } & 4\end{array}$

$\begin{array}{ll}\text { Wilayah penelitian } & 7\end{array}$

$\begin{array}{ll}\text { Lokasi } & 7\end{array}$

Manusia dan perubahan 9

$\begin{array}{lr}\text { Desentralisasi } & 12\end{array}$

$\begin{array}{ll}\text { Pengelolaan hutan } & 12\end{array}$

$\begin{array}{lr}\text { Survei satwa liar } & 12\end{array}$

BAGIAN I. KAJIAN PUSTAKA

Kajian pustaka mengenai penebangan kayu dan hidupan satwa liar 17

Metode $\quad 17$

$\begin{array}{ll}\text { Masukan dari para pakar } & 21\end{array}$

$\begin{array}{ll}\text { Keterbatasan metodologi } & 21\end{array}$

$\begin{array}{ll}\text { Ketersediaan pustaka } & 24\end{array}$

$\begin{array}{ll}\text { Lingkup pustaka } & 28\end{array}$

$\begin{array}{ll}\text { Kajian tentang burung } & 28\end{array}$

Kajian tentang mamalia $\quad 29$ 
Kajian tentang amfibia dan reptilia $\quad 30$

Kajian tentang ikan $\quad 30$

Latar belakang konsep $\quad 31$

$\begin{array}{ll}\text { Perubahan fauna } & 31\end{array}$

$\begin{array}{ll}\text { Perubahan vegetasi } & 33\end{array}$

Keterbatasan produktivitas $\quad 38$

Sistem silvikultur 39

Intensitas pengelolaan $\quad 41$

Pembebasan dan pembersihan tumbuhan bawah $\quad 43$

Bentang alam (lansekap) bekas tebangan dan terfragmentasi 43

$\begin{array}{ll}\text { Karakteristik (gambaran) bentang alam } & 45\end{array}$

$\begin{array}{ll}\text { Ancaman perburuan } & 47\end{array}$

Berburu untuk makanan sehari-hari 49

Konsesi dan perburuan $\quad 50$

Jalan dan perburuan $\quad 51$

Hasil hutan nonkayu $\quad 52$

Lalu lintas penebangan $\quad 53$

Spesies yang invasif $\quad 53$

Kebakaran $\quad 55$

$\begin{array}{lr}\text { Sertifikasi } & 57\end{array}$

Burung $\quad 59$

Umum $\quad 59$

Spesies-spesies yang sensitif $\quad 62$

Rangkong $\quad 63$

$\begin{array}{ll}\text { Pelatuk } & 67\end{array}$

$\begin{array}{ll}\text { Sempidan } & 72\end{array}$

$\begin{array}{ll}\text { Taxa lain } & 75\end{array}$

$\begin{array}{ll}\text { Burung luntur } & 75\end{array}$

Kutilang $\quad 76$

$\begin{array}{ll}\text { Kancilan, Berencet, Tepus } & 76\end{array}$

$\begin{array}{ll}\text { Sikatan } & 77\end{array}$

Burung Kukuk, Kadalan, Bubut, dan Tokhtor $\quad 78$

$\begin{array}{ll}\text { Burung buas } & 78\end{array}$

$\begin{array}{ll}\text { Mamalia } & 79\end{array}$

$\begin{array}{ll}\text { Umum } & 79\end{array}$

$\begin{array}{lr}\text { Primata } & 80\end{array}$

$\begin{array}{ll}\text { Bajing } & 87\end{array}$

$\begin{array}{ll}\text { Spesies-spesies tikus } & 91\end{array}$

$\begin{array}{ll}\text { Pemakan serangga } & 92\end{array}$

$\begin{array}{ll}\text { Tupai } & 93\end{array}$

Kelelawar $\quad 94$

$\begin{array}{ll}\text { Kucing hutan } & 98\end{array}$

$\begin{array}{lr}\text { Musang } & 98\end{array}$

$\begin{array}{ll}\text { Beruang madu } & 101\end{array}$

$\begin{array}{ll}\text { Satwa berkuku belah (ungulata) } & 104\end{array}$ 
Amfibia dan reptil

Katak dan kodok

Reptilia

Ikan

BAGIAN II. ANALISIS

Analisis kepekaan spesies

Pendekatan dan metode $\quad 129$

Hasil

Diskusi

$\begin{array}{ll}\text { Pertimbangan metodologi } & 142\end{array}$

$\begin{array}{ll}\text { Pengaruh langsung pengambilan kayu } & 143\end{array}$

Filogeni, distribusi, dan taksonomi 144

$\begin{array}{ll}\text { Strategi pencarian makanan } & 146\end{array}$

$\begin{array}{ll}\text { Peran jenis pohon kayu } & 148\end{array}$

$\begin{array}{ll}\text { Perubahan karakteristik struktur hutan } & 148\end{array}$

$\begin{array}{lr}\text { Pengaruh yang terkait dengan ekstraksi kayu } & 150\end{array}$

$\begin{array}{lr}\text { Fragmentasi hutan } & 150\end{array}$

$\begin{array}{ll}\text { Perburuan } & 153\end{array}$

BAGIAN III. PENGELOLAAN 155

$\begin{array}{ll}\text { Kesimpulan } & 157\end{array}$

Implikasi bagi pengelolaan kehutanan dan konsesi 161

$\begin{array}{ll}\text { Rekomendasi bagi para pengelola hutan } & 163\end{array}$

$\begin{array}{ll}\text { Perencanaan yang matang sebelum kegiatan penebangan } & 164\end{array}$

Meminimalkan kerusakan selama kegiatan penebangan dan kegiatan

$\begin{array}{ll}\text { lain yang terkait } & 169\end{array}$

$\begin{array}{ll}\text { Meminimalkan dampak dan ancaman tak langsung } & 178\end{array}$

Penebangan kayu dan konservasi bagi masyarakat setempat $\quad 184$

$\begin{array}{ll}\text { Implementasi dan pengawasan } & 185\end{array}$

$\begin{array}{ll}\text { Saran-saran khusus } & 189\end{array}$

$\begin{array}{ll}\text { Rekomendasi bagi perencana pemerintah } & 201\end{array}$

$\begin{array}{ll}\text { Perlunya rencana induk (masterplan) bagi satwa liar } & 201\end{array}$

$\begin{array}{ll}\text { Kesepakatan kepemilikan lahan } & 202\end{array}$

$\begin{array}{ll}\text { Perencanaan berskala besar } & 203\end{array}$

$\begin{array}{ll}\text { Perburuan dan penangkapan ikan } & 204\end{array}$

Penegakan hukum dan tata kelola kehutanan 206

$\begin{array}{ll}\text { Pelaksanaan yang efektif } & 209\end{array}$

$\begin{array}{ll}\text { Persyaratan Sertifikasi } & 211\end{array}$

BAGIAN IV. PENELITIAN 213

Rekomendasi bagi penelitian dan para peneliti 215

$\begin{array}{ll}\text { Rekomendasi bagi para peneliti } & 217\end{array}$

$\begin{array}{ll}\text { Pemanenan kayu } & 220\end{array}$

$\begin{array}{ll}\text { Kegiatan operasional konsesi penebangan kayu } & 221\end{array}$

$\begin{array}{ll}\text { Karakteristik bentang alam (lansekap) } & 221\end{array}$ 
Buah

Ketergantungan spesies

Struktur habitat

Konektivitas, ruang dan pergerakan

Perburuan

Ancaman lainnya

Penelitian mengenai burung

Penelitian tentang mamalia

Penelitian mengenai amfibia dan reptilia

Penelitian mengenai ikan

Literatur

\section{Lampiran}

Lampiran 1. Data spesies 233

Lampiran 2. Status IUCN 236

Lampiran 3. Kajian kepentingan spesies-spesies vertebrata bagi masyarakat lokal di MRF 241

Lampiran 4. Rangkuman spesies burung 243

Lampiran 5. Rangkuman spesies mamalia $\quad 274$

Lampiran 6. Rangkuman spesies amfibia $\quad 312$

Lampiran 7. Rangkuman spesies reptil 314

Lampiran 8. Laporan spesies ikan dari MRF 318

Lampiran 9. Pasal-pasal yang berkaitan dengan UU No. 5 tahun $1990 \quad 320$

Lampiran 10. Pasal-pasal yang berkaitan dengan UU No. 41 tahun 1999 tentang Kehutanan 322

Lampiran 11. Sistem Silvikultur Tebang Pilih Tanam Indonesia (TPTI) 326

Lampiran 12. Peraturan yang terkait dalam pemanenan jenis satwa yang tidak dilindungi di Indonesia - tahun 2004

\section{Gambar}

Gambar 1. Peta lokasi Kabupaten Malinau, provinsi Kalimantan Timur, yang berada di wilayah Indonesia, serta wilayah Malaysia (Serawak dan Sabah) dan Brunei

Gambar 2. Lokasi hutan penelitian Malinau

Gambar 3. Penebangan dan kebakaran hutan yang berulang di tanah yang miskin hara di Kalimantan Timur menyebabkan timbulnya lahan alang-alang (Imperata cylindrical) tidak produktif yang sangat luas

Gambar 4. Jalan dan penggunaan alat berat menyebabkan fragmentasi dan menimbulkan gangguan tanah yang parah dan erosi 
Gambar 5. Kubangan yang dalam di MRF

Gambar 6. Srindit Jambul Biru (Loriculus galgulus) yang ditangkap di

Larut Birai untuk diperdagangkan

Gambar 7. Pelatuk Besar Kelabu (Mulleripicus pulverulentus)

betina; kepadatan pelatuk ini sangat berkurang di hutan

bekas tebangan

Gambar 8. Sempidan Merah (Lophura ignita) jantan dan betina di hutan utuh di MRF

Gambar 9. Sundasciurus lowii, yang terlihat pada gambar sedang memakan buah Nangka (Artocarpus), adalah tupai yang biasa ditemukan di hutan dataran rendah yang utuh maupun yang terganggu

Gambar 10. Tenggalung Malaya (Viverra tangalunga), salah satu spesies musang Borneo yang terpengaruh negatif oleh efek pemanenan kayu

Gambar 11. Limnonectes leporinus, spesies endemik Borneo yang umumnya hidup dekat sungai berukuran besar atau sedang

Gambar 12. Sejumlah amfibia yang ditemukan di areal hutan utuh di Lembah Danum, areal tebangan RIL, dan areal tebangan dengan CL

Gambar 13. Plot "box-and-whisker" untuk toleransi spesies terhadap penebangan kaitannya dengan umur spesies

Gambar 14. Analisis diskriminans tiga variabel (jumlah pulau di wilayah Sunda berukuran kecil tempat spesies hidup, jumlah spesies per genus, dan jumlah subspesies per spesies), serta nilai prediksinya bagi kepekaan spesies mamalia terhadap kegiatan penebangan

Gambar 15. Plot "kotak dan garis” kategori yang menunjukkan toleransi terhadap kegiatan penebangan kaitannya dengan distribusi spesies di pulau-pulau kecil (hanya mamalia)

Gambar 16. Plot "kotak dan garis" kategori untuk toleransi terhadap kegiatan penebangan kaitannya dengan jumlah anak per sarang atau kelahiran (burung dan mamalia)

Gambar 17. Grafik kepekaan terhadap kegiatan penebangan kaitannya dengan daerah penyebaran

Gambar 18. Grafik kepekaan terhadap kegiatan penebangan kaitannya dengan strata pencarian makan

Gambar 19. Grafik kepekaan terhadap kegiatan penebangan kaitannya dengan kategori makanan

Gambar 20a-c. CATPCA dari 21 spesies mamalia dengan 5 variabel, yaitu: kepekaan terhadap penebangan, strategi pencarian makan, strata pencarian makanan, luas penyebaran, dan jumlah anak 
Gambar 20d, e. CATPCA dari 21 spesies mamalia. Gambar 20d menunjukkan titik objek dengan label strategi pencarian makan; Gambar 20e menunjukkan titik objek dengan label strata pencarian makanan

Gambar 21. Pohon berongga merupakan komponen ekologi yang penting pada hutan yang sehat

Gambar 22. Jalan untuk kegiatan penebangan sering kali memiliki lebar yang berlebihan, meningkatkan efek fragmentasi hutan dengan membatasi pergerakan satwa dan meningkatkan tingkat sedimentasi dan erosi

Gambar 23. Nepenthes gracilis, tumbuhan kantung semar yang dapat ditemukan di hutan dataran rendah

Gambar 24. Sisa-sisa hutan di Kalimantan Timur setelah kebakaran hutan yang berulang

Gambar 25. Lutung Merah (Presbytis rubicunda) memerlukan konektivitas tajuk untuk keberlangsungan hidupnya di atas pohon

Gambar 26. Peneliti lokal sedang mengkaji kerusakan akibat kebakaran hutan di Kalimantan Timur

Gambar 27. Kulit Beruang Madu dan bulu rangkong yang digunakan dalam upacara tradisional

Gambar 28. Babi Berjenggot (Sus barbatus) yang kurang dikenal merupakan perekayasa ekosistem yang penting dan merupakan sumber utama protein hewani bagi masyarakat pedalaman

Gambar 29. Tegakan pohon yang mati sangat diperlukan oleh banyak spesies

Gambar 30. Pelatuk Merah Betina (Picus miniaceus); pelatuk ini hidup dengan kepadatan yang lebih tinggi di hutan yang terganggu dan daerah pedesaan dibandingkan dengan hutan primer

\section{Tabel}

Tabel 1. Burung yang dilindungi di wilayah Malinau (informasi diambil dari Lampiran dokumen ini serta dari Departemen Kehutanan 1992; PHPA 1996a, b; Noerdjito \& Maryanto 2001)

Tabel 2. Rangkong dan reaksinya terhadap kegiatan

Tabel 3. Spesies pelatuk dan reaksinya terhadap kegiatan penebangan

Tabel 4. Sempidan dan reaksinya terhadap kegiatan penebangan

Tabel 5. Spesies mamalia kecil yang umumnya terjerat dalam sejumlah penelitian di Semenanjung Malaya

Tabel 6. Primata dan reaksinya terhadap penebangan 
Tabel 7. Tupai darat dan reaksinya terhadap kegiatan penebangan

Tabel 8. Musang dan responsnya terhadap kegiatan penebangan

Tabel 9. Perubahan kepadatan suku Cervidae dan Tragulidae setelah kegiatan tebang pilih

Tabel 10. Perbandingan kelimpahan dan keberadaan ikan antara stasiun penelitian di hutan utuh dan hutan bekas tebangan di Sungai Seturan, Malinau

Tabel 11. Satwa ikan yang hidup dalam kolam yang terbentuk karena konstruksi jalan yang buruk di Malinau

Tabel 12. Perbandingan nilai tengah 8 variabel penduga kaitannya dengan kepekaan sejumlah spesies mamalia terhadap kegiatan penebangan

Tabel 13. Jumlah dan titik tengah ukuran pulau-pulau di kawasan Indo-Malaya yang menjadi tempat tinggal spesies mamalia dari berbagai suku

Tabel 14. Daftar spesies Borneo yang paling mendapatkan manfaat dari pengelolaan konsesi hutan yang lebih mendukung keberadaan satwa liar

Tabel 15. Tiga puluh spesies utama yang dimanfaatkan oleh masyarakat setempat dan yang terdaftar dalam Daftar Merah Spesies yang Terancam IUCN

Tabel 16. Spesies yang terdaftar sebagai Terancam Punah atau Rentan oleh IUCN (2002) 


\section{Prakata}

Buku ini berisi kajian teknis mengenai informasi ekologis dan kehidupan serangkaian spesies satwa liar Borneo. Kajian ini ditujukan untuk mengidentifikasi penyebab berbagai spesies satwa peka terhadap kegiatan penebangan kayu dan dampak yang ditimbulkannya. Buku ini ditujukan bagi mereka yang: 1) terlibat dalam pengkajian dan pengaturan kegiatan pemanenan kayu di Asia Tenggara, 2) terlibat dalam upaya pencapaian tujuan konservasi di wilayah ini, dan 3) melakukan penelitian untuk meningkatkan kualitas pengelolaan hutan yang multifungsi. Kami menunjukkan bahwa pengelolaan hutan dapat ditingkatkan dengan berbagai cara sederhana untuk menyelaraskan tujuan pemanenan kayu dan konservasi hidupan liar. Rekomendasi yang disampaikan dapat bermanfaat bagi lembaga-lembaga pemerintah dan organisasi nonpemerintah yang berupaya untuk memajukan pengelolaan hutan yang berkelanjutan dan ekolabel. Untuk itu kami mengidentifikasi sejumlah kelemahan dan celah dari pemahaman dan pengetahuan yang ada, dan selanjutnya kami berharap dapat menarik minat masyarakat ilmiah dan memicu penelitian lebih lanjut.

Kami menganggap bahwa kajian ini merupakan langkah ilmiah yang penting bagi pemahaman dan perbaikan praktek kehutanan yang berkelanjutan untuk upaya konservasi keanekaragaman hayati jangka panjang. Bahkan dalam jangka pendek, perbaikan yang nyata dapat dilakukan untuk meningkatkan upaya konservasi dan efisiensi pengelolaan kehutanan. Hal ini tidak bisa lagi ditunda dengan alasan kurangnya informasi. Dalam jangka panjang, kami berharap rekomendasi dari kajian ini dapat diterapkan, serta penelitian lebih lanjut dapat membuka peluang terjadinya pilihan-pilihan yang bijak untuk memelihara keseimbangan antara populasi satwa liar yang sehat dan keanekaragaman hayati di hutan produksi.

Versi bahasa Indonesia ini merupakan langkah lanjutan dari versi Bahasa Inggris yang telah diterbitkan sebelumnya. Dengan adanya kajian ini maka terbuka pula peluang perbaikan di masa datang. Kajian yang dibangun dari berbagai sumber dan sudut pandang yang sangat beragam bukanlah sesuatu yang absolut. Kekeliruan dan perkembangan baru tentunya tidak dapat dihindari. Untuk itu kami sangat 
berterimakasih bila pembaca dapat menyampaikan perbaikan kesalahan, usulan atau tambahan informasi bagi buku ini. Mohon hubungi Erik di alamat emeijaard@tnc.org atau Douglas di alamatd.sheil@cgiar.org

Erik Meijaard dan Douglas Sheil

Bogor, Indonesia

12 Oktober 2004 


\section{Biodata para kontributor}

Augeri, David. Lahir pada tahun 1962 di Connecticut, USA. Menyandang gelar M.Sc. di bidang Ekologi dan Ilmu Kehutanan dan Ph.D di bidang Ekologi Hidupan Liar (Wildlife Ecology). David banyak terlibat dalam penelitian dan konservasi hidupan liar dan hutan di Indonesia dan Asia Tenggara sejak tahun 1990. Penelitiannya terutama berfokus pada ekologi hidupan liar tropis dan pengaruh gangguan habitat terhadap ekologi Beruang Madu, mamalia lain, dan dinamika komunitas satwa liar di Borneo dan Sumatera.

van Balen, Sebastianus (Bas). Lahir pada tahun 1954 di Arnhem, Belanda. Meraih gelar Ph.D. dengan topik tesis konservasi burung hutan Jawa. Bas terlibat dalam penelitian burung di Indonesia sejak 1980. Saat ini penelitiannya berfokus pada spesies burung di Dataran Sunda Besar dan Papua.

Dennis, Rona A. Lahir pada tahun 1964 di Inverness, Skotlandia. Memiliki gelar M.Sc. di Environmental Remote Sensing dan sejak tahun 1988 memfokuskan keahliannya pada bidang penerapan penginderaan jauh dan SIG bagi pemantauan serta pengelolaan sumberdaya alam di wilayah Asia daratan dan Asia Tenggara, dan khususnya Indonesia.

Duckworth, Will. Lahir pada tahun 1964 di Inggris dan memiliki gelar Ph.D di bidang Zoologi. Will terlibat dalam berbagai penelitian untuk hidupan liar di Asia Tenggara sejak tahun 1986 dan memfokuskan penelitiannya di wilayah Laos dan negara-negara di sekitarnya.

Fredriksson, Gabriella. Lahir pada tahun 1971 di Amsterdam, Belanda. Saat ini sedang menyelesaikan Ph.D-nya di bidang Biologi Konservasi (Conservation Biology). Gabriella banyak terlibat dalam penelitian tentang Beruang Madu dan pengelolaan kawasan konservasi di Kalimantan sejak 1994. 
Gunawan, Tiene. Lahir pada tahun 1962 di Malang, Indonesia. Menyandang gelar Doktor di bidang Pengelolaan Sumberdaya Pesisir dan Laut dari Institut Pertanian Bogor dan MSc. di bidang Geografi dari Texas A\&M University di Amerika Serikat. Tiene bekerja sebagai perencana konservasi dengan spesialisasi dalam pengkajian dan perencanaan konservasi ekoregional. Selama ini terlibat secara aktif dalam sejumlah kegiatan perencanaan konservasi ekoregional, terutama di Sulawesi melalui kerjasama antara pemerintah provinsi dan sejumlah organisasi konservasi internasional.

Indrawan, Muchamad. Lahir pada tahun 1962 di Surabaya, Indonesia. Memiliki gelar Doktor di bidang Biologi Konservasi. Indrawan banyak terlibat dalam penelitian yang berkaitan dengan hidupan liar Indonesia sejak tahun 1985. Minatnya saat ini meluas kepada keanekaragaman hayati secara menyeluruh, lingkungan hidup, serta otonomi daerah di Indonesia.

Inger, Robert F. Lahir tahun 1920 di St. Louis, Missouri, USA. Robert banyak terlibat dalam penelitian sistematika dan komunitas ekologi dari amfibia dan reptilia di Asia Tenggara, terutama Borneo, sejak 1950.

Iskandar, Djoko T. Lahir pada tahun 1950 di Bandung, Jawa Barat, Indonesia. Meraih gelar Doktor dari Université des Sciences et Technique du Languedoc, Montpellier, Perancis pada tahun 1984. Saat ini Djoko adalah Guru Besar dan mengajar di bidang Ekologi dan Biosistematika. Minat penelitiannya mencakup evolusi, ekologi, konservasi, dan keanekaragaman hayati vertebrata kecil di Asia Tenggara.

Kartawinata, Kuswata. Lahir pada tahun 1936 di Garut, Jawa Barat, Indonesia. Memiliki gelar Ph.D. di bidang Ekologi Tumbuhan (Plant Ecology). Kuswata terlibat dalam penelitian tentang ekologi hutan, vegetasi, taksonomi tumbuhan, konservasi, dan ekologi manusia di Indonesia, terutama Kalimantan.

Kingston, Tigga. Lahir pada tahun 1968 di Vacoas, Mauritius. Tigga adalah warga negara Inggris yang memiliki gelar Ph.D. di bidang Ekologi, Perilaku, dan Evolusi. Tigga adalah Research Associate di Boston University dan Direktur Unit Penelitian Konservasi Kelelawar Malaysia (Malaysian Bat Conservation Research Unit). Penelitiannya berfokus pada keragaman kelelawar pemakan serangga di Asia Tenggara dan bekerja di Malaysia, Sulawesi, Indonesia, dan Myanmar.

Lammertink, Martjan. Lahir pada tahun 1971 di Amsterdam, Belanda. Saat ini sedang menulis disertasi untuk gelar Ph.D.-nya tentang ekologi komunitas dan reaksi pelatuk Asia terhadap gangguan habitatnya. Bekerja di lapangan di Indonesia sejak tahun 1997 dan sebelum itu meneliti spesies pelatuk Eurasia dan Neotropis. 
Meijaard, Erik. Lahir pada tahun 1967 di Haarlem, Belanda. Memiliki gelar Ph.D di bidang Biological Anthropology. Erik terlibat dalam penelitian tentang satwa liar di Indonesia sejak 1992, terutama mamalia berukuran besar di Indonesia bagian Barat.

Nasi, Robert. Lahir pada tahun 1959 di Nice, Perancis. Robert memiliki gelar Ph.D. di bidang Ilmu-ilmu Biologi (Ekologi). Terlibat dalam penelitian tentang keanekaan hayati dan hutan yang dikelola sejak 1982. Minatnya terutama pada vegetasi di Afrika Tengah, Oceania, dan pedalaman Asia Tenggara. Saat ini menjadi Ilmuwan Utama (Principal Scientist) pada program Jasa Lingkungan dan Pemanfaatan Hutan yang Berkelanjutan (Environmental Services and Sustainable Use of Forests) di CIFOR.

O’Brien, Timothy. Lahir pada tahun 1955 di Ashtabula, Ohio, Amerika Serikat. Memiliki gelar Ph.D. di bidang Ekologi Hidupan Liar (Wildlife Ecology). Timothy terlibat dalam penelitian dan pengelolaan konservasi sejak tahun 1975 , dan memiliki bidang keahlian tentang mamalia berukuran besar dan burung di dalam ekosistem hutan tropis.

Rachmatika, Ike. Lahir pada tahun 1959 di kuningan, Jawa Barat. Memiliki gelar M.Sc. di bidang Perikanan dan Akuakultur (Fisheries and Allied Aquacultures). Sejak tahun 1983, terlibat dalam penelitian tentang sistematika dan ekologi ikan, terutama untuk spesies di bagian barat Indonesia.

Rosenbaum, Barry. Lahir pada tahun 1953 di Amerika Serikat. Barry memiliki gelar Ph.D. di bidang Biologi. Penelitian yang dilakukannya sejak 1990 terutama berfokus pada pengaruh gangguan manusia terhadap primata di Asia Selatan dan Asia Tenggara.

Setyawati, Titiek. Lahir pada tahun 1962 di Jawa Timur, Indonesia. Menyelesaikan gelar Ph.D.nya di bidang Kehutanan dan Pengelolaan Hidupan Liar di University of Melbourne, Australia dengan fokus utama pada interaksi hewan-tumbuhan di hutan tropis dataran rendah di Indonesia.

Sheil, Douglas. Lahir pada tahun 1965 di Belfast Irlandia Utara dan memiliki gelar D.Phil di bidang Ekologi Hutan. Minat penelitiannya di bidang pemantauan dan ekologi perubahan hutan (baik yang alami maupun oleh manusia) di Afrika Timur dan Indonesia serta implikasinya terhadap konservasi dan pengelolaan. Saat ini melakukan penelitian yang berfokus pada identifikasi prioritas konservasi yang ditetapkan oleh masyarakat yang hidup di hutan.

Soehartono, Tonny R. Lahir di Sukabumi pada tahun 1955. Memiliki gelar Ph.D. di bidang Ekologi Hutan dan terlibat dalam penelitian dan pengelolaan hutan dan hidupan liar tropis sejak tahun 1983, terutama di bidang hasil hutan nonkayu di bagian barat Indonesia. 
Stanley, Scott. Lulus dari North Carolina State University pada tahun 1981 dan meraih gelar M.Sc. di bidang Kehutanan dan Ekologi. Scott telah bekerja di Amerika Serikat, Costa Rica, dan Guatemala sebagai ahli kehutanan dan peneliti silvikultur. Sejak tahun 1999 Scott memimpin kegiatan kehutanan berbasis masyarakat untuk Harvard University di Kalimantan Barat. Pada tahun 2001 Scott bekerja di The Nature Conservancy di Kalimantan Timur.

Wong, Anna. Lahir di Kota Kinibalu, Sabah pada tahun 1965. Memiliki gelar M.Sc. dan saat ini sedang menyelesaikan gelar Ph.D-nya di bidang Zoologi. Anna terlibat dalam berbagai penelitian tentang satwa liar Sabah sejak tahun 1989, terutama berfokus pada amfibia dan reptilia Sabah dan Sarawak. Saat ini mengajar Zoologi di Universiti Malaysia Sabah.

Wulffraat, Stephan. Lahir pada tahun 1966 di Belanda. Stephan adalah ahli Ekologi Bentang Alam (Landscape Ecologist). Bekerja sebagai koordinator Biologi Konservasi di proyek WWF Kayan Mentarang sejak 1998. Stephan bertanggung jawab untuk inventori dan penelitian bidang ekologi dan hidupan liar di Taman Nasional, terutama di stasiun lapangan Lalut Birai. 


\section{Ucapan terimakasih}

Kami sangat menghargai dukungan dari Pemerintah Indonesia melalui Departemen Kehutanan dan Lembaga Ilmu Pengetahuan Indonesia (LIPI). Penelitian ini pada awalnya adalah bagian dari proyek Forest, Sience and Sustainability: Bulungan (Malinau) Model Forest, PD12/97 Rev.1 (F) (proyek kehutanan, ilmu pengetahuan, dan keberlanjutannya: Model Hutan Bulungan (Malinau)) yang didanai oleh International Tropical Timber Organization (ITTO) dan dilaksanakan oleh Center for International Forestry Research (CIFOR), dan Lembaga Penelitian dan Pengembangan Hutan (Forest Research and Development Agency —FORDA), Departemen Kehutanan dan bagian kehutanan dari Centre de Coopération Internationale pour la Recherche Agronomique en Développement (CIRAD-Forêt). Kajian awal fauna dilaksanakan melalui kerjasama antara CIFOR dan Wildlife Conservation Society Indonesia Program (WCS-IP).

Pendanaan utama yang memungkinkan kami untuk melaksanakan dan mengembangkan penelitian ini berasal dari ITTO dan Komisi Eropa (European Commission-EC) yang mendukung kegiatan penelitian keanekaragaman hayati CIFOR. Bantuan dana tambahan berasal dari Bank Dunia dan MacArthur Foundation (melalui Kuswata Kartawinata). SwedBio (Swedish International Biodiversity Programme) menyediakan sebagian dana sisanya untuk pembuatan buku ini. UNESCO, dalam kerangka program Man and Biosphere Program (MAB), membantu pendanaan untuk pencetakan dan penyebaran buku ini (terimakasih khususnya bagi Han Qunli, Enis Widjanarti, dan Kuswata Kartawinata). Kami berterimakasih pula pada beberapa orang dari berbagai organisasi yang telah menyediakan waktunya.

Kami berterimakasih pada para ahli yang telah memberikan bantuan dan masukannya terhadap aspek spesifik dalam penelitian ini, yaitu Chandra Boer (Universitas Mulawarman), Carol Colfer (CIFOR), Ed Colijn (Indonesian Nature Conservation Database), Bas E. van Helvoort (Tropenbos), James Jarvie (The Nature Conservancy), Frank Lambert, Vincent Nijman, Art Klasson, Martin Tyson, Eva Wollenberg (CIFOR), dan Carey Yeager (USAID). 
Kami mengucapkan terimakasih atas komentarnya terhadap teks—dan polesan editorial—dari Yudi Iskandarsyah, Yosep Ruslim, Marius Gunawan, Soeryo Wibowo, Marieke Sassen, Meilinda Wan, Sally Wellesley, dan Claire Miller.

Sejumlah staf CIFOR juga membantu dalam tahap-tahap yang berbeda. Khususnya kami berterimakasih atas dukungan Petrus Gunarso, Hari Priyadi, Nining Liswanti, Greg Clough, Glen Mulcahy, Ismayadi Samsoedin, Indah Susilanasari, Levania Santosa, Catur Wahyu, Gideon Suharyanto, Luluk Suhada, staf perpustakaan CIFOR, dan staf Lapangan Seturan.

Kami berterimakasih kepada Kimabajo, Rona Dennis, Gabriella Fredriksson, Rob Fimbel, Margaret Kinnaird, Martjan Lammertink, Dave Augeri, dan Sven Wunder atas sumbangan fotonya untuk digunakan dalam buku ini. 


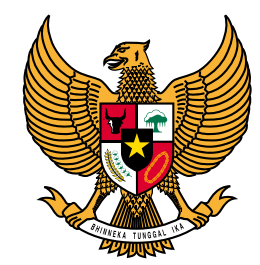

MENTERI KEHUTANAN

REPUBLIK INDONESIA

\section{Pengantar oleh Menteri Kehutanan}

Kenyataan bahwa Indonesia merupakan pusat keanekaragaman hayati yang kedua terbesar di dunia setelah Brazil, telah diakui oleh banyak pihak di dunia. $\mathrm{Hal}$ ini, di satu pihak menjadi kebanggaan kita, bangsa Indonesia, tetapi di lain pihak kenyataan itu juga menjadi beban dan tanggung jawab dalam menjaga dan melestarikan keanekaragaman hayati di pihak kita.

Pada saat ini, kenyataan menggambarkan bahwa keanekaragaman jenis yang kita miliki, telah mengalami tekanan dan penurunan, baik kualitas maupun kuantitasnya. Saya menyadari bahwa sejauh ini kita belum berhasil menghentikan penurunan tersebut.

Salah satu yang menjadi penyebabnya antara lain ketidakmampuan kita menyeimbangkan pemanfaatan sumber daya hutan untuk pembangunan ekonomi dengan konservasi keanekaragaman hayati. Oleh karena itu, kita perlu secara cermat memperhitungkan tingkat pemanfaatan sumber daya alam hayati dengan daya dukung dan daya pulih sumber daya tersebut, sehingga kaidah pemanfaatan secara lestari terpenuhi.

Salah satu komitmen pemerintah Indonesia yang tidak bisa ditawar lagi adalah memanfaatkan sumber daya hutan secara lestari. Hal tersebut dapat dicapai melalui tata guna lahan yang lebih baik, dan pengelolaan hutan lestari. Tantangan utamanya adalah menjamin pemanfaatan hutan yang lestari dapat meningkatkan kesejahteraan masyarakat Indonesia dan mempertahankan nilainilai keanekaragaman hayati sumber daya hutan tersebut.

Buku ini menawarkan peluang yang penting bagi Departemen Kehutanan serta semua pihak yang terkait dengan pengusahaan hutan produksi, untuk melaksanakan pengelolaan hutan yang lebih baik. Buku ini disusun berdasarkan pemahaman yang mendalam mengenai dampak aktivitas kehutanan terhadap berbagai kehidupan di dalam ekosistem hutan sehingga dapat dijadikan acuan dalam mengelola hutan produksi, termasuk contoh yang menggambarkan pengelolaan hutan produksi secara lestari, dengan tetap biasa. 
Terjemahan buku "Life After Logging: Reconciling Wildlife Conservation and Production Forestry in Indonesian Borneo" dalam Edisi Bahasa Indonesia (Hutan Pasca Pemanenan) ini diharapkan akan sangat bermanfaat bagi pengelola kehutanan, para pihak pemangku kepentingan lain seperti Universitas dan Lembaga Swadaya Masyarakat serta masyarakat lainnya.

Saya berharap rekomendasi dalam buku ini akan dapat menjadi acuan bagi pengelolaan hutan secara lestari serta dapat menjadi masukan dalam perbaikan peraturan perundangundangan di bidang kehutanan. Melalui pengelolaan hutan yang tepat kita dapat memberi kontribusi yang lebih berarti dalam menghentikan laju penurunan sumber daya alam hayati di Indonesia.

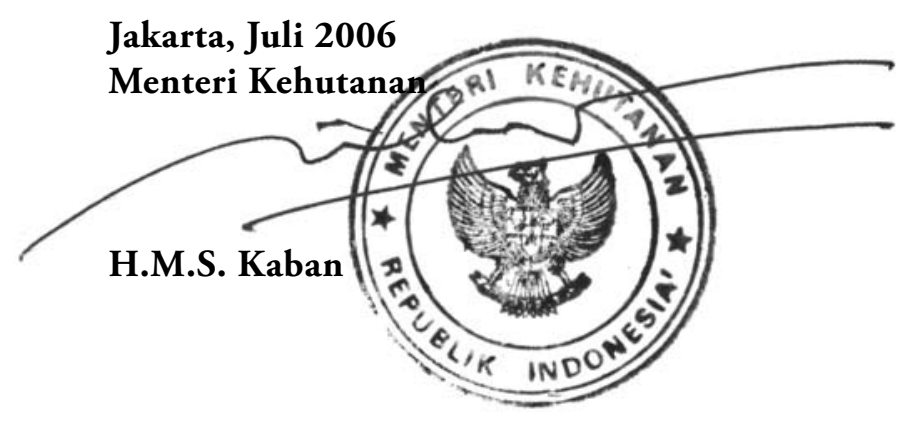




\section{Pengantar oleh Jeffrey A. Sayer}

Penebangan kayu di hutan hujan tropis memiliki citra yang buruk dalam pandangan publik. Penebangan kayu bagi industri sering dikaitkan dengan pembersihan lahan bagi kegiatan pertanian atau perkebunan. Hak masyarakat setempat sering kali diabaikan oleh pihak yang memanen kayu. Korupsi dan tindak kekerasan sering dikaitkan dengan kegiatan penebangan kayu. Kegiatan penebangan kayu sering disamakan dengan deforestasi dan hilangnya keanekaragaman hayati, bahkan oleh pihak yang memiliki pemahaman yang baik sekali pun. Reaksi umum yang diberikan oleh komunitas konservasi adalah menolak kegiatan penebangan.

Pada kenyataannya, penebangan kayu merupakan isu yang lebih rumit. Penebangan kayu hutan tropis sering dilakukan secara selektif; hanya beberapa pohon saja per hektarnya yang diambil. Sejumlah penelitian menunjukkan bahwa hutan bekas tebangan masih memiliki sebagian dari keanekaragaman hayati asalnya (Whitmore \& Sayer 1992). Jumlah hutan yang dicadangkan untuk kegiatan penebangan jauh lebih banyak dibandingkan dengan yang dicadangkan untuk taman nasional. Daerah lindung dan hutan bekas tebangan sama pentingnya bagi sumber keanekaragaman hayati. Pragmatisme mendorong kita untuk berupaya membuat hutan bekas tebangan dan daerah lindung menjadi satu bentang alam konservasi yang multi fungsi. Namun demikian, kemajuan yang dicapai untuk menuangkan pemikiran tersebut menjadi kenyataan di lapangan hanya sedikit saja. Ilmu pengetahuan yang diperlukan untuk mencapai tujuan baik ini secara umum kurang memadai.

Namun demikian, pengakuan bahwa hutan bekas tebangan memiliki nilai konservasi tidak berarti bahwa hutan Borneo yang tersisa boleh dipanen kayunya. Daerah yang dilindungi secara ketat masih memiliki nilai penting bagi spesies yang hidup di hutan pedalaman. Pengelolaan yang efektif baik bagi hutan lindung maupun hutan bekas tebangan masih menjadi kunci bagi keberhasilan konservasi dan hal ini harus didasari oleh pemahaman tentang ekologi hutan.

Satu masalah konservasi yang masih muncul sampai saat ini adalah seringnya ekologi dianggap sebagai hal yang tidak penting. Yang disebut sebagai "Prinsip 
Ekosistem" yang belum lama ini diadopsi oleh Konferensi Para Pihak (Conference of Parties_COP) dari Konvensi Keanekaragaman Hayati (Convention on Biological Diversity) sebagian besar berupa proses sosial dan ekonomi. Dari ke 12 prinsip hanya satu saja yang mengacu pada ekologi dan dua acuan terhadap kata keanekaragaman hayati, keduanya berfokus pada pencapaian keseimbangan antara konservasi dan pemanfaatan (IUCN-WWF 2004). Bandingkan hal ini dengan pustaka "Ecosystem Management (Pengelolaan Ekosistem)" yang digunakan di Amerika Serikat. Dalam pustaka ini, pemahaman yang rinci mengenai proses ekologis merupakan inti dari pengelolaan hutan (Inter-Agency Ecosystem Taskforce 1995).

Buku ini memberikan informasi dan analisis baru bagi pengelolaan hutan dan ekologi yang dibangun berdasarkan hasil penelitian hutan CIFOR di daerah Malinau, Kalimantan. Sebelum buku ini dibuat, penelitian mengenai manusia dan sumberdaya alam di wilayah tersebut telah dilakukan (Puri 2001; Sellato 2001). CIFOR memilih Malinau sebagai daerah penelitiannya karena wilayah ini merupakan contoh yang sangat baik dengan daerah hutan yang luas, kaya akan keanekaragaman hayati dan memiliki cukup banyak penduduk yang tinggal dekat dengan hutan tersebut. Pada saat yang sama, daerah ini dibuka untuk penebangan kayu industri, pertambangan, dan pengembangan perkebunan. Malinau dipandang sebagai tempat yang memungkinkan untuk mengarahkan pembangunan menuju suatu tatanan bentang alam yang seimbang. Daerah hutan lindung, hutan yang dikelola, dan daerah pertanian yang dikembangkan secara intensif dapat dikombinasikan dalam suatu mosaik terpadu untuk mencapai tujuan konservasi dan pembangunan.

Salah satu masalah yang retorik mengenai konservasi keanekaragaman hayati yang belum terjawab adalah keanekaragaman hayati yang mana yang harus dikonservasi dan mengapa. Banyak upaya konservasi yang nampaknya hanya dibuat karena keinginan untuk mengkonservasi sebanyak mungkin keanekaragaman hayati, tidak peduli apapun konsekuensinya bagi masyarakat yang mata pencahariannya bergantung pada hutan. Argumentasi dan alasan pentingnya keanekaragaman hayati bagi fungsi ekologis seringkali membesar-besarkan masalah potensi risiko kepunahan spesies. Buku ini membantu menyediakan kerangka dasar/acuan bagi program konservasi dan pengelolaan hutan. Buku ini juga menunjukkan tentang perlunya pemahaman aspek ekologi hutan dan individu species agar program yang rasional bisa dilaksanakan. Hal ini dapat membantu menjawab pertanyaan tentang apa yang akan terjadi apabila pembangunan yang tidak terbatas dibiarkan saja.

Dari buku ini dapat diambil pelajaran bahwa mengumpulkan informasi yang memadai tentang ekologi bentang alam tropis yang luas untuk memperkirakan dampak yang timbul dari berbagai skenario pembangunan adalah hal yang mungkin. Buku ini menunjukkan bahwa kombinasi kegiatan penebangan dan perlindungan yang berbeda dengan pola pembangunan infrastruktur yang berbeda akan menghasilkan dampak terhadap keanekaragaman hayati yang berbeda pula. Dan selanjutnya akan menimbulkan dampak terhadap mata pencaharian masyarakat yang bergantung pada keanekaragaman hayati ini.

Buku ini bersumber dari beragam pustaka, penelitian dan pemikiran. Kajian semacam ini sangat penting bila kita ingin berupaya nyata menyelamatkan hutan alam tropis yang kompleks dengan cara yang pragmatis tanpa membatasi pilihan 
pembangunan di negara yang bersangkutan secara berlebihan. Pengelolaan ekosistem saat ini merupakan kenyataan yang ada di negara-negara beriklim sedang dan dingin, dan selalu didasari oleh pemahaman ekologi hutan yang mendalam. Hutan di negara maju dikelola dengan cara menjembatani kebutuhan konservasi dengan kebutuhan ekonomi serta mata pencaharian masyarakat setempat. Kemajuan dalam mencapai keseimbangan seperti ini di hutan tropis negara-negara berkembang sangat lambat. Buku ini memberikan kontribusi yang besar terutama untuk menunjukkan bahwa kajian ekologis yang menggunakan pendekatan ekosistem sangat diperlukan untuk mencapai pengelolaan yang baik di daerah hutan tropis.

\section{Professor Jeffrey A. Sayer}

Senior Associate

WWF, Avenue du Mont Blanc

1196, Gland

Switzerland 


\section{Ringkasan eksekutif}

Deforestasi, degradasi hutan, dan perburuan memberikan dampak yang semakin meningkat dan mengancam berbagai spesies satwa liar di Borneo. Pemerintah Indonesia telah berupaya sekuat mungkin untuk mengendalikan permasalahan ini. Upaya tersebut diwujudkan dalam serangkaian peraturan dan perundangan serta kesepakatan internasional mengenai hidupan liar. Namun meskipun tindakan yang nyata dirasakan sangat mendesak, pencapaian tujuan konservasi masih menghadapi berbagai tantangan. Masalah ini sebagian disebabkan oleh kenyataan bahwa upaya konservasi masih berfokus pada hutan lindung dan hutan yang utuh. Kita harus mengakui bahwa hutan bekas tebangan juga merupakan komponen penting bagi pendekatan konservasi secara menyeluruh di tingkat bentang alam.

Fokus kajian kami adalah aspek ekologi dan sejarah alam vertebrata Borneo serta bagaimana hal ini terkait dengan pengelolaan hutan, terutama dengan penekanan pada hutan Dipterokarpa dataran rendah dan perbukitan. Namun penelitian ekologi jarang menghasilkan perbaikan praktek pengelolaan hutan. Kajian kami menyediakan tiga jawaban bagi masalah ini:

1. Informasi yang ada dalam berbagai pustaka yang terkait dikumpulkan dan diterjemahkan untuk implikasi pengelolaan. Informasi ini dapat diberikan kepada siapa pun yang memerlukannya.

2. Memahami bahwa penurunan jumlah spesies akibat intervensi kegiatan kehutanan tidak selalu dapat menjelaskan bagaimana kegiatan kehutanan dapat diadaptasi (dilarang) untuk mengurangi dampak negatif. Kami mengaitkan kepekaan spesies dengan korelasi ekologis dan sejarah alam untuk mengembangkan pemahaman tentang kerentanan suatu taksa tertentu. Hal ini dapat memberikan pendekatan yang sifatnya spesifik terhadap spesies tertentu dalam rangka perlindungan karakteristik dan komponen habitat.

3. Kebutuhan penelitian untuk menjawab masalah-masalah pengelolaan yang terkait. Kami mengidentifikasi topik-topik yang merupakan prioritas bagi penelitian. 
Dengan demikian, tujuan utama kami adalah untuk mengidentifikasi dan mengklarifikasi penyebab satwa menjadi rentan terhadap berbagai intervensi yang terkait dengan kegiatan kehutanan. Berdasarkan hasil yang didapat, berbagai pertimbangan, serta hipotesis yang relevan, kami mengkompilasi dan mengembangkan rekomendasi bagi perbaikan praktek pengelolaan serta mengidentifikasi prioritas penelitian selanjutnya yang diperlukan. Secara pragmatis, dalam rangka mengimplementasikan usulan, kami mengakui adanya pengaruh yang sangat penting dalam konteks sosial politik. Namun demikian, meskipun ada sejumlah isu yang diangkat dalam kajian ini, cepatnya laju perubahan di Indonesia saat ini disertai dengan isu-isu yang sangat kompleks menyebabkan sulitnya kajian sosial-politik digunakan untuk menyelesaikan dan memanfaatkan peluang yang ada, baik untuk saat ini maupun masa mendatang. Untuk itu kami berfokus pada informasi teknis yang berkaitan dengan informasi ekologis yang validitasnya terlepas dari isu politik setempat yang penuh pergolakan.

Kami menemukan informasi ekologis yang cukup banyak yang berkaitan dengan pengelolaan hutan tropis dan hidupan liarnya. Perbaikan sistem pengelolaan yang ada memerlukan kerjasama yang baik antara para pakar ekologi dan pengelola hutan untuk mengembangkan panduan yang pragmatis bagi perbaikan praktek kehutanan ke arah yang lebih baik. Kajian dan sintesis ini merupakan salah satu komponen untuk mencapai kolaborasi dengan menitikberatkan pada fauna yang ada di daerah Malinau, Kalimantan Timur.

Bagian I buku ini merangkum pengetahuan tentang intervensi kehutanan yang ada serta bagaimana hal ini mempengaruhi sejumlah spesies satwa liar tertentu. Serangkaian efek yang ditimbulkan oleh kegiatan penebangan kayu diidentifikasi dan kemudian dikembangkan menjadi suatu catatan lengkap mengenai pengaruh yang ditimbulkan oleh perburuan dan fragmentasi hutan. Selanjutnya dilakukan identifikasi masalah lain yang ditimbulkan oleh spesies asing (eksotis), penegakan hukum, kebakaran hutan, dan berbagai faktor lain. Namun demikian, walaupun penelitian tentang satwa liar telah dilakukan selama puluhan tahun di Borneo, informasi yang ada mengenai besarnya dan mekanisme ancaman terhadap satwa liar sangat sedikit. Kebanyakan penelitian yang diulas dalam buku ini menyajikan penelitian tentang ekologi satu spesies (autecology) dari berbagai spesies yang ada, tetapi tidak menganalisis karakteristik spesies tersebut kaitannya dengan tingkat ancaman yang berbeda. Meskipun demikian, dari berbagai penelitian yang dikaji ini masih dapat ditarik berbagai kesimpulan tentang pengaruh penebangan kayu dan faktor-faktor yang terkait terhadap satwa liar, serta dapat disajikan rekomendasi pengelolaan secara umum.

Kegiatan tebang pilih berdampak negatif secara langsung yang lebih kecil terhadap berbagai spesies vertebrata dibandingkan dengan apa yang sering diperkirakan. Kegiatan ini mempengaruhi kelompok spesies tertentu, seperti mamalia, burung terestrial dan pemakan serangga yang biasanya dirugikan karena berkurangnya jumlah tutupan tanah. Hal ini terutama disebabkan oleh penebasan liana dan tumbuhan bawah, yang disyaratkan dalam peraturan tebang pilih. Namun demikian, sejumlah spesies, seperti rusa dan banteng, terlihat beradaptasi dengan baik dan pada habitat yang lebih terbuka kepadatannya dapat meningkat setelah kegiatan penebangan. 
Penebangan kayu secara umum mengakibatkan sejumlah masalah, disamping rusaknya habitat hutan. Dari sudut pandang konservasi satwa liar, ada dua aspek penting yang timbul yaitu peningkatan kegiatan perburuan dan fragmentasi hutan.

Perburuan dapat menimbulkan ancaman yang cukup besar bagi sejumlah fauna hutan dan ancaman ini seringkali meningkat sejalan dengan peningkatan jumlah jalan tebangan, peningkatan akses ke dalam hutan, dan pengembangan kebutuhan pemukiman sementara bagi kegiatan penebangan (camp). Perbaikan teknologi perburuan dan tersedianya senjata perburuan menambah tekanan ini.

Jaringan jalan, jalan sarad, dan daerah yang rusak memecah-mecah habitat hutan. Populasi yang kecil dan terisolasi, seperti yang timbul karena bentang alam yang terpecah-pecah atau yang dipanen secara berlebihan, memiliki risiko lebih besar akibat pengaruh negatif yang selanjutnya dapat menyebabkan kepunahan. Sebagian spesies memiliki persyaratan ukuran habitat yang sesuai bagi kelangsungan hidup populasinya. Penelitian yang dilakukan belum lama ini menunjukkan bahwa memelihara/mempertahankan habitat yang "seperti hutan" atau jaringan habitat berupa bagian hutan yang berfungsi sebagai batu loncatan antara bentang alam yang dominan merupakan hal yang sangat penting. Pengaruh fragmentasi ini terlihat lebih buruk pada hutan dengan kepadatan jalan yang tinggi, pembersihan lahan yang luas, dan bukaan daerah hutan yang luas. Tepian hutan akan menimbulkan pengaruh nyata bagi dinamika individual, populasi, dan komunitas di daerah hutan yang tersisa. Sejumlah penelitian melaporkan bahwa pengaruh penebangan kayu dapat meluas dalam jarak yang cukup besar ke dalam hutan utuh di sekitarnya.

Bagian II dari buku ini menganalisis spesies kaitannya dengan toleransi terhadap pengaruh kegiatan penebangan dan perubahan hutan. Dengan menggunakan analisis multivarian, serangkaian faktor yang berkaitan dengan kerentanan spesies burung dan mamalia terhadap kegiatan penebangan diidentifikasi. Faktor ini mencakup spesialisasi pola makan, strata pencarian makanan yang terbatas, endemisitas, umur evolusi yang terlihat (satwa yang berevolusi selama masa Miosen dan Awal Pliosen), serta ketidakberadaannya dalam pulau kecil. Faktor yang dianggap tidak nyata dalam seperangkat data adalah ukuran kelompok, jumlah anak per kelahiran, berat badan, dan ukuran wilayah jelajah. Pemakan serangga dan pemakan buah terestrial terlihat sensitif terhadap kegiatan penebangan kayu. Sementara pemakan tumbuhan (herbivora) dan pemakan segala (omnivora) lebih toleran atau bahkan mendapat manfaat dari kegiatan penebangan tersebut.

Berdasarkan temuan ini, pada Bagian III dikembangkan rekomendasi mengenai pengelolaan hutan bagi pengelola konsesi, pemerintah setempat, dan pemerintah pusat. Rekomendasi berisi dorongan terhadap pelaksanaan perencanaan konservasi yang baik, pembangunan jalan yang baik, dan metoda penebangan dengan dampak minimal. Rekomendasi secara spesifik mencakup pelestarian struktur habitat (pohon yang besar, pohon berongga, dan jenis-jenis pohon berbuah) serta lokasi (sumber air mineral dan aliran air) yang penting secara ekologis. Dalam kegiatan silvikultur, diusulkan penghentian kegiatan penebasan tumbuhan bawah yang saat ini merupakan persyaratan peraturan tebang pilih. 
Peraturan yang berkaitan dengan perburuan di konsesi penebangan kayu, kewenangan penegakan dan penaatan hukum, serta pengelola konsesi yang harus mampu mengendalikan faktor ini juga masuk dalam rekomendasi.

Melestarikan hutan yang berkesinambungan merupakan hal yang penting. Akibat fragmentasi hutan oleh jaringan jalan, kegiatan penebangan dan pertanian, maka koridor hutan harus dipertahankan selebar mungkin untuk memaksimalkan konektivitas dalam matriks hutan. Pada tingkat konsesi, mempertahankan elemen hutan yang linier (seperti hutan di sepanjang sungai) sebagai koridor antara blok-blok hutan dapat meningkatkan penyebaran satwa dan dengan demikian meningkatkan peluang bagi spesies tersebut untuk dapat hidup dalam bagian hutan. Memperkecil lebar jalan tebangan dan jalan sarad, memelihara kesinambungan tajuk di atas jaringan jalan, dan membatasi ukuran rumpang penumbangan, dapat mengurangi efek fragmentasi hutan terhadap spesies yang hidup di pohon-pohon (arboreal).

Selain rekomendasi yang sifatnya umum di atas, diusulkan pula tindakan yang spesifik yang dapat membantu konservasi berbagai spesies khas. Contohcontoh yang ditampilkan termasuk perlunya mencadangkan daerah yang cukup luas bagi perlindungan karnivora berukuran besar (Beruang Madu, Macan Dahan), mempertahankan pohon Dipterokarpa untuk Rangkong Gading bersarang dan bagi Pelatuk Besar Kelabu untuk mencari makan, serta mengatur pengambilan kura-kura air tawar.

Dalam hal ini, diulas juga bagaimana pemerintah dapat mendukung konservasi satwa liar secara lebih baik di daerah konsesi hutan. Pemerintah memiliki tugas yang penting untuk mengevaluasi daftar spesies yang saat ini dilindungi di Indonesia, karena banyak spesies yang langka dan terancam punah tidak ada dalam daftar yang dilindungi Undang-undang tersebut (contohnya Cucak Rawa). Diusulkan pengembangan rencana tindak operasional untuk memastikan bahwa tujuan konservasi yang jelas dapat dilaksanakan secara efektif di tingkat daerah konsesi (persyaratan yang ada, meskipun bertujuan baik, berdampak kecil bagi pilihan/kebijakan pengelolaan). Di beberapa bidang, terlihat pula bahwa kurangnya pemahaman dan pengetahuan membatasi pengelolaan kehutanan yang ramah dan efektif bagi keanekaragaman hayati.

Bagian IV berfokus pada isu keanekaragaman hayati dan usulan penelitian. Kegiatan penelitian dapat terus memberikan sumbangan kepada pemahaman tentang kegiatan penebangan kayu dan bagaimana dampaknya dapat diperbaiki untuk manfaat konservasi satwa liar. Kurangnya pengetahuan tidak dapat dijadikan alasan pembenaran untuk menangguhkan implementasi rekomendasi yang diusulkan. Buku ini memang belum dapat menjelaskan dan mendorong pengelolaan yang sempurna, namun kajian ini dapat memberikan usulan perbaikan yang cukup besar dalam kegiatan penebangan yang saat ini sedang berlangsung. 


\section{Daftar singkatan}

ANOVA Analysis of Variance (metode statistik)

dpl di atas permukaan laut

CATPCA Categorical Principal Components Analysis (metode statistik)

CIFOR Center for International Forestry Research

CIRAD Centre de Coopération Internationale pour la Recherche Agronomique en Développement

CITES Convention on International Trade in Endangered Species

dbh diameter at breast-height (diameter setinggi dada)

EC European Commission (Komisi Eropa)

AMDAL Analisis Mengenai Dampak Lingkungan

FORDA Forestry Research and Development Agency—Badan Penelitian dan Pengembangan Kehutanan

FSC Forest Stewardship Council

SIG Sistem Informasi Geografis

HTI Hutan Tanaman Industri

In litt. In literature

ITTO The International Tropical Timber Organization

IUCN The World Conservation Union

KSDA Konservasi Sumber Daya Alam

LIPI Lembaga Ilmu Pengetahuan Indonesia

DepHut Departemen Kehutanan

MRF Malinau Research Forest

MUS Malayan Uniform System

Jt Juta

NGO/ornop Non-Governmental Organization/Organisasi Nonpemerintah

TN Taman Nasional

NPLD Non-Pioneer-Light-Demanding species—Spesies nonperintis yang membutuhkan cahaya yang tinggi 
xxx | Daftar singkatan

RIL Reduced Impact Logging

SD Standard Deviation - standar deviasi

THPB Tebang Habis Permudaaan Buatan

TNC The Nature Conservancy

TPTI Tebang Pilih Tanam Indonesia

Unpubl Unpublished (Tidak dipublikasikan)

UNESCO United Nations Educational, Scientific and Cultural Organization

WCS Wildlife Conservation Society

WWF World Wide Fund for Nature 


\section{Pendahuluan}

\section{Justifikasi}

Hutan hujan tropis merupakan ekosistem daratan yang paling kaya di bumi ini. Namun demikian, kawasan hutan ini berkurang secara cepat akibat dibuka untuk dimanfaatkan kayunya, untuk lahan pertanian dan pemanfaatan lahan lainnya. Luas kawasan hutan yang dilindungi tidak cukup untuk melestarikan semua jenis yang ada (Fimbel et al. 2001). Dengan demikian, nasib berbagai jenis satwa liar sangat bergantung pada kondisi hutan yang berada di luar kawasan lindung.

Areal hutan yang dikelola untuk produksi kayu merupakan peluang bagi konservasi keanekaragaman hayati. Meskipun areal hutan ini tidak dapat menjadi pengganti cagar alam yang diperlukan, banyak jenis satwa liar dapat dilestarikan keberadaannya dalam suatu kawasan konsesi hutan yang dikelola sehingga fungsi ekologisnya terjaga dengan baik (Frumhoff 1995). Secara umum, eksploitasi hutan alam mencakup kegiatan perubahan terhadap ekosistem, yang menyebabkan perubahan flora dan fauna. Namun demikian, pilihan-pilihan pengelolaan serta kegiatan operasionalnya akan mempengaruhi kondisi alam dan tingkat perubahan tersebut. Karena sebagian besar hutan tropis dianggap tidak dikelola dengan baik, bukan saja bagi konservasi keanekaragaman hayati, tetapi juga bagi produksi (Poore et al. 1989, Putz et al. 2000, 2001a), sehingga banyak peluang bagi perbaikan pengelolaan tersebut (Hunter 1990, John 1997, Sheil \& van Heist 2000). Berbagai prakarsa nasional dan internasional dilakukan untuk mencari cara yang konstruktif dalam menghadapi tantangan ini. Prakarsa-prakarsa ini juga harus didorong untuk melalukan pertimbangan kepentingan dan menambah nilai pengetahuan yang tersedia, serta membuat pilihan perbaikan bagi tujuan pengelolaan yang akan dicapai.

Pada saat ini upaya-upaya untuk memperbaiki pengelolaan hutan tropis berfokus pada kegiatan silvikultur (berkaitan dengan produksi kayu) dan isu sosial budaya. Padahal, berbagai studi ekologi dan zoologi, meskipun tidak mengedepankan dampak hutan secara langsung, mengandung informasi yang berkaitan dengan sejarah hidup dan persyaratan habitat taxa yang rentan serta informasi mengenai berbagai nilai hutan. 
Studi ekologi tentang masing-masing jenis dapat mengidentifikasi kemungkinan perubahan pakan, penyebaran benih (biji), polinasi, wilayah jelajah, dan perilaku lain yang timbul setelah penebangan, dan bagaimana perubahan tersebut berpengaruh terhadap perubahan populasi satwa dan ekologi hutan. Informasi seperti ini dapat memberikan arahan bagi kegiatan kehutanan dan studi-studi lain yang berfokus pada dampak penebangan terhadap kepadatan dan penyebaran jenis.

Kajian ini dilakukan berdasar pada prinsip bahwa mempertahankan keanekaragaman hayati di hutan produksi menuntut kegiatan pengelolaan yang ramah lingkungan dengan mempertimbangkan pengetahuan yang tersedia mengenai kerentanan jenis terhadap kegiatan intervensi, serta prinsip bahwa hal ini dapat dicapai. Ahli ekologi tropis sering menekankan masalah kurangnya pengetahuan dan informasi mengenai hutan tropis. Penelitian memang sangat diperlukan, namun "kurangnya pengetahuan" tidak dapat dijadikan alasan bagi berlangsungnya kegiatan pengelolaan hutan tropis yang kurang baik. Kami menyadari bahwa pihak-pihak yang terlibat dalam pengelolaan hutan tropis seringkali menghadapi keterbatasan akses pustaka ekologi dan pengetahuan yang diperlukan bagi tindakan yang efektif, atau keterbatasan dalam menterjemahkan informasi yang ada ke dalam suatu tindakan yang nyata. Untuk itu diperlukan bantuan dan kerjasama dari para peneliti di bidang ilmu biologi tropis yang memiliki pengalaman kerja baik langsung maupun tidak langsung dalam memperbaiki praktek kehutanan di hutan alam tropis (Sheil \& van Heist 2000).

\section{Tujuan}

Banyak penelitian bertujuan untuk mengidentifikasi taxa yang rentan terhadap pemanenan kayu. Para peneliti biasanya menyatakan bahwa tujuannya adalah untuk konservasi yang lebih baik. Namun demikian, saat ini hasil penelitian tersebut tidak memiliki pengaruh yang besar. Ada tiga pokok masalah yang berkaitan dengan hal ini. Pertama, rekomendasi yang disiapkan dalam studi-studi yang telah dilakukan biasanya tidak disusun dan disajikan bagi pihak yang memerlukan pengetahuan dan informasi tersebut untuk pengelolaan hutan yang lebih baik. Untuk mengatasi hal ini, kami bermaksud untuk menelusuri berbagai publikasi dan mengumpulkan rekomendasirekomendasi tersebut. Pokok masalah kedua yaitu, suatu studi mungkin menunjukkan penurunan jumlah jenis. Tetapi, ini jarang digunakan untuk mengklarifikasi praktekpraktek kehutanan yang dilakukan (sebagai pembatasan) sehingga dampak negatifnya dapat dikurangi. Sebagai bagian dari kajian dalam menangani hal ini, kami mencoba untuk mengaitkan korelasi antara kepekaan jenis terhadap kondisi ekologis dengan sejarah kehidupannya. Yang demikian dapat membantu kita untuk mengembangkan pengetahuan yang lebih baik tentang penyebab kerentanan suatu taxa. Pengetahuan ini akan memberikan pendekatan yang lebih komprehensif di bidang konservasi satwa liar di hutan produksi melalui kerja sama dengan para pengelola untuk memperbaiki perlindungan karakteristik atau habitat yang spesifik, dan pendekatan ilmu pengelolaan hutan yang didasarkan pada hipotesis. Ketiga, suatu penelitian dapat dilakukan pengulangan untuk tindakan klarifikasi (misalnya, apakah suatu penelitian menjawab pertanyaan yang ada, Pertanyaan-pertanyaan apa saja yang 
diperlukan, dan sebagainya). Dalam kajian ini, diusulkan beberapa topik penelitian yang merupakan prioritas bagi pengelolaan hutan yang lebih baik.

\section{Lingkup kajian dan kaitannya}

Pada dasarnya kami menaruh perhatian besar pada hutan Dipterokarpa di Kalimantan (<600 $\mathrm{m}$ di atas permukaan laut). Namun demikian, sebagian besar informasi yang disajikan dapat diterapkan pada hutan dengan struktur dan fauna yang memiliki kemiripan. Kajian kami berfokus pada hutan dan fauna yang ada di daerah aliran sungai (DAS) Malinau, di Kabupaten Malinau, Kalimantan Timur, Indonesia (Gambar 1). Di wilayah ini, CIFOR melakukan serangkaian penelitian di Hutan Penelitian Malinau (MRF-Malinau Research Forest). Sampai saat ini, sedikit sekali informasi mengenai kondisi biologis DAS Malinau. Bentang alam yang terjal dan berhutan di dekat Taman Nasional Kayan Mentarang ini diduga bernilai tinggi berdasarkan potensi tumbuhan dan satwanya. Sebagai contoh, Meijaard dan

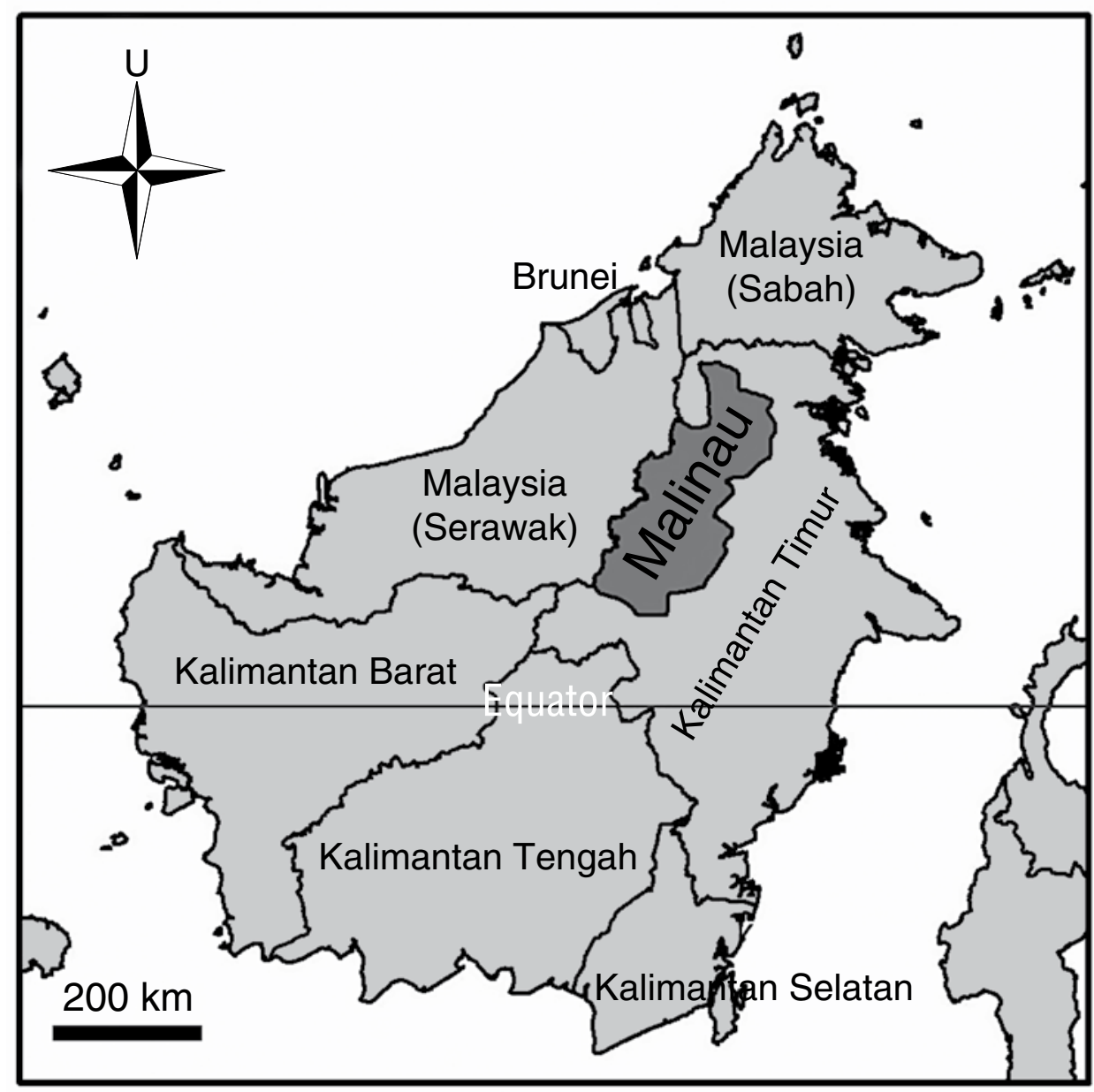

Gambar 1. Peta lokasi Kabupaten Malinau, provinsi Kalimantan Timur, yang berada di wilayah Indonesia, serta wilayah Malaysia (Serawak dan Sabah) dan Brunei. 
Nijman (2003) baru-baru ini menemukan bahwa daerah ini memiliki keragaman primata yang tertinggi di Borneo. Data dari plot hutan menunjukkan kerapatan jenis pohon yang lebih tinggi dibandingkan daerah lain yang belum tercatat di Indonesia (CIFOR, belum dipublikasikan).

Penelitian yang dilakukan CIFOR, berkolaborasi dengan LIPI, Badan Litbang Kehutanan, WCS, dan lembaga lainnya, menekankan upaya dokumentasi kekayaan biologis wilayah Malinau. Penelitian ini memiliki tiga fokus utama:

1) Menentukan penyebaran flora dan fauna (Hedges \& Dwiyahreni 2002, Iskandar 2004, O’Brien 1998, O’Brien \& Fimbel 2002, Rachmatika et al. 2005)

2) Melakukan pengkajian tentang bagaimana dan kepada siapa keanekaragaman hayati ini berpengaruh (misalnya, Sheil et al. 2003a), dan

3) Melakukan identifikasi tahap-tahap yang diperlukan untuk memastikan keberlanjutan penelitian ini di masa mendatang.

Ketiga kelompok informasi ini dapat mendukung beragam proses, mulai dari pengembangan panduan pengurangan dampak penebangan hingga kebijakan kehutanan dan konservasi di tingkat internasional.

Jenis-jenis yang kami kaji secara umum dapat ditemui di wilayah Kalimantan lainnya (termasuk wilayah Sabah, Sarawak, dan Kesultanan Brunei) serta di tipetipe hutan yang sama di Sumatera dan Semenanjung Malaysia. Penyusun informasi mengenai satwa liar di Malinau juga mengacu pada hasil-hasil studi yang dilakukan di daerah lain di wilayah ini. Rawa gambut dan hutan kerangas merupakan jenis hutan di luar lingkup kajian kami karena sifat ekologisnya yang berbeda. Namun berbagai aspek, termasuk di antaranya kesimpulan kami, memiliki kaitan yang lebih luas dengan hutan Dipterokarpa lain di Asia Tenggara.

Menentukan mekanisme intervensi pengelolaan hutan yang mempengaruhi satwa liar seringkali sangat sulit. Sebuah penelitian mungkin menunjukkan bahwa suatu jenis lebih langka di hutan bekas tebangan dibandingkan daerah yang masih utuh. Namun, tanpa pengetahuan mekanisme dan proses yang mendasari perbedaan tersebut, sulit untuk menetapkan bagaimana kegiatan pengelolaan hutan dapat dan harus diubah untuk mencapai dampak yang minimal.

Studi ekologi dapat membantu menentukan serangkaian faktor nyata dan potensial yang dapat mempengaruhi berbagai taxa dalam kondisi yang khusus. Pertimbangan ekologis yang jelas dan dapat dipertanggungjawabkan dalam rangka kegiatan pemanenan yang baik dapat berfungsi sebagai panduan bagi pengelolaan hutan yang lebih memperhatikan satwa liar.

\section{Pentingnya hidupan liar}

Mengapa Indonesia ingin melestarikan satwa liarnya? Pertama, Undang-undang No. 5 Tahun 1990 secara hukum melindungi berbagai jenis vertebrata di wilayah Malinau. Undang-undang ini mengakui bahwa seluruh elemen sumber kehidupan dan ekosistemnya merupakan hal yang saling terkait, dan penurunan atau pemusnahan dari satu elemen akan menyebabkan rusaknya ekosistem (Departemen Kehutanan, 
1990). Di samping itu, Undang-undang ini melarang setiap kegiatan yang merusak kehidupan spesies yang dilindungi (Departemen Kehutanan, 1990, lihat Lampiran 9). Peraturan Pemerintah No. 41 tahun 1999 tentang Kehutanan (lihat Lampiran 10) lebih lanjut menjelaskan perlunya konservasi satwa liar. Pada umumnya, konservasi spesies ditangani dan dilakukan di wilayah yang telah ditetapkan. Namun demikian, sudah banyak diakui bahwa hutan produksi juga membuka peluang bagi konservasi spesies tersebut. Pengelolaan "Hutan Bernilai Konservasi Tinggi" (High Conservation Value Forest) kemudian menjadi elemen baru yang amat penting dalam kebijakan kehutanan di tingkat nasional maupun internasional. Hutan Bernilai Konservasi Tinggi tersebut (Colchester 2000, Jarvie et al. 2002, Jennings et al. 2002) juga bertujuan untuk melindungi satwa liar yang memiliki nilai tinggi bukan saja bagi masyarakat internasional, tetapi juga bagi masyarakat setempat (Sheil et al. 2003c, P. Levang komunikasi pribadi). Misalnya, sebagian besar asupan protein hewani bagi sebagian besar masyarakat asli di Kalimantan diperoleh dari sumber-sumber satwa liar, terutama vertebrata (lihat Bennett et al. 1999, Caldecott 1988, Puri 1997, Rijksen \& Meijaard 1999). Produk-produk hewani lain juga penting dalam perdagangan, seperti sarang burung walet (Collocalia spp.) dan batu empedu (lihat Puri 2001, Sellato 2001). Lebih jauh lagi, ada permintaan yang tinggi bagi sejumlah spesies satwa (rangkong, ayam hutan, Macan Dahan) untuk memenuhi kebutuhan ritual dan budaya, serta sebagian spesies berkhasiat obat (seperti Beruang Madu dan empedu penyu untuk mengobati penyakit mata dan penyakit lain) (Sheil et al. 2003b).

Penelitian lapangan tentang vertebrata yang dilakukan selama dua dekade menunjukkan bahwa mamalia dan burung merupakan elemen penting dalam jaringan hubungan timbal balik yang kompleks, yang selanjutnya membentuk keragaman taksonomi dan struktur hutan tropis (Fimbel et al. 2001). Penyebaran biji dan pemangsaan merupakan dua peran yang paling sering dipelajari pada mamalia dan burung di hutan hujan tropis (Gautier-Hion 1984, Gautier-Hion et al. 1985). Banyak mamalia dan burung menunjukkan strategi pencarian makan yang mencakup konsumsi buah-buahan atau bagian-bagiannya. Bersamaan dengan itu, sejumlah tumbuhan mengandalkan vertebrata sebagai penyebar benih dan sebagai penyerbuk (pollinator). Fungsi tersebut dapat mengatur tumbuhnya pohon dengan cara memakan dan/atau menyebarkan biji secara selektif (Curran \& Webb 2000). Melalui pemilihan biji dari jenis tertentu, vertebrata ini dapat secara aktif mempengaruhi hirarki kompetisi yang mendasari terbentuknya hubungan relatif antara jenis pohon bertajuk yang tumbuh berdampingan. Vertebrata mengembangkan strategi untuk mengakses sumber makanan yang langka dan menghindari kompetisi dengan spesies yang berhubungan secara ekologis (Brown et al. 1976, Lambert 1989a). Berikut ini adalah beberapa cara yang digunakan vertebrata dalam mempengaruhi ekosistem hutan:

- Herbivora: satwa pemakan rumput dan daun mempengaruhi struktur dan komposisi vegetasi, sedangkan satwa besar dan berkuku memadatkan tanah dan membantu memecahkan bahan-bahan organik dan mempengaruhi erosi;

- Pemangsaan jenis yang berpotensi menjadi satwa hama: satwa pemangsa, besar dan kecil dapat menahan berkembangnya satwa hama; 
- Perkecambahan biji: biji-bijian dari jenis tumbuhan tertentu mendapat manfaat melalui saluran pencernaan mamalia atau burung yang dapat mempermudah perkecambahan dan meningkatkan daya tahannya. Lebih jauh, satwa mengubur biji-bijian tersebut atau menggalinya;

- Rekayasa habitat: satwa menggali lubang, membuat kolam dan kubangan (seperti Sus barbatus), membalikkan dan memberikan aerasi kepada tanah dan humus/ serasah, serta membantu proses dan pemecahan bahan-bahan organik. Semua kegiatan ini memiliki beragam efek lanjutan pada ekosistem setempat. Misalnya hal ini berpengaruh terhadap pertukaran dan pergerakan unsur hara.

Dari sudut pandang pemanfaatan hutan, ada sejumlah alasan untuk melindungi satwa liar. Banyak jenis yang mempengaruhi proses regenerasi hutan secara langsung yang diperlukan bagi keberlangsungan produksi kayu (Kinnaird 1998, Curran \& Leighton 2000, Curran \& Webb 2000). Peran jenis satwa liar tersebut antara lain adalah penyerbukan, penyebaran, dan pemangsaan biji. Salah satu pohon yang paling disukai di Asia, yaitu durian (Durio spp.), penyerbukannya dibantu oleh kelelawar yang tinggal di gua. Tanaman komersial seperti kopi (Coffea canephora) mendapatkan manfaat dari melimpahnya lebah dengan keragaman jenis tinggi, yang kemudian bergantung pada keberadaan hutan alami dan bagian hutan yang ada di sekitar sistem wanatani (agroforestry) kopi tersebut (yaitu < $500 \mathrm{~m}$ ) (Klein et al. 2003).

Hilangnya satwa liar yang ada di seluruh hutan tropis sering disebut sebagai sindrom "hutan kosong" (empty forest syndrome). Beberapa pihak bahkan menyebut hutan tanpa satwa liar sebagai "mati secara ekologis" (ecologically dead) (Redford 1992). Dampak hilangnya satwa liar dalam jangka panjang masih sulit untuk ditentukan karena kurangnya informasi dasar. Namun, dampak tersebut diperkirakan sangat penting dan melibatkan perubahan komposisi dan struktur hutan (Campbell 1991, De la Cruz \& Dirzo 1987, Sheil 1998), bersamaan dengan menurunnya kualitas atau bahkan hilangnya fungsi penting jasa ekologis hutan ('half-empty forest': Redford \& Feinsinger 2001).

Secara umum, konservasi satwa liar di wilayah konsesi penebangan bukan saja merupakan persyaratan hukum, tapi juga dapat memperbaiki keberlangsungan produksi kayu dalam jangka panjang. Sejauh ini, hanya beberapa peneliti bidang kehutanan yang mengedepankan isu satwa liar ini. Sebagai contoh, dari 1000 makalah yang disajikan pada Kongres Kehutanan Dunia tahun 2003 (2003, World Forestry Congress), kurang dari 1\% menyajikan dan mendiskusikan isu yang terkait dengan keanekaragaman hayati, jenis satwa liar, maupun ekologi satwa liar tersebut. Meskipun banyak peneliti dan pakar yang telah mengkaji isu penting ini, hanya sedikit yang menyampaikan kesimpulan hasil penelitian tentang hutan secara efektif kepada para pengambil keputusan. Tujuan dan pendekatan penelitian sebaiknya direvisi guna memenuhi kebutuhan informasi dan rekomendasi yang sudah sangat mendesak bagi para pengelola hutan menyangkut peran satwa liar. 


\section{Wilayah penelitian}

Hutan Kalimantan secara umum dikenal karena kekayaan spesies dan tingkat endemismenya (MacKinnon et al. 1996, Meijaard \& Nijman 2003). Hutan di wilayah ini merupakan salah satu yang terkaya akan spesiesnya di dunia (Richards 1996, Whitmore 1990a), dengan 150 hingga 200 spesies pohon yang berdiameter lebih dari $10 \mathrm{~cm}$ per hektarnya. Ada sekitar 37 spesies burung, 44 jenis mamalia daratan, dan sekitar $34 \%$ dari seluruh tumbuhan bersifat endemik, hanya ada di pulau ini (MacKinnon et al. 1996).

Kalimantan masih memiliki populasi spesies vertebrata penting yang saat ini telah langka atau punah di tempat-tempat lain dalam wilayah jelajahnya, seperti Beruang Madu (Ursus malayanus) dan Macan Dahan (Neofelis nebulosa).

\section{Lokasi}

Lokasi penelitian kami terletak di Kabupaten Malinau, Kalimantan Timur, sekitar 3 derajat di utara khatulistiwa yang terletak pada blok 2045' sampai 3021' LU dan 115048' sampai 116³4' BT, dekat Taman Nasional Kayan Mentarang. Daerah ini diperkirakan merupakan wilayah hutan hujan utuh yang terbesar di daerah tropis Asia dengan luasan mencapai 5 juta hektar, mencakup bagian Kalimantan Tengah dan Kalimantan Timur, Sarawak, serta Sabah (Gambar 2). Iklim wilayah dipengaruhi oleh garis khatulistiwa dengan curah hujan tahunan sekitar $4000 \mathrm{~mm}$.

Saat CIFOR berdiri pada tahun 1993, Pemerintah Indonesia memberikan komitmennya untuk menyediakan suatu wilayah hutan bagi CIFOR untuk melakukan penelitian jangka panjang. Lokasi penelitian yang dipilih berada di wilayah Kalimantan Timur, saat itu masih termasuk dalam Kabupaten Bulungan. Lokasi utama penelitian CIFOR (seluas 48000 hektar) terletak di antara Sungai Seturan dan Rian (sungai utama di wilayah Malinau), di bagian hulu DAS Malinau, dalam konsesi hutan yang dikelola oleh PT INHUTANI II.

Ketinggian di daerah penelitian berkisar antara 100 hingga $500 \mathrm{~m}$ di atas permukaan laut (dpl), ditambah dengan beberapa survei jerat kamera yang dilakukan 
pada ketinggian $900 \mathrm{~m}$ dpl. Topografi wilayah ini sangat terjal dengan sederetan tebing serta lembah-lembah curam. Daerah terjal ini menunjukkan terjadinya erosi yang dalam, bahkan di hutan primer sekalipun, secara umum memiliki risiko erosi yang tinggi. Di beberapa daerah, pemanenan kayu menyebabkan pemadatan tanah yang kemudian memperlambat pulihnya kondisi hutan.

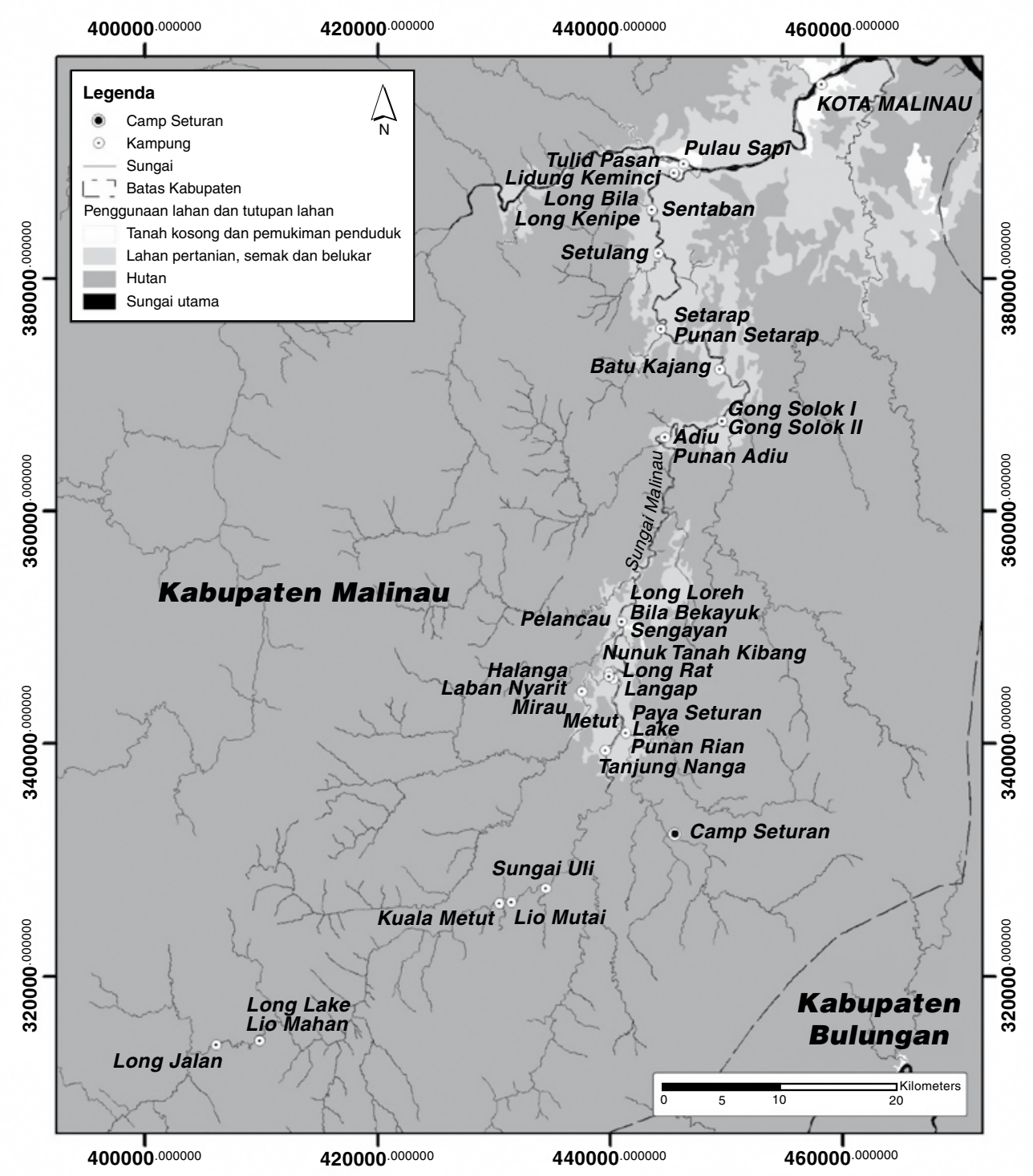

Gambar 2. Lokasi hutan penelitian Malinau.

Wilayah ini memiliki bentukan geologis yang beragam mencakup batuan vulkanik, sedimen, serta aluvial. Di wilayah ini terdapat juga lapisan batubara dan batu karang kapur tua, namun hanya ada sedikit informasi mengenai tanah atau potensi pemanfaatan lahan bukan hutan. Penelitian menunjukkan bahwa tanah di wilayah ini, meskipun beragam kondisinya, sangat miskin unsur hara yang diperlukan 
untuk pertumbuhan tanaman (Basuki \& Sheil 2005). Kesuburan tanahnya rendah disebabkan oleh tingginya tingkat keasaman dan terbatasnya kapasitas tukar kation, keterbatasan karbon organik, fosfor, dan kejenuhan hara dasar. Formasi lapisan paling dasar, kadar toksik aluminium, dan lahan yang curam serta sulit, lebih jauh menghambat peluang pertanian. Pengerasan dan pemadatan tanah yang ditemukan di hampir sepertiga plot menyebabkan berkurangnya pilihan pemanfaatan lahan. Tanah yang paling rawan adalah tanah tipis (entisols) di lereng curam serta tanah yang berkembang pada pasir putih (juga entisols); tutupan vegetasi alami di lokasi tersebut dapat mencegah pertumbuhan alang-alang yang rendah produktivitasnya (Gambar 3). Basuki dan Sheil (2005) menunjukkan bahwa seluruh tanah yang diteliti di 200 lokasi di hulu Malinau (termasuk yang diperkirakan sebagai lahan paling berpeluang), tidak sesuai bagi produksi lestari jenis-jenis tanaman perkebunan seperti lada, kopi, coklat, kemiri, karet, serta sawit. Namun demikian, ada sejumlah kecil lahan yang berpotensi diolah untuk tanaman padi ladang dan budidaya kelapa. Seluruh lokasi yang dianggap sesuai ditanami padi sudah ditanami padi (atau merupakan lahan tidur), meskipun lahan tersebut sangat jauh dari kondisi ideal karena rendahnya tingkat unsur hara dan tingginya risiko banjir. Kerawanan lokasi, terutama dengan risiko erosi yang tinggi, semestinya menjadi kendala bagi perkebunan di luar dataran aluvial yang luasnya terbatas. Dengan demikian, tanaman pertanian dan perkebunan skala besar tidak memiliki peluang yang baik di wilayah ini.

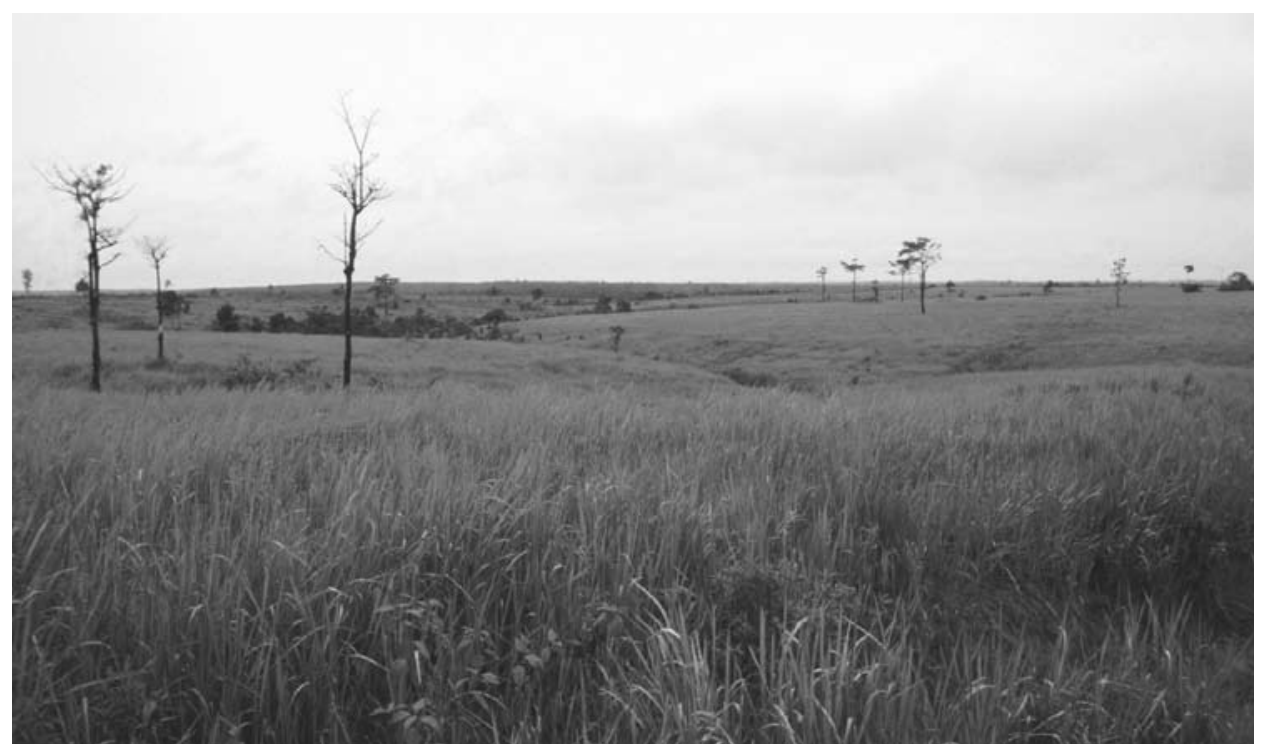

Gambar 3. Penebangan dan kebakaran hutan yang berulang di tanah yang miskin hara di Kalimantan Timur menyebabkan timbulnya lahan alang-alang (Imperata cylindrica) tidak produktif yang sangat luas. (Foto oleh Rona Dennis)

\section{Manusia dan perubahan}

Penduduk asli di DAS Malinau terdiri dari berbagai kelompok etnis, yaitu Merap, Punan, dan Kenyah. Di wilayah ini ditemui pula transmigran dari kelompok etnis Jawa dan Madura yang meskipun sedikit jumlahnya, tetapi memiliki pengaruh yang 
besar. Di beberapa desa, jumlah pendatang berubah dengan cepat karena sebagian besar kegiatan konsesi hutan mengandalkan tenaga kerja pendatang tersebut. Dalam beberapa kasus, terdapat kegiatan konsesi setempat yang dilaksanakan oleh penduduk desa sendiri, namun tidak jelas bagaimana kondisi ini mempengaruhi rasio tenaga kerja lokal terhadap pendatang. Kepadatan populasi manusia di hulu DAS masih rendah $\left(<1 \mathrm{~km}^{2}\right.$, dalam Sheil et al. 2003c) dan sebagian besar pemukiman berada dekat sungai.

Mata pencaharian utama penduduk adalah bercocok tanam dan mengumpulkan hasil hutan yang bernilai tinggi seperti gaharu (yang diambil dari Aquilaria spp), sarang burung, dan sebagainya. Namun demikian, sebagian besar penduduk masih mengandalkan satwa liar untuk kebutuhan sehari-hari. Pemenuhan kebutuhan protein hewani merupakan pemanfaatan satwa liar yang paling tinggi. Selain itu, banyak pemanfaatan satwa liar ini memiliki kaitan yang kuat dengan adat dan budaya setempat, termasuk pemanfaatan jenis rangkong, beruang madu, dan macan tutul pohon sebagai bahan ornamen (Uluk et al. 2001). Perburuan sebagian besar dilakukan dengan cara tradisional, namun senjata api (meskipun secara teknis ilegal) merupakan alat yang biasa pula digunakan. Cara yang banyak digunakan dalam berburu satwa berukuran besar adalah dengan menggunakan anjing untuk menyerang babi atau rusa. Cara lain yang sering digunakan adalah dengan menangkap secara diam-diam atau dengan jerat - kadang-kadang dari tempat yang dibuat secara khusus - di tempat-tempat yang disukai binatang seperti mata air atau lokasi tumbuhan yang berbuah. Untuk cara ini, sering digunakan panah beracun yang ditiupkan karena senjata api biasanya mengagetkan binatang yang berkelompok. Perdagangan daging satwa semakin popular sebagai cara untuk mendapatkan nafkah dan banyak rumah makan yang menyajikan daging rusa lokal (meskipun spesies ini dilindungi). Dalam masyarakat lokal, ada larangan untuk memakan beragam spesies satwa liar. Meskipun gereja telah mengubah pandangan (yang sudah jarang di kalangan generasi muda), larangan ini masih ada. Sebagai contoh adalah, berdasarkan kepercayaan tradisional banyak generasi tua menghindari memakan daging monyet dan ular. Para wanita menghindari memakan beruang (Sheil, belum diterbitkan).

Jalan dan perahu bermotor merupakan cara untuk memenuhi permintaan daging di wilayah yang lebih terpencil. Perdagangan hewan halal bagi konsumsi penduduk yang beragama Islam juga berkembang di kota Malinau. Meskipun data untuk wilayah Malinau sendiri kurang, di Taman Nasional Kayan Mentarang (Meijaard 2003a) dan sebagian besar Sarawak (Bennett et al. 1999, Bennett \& Robinson 2000) menunjukkan bahwa perburuan di daerah tersebut terus meningkat hingga mencapai tingkat yang tidak aman.

Proses perizinan penebangan atau konsesi yang diberikan pemerintah telah lama mengabaikan hak kepemilikan tradisional (lihat 'Down to Earth' 2002). Perbedaan sistem kepemilikan lahan negara dan kepemilikan tradisional merupakan salah satu tantangan terbesar dalam pengelolaan hutan yang berkelanjutan, dan kasus ini banyak ditemui di tempat-tempat lain di dunia. Di Malinau, seluruh wilayah dibagi berdasarkan sistem kepemilikan lahan tradisional. Namun demikian, Pemerintah Indonesia menetapkan sebagian besar wilayah tersebut menjadi wilayah konsesi kayu 
tanpa mempertimbangkan keberadaan kepemilikan tradisional tersebut. Kebijakan pemerintah yang lalu selalu berpihak pada kepemilikan pengusaha/konsesi daripada hak tradisional dan sebagian besar wilayah tersebut kini ditetapkan sebagai hutan produksi tanaman. Sebagian areal yang berada di lahan curam ditetapkan sebagai hutan lindung meskipun penetapan ini sering kali dilakukan secara acak, tidak terencana dengan baik. Sejumlah besar wilayah dengan aksesibilitas yang lebih baik telah ditebang atau akan ditebang dalam waktu dekat. Namun demikian, banyak wilayah yang menurut peta "telah ditebang" ternyata merupakan areal yang tidak dapat diakses. Hal ini berarti bahwa kantung-kantung vegetasi hutan primer berada di areal yang secara formal merupakan areal pasca-tebangan.

Masalah sosial timbul karena kebijakan di tingkat provinsi yang memindahkan penduduk di daerah terpencil ke daerah yang mudah dicapai yang secara tradisional milik desa atau penduduk yang lain. Namun demikian, pemerintah melakukan upaya khusus untuk memukimkan suku Punan dan suku-suku lain yang tinggal di hulu sungai dan mendorong mereka untuk mengembangkan pertanian yang sifatnya menetap (Kaskija 1995, Puri 1998, Sellato 2001). Pelayanan kesehatan yang lebih baik dan peluang pendidikan di Malinau dan di sebagian pemukiman yang lebih besar juga menarik minat keluarga-keluarga di wilayah terpencil. Hal ini menyebabkan tekanan dan konflik baru serta mengakibatkan pengambil alihan lahan masyarakat tradisional yang lokasinya jauh dari tempatnya saat ini (van Heist \& Wollenberg 2000).

Pertumbuhan ekonomi selama akhir tahun 1970-an, memberikan berbagai pengaruh kepada masyarakat setempat seperti, akses ke mesin perahu dan chainsaw, serta membuka peluang program pendidikan dan pelayanan kesehatan nasional. Pengaruh luar ini semakin meningkat ketika tahun 1996 pertambangan batu bara mulai merambah ke wilayah ini dan berkembangnya dampak terhadap sumberdaya hutan dan perpindahan penduduk ke tempat ini. Krisis ekonomi yang terjadi di Indonesia pada awal 1997 menimbulkan perubahan lebih lanjut. Depresiasi rupiah dan meningkatnya nilai pasar ekspor minyak sawit dan batubara menyebabkan kegiatan eksplorasi meluas dengan cepat. Kegiatan eksplorasi ini seringkali dilakukan oleh investor swasta yang tidak tertata dengan baik.

Di wilayah ini ada beberapa rencana proyek pembangunan jalan besar. Sebagai contoh, rencana jalan yang akan menghubungkan Malinau dan wilayah hulu Baram di Sarawak dan satu proyek jalan lainnya sedang dalam proses pembangunan, yaitu antara Malinau dan Long Alango di wilayah hulu Sungai Bahau di perbatasan Taman Nasional Kayan Mentarang. Pembangunan jalan ini dan jalan-jalan lainnya, disertai dengan hak pengambilan kayu dari lajur hutan di kedua sisi jalan tersebut. Di beberapa daerah, pembukaan lahan dan pengambilan kayu tersebut bisa mencapai selebar $1 \mathrm{~km}$ sepanjang jalan. Dapat diramalkan, akibat jalan yang direncanakan serta jejak konstruksi yang berkembang di sekitar jalan utama tersebut menyebabkan meningkatnya fragmentasi bentang alam hutan yang ada. Karena keterjalan lahannya, pembangunan dan pemeliharaan jalan-jalan ini menjadi sangat mahal dan kelayakannya secara ekonomi masih terus dipertanyakan. 


\section{Desentralisasi}

Era Soeharto dicirikan oleh pengendalian pemerintahan yang sifatnya sentralistik (Lynch \& Harwell 2002). Sejak tahun 1999 (Undang-undang No. 22/1999 tentang Otonomi Pemerintahan Daerah dan Undang-undang No.25/2000 tentang Perimbangan Keuangan Pusat dan Daerah), terjadi pengalihan kewenangan dari pusat ke kabupaten/kota. Masyarakat setempat merasa diberdayakan dalam hal kewenangan keputusan yang dapat mempengaruhi mereka secara langsung. Selain itu ada kecenderungan peningkatan keinginan untuk membawa konflik dan protes ke pemerintah setempat (untuk gambaran umum, lihat Sellato 2001).

Pengalihan kewenangan dari pemerintah pusat ke pemerintah kabupaten menimbulkan pengaruh yang besar. Pemerintah setempat kini berwenang untuk mengalokasikan izin penebangan dan pembebasan/pembersihan lahan. Sebagai contoh, izin perkebunan kelapa sawit diberikan bagi daerah yang masih dalam perjanjian peruntukan penebangan. Perubahan ini banyak dipertentangkan, dan di Malinau, perizinan tersebut tidak lagi diberikan. Pada saat penulisan buku ini, Pemerintah Pusat mencoba untuk mengambil kembali kendali berbagai aspek yang berkaitan dengan pengelolaan sumberdaya. Secara keseluruhan situasi ini membingungkan akibat kacaunya peraturan, keterlibatan dan kewenangan penuh dalam menangani isu lahan (Colfer \& Resosudarmo 2002).

\section{Pengelolaan hutan}

Penebangan kayu di wilayah ini seharusnya dilakukan berdasarkan sistem Tebang Pilih Tanam Indonesia, suatu sistem silvikultur yang didasari oleh batas diameter pohon dan penanaman kembali hutan (lihat Lampiran 11 untuk penjelasan rinci). INHUTANI II, suatu Badan Usaha Milik Pemerintah di bidang kehutanan (BUMN), mungkin merupakan operator yang lebih hati-hati dibanding operator lainnya, dan seringkali INHUTANI II menebang dengan volume yang jauh lebih kecil dari batas di dalam surat izin yang dimilikinya.

Selain kegiatan penebangan, ancaman bagi hutan dan hidupan liar di Hutan Penelitian Malinau (Malinau Research Forest - MRF) adalah pertambangan batubara. Pertambangan batubara terkait dengan kegiatan penebangan kayu dalam skala kecil dan karyawan perusahaan tambang tersebut biasanya terlibat dalam perburuan dengan memanfaatkan jalan tebangan yang sudah ada. Kemudian, perkembangan pemukiman baru di dekat Long Loreh (lihat Gambar 2) menyebabkan meluasnya kebun-kebun yang ada.

\section{Survei satwa liar}

Untuk memulai upaya evaluasi dan pemantauan di MRF, CIFOR mengundang Wildlife Conservation Society - Indonesia Program (WCS-IP) untuk melakukan dua kajian pendahuluan tentang keanekaragaman satwa di kawasan ini pada tahun 1997 dan 1999. Salah satu tujuan survei tersebut adalah pengembangan data dasar bagi taxa vertebrata utama (burung, primata, dan mamalia yang lain). Survei yang distandardisasi ini berhasil mengidentifikasi 37 spesies mamalia (di luar kelelawar) 
dan 239 spesies burung. Survei ini mendokumentasikan sekitar 56\% spesies mamalia dan 86\% spesies burung yang diperkirakan hidup di MRF (O'Brien 1998, O’Brien \& Fimbel 1999). Survei yang dilakukan pada tahun 2003, termasuk survei dengan jerat kamera, melakukan validasi dan menambah daftar mamalia yang telah diidentifikasi (Augeri, in prep). Survei lain yang baru-baru dilakukan mendokumentasikan 42 spesies ikan (Rachmatika et al. 2005, lihat Lampiran 8), 40 spesies amfibia (Iskandar 2004, Lang \& Hubble 2003, lihat Lampiran 6), dan 55 spesies reptilia yang hidup di MRF (Lampiran 7). Dari spesies-spesies yang disurvei, 65 spesies (17 spesies mamalia dan 48 spesies burung) merupakan spesies yang dilindungi (Tabel 1 dan Lampiran 5).

Tabel 1. Burung yang dilindungi di wilayah Malinau (informasi diambil dari Lampiran dokumen ini serta dari Departemen Kehutanan 1992; PHPA 1996a, b; Noerdjito \& Maryanto 2001).

\begin{tabular}{|c|c|c|}
\hline Nama IImiah & Nama dalam Bahasa Inggris & $\begin{array}{l}\text { Nama dalam Bahasa } \\
\text { Indonesia }\end{array}$ \\
\hline Casnierodius albus & Great Egret & Kuntul besar \\
\hline Egretta intermedia & Plumed Egret & Kuntul perak \\
\hline Egretta garzetta & Little Egret & Kuntul kecil \\
\hline Aviceda jerdoni & Jerdon's Hawk & Baza Jerdon \\
\hline Pernis ptilorhynchus & Oriental Honey-Buzzard & Sikep-madu Asia \\
\hline Haliastur indus & Brahminy Kite & Elang bondol \\
\hline Ichthyophaga humilis & Lesser Fish-Eagle & Elang-ikan kecil \\
\hline Spilornis cheela & Crested Serpent-Eagle & Elang-ular Bido \\
\hline Accipiter trivirgatus & Crested Goshawk & Elang-alap jambul \\
\hline Ictinaetus malayensis & Black Eagle & Elang hitam \\
\hline Hieraaetus kienerii & Rufous-bellied Eagle & Elang perut-karat \\
\hline Spizaetus cirrhatus & Changeable Hawk-Eagle & Elang brontok \\
\hline Spizaetus alboniger & Blyth's Hawk-Eagle & Elang gunumg \\
\hline Microhierax fringillarius & Black-thighed Falconet & Alap-alap capung \\
\hline Lobiophasis bulweri & Bulwer's Pheasant & Sempidan Kalimantan \\
\hline Argusianus argus & Great Argus & Kuau raja \\
\hline Sterna albifrons & Little Tern & Dara-laut kecil \\
\hline Sterna hirundo & Common Tern & Dara-laut biasa \\
\hline Harpactes kasumba & Red-Naped Trogon & Luntur kasumba \\
\hline Harpactes diardii & Diard's Trogon & Luntur Diard \\
\hline Harpactes duvaucelii & Scarlet-rumped Trogon & Luntur putri \\
\hline Harpactes oreskios & Orange-breasted Trogon & Luntur harimau \\
\hline Alcedo atthis & Common Kingfisher & Raja-udang Erasia \\
\hline Alcedo euryzona & Blue-banded Kingfisher & Raja-udang kalung-biru \\
\hline Ceyx erithacus & Oriental Dwarf Kingfisher & Raja-udang api \\
\hline
\end{tabular}


14 | Wilayah penelitian

\begin{tabular}{|c|c|c|}
\hline Nama IImiah & Nama dalam Bahasa Inggris & $\begin{array}{l}\text { Nama dalam Bahasa } \\
\text { Indonesia }\end{array}$ \\
\hline Pelargopsis capensis & Stork-billed Kingfisher & Pekaka emas \\
\hline Lacedo pulchella & Banded Kingfisher & Cekakak batu \\
\hline Halcyon pileata & Black-capped Kingfisher & Cekakak Cina \\
\hline Berenicornis comatus & White-crowned Hornbill & Enggang jambul \\
\hline Anorrhinus galeritus & Bushy-crested Hornbill & Enggang klihingan \\
\hline Rhyticeros undulatus & Wreathed Hornbill & Julang emas \\
\hline Anthracoceros malayanus & Black Hornbill & Kangkareng hitam \\
\hline Buceros rhinoceros & Rhinoceros Hornbill & Rangkong badak \\
\hline Rhinoplax vigil & Helmeted Hornbill & Rangkong gading \\
\hline Pitta caerulea & Giant Pitta & Paok sintau \\
\hline Pitta granatina & Garnet Pitta & Paok delima \\
\hline Rhipidura javanica & Pied Fantail & Kipasan belang \\
\hline Anthreptes malacensis & Brown-throated Sunbird & Burung-madu kelapa \\
\hline Anthreptes rhodolaema & Red-throated Sunbird & Burung-madu leher-merah \\
\hline Anthreptes singalensis & Ruby-cheeked Sunbird & Burung-madu belukar \\
\hline Hypogranmia hypogranmmici & Purple-naped Sunbird & Burung-madu rimba \\
\hline Nectarinia sperata & Purple-throated Sunbird & Burung-madu pengantin \\
\hline Aethopyga siparaja & Crimson Sunbird & Burung-madu sepah-raja \\
\hline Arachnothera longirostra & Little Spiderhunter & Pijantung kecil \\
\hline Arachnothera robusta & Long-billed Spiderhunter & Pijantung besar \\
\hline Arachnothera flavigaster & Spectacled Spiderhunter & Pijantung tasmak \\
\hline Arachnothera chrysogenys & Yellow-eared Spiderhunter & Pijantung telinga-kuning \\
\hline Arachnothera affinis & Grey-breasted Spiderhunter & Pijantung gunung \\
\hline
\end{tabular}




\section{KAJIAN PUSTAKA}

\section{Apa yang kita ketahui tentang kehutanan dan hidupan liar?}

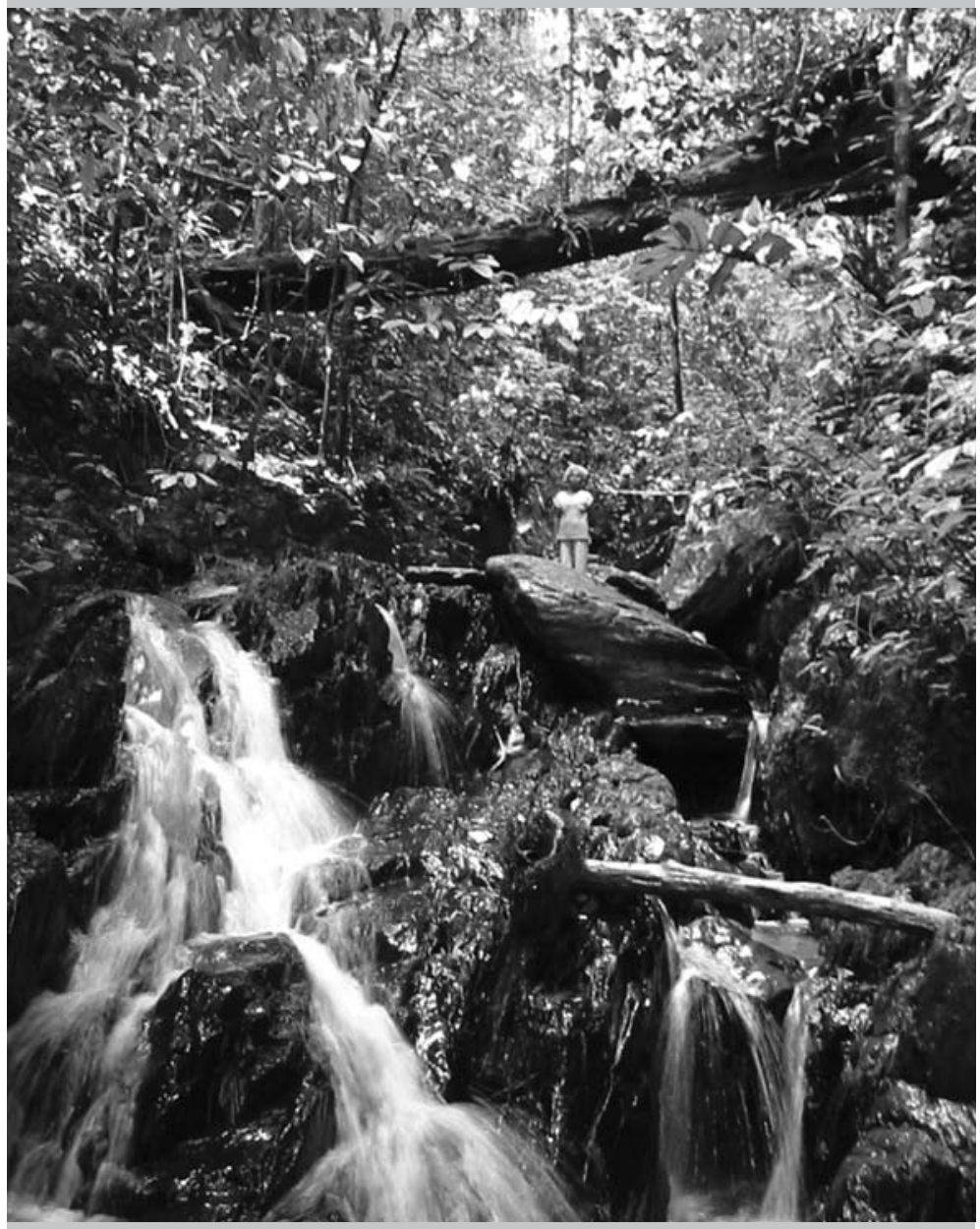

Sungai di hutan primer hulu Malinau. Berbagai spesies-terlebih lagi masyarakat setempat-mengalami dampak negatif berupa pengendapan dan penurunan kualitas air yang sering disebabkan oleh buruknya pembuatan jalan dan pengambilan kayu. (Foto oleh Douglas Sheil) 



\title{
Kajian pustaka mengenai penebangan kayu dan hidupan satwa liar
}

\begin{abstract}
Metode
Dari hasil survei vertebrata di hulu Malinau, kami memilih kelompok spesies yang paling dikenal dengan baik untuk diidentifikasi sifatnya sehingga dapat dikembangkan untuk praktek pemanenan kayu yang lebih ramah lingkungan. Selain itu, proses ini membantu mengkaji status pengetahuan dan informasi saat ini mengenai persyaratan biologis dan ekologis bagi taxa vertebrata yang hidup di hutan dataran rendah Kalimantan Timur. Melalui kajian pustaka dan kajian lainnya, kami berupaya untuk mendokumentasikan sejarah alam yang berkaitan dengan sifat masing-masing spesies atau kelompok spesies dengan berbagai tingkat kerentanan terhadap dampak pemanenan kayu dan kegiatan yang berkaitan dengan pemanenan kayu. Setelah tersusun, basis data ini membantu kami mengusulkan beberapa perbaikan bagi panduan pengelolaan hutan Dipterokarpa yang ada saat ini sehingga meningkatkan nilai hutan tersebut bagi konservasi satwa liar.

Vertebrata merupakan bagian penting dari biomassa satwa di kawasan tropis berhutan dan menjadi komponen kunci dalam proses-proses ekologis. Vertebrata merupakan kelompok yang tepat untuk dikaji mengingat banyaknya hasil penelitian yang tersedia, peran pentingnya bagi dinamika ekosistem tropis, potensinya sebagai indikator biologis, serta kepentingannya dalam prioritas konservasi di tingkat lokal dan internasional secara umum. Sebagai contoh, May (1988) menunjukkan bahwa jumlah makalah ilmiah tentang mamalia 100 kali lebih banyak dibandingkan dengan makalah ilmiah tentang serangga. Spesies vertebrata, terutama mamalia dan burung yang seringkali dijadikan sebagai taxa perwakilan (flagship), relatif lebih mudah untuk diobservasi dan kemiripan habitatnya lebih banyak diketahui. Amfibia dan ikan tidak begitu banyak ditemukan dalam pustaka konservasi. Namun demikian, taxa ini diduga memiliki kepekaan yang tinggi terhadap pengaruh penebangan (misalnya, lokasi pemijahan). Spesies taxa vertebrata ini juga secara ekologis penting bagi ekosistem serta kehidupan sehari-hari. Kajian vertebrata merupakan titik awal yang baik bagi usulan perbaikan tujuan dan praktek kegiatan pengelolaan hutan, karena jumlah penelitian dan pustaka yang tersedia cukup banyak.
\end{abstract}


Kami berasumsi bahwa untuk memahami kepekaan vertebrata terhadap gangguan hutan, pemahaman mengenai karakteristik dan persyaratan ekologis di tingkat individu, populasi, serta komunitas sangatlah penting. Meskipun banyak dari faktor-faktor tersebut belum diketahui dan diteliti bagi sebagian besar vertebrata, penggunaan prediksi ekologis yang ditunjang oleh probabilitas kepunahan setempat memungkinkan dilakukannya kajian awal tentang respons kelompok taksonomis yang dipilih terhadap kondisi hutan. Ochoa (1997) mengembangkan model probabilitas kepunahan bagi 140 spesies mamalia di suatu konsesi penebangan kayu di Venezuela. Dalam analisis tersebut, kemungkinan kepunahan lokal dari beberapa anggota komunitas mamalia terkait dengan:

- Kemiripan spesies-spesies tertentu dengan spesies yang ada di lingkungan hutan primer;

- Ketergantungan terhadap sumber-sumber arboreal (terutama tajuk);

- Pola sebaran geografis dan kepadatan populasi;

- Perkiraan persyaratan eko-fisiologis;

- Karakteristik demografis;

- Kerentanan terhadap kegiatan perburuan, baik oleh penduduk setempat maupun penebang kayu.

Dalam penelitian ini, kami mengumpulkan informasi yang tersedia dari enam variabel yang diidentifikasi oleh Ochoa (1997) untuk membuat prediksi yang serupa tentang kemungkinan kepunahan spesies satwa liar di Malinau. Pertama-tama kami mengkaji pustaka ilmiah, baik pustaka yang diterbitkan secara formal (peer-reviewed) maupun pustaka seperti laporan, tesis, disertasi, dan sebagainya, yang berkaitan dengan ekologi dan sejarah alam spesies vertebrata di Kalimantan Timur. Pakar dalam bidang spesialis satwa tertentu diundang untuk memberikan kontribusi informasi dan pandangan tentang spesies terkait yang menjadi kepakarannya. Pakar-pakar tersebut juga kami mintai tanggapan tentang hasil kajian pustaka awal dan usulan pengelolaan lebih lanjut. Informasi yang sesuai kemudian dimasukkan ke dalam laporan ini. Dari survei yang dilakukan Sheil dan kawan-kawan (2001a, 2003c) baru-baru ini, salah satu hal yang dapat diidentifikasi adalah nilai dari unit bentang alam setempat dan produk yang dihasilkannya. Pentingnya hasil hutan dan unit bentang alam dari hasil kajian kelompok tersebut kemudian dikuantifikasi dengan menggunakan sistem skoring (untuk hasil secara rinci lihat Sheil et al. 2003c). Hasil penelitian secara rinci akan dipublikasikan dalam dokumen lain, namun demikian, hasil awal dimuat dalam dokumen ini.

Kami mengkompilasi dan mengumpulkan informasi yang terkait dengan faktor yang berpotensi untuk mempengaruhi kerentanan masing-masing kelompok spesies yang dipilih (lihat Lampiran 1). Kami juga memasukkan kategori dan atribut ekologi sebanyak mungkin dari informasi yang ada mengenai satwa vertebrata sepanjang hal ini beralasan kuat. Sebagian besar sejarah alam dari berbagai spesies, seperti misalnya ekologi reproduksi spesies, sangatlah kurang. Beberapa atribut yang dapat digunakan untuk menjelaskan kerentanan, seperti tingkat toleransi fisiologis, tidak dapat dimasukkan ke dalam analisis karena kurangnya informasi mengenai hal ini. 
Namun demikian, atribut dan kategori yang digunakan sedikit banyak dapat mewakili sebagian besar cara pembedaan vertebrata secara ekologis dan dapat digunakan untuk mengidentifikasi pola kerentanan spesies secara umum. Kami membuat daftar rinci atribut biologis dan ekologis bagi masing-masing spesies yang dapat meningkatkan atau menurunkan kerentanannya terhadap dampak kegiatan hutan (Lampiran 4-7), misalnya hal-hal yang menimbulkan kemungkinan perubahan dalam kepunahan lokal. Daftar ini mencakup kategori yang luas sebagai berikut:

1. Wilayah sebaran secara umum - Spesies dengan wilayah sebaran geografis yang kecil lebih rentan terhadap gangguan bila wilayah sebaran geografisnya berkolerasi dengan habitat yang khas (lihat Harcourt et al. 2002), karena besarnya kemungkinan bahwa intervensi kegiatan kehutanan akan memberikan dampak negatif bagi relung ekologi yang memang sudah sempit;

2. Status dan kepadatan populasi di Borneo - Spesies-spesies yang umum mungkin tidak terancam oleh kegiatan penebangan dibandingkan dengan spesies langka dengan penyebaran yang terbatas. Namun, korelasi ini belum pasti karena keberadaan populasi tersebut tidak hanya bergantung dari kelimpahan spesies tersebut (Gaston et al. 2000). Kepadatan populasi dapat digunakan sebagai ukuran tidak langsung dari besarnya populasi;

3. Habitat - Habitat termasuk didalamnya tingkat kompleksitas struktur hutan serta stratifikasi vertikal, yang secara kasar menjadi indikasi kemampuan atau kecenderungan satwa terestrial untuk melintasi lahan terbuka, meskipun tutupan lahan dan keberadaan tempat berlindung juga penting. Spesies arboreal memiliki risiko yang lebih tinggi jika hutan lebih terbuka dan terfragmentasi (Laurance \& Laurance 1996). Aspek penting lainnya dari parameter habitat adalah pengetahuan mengenai distribusi satwa berdasarkan ketinggian serta tipe vegetasi yang diperlukan spesies tersebut untuk kelangsungan hidupnya atau untuk berkembang biak;

4. Pergerakan - Wilayah jelajah merupakan indikasi kebutuhan wilayah dari satwa tertentu. Spesies yang bermigrasi umumnya memiliki wilayah jelajah yang sangat luas. Penentu ekologisnya biasanya adalah makanan. Namun faktor lain seperti tempat bersarang, dapat menjadi penentu pula termasuk kemampuan spesies untuk bermigrasi. Di antara kelompok satwa yang diteliti menunjukkan pola migrasi musiman dan pergerakan harian;

5. Ekologi pakan - Hampir seluruh aspek biologis satwa terkait dengan apa yang dimakannya. Spesies dengan sumber pakan yang tersebar serta langka bisa lebih terancam keberadaannya jika pasokan pakan tersebut terganggu. Hal yang sama juga berlaku bagi spesies spesialis (specialist), kecuali spesies spesialis tersebut menduduki wilayah jelajah yang lebih kecil dibandingkan dengan spesies generalis (Harris 1984). Tidak seperti kelompok spesies lainnya, ekologi pakan rangkong dan primata sudah banyak diketahui dan dipelajari;

6. Ekologi perkembangbiakan - Ada kaitan yang jelas antara ekologi perkembangbiakan dan risiko kepunahan (lihat Fagan et al. 2001, Jonsson \& Ebenman 2001). Spesies dengan perkembangbiakan lambat serta reproduksi awal pada umur yang relatif tua paling rentan terhadap turunnya populasi secara 
drastis. Hanya sedikit saja taxa yang terwakili dalam studi ini yang ekologi perkembangbiakannya telah diteliti dengan baik seperti rangkong, kelelawar buah, dan primata. Pengetahuan ekologi perkembangbiakan kelompok spesies lainnya sangatlah kurang, kecuali telur dan anakan spesies amfibia tertentu yang dalam persyaratan ekologisnya memiliki perbedaan mencolok dengan amfibia dewasa. Persyaratan ini dapat mengidentifikasi elemen karakter habitat yang rentan terhadap intervensi;

7. Degradasi dan hilangnya habitat - Dampak dari konversi habitat tidak sama bagi setiap kelompok spesies yang diteliti. Sebagian spesies mendapat manfaat dari gangguan terhadap habitat, sementara spesies lainnya lebih rentan.

Untuk menentukan variabel terbaik yang dapat menduga kepekaan spesies terhadap penebangan dan pengaruh lain yang terkait, kami memilih spesies yang memiliki informasi lengkap mencakup variabel ekologi, sejarah hidup, dan respons terhadap pengaruh penebangan dan fragmentasi tutupan hutan. Kami menganalisis variabel sejarah kehidupan spesies tersebut menggunakan analisis multivariat untuk mencari variabel yang dapat menjelaskan tingkat perbedaan kepekaan terhadap penebangan. Metode analisis ini secara rinci dapat dilihat pada bagian berikut ini.

Spesies yang digunakan dalam kajian ini dipilih karena (a) dapat ditemui di daerah Malinau, (b) kajian dan penelitian sebelumnya menunjukkan kerentanannya terhadap penebangan, atau (c) ketersediaan pustaka penunjang. Spesies-spesies yang diteliti, meskipun tidak terbatas pada daftar di bawah ini:

1. Burung: spesies burung yang bersarang di rongga pohon, hidup di hutan primer, teritorial, dan hidup di tumbuhan bawah;

2. Mamalia: yang hidup di rongga pohon, spesialis hutan primer serta penjelajah, teritorial, memanfaatkan pohon yang mati dan tumbang, dan memiliki jelajah luas;

3. Amfibia: dipusatkan pada tempat-tempat perkembangbiakan.

Selain membuat rekomendasi bagi pengelolaan hidupan liar yang lebih baik di konsesi penebangan kayu, kami juga memberikan rekomendasi pengelolaan khusus bagi spesies vertebrata di wilayah Malinau. Tujuan kami adalah memberikan gambaran dan panduan bagi pengelola wilayah konsesi mengenai spesies satwa yang mendapatkan manfaat paling banyak dari intervensi pengelolaan khusus tersebut. Spesies-spesies yang masuk dalam rekomendasi khusus ini adalah spesies yang (1) memiliki peringkat konservasi yang paling tinggi berdasarkan peringkat yang dibuat IUCN (IUCN 2002, Lampiran 2) (2) dilindungi oleh hukum dan perundangan di Indonesia (lihat Tabel 1), dan (3) memiliki tingkat permintaan yang tinggi atau dinilai sangat tinggi oleh masyarakat setempat (lihat Lampiran 3). Kategori terakhir ini dibuat berdasarkan penelitian oleh Sheil et al. (2003c). 


\section{Masukan dari para pakar}

Dua puluh orang pakar ekologi diundang untuk memberikan masukan menyangkut sejarah alam spesies-spesies satwa yang menjadi bidang keahliannya serta untuk memberikan tanggapan tentang isu pengelolaan hutan yang terkait. Informasi yang diperoleh dari komunikasi tersebut lebih banyak bersifat subyektif dan dapat dijumpai di sejumlah terbitan pustaka. Namun demikian, para pakar tersebut dapat membuat kesimpulan dari sebagian besar data yang tersedia menjadi informasi yang berguna. Sepuluh di antara para pakar tersebut kami mintai kajian dan tanggapan naskah awal dokumen ini. Setelah naskah dokumen ini selesai sepenuhnya, kami meminta 13 orang pakar lainnya untuk mengkaji ulang laporan ini.

\section{Keterbatasan metodologi}

Validitas dan interpretasi analisis data bergantung pada berbagai faktor dan asumsi. Masalah atau kegagalan dari faktor dan asumsi tersebut akan mempengaruhi validitas dari keluaran dan kesimpulan yang dihasilkan. Meskipun tidak seluruh faktor dan asumsi dapat dikaji secara eksplisit, ketidakpastian yang dihasilkannya sangat penting untuk dipertimbangkan.

Ketidakpastian kajian kami disebabkan oleh beberapa hal. Penelitian yang ada seringkali terlalu singkat, tidak dirancang dengan baik, dan tidak layak secara statistik. Hal ini dapat disebabkan oleh data yang "sangat terbatas", seperti diakui oleh John tentang interpretasi penelitiannya di tahun 1983. Selain itu, tidak semua tipe hutan yang dikaji sama. Ada perbedaan yang kontras maupun yang halus dalam hal jenis tanah, vegetasi, iklim mikro, kepadatan hidupan liar, tekanan dari perburuan, serta faktor-faktor lain yang kurang dikaji di awal penelitian tentang pengaruh penebangan. Banyak peneliti yang menyadari hal ini, namun keterbatasan ini sulit untuk digunakan dalam kajian yang lebih luas.

Dalam kajian pustaka, kami bahkan menemukan bahwa dalam ekosistem yang sama, adanya sedikit perbedaan dalam lokasi geografis atau habitat dapat mempengaruhi bagaimana suatu sistem dan komunitasnya bereaksi terhadap gangguan, termasuk gangguan seperti episode musim buah atau musim kering yang dipengaruhi oleh El Niño. Sekali lagi, faktor lain seperti luasnya hutan utuh yang lokasinya berdekatan, intensitas penebangan, dan sebagainya, dapat berinteraksi dan mempengaruhi sistem dengan cara yang berbeda-beda.

Ekstrapolasi hasil dan kesimpulan penelitian yang diperoleh dari berbagai daerah menuntut pengkajian yang teliti. Marsh et al. (1987) menunjukkan pentingnya mengkaji intensitas penebangan pohon kaitannya terhadap perubahan kepadatan populasi satwa liar. Sebagai contoh, data Wilson dan Wilson (1975) tentang pengaruh penebangan terhadap spesies primata yang dilakukan di suatu daerah tebangan dengan intensitas tebangan 8 hingga 10 pohon per hektarnya, menyebabkan perubahan kepadatan populasi primata yang relatif kecil. Di lain pihak, John (1983) menemukan terjadinya penurunan populasi primata yang cukup besar serta kerusakan yang cukup berarti di daerah penelitiannya yang ditebangi sebanyak sekitar 18 pohon per hektar dengan laju penebangan 3,3\%. Burgess (1971) mengungkapkan dampak buruk penebangan terhadap satwa yang hidup di daerah tebangan dengan 
intensitas penebangan 25 pohon per hektarnya. Meskipun tingkat penebangan yang mempengaruhi dampak terhadap hidupan liar merupakan hal yang masuk di akal, hal ini jarang dikemukakan dalam penelitian yang berupaya untuk melihat pengaruh penebangan terhadap hidupan liar. Seperti halnya penelitian yang mencari kaitan dampak kegiatan seperti perburuan, fragmentasi hutan, atau pembangunan jalan, hanya dapat mengidentifikasi dan mengkaji pengaruh yang muncul terbatas dalam lingkup penelitian tersebut. Sehingga hasil penelitian yang menunjukkan bahwa satu faktor lebih penting dari faktor yang lain secara eksplisit perlu memahami dan mempertimbangkan variasi relatif yang ada.

Dampak kegiatan intervensi kegiatan kehutanan bergantung pada skala ruang dan waktu observasi. Sebagai contoh, amfibia bisa menurun jumlah populasinya dalam celah/rumpang akibat tumbangnya pohon dan penebangan. Namun, pengaruh tersebut bisa jadi bersifat lokal dalam ruang dan waktu, dan dampaknya kecil pada vegetasi di sekelilingnya dalam kurun dua atau tiga tahun kemudian (Iskandar 2004). Skala pengaruh seperti ini menjadi masalah, terutama dengan adanya efek tepi (edge effect) (Laurance 2000) dan dampak terhadap spesies berjelajah luas (Curran \& Webb 2000). Telah banyak dipahami bahwa perubahan bentang alam akan berbeda dalam skala yang berbeda (Ritters et al. 1997). Hal ini berlaku terutama bagi isu yang menyangkut keragaman spesies (Stoms 1994; Kunin 1998).

Banyak kasus yang digunakan dalam studi ini merupakan penelitian yang relatif singkat (lihat bagian Ketersediaan Pustaka). Dengan mempertimbangkan pengaruh penting dari episode yang berulang secara tahunan seperti musim pembuahan/ reproduksi yang bersamaan waktunya (mass fruiting) bagi sejumlah populasi spesies vertebrata di Borneo (lihat Curran \& Leighton 2000, Fredriksson \& Wich in prep.), penelitian jangka pendek hanya mengungkapkan pemahaman mengenai ekologi spesies secara parsial saja. Sebagai contoh, seorang peneliti membuat kesimpulan dari data riset dalam waktu singkat bahwa suatu spesies mampu bertahan setelah adanya kegiatan penebangan. Data tersebut mungkin tidak dapat mengungkapkan bahwa spesies yang diteliti tersebut meningkat populasinya dan kemudian menurun, atau sebaliknya. Masalah yang sama muncul pada penelitian pengaruh penebangan terhadap hidupan liar yang dilakukan sesaat setelah kegiatan penebangan itu sendiri. Pemahaman kita tentang seberapa lama suatu spesies bereaksi terhadap penebangan, atau bagaimana reaksinya terhadap daur tebangan sangat terbatas. Karena itu kami mengusulkan untuk selalu berhati-hati dalam menggunakan hasil penelitian tentang kajian hidupan liar di hutan primer atau hutan bekas tebangan yang menggunakan hanya satu daur pemanenan kayu untuk menyatakan jumlah atau spesies apa yang hilang karena penebangan kayu.

Pada bagian lain (Tabel 2-9, lihat bab Burung dan Mamalia) kami akan menunjukkan bahwa beragam pengamatan mengenai wilayah jelajah spesies kaitannya dengan pengaruh penebangan terhadap hidupan liar menghasilkan kesimpulan yang berbeda. Menurut kami hal ini terjadi paling tidak karena perbedaan metodologi. Beberapa penulis (Bennett \& Dahaban 1995, Lambert 1990a, Lambert \& Collar 2002) mengungkapkan bahwa penelitian yang dilakukan Johns (1983, 1986b, 1989b, 1996, 1997) memiliki bias karena menggunakan jalan sarad sebagai transek. Lambert dan Collar (2002) juga menyatakan bahwa keahlian dan pengalaman pengamat dapat 
mempengaruhi jumlah dan spesies yang terdeteksi. Spesies yang tertutup dan pemalu, hanya dapat dideteksi secara efektif oleh pengamat yang benar-benar ahli.

Bias tambahan terjadi pada saat survei hidupan liar dilakukan oleh pengamat melalui teknik perjumpaan. Ini terjadi karena spesies tersebut lebih mudah (atau lebih sulit) diteliti di hutan bekas tebangan. Seperti contohnya, tajuk pohon yang kurang rapat di hutan bekas tebangan menyebabkan burung-burung yang biasanya hidup pada tajuk bagian atas terpaksa mencari makan di tajuk yang lebih rendah, sehingga burung yang tadinya sulit dilihat menjadi mudah dideteksi. Pada umumnya survei di hutan tropis cenderung memiliki bias yang mencakup kemudahan spesies untuk dideteksi, perbedaan keahlian dan kemampuan peneliti untuk melakukan penelusuran gambar, waktu pelaksanaan survei, ukuran dan lokasi transek, transek yang ada atau jalan setapak dan jalan yang baru dibuat, atau transek yang dibuat secara acak di hutan, keterbiasaan beragam spesies target terhadap manusia, pengaruh suara dan bau manusia terhadap kehadiran spesies tertentu. Aspek yang lain adalah kondisi lingkungan yang dapat mempengaruhi penglihatan atau jarak pandang (seperti hujan, kabut, cahaya, dan sebagainya.) dan morfologi berbagai spesies yang belum diketahui, serta heterogenitas individu dan spesies tersebut.

Sejauh ini kita belum mendiskusikan perangkat statistik, yaitu kemungkinan menolak hipotesis nol bila hasilnya salah (dengan demikian harus ditolak) — yang berarti pengukuran menghasilkan kesimpulan yang benar. Kesalahan yang biasa terjadi dalam menginterpretasi data adalah kegagalan menolak hipotesis nol yang umumnya dianggap sebagai bukti bahwa hipotesis nol adalah benar (Ludwig et al. 2001). Namun demikian, sebagaimana diungkapkan oleh Ludwig et al., taraf beda nyata secara statistik hanya mengutamakan penolakan hipotesis yang salah, padahal kenyataannya benar. Hal ini disebut kesalahan tipe 1. Bila hipotesis nol tidak ditolak, kemungkinannya adalah bahwa hipotesis nol diterima, meskipun salah. Hal ini disebut sebagai kesalahan Tipe 2. Pengimbang jumlah ini disebut sebagai kekuatan uji, atau dengan kata lain "kekuatan bukti" (Siegel \& Castellan 1988). Kekuatan pengujian bergantung pada sifat hipotesis alternatif tersebut. Hal ini kemudian dikaitkan dengan pengujian baik menggunakan uji satu- atau dua arah, besarnya sampel, ragam, dan tingkat nyata (Siegel \& Castellan 1988). Kesimpulan a posteriori merupakan pendekatan yang lebih layak digunakan untuk penelitian menyangkut pengaruh penebangan, karena mensyaratkan kejelasan perlunya pengujian satu atau dua arah. Penggunaan pengujian satu arah, terutama dengan jumlah sampel yang kecil tidak dibenarkan.

Banyak asumsi sangat mendasar yang dibuat dalam menginterpretasikan kecenderungan dan pola data suatu spesies sehingga kita tidak mempertanyakan kembali asumsi tersebut. Namun demikian, asumsi tersebut dapat saja didasari oleh pemikiran yang patut dipertanyakan. Kenyataan bahwa spesies tertentu tidak menurun kepadatannya tidak berarti bahwa tidak ada dampak negatif lain yang mempengaruhi kondisi jangka panjangnya. Peningkatan kelimpahan sejumlah spesies yang diamati setelah perubahan bentang alam biasanya dianggap sebagai hal yang baik - padahal bila secara umum suatu spesies rentan terhadap penyakit menular, peningkatan populasinya bisa menyebabkan spesies tersebut lebih rentan terhadap penyakit epidemik yang mematikan, seperti yang diungkapkan dalam penelitian 
Gorila di Afrika Tengah (Walsh et al. 2003). Selain itu ada banyak pengaruh negatif yang timbul seperti peningkatan perkawinan dalam satu keturunan (inbreeding) setelah hutan dan bentang alam terfragmentasi.

Jadi bagaimana dengan keabsahan kesimpulan kami? Semua spesies cenderung mengalami perubahan akibat penebangan karena perubahan lingkungan bisa menyebabkan perubahan pemanfaatan lingkungan oleh spesies-spesies tersebut. Dengan demikian, pada dasarnya hipotesis nol salah. Kami juga memahami bahwa makin sedikit kerusakan hutan makin kecil dampak penebangan yang akan terjadi terhadap hidupan liar, meskipun beberapa spesies satwa liar bisa musnah hanya karena gangguan yang kecil saja. Interpretasi secara umum ini mungkin sama pentingnya dengan keseluruhan kajian tentang kepadatan spesies. Banyak upaya dilakukan untuk menentukan kepadatan spesies pada berbagai tingkat ancaman, namun tidak ada yang tahu (ataupun ingin tahu) tentang kepadatan optimum suatu spesies tertentu. Karena kepadatan spesies sedemikian rupa terkait dengan setiap aspek lingkungan hutan di sekitarnya, maka kajian sederhana menyangkut kepadatan dan kelimpahan hanya memberikan sedikit informasi mengenai peluang kemungkinan hidup suatu spesies tertentu.

\section{Ketersediaan pustaka}

Pustaka yang dikaji dalam laporan ini dikumpulkan dari buku dan jurnal internasional, serta dari prosiding lokakarya, dan laporan yang dihasilkan oleh organisasi nonpemerintah di bidang konservasi. Kami juga mengkaji pustaka sekunder seperti buku panduan, dan materi referensi umum. Penelitian di kebun binatang umumnya tidak dikaji. Meskipun studi di kebun binatang merupakan sumber informasi biologi satwa target, namun secara ekologis nilainya terbatas. Karena sulitnya akses, jumlah tesis dari perguruan tinggi di Amerika dan Eropa yang digunakan dalam riset ini hanya sedikit. Tesis dari perguruan tinggi di Indonesia dan Malaysia sebagian besar tidak tersedia.

Banyak penelitian di bidang satwa dalam tiga puluh tahun belakangan ini berfokus pada hubungan biologis antara spesies tertentu dengan lingkungannya (autoecology), khususnya tentang distribusi dan preferensi habitat di daerah yang aman dari penebangan. Meskipun demikian, kondisi pemahaman tentang distribusi dan kelimpahan spesies masih jauh dari sempurna. Bahkan pemahaman mengenai kompleksitas hubungan antara spesies dengan beragam habitatnya sangat sedikit.

Seratus empat puluh spesies vertebrata dikaji secara rinci dalam studi ini (23 spesies burung, 28 spesies mamalia, 54 spesies reptil, dan 40 spesies amfibia). Terdapat bias yang sangat besar dalam jumlah pustaka untuk taxa vertebrata. Kajian awal (Rosenbaum 2001) menunjukkan bahwa mamalia merupakan taxa yang paling terwakili dalam pustaka yang tersedia. Burung merupakan taxa yang paling terwakili setelah mamalia. Ketersediaan pustaka mengenai amfibia dan reptilia sangat sedikit. Untuk kepentingan penelitian ini, kami mengumpulkan 280 pustaka mengenai vertebrata Borneo, antara lain penelitian mengenai hidupan liar yang berdasarkan pada studi lapangan di Borneo. Selain itu, kami menggunakan pustaka dari Sumatera, Semenanjung Malaya, dan Daratan Asia, jika pustaka tersebut mendeskripsikan 
karakteristik spesies yang juga hidup di Borneo. Dari 280 pustaka yang berkaitan dengan Borneo, 118 (atau 42\%) berdasarkan pekerjaan lapangan di Kalimantan, 126 (atau 45\%) dari Sabah dan Sarawak (Malaysia), 9 (3\%) dari Brunei, dan sisanya mengacu kepada penelitian yang ada di seluruh Borneo. Kami berpendapat bahwa sampel ini bisa mewakili seluruh pustaka mengenai hidupan liar di Borneo, meskipun ada bias terhadap penelitian tentang mamalia. Empat puluh tujuh $(=16 \%)$ pustaka yang ada berbentuk buku atau bagian dari buku, 152 (55\%) dipublikasikan dalam newsletters dan jurnal yang di-peer-reviewed dan 80 merupakan laporan yang tidak dipublikasikan atau tesis.

Artikel dan laporan yang dikaji pada umumnya dapat dikelompokkan ke dalam catatan museum, survei, dan penelitian ekologis. Catatan museum sangat berguna terutama dalam menentukan distribusi hidupan liar. Informasi yang lain dapat ditemukan dalam laporan (seperti catatan mengenai ukuran, musim kawin, habitat mikro, isi perut, serta jumlah sarang), namun data tidak selalu konsisten. Dengan demikian kegunaan informasi ini sangat terbatas untuk menentukan karakteristik ekologis suatu spesies. Namun demikian, ketidakkonsistenan yang ada sering kali memiliki nilai tinggi. Misalnya, perbedaan isi perut satwa yang hidup pada lokasi atau kondisi lingkungan yang berbeda dapat mengungkapkan preferensi dan nilai habitat. Dengan segala keterbatasannya, untuk sejumlah spesies, catatan ini merupakan satusatunya sumber data yang tersedia.

Pustaka-pustaka yang tersedia didominasi oleh hasil survei. Survei tersebut sangat berguna untuk menentukan distribusi, gradien ketinggian, kepadatan populasi, preferensi habitat, dan pada kondisi tertentu, ekologi perilaku. Hasil kajian studi banding antara areal bekas tebangan dan areal utuh lebih banyak digunakan dalam kajian ini untuk mengetahui respons populasi suatu spesies terhadap perubahan habitat. Beberapa studi tersebut mengindikasikan kehadiran/ketidakhadiran dan kelimpahan suatu spesies pada habitat tertentu, namun tidak dapat mengungkapkan karakteristik ekologis habitat yang digunakan untuk menentukan jumlah relatif individu spesies tersebut (lihat Dahaban et al. 1996, Carter 1985, Danielsen \& Heegaard 1994). Meskipun demikian, beberapa studi yang dilakukan di daerah yang berbeda mengungkapkan bahwa kecenderungan kelimpahan sebelum dan sesudah penebangan memungkinkan kita untuk menyimpulkan pengaruh penebangan terhadap spesies tertentu. Hal ini terjadi jika hasil survei tersebut digabungkan dengan studi yang menitikberatkan hubungan biologis spesies tertentu dengan lingkungannya.

Studi monograf individu spesies sangat berguna untuk mengidentifikasi perubahan dalam pakan, perilaku jelajah dan perilaku lain setelah penebangan, dan bagaimana hal ini mempengaruhi kepadatan populasinya di hutan bekas tebangan. Namun demikian, terdapat masalah dan bias dalam isi pustaka ini. Yang pertama adalah kurangnya pustaka studi ekologis secara umum dari Indonesia dan Asia Tenggara yang dipublikasikan (Sodhi \& Liow 2000). Meskipun Indonesia dianggap sebagai negara mega-diversitas, atau kaya akan keanekaragaman hayati (Mittermeier \& Mittermeier 1998), namun sangat sedikit makalah yang dipublikasikan dalam jurnal ekologi internasional. Dari tahun 1998 hingga 2000, kurang dari 1 persen makalah penelitian dengan subjek fauna Indonesia terbit dalam jurnal-jurnal seperti 
Acta Oecologica, Ecology, Functional Ecology, Journal of Ecology, Oecologica dan Tropical Ecology. Kurangnya publikasi ini tidak hanya terjadi di Indonesia. Sebagai perbandingan, untuk seluruh wilayah Asia Tenggara, makalah yang dipublikasikan pada jurnal-jurnal di atas bahkan kurang dari 4\% saja. Kecuali Oryx, sebuah jurnal konservasi internasional yang lebih mengutamakan penelitian deskriptif (misalnya, status dan distribusi taxa yang terancam) dan Tropical Biodiversity, sebuah jurnal regional yang banyak menerbitkan makalah dari Indonesia. Tujuh persen makalah penelitian dalam Oryx dan 60\% makalah dalam Tropical Biodiversity memuat subyek fauna Indonesia (Sodhi \& Liow 2000). Lebih lanjut, sejumlah jurnal regional lainnya mengutamakan ekologi spesies dan isu konservasi, meskipun jurnal-jurnal tersebut sulit didapat oleh peneliti dari daerah yang lain. Jurnal regional tersebut antara lain Kukila, Treubia, Malayan Nature Journal, The Malaysian Forester, Malaysian Applied Biology, Hornbill, Bulletin of Siam Natural History Bulletin dan the Raffles Bulletin of Zoology. Contoh-contoh ini menegaskan kembali pentingnya penelitian serta pentingnya pustaka yang tidak dipublikasikan (grey literature) dalam rangka penelusuran informasi ekologis mengenai fauna Indonesia.

Permasalahan kedua yang ada pada pustaka-pustaka yang ada yaitu keterbatasan waktu studi. Sebagian besar studi dilakukan dalam waktu yang singkat (3-6 bulan) dan studi jangka panjang rata-rata diperkirakan hanya sampai satu tahun lamanya. Karena ekosistem hutan memiliki pola tahunan yang bervariasi, kesimpulan penelitian tersebut hanya dapat dianggap sebagai kesimpulan sementara. Namun, hanya sebagian kecil pihak yang memahami ketidakpastian hasil studi jangka pendek ini. Untuk jangka waktu tertentu studi bisa memberikan hasil yang tampaknya baik, namun tidak demikian untuk jangka panjang serta dalam luasan geografis yang lebih besar.

Ketiga, sebagian besar penelitian ekologis mengenai Borneo dilakukan di sejumlah kecil stasiun penelitian yang sudah lama berdiri. Di Kalimantan Timur, stasiun penelitian ini mencakup Program Internasional Departemen Kehutanan dan Tropenbos Kalimantan (International MoF-Tropenbos Kalimantan Program) (van der Hoeven et al. 2000) dan Proyek Penelitian Hutan Hujan Tropis JICA (Tropical Rain Forest Research Project_-Japan International Cooperation Agency). Untuk wilayah lain di Kalimantan, lokasi penelitian ekologi jangka panjang terdapat di Kalimantan Tengah (Barito Ulu, Sebangau dan Tanjung Puting) serta Kalimantan Barat (Gunung Palung). Di hutan primer, hanya dengan jarak yang relatif pendek, keragaman kepadatan habitat spesifik dan spesies tumbuhan serta satwa yang terkait bisa cukup besar. Pada lingkup geografis yang lebih luas keragaman tersebut bahkan lebih besar lagi. Hal ini menyebabkan tingginya variasi antar lokasi studi dimana spesies tersebut berada. Karena individu spesies dan karakteristik ekologis habitat beragam, fungsi dan relung spesies dalam habitat juga beragam, setidaknya pada tingkat tertentu. Dengan demikian perilaku spesies juga akan beragam dalam setiap lokasi. Bila bias yang diungkapkan sebelumnya ikut dipertimbangkan, informasi tentang spesies tertentu yang diperoleh dari hanya sejumlah kecil lokasi akan tampak kurang meyakinkan dan hasilnya sangat terbatas untuk digeneralisasi.

Pustaka yang tidak dipublikasikan (grey literature) mengisi informasi yang tidak terdapat pada pustaka-pustaka yang dipublikasikan. Keterbatasan utama dari 
sumber informasi ini (pustaka yang tidak dipublikasikan) adalah kesulitan dalam memperoleh laporan. Keterbatasan lainnya yaitu ragam kualitas laporan yang sangat besar, yang sebagian disebabkan oleh kurangnya peer-review ilmiah yang serius. Pustaka ini sebagian besar disimpan di kantor-kantor regional dalam jumlah yang terbatas. Beberapa kantor tersebut memiliki sistem penelusuran basis data yang sangat terbatas, sehingga menyulitkan pencarian data secara umum. Biasanya laporan yang diperlukan tersebut harus sudah dikenal. Setelah ditemukan, laporan tersebut harus dibuatkan salinannya dan dikirimkan. Dengan demikian, akses kepada informasi seperti ini bergantung pada infrastruktur dan efisiensi waktu dari masing-masing kantor. Namun demikian, sebagian besar kantor-kantor ini sangat membantu dalam pencarian laporan-laporan tertentu yang diperlukan.

Untuk menganalisis lebih lanjut daftar publikasi yang tersedia, terutama untuk melihat manfaat terhadap pengelolaan hidupan liar yang lebih baik, kami membaginya ke dalam lima kategori, yaitu:

1. deskriptif (taksonomi, daftar spesies, survei, morfologi)

2. yang berkaitan dengan hubungan biologis spesies tertentu dengan lingkungannya (autecology, yang mencakup pergerakan, perilaku makan, perilaku perkembangbiakan, dan lain-lain)

3. sinekologis (berfokus pada interaksi ekologis dalam kelompok spesies atau antar spesies dengan lingkungannya)

4. ancaman (penelitian mengenai ancaman terhadap suatu spesies), dan

5. studi sebab-akibat (meneliti perubahan populasi kaitannya dengan ancaman tertentu).

Pada pustaka yang memiliki lebih dari satu kategori, kami memilih salah satu yang paling mewakili tema dominan dari pustaka tersebut. 146 publikasi $(=52 \%)$ masuk ke dalam kategori 1, 50 pustaka (=18\%) masuk ke dalam kategori 2, 24 pustaka (=9\%) masuk ke dalam kategori 3, 25 (=9\%) masuk dalam kategori 4, dan 35 $(=12 \%)$ masuk ke dalam kategori 5 . Dengan demikian, ada bias yang kuat terhadap studi yang hanya berfokus pada deskripsi karakteristik spesies tanpa melihat ancaman yang ada; contohnya, terdapat pada hampir $80 \%$ publikasi (kategori 1-3). Mayoritas studi dalam kategori 4 mencakup penelitian tentang perburuan dan perdagangan satwa liar, dengan beberapa penelitian yang mengulas isu seperti kebakaran hutan dan kekeringan, penyakit pada satwa liar, atau deforestasi. Tidak satu pun dari pustaka dalam kategori 4 ini secara kuantitatif mengulas tentang bagaimana faktor yang ada mempengaruhi kepadatan populasi satwa liar. Hanya publikasi dalam kategori 5 yang memberikan pandangan mengenai kecenderungan populasi spesies yang berkaitan dengan ancaman dan secara langsung bermanfaat bagi biologi konservasi. Studi dalam kategori 5 ini menjawab pertanyaan yang sangat penting dalam penelitian konservasi, yaitu: "spesies mana yang memerlukan perhatian konservasi?". Sayangnya, ke-35 pustaka dalam kategori 5 tersebut hanya sedikit saja yang berfokus pada kelompok spesies. Sebelas dari 35 pustaka tersebut mengulas pengaruh penebangan dan perburuan terhadap primata, dan sisanya mengulas Beruang Madu (3), Musang (civet, 2), mamalia berkuku belah (4), mamalia secara umum (4), burung secara 
umum (4), burung pelatuk (2), amfibia (4) dan ikan (1). Dengan demikian, pustaka yang tersedia tidak dapat memberikan penjelasan umum secara menyeluruh tentang biota Borneo dan kebutuhan konservasinya.

\section{Lingkup pustaka}

Hasil kajian pustaka ini menekankan perlunya penelitian ekologis lebih lanjut tentang satwa Indonesia. Sebagian besar spesies yang ditemukan di MRF tidak memiliki pustaka yang berisikan informasi di luar wilayah jelajahnya, kaitannya dengan habitat, dan makanannya secara kualitatif, terutama untuk ikan, amfibia, serta sejumlah burung. Bahkan di antara mamalia yang merupakan kelompok vertebrata yang banyak diteliti sekali pun, ada sejumlah spesies tidak memiliki studi lapangan ekologis yang sistematis. Lebih jauh lagi, dampak penebangan dan pengaruh yang berkaitan dengan penebangan hanya diketahui untuk sekitar dua puluh spesies saja.

\section{Kajian tentang burung}

Dari dua puluh empat spesies burung yang dipilih untuk dikaji, ada perbedaan yang besar dalam hal topik yang diteliti dan informasi yang diketahui. Kesimpulan umum yang dapat diambil adalah hanya sedikit saja spesies yang ekologinya diketahui dengan baik, antara lain ditemukan pada satu studi lapangan jangka panjang di Borneo. Spesies burung yang paling dikenal dan dipahami adalah Rangkong, yang merupakan burung dengan ukuran besar, diurnal (aktif di siang hari) sehingga dapat dilihat dengan mudah. Sempidan (Lobiophasis spp.) cukup dikenal karena adanya perhatian dan dukungan dana dari kelompok penggemar Sempidan. Dari spesies-spesies burung yang kurang dikenal, yang dianggap paling rentan terhadap penebangan adalah Luntur, Pelatuk (meskipun baru-baru ini sejumlah penelitian telah dilakukan untuk kelompok ini, lihat Lammertink 1999, 2004, Styring \& Hussin 2004a), Pelanduk dan Takur (Lambert 1992). Pustaka yang khusus ditujukan bagi spesies Kipasan dan Berencet, yaitu kelompok yang dianggap sangat sensitif terhadap pengaruh penebangan (Lambert 1992), sangat sedikit jumlahnya sehingga kami tidak memasukkannya dalam kajian pustaka. Fokus lebih jauh ditujukan pada rangkong, ayam hutan (sempidan), pelatuk, dan luntur untuk analisis yang lebih rinci mengenai variabel ekologi dan siklus hidupnya yang dapat memprediksi kepekaan terhadap penebangan.

Terbatasnya data yang tersedia tentang burung dan sejumlah penelitian ekologis yang terkait disebabkan langkanya spesies-spesies burung Asia Tenggara tersebut. Mayoritas burung hutan tropis hidup dengan kepadatan rendah yang sering kali memiliki wilayah jelajah yang luas, yang kemudian mencerminkan habitat makro yang terpecah-pecah dan/atau terbatasnya kemampuannya dalam memprediksi sumber makanan utamanya. Oleh karena itu, mempelajari spesies tersebut di lapangan menjadi sangat sulit dan memerlukan waktu lama. 


\section{Kajian tentang mamalia}

Meskipun mamalia merupakan kelompok vertebrata yang paling banyak dipelajari di Asia, ketersediaan pustaka sama dengan taxa yang disebutkan sebelumnya. Sejumlah 25 spesies mamalia dari 80 spesies yang berpotensi untuk ditemukan di daerah Malinau diulas dalam kajian pustaka ini berdasarkan ketersediaan pustaka ekologisnya. Karena kelelawar tidak disurvei di Malinau, maka kami hanya memberikan kajian umumnya saja.

Dari spesies mamalia yang dipilih, 41\% dianggap sudah cukup dipahami sifat biologis dan ekologisnya (paling tidak ada satu penelitian jangka panjang, lebih dari 2 tahun penelitian lapangan), 38\% dapat dianggap sudah dikenal (paling tidak ada satu penelitian jangka pendek, kurang dari 2 tahun), dan 21\% dapat dianggap kurang dikenal/dipahami. Dari yang sudah dipahami tersebut termasuk 5 primata diurnal, 2 rusa, 1 beruang (Ursus malayanus), 1 musang (Viverra tangalunga), 1 spesies kucing (Prionailurus bengalensis), 1 spesies babi (Sus barbatus), dan 1 spesies tupai besar (Ratufa affinis). Dari spesies-spesies tersebut, satu spesies rusa (Cervus unicolor) dan kucing berasal dari Asia Selatan. Spesies rusa-tikus (Tragulus spp.) terutama dikenal dari satu penelitian ekologis yang mendalam, sementara baru-baru ini perhatian terhadap penelitian spesies beruang (Ursus malayanus) meningkat (Augeri 2002; Fredriksson 2001; Wong 2002; Wong et al. 2004). Primata secara umum banyak diteliti, namun ekologi spesies lutung (Presbytis hosei) diketahui hanya dari satu disertasi doktoral saja. Beberapa spesies mamalia yang kurang dikenal yaitu tiga spesies tupai, dua bajing dan satu spesies musang, kesemuanya merupakan agen penting bagi penyebaran benih dan regenerasi hutan.

Alasan mengapa sedikit sekali penelitian tentang mamalia di Asia Tenggara sama halnya dengan kasus penelitian mengenai burung. Banyak spesies yang sifatnya nokturnal (aktif pada malam hari), tertutup dan pemalu, serta hidup dalam kepadatan rendah, sementara beberapa spesies yang lebih besar ada yang semi-nomad. Selain itu, dari segi logistik penelitian tentang hutan tropis sangat sulit dan sering kali sangat mahal, serta sebagian besar spesies sangat sulit untuk diamati dibandingkan dengan spesies yang hidup pada tipe vegetasi yang lebih jarang, terutama yang menjadi target perburuan dan bersifat sangat pemalu. Spesies mamalia yang paling banyak diteliti bersifat diurnal dan dapat diamati/dilihat dengan mudah. Masalah yang ada bukan hanya masalah biologis. Terbatasnya penelitian lapangan tentang hidupan liar yang dilakukan oleh pemerintah dan komunitas akademik di Indonesia terutama disebabkan oleh keterbatasan bahasa. Demikian pula dengan terbatasnya temuan ilmiah yang dipublikasikan dalam jurnal internasional. Kebanyakan penelitian dilakukan oleh ilmuwan asing, meskipun sering kali izin penelitian di Indonesia bagi peneliti asing tidak mudah diperoleh, terutama saat terjadi konflik politik. Terutama sulitnya memperoleh izin penelitian ke daerah terpencil dengan kondisi politik yang tidak stabil. Di samping itu, ada sejumlah peneliti asing yang tidak melakukan penelitian di Indonesia karena alasan-alasan sosial-politis. 


\section{Kajian tentang amfibia dan reptilia}

Data ekologis tentang amfibia dan reptilia diperoleh melalui hasil survei dan sebagian besar mencakup preferensi/kecenderungan habitat. Data mengenai preferensi makanan sangat terbatas bagi taxa ini. Namun demikian, pada tahap dewasa kedua kelompok spesies ini cenderung untuk menjadi karnivora generalis (secara umum pemakan daging), sehingga tidak ada preferensi makanan secara khusus, atau dianggap tidak penting. Meskipun demikian, banyak amfibia dan reptilia yang memiliki persyaratan pemijahan yang sangat spesifik. Selain itu pada tahap muda dan larva, amfibia seringkali menunjukkan adaptasi morfologi yang sangat khas terhadap jenis mangsa yang dimakannya. Dengan demikian, spesialisasi habitat mikro berperan penting pada tahap awal kehidupannya.

\section{Kajian tentang ikan}

Ikan air tawar Borneo dipelajari dengan rinci, meskipun pustaka yang ada kebanyakan mengulas taksonomi atau berfokus pada ekologi dan distribusi spesies. Hanya sedikit saja penelitian yang mengulas pengaruh pemanenan kayu terhadap ikan. 


\section{Latar belakang konsep}

Pustaka yang ada tentang hutan tropis dan kehutanan secara umum berisi sejumlah pemikiran dan konsep-konsep yang penting. Pemikiran-pemikiran tersebut kami pertimbangkan pada bagian-bagian berikut ini, dengan tujuan untuk memberikan gambaran secara umum dalam menginterpretasikan hasil evaluasi spesies yang sifatnya spesifik.

\section{Perubahan fauna}

Survei perbandingan satwa mendominasi pustaka tentang konservasi keanekaragaman hayati dan penebangan kayu. Survei yang dilakukan di hutan primer maupun hutan bekas tebangan, mencatat perubahan kelimpahan spesies. Perubahan tersebut biasanya diperoleh melalui perbandingan lokasi, atau pemantauan dalam kurun waktu tertentu (sebagai contoh, lihat Johns 1997). Dari penelitian tersebut terungkap bagaimana spesies dan kelompok spesies bereaksi terhadap penebangan.

Pustaka yang ada dapat digunakan untuk mengidentifikasi "indikator keutuhan (integritas) hutan" secara biologis setelah penebangan (Cleary 2004, Davis 2000, van der Hoeven et al. 2000). Indikator tersebut merupakan perangkat yang penting untuk memantau efektivitas pengelolaan hutan. Dalam laporan ini, kami hanya mendiskusikan masalah indikator. Namun, perlu dicatat bahwa para pengelola harus mampu menggunakan indikator tersebut untuk mengadaptasi dan memperbaiki kegiatan pengelolaannya. Saat ini, kemampuan para pengelola tersebut masih harus ditingkatkan. Fokus lebih diarahkan kepada pengembangan panduan produksi kayu untuk mengurangi dampak negatif terhadap spesies-spesies yang sensitif. Meskipun survei perbandingan fauna dapat mengungkapkan perubahan kelimpahan spesies setelah penebangan, penelitian tersebut seringkali didasari oleh informasi kehadiran/ ketidakhadiran (ada/tidak ada, presencelabsence) tanpa menjelaskan mekanisme dan proses yang sedang berjalan. Penelitian lainnya tidak menggambarkan bagaimana kegiatan penebangan dapat dimodifikasi sehingga perubahan yang ada dapat diperbaiki. 
Tidak mudah untuk menentukan secara pasti bagaimana penebangan mempengaruhi kehidupan vertebrata. Dampak yang dihasilkan bergantung pada spesies target, kondisi lokasi, dan variabel yang lain. Meskipun demikian, penurunan populasi merupakan perubahan yang paling jelas terlihat. Penurunan populasi tersebut antara lain disebabkan oleh:

- Kepadatan yang berlebihan pada sisa-sisa habitat yang luasannya sangat terbatas, sehingga menyebabkan peningkatan kematian (mortalitas) akibat kompetisi. Waktu yang dibutuhkan untuk kembali ke kondisi awal yang stabil belum jelas. Selain itu, beberapa penelitian bisa saja gagal mendeteksi adanya pengaruh yang nyata bila penelitian tersebut dilakukan sesaat setelah penebangan dilakukan di lokasi yang mengalami peningkatan kepadatan populasi sementara;

- Cadangan makanan yang menurun jumlahnya

- Hilangnya habitat mikro yang penting serta perubahan iklim dan habitat mikro;

- Meningkatnya kematian pada anak-anak dan dewasa sejalan dengan meningkatnya pemangsaan, perburuan, kompetisi, atau hilangnya bahan makanan. Kematian tersebut dapat mengubah demografi, menurunkan keberhasilan dan proses pembuahan serta perkembangbiakan dan kesehatannya. Selanjutnya akan terjadi penurunan jumlah populasi, dan lebih jauh lagi akan mengubah kondisi demografi serta kepadatan populasi tersebut. Sedikitnya jumlah anakan dapat mengurangi kemampuan persaingan untuk mempertahankan hidup, mengurangi tekanan seleksi pada areal dengan sumber plasma nutfah yang kurang beragam dan pada akhirnya akan mengurangi kemampuan adaptasi dalam jangka panjang;

- Meningkatnya kematian pada anakan melalui tingkat pemangsaan yang lebih tinggi;

- Habitat yang lebih terbuka dan terganggu lebih mendukung munculnya pemangsa asli dan eksotis;

- Spesies pendatang (nonresiden) atau bersifat invasif menyebar dan memperuncing kompetisi sumberdaya yang makin menurun;

- Perubahan secara kompetitif atau pengurangan sumberdaya yang kritis seperti makanan, tempat berlindung, lokasi kawin dan bersarang;

- Peningkatan kepasifan karena adanya jenis penyakit baru dan menurunnya kesehatan populasi;

- Peningkatan tekanan perburuan;

- Penebangan pohon, penyaradan kayu, dan kegiatan ekstraksi kayu secara langsung mematikan atau mencederai satwa secara fatal.

Pada kenyataannya, banyak perubahan dalam keragaman dan kelimpahan terjadi secara simultan. Perubahan tersebut dapat mempengaruhi spesies lain atau mempengaruhi aspek komunitas hidupan biologis secara keseluruhan. Penelitian ekologi biasanya memudahkan kita untuk memisahkan potensi pengaruh negatif, mengidentifikasi mekanisme penyebab pengaruh negatif penebangan, dan menentukan penyebab keragaman akibat perbedaan lokasi, takson dan bentuk intervensi yang dilakukan. Setelah spesies yang paling sensitif dapat diidentifikasi, panduan yang dapat membantu pengelola hutan untuk mengembangkan kegiatan 
dan tindakan yang lebih baik dapat dimasukkan ke dalam rencana pengelolaan serta pelaksanaan kegiatan secara umum.

\section{Perubahan vegetasi}

Buku ini berfokus pada konsekuensi hutan produksi bagi satwa vertebrata yang hidup di hutan Dipterokarpa di Indonesia. Konsekuensi tersebut bergantung pada vegetasi hutan yang berubah akibat kegiatan hutan produksi. Kami tidak mencoba untuk memberikan ulasan yang komprehensif mengenai perubahan vegetasi yang berkaitan dengan pengambilan kayu, silvikultur, maupun kegiatan serupa. Namun, di sini kami dapat menyarankan beberapa acuan yang bermanfaat. Sejumlah kumpulan/kompilasi pustaka dan sintesis juga tersedia. Untuk ulasan umum mengenai dampak pengelolaan kayu terhadap ekologi hutan dan nilai konservasi, kami merekomendasikan beberapa pustaka berikut: Bertault \& Sist (1995), Bruenig (1996), Fimbel et al. (2001), Kartawinata \& Vayda (1984), Kartawinata et al. (1989), Kartawinata et al. (2001), Putz et al. (2001a), Szaro et al. (1999), Whitmore (1990a, b) dan Whitmore \& Sayer (1992). Pustaka yang sampai saat ini belum tersaingi adalah tulisan yang dibuat oleh Whitmore (1994) berisi pendahuluan umum tentang respons hutan Dipterokarpa di Asia Tenggara terhadap penebangan dan gangguan lainnya, meskipun pustaka terbaru yang ditulis oleh Appanah \& Turnbull (1998) tentang Dipterokarpa juga tersedia. Beberapa pustaka yang membahas penelitian khusus dampak kegiatan dan praktek kehutanan terhadap hutan di wilayah ini antara lain bisa dilihat dalam Abdulhadi et al. (1981, 1987), Adjers et al. (1996), Bertault \& Kadir (1998), Bertault \& Sist (1997), Bratawinata (1994), Cannon et al. (1994), Clearwater et al. (1999), Djamaludin (1991), Elias (1998), Gintings (1969), Howlett \& Davidson (1996), Kammesheidt et al. (2003), Kartawinata (1981), Kuusipalo et al. (1996), Nicholson (1979), Nussbaum (1995), Prawiraatmadja (1970), Riswan \& Kartawinata (1991), Sastrawinata \& Effendy (1991), Setyarso (1991), Sist \& Nguyen-Thé (2002), Sist et al. (1998a, 1999), Sudarmaji (1999), Sumitro (1991), Supriyatno \& Becker (1999), Sutisna (1996, 1998), Tinal \& Palinewen (1978), Tuomela et al. (1996), Van Gardingen et al. (1998) dan Wyatt-Smith (1995). Informasi menyangkut kegiatan pembalakan hutan terkendali (reduced impact logging) dan pendekatan lain yang terkait serta pelaksanaannya dapat dilihat dalam Applegate et al. (2004), Elias et al. (2001), Enters et al. (2002) dan Sist et al. (1998b). Berikut adalah pengenalan secara singkat tentang topik-topik ini.

Dalam beberapa dekade belakangan ini, keberadaan celah/rumpang tajuk mendominasi pemikiran ekologis tentang dinamika hutan tropis (Brokaw 1987, Brandani et al. 1988, Campbell 1991, Denslow 1987, Whitmore 1997, Whitmore \& Brown 1996). Pada umumnya, rumpang yang terbentuk secara alami berdampak rendah terhadap komposisi dan kekayaan hutan alam (Brown \& Jennings 1998, Hubbell et al. 1999). Namun demikian, rumpang-rumpang tersebut, yang secara umum berukuran kecil dan dengan cepat tertutup kembali oleh regenerasi selanjutnya, sangat penting bagi spesies yang tumbuh subur dalam kondisi hutan yang terganggu. 
Di hutan yang telah dipanen kayunya, rumpang yang timbul biasanya lebih besar dan lebih banyak jumlahnya. Di samping itu terjadi pemadatan dan pembalikan tanah oleh alat-alat berat sehingga perkembangan regenerasi hutan seringkali terganggu. Dalam kasus ini, vegetasi perintis yang tumbuh dari biji dapat mendominasi pertumbuhan awal tumbuhan (Denslow et al. 1990, Pelissier et al. 1998, Silva et al. 1996, Swaine \& Hall 1983).

Ulasan yang mendalam oleh Hawthorne et al. (1998) memberikan gambaran umum mengenai tipe-tipe vegetasi hutan. Spesies nonperintis yang memerlukan banyak cahaya merupakan spesies yang awalnya tumbuh di bawah naungan pohon seperti umumnya spesies Dipterokarpa, membutuhkan peningkatan cahaya untuk mencapai tajuk. Kelompok ini umumnya mendapatkan manfaat dari bukaan tajuk, sedangkan tumbuhan yang membutuhkan naungan biasanya berkurang jumlahnya saat celah terbuka. Sebagai contoh, Kayu besi (Eusideroxylon zwageri), berkecambah dan tumbuh tanpa cahaya tambahan di hutan yang tertutup.

Lokasi tempat angkutan dan jalan tebangan kayu disukai oleh spesies perintis seperti Macaranga spp., Trema orientalis, dan Ceiba pentandra, sedangkan jalan sarad dan celah penebangan mendukung pertumbuhan spesies bukan perintis (nonpioneer) yang memerlukan banyak cahaya. Lokasi yang berdekatan dengan hutan biasanya pulih lebih cepat setelah ditebang. Mempertahankan cagar-cagar yang tersebar di hutan yang dikelola, seperti Cagar Hutan di Malaysia (Virgin Jungle Reserves), merupakan upaya pencegahan praktis yang dapat dilakukan.

Bukaan tajuk yang berlebihan dapat menimbulkan masalah regenerasi, terutama pada kondisi yang sangat terbuka sehingga tanah cepat mengering dan unsur hara hilang karena aliran permukaan yang deras. Vegetasi herba dan semak belukar yang biasanya terkait dengan bukaan yang lebar dapat mengganggu regenerasi dan memperlambat pemulihan (Epp 1987, Hawthorne 1993, 1994). Hal ini menjadi masalah yang pelik, terutama bila semak belukar tersebut bukan tumbuhan asli. Disamping itu bukaan tajuk yang lebar secara signifikan mengubah kondisi tanah. Pertumbuhan kembali yang lambat dapat mengundang satwa pemakan tumbuhan bawah. Di satu sisi, satwa tersebut dapat merusak tumbuhan baru dan menjadikan daerah tetap terbuka. Namun di sisi lain, peningkatan kepadatan satwa dapat memberikan sumbangan yang positif terhadap dinamika hutan alam serta menyediakan mangsa bagi karnivora dan pemburu (manusia).

Reproduksi pohon merupakan topik pembanding yang sering terabaikan. Pohon biasanya tidak memiliki kemampuan berbunga dan menghasilkan biji hingga pohon mencapai ukuran yang minimum. Meskipun reproduksi dimulai pada saat ukuran pohon jauh di bawah batas masak tebang (Jennings et al. 2001), cabang terbesar biasanya menunjukkan tingkat kesuburan tertinggi (Appanah \& Mohd-rasol 1990, Thomas 1996). "Ukuran masak tebang minimum", dengan demikian tidak layak digunakan untuk melindungi produksi biji, jika digunakan sebagai satu-satunya kontrol silvikultur (lihat Fredericksen \& Putz 2003, Sist et al. 2003b).

Bahkan ketika pohon induk ada/tersedia, tetap diperlukan perlindungan lebih lanjut. Ilmu pengetahuan tentang reproduksi pohon berkayu masih sangat terbatas, namun demikian penelitian menekankan perlunya peran banyak spesies satwa dalam penyerbukan dan penyebaran biji. Pengetahuan ekologi yang kompleks 
tentang aspek ini tersedia, namun seringkali informasi ini berfokus pada spesies tertentu saja dan dengan demikian tidak dapat digeneralisasikan (Gautier-Hion et al. 1985). Penelitian yang dilakukan baru-baru ini juga menunjukkan bahwa jarak penyebaran biji seringkali lebih rendah dibandingkan prediksi sebelumnya, bahkan untuk spesies-spesies tumbuhan yang disebarkan oleh binatang (contohnya Hubbell et al. 1999, namun lihat Webb \& Peart 2001). Kenyataan ini menunjukkan bahwa diperlukan pohon induk dengan distribusi yang lebih rapat, atau setidaknya lebih merata. Ketersediaan panduan prinsip yang memuat informasi tentang rata-rata jumlah pohon induk yang harus dipertahankan, ditambah dengan klasifikasi biji dan buah yang lebih lengkap merupakan suatu keharusan (contohnya Gautier-Hion et al. 1985, Howe \& Westley 1988).

Pada akhirnya, penyebaran dan penyerbukan, serta potensi kesuburan, seharusnya bisa membantu menentukan rata-rata jumlah pohon induk yang dipertahankan, serta pengelolaan lokasi yang terkait (Baur \& Hadley 1990, Schupp 1990). Sebagai contoh, kepadatan pohon berumah tunggal seharusnya dipertahankan dua kali lipat atau sama dengan kepadatan spesies yang berumah ganda (Kigomo et al. 1994, Lawton 1955). Namun data yang tersedia untuk menentukan kelayakan kepadatan penyerbukan spesies-spesies pohon tropis sangat terbatas (contohnya, Ghazoul et al. 1998, Stacy et al. 1996), dan banyak yang masih bersifat spekulatif.

Melindungi pohon-pohon induk dan wilayah "cagar" yang tidak dipanen dalam suatu bentang alam hutan memberikan suatu jaminan, tetapi mempertahankan populasi satwa kunci juga sangat penting untuk memastikan kesehatan hutan dalam jangka panjang dan hal ini memerlukan perhatian tambahan (sebagai contoh lihat Bakuneeta et al. 1995, Hawthorne \& Parren 2000, Howe \& Westley 1988, Parren 1991). Gordon et al. (1990) menunjukkan bahwa beberapa penyerbuk (pollinator) hutan di Amerika Tengah juga bergantung pada wilayah yang tidak berhutan di luar cagar yang telah ditetapkan. Hal ini mengungkapkan bahwa daerah dan fungsi di luar cagar tersebut perlu untuk dimasukkan ke dalam pengelolaan jangka panjang.

Pohon-pohon yang tersisa berfungsi lebih dari sekedar sumber biji dan benih. Sebagian besar pohon bertahan hidup dan tumbuh lebih baik di sekitar sumber mycorrhizae, jenis jamur (fungi) bermanfaat yang berasosiasi dengan akar berbagai spesies tumbuhan. Sumber mycorrhizae ini sering kali dari pohon yang berbeda (Alexander et al. 1992, Hogberg \& Wester 1998, Moyersoen et al. 1998). Pohon tua berukuran besar juga memiliki karakteristik struktur yang kompleks yang banyak dibutuhkan satwa liar, seperti cabang yang berongga, tajuk yang lebar, dan bagianbagian yang membusuk. Proporsi spesies satwa hutan yang hidupnya bergantung pada kayu mati tidak diketahui, namun di Australia diperkirakan seperlima dari taxa yang ada hanya berasosiasi dengan kelas ukuran pohon besar yang menghasilkan kayu mati dalam jumlah besar (Groove 2001).

Banyak taxa hutan yang memanfaatkan atau bergantung pada pohon tua, besar, dan berongga. Taxa tersebut di antaranya rangkong (Datta 1998, Whitney et al. 1998, Whitney \& Smith 1998), pelatuk (McNally \& Schneider 1996), beruang, musang, dan landak. Penyerbuk penting seperti lebah (Kerr et al. 1994, McNally \& Schneider 1996) dan penyebar biji ((Whitney \& Smith 1998, Whitney et al. 1998) juga bergantung pada pohon-pohon berongga. Sementara itu, banyak satwa 
yang memanfaatkan batang pohon berongga yang tumbang untuk bersarang atau beristirahat, contohnya adalah Lariscus insignis (Yasuma \& Andau 2000) dan Tragulus javanicus (Matsubayashi et al. 2003). Hilangnya percabangan yang besar tentunya memiliki konsekuensi jangka panjang (Gordon et al. 1990), dan berpotensi menjadi penyebab terjadinya penurunan atau kegagalan regenerasi hutan di dunia (Sheil \& van Heist 2000). Faktor lain adalah hilangnya jamur (fungi) mikoriza yang berpotensi menjadi penyebab melambatnya regenerasi setelah kegiatan tebang habis.

Sejumlah buah-buahan berfungsi sebagai katalis dengan menarik perhatian vertebrata penyebar buah dan memperkaya produksi biji setempat (Guevara 1986, Hietz-Seifert et al. 1996). Melindungi atau menanam spesies tersebut di dekat lokasi yang tidak ditebang dapat mempercepat pemulihan di lokasi yang telah rusak.

Sejumlah pohon, terutama ara (Ficus spp.), sangat penting bagi satwa liar, karena pohon tersebut menyediakan buah sepanjang tahun (Heydon \& Bulloh 1997, Jordano 1983, Kinnaird et al. 1999, Lambert 1989b, c, d, 1990b, 1991, O’Brien et al. 1998a). Pohon-pohon tersebut memenuhi kebutuhan nutrisi satwa liar, seperti kalsium pada makanan yang miskin mineral (lihat O’Brien 1998). Namun, tegakan pohon ara yang tumbuh tersebar tidak menyediakan makanan sepanjang tahun, sehingga diperlukan daerah yang cukup luas dengan jumlah pohon yang cukup untuk pasokan. Sejumlah penelitian mengungkapkan terjadinya penurunan kerapatan pohon ara setelah kegiatan penebangan (Heydon \& Bulloh 1997; Johns 1983; Lambert 1990a; Leighton \& Leighton 1983). Hal ini menunjukkan bahwa penebangan menurunkan daya dukung hutan bagi spesies yang makanan utamanya buah-buahan tersebut.

Liana (tumbuhan merambat) memiliki peran ekologis yang sangat penting. Fungsi ekologis tersebut antara lain menekan regenerasi pohon dan meningkatkan mortalitas (kematian) pohon. Peran ini memiliki konotasi silvikultur yang negatif, namun demikian, liana juga mempengaruhi persaingan antar pohon sehingga mempengaruhi komposisi hutan (Schnitzer \& Bongers 2002). Liana juga merupakan sumber makanan yang bernilai tinggi bagi sejumlah satwa serta sejumlah masyarakat asli setempat. Selain itu, liana menjadi akses bagi satwa arboreal yang menggunakan liana untuk melintas dari tajuk satu ke tajuk lainnya (Emmons \& Gentry 1983, Putz \& Mooney 1991).

Putz (1984) menemukan bahwa sekitar 19\% liana dewasa bertahan hidup saat terseret oleh pohon yang tumbang. Ketahanan ini, ditambah dengan kemampuan untuk hidup di daerah yang terganggu, menjadikan liana sebagai jenis pembentuk koloni yang sukses di rumpang hutan. Di daerah tebangan, liana memberikan dampak terhadap tegakan pohon yang tersisa. Liana memperlambat laju pertumbuhan pohon, meningkatkan jumlah kematian dan kerusakan pohon saat proses penebangan, dan menyebabkan batang pohon membengkok. Distorsi ini kemudian dapat menurunkan nilai pohon sebagai kayu dan konsekuensinya, para pakar kehutanan dan pakar ekologi hutan merekomendasikan liana untuk dikelola secara aktif melalui pemotongan secara periodik dan sebelum pohon dipanen. Namun demikian, karena memiliki nilai ekologi yang tinggi bagi satwa dan masyarakat setempat, Schnitzer dan Bongers (2002) menyarankan bahwa pemotongan liana harus dilakukan secara selektif dan dilakukan pohon per pohon. 
Memanipulasi komposisi hutan berimplikasi terhadap herbivora. Meskipun kimiawi vegetasi sangat kompleks (Gartlan et al. 1980, Waterman 1983, Waterman et al. 1988), pandangan umum menyebutkan bahwa spesies yang tumbuh dengan perlahan serta berkayu padat seperti Eusideroxylon zwageri secara umum memiliki ketahanan yang lebih baik terhadap gangguan satwa penjelajah serta tidak banyak memberikan sumber makanan bagi vertebrata. Hal ini berlawanan dengan spesies tumbuhan yang tumbuh dengan cepat serta berkayu lebih ringan (Gartlan et al. 1980, Janzen 1979, Loehle 1988, Sheil \& van Heist 2000).

Musim berbuah menunjukkan pola yang kurang lebih sama, meskipun generalisasi tersebut memiliki sejumlah besar pengecualian. Spesies perintis yang berukuran kecil secara umum menyebarkan bijinya melalui angin atau burung (Loiselle et al. 1996). Spesies yang berumur lebih panjang serta tumbuh dengan cepat seperti Sapotaceae dan Moraceae menghasilkan buah berukuran besar dan berdaging. Sejumlah spesies yang hidup di bawah naungan memiliki biji yang disebarkan melalui gravitasi. Hal ini berarti bahwa dalam situasi tertentu, buah dan vegetasi yang dapat dimakan oleh satwa generalis (tidak memiliki preferensi khusus) kelimpahannya kurang di hutan berumur tua. Di lain pihak, wilayah yang terganggu atau memiliki banyak tumbuhan muda dapat mendukung kepadatan vertebrata yang lebih tinggi dibandingkan dengan daerah hutan tua. Hal ini bergantung pada kondisi dan variabel lingkungan seperti umur hutan, keanekaragaman hayati vegetasi, tipe habitat, luas dan intensitas gangguan, serta pertumbuhan tanaman herba di areal yang ditebang habis.

Beberapa spesies yang hidup di bawah pohon dan celah menghasilkan buah beberapa kali dalam setahunnya bila mendapatkan cahaya yang baik (contohnya sejumlah Rubiaceae dan Moraceae). Sementara spesies klimaks di hutan dewasa (seperti Dipterocarps) menghasilkan buah sekali setahun atau kurang dari sekali setahun (Whitmore 1998). Tidak semua gangguan membawa manfaat karena sejumlah spesies perintis (contoh Trema spp.) tidak menghasilkan buah yang bisa dimakan. Selain itu, harus ditekankan bahwa hutan primer bisa sangat produktif bagi sejumlah ragam vertebrata. Sementara spesies spesialis yang bergantung pada hutan tua lebih rentan terhadap gangguan dan pemusnahan. Spesies ini memiliki status konservasi yang lebih tinggi sehingga harus dipertimbangkan dalam pengelolaannya.

Populasi yang kecil dan terisolasi di dalam bentang alam yang terfragmentasi atau telah dipanen secara besar-besaran memiliki risiko penurunan reproduksi, kondisi genetis yang memburuk, dan kepunahan karena episode yang sifatnya stokastik (Nason \& Hamrick 1997). Bahkan dalam kondisi tidak terisolasi sekalipun tepian hutan yang baru terbentuk dapat secara nyata mempengaruhi dinamika individu, populasi, serta komunitas (Augeri 1995, Whitmore 1997, Wiens 1997). Adanya celah/bukaan kanopi dan jalan sarad menunjukkan bahwa hutan yang luasnya beribu-ribu hektar sekalipun dapat didominasi oleh pengaruh tepi (edge effects) setelah penebangan (Augeri 1995, Chen et al. 1992, Harrison \& Bruna 1999, Wiens 1989, 1992).

Sejumlah penelitian mengungkapkan bahwa pengaruh penebangan dalam jangka panjang dapat meluas ke hutan primer di sekelilingnya (Lovejoy et al. 1986, Augeri 1995, Laurance \& Bierregaard 1997, Bierregaard et al. 2001). Pengaruh tersebut membentuk iklim mikro yang khas dan spesifik yang kemudian akan berpengaruh pada spesies tumbuhan dan satwa melalui penurunan produksi biji, proses berbunga 
dan berbuahnya pohon (Laurance 2001, Rankin-De Merona \& Hutchings 2001). Efek tepian seperti perubahan iklim mikro, peningkatan turbulensi angin dan cahaya matahari akan mempengaruhi flora dan fauna yang hidup beratus-ratus meter dari tepi sampai ke dalam hutan (Chen et al. 1992, Laurance 1999, Lovejoy et al. 1986, Wiens 1992). Laurance (2001) melaporkan bahwa pohon besar di Amazon (diameter $>60 \mathrm{~cm}$ ) sangat rentan terhadap efek tepi yang dapat mempengaruhi dalam jarak $500 \mathrm{~m}$ lebih dari jarak tepian hutan yang terfragmen tersebut (Laurance komunikasi pribadi). Sebagai konsekuensinya, proses biologi serta individu dan spesies yang hidup di bagian/kantung hutan (forest patch) tersebut dapat terpengaruh pula (Forman $\&$ Moore 1992, Gosz 1991, Lovejoy et al. 1986, Wiens 1992). Perburuan di bagian hutan yang terfragmentasi juga menimbulkan pengaruh yang lebih besar terhadap hidupan liar.

\section{Keterbatasan produktivitas}

Sebagian besar wilayah Borneo memiliki tanah yang miskin, terutama Malinau bagian hulu, memiliki unsur hara tumbuhan yang rendah (Basuki \& Sheil 2005). Meskipun sering diabaikan, sudah banyak diketahui bahwa hutan yang tumbuh di atas tanah yang miskin secara umum menyediakan sedikit saja bahan pakan bagi herbivora generalis (Cebrián 1994, Coley 1987, Coley et al. 1985, Edwards 1989, Loehle 1988). Hal ini terlihat dengan jelas pada hutan Dipterokarpa. Pohon-pohon yang mendominasi ini tidak beraturan musim berbuahnya dan memiliki dedaunan yang lebat (Janzen 1974). Hal ini kemungkinan karena pada tahap anakan selama bertahun-tahun berada di bawah naungan pohon dan memerlukan perlindungan dari hewan penjelajah untuk tumbuh menjadi pohon besar.

Sumber makanan yang jumlahnya sedikit menyebabkan rendahnya kepadatan populasi herbivora, yang kemudian dapat menentukan pola keberadaan karnivora besar. Meijaard (2004) mengungkapkan bahwa di Taman Nasional Kayan Mentarang, biomassa satwa berkuku belah adalah $107 \mathrm{~kg} / \mathrm{km}^{2}$ (Yeager 1999), sementara di Taman Nasional Bukit Barisan di Sumatera Selatan, biomassa ini mencapai $631 \mathrm{~kg} /$ $\mathrm{km}^{2}$ (O'Brien et al. 2003), dan di Taman Nasional Ujung Kulon di Jawa besaran ini mencapai $492 \mathrm{~kg} / \mathrm{km}^{2}$ (Hoogerwerf 1970).

Dengan pola yang mirip, biomassa primata di Borneo adalah $300 \mathrm{~kg} / \mathrm{km}^{2}$, sementara di Sumatera dan Semenanjung Malaya mencapai lebih dari $800 \mathrm{~kg} / \mathrm{km}^{2}$, serta di daerah di Afrika besaran ini mencapai lebih dari $2000 \mathrm{~kg} / \mathrm{km}^{2}$. Satu-satunya famili kucing-kucingan di Borneo adalah macan tutul pohon (Neofelis nebulosa), sementara di Sumatera ada macan tutul pohon dan harimau (Panthera tigris), dan di Jawa hidup macan tutul (Panthera pardus) dan harimau yang menurut Meijaard (2004) hal ini disebabkan kurangnya kepadatan hewan pemangsa tingkat tinggi di Borneo. Payne (1990) mengungkapkan pula bahwa hutan di Semenanjung Malaya mendukung 5 hingga 10 kali lipat jumlah monyet dibandingkan dengan hutan di Sabah.

Dalam lingkungan dengan keterbatasan unsur hara tersebut, potensi penurunan jumlah satwa liar menjadi lebih besar. Ada sejumlah penelitian yang menyatakan bahwa pemanenan kayu sering menyebabkan hilangnya lapisan tanah atas yang 
memiliki jumlah unsur hara biologis yang tinggi, erosi, dan percepatan perembesan bahan nutrisi tersebut (Douglas et al. 1993). Tambahan hilangnya unsur hara terjadi saat biomassa dipindahkan atau diambil—seperti saat pohon diangkat dalam penebangan. Unsur hara dan mineral yang diambil merupakan bagian yang sangat kecil saja dari masa kayu, namun terjadi akumulasi pengambilan unsur hara ini. Saat unsur hara baru memasuki sistem, seperti dari batuan atau sedimen baru, hilangnya bahan nutrisi tersebut tidak menjadi masalah-namun masukan seperti itu sering kali sangat sedikit (seperti di hulu Malinau). Tentu saja, pengangkatan/pengambilan biomassa akan berpengaruh terhadap sejumlah kumpulan unsur hara (lihat Nykvist et al. 1994, untuk informasi mengenai perkiraan jumlah bahan nutrisi yang hilang akibat penebangan pohon di Sabah).

Contoh mengenai kalsium di sini menggambarkan kompleksitas yang lebih luas dari perubahan pasokan dan aliran unsur hara di hutan yang rusak. Kalsium biasanya dipandang sebagai mineral kunci dalam perkembangan sejumlah besar spesies vertebrata (O’Brien 1998) dan kalsium juga merupakan faktor kunci dalam perhitungan kelimpahan vertebrata yang rendah di Malinau. Di Borneo, hilangnya hutan dinyatakan sebagai penyebab penurunan kalsium (Nykvist 1998, mengulas data dari berbagai lokasi dan mengimplikasikan bahwa percabangan dengan diameter lebih besar dari $20 \mathrm{~cm}$ di satu lokasi di Sabah mengandung sekitar 20\% dari kalsium yang tersedia). Peningkatan suhu tanah (yang terjadi saat hutan dibuka) bisa mempercepat hilangnya kalsium (Innes 1993). Jamur pengurai material berkayu bisa menimbun kalsium dan fosfor sehingga secara temporer dapat mengurangi ketersediaan kedua unsur tersebut bagi organisme yang lain (hal ini berlaku juga pada magnesium, mangan, tembaga, besi, dan nitrogen-Coleman \& Crossley 2003, Kurek 2002). Perubahan ketersediaan nutrisi termasuk penurunan kalsium dan penimbunan nitrogen secara perlahan akan berpengaruh terhadap pertumbuhan dan komposisi hutan dalam jangka panjang.

\section{Sistem silvikultur}

Hutan Dipterokarpa di Asia Tenggara dianggap sebagai salah satu hutan yang berpotensi untuk berhasil dalam pengelolaan hutan berkelanjutan. Appanah (1998) menyatakan bahwa: "Bila ternyata ada hutan tropis yang mungkin bisa dikelola, yang paling mungkin adalah hutan Dipterokarpa”. Alasannya antara lain adalah laju pertumbuhan yang tinggi, pasokan/persediaan spesies komersial yang melimpah, dan ekologi regenerasi yang sesuai bagi pembukaan kanopi/tajuk (Appanah 1998). Dari sudut pandang produksi kayu yang berkelanjutan, upaya untuk mencapai kemungkinan ini memiliki tingkat keberhasilan yang beragam (Appanah \& Turnbull 1998).

Ulasan mengenai sistem silvikultur di sini sebagian besar diambil dari Appanah (1998) dan Sist et al. (2003a, b). Hutan Dipterokarpa Malesia Barat (Malesia: Kawasan yang membentang dari barat ke timur sepanjang garis khatulistiwa mulai dari sebelah selatan tanah genting Kra di Semenanjung Malaya terus ke nusantara sampai ke kepulauan Solomon) merupakan hutan tropis yang paling produktif di Asia dengan nilai kayu yang tinggi. Sebagai contoh, dari 41 juta hektar konsesi hutan 
di Indonesia, 43\% di antaranya merupakan hutan primer, dan 27\% dari hutan bekas tebangan dianggap sebagai hutan dengan kondisi sedang hingga bagus. Spesies-spesies dari famili Dipterokarpa merupakan kelompok terbesar yang dimanfaatkan sebagai kayu komersial. Volume yang diambil bervariasi mulai dari $50 \mathrm{~m}^{3} /$ ha hingga 100 $\mathrm{m}^{3} /$ ha (Sist et al. 1998b).

Dipterocapaceae (Dipterokarpa) merupakan famili dominan yang mewakili $25 \%$ batang (120 batang dengan diameter lebih besar dari $10 \mathrm{~cm} / \mathrm{ha}$ ), dengan batang berukuran besar mencakup 75 hingga $80 \%$ tajuk dan pohon-pohon besar, serta mencakup setengah dari seluruh bidang dasar pohon $\left(15 \mathrm{~m}^{2} / \mathrm{ha}\right)$.

Malayan Uniform System (MUS - sistem uniform Malaya, untuk selanjutnya disebut MUS), diperkenalkan pada tahun 1948 (Wyatt-Smith 1963)), merupakan salah satu sistem silvikultur yang paling awal. MUS mencakup penebangan pohon dengan diameter setinggi dada (dbh) di atas $45 \mathrm{~cm}$, dan mematikan semua (poison girdling) pohon cacat serta spesies nonkomersial hingga lima $\mathrm{cm}$ dbh dengan menggunakan racun. Hal ini kemudian diikuti dengan perlakuan "pembebasan" yaitu membersihkan tumbuhan bawah dan memotong liana dalam kurun 20,35, dan 35 tahun setelah penebangan. Perlakukan ini ditujukan untuk mengubah hutan campuran yang tidak merata umurnya menjadi hutan dengan umur tegakan yang merata.

Pada pertengahan tahun tujuh puluhan, sejumlah hutan dataran rendah di Semenanjung Malaya dipanen dan di beberapa tempat hutan tersebut diubah menjadi perkebunan. Pemanenan seterusnya beralih ke hutan perbukitan. Di daerah yang lebih curam tersebut MUS dianggap tidak sesuai karena regenerasinya tidak merata. Meskipun MUS diadaptasi (menjadi Modified Malayan Uniform System) guna melakukan pengkayaan tanaman bila regenerasi alam buruk, hasilnya seringkali tidak memuaskan sehingga pendekatan tersebut ditinggalkan.

Di akhir tahun tujuh puluhan, dikembangkan sistem pengelolaan secara selektif (Selective Management System). Pendekatan ini mencakup penebangan semua spesies komersial dengan diameter setinggi dada lebih dari $45 \mathrm{~cm}$ untuk nondipterocarps dan lebih dari $50 \mathrm{~cm}$ bagi dipterocarps dengan pertimbangan tersedianya jumlah batang sehat yang layak bagi pemanenan selanjutnya 30 tahun kemudian (Appanah 1998). Berdasarkan pengalaman silvikultur Malaysia tersebut, negara-negara lainnya di Asia Tenggara mengembangkan dan menerapkan pendekatan daur ganda (polycyclic beragam umur) yang serupa dengan Selective Management System (Appanah 1998). Sistem ini seluruhnya mengacu pada batas diameter minimum.

Sistem penebangan dan penanaman kembali yang disebut sebagai "Tebang Pilih Tanam Indonesia" (TPTI, untuk penjelasan rinci lihat Lampiran 11) diterapkan di seluruh hutan Dipterokarpa Indonesia. Dalam sistem TPTI seluruh pohon komersial di atas $60 \mathrm{~cm}$ dbh dapat ditebang dalam kurun 35 tahun siklus penebangan. TPTI mensyaratkan penebangan yang menyisakan kerapatan pohon induk minimum sebanyak 25 pohon per hektar, yaitu spesies tegakan komersial yang baik $(20 \mathrm{~cm}$ dbh atau lebih). Bila hal ini tidak terpenuhi, harus dilakukan penanaman pengkayaan tiga tahun setelah penebangan. Perlakuan pembebasan dari seluruh tanaman rambat yang berkayu serta tegakan sapih (sapling) nonkomersial yang hidup di bawah naungan dilaksanakan dua, empat, dan enam tahun setelah penebangan. Kegiatan ini dimaksudkan untuk memperbaiki regenerasi dan pertumbuhan jenis pohon kayu. 
Perusahaan (HPH) terbebani biaya dalam menerapkan sistem TPTI ini. Kualitas perlakuan seringkali gagal untuk memenuhi tujuan awal TPTI. Contohnya, tujuan inventarisasi sebelum pemanenan adalah untuk memperoleh jatah tebangan tahunan (annual allowable cut/AAC). Namun, peta yang dihasilkan dari inventarisasi tersebut tidak digunakan untuk merencanakan jaringan jalan sarad. Kegiatan lain seperti kegiatan pembebasan setelah penebangan dan pengkayaan tanaman merupakan hal yang patut dipertanyakan.

Di hutan yang banyak kayunya (contohnya di Kalimantan Timur yang memiliki 16 hingga 23 batang kayu komersial per hektarnya), kegiatan tebang pilih sering merusakkan lebih dari 50\% tegakan. Hal ini mempengaruhi struktur hutan dan produktivitasnya, serta mengurangi ketersediaan volume kayu untuk sedikitnya 30 hingga 40 tahun. Keberlanjutan sistem ini banyak dipertanyakan (contohnya di Sabah: Kleine \& Heuveldop 1993, dan di Indonesia: Sist et al. 1998a, 2003a, b). Lebih dari 15 tahun belakangan ini, permintaan kayu terus berubah dan pemanenan kayu tidak terbatas pada Shorea spp. saja (spesies meranti). Hampir seluruh Dipterocarpaceae, kecuali Vatica spp., kini telah dianggap spesies komersial. Kecenderungan ini terus berlangsung dengan semakin bertambahnya spesies yang dianggap bernilai.

\section{Intensitas pengelolaan}

Ekologi hutan Dipterokarpa Asia Tenggara yang khas dan penerapan sistem silvikulturnya memiliki sejumlah aspek yang harus dipahami sebelum kita bisa membicarakan upaya perbaikan pengelolaan hutan tersebut. Salah satu aspeknya, yaitu intensitas relatif tebang pilih terhadap gangguan hutan. Fredericksen dan Putz (2003) dalam makalahnya baru-baru ini menyatakan bahwa gangguan dan kerusakan tidak harus dipandang sebagai masalah. Dengan mengacu pada sejumlah publikasi ilmiah, mereka mempertimbangkan bahwa dalam proses regenerasi jenis-jenis pohon bernilai kayu tinggi, diperlukan gangguan yang lebih besar daripada gangguan yang biasanya disebabkan oleh teknik penebangan berdampak rendah/ramah lingkungan. Alasan mereka adalah bahwa untuk mendukung tumbuhnya anakan dan mempercepat pertumbuhan spesies komersial yang membutuhkan intensitas cahaya tinggi, seringkali diperlukan dan perlu adanya pembentukan celah tajuk yang lebih besar. Fredericksen dan Putz mengusulkan peningkatan intensitas pengelolaan hutan agar bagian-bagian hutan yang belum ditebang dapat dipertahankan. Sebagaimana diungkapkan sebelumnya, mempertahankan konektivitas jaringan areal hutan sangat penting bagi ketahanan hidup dan kelayakan populasi satwa liar. Namun demikian, kami tekankan bahwa peningkatan intensitas penebangan seperti diusulkan oleh Fredericken dan Putz bukan cara yang terbaik untuk meningkatkan produktivitas dan mempertahankan hidupan liar di hutan Dipterokarpa (Sist \& Brown 2004).

Penebangan dan reproduksi pohon di Paparan Sunda berbeda dengan penebangan dan reproduksi pohon di Bolivia, tempat Fredericksen dan Putz melakukan penelitiannya. Yang pertama, tidak ada cadangan benih Dipterokarpa di Bolivia. Pohon-pohon Dipterokarpa hidup di bawah naungan pohon sebagai anakan dan sapihan kadang-kadang hingga puluhan tahun (Whitmore \& Brown 1996), menunggu terbukanya tajuk. Anakan dan sapihan ini sangat rentan terhadap 
kerusakan akibat alat-alat berat, penebangan, dan pemanenan. Anakan biasanya hanya tumbuh selang beberapa tahun saat berbuah, yaitu saat biji langsung berkecambah atau mati. Dengan demikian, pemeliharaan (keberadaan) hutan sangat bergantung pada pemeliharaan lapisan anakan dan sapihan, serta pemeliharaan kerapatan pohon benih yang memadai. Tetapi, penebang pohon biasanya mengarah kepada tegakan pohon benih karena tegakan memiliki kayu yang bernilai tinggi.

Banyak pohon yang mendapat manfaat dari bukaan tajuk, bahkan di beberapa bagian di wilayah tropis yang lembab hal ini perlu direncanakan sebagai "perlakuan". Namun demikian, di hutan Dipterokarpa di wilayah paparan Sunda, pembukaan tajuk bukan suatu masalah yang besar mengingat jumlah tebangan pohon per hektarnya lebih besar dibandingkan hutan di Amerika Selatan sehingga bukaan tajuk lebih lebar. Marsh dan Greer (1992, dalam Davies et al. 2001) melaporkan bahwa pemanenan kayu di Borneo mencapai lebih dari 10 batang/ha atau 70-130 $\mathrm{m}^{3}$ kayu/ha. Curran et al. (1999), Pinard dan Putz (1996) dan Sist et al. (1998a) melaporkan di beberapa tempat di Borneo bahwa laju pengambilan kayu mencapai 54 hingga $104 \mathrm{~m}^{3}$ kayu per hektarnya (Curran et al. 1999 mengungkapkan bahwa hanya $40-55 \%$ dari volume penebangan yang dilaporkan). Sebagian besar pohonpohon besar di Borneo adalah spesies berkayu (Sist et al. 2003b). Di Afrika, kayu yang dihasilkan jarang sekali mencapai lebih dari $13 \mathrm{~m}^{3}$ kayu/ha dengan 2 hingga 3 pohon yang diambil per hektarnya (CIFOR 2004), sementara di hutan Amazon, hasil kayu bahkan lebih sedikit jumlahnya (Davies et al. 2001). Dengan demikian, penebangan di hutan Asia Tenggara diperkirakan memiliki dampak yang lebih parah dengan kerusakan tajuk mencapai 62 hingga 80 \% (Johns 1989b).

Di Paparan Sunda pakar kehutanan seperti Fredericksen dan Putz (2003) tidak perlu mengusulkan peningkatan pembukaan tajuk. Pohon-pohon di hutan Dipterokarpa mampu beregenerasi secara alami tanpa penebangan (meskipun pohon tersebut merupakan spesies yang membutuhkan cahaya). Manfaat yang belum jelas dari peningkatan cahaya akibat penebangan harus juga mempertimbangkan besarnya kerusakan tegakan dan tumbuhan bawahnya. Pembukaan tajuk yang berlebihan dapat menghambat regenerasi karena tanaman merambat dan semak belukar akan menutupi lokasi regenerasi tersebut. Di Bolivia, ada sejumlah bukti yang menunjukkan bahwa pembukaan lahan menggunakan mesin bermanfaat bagi regenerasi (Fredericksen \& Putz 2003). Namun tidak demikian di Asia Tenggara. Di Paparan Sunda, hampir seluruh mesin yang digunakan merupakan alat berat, karena kayu gelondongan yang dihasilkan biasanya berukuran besar, serta sebagian besar tanah bersifat sangat rentan. Penggunaan mesin dapat menimbulkan pemadatan tanah yang parah yang menghambat pemulihan (Hutchings et al. 2002). Pembukaan tajuk yang terlalu banyak serta penggunaan alat-alat berat membuat erosi sulit untuk dihindari. Memelihara jalur air agar tetap bersih, serta mencegah tumbuhan bawah agar tidak meluas menjadi sangat sulit. Rekomendasi peningkatan intensitas penebangan bukan pilihan yang baik di wilayah Sunda yang memiliki daerah tebang pilih yang paling intensif di daerah tropis. 


\section{Pembebasan dan pembersihan tumbuhan bawah}

Dalam hukum dan peraturan TPTI, pemilik konsesi disyaratkan untuk memotong seluruh tumbuhan bawah dan tumbuhan pemanjat selama beberapa tahun setelah penebangan (lihat Lampiran 11, kegiatan ini dinamakan pembebasan dan penjarangan). Hal ini ditujukan untuk mengendalikan gulma/belukar yang agresif dan mendorong regenerasi hutan. Namun dalam kenyataannya, kegiatan ini berpengaruh buruk bagi sejumlah spesies tumbuhan, termasuk rotan dan anakan pohon berkayu (Sheil 2003a, Sheil et al. 2003b), serta sejumlah spesies mamalia dan burung terestrial. Sayangnya pada umumnya para konservasionis tidak memahami kondisi ini dan kegiatan ini belum pernah dikaji. Sehingga kesimpulan yang kami ambil masih terbatas pada observasi langsung dan hasil evaluasi kami sendiri (Sheil et al. 2003a, b, Sist et al. 2003a). Berdasarkan observasi yang kami lakukan di Malinau, ada beberapa dampak penebangan yang memerlukan perhatian (Sheil et al. 2003b).

Hal yang perlu menjadi perhatian adalah, tertutupnya akses areal yang ditebas untuk penebangan karena lokasi yang miring dan terjal, sehingga sering terjadi di lebih dari separuh areal tebangan tidak ditebang setelah pemanenan "selesai". Sebaliknya, perlakuan penebasan (slashing) dilakukan dengan berjalan kaki tanpa ada daerah yang terlewat, sehingga dampak lebih jelas terlihat pada 'areal bekas tebangan' (Sheil pengamatan pribadi, 1998-2003). Sekalipun teknik silvikultur ini dilaksanakan secara benar, namun manfaat yang diperoleh terbatas. Sementara dampak terhadap keanekaragaman hayati dan komunitasnya cukup besar. Dampak hilangnya tumbuhan bawah hutan antara lain adalah hilangnya spesies satwa pemakan daun (browser), mengeringnya serasah daun, hancurnya mikroorganisme tumbuhan bawah, serta meningkatnya jarak pandang (meskipun belum jelas apakah hal ini akan menguntungkan mangsa atau pemangsa). Kami berpendapat bahwa penebasan tumbuhan bawah dan tumbuhan merambat bisa merusak hutan seperti halnya penebangan kayu.

\section{Bentang alam (lansekap) bekas tebangan dan terfragmentasi}

Berbagai aspek pemanenan kayu dan pengembangan konsesi memberikan dampak yang berbeda terhadap bentang alam, habitat, dan daur hidup spesies endemik. Dalam konsesi hutan, pengaruh tersebut timbul secara bersamaan sehingga sulit untuk mengidentifikasi penyebab utama perubahan kelimpahan spesies tanpa suatu penelitian yang mendalam. Meskipun demikian, ada sejumlah pemahaman mengenai berbagai proses tersebut.

Selain mengambil pohon kayu pilihan, isu yang menjadi perhatian adalah kerusakan terhadap pohon yang tersisa, penyumbatan sungai oleh limbah tebangan, pemadatan tanah, peningkatan erosi dan banjir (DFID 1999). Peningkatan akses ke dalam hutan ini menimbulkan ancaman yang lebih besar bagi penebangan selanjutnya, pembukaan untuk penggunaan lahan lain, serta peningkatan tekanan perburuan (Robinson \& Bennett 2000). Sebagian isu tersebut didiskusikan dengan lebih rinci pada bagian berikut. Perencanaan dan pelaksanaan penebangan yang tidak dirancang dengan baik dapat menyebabkan keterbukaan areal yang luas, 


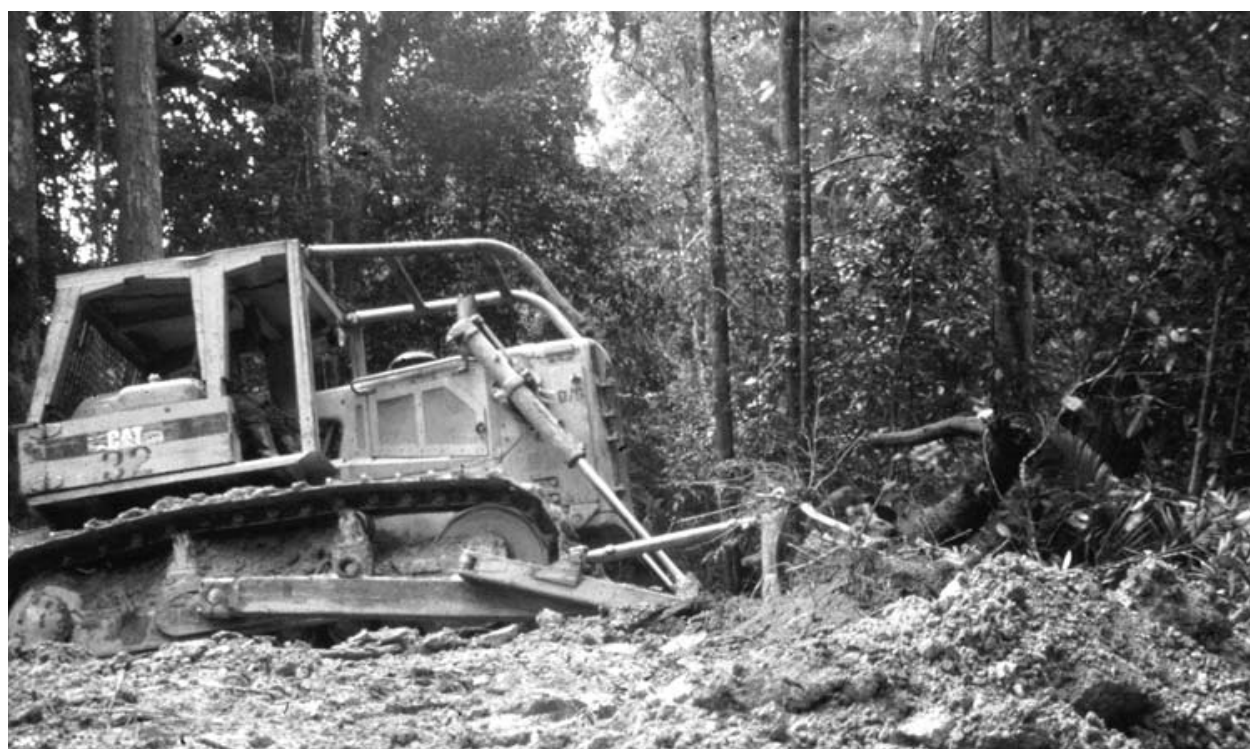

Gambar 4. Jalan dan penggunaan alat berat menyebabkan fragmentasi dan menimbulkan gangguan tanah yang parah dan erosi. (Foto oleh Rob Fimbel)

terfragmentasi, serta tidak produktif, terutama di hutan dengan kepadatan jalan yang tinggi, daerah bukaan yang lebar, dan pembukaan areal yang sifatnya coba-coba (Putz et al. 2000, 2001a, b).

Jalan dan jalan sarad memberikan sumbangan yang cukup besar terhadap hilangnya tajuk saat penebangan. Sebagai contoh, di Queensland, Australia, jalan menjadi penyebab 21.8\% dari hilangnya tajuk secara total (Crome et al. 1992, dalam Malcolm \& Ray 2000). Dalam penelitian yang lain, terungkap bahwa 40-50\% kematian dan kerusakan pohon setelah penebangan terkait dengan jalur pengangkutan (Johns et al. 1996, Webb 1997, White 1994). Penelitian di Neotropics (daerah hutan hujan tropis di Amerika Tengah dan Selatan) tentang topografi menunjukkan bahwa perencanaan jaringan pemanenan kayu yang berbentuk "pola tulang ikan" dengan penempatan lokasi pengumpulan kayu sesuai dengan jalur pemanenan sebelumnya dapat memperbaiki pengaruh ekologi yang negatif dari tebang pilih dibandingkan dengan pembuatan jalur yang tidak direncanakan (Johns et al. 1996).

Penelitian di MRF menyimpulkan bahwa menurunkan dampak pembuatan jalan dapat meningkatkan produktivitas konsesi (Dwiprabowo et al. 2002, Sist et al. 2003b). Pinard et al. (2000) melaporkan temuan serupa dari Sabah, yaitu wilayah yang jalan dan jalur tebangnya diturunkan dari 17\% (metoda penebangan konvensional) hingga 6\% menggunakan teknik penebangan berdampak minimal (RIL) yang dilakukan secara benar. Di petak yang ditebang secara konvensional dalam penelitian CIFOR di Malinau, perbandingan pohon yang mati akibat penyaradan dua kali lipat daripada pohon mati akibat penumbangan (Sist et al. 2003b).

Selain memperkirakan dampak terhadap habitat, satwa liar juga dipengaruhi oleh jalan, jalur tebang, dan hutan yang dikonversi untuk penggunaan lain. Isu utamanya adalah berkurangnya konektivitas hutan, penurunan luas habitat, dan peningkatan aksesibilitas yang lebih jauh meningkatkan tekanan perburuan, serta 
menghambat regenerasi hutan (Pinard et al. 1996, 2000). Dalam hal ini, fragmentasi hutan memberikan dampak ekologi yang sangat besar. Hubungan antara faktor-faktor tersebut dengan hutan di Borneo belum jelas, karena belum jelas terungkap apa yang dimaksud dengan degradasi dan hilangnya habitat, matriks, dan konektivitas (Jules \& Shahani 2003). Meskipun banyak yang belum diketahui jawabannya, hubungan tersebut tentunya bergantung pada taxa yang dimaksud, pergerakan dan persistensi spesies.

Fragmentasi masih merupakan topik penelitian yang aktif di wilayah subtropis dan neotropis, namun informasi yang tersedia dari Asia relatif sedikit (Laurance \& Bierregaard 1997, O’Brien et al. 1998b, Sitompul et al. in press, Turner 1996, Turner et al. 1996). Meskipun demikian, ada sejumlah hubungan yang dapat diterima secara umum. Dalam jangka panjang, areal berukuran kecil yang terisolasi di dalam hutan tidak dapat mendukung spesies dengan jumlah yang sama banyaknya dengan yang ada di areal dengan luasan sama, namun berada di kawasan hutan yang lebih besar (Brook et al. 2003, Harris 1984, Harris \& Silva-Lopez 1992, Laidlaw 2000).

Sejumlah spesies memerlukan koridor di antara fragmen-fragmen hutan, namun koridor tersebut harus memenuhi kondisi ekologis tertentu sehingga layak untuk penyebaran satwa. Sebagai contoh, pengaruh fragmentasi dapat dikurangi bila jarak antar bagian-bagian hutan yang utuh relatif pendek. Khususnya satwa liar yang rentan terhadap fragmentasi habitat tidak akan menyeberangi daerah terbuka dan bahkan akan menghindari tepi hutan (Augeri 1995, Kinnaird et al. 2003, Woodruffe \& Ginsberg 1998, 2000). Contohnya, Newmark (1991) mengungkapkan bahwa ukuran lebar koridor hutan setidaknya 200 m untuk pergerakan burung-burung hutan Afrika Timur yang sensitif (Beier \& Noss 1998). Sehingga penelitian menyoroti pentingnya habitat yang mirip dengan hutan dalam bentang alam yang terganggu (Gascon et al. 2000, Kinnaird et al. 2003, Laurance \& Bierregaard 1997, Wiens 1989).

Beberapa spesies memiliki persyaratan luasan minimum habitat atau hutan untuk dapat mempertahankan populasinya (O’Brien et al. 1998b). Di Malaysia contohnya, karnivora dan herbivora terestrial berukuran besar hanya bisa diamati di fragmen hutan yang lebih besar (lebih dari $6.551 \mathrm{ha}$ ). Selain itu, keanekaragaman spesies menurun secara tajam antara fragmen hutan yang berukuran 459 ha dibandingkan dengan yang berukuran 164 ha (Laidlaw 2000). Pengaruh fragmentasi terhadap satwa terbang nokturnal (termasuk pollinator/penyerbuk dan penyebar biji) lebih kecil dibandingkan dengan spesies diurnal. Contohnya, ngengat tidak terlalu peka dibandingkan dengan kupu-kupu atau kelelawar dibandingkan burung (Daily \& Ehrlich 1996). Fragmen-fragmen hutan juga lebih rentan terhadap kebakaran (Buechner \& Dawkins 1961), invasi spesies gulma/belukar, serta proses erosif lainnya (Gascon et al. 2000).

\section{Karakteristik (gambaran) bentang alam}

Sejumlah spesies bergantung pada lokasi atau habitat yang khusus dan hal ini harus diidentifikasi karena kerusakan hutan bisa memberikan dampak negatif bagi spesies tersebut. Di Malinau, lokasi tersebut termasuk lokasi dimana satwa berkumpul untuk menjilati rembesan mata air yang mengandung mineral ("salt spring" atau 
"salt licks"). Meskipun lokasi-lokasi khusus tersebut banyak dipelajari di daerah lain di dunia (Klaus et al. 1998) namun di Malinau belum banyak dipahami. Tempattempat khusus tersebut seringkali hancur karena jalan sarad kayu padahal penduduk asli memahami dengan baik pentingnya lokasi yang merupakan tempat berburu satwa. Genangan air, kubangan, dan habitat di tepi sungai yang merupakan tempat bersarang bagi reptil dan amfibia juga memerlukan perlindungan.

Kolam (genangan air) atau kubangan (Gambar 5) relatif mudah ditemui di hutan, namun informasinya sedikit sekali diketahui. Banyak kolam di Kalimantan terkait dengan penggalian oleh babi, meskipun mamalia yang lain seperti Sambar (Cervus unicolor) juga memanfaatkan kubangan-kubangan tersebut. Babi berjanggut tidak memiliki kelenjar keringat sehingga mendinginkan badannya dalam air yang berlumpur (Curtis 1983, van Putten 2000). Kubangan bisa dikaitkan dengan pencarian cacing atau sejumlah mineral tanah. Kubangan dan kolam sering kali berada tepat di bawah puncak bukit, atau cekungan yang terbentuk secara alami. Sifat drainase tanah juga menentukan lokasi genangan air. Luas rata-rata kolam dan kubangan di Malinau adalah $13,9 \mathrm{~m}^{2}(\mathrm{SD}=27.1 ; \mathrm{n}=43$, Setyawati, tidak dipublikasikan). Sejumlah kolam mencapai luas $165 \mathrm{~m}^{2}$ dan kedalamannya menunjukkan bahwa Banteng (Bos javanicus) atau Badak (Dicerorbinus sumatrensis) kemungkinan ikut menyebabkan terbentuknya kolam tersebut (Wulfraat pengamatan pribadi). Kubangan merupakan lokasi penting bagi vertebrata yang lain, seperti untuk lokasi pemijahan amfibia, namun diperlukan kajian lebih lanjut. Kegiatan berkubang dan menggali ini dapat meningkatkan erosi tanah dan mengubah kualitas air di sungai dan kolam air alami (Hone 2002), dan lebih lajut akan mempengaruhi satwa akuatik.

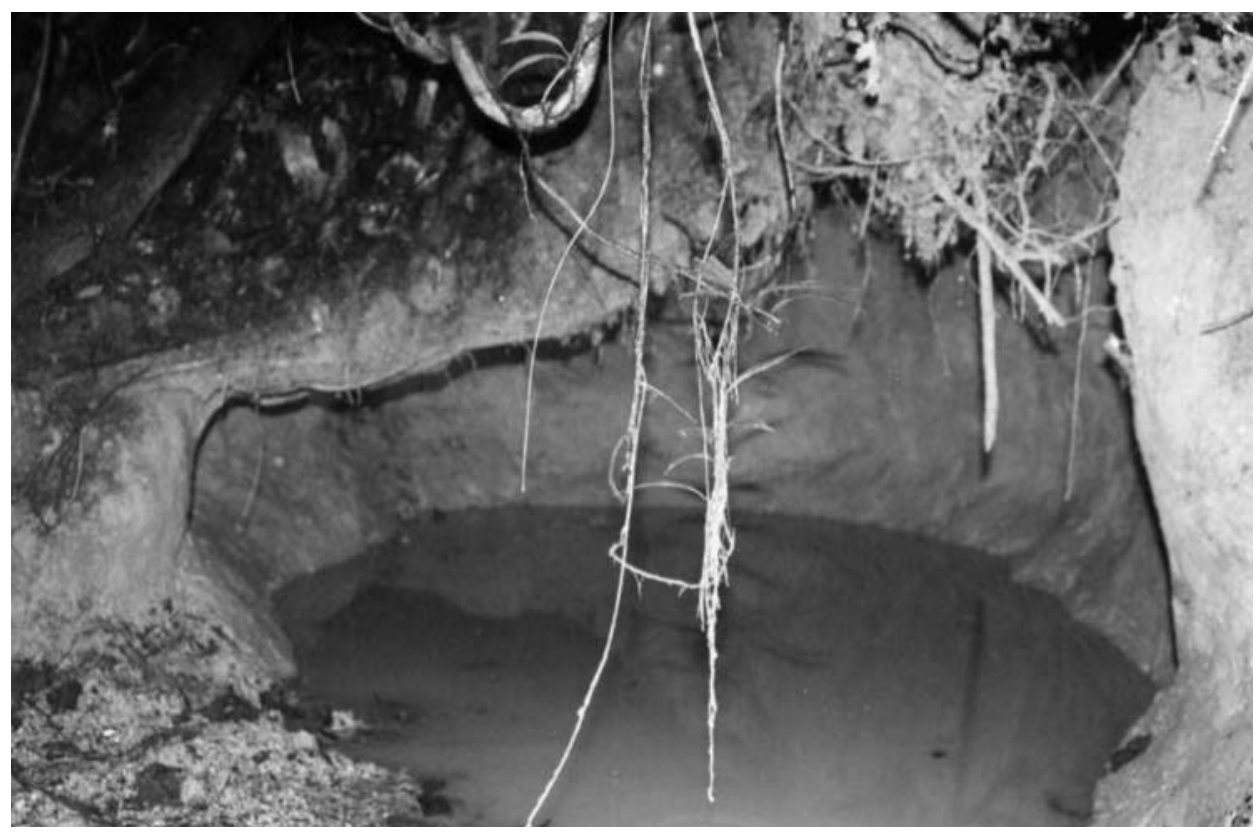

Gambar 5. Kubangan yang dalam di MRF. (Foto oleh Titiek Setyawati) 
Jalan yang dibangun secara sembrono juga membentuk kolam, dan pengaruhnya sangat nyata di sepanjang jalan sarad di Kalimantan. Sejumlah pihak berpendapat bahwa pengaruhnya hanya bersifat lokal. Di sejumlah kasus, beberapa hektar pohon mati dan kolam yang luas tersebut menjadi tempat nyamuk dan hama lain berkembang biak. Rachmatika et al. (2005) mengungkapkan beberapa perubahan dalam komunitas ikan yang berkaitan dengan kolam tersebut. Diperlukan suatu kajian untuk melihat dampak ekologis yang lebih luas.

\section{Ancaman perburuan}

Perburuan merupakan ancaman yang lebih besar terhadap satwa dibandingkan pemanenan kayu di banyak daerah tropis lembab (contohnya Auzel \& Wilkie 2000, Bennett et al. 2002, Linkie et al. 2003, Mathews \& Matthews 2002, Robinson \& Bennett 2000, Walsh et al. 2003, Wilkie \& Carpenter 1999). Ancaman perburuan terhadap satwa liar seringkali lebih besar dibandingkan dengan ancaman akibat hilangnya habitat (Bennett et al. 2002, untuk daerah yang tidak terlalu terpengaruh lihat Hedges et al. in prep., Kinnaird et al. 2003, Robertson \& van Schaik 2001).

Banyak vertebrata berukuran besar di Borneo dan beberapa spesies satwa khas buruan seperti penyu, buaya, dan beberapa spesies burung tertentu banyak diburu hingga hampir punah (Bennett et al. 1997, 1999, Bennett \& Robinson 2000, Robinson et al. 1999). Perburuan yang berlebihan mengubah kepadatan populasi, distribusi, dan demografi hidupan liar yang lebih lanjut dapat menyebabkan peralihan dalam penyebaran biji, konsumsi daun-daunan, kompetisi, pemangsaan, dan dinamika komunitas yang lain.

Meskipun daerah perlindungan ditetapkan pada lokasi hutan yang sebagian besar belum tersentuh oleh penebangan, banyak daerah perlindungan (cagar) tersebut menjadi "hutan kosong" (Redford 1992). Contoh dapat ditemui di Taman Nasional Kayan Mentarang. Dalam suatu penelitian singkat, diindikasikan bahwa setelah beberapa tahun perburuan tak terkendali terjadi, populasi primata mengalami penurunan meskipun hutan yang ada hampir tidak tersentuh oleh penebangan (Nijman in press). Perburuan merupakan ancaman besar di hutan tropis Asia dan khususnya Borneo, karena satwa liar yang dapat dimakan sangat jarang didapat (Bennett et al. 2002).

Paling tidak hingga tahun tujuhpuluhan, perburuan di Borneo bersifat lestari/ berkelanjutan, kecuali perburuan Badak Sumatera (Dicerorbinus sumatrensis), yang memang telah turun populasinya menginjak tahun tiga puluhan (NVIN 1939). Pada tahun-tahun sesudahnya sejumlah faktor mengalami perubahan yang dramatis yang menyebabkan peningkatan tekanan perburuan yang cukup besar serta penurunan populasi sejumlah spesies vertebrata. Di Borneo, penurunan ini terjadi pada populasi Sambar, Muncak, Babi hutan, rangkong, sejumlah primata seperti Orangutan, dan kemungkinan juga Beruang Madu dan Macan Dahan (Bennett et al. 1999).

Ada perbedaan yang besar dalam peta distribusi mamalia Borneo berukuran besar yang tampaknya tidak dipengaruhi oleh kesesuaian habitat. Keberadaan suatu spesies yang mempunyai hubungan dekat bisa dijelaskan dengan terjadinya kompetisi antar spesies yang menyebabkan pengasingan spesies tersebut (contohnya, sejumlah tupai 
Callosciurus dan monyet daun Presbytis). Meskipun hubungan antara kimia tanah dan tumbuhan serta distribusi spesies masih belum terbukti, ketersediaan mineralmineral tertentu dapat juga menjelaskan sejumlah pola keberadaan (presencelabsence) (Payne 1990). Hal ini merupakan faktor yang perlu dipertimbangkan sebagai dampak perburuan.

Meskipun belum ada penelitian yang komprehensif, tekanan perburuan di beberapa tempat di Borneo beragam intensitasnya. Di Sabah, terdapat perbedaan yang besar antara hutan di daerah timur yang kaya keanekaragaman hayatinya dimana terdapat banyak mamalia berukuran besar dengan kepadatan yang lebih tinggi (termasuk gajah, elephants Elephas maximus, Badak Sumatera D. sumatrensis, Orangutan Borneo Pongo pygmaeus, dan Banteng Bos javanicus) dengan hutan di daerah barat dimana tidak ditemukan species-species tersebut. Secara umum dapat dikatakan bahwa hal ini terjadi karena alasan-alasan budaya dan religius. Tekanan perburuan di hutan bagian timur lebih rendah dibandingkan daerah hutan bagian barat yang budaya perburuan penduduk aslinya kuat.

Dengan pola yang mirip, paling tidak sebelum deforestasi terjadi, kepadatan Orangutan yang paling tinggi di Kalimantan terdapat di sepanjang pesisir. Penduduk di pesisir pantai sebagian besar adalah petani penganut agama Islam, dan sangat jarang mengkonsumsi primata. Sebaliknya, penduduk asli yang hidup sebagai masyarakat pemburu-pengumpul dan petani ladang berpindah di bagian pendalaman sebagian besar beragama Kristen (Rijksen \& Meijaard 1999).

Namun, hubungan antara tekanan perburuan dan persebaran spesies masih harus dibuktikan dan tentunya tidak dapat menjelaskan seluruh pola distribusi yang menyimpang. Kenyataannya, sejumlah faktor yang ada tersebut kemungkinan besar saling berinteraksi. Antara lain:

- Kesuburan tanah di Borneo secara umum rendah (dibandingkan, misalnya, dengan pulau-pulau vulkanik di Jawa dan Sumatera) yang menyebabkan rendahnya kepadatan satwa;

- Variasi kimia tanah berpengaruh terhadap kepadatan satwa serta potensi sebagai lahan pertanian. Yang terakhir ini menyebabkan gaya hidup pertanian yang pasif atau berpindah-pindah (nomad), berburu-mengumpulkan, dan kegiatan di antaranya.

Kemampuan spesies untuk bertahan hidup secara ekologis berada pada interaksi faktor manusia dan alam tersebut. Pengetahuan mengenai faktor tersebut masih sangat terbatas dan penelitian-penelitian lanjut mengenai bidang yang penting ini sangat diperlukan. Perburuan belum tentu berpengaruh negatif terhadap semua spesies. Bennett dan Dahaban (1995) menemukan bahwa spesies-spesies tertentu seperti tupai yang berukuran besar dan sedang meningkat jumlahnya secara nyata di daerah yang dianggap memiliki tekanan perburuan yang tinggi. Kemungkinan hal ini terjadi karena pemburu lebih suka menangkap mamalia berukuran besar. Tidak semua perburuan untuk makanan. Sejumlah spesies diambil untuk obat, hiasan, dan penggunaan lain (Puri 2001). 


\section{Berburu untuk makanan sehari-hari}

Berburu satwa merupakan kegiatan sehari-hari penduduk asli yang tinggal di hutan sejak zaman batu untuk memperoleh sumber protein (Stanford \& Bunn 2001). Hal ini kemudian menimbulkan pertanyaan: mengapa baru sekarang perburuan berdampak besar bagi hidupan liar. Meskipun tidak sepenuhnya benar, pada kenyataannya, terjadi kepunahan mega-fauna secara besar-besaran di seluruh Amerika, Eurasia, dan Australia setelah zaman es. Kepunahan ini sebagian disebabkan perburuan oleh manusia seperti contohnya kepunahan spesies burung secara massal di Kepulauan Pasifik setelah manusia tiba di tempat tersebut (Duncan et al. 2002).

Sebagai perkiraan kasar, batas kepadatan populasi manusia untuk berburu sehari-hari di daerah tropis sekitar satu orang per $\mathrm{km}^{2}$ (Robinson \& Bennett 2000). Meskipun perhitungan ini tampaknya teoritis, namun menghasilkan banyak asumsi yang salah dan kurang kuat, seperti sifat demografi yang stabil dalam populasi satwa liar yang tidak diburu. Salah membuat kesimpulan serta pemahaman yang kurang tentang proses dinamika populasi menyebabkan pemusnahan spesies, bahkan saat laju pemanenan tahunan jauh di bawah perhitungan tingkat maksimum lestari. Banyak spesies yang hidup dalam ekosistem yang tertutup menjadi punah dalam waktu yang relatif singkat melalui proses alami (Brown et al. 2001). Populasi yang diperkirakan dipanen pada tingkat yang lestari, kenyataannya bisa saja kurang dari atau melebih batas pemanenan yang lestari (Milner-Gulland \& Akçakaya 2001, Slade et al. 1998, Struhsaker 2001).

Secara umum, di beberapa tempat di Borneo kepadatan populasi manusia sering melebihi 1 orang $/ \mathrm{km}^{2}$. Seperti contohnya Taman Nasional Kayan Mentarang dengan luas kawasan sebesar $14.000 \mathrm{~km}^{2}$, di tahun 2001 memiliki jumlah populasi manusia sebanyak 16.645 jiwa. Populasi tersebut diperkirakan tumbuh hingga mencapai 26.773 jiwa di tahun 2025 (Effendi et al. 2002). Hal ini menunjukkan bahwa di wilayah yang terpencil dan bergunung-gunung sekalipun kepadatan populasi manusia terlalu tinggi untuk bisa menerapkan perburuan yang lestari, terutama bila hutannya rusak. Di hulu DAS Malinau kepadatan manusia kurang dari 1 orang $/ \mathrm{km}^{2}$ (Sheil 2001a), meskipun angka ini dapat naik dalam waktu dekat dengan meningkatnya kegiatan pembangunan jalan.

Sekelompok masyarakat sangat bergantung pada sumber protein yang didapat dari hutan. Puri (1997) memperkirakan bahwa perburuan menyumbang 20\% hingga $40 \%$ kalori makanan masyarakat Punan di Kayan Mentarang. Namun demikian, karena tingginya variasi tahunan ketersediaan satwa liar, ada saat-saat dimana perburuan menghasilkan kecukupan pangan bagi masyarakat Punan dan ada saat-saat yang tidak sama sekali. Caldecott (1988) mengungkapkan bahwa turunnya populasi satwa liar antara lain menyebabkan kekurangan gizi kronis dan pertumbuhan anakanak yang terhambat seperti dilaporkan oleh Anderson (1979) pada penduduk di sejumlah kawasan pedesaan di Sarawak.

Saat populasi satwa liar turun secara signifikan, masyarakat harus membeli makanannya. Pemahaman yang baik terkait isu tersebut dapat menjadi insentif untuk memperbaiki teknik perburuan yang lestari. Perburuan tradisional seringkali tidak pandang bulu, dengan menggunakan anjing, jebakan, atau jerat. Binatang seringkali mati dengan berbagai kondisi—kurus atau gemuk, memiliki anak, hamil atau tidak- 
dan perburuan tersebut seringkali sia-sia karena yang diambil hanya bagian-bagian tertentu saja (Meijaard pengamatan pribadi).

Faktor lain yang meningkatkan dampak perburuan terhadap hidupan liar Borneo adalah meningkatnya aksesibilitas hutan; transportasi yang lebih baik dengan mobil, sepeda motor, perahu bermotor serta pesawat terbang ringan; amunisi dan senjata; terkikisnya nilai tradisi yang melarang membunuh dan memakan spesies hewan tertentu; peningkatan migrasi pendatang ke pedalaman; dan peningkatan pasar bagi produk satwa liar, baik sebagai makanan, perhiasan/pajangan, atau obat-obatan. Faktor yang terakhir tampak meningkat di Malinau, namun secara bersamaan, faktorfaktor tersebut sering menyebabkan perburuan yang tadinya hanya untuk memenuhi kebutuhan makanan sehari-hari menjadi bersifat komersial.

Sheil (2001a) menemukan bahwa banyak penduduk desa di Malinau memahami terjadinya penurunan sumberdaya yang penting bagi kehidupannya, terutama penurunan ketersediaan satwa buruan untuk makanan dan tumbuhan yang mereka butuhkan sehari-hari maupun untuk diperdagangkan. Para penduduk umumnya menyalahkan penebangan yang mengakibatkan penurunan tersebut, karena pemburu dari penduduk asli harus bersaing dengan pekerja imigran yang bekerja di industri penebangan dan pertambangan (pola ini diamati juga di tempat-tempat lain, lihat bagian selanjutnya). Hutan yang belum ditebang dianggap sebagai lahan yang penting bagi masyarakat, karena keberadaan babi hutan dan pohon-pohon kayu di dalamnya. Sebaliknya, masyarakat setempat memiliki preferensi/kecenderungan yang rendah terhadap hutan bekas tebangan. Alasannya antara lain adalah berkurangnya sumber daya utama mereka, kualitas habitat untuk ikan dan satwa liar lain lebih rendah, berkurangnya aksesibilitas secara fisik, dan berkurangnya hak mengakses hutan. Babi yang merupakan jenis makanan yang disukai, jumlahnya lebih sedikit di daerah bekas tebangan, meskipun hal ini sulit untuk dikaji karena besarnya fluktuasi populasi spesies tersebut. Penebangan juga menyebabkan kurangnya makanan hutan waktu paceklik, seperti sagu. Jalan sarad sering merusak Eugeissona utilis, yang merupakan tanaman sagu terpenting yang tumbuh di puncak-puncak bukit (Sheil 2001a). Dampak ini akan mempengaruhi permintaan sumber makanan lainnya di hutan.

\section{Konsesi dan perburuan}

Tekanan perburuan meningkat sejalan dengan perbaikan akses jalan hutan serta jalan pasokan menuju lokasi pekerja penebangan (camp) (Robinson et al. 1999, Wilkie et al. 2000). Data yang dapat diandalkan tidak selalu mudah untuk dikumpulkan dan tidak ada angka yang pasti untuk wilayah Malinau. Namun demikian, penelitian di tempat lain menunjukkan bahwa perburuan yang berkaitan dengan kegiatan konsesi harus menjadi perhatian. Sebagai contoh, di Sarawak tahun 1996, hasil tangkapan tahunan satu camp penebangan dengan jumlah 500 orang adalah 1.150 satwa, atau 29 ton daging per tahun. Pekerja dalam lokasi seperti ini yang ada di seluruh Sarawak diperkirakan secara konservatif berhasil menangkap buruan sebanyak 55.045 satwa atau 1.400 ton daging satwa liar per tahun untuk konsumsi mereka sendiri (Bennett \& Robinson 2000). Dalam satu camp penebangan dengan jumlah pekerja 648 orang di Republik Kongo, hasil panen tahunannya mencapai 8.250 satwa atau sama 
dengan 123,5 ton daging satwa liar yang sebagian dimakan sendiri dan sebagian diperdagangkan di pasar (Auzel \& Wilkie 2000). Kegiatan ini menyebabkan turunnya kepadatan satwa liar dengan sangat cepat, terutama spesies-spesies yang memiliki wilayah jelajah sempit atau berkurang wilayah jelajahnya karena deforestasi. Dengan demikian tingkat kelestarian populasinya masih belum jelas.

\section{Jalan dan perburuan}

Bennett et al. (1999) menemukan adanya hubungan antara kualitas dan kepadatan jaringan transportasi dengan perburuan di Sarawak dan Sabah. Hingga tahun 1960, sejumlah besar daerah di Sarawak dan Sabah tidak dapat diakses, kecuali oleh pemburupemburu yang berjalan kaki selama berhari-hari. Setelah itu, baik jalan sarad maupun jalan-jalan yang lain menyebar di seluruh wilayah hutan dan transportasi sungai serta pelayanan transportasi udara meningkat kualitasnya. Sebagian besar wilayah hutan saat ini dapat ditempuh dalam waktu sehari saja dari pemukiman terdekat serta bisa diakses dari kota. Hal ini menyebabkan peningkatan tekanan perburuan secara nyata. Auzel dan Wilkie (2000) dan Wilkie et al. (2000) mengungkapkan dampak jalan terhadap konservasi spesies. Penelitian mereka di Republik Kongo menunjukkan bahwa jalan yang dibangun dan dipelihara oleh konsesi penebangan meningkatkan intensitas perburuan daging satwa liar karena terbukanya akses jalan yang relatif belum tereksploitasi serta menurunkan biaya transportasi daging satwa liar ke pasar.

Jalan menyebabkan pemanenan hidupan liar secara berlebihan dan menurunkan populasi satwa liar dengan cara sebagai berikut (Bennett et al. 1999, Bennett \& Robinson 2000):

- Memfasilitasi terjadinya peningkatan imigrasi (perpindahan penduduk ke daerah tersebut)

- Meningkatkan penebangan hutan di sepanjang sisi jalan, sehingga mengurangi luas dan memecah habitat serta meningkatkan kepadatan populasi manusia di hutan yang tersisa;

- Hilangnya daerah-daerah yang tidak bisa diakses dan lokasi "sumberdaya” yang masih utuh untuk memperbaiki kondisi populasi;

- Meningkatnya akses ke pasar. Hal ini membuka peluang bagi penduduk setempat untuk menjual daging satwa liar dan membeli perangkat seperti senapan, amunisi, kawat penjerat, baterai, kendaraan, dan bahan bakar. Perangkat ini mendorong perburuan yang berlebihan tanpa pandang bulu serta mengaburkan istilah perburuan subsistens (untuk keperluan sehari-hari) yang diperbolehkan, selain juga menaikkan hasil buruan ke tingkat yang tidak lestari;

- Meningkatnya aksesibilitas penduduk setempat dan pendatang dari puluhan kilometer jauhnya yang sebagian adalah pemburu, dan lainnya merupakan pedagang yang akan membeli daging satwa atau bagian-bagian dari satwa liar yang mati diburu. 
Dalam Bagian III kami akan menjelaskan bagaimana konsesi kayu dapat mengurangi perburuan.

\section{Hasil hutan nonkayu}

Sejumlah peneliti baru-baru ini mempelajari pemanfaatan hasil hutan nonkayu di daerah Malinau (Puri 2001, Sellato 2001, Sheil 2001a). Penduduk setempat menyadap damar, karet, dan getah, mengambil rotan, kayu harum, dan beragam hasil tanaman serta satwa. Banyak spesies satwa liar yang dimanfaatkan untuk beragam tujuan, termasuk makanan, obat-obatan, alat, ritual, dekorasi, umpan, sebagai satwa peliharaan, atau sebagai bahan perdagangan (Puri 2001). Perdagangan produk satwa liar antara lain adalah sarang burung walet, batu ginjal monyet pohon, beruang, dan landak, satwa peliharaan termasuk monyet dan beruang, gigi, kuku dan cakar, hiasan (Banteng dan Sambar), daging atau lemak Babi Berjanggut, beragam spesies rusa, pangolin, ular piton, dan primata (Puri 2001, Augeri, tidak dipublikasikan).

Kelestarian hasil hutan nonkayu ini kurang dipahami, namun setidaknya sejumlah produk dimanfaatkan tanpa mengindahkan azas kelestarian. Sellato (2001) melaporkan bahwa gua sarang burung walet di Kabupaten Malinau telah dieksploitasi secara berlebihan sejak tahun 1980, dan sarang burung yang dihasilkan mengalami penurunan hingga hampir tidak ada hasilnya. Sesekali gua-gua baru ditemukan yang menyebabkan peningkatan produksi sementara. Namun, secara umum pemanenan sarang burung walet ini tidak lestari.

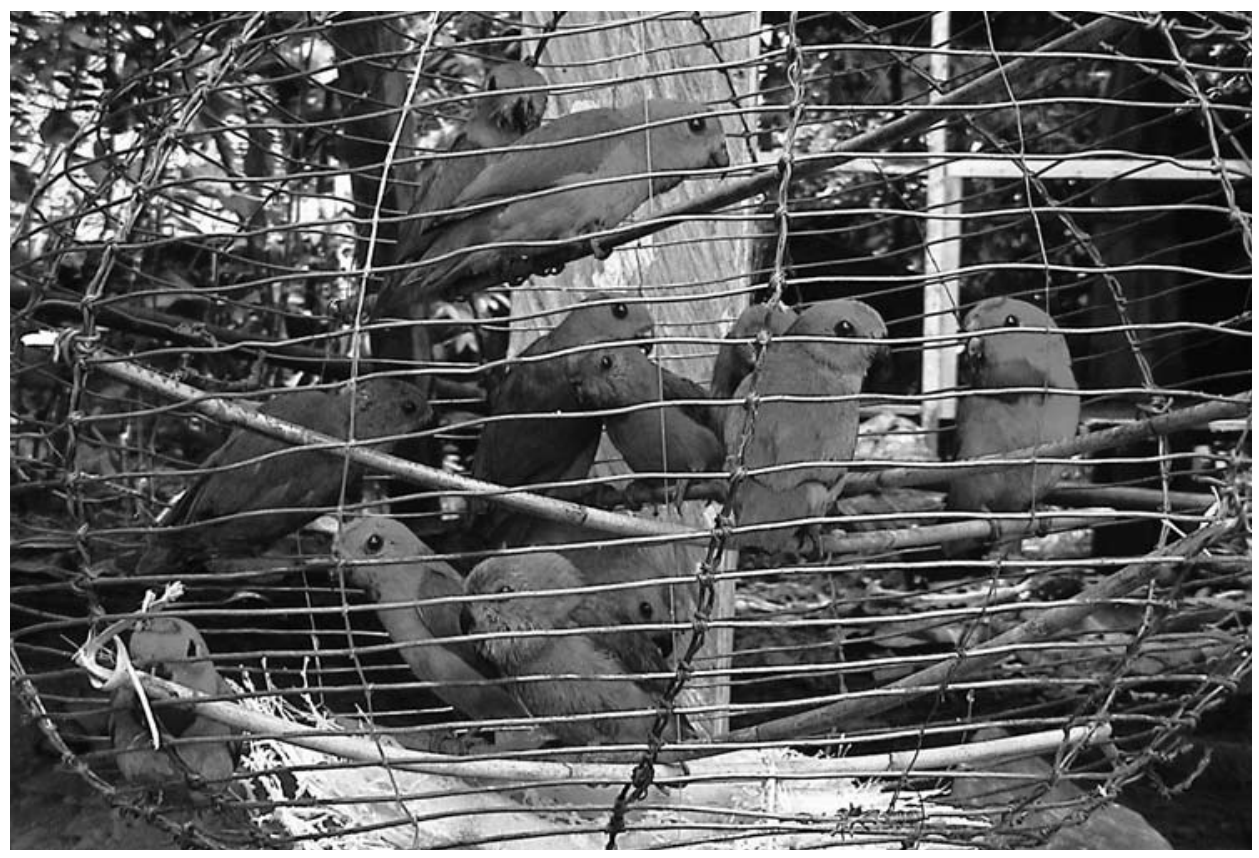

Gambar 6. Srindit Jambul Biru (Loriculus galgulus) yang ditangkap di Larut Birai untuk diperdagangkan. (Foto oleh Dave Augeri) 
Sejumlah spesies burung ditangkap untuk dipelihara dalam sangkar seperti Beo Nias (Gracula religiosa) dan Srindit Jambul Biru (Loriculus galgulus) (Gambar 6) yang masih ditemukan dalam jumlah yang cukup di hutan. Burung lainnya seperti Pycnonotus zeylanicus (Cucakrawa) yang merupakan burung berkicau yang popular kemungkinan habis diburu hingga mencapai kepunahan lokalnya (Sheil 2001a).

Perdagangan penyu air tawar dan kura-kura untuk diambil dagingnya dan obat-obatan di Asia terlihat meningkat pada 10 hingga 15 tahun belakangan ini (Walters 2000). Tidak ada data mengenai bagaimana perdagangan ini mempengaruhi populasi penyu dan kura-kura di daerah Malinau. Namun di tempat lain, kegiatan perdagangan yang tidak ada peraturannya ini menyebabkan penurunan populasi. Sejumlah spesies penyu dan kura-kura di daerah Malinau terdaftar dalam Daftar Merah Satwa Terancam IUCN (IUCN Red List of Threatened Spesies) (Hilton-Taylor 2000), Namun, tidak satupun spesies tersebut dilindungi oleh hukum di Indonesia.

\section{Lalu lintas penebangan}

Meskipun tidak ada penelitiannya di hutan tropis, kami memperkirakan lalu lintas penebangan memberikan pengaruh negatif terhadap hidupan liar (lihat juga Forman \& Alexander 1998). Tiga pengaruh utamanya, yaitu:

- Satwa yang mati terlindas (Taylor \& Goldingay 2004, tentang fauna tropis nonhutan; dan Jackson 2002, tentang Taktarau Afrika, Clevenger et al. 2003 di Canada);

- Satwa yang mulai terbiasa makan dari atau tertarik pada satwa mati yang terlindas (Dale 2001);

- suara yang ribut.

Ancaman lalu lintas yang tidak beraturan frekuensinya biasanya lebih besar dibandingkan dengan lalu lintas yang padat. Risiko lalu lintas ini meningkat dengan meningkatnya tutupan vegetasi (Clevenger et al. 2003). Sejumlah satwa tertarik pada permukaan jalan yang hangat (Jakcson 2002), sementara sejumlah spesies lainnya mulai terbiasa menggunakan jalan sebagai sarana pergerakannya, terutama pada malam hari. Bagi sejumlah spesies risiko ini bisa meningkat secara musiman sehingga memerlukan perhatian yang lebih. Di beberapa bagian di dunia, amfibia sangat terpengaruh oleh lalu lintas kendaraan. Sebagai contoh, menyeberangi jalan di beberapa tempat di Eropa menaikkan tingkat mortalitas 30 hingga 98\% (Hels \& Buchwald 2001).

\section{Spesies yang invasif}

Masuknya flora dan fauna eksotis dari luar daerah ke dalam hutan yang terfragmentasi melalui infrastruktur penebangan dapat mengancam populasi satwa liar, meskipun di Asia Tenggara hal ini masih sedikit sekali dipelajari. Contohnya antara lain adalah katak dan ikan eksotis yang dapat mengalahkan spesies asli, tumbuhan seperti Eupatorium (Chromolaena) spp. yang menjadi dominan pada tumbuhan bawah dan menghambat regenerasi alam, serta pertumbuhan Eichornia crassipes yang sangat 
cepat (terjadi di Malinau) atau Salivinia spp. yang dapat menyumbat jalan air dan mengurangi infiltrasi cahaya ke dalam danau dan memperlambat pergerakan sungai.

Di Bangladesh, regenerasi spesies-spesies pohon hutan mengalami penurunan yang sangat tajam (terutama Dipterokarpa) disertai terjadinya peningkatan jumlah belukar eksotis, rumput-rumputan, dan tanaman merambat yang biasa hidup di habitat terbuka di lokasi hutan rusak. Belukar (contohnya Melastoma spp., Lantana camara, Clerodendrum infortunatum dan Jasminium spp.), rumput dan tumbuhan merambat. Tumbuhan merambat (Imperata cylindrica, I. arundinacea, Mikania scandens, Saccharum spontaneum dan Eupatorium odoratum) lambat laun menggantikan spesies regenerasi hutan yang utama (Islam et al. 2001).

Spesies merambat eksotis seperti Mikania micantha yang dapat menyelimuti daerah terbuka, menjadi masalah besar di daerah lain di Indonesia (Whitten et al. 1996). Spesies yang lain adalah Clidemia hirta, merupakan belukar yang sangat invasif, dan mengisolasi burung yang hidup di hutan-hutan tropis tua. Spesies belukar ini menginvasi bukaan hutan, terutama tempat yang tanahnya telah mengalami gangguan (Peters 2001, Teo et al. 2003). Marga yang banyak ditanam, seperti Psidium spp., Passiflora spp. dan Leucaena spp. dikenal sebagai spesies yang invasif di sejumlah kawasan di dunia. Spesies tersebut ditemukan di hutan alam yang tertutup, namun secara umum ditemui di daerah yang terganggu (Cronk \& Fuller 1994; Sheil 1994).

Jalan dan penebangan memungkinkan spesies tersebut untuk masuk dan hidup di hutan tertutup (Janzen 1983). Dari pengalaman di daerah lain, sifat invasif sering berkembang seiring dengan berjalannya waktu saat spesies berkembang dan beradaptasi dengan kondisi setempat. Satwa umumnya menyebarkan spesies ini, dan dapat diperkirakan dengan mudah bahwa spesies tumbuhan ini mempengaruhi fauna hutan, meskipun hal ini tidak banyak dipelajari. Spesies generalis pemakan buah (tidak memiliki preferensi/persyaratan khusus) dan spesies penyerbuk seringkali mendapatkan manfaat dengan merugikan spesies yang lebih bersifat spesialis (memiliki preferensi khusus)_pengaruh yang bisa memiliki konsekuensi ekologis besar yang mungkin belum diantisipasi.

Ancaman spesies invasif ini tidak terbatas pada tumbuhan saja, tetapi juga organisme lainnya. Babi Hutan Eurasia (Sus scrofa) diperkirakan telah beradaptasi di Malinau dan diyakini telah menggantikan S. barbatus di Semenanjung Malaya (MacKinnon 2002). Berbagai Srindit seperti Nuri Trichoglossus haematodus dan Kakatua Jambul Kuning Cacatua sulphurea, juga merupakan spesies yang berpotensi menjadi invasif. Seperti halnya berbagai burung gereja, gagak, serta jalak, bahkan beberapa di antaranya membawa penyakit malaria burung (MacKinnon 2002). Siput Afrika Achatina fulica, meskipun tidak ditemukan masuk ke dalam hutan, dapat ditemui di tepi hutan dan memiliki kemampuan adaptasi tinggi. Keong Emas (Pomacea canaliculatus) dari Amerika Selatan dengan telur berwarna merah muda bertelur di tepian kolam/air tergenang dan dapat menghancurkan 50\% hingga 80\% sawah (Whitten et al. 1996).

Hoplobatrachus rugulosus, sejenis katak berukuran sedang yang tumbuh hingga $10 \mathrm{~cm}$ besarnya dibawa ke Borneo Utara untuk diternakkan, namun lepas ke alam. Matsui (1979) pertama kali melaporkannya dari Sabah pada tahun 1978. Di Kalimantan Timur, penduduk setempat menyatakan bahwa pertama kali mereka 
menemukan spesies tersebut sekitar tahun 1997, yang saat itu berada pada jarak 400 hingga $700 \mathrm{~km}$. Rute yang diambil oleh katak tersebut tidak diketahui, namun diperkirakan spesies ini menyukai habitat yang terganggu. Menurut Iskandar (2004), penduduk setempat mencatat adanya spesies katak baru di Malinau yang dapat mengancam spesies asli. Identifikasi spesies ini menjadi sangat penting, berdasarkan deskripsi penduduk, belum jelas apakah spesies tersebut adalah $H$. rugulosus, atau Rana catesbeiana. Kaitan dengan habitat yang terganggu pun belum jelas.

Akhirnya, peningkatan kedekatan antara satwa peliharaan yang diliarkan terhadap satwa liar dari satu keluarga meningkatkan terjadinya pemindahan penyakit, seperti penyakit 'rinderpest' pada sapi yang diliarkan dan babi (Sus scrofa) yang menghilangkan sejumlah besar Babi Berjanggut (Sus barbatus) pada tahun 1870-an, 1890-an, dan awal 1900-an (Feuilletau-de Bruyn 1933, Knapen 1997).

Strategi yang memadai dapat digunakan untuk mengantisipasi ancaman yang lain. Ancaman tersebut antara lain impor patogen tanah seperti Phytophera yang mengancam hutan hujan Australia (Brown 1976), cacing tanah eksotis (masalah besar di Afrika Barat (De Leon et al. 2003), semut eksotis (menyebabkan kebutaan binatang di sebagian daerah di Gabon, Wetterer et al. 1999), dan introduksi siput raksasa Afrika, Achatina fulica, (Civeyrel \& Simberloff 1996). Sejumlah semut tercatat menimbulkan masalah di daerah ini (MacKinnon 2002). Diperlukan upaya pengelolaan untuk meminimalkan terjadinya pemindahan tanah dan materi yang berpotensi terinfeksi antar lokasi. Rekomendasi umum yang diusulkan adalah membangun kendali/kontrol secara regional yang berkaitan dengan impor dan pemindahan tanah hidup, tumbuhan dan hewan, serta peraturan kesehatan yang terkait. Pencegahan secara serius telah dilakukan oleh negara-negara seperti Australia dan New Zealand yang melakukan pencegahan terhadap masuknya spesies asing yang dapat mempengaruhi flora dan fauna asli.

\section{Kebakaran}

Kebakaran liar hampir tidak mungkin terjadi di hutan hujan tropis yang tidak terganggu dengan pohon-pohon tinggi, bertajuk tertutup dan dalam kondisi normal, yaitu: iklim mikro yang lembab, kayu yang lembab, kecepatan angin rendah, dan curah hujan tinggi. Kondisi ini menyebabkan hutan tidak mudah terbakar (Cochrane et al. 1999, Holdsworth \& Uhl 1997, Kauffmann \& Uhl 1990, Nepstad et al. 1999a, b). Namun demikian, anggapan umum bahwa kebakaran berskala besar bukan ancaman besar bagi hutan tersebut telah berubah sejak tahun 1982-83, saat terjadi kekeringan panjang dan kebakaran disertai dengan hancurnya daerah hutan tropis yang luas di Borneo dan Afrika Barat.

Kebakaran di hutan hujan tropis secara umum dapat diklasifikasikan sebagai kebakaran permukaan dan kebakaran deforestasi (Nepstad et al. 1999a). Kebakaran deforestasi dianggap memiliki dampak ekologis yang tinggi. Kebakaran permukaan yang menyulut limbah organik yang berada di dasar hutan sering disalahartikan sebagai berimbas kecil dan bergerak dengan lambat. Saat api menjalar di dasar hutan dengan kecepatan 10 hingga 30 meter per jam, sejumlah kecil serangga, kadal, dan fauna lain yang tinggal di dasar hutan mampu melarikan diri, sementara yang lain 
kurang beruntung (Nepstad et al. 1999a). Kerusakan hutan secara prinsip bukan berasal dari perusakan bahan organik, tetapi melalui batang pohon dan liana yang memanas oleh api (Nepstad et al. 1999a) dan menyebabkan tumbuhan tersebut mati beberapa bulan atau beberapa tahun kemudian.

Bergantung dari intensitasnya, kebakaran dapat mematikan hampir seluruh anakan, kecambah, liana, dan pohon-pohon muda yang tidak dilindungi oleh kulit kayu yang tebal. Jenis pohon yang paling penting di Borneo adalah famili Dipterocarpaceae yang dirugikan oleh adanya kebakaran karena kulit batangnya tipis, getahnya mudah terbakar, dan tidak memiliki kemampuan berkecambah yang tinggi (Whitmore 1990b). Namun demikian, Dipterokarpa mampu beregenerasi di daerah yang terbakar ringan (Leighton \& Wirawan 1986).

Gangguan hutan berkorelasi kuat dengan kerentanan terhadap kebakaran. Secara umum, sebagian besar peneliti kebakaran tahun 1982-83 di Borneo menemukan adanya hubungan antara tingkat kerusakan dan intensitas kebakaran dengan intensitas penebangan sebelumnya dan sisa-sisa tebangan pada dasar hutan (Leighton 1984, Lennertz \& Panzer 1983, Mackie 1984, Malingreau et al. 1985, Wirawan 1993, Woods 1989). Penebangan kayu sering menyebabkan sisa-sisa kayu menumpuk di tanah dan di bawah bukaan tajuk. Konsekuensinya, hutan secara umum mengering (bertambah banyak/luas) dan spesies yang memiliki toleransi terhadap cahaya seperti rumput dan belukar mengkoloni dasar hutan.

Kebakaran meningkatkan kemungkinan terbakar kembali di tahun-tahun berikutnya. Saat pohon tumbang, lantai hutan menjadi terbuka dan mengering, sementara api menyukai spesies yang rentan terhadap api yang bisa menambah bahan bakar. Kebakaran yang paling menghancurkan terjadi di hutan yang sebelumnya terbakar (Cochrane \& Schulze 1999). Banyak hutan yang terbakar di Borneo pada tahun 1982-83, atau selama kekeringan dalam episode El Niño selanjutnya, terbakar kembali di tahun 1997-1998 (Hoffmann et al. 1999). Kebakaran berulang merupakan faktor kunci hilangnya keanekaragaman hayati di hutan tropis.

Penelitian mendalam tentang pengaruh kebakaran terhadap keanekaragaman hayati hutan tropis masih terbatas (Dennis et al. 2001, Nasi et al. 2002), namun dampaknya dapat diacu dari studi kasus yang dilakukan setelah kebakaran di tahun 1982-83 dan 1997-98 di Indonesia. Kebakaran di Taman Nasional Kutai di Kalimantan Timur pada tahun 1982-83 menyebabkan kematian reptilia dan amfibia (Leighton 1984, MacKinnon et al. 1996). Burung pemakan buah seperti rangkong menurun secara dramatis dan hanya burung pemakan serangga seperti pelatuk yang dapat ditemukan karena melimpahnya serangga pemakan kayu. Rabinowitz (1990) melaporkan bahwa mamalia kecil, burung, dan reptilia langka ditemukan di hutan Dipterokarpa di Thailand, dan karnivora cenderung untuk menghindari daerah yang sebelumnya terbakar.

Di Sumatera, Kinnaird dan O’Brien (1998) menjelaskan terjadinya kerusakan akibat kebakaran di Taman Nasional Bukit Barisan selama kebakaran tahun 1997. Mereka mengungkapkan bahwa hilangnya pohon buah-buahan menurunkan makanan sejumlah besar spesies omnivora seperti primata dan tupai, Beruang Madu (Ursus malayanus) dan musang, serta satwa berkuku belah (Tragulus spp.) dan muncak (Muntiacus spp.) (Catatan: buah-buahan di tahun 1997 secara umum langka, bahkan 
di daerah yang tidak terbakar). Penurunan jumlah tupai tanah dan tikus pohon mengindikasikan bahwa secara umum kepadatan tikus mengalami penurunan, sehingga berpengaruh negatif terhadap sumber makanan bagi karnivora kecil seperti Kucing Congkok (Prionailurus bengalensis). Meskipun belum jelas apakah kebakaran menyebabkan penurunan populasi tersebut secara langsung.

Hancurnya rongga-rongga pohon juga dapat berpengaruh terhadap burung dan mamalia seperti tarsius dan kelelawar. Terakhir, kebakaran yang ekstensif menghancurkan serasah daun dan komunitas artropoda yang terkait, mengurangi ketersediaan pakan bagi omnivora dan karnivora (Kinnaird \& O’Brien 1998). Di tempat lain, terdapat penurunan jumlah binatang yang bergerak lambat, pemakan buah dan fauna serasah setelah terjadinya kebakaran permukaan di Amazon Brazilia (Nepstad et al. 1999a).

Kebakaran tidak seluruhnya buruk bagi hidupan liar. Beberapa spesies, seperti herbivora besar mendapat manfaat dari rumput-rumput yang baru tumbuh setelah kebakaran. Pengamatan dari Kamboja menunjukkan bahwa sapi liar, seperti Banteng (Bos javanicus) dan Gaur (Bos gaurus), hidup subur di hutan yang baru terbakar karena tumbuhnya rumput-rumputan (Wharton 1966). Hal ini bisa diamati juga di Kalimantan Timur dimana penduduk setempat dari suku Kenyah dan Kayan secara teratur membakar daerah terbuka untuk mengundang satwa buruan seperti rusa, muncak, dan Banteng (Hedges \& Meijaard 1999).

Van Nieuwstadt et al. (2001, 2002) melaporkan penelitiannya mengenai dinamika vegetasi setelah kebakaran di hutan hujan Dipterokarpa yang belum ditebang di Sungai Wain, dekat Balikpapan, bahwa pertumbuhan kembali hutan merupakan hal yang mungkin, namun gangguan berikutnya (termasuk penebangan) dapat menyebabkan hilangnya hutan. Singkatnya, satu kebakaran saja tidak akan menyebabkan konversi ke vegetasi nonhutan. Kemampuan hutan primer untuk mempertahankan diri dan tumbuh kembali, serta terbentuknya anakan pohon perintis dan belukar menekan terbentuknya spesies-spesies nonhutan yang paling tidak diinginkan. Namun demikian, vegetasi yang tumbuh setelah kebakaran tidak akan setahan vegetasi sebelum kebakaran dalam menghadapi gangguan yang berulang seperti anggapan banyak pihak yang menyaksikan vegetasi yang tumbuh kembali dengan cepat setelah kebakaran. Individu spesies yang mengecambah sebelumnya menunjukkan penurunan potensi kemampuan berkecambah dan kemampuan bertahan setelah rusak untuk kedua kalinya, sumber benih kebanyakan menurun setelah lonjakan awal perkecambahan setelah kebakaran, serta kerapatan biji pohonpohon penting menjadi rendah. Daerah bukaan yang terbentuk pada tumbuhan bawah karena alat berat konvensional yang digunakan untuk menyelamatkan pohon tumbang mendorong terbentuknya vegetasi nonhutan secara cepat dan menurunkan potensi pemulihan hutan secara drastis.

\section{Sertifikasi}

Sejumlah sistem sertifikasi untuk pengelolaan konsesi hutan yang berkelanjutan sedang dalam tahap pengembangan di Indonesia. Di antara yang paling dikenal adalah, Lembaga Ekolabel Indonesia (LEI) dan Forest Stewardship Council (FSC_- 
Dewan Pemelihara Hutan). LEI, yang didirikan tahun 1993, mengembangkan sistem sertifikasi hasil hutan Indonesia. Sistem ini dibangun berdasarkan kelestarian nilai ekonomi, ekologi, dan sosial.

FSC adalah organisasi global yang didirikan pada tahun 1993 oleh kelompok yang bekerja di bidang lingkungan, industri kehutanan, pakar kehutanan, masyarakat asli dan kelompok masyarakat dari 25 negara. Prinsip FSC yang keenam dan kesembilan merupakan prinsip yang paling berkaitan dengan penelitian ini. Prinsip keenam mengulas dampak lingkungan pengambilan kayu dan prinsip kesembilan mendorong pemeliharaan (perlindungan) hutan yang bernilai konservasi tinggi (High Conservation Value Forest). Prinsip-prinsip FSC yang penting lainnya terkait dengan hak masyarakat setempat dan penataan hukum dan peraturan. Prinsip FSC dimuat dalam situs web (http://www.fscus.org). Pada bagian yang lain kami akan mengulas dengan singkat bagaimana prinsip-prinsip tersebut terkait dengan rekomendasi yang kami ajukan. 


\section{Burung}

\section{Umum}

Antara September hingga Oktober 1998, sejumlah 239 spesies burung dijumpai di MRF (O’Brien \& Fimbel 2002). Jumlah ini lebih banyak dari yang pernah ditemukan di daerah lain. Contohnya, di Taman Nasional Gunung Palung dengan waktu pengamatan lebih panjang (2-3 tahun, luas $200 \mathrm{ha}$ ) dan dengan rentang ketinggian yang lebih besar dijumpai 187 spesies burung (Laman et al. 1996), atau di Barito Ulu dengan waktu pengamatan 39 hari dan luas 200 ha, dijumpai 190 spesies burung (Wilkinson et al. 1991). Marga burung yang tercatat mencakup Timaliidae (18 spesies), Pycnonotidae (12 spesies) dan Picidae (12 spesies). Gambaran yang menunjukkan hubungan antara upaya pengamatan dan jumlah spesies yang terdeteksi (lihat O’Brien \& Fimbel 2002) menunjukkan bahwa intensitas pengambilan contoh yang digunakan dalam pengamatan burung di MRF tidak cukup untuk mendeteksi seluruh spesies yang ada di wilayah itu.

Penelitian mengenai respons burung terhadap tebang pilih dan terhadap gangguan hutan lainnya lebih banyak dilakukan dibandingkan dengan mayoritas taxa vertebrata. Sebagai suatu kelompok, burung sangat bermanfaat untuk mengevaluasi efek penebangan terhadap fauna, karena hal-hal sebagai berikut:

1. Taksonomi burung yang lebih baik dan kemudahannya untuk diidentifikasi di lapangan;

2. Ketersediaan informasi biologis dan ekologis mengenai sebagian besar suku burung dan spesiesnya;

3. Kepekaan burung terhadap perubahan struktur, iklim mikro, dan komposisi hutan; dan

4. Fungsi ekologis burung (misalnya sebagai pollinator, penyebar dan pemangsa benih, Fimbel et al 2001). 
Seringkali kekayaan spesies burung menurun setelah penebangan. Marsden (1998) menemukan 73 spesies burung di hutan utuh (tidak ada penebangan) di Seram, Indonesia, dan hanya menemukan sebanyak 53 spesies di hutan yang ditebang 1 hingga 5 tahun sebelumnya (intensitas penebangan tidak diketahui). Thiollay (1992) mengungkapkan bahwa di Guyana Perancis, meskipun sejumlah spesies meningkat kelimpahannya, kekayaan spesies secara umum di hutan yang ditebang setahun sebelumnya $47 \%$ lebih rendah dibandingkan jumlah spesies di hutan yang masih utuh. Namun demikian, ada beberapa penelitian yang menunjukkan terjadinya peningkatan kekayaan spesies burung setelah penebangan. Johns (1997) mencatat lebih banyak spesies burung yang ditemukan di hutan bekas tebangan Dipterocarpaceae di Sabah karena bertambahnya spesies burung yang hidup di pinggiran hutan. Demikian pula hasil riset Danielsen dan Heegard (1994) di Sumatera yang menemukan bahwa jumlah spesies burung meningkat setelah penebangan. Namun, pengamatan di Sumatera ini menutupi kenyataan bahwa tidak kurang dari 31 spesies hanya ditemukan di hutan primer dan hutan yang tidak begitu banyak ditebangi (Lambert \& Collar 2002). Di kawasan hutan Uganda, keragaman spesies burung yang ada di hutan tebang pilih sama dengan di hutan utuh, meskipun respons bergantung dari spesies burung (Owiunji 2000). Di kawasan ini pula, terdapat kesamaan antara komposisi komunitas burung yang ada di dalam bukaan hutan (forest gaps) dengan yang ada di hutan rusak yang berada di dekatnya, meskipun kepadatan burung-burung di dalam bukaan hutan lebih rendah (Ngabo \& Dranzoa 2001). Di Belize, penebangan hutan hampir tidak berpengaruh terhadap keanekaragaman burung (Whitman et al. 1998).

Pada umumnya, penurunan jumlah spesies pada komunitas burung di hutan hujan tropis terjadi sesaat setelah penebangan. Johns (1996) mencatat bahwa seluruh spesies yang ditemukan di hutan utuh juga ditemukan di areal hutan bekas tebangan di Sabah. Lambert dan Collar (2002) mengungkapkan bahwa penelitian yang dilakukan Johns memiliki bias kaitannya dengan pemanfaatan jalan tebangan sebagai transek. Sejumlah penelitian mengungkapkan bahwa keanekaragaman spesies di hutan bekas tebangan dan habitat yang terganggu lebih rendah, dan hal ini seringkali disebabkan oleh dominasi beberapa spesies burung yang mampu beradaptasi terhadap gangguan. Penelitian lain menemukan spesies tertentu yang tidak ditemukan di hutan tebangan. Kofron dan Chapman (1995) menemukan bahwa 38\% spesies spesialis yang hidup di interior hutan tidak ditemukan di hutan tebang pilih di Liberia.

Saat menginterpretasikan hasil, perlu dibedakan antara kekayaan/kelimpahan (jumlah total spesies dalam wilayah tertentu), keragaman (proporsi keterwakilan dari masing-masing spesies), kemiripan taksonomis, dan kemiripan ekologis. Suatu komunitas bisa memiliki jumlah spesies yang sama, bahkan dengan komposisi spesies yang sama. Tetapi bila perbandingan keterwakilan spesies tersebut berbeda sama sekali, fungsi dan perilaku komunitas tersebut bisa berbeda tergantung dari ekologi beragam spesies tersebut. Selain itu, perubahan dalam kelimpahan spesies bukan indikator kerentanan taxa dan juga tidak dapat digunakan untuk mengidentifikasi mekanismenya. Lebih jauh lagi, perubahan tersebut tidak dapat memberikan informasi mengenai terjadinya perubahan "nilai konservasi", meskipun anggapan umum yang ada sekarang adalah bahwa daerah dengan kelimpahan spesies dari suatu kelompok taksonomis yang diteliti memiliki nilai konservasi yang lebih tinggi. 
Sebagai contoh, Augeri (1995) menemukan bahwa peningkatan spesies generalis dan spesies yang hidup di daerah tepi (edge spesies) dapat menurunkan keragaman fungsional dalam sistem dengan penurunan jumlah spesies yang bersifat spesialis serta peningkatan spesies generalis yang memiliki karakter ekologis sama. Sehingga terjadi suatu proses yang disebut homogenisasi biologis (biohomogenization), yang dapat berdampak negatif terhadap spesies-spesies endemik atau spesies spesialis yang terancam melalui kompetisi, pemangsaan, atau parasitisme, terutama spesies-spesies interior. Perubahan tersebut juga dapat mempengaruhi dan mengubah proses ekologi pada tingkat komunitas. Dengan demikian, peningkatan kelimpahan atau keragaman spesies tidak selalu memberikan indikasi keluaran yang positif dalam sistem tersebut, terutama jika peningkatan tersebut terjadi pada spesies dengan fungsi ekologis yang sama dalam suatu wilayah yang sebelumnya didominasi oleh spesies spesialis. Informasi yang diperoleh dari sejumlah penelitian yang menunjukkan peningkatan spesies setelah terjadinya gangguan harus dipertimbangkan dengan melihat spesies yang ada/ditemukan serta perannya secara fungsional (misalnya, generalis, spesialis, dan sebagainya.). Juga perlu diperhatikan bagaimana dampak jangka panjangnya terhadap sistem (lihat Sheil et al. 1999 dan Sheil \& Burslem 2003 untuk ulasan yang sama tentang peningkatan keragaman pohon yang kadang-kadang terjadi setelah penebangan).

Terdapatnya kelompok spesies campuran dalam komunitas burung di hutan diperkirakan dapat meningkatkan efisiensi mencari makan dan terhindar dari predator (Julien \& Clobert 2000). Thiollay (1999) membandingkan komposisi dan frekuensi hadirnya kelompok spesies campuran burung pemakan serangga tropis dari Asia dan Amerika Selatan pada berbagai tingkat kerusakan hutan. Kecenderungan untuk mengelompok menurun sejalan dengan kondisi hutan: dari hutan primer dataran rendah, ke hutan terbuka (berdaun lebar), rusak (bukaan akibat tebangan), dan hutan pegunungan atau hutan yang dikelola (dengan tajuk yang terfragmentasi). Thiollay mengungkapkan bahwa kemampuan burung dalam mendeteksi pemangsa merupakan mekanisme yang mendasari proses ini. Burung menjadi lebih mudah mendeteksi pemangsa di hutan terbuka sehingga mengurangi kebutuhan mencari makan dengan cara berkelompok. Karena beberapa spesies bergantung pada kelompok campuran (setidaknya di daerah Neotropis, lihat Julien \& Clobert 2000), menurunnya frekuensi perilaku mencari makanan dalam kelompok campuran setelah penebangan dapat menyebabkan terjadinya ketidakseimbangan pada spesies-spesies tertentu.

Di seluruh benua Asia, Afrika, dan Amerika, kelompok burung tertentu memiliki respons yang konsisten terhadap kegiatan tebang pilih. Populasi pemakan madu dan generalis pemakan buah/pemakan serangga yang hidup pada bagian tajuk meningkat karena penebangan (Hussin 1994; Johns 1989a, 1996; Lambert 1992). Generalis yang berjelajah luas mampu beradaptasi dengan lingkungan suksesi berskala luas. Hal ini ditambah dengan banyaknya spesies pemakan buah dan pemakan madu yang diuntungkan dengan terjadinya peningkatan buah dan bunga tumbuhan yang mengkoloni lahan yang terganggu (Lambert 1992). Secara umum, kelimpahan spesies dalam kelompok yang mencari makan bersama yang terdiri dari satu kelompok atau lebih (pemakan serangga/pemakan buah, pemakan serangga/pemakan madu, dan 
sebagainya) cenderung meningkat setelah penebangan, sementara kelompok pencari makan dari satu sumber sering menurun kelimpahannya (Setyawati 1999).

Lambert dan Collar (2002) mengungkapkan bahwa fragmentasi hutan secara menyeluruh, yang mencakup wilayah nonhutan, memiliki dampak yang lebih besar terhadap populasi burung dibandingkan dengan pengaruh lokal dari tebang pilih. Kompilasi data Lambert dan Collar menunjukkan bahwa 274 spesies burung yang hidupnya terbatas hanya di hutan dataran rendah subregion Sunda (kecuali Palawan), 83 (30\% dari avifauna) spesies mengalami pengaruh negatif fragmentasi, dan 26 $(9,5 \%)$ spesies dipengaruhi secara negatif oleh penebangan hutan. Hal ini juga tercermin dalam penelitian yang dilakukan oleh van Balen (1999c), yang menemukan bahwa banyak spesies hanya hidup di fragmen hutan yang terbesar (lebih dari 100 $\mathrm{km}^{2}$ ). Menariknya, taxa yang paling tidak toleran terhadap hutan yang rusak seperti: sempur hujan, bultok, pelatuk, luntur, dan satu spesies rangkong, sama dengan spesies yang hilang dari hutan yang terisolasi di Singapura (Corlett \& Turner 1997). Hal ini bisa menjadi indikasi bahwa spesies yang tidak toleran terhadap degradasi hutan juga tidak toleran terhadap bagian hutan yang terisolasi (meskipun kondisi bagian hutan ini bisa berpengaruh nyata). Temuan-temuan ini memiliki implikasi pengelolaan yang penting, sehingga upaya mempertahankan konektivitas antara fragmen-fragmen hutan dan upaya melindungi kawasan hutan permanen yang luas harus menjadi prioritas utama. Sejalan dengan itu, kegiatan sistem tebang pilih di hutan-hutan tersebut bisa terus dilakukan tanpa membawa dampak yang terlalu besar terhadap populasi burung asli (kecuali spesies-spesies yang dipengaruhi secara negatif oleh kegiatan penebangan, misalnya Sempur-Hujan Rimba (Calyptomena viridis)), dan dengan asumsi bahwa tekanan kegiatan perburuan dan pengambilan yang ada rendah (Lambert \& Collar 2002).

\section{Spesies-spesies yang sensitif}

Lambert dan Collar (2002) baru-baru ini memasukkan spesies burung yang hidup di paparan Sunda ke dalam daftar spesies yang dipengaruhi oleh proses kegiatan penebangan, fragmentasi hutan, dan perburuan. Spesies pemakan serangga (insektivora) yang hidup di atas tanah (terrestrial) dan tumbuhan bawah merupakan spesies yang paling peka terhadap kegiatan penebangan. Beberapa spesies lainnya terutama insektivora yang mencari makan dengan melompat ke udara dari dedaunan (sallying) — seperti spesies kipasan—yang tinggal di hutan bagian bawah dan tengah. Burung yang hidup di bagian tajuk terlihat lebih memiliki ketahanan. Spesies pemakan buah dan pemakan madu jarang turun populasinya di hutan bekas tebangan, kecuali Sempur-Hujan Rimba yang merupakan spesies spesialis. Kelompok burung yang terpengaruh oleh kegiatan penebangan terdiri dari: 1) beberapa spesies spesialis ekstrim yang hidup di dataran rendah seperti Kangkareng Hitam, Anthracoceros malayanus, Sempidan Merah, dan Lophura erythrophthalma (lihat bagian selanjutnya); 2) spesies-spesies nomad atau yang memerlukan daerah yang luas (rangkong, raptor); 3) spesies yang hidup di hutan primer dan intoleran terhadap gangguan (Kuau Raja, Argusianus argus; beberapa spesies luntur, beberapa burung pelatuk, sejumlah berencet dan kipasan); serta spesies yang membutuhkan rongga pada pohon untuk bersarang. 
Taxa yang paling dipengaruhi oleh penebangan adalah spesies yang hidup di interior hutan primer. Pemakan serangga dan kipasan yang hidup di bagian dasar dan bagian tengah tumbuhan bawah hutan merupakan spesies yang sangat tidak toleran terhadap kegiatan penebangan (Johns 1989a; Lambert 1992; Thiollay 1992). Dibandingkan dengan spesies lain, populasinya menurun setelah terjadinya gangguan. Spesies pemakan serangga yang hidup pada tumbuhan bawah, baik jumlah spesies yang dijumpai maupun proporsi keterwakilannya dalam sampel populasi, menurun setelah kegiatan penebangan dengan intensitas sedang. Lambert (1992) mengidentifikasi bahwa dari sejumlah spesies yang ada, luntur (Harpactes spp.), pelatuk (Picidae), berencet (Kenopia striata dan Napothera spp.) dan sikatan (Cyornis spp. dan Ficedula spp), adalah spesies-spesies yang cenderung menurun populasinya di daerah hutan bekas tebangan.

Johns (1996) membandingkan hasil penelitiannya dengan penelitian Lambert (1992). Dari perbandingan itu Johns berhasil mengidentifikasi enam spesies yang secara konsisten menurun jumlahnya setelah penebangan. Spesies-spesies tersebut yaitu: Berencet Loreng (Kenopia striata), Luntur Diard (Harpactes diardii), dan empat spesies sikatan yang hidup di tumbuhan bawah (Sikatan Kepala-abu, Culicapa ceylonensis, Rhipidura perlata, Philentoma philentome verlatum, dan Rhinomyias umbratilis). Penurunan jumlah tersebut mungkin mencerminkan hilangnya vegetasi tumbuhan bawah, tingkat pencarian makan, dan spesies serangga yang biasanya dimangsa oleh insektivora tumbuhan bawah (Robinson 1969). Namun demikian, diperkirakan bahwa dalam menentukan wilayah jelajah spesies-spesies yang hidup pada tumbuhan bawah di hutan-hutan Panama (Karr \& Freemark 1983), kondisi fisiologis (seperti suhu yang tinggi dan tekanan air) terlihat lebih signifikan dibandingkan dengan kelimpahan makanan. Kondisi iklim mikro dapat berubah karena hilangnya tutupan tajuk dan spesies burung yang hidup di tumbuhan bawah seringkali enggan menyeberangi daerah terbuka atau tumbuhan sekunder padat yang memisahkan sisa bagian-bagian hutan yang masih utuh.

Setelah kegiatan penebangan hutan, pemakan serangga yang hidup di interior hutan bisa digantikan oleh spesies sikatan yang memiliki karakteristik habitat pinggiran hutan, atau masuknya spesies cucak-cucakan (Pycnonotidae). Spesies pemakan buah tersebut umumnya berasosiasi dengan spesies tumbuhan perintis yang cepat tumbuh, tetapi juga mengkonsumsi serangga. Buah-buahan dari tumbuhan muda dapat mendukung meningkatnya kelimpahan pemakan serangga/pemakan buah seperti bulbul, serta menyebabkan timbulnya kompetisi dengan spesialis pemakan serangga, meskipun bukti untuk kesimpulan ini tidak memadai.

\section{Rangkong}

Rangkong adalah kelompok burung pemakan buah yang berukuran sedang hingga besar dan kadang memiliki preferensi makanan yang khusus, serta umumnya membutuhkan daerah hutan yang luas. Di Borneo, sebagian besar penelitian, terutama mengenai biologi dan ekologi rangkong, dilakukan di Kalimantan Timur (Leighton 1982). Penelitian penting yang lain adalah tentang Kangkareng (Penelopides exarhatus) dan Julang Sulawesi (Rhyticeros cassidix)—dua spesies rangkong endemik di 
Sulawesi (Kinnaird 1998, Kinnaird et al. 1996, O’Brien 1997), kelompok rangkong di Sumatera (Anggraini et al. 2000, Hadiprakarsa et al. in press), dan Rangkong Sumba (Rhyticeros everetti) (O’Brien et al. 1998b).

Rangkong memiliki distribusi yang tidak merata di Kalimantan. Contohnya Kangkareng Perut Putih (Anthracoceros albirostris) yang baru-baru ini dilaporkan dari Kalimantan Selatan dan Tengah (Holmes 1997), dari Delta Sungai Mahakam di Kalimantan Timur (Eve \& Guigue 1989), dan dari bagian hulu rawa Kapuas di Kalimantan Barat (Jeanes \& Meijaard 2000). Namun burung ini tidak ditemui di dataran rendah lain seperti di Taman Nasional Gunung Palung (Laman et al. 1996). Kelangkaan burung spesies ini kemungkinan disebabkan oleh perburuan (Holmes 1997). Kesimpulan ini diambil dengan pertimbangan bahwa dari spesies-spesies rangkong yang ada, spesies ini dilaporkan sebagai yang paling toleran terhadap degradasi hutan (MacKinnon \& Phillips 1993). Di Taman Nasional Kutai, ada tujuh spesies rangkong yang diamati (Leighton 1982). Dari semua spesies tersebut, Enggang Jambul (Aceros comatus) terlihat di daerah Hulu Mahakam pada tahun 1996 (Sözer dalam Holmes 1997). Tujuh dari delapan spesies rangkong Borneo, dapat ditemui di daerah studi di Malinau (O’Brien \& Fimbel 1999). Spesies rangkong Borneo yang kedelapan, Julang Jambul-hitam (Rhyticeros corrugatus), hidup di dataran rendah yang berbatasan ke arah timur dengan daerah studi di Malinau. Tingginya tingkat "sympatry" (kemampuan hidup bersama pada satu wilayah) tersebut dimungkinkan karena spesies teritorial (menetap) dan nomad (berpindah tempat) hidup berdampingan, karena ada perbedaan ukuran, serta spesialisasi dalam jenis makanan dan pola pencarian makanan. Tiga spesies rangkong yang sedikit sekali diketahui, yaitu Rangkong Gading (Rhinoplax vigil), Kangkareng Hitam (Anthracoceros malayanus), dan Julang Jambul-Hitam (Aceros corrugatus) merupakan spesies yang terancam atau hampir terancam berdasarkan kategori Daftar Merah IUCN (IUCN 2002).

Rangkong dianggap sebagai spesies yang merupakan indikator keberhasilan regenerasi hutan dan indikator keberadaan cadangan keanekaragaman hayati pohon. Ada tiga jenis buah yang dimakan oleh rangkong Asia, yaitu: buah yang kaya asam lemak dan berbentuk kapsul seperti Aglaia spp. dan Myristica spp., buah berdaging dan berbiji dari marga Lauraceae dan Annonaceae, serta buah berkandungan gula tinggi seperti Ficus spp. Leighton dan Leighton (1983) menganggap buah ara sebagai buah yang sangat penting bagi rangkong teritorial di Kalimantan Timur, meskipun O'Brien et al. (unpubl.) menemukan bahwa di Sumatera buah ara lebih penting bagi spesies-spesies nonteritorial. Pohon ara sering rusak selama kegiatan penebangan atau setelah melalui prosedur silvikultur tertentu bila pohon kayu induknya bertajuk tinggi. Di Semenanjung Malaya, laju hilangnya pohon ara ini mencapai $74 \%$ sejalan dengan hilangnya pohon yang menjadi sumber makanan rangkong rata-rata sebanyak 56\% (Johns 1987). Dapat disimpulkan bahwa kerusakan pohon buah bagi rangkong terjadi secara acak, namun pohon ara rusak/hancur saat pemanenan kayu dan saat kegiatan silvikultur. Buah-buahan dari pohon perintis umumnya tidak dapat dimakan oleh rangkong, meskipun buah-buahan manis dari tanaman memanjat yang cepat tumbuh dimakan oleh Anthracoceros dari spesies teritorial. Hilangnya pohon-pohon bertajuk tinggi juga mengurangi tempat-tempat burung untuk mencari makanan, 
Tabel 2. Rangkong dan reaksinya terhadap kegiatan

\begin{tabular}{|c|c|c|c|}
\hline Spesies & $\begin{array}{l}\text { Ukuran } \\
\text { badan } \\
(\mathbf{k g}) \\
\end{array}$ & $\begin{array}{l}\text { Kecenderungan } \\
\text { keragaman setelah } \\
\text { penebangan }\end{array}$ & Referensi \\
\hline \multirow{3}{*}{$\begin{array}{l}\text { Enggang Klihingan } \\
\text { (Anorrhinus galeritus) }\end{array}$} & \multirow[t]{3}{*}{1,17} & - & (Rijksen 1978) \\
\hline & & - & (Lambert 1992) \\
\hline & & $\downarrow$ & (Johns 1997) \\
\hline Elang Jambul (Berenicornis comatus) & 1,47 & $\downarrow$ & (Lambert \& Collar 2002) \\
\hline Julang Emas (Rhyticeros undulatus) & 2,52 & - & (Lambert 1992) \\
\hline $\begin{array}{l}\text { Kangkareng Hitam } \\
\text { (Anthracoceros malayanus) }\end{array}$ & 1,05 & $\downarrow$ & (Lambert \& Collar 2002) \\
\hline \multirow[t]{2}{*}{ Rangkong Badak (Buceros rhinoceros) } & \multirow[t]{2}{*}{2,72} & \multirow{2}{*}{$\overline{\downarrow \downarrow}$} & (Lambert 1992) \\
\hline & & & (Rijksen 1978) \\
\hline \multirow[t]{3}{*}{ Rangkong Gading (Rhinoplax vigil) } & \multirow[t]{3}{*}{3,06} & - & (Lambert 1992) \\
\hline & & $\downarrow$ & (Wilson \& Wilson 1975) \\
\hline & & & (Rijksen 1978) \\
\hline
\end{tabular}

$-=<20 \%$ perbedaan nilai tengah kepadatan di hutan bekas tebangan dan hutan primer; $\uparrow / \downarrow=$ kenaikan/ penurunan antara 20 hingga $60 \%$ antara hutan bekas tebangan dan hutan primer; $\uparrow \uparrow / \downarrow \downarrow=$ kenaikan/ penurunan lebih dari $60 \%$ antara hutan bekas tebangan dan hutan primer. Berat badan diukur hanya untuk jantan.

seperti kulit-kulit kayu yang lepas dan epifit, yang merupakan tempat hidup binatang yang biasa dimangsa oleh rangkong berukuran besar dan merupakan sumber protein dan mineral dalam makanannya (Johns 1997).

Meskipun terjadi penurunan kepadatan pohon yang menjadi sumber makanannya, populasi rangkong di hutan bekas tebangan di Malaysia tidak menurun secara drastis (Kemp \& Kemp 1975; Johns 1997). C. Francis (komunikasi pribadi) mengungkapkan bahwa alasan utama tingginya toleransi rangkong terhadap kegiatan penebangan, setidaknya dalam jangka pendek, adalah umurnya yang panjang, yang memungkinkan burung tersebut untuk bertahan selama beberapa tahun meskipun berada/hidup di daerah yang tidak sesuai. Bila hutan memiliki makanan yang memadai bagi burung-burung dewasa untuk bertahan hidup saja, tetapi tidak untuk berkembang biak (yang memerlukan jumlah makanan yang lebih besar dan tempat untuk bersarang), maka rangkong dapat bertahan untuk beberapa tahun setelah hutan tidak layak lagi untuk berkembang biak. Meskipun beberapa spesies rangkong tersebut bersifat teritorial, wilayah jelajahnya yang luas memungkinkan mereka untuk mendapatkan sumber makanan di hutan-hutan yang lokasinya lebih jauh. Perburuan, terutama untuk bulunya yang digunakan pada upacara-upacara tradisional, mungkin merupakan faktor yang lebih penting dalam penurunan populasi rangkong dibandingkan dengan pemanenan kayu (Bennett \& Dahaban 1995). Di Malinau, sejumlah spesies rangkong memiliki nilai simbolis (tradisional dan spiritual) penting bagi masyarakat setempat. Binatang tersebut ditangkap untuk diambil bulu dan kepalanya (sering diawetkan sebagai hiasan), dan dimakan dagingnya. Bila sarang burung rangkong yang aktif ditemukan di lokasi yang dapat dengan mudah dicapai, sarang tersebut biasanya dirusak (Sheil pengamatan pribadi). 
Burung rangkong, terutama jenis nomad, mempunyai wilayah jelajah yang sangat luas dan kelimpahannya lebih berfluktuasi terhadap terjadinya perubahan pasokan makanan secara musiman daripada terhadap perubahan karakteristik habitat saja (Kinnaird et al. 1996; Johns 1997). Contohnya adalah Rangkong Gading (Rhinoplax vigil), yang dianggap sebagai spesies yang akan mendapatkan dampak negatif dari kegiatan penebangan karena sifatnya yang spesialis terhadap buah ara. Spesies ini juga kebanyakan bersarang di pohon-pohon Dipterokarpa yang besar (lihat bagian selanjutnya), sehingga dapat dipengaruhi secara negatif oleh kegiatan penebangan. Yang terpenting adalah hilangnya pohon buah karena kegiatan penebangan dapat memperburuk pengaruh musiman ketersediaan makanan bagi sebagian besar rangkong. Selain itu, saat kepadatan pohon buah menurun setelah kegiatan penebangan, rangkong yang mengunjungi masing-masing pohon buah tersebut meningkat jumlahnya. Hal ini berpengaruh terhadap kompetisi antar dan sesama spesies, seperti diulas panjang lebar oleh Leighton (1982). Ada satu penelitian yang menemukan bahwa rangkong yang berukuran kecil lebih toleran terhadap peningkatan kompetisi yang timbul akibat hilangnya sumber makanan karena mereka lebih mampu bergerak di hutan regenerasi yang berbelukar (Wilson \& Johns 1982). Meskipun demikian pengaruh ini dapat ditiadakan oleh kenyataan bahwa rangkong berukuran kecil bersifat teritorial dan tidak dianggap bisa bertoleransi terhadap kompetisi antar spesies. Sebagai contoh, nilai tengah ukuran kelompok Enggang Klihingan Anorrhinus galeritus di Ulu Segama, Sabah, menurun dari 7,0 di hutan utuh ke 3,7 di hutan tebangan (Johns 1997). Efek tambahan dari kegiatan penebangan yang diulas oleh Lambert dan Collar (2002) adalah bahwa dengan hilangnya pohon-pohon sumber makanan melalui kegiatan penebangan, burung dengan ukuran yang cukup besar dan dapat dimakan tersebut berkumpul di pohon-pohon yang kian menipis jumlahnya serta di lokasi hutan yang lebih mudah dicapai. Hal ini menyebabkan burung tersebut semakin rentan terhadap perburuan. Lambert dan Collar (2002) memberikan contoh dari Filipina bahwa pada tahun 1997, sebanyak 40 ekor Aceros waldeni, yang mewakili setidaknya $25 \%$ populasi global, ditembak dalam kurun satu hari pada sebatang pohon.

Bila makanan bukan merupakan faktor penghambat, pengurangan tempat bersarang bisa dianggap sebagai faktor penghambat populasi burung yang hidup di hutan bekas tebangan. Rangkong memerlukan lubang yang besar yang ada di pohon yang masih hidup. Spesies dengan ukuran yang relatif kecil memerlukan pohon dengan diameter lebih dari $50 \mathrm{~cm}$ (diameter sebatas dada) dan spesies yang lebih besar memerlukan setidaknya lubang pada pohon dengan diameter lebih dari 60 $\mathrm{cm}$. Di Thailand, $R$. vigil lebih menyukai spesies-spesies pohon Dipterokarpa (Hopea spp. dan Shorea spp.) yang berdiameter lebih dari $105 \mathrm{~cm}$ sebagai tempat bersarang (Thiensongrusamee et al. 2001). Lubang alami biasanya terbentuk oleh jenis jamur (fungi) yang menularkan penyakit melalui luka pohon. Contohnya, tempat-tempat dengan percabangan yang patah, atau bagian-bagian pohon yang rusak karena tumbangnya pohon lain atau karena kegiatan manusia (Elouard 1998). Pohon yang membusuk bagian tengahnya dari luar bisa terlihat seperti pohon sehat karena pertumbuhannya yang cepat, meskipun inti kayunya membusuk dengan perlahan. Penyakit busuk gubal pada jenis kayu komersial dapat menyebabkan banyaknya kayu 
yang hilang. Bakshi et al. (1967) contohnya, melaporkan sekitar 9-13\% kayu Shorea robusta yang hilang karena $73 \%$ pohon tersebut berpenyakit. Dengan demikian, mengkaji pohon mana yang terinfeksi oleh penyakit busuk gubal dan membiarkan pohon tersebut tidak ditebang merupakan hal yang sangat penting bagi para pemegang konsesi penebangan. Kayu yang terinfeksi penyakit menghasilkan kayu dengan kualitas yang kurang baik (bahkan untuk pulp sekali pun), namun pohon tersebut berpotensi menjadi tempat beristirahat, bersarang, dan menyimpan makanan bagi banyak vertebrata. Karena memiliki batang yang besar, pohon tersebut juga memiliki sejumlah fungsi penting lainnya (seperti diulas di tempat lain).

\section{Pelatuk}

Pelatuk membentuk kelompok spesialis pemakan kulit kayu dan berkembang biak dalam lubang kayu dengan adaptasi yang memungkinkannya untuk membuat lubang sarang dalam pohon, memanjat batang pohon secara vertikal, dan mempertahankan posisi yang sesuai untuk mencari makan dan membuat lubang. Kompetisi diperkirakan terjadi di antara spesies pelatuk karena seluruh spesies menunjukkan adaptasi tersebut (tidak bergantung kekerabatan). Namun demikian, ukuran pelatuk beragam mulai dari Tukik Tikus Sasia abnormis (dengan berat sekitar $10 \mathrm{~g}$ ) hingga Pelatuk Besar Kelabu Mulleripicus pulverulentus (berat sekitar $430 \mathrm{~g}$ hingga $563 \mathrm{~g}$ ) (Gambar 7). Cara dan tempat makan juga berbeda-beda, terutama di antara spesies dengan ukuran yang sama. Analisis multivariat yang dilakukan terhadap perilaku mencari makan menunjukkan bahwa pelatuk Borneo yang hidup di daerah yang sama (sympatric), memiliki perbedaan terutama dalam habitat mikronya (dimana mereka mencari makanan) dan selanjutnya berbeda dalam teknik mencari makan atau strategi pencarian makanan tersebut (bagaimana mereka mencari makanan). Faktor-faktor yang penting untuk membedakan habitat mikro adalah ketinggian lokasi pencarian makanan, diameter substrat, pemanfaatan kayu hidup atau kayu mati, diameter pohon, dan pemanfaatan bahan nonkayu seperti liana, rotan, dan sarang semut atau rayap (Lammertink 2004b, Styring 2002b, Styring \& Hussin 2004b). Tidak seperti anggapan umum, hanya ada dua spesies pelatuk Borneo yang merupakan spesialis kayu mati. Spesies ini adalah Pelatuk Ayam (Dryocopus javensis) dan Pelatuk Kundang Hutan (Reinwardtipicus validus) yang mencari makanan pada kayu mati Dryocopus javensis (97\%) dan Reinwardtipicus validus (58\%) (Lammertink 2004). Kedua spesies ini ditemukan hidup di Malinau. Di sisi lain, untuk bersarang, sebagian besar pelatuk Borneo menyukai kayu mati yang masih tegak atau bagianbagian pohon yang mati.

Pelatuk berkemungkinan untuk memiliki fungsi ekologi yang penting karena kelompok ini melubangi rongga pohon yang dibutuhkan oleh banyak spesies lain. Perbandingan rongga pohon yang dihasilkan oleh pelatuk masih belum diketahui dan demikian juga kepentingannya dalam pemanfaatan rongga sekunder oleh kelelawar, burung hantu yang bersarang dalam rongga, spesies lalat tertentu, ular, kadal, dan tupai pohon. Namun demikian, karena tidak banyak spesies yang melubangi rongga pohon, pelatuk sangat berpotensi sebagai kelompok ekologis yang bernilai tinggi untuk konservasi kelompok vertebrata dan invertebrata tropis. 


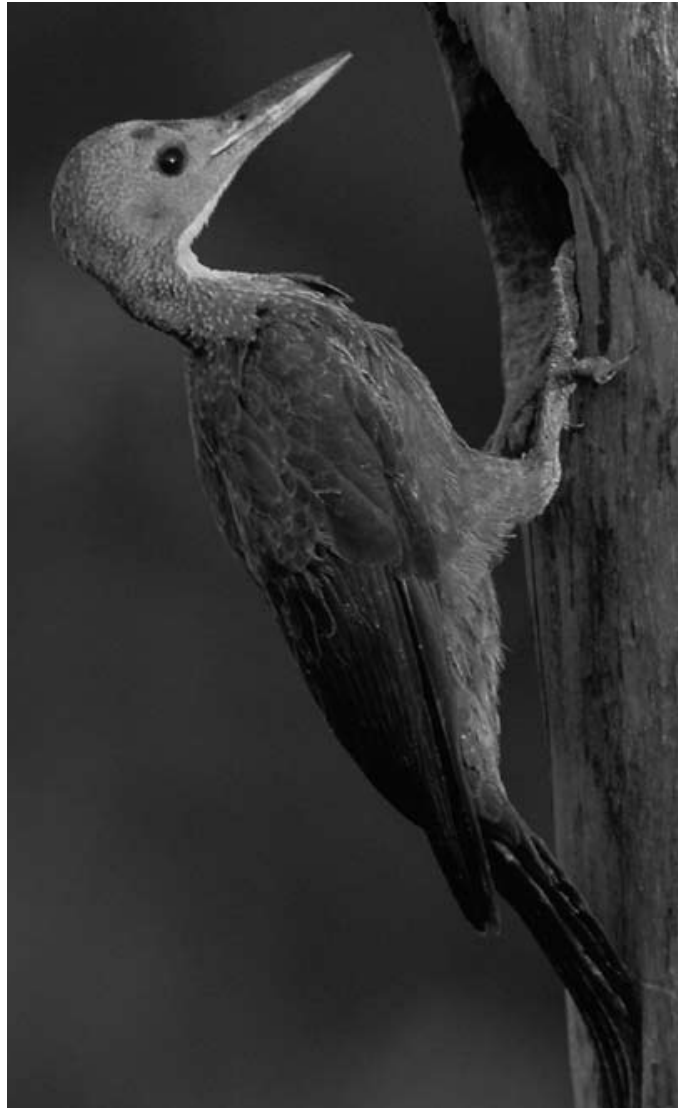

Gambar 7. Pelatuk Besar Kelabu (Mulleripicus pulverulentus) betina; kepadatan pelatuk ini sangat berkurang di hutan bekas tebangan. (Foto oleh Martjan Lammertink)
Van Balen (in litt. 9 November 2004) mencatat 13 spesies pelatuk di Malinau. Delapan di antaranya dijelaskan secara rinci di Lampiran 4. Lima spesies yang lain adalah Pelatuk Ayam (Dryocopus javensis), Pelatuk Rafles (Dinopium rafflesii), Pelatuk Kundang Hutan (Reinwardtipicus validus), Caladi Tikotok (Hemicircus concretus), dan Pelatuk Besar Kelabu (Mulleripicus pulverulentus). Spesies-spesies ini tersebar di Borneo dan diperkirakan hidup di Malinau. Selain itu, Tukik Belang (Picumnus innominatus), yang berasal dari hutan di bagian utara Borneo mungkin dapat hidup di daerah Malinau, meskipun belum terdokumentasi.

Dari pelatuk yang ditemukan di Malinau, Pelatuk Pangkas Blythipicus rubiginosus yang paling aktif menotok dan mematuk, meskipun Tukik Tikus Sasia abnormis dan Pelatuk Merah Picus puniceus memiliki frekuensi mematuk dan menotok yang cukup tinggi. Pelatuk yang menotok ini dibedakan berdasarkan ketinggian tempat pencarian makan, diameter, dan jenis-jenis substrat. Ketiga faktor ini menunjukkan bahwa pengaruh pemanenan kayu terhadap masing-masing spesies burung pelatuk tersebut berbeda. Spesies pelatuk lain yang merupakan spesies yang tidak begitu khas preferensinya tidak begitu banyak menotok dan mematuk. Spesies ini terutama memakan semut dan rayap yang didapatkan dari permukaan pohon atau mencarinya ke dalam retakan-retakan kulit kayu dan ronggarongga alami. Spesies ini sedikit berbeda ukurannya. Namun, keragaman dalam lokasi mencari makanan, kebiasaan, cara, dan pergerakan serta kegiatannya membatasi persaingan. Pelatuk Batu Meiglyptes tristis dan Pelatuk Kumis Kelabu Picus mentalis merupakan spesies yang aktif berjelajah mencari makan di bawah percabangan horizontal, sementara pelatuk lainnya di Malinau tidak aktif berjelajah (Lammertink 2004). Namun demikian, persaingan dalam pencarian makanan sangat mungkin terjadi, terutama dari marga pelatuk dengan ukuran yang sama, apa pun kebiasaan mencari makanannya karena sebagian besar pelatuk juga jenis yang oportunis (Short 1982). Pelatuk yang melubangi kulit kayu dan kayu juga bisa mengumpulkan makanan dari permukaan (penyapu-glean) sehingga menyaingi pelatuk yang hidup 
bersama-sama dalam satu daerah yang juga merupakan jenis penyapu. Seluruh spesies pelatuk akan bersaing dalam mencari tempat bersarang dan istirahat.

Kegiatan penebangan sangat mempengaruhi komunitas pelatuk Borneo (Tabel 3). Di sepanjang lokasi hutan dataran rendah yang ditutupi oleh hutan primer hingga lokasi konsesi hutan tebang pilih, biomassa pelatuk diperkirakan menurun sekitar 60\% dan kepadatan populasi pelatuk secara total menurun hingga 40\%. Perkiraan penurunan kepadatan ini bahkan lebih parah untuk individu spesies. Jumlah individu Picus mentalis dan Mulleripicus pulverulentus menurun hingga lebih dari $80 \%$ (Lammertink 2004). Namun demikian, hingga kini, spesies pelatuk hutan primer hingga tingkat tertentu dapat bertahan di hutan dataran rendah bekas tebangan. Namun demikian, di hutan perbukitan yang utuh dengan ketinggian antara 120 hingga $400 \mathrm{~m}$ di atas permukaan laut (dpl) keragaman pelatuk lebih rendah, yang menunjukkan bahwa hutan dataran rendah bekas tebangan bisa memiliki potensi konservasi yang lebih tinggi dibandingkan dengan hutan primer di perbukitan, setidaknya bagi pelatuk (Lammertink 2004). Tidak satu pun spesies pelatuk Borneo yang terancam secara global. Spesies yang dipengaruhi oleh kegiatan penebangan tinggal di hutan perbukitan (contohnya, Picus mentalis) yang pemanenan kayunya lebih rendah intensitasnya dibandingkan penebangan di hutan dataran rendah, atau wilayah yang luas yang dilindungi atau memiliki rentang distribusi yang luasnya lebih dari Daerah Sunda (contohnya Mulleripicus pulverulentus). Bila kegiatan penebangan meluas ke seluruh rentang penyebaran (ketinggian), spesies-spesies tersebut dapat saja menjadi terancam.

Tabel 3. Spesies pelatuk dan reaksinya terhadap kegiatan penebangan.

\begin{tabular}{|c|c|c|c|c|c|}
\hline Spesies & $\begin{array}{l}\text { Berat } \\
\text { (g) }\end{array}$ & $\mathbf{L}$ & $\begin{array}{l}\text { Stratifikasi } \\
\text { ekologis }\end{array}$ & $\begin{array}{l}\text { Kecenderungan } \\
\text { kepadatan setelah } \\
\text { penebangan }\end{array}$ & Referensi \\
\hline Sasia abnormis & 9 & $\begin{array}{r}89 \\
? \\
18 \\
9 \\
12 \\
1\end{array}$ & $\begin{array}{l}\text { Tumbuhan } \\
\text { bawah, rotan, } \\
\text { tumbuhan } \\
\text { rambat }\end{array}$ & $\begin{array}{l}\uparrow \\
- \\
\downarrow \\
\downarrow \\
\downarrow \downarrow\end{array}$ & $\begin{array}{l}\text { (Lammertink 2004) } \\
\text { (Danielsen \& Heegaard 1995) } \\
\text { (Lambert 1992) } \\
\text { (Styring \& Hussin 2004a) } \\
\text { (Johns 1989a) } \\
\text { (Styring \& Ickes 2001a) }\end{array}$ \\
\hline $\begin{array}{l}\text { Dendrocopus } \\
\text { canicapillus }\end{array}$ & 27 & $\begin{array}{l}2 \\
2\end{array}$ & Tajuk, ranting & $\overline{\downarrow \downarrow}$ & $\begin{array}{l}\text { (Lammertink 2004) } \\
\text { (Lambert 1992) }\end{array}$ \\
\hline $\begin{array}{l}\text { Celeus } \\
\text { brachyurus }\end{array}$ & 83 & $\begin{array}{r}21 \\
? \\
4 \\
74 \\
6 \\
4\end{array}$ & $\begin{array}{l}\text { Tumbuhan } \\
\text { tengah dan } \\
\text { atas, kayu } \\
\text { hidup }\end{array}$ & $\begin{array}{l}- \\
- \\
\downarrow \\
\downarrow \\
\downarrow \downarrow\end{array}$ & $\begin{array}{l}\text { (Styring \& Hussin 2004a) } \\
\text { (Danielsen \& Heegaard 1995) } \\
\text { (Johns 1989a) } \\
\text { (Lammertink 2004) } \\
\text { (Styring \& Ickes 2001a) } \\
\text { (Lambert 1992) }\end{array}$ \\
\hline $\begin{array}{l}\text { Dryocopus } \\
\text { javensis }\end{array}$ & 253 & $\begin{array}{r}63 \\
26 \\
? \\
2 \\
7 \\
5\end{array}$ & $\begin{array}{l}\text { Tumbuhan } \\
\text { dasar dan } \\
\text { tengah, } \\
\text { kayu mati } \\
\text { berdiameter } \\
\text { besar }\end{array}$ & $\begin{array}{l}\uparrow \\
\downarrow \\
\downarrow \\
\downarrow \\
\downarrow \downarrow \\
\downarrow \downarrow\end{array}$ & $\begin{array}{l}\text { (Lammertink 2004) } \\
\text { (Styring \& Hussin 2004a) } \\
\text { (Danielsen \& Heegaard 1995) } \\
\text { (Johns 1989a) } \\
\text { (Styring \& Ickes 2001a) } \\
\text { (Lambert 1992) }\end{array}$ \\
\hline
\end{tabular}




\begin{tabular}{|c|c|c|c|c|c|}
\hline Spesies & $\begin{array}{l}\text { Berat } \\
\text { (g) }\end{array}$ & $\mathbf{L}$ & $\begin{array}{ll}\text { Stratifikasi } \\
\text { ekologis }\end{array}$ & $\begin{array}{l}\text { Kecenderungan } \\
\text { kepadatan setelah } \\
\text { penebangan }\end{array}$ & Referensi \\
\hline Picus miniaceus & 90 & $\begin{array}{r}25 \\
7 \\
6 \\
? \\
4 \\
2\end{array}$ & $\begin{array}{l}\text { Tumbuhan } \\
\text { tengah } \\
\text { dan atas, } \\
\text { kayu hidup, } \\
\text { rambat, dan } \\
\text { liana }\end{array}$ & $\begin{array}{c}\uparrow \uparrow \\
\uparrow \uparrow \\
\uparrow \\
\uparrow \\
\uparrow \\
-\end{array}$ & $\begin{array}{l}\text { (Lammertink 2004) } \\
\text { (Styring \& Hussin 2004a) } \\
\text { (Styring \& Ickes 2001a) } \\
\text { (Danielsen \& Heegaard 1995) } \\
\text { (Johns 1989a) } \\
\text { (Lambert 1992) }\end{array}$ \\
\hline P. puniceus & 81 & $\begin{array}{r}28 \\
? \\
71 \\
28 \\
1 \\
33\end{array}$ & $\begin{array}{l}\text { Tumbuhan } \\
\text { tengah dan } \\
\text { atas, sebagian } \\
\text { besar pada } \\
\text { kayu hidup }\end{array}$ & $\begin{array}{l}\uparrow \uparrow \\
\uparrow \\
\frac{\downarrow}{\downarrow} \\
\downarrow \\
\downarrow \downarrow\end{array}$ & $\begin{array}{l}\text { (Styring \& Ickes 2001a) } \\
\text { (Danielsen \& Heegaard 1995) } \\
\text { (Lammertink 2004) } \\
\text { (Styring \& Hussin 2004a) } \\
\text { (Lambert 1992) } \\
\text { (Johns 1989a) }\end{array}$ \\
\hline P. mentalis & 100 & $\begin{array}{r}21 \\
? \\
39 \\
1 \\
116\end{array}$ & $\begin{array}{l}\text { Tumbuhan } \\
\text { dasar dan } \\
\text { menengah, } \\
\text { sering kali } \\
\text { pada liana }\end{array}$ & $\begin{array}{c}\uparrow \uparrow \\
\uparrow \\
\downarrow \\
\downarrow \\
\downarrow \downarrow\end{array}$ & $\begin{array}{l}\text { (Styring \& Ickes 2001a) } \\
\text { (Danielsen \& Heegaard 1995) } \\
\text { (Styring \& Hussin 2004a) } \\
\text { (Lambert 1992) } \\
\text { (Lammertink 2004) }\end{array}$ \\
\hline $\begin{array}{l}\text { Dinopium } \\
\text { rafflesii }\end{array}$ & 91 & $\begin{array}{r}1 \\
1 \\
? \\
19 \\
2 \\
1\end{array}$ & $\begin{array}{l}\text { Tumbuhan } \\
\text { tengah } \\
\text { dan atas, } \\
\text { melubangi } \\
\text { kayu hidup }\end{array}$ & $\begin{array}{l}\uparrow \\
\uparrow \\
\uparrow \\
\downarrow \downarrow \\
\downarrow \downarrow \\
\downarrow \downarrow\end{array}$ & $\begin{array}{l}\text { (Danielsen \& Heegaard 1995) } \\
\text { (Styring \& Hussin 2004a) } \\
\text { (Johns 1989a) } \\
\text { (Lammertink 2004) } \\
\text { (Styring \& Ickes 2001a) } \\
\text { (Lambert 1992) }\end{array}$ \\
\hline $\begin{array}{l}\text { Blythipicus } \\
\text { rubiginosus }\end{array}$ & 81 & $\begin{array}{r}35 \\
128 \\
? \\
5 \\
18 \\
24\end{array}$ & $\begin{array}{l}\text { Tumbuhan } \\
\text { bawah, kayu } \\
\text { hidup, dan } \\
\text { kayu mati }\end{array}$ & $\begin{array}{l}\uparrow \uparrow \\
\downarrow \\
\downarrow \\
\downarrow \downarrow \\
\downarrow \downarrow \\
\downarrow \downarrow\end{array}$ & $\begin{array}{l}\text { (Styring \& Hussin 2004a) } \\
\text { (Lammertink 2004) } \\
\text { (Danielsen \& Heegaard 1995) } \\
\text { (Styring \& Ickes 2001a) } \\
\text { (Lambert 1992) } \\
\text { (Johns 1989a) }\end{array}$ \\
\hline $\begin{array}{l}\text { Reinwardtipicus } \\
\text { validus }\end{array}$ & 157 & $\begin{array}{r}17 \\
77 \\
30 \\
? \\
21 \\
4\end{array}$ & $\begin{array}{l}\text { Seluruh bagian } \\
\text { tumbuhan. } \\
\text { Kayu mati } \\
\text { berdiameter } \\
\text { sedang }\end{array}$ & $\begin{array}{l}- \\
\downarrow \\
\downarrow \\
\downarrow \\
\downarrow \\
\downarrow \downarrow\end{array}$ & $\begin{array}{l}\text { (Johns 1989a) } \\
\text { (Lammertink 2004) } \\
\text { (Styring \& Hussin 2004a) } \\
\text { (Danielsen \& Heegaard 1995) } \\
\text { (Styring \& Ickes 2001a) } \\
\text { (Lambert 1992) }\end{array}$ \\
\hline Meiglyptes tristis & 45 & $\begin{array}{r}20 \\
12 \\
50 \\
? \\
18\end{array}$ & $\begin{array}{l}\text { Seluruh bagian } \\
\text { tumbuhan, } \\
\text { sering kali } \\
\text { pada daun dan } \\
\text { ranting }\end{array}$ & $\begin{array}{l}\uparrow \uparrow \\
\uparrow \uparrow \\
\overline{-} \\
\downarrow\end{array}$ & $\begin{array}{l}\text { (Styring \& Hussin 2004a) } \\
\text { (Lambert 1992) } \\
\text { (Lammertink 2004) } \\
\text { (Danielsen \& Heegaard 1995) } \\
\text { (Styring \& Ickes 2001) }\end{array}$ \\
\hline M. tukki & 54 & $\begin{array}{r}4 \\
45 \\
9 \\
? \\
22 \\
24\end{array}$ & $\begin{array}{l}\text { Tumbuhan } \\
\text { dasar dan } \\
\text { tengah, } \\
\text { berbagai } \\
\text { substrat }\end{array}$ & $\begin{array}{l}\uparrow \uparrow \\
\overline{-} \\
\overline{-} \\
\bar{\downarrow}\end{array}$ & $\begin{array}{l}\text { (Lambert 1992) } \\
\text { (Lammertink 2004) } \\
\text { (Styring \& Ickes 2001a) } \\
\text { (Danielsen \& Heegaard 1995) } \\
\text { (Johns 1989a) } \\
\text { (Styring \& Hussin 2004a) }\end{array}$ \\
\hline $\begin{array}{l}\text { Hemicircus } \\
\text { concretus }\end{array}$ & 33 & $\begin{array}{r}1 \\
35 \\
1 \\
31 \\
11\end{array}$ & $\begin{array}{l}\text { Tumbuhan } \\
\text { tengah dan } \\
\text { atas, cabang } \\
\text { kecil dan } \\
\text { besar }\end{array}$ & $\begin{array}{l}\uparrow \\
\downarrow \\
\downarrow \\
\downarrow \\
\downarrow \downarrow\end{array}$ & $\begin{array}{l}\text { (Styring \& Ickes 2001a) } \\
\text { (Lammertink 2004) } \\
\text { (Lambert 1992) } \\
\text { (Johns 1989a) } \\
\text { (Styring \& Hussin 2004a) }\end{array}$ \\
\hline
\end{tabular}




\begin{tabular}{|c|c|c|c|c|c|}
\hline Spesies & $\begin{array}{l}\text { Berat } \\
\text { (g) }\end{array}$ & $\mathbf{L}$ & $\begin{array}{ll}\text { Stratifikasi } & \mathbf{k} \\
\text { ekologis } & \mathbf{k} \\
& \mathbf{p} \\
\end{array}$ & $\begin{array}{l}\text { Kecenderungan } \\
\text { kepadatan setelah } \\
\text { penebangan }\end{array}$ & Referensi \\
\hline $\begin{array}{l}\text { Mulleripicus } \\
\text { pulverulentus }\end{array}$ & 430 & $\begin{array}{r}13 \\
5 \\
61 \\
1\end{array}$ & $\begin{array}{l}\text { Tumbuhan } \\
\text { tengah dan } \\
\text { atas, cabang } \\
\text { berdiameter } \\
\text { besar di pohon } \\
\text { yang besar. }\end{array}$ & $\begin{array}{l}\bar{\downarrow} \\
\downarrow \downarrow \\
\downarrow \downarrow\end{array}$ & $\begin{array}{l}\text { (Styring \& Hussin 2004a) } \\
\text { (Lambert 1992) } \\
\text { (Lammertink 2004) } \\
\text { (Styring \& Ickes 2001a) }\end{array}$ \\
\hline
\end{tabular}

$-=<20 \%$ perbedaan nilai tengah kepadatan di hutan bekas tebangan dan hutan primer; $\uparrow / \downarrow=$ kenaikan/penurunan antara 20 hingga $60 \%$ antara hutan bekas tebangan dan hutan primer; $\uparrow \uparrow / \downarrow \downarrow=$ kenaikan/ penurunan lebih dari $60 \%$ antara hutan bekas tebangan dan hutan primer. ${ }^{*} \mathrm{~N}=$ jumlah total transek dalam penelitian yang menjadi acuan penghitungan kepadatan.

Pelatuk juga dilaporkan menurun kepadatannya di hutan bekas tebangan di Sabah (Lambert 1992). Diperkirakan pengurangan kepadatan tersebut mencapai sebesar 23\% dan 50\% di hutan bekas tebangan di Sabah (Johns 1996). Namun demikian, Johns menilai kedua temuan tersebut tidak konklusif. Baik Lambert (1992) maupun Johns (1996) menilai, jumlah lokasi penelitiannya terlalu sedikit untuk menguji dengan layak perbedaan antara kelimpahan burung di hutan bekas tebangan dan hutan primer.

Styring dan Hussin (2004a) menyatakan bahwa pelatuk tidak memiliki reaksi yang khusus terhadap penebangan. Spesies burung yang lain akan turun kelimpahannya di hutan yang baru saja ditebang dan meningkat di hutan bekas tebangan yang lebih tua (jumlah peningkatan pada setiap spesies beragam), atau menjadi lebih berlimpah di hutan yang belum lama ditebang dan menurun kelimpahannya di hutan bekas tebangan yang lebih tua. Di lain pihak, burung pelatuk memiliki kelimpahan yang lebih kecil di hutan yang belum lama ditebang (umur 5 tahun) dan kelimpahannya lebih rendah lagi di hutan bekas tebangan yang lebih tua di Semenanjung Malaya. Pola ini dapat dijelaskan dengan ketersediaan makanan. Sebagai contoh Pelatuk Batu (Meiglyptes tristis), memiliki spesialisasi memakan semut yang hidup di pohon Macaranga spp. yang merupakan spesies pohon yang umum di habitat yang rusak, dan pelatuk ini umumnya meningkat kelimpahannya setelah penebangan (Styring \& Hussin 2004a, b). Spesies lain menyukai tajuk dan menghindari pohon-pohon yang rendah di hutan yang belum lama ditebang. Spesies-spesies ini menurun secara nyata sesaat setelah terjadinya penebangan. Kelompok ketiga merupakan kelompok yang umumnya hidup di hutan utuh dan hutan yang baru saja ditebang. Hal ini terjadi karena kelompok ini khusus mencari makan di vegetasi yang padat pada ketinggian yang rendah dan umumnya kurang banyak ditemukan di hutan regenerasi yang lebih tua.

Penurunan kepadatan pelatuk di areal tebangan diperkirakan terutama karena hilangnya tempat-tempat pencarian makanan. Di dalam areal hutan bekas tebangan di Kalimantan Timur, pelatuk mencari makan terutama pada bagian-bagian hutan yang tidak ditebang. Di sisi lain, kepadatan populasi pelatuk lebih terkait erat dengan jumlah kayu yang ditebang dibandingkan dengan wilayah hutan utuh yang tersisa. Hal ini mengungkapkan bahwa intensitas penebangan di sekeliling bagian- 
bagian hutan yang utuh mengaburkan pentingnya menentukan kepadatan pelatuk (Lammertink 2004).

Tabel 3 menunjukkan adanya banyak variasi dari berbagai penelitian dalam hal cakupan dan arah perubahan kepadatan populasi setelah kegiatan penebangan. Dari seluruh atau sebagaian besar penelitian, spesies yang terlihat dipengaruhi secara negatif oleh penebangan adalah Dryocopus javensis, Blythipicus rubiginosus, Reinwardtipicus validus, Hemicircus concretus dan Mulleripicus pulverulentus. Analisis komponen utama (Principal Component Analyses) yang dilakukan oleh Styring dan Hussin (2004b) menunjukkan bahwa spesies-spesies tersebut memiliki kesamaan cara (mencari) makan: di ketinggian seperti di tajuk dengan diameter substrat yang tinggi, atau di lantai hutan dengan subtrat menengah hingga besar. Styring dan Hussin mengelompokkan spesies ini bersama-sama dengan dua spesies Picus ( $P$. mentalis dan $P$. puniceus) sebagai kelompok pelatuk "konvensional", yaitu kelompok pelatuk berbadan besar yang mencari makan di onggokan kayu-kayu mati atau pada tunggul-tunggul kayu. Kecuali mungkin Caladi Tikotok (Hemicircus concretus), spesies yang lebih toleran terhadap penebangan kayu sama dengan kelompok yang menurut istilah Styring dan Hussin (2004b) "pelatuk yang khas" (novel). Spesies ini memakan substrat seperti bambu, sarang semut pohon, dan daun-daun dari vegetasi berdaun lebar yang hijau sepanjang musim (evergreen broadleaved).

Picus mentalis dan Mulleripicus pulverulentus mencari makan pada bagian-bagian hutan primer di dalam bentang alam hutan bekas tebangan, sehingga frekuensi kehadirannya dapat menjadi indikasi kualitas dan pulihnya hutan setelah penebangan (yaitu pada skala di bawah ukuran wilayah jelajahnya). Mulleripicus pulverulentus mencari makan secara berkelompok di pohon-pohon hidup, mengeksploitasi lebah tak bersengat, sarang semut, dan sarang rayap dalam rongga yang terbentuk secara alami di dahan yang besar serta batang pohon. Spesies ini terutama mencari makanan pada pohon-pohon berukuran besar. Penurunan kepadatan populasi spesies tersebut di hutan tebang pilih diperkirakan karena tumbuhan bawah dan tumbuhan tengah hutan menjadi lebih padat (Lammertink unpubl.). Pelatuk Gunung Bergaris (Picus miniaceus) bisa digunakan sebagai indikator gangguan dengan intensitas sedang karena spesies ini tumbuh subur di hutan tebang pilih.

\section{Sempidan}

Sempidan adalah burung yang berukuran besar dan pemalu. Burung ini merupakan salah satu spesies yang pertama hilang dari hutan yang dikelilingi pemukiman dan konsesi penebangan hutan (lihat BirdLife International 2001), meskipun hal ini bisa jadi disebabkan oleh meningkatnya perburuan dibandingkan dengan kepekaan burung tersebut terhadap kegiatan penebangan. Di daerah Malinau, tercatat tiga spesies sempidan, yaitu Kuau Raja (Argusianus argus), Sempidan Merah (Lophura ignita), dan Sempidan Kalimantan (Lobiophasis bulweri) (Nijman 1997; O’Brien \& Fimbel 2002; Augeri in prep.). Spesies Borneo yang ke empat, yaitu Sempidan Merah (Lophura erythrophthalma) tidak ditemukan di MRF. van Ballen (dalam O'Brien \& Fimbel 2002) menyatakan bahwa MRF berada pada rentang ketinggian spesies spesialis dataran rendah ini. Kuau-Kerdil Kalimantan (Polyplectron schleiermacheri) 
yang langka dan terancam punah ditemukan di daerah selatan, utara, dan barat Malinau (BirdLife International 2001). Meskipun penyebarannya tidak merata, spesies ini mungkin hidup di MRF (dengan catatan bahwa BirdLife Red Data Book memperkirakan spesies ini tidak ditemukan di sebelah utara $1^{\circ} 20^{\prime}$ LU di Kalimantan Timur). Penelitian yang dilakukan baru-baru ini menyatakan bahwa Kuau-Kerdil Kalimantan (Polyplectron schleiermacheri) bisa bertahan hidup pada fragmen hutan yang kecil (kurang lebih 6.000 ha) dekat kota Balikpapan, Kalimantan Timur (Fredriksson \& Nijman 2004). Hal ini mengungkapkan bahwa spesies ini relatif resisten terhadap fragmentasi hutan, setidaknya dalam jangka pendek.

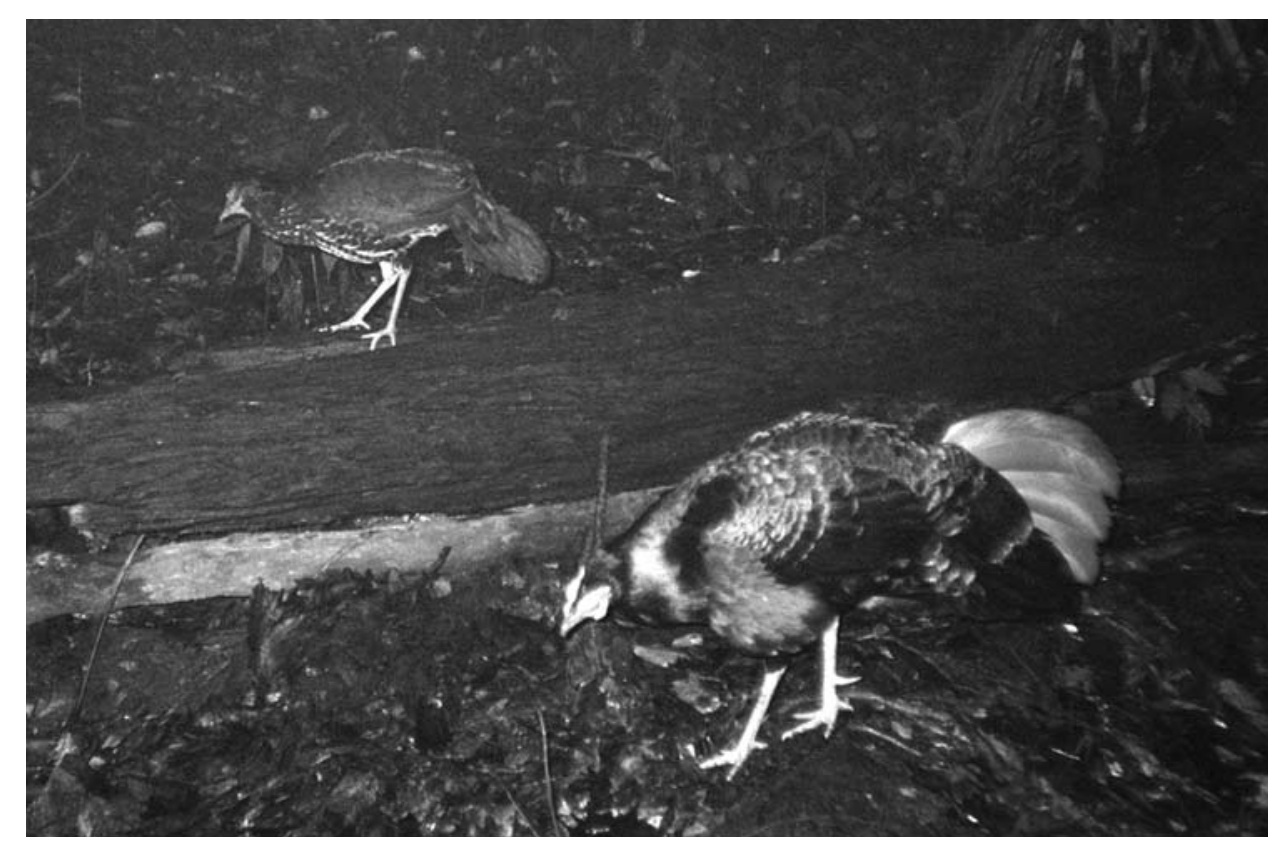

Gambar 8. Sempidan Merah (Lophura ignita) jantan dan betina di hutan utuh di MRF. (Foto oleh Dave Augeri)

Seluruh spesies sempidan Borneo memiliki wilayah jelajah yang relatif kecil; tidak satu pun yang hidup di luar Semenanjung Malaysia, Sumatera, dan Borneo. Sebagian besar memiliki status terancam. Kecuali untuk Kuau Raja, penelitian yang dilakukan untuk spesies sempidan Borneo relatif sedikit jumlahnya. Rijksen (1978) melaporkan bahwa bunyi panggilan Kuau tidak menurun banyak di hutan dengan sedikit gangguan, meskipun di hutan bekas tebangan frekuensi bunyinya menurun drastis. Sözer et al. (1999) melaporkan bahwa Kuau Raja umum hidup di hutan dataran rendah primer dan sekunder, bahkan di daerah tebangan. Bennett dan Dahaban (1995) menemukan bahwa bunyi panggilan Kuau Raja meningkat secara nyata $(p<0,05)$ di areal ladang berpindah yang sudah lama ada (sekitar 30 tahun) dibandingkan dengan hutan primer. Peningkatan bunyi panggilan ini mungkin hanya disebabkan oleh gangguan bentang alam, namun di daerah ini kegiatan perladangannya sudah berjalan sangat lama sehingga gangguan habitat sepertinya 
tidak begitu mempengaruhi jumlah bunyi panggilan. Tingkat bunyi panggilan yang tinggi mungkin dapat menjadi petunjuk tingginya kepadatan. Di wilayah lain, bunyi panggilan kuau terlihat memiliki toleransi terhadap penebangan, tetapi bukan terhadap perburuan. Hal ini dapat menjelaskan temuan Augeri (unpubl.) yang mengungkapkan bahwa bunyi panggilan, tempat bertemu, serta rekaman gambar Kuau Raja ini lebih rendah jumlahnya di dalam dan di sekitar hutan sekunder yang masih muda dan daerah yang belum lama ditebang serta daerah perladangan di ekosistem MRF, Kayan Mentarang, dan Leuser. Perbedaan ini kemungkinan terkait dengan tekanan perburuan.

Sözer et al. (1999) menemukan bahwa L. ignita umum didapati di hutan bekas tebangan dan bahkan di daerah perladangan. Augeri (unpbl.) mendapatkan frekuensi rekaman gambar yang lebih rendah di daerah dengan habitat yang terganggu dibandingkan dengan hutan yang utuh. O’Brien et al. (1998c) mencatat bahwa Kuau-Kerdil Kalimantan (Polyplectron schleiermacheri) dipengaruhi secara negatif oleh kegiatan penebangan, terutama karena hutan rawa, hutan di koridor sungai, dan hutan Dipterokarpa di dataran rendah yang menjadi habitatnya (lihat Fredriksson \& Nijman 2004), merupakan jenis hutan yang sangat terancam keberadaannya (van Balen \& Holmes 1993; O’Brien et al. 1998c). Selain itu, spesies burung ini menjadi sasaran perburuan.

Tabel 4. Sempidan dan reaksinya terhadap kegiatan penebangan.

\begin{tabular}{|c|c|c|c|c|}
\hline Spesies & $\begin{array}{l}\text { Berat } \\
\text { badan } \\
\text { (kg) } \\
+ \\
\end{array}$ & $\begin{array}{l}\text { Stratifikasi } \\
\text { ekologis }\end{array}$ & $\begin{array}{l}\text { Kecenderungan } \\
\text { kepadatan } \\
\text { populasi setelah } \\
\text { penebangan }\end{array}$ & Referensi \\
\hline $\begin{array}{l}\text { Lophura } \\
\text { erythrophthalma }\end{array}$ & 0,85 & $\begin{array}{l}\text { Terestrial; pemakan } \\
\text { buah dan serangga }\end{array}$ & $\begin{array}{l}\uparrow \\
- \\
\end{array}$ & $\begin{array}{l}\text { (Davison \& Scriven undated in } \\
\text { BirdLife International 2001) } \\
\text { (Danielsen \& Heegaard 1995) }\end{array}$ \\
\hline Lophura ignita & 1,6 & $\begin{array}{l}\text { Terestrial; } \\
\text { kemungkinan } \\
\text { pemakan buah dan } \\
\text { serangga }\end{array}$ & $\begin{array}{l}\uparrow \\
- \\
-\end{array}$ & $\begin{array}{l}\text { (Danielsen \& Heegaard 1995) } \\
\text { (BirdLife International 2001) } \\
\text { (Sözer et al. 1999) }\end{array}$ \\
\hline $\begin{array}{l}\text { Lobiophasis } \\
\text { bulweri }\end{array}$ & 1 & $\begin{array}{l}\text { Terestrial; pemakan } \\
\text { buah dan serangga; } \\
\text { bermigrasi }\end{array}$ & $\downarrow \downarrow$ & (BirdLife International 2001) \\
\hline $\begin{array}{l}\text { Argusianus } \\
\text { argus }\end{array}$ & 3 & $\begin{array}{l}\text { Pemilih makanan } \\
\text { dari serangga dan } \\
\text { buah }\end{array}$ & $\begin{array}{l}\uparrow \\
- \\
- \\
- \\
-\downarrow \\
-\end{array}$ & $\begin{array}{l}\text { (O'Brien et al. 2003) } \\
\text { (Rijksen 1978) } \\
\text { (BirdLife International 2001) } \\
\text { (Sözer et al. 1999) } \\
\text { (Wilson \& Wilson 1975) } \\
\text { (Winarni 2002) } \\
\text { (Danielsen \& Heegaard 1995) } \\
\text { (Bennett \& Dabahan 1995) }\end{array}$ \\
\hline
\end{tabular}


Datta (2000) mempublikasikan salah satu dari sedikit penelitiannya mengenai pengaruh kegiatan penebangan terhadap populasi sempidan. Di lokasi penelitiannya di bagian barat Aruchnal Pradesh, India, Datta mencatat kelimpahan relatif dari tiga spesies sempidan di lima lokasi yang berbeda, yaitu: perkebunan, hutan yang agak terganggu, dan hutan bekas tebangan berumur 20 hingga 25 tahun, hutan yang baru ditebang, dan hutan utuh (tidak ditebang). Ketiga spesies sempidan yang tercatat adalah Ayam Hutan Merah (Gallus gallus), Kuau Dada Hitam Khaleej (Lophura leucomelana lathami), dan Kuau-Kerdil Kelabu (Polyplectron bicalcaratum); dua genera terakhir ini hidup berdampingan di Borneo. Secara umum kelimpahan ayam hutan tertinggi didapati di hutan utuh dan kelimpahan rendah didapati di lokasi lainnya, sementara di perkebunan tidak didapati satu pun ayam hutan. Datta (2000) mengungkapkan bahwa alasan utama rendahnya kelimpahan sempidan di hutan bekas tebangan adalah: 1) pengaruh kegiatan penebangan terhadap fauna pemakan daun mati (tidak dapat ditemui di hutan yang baru saja ditebang), 2) rusaknya vegetasi tumbuhan bawah, 3) dan peningkatan gangguan dari manusia dan perburuan karena kemudahan akses melalui jalan tebangan. Gangguan selama kegiatan penebangan dan peningkatan aksesibilitas akibat pembangunan jalan tebangan berpengaruh negatif terhadap kelimpahan sempidan, meskipun ada pula kemungkinan yang tidak dapat diabaikan, yaitu burung-burung menjadi lebih waspada dan berhati-hati serta lebih sulit untuk dilihat di hutan yang terganggu.

\section{Taxa lain}

Beberapa taxa dijelaskan secara singkat di bawah ini. Meskipun informasi yang diperoleh terbatas, namun taxa berikut mencakup seluruh spesies yang terpengaruh oleh gangguan.

\section{Burung luntur}

Burung luntur (Trogonidae) adalah pemakan serangga di hutan tropis dan subtropis yang mencari makan dengan cara menyapu permukaan substrat dan dengan menyerang secara tiba-tiba. Di bagian selatan Thailand, luntur merupakan spesies yang tidak dapat bertoleransi terhadap rusaknya hutan (Round \& Brockelman 1998). Kelompok spesies ini juga tidak dapat bertoleransi terhadap fragmentasi dan isolasi hutan sebagaimana ditunjukkan oleh hilangnya dua spesies luntur dari Singapura (Corlett \& Turner 1997). Selain itu, rendahnya toleransi luntur ini terlihat dari hanya satu spesies luntur yang dapat bertahan hidup di fragmen hutan dataran rendah di Pulau Jawa, dibandingkan dengan empat hingga lima spesies yang dapat bertahan di tempat lain di wilayah Sunda (van Balen 1999b). Spesies luntur yang ada di dataran rendah Pulau Jawa, yaitu Luntur Gunung $(H$. reinwardtii), adalah spesies yang tinggal di sub-pegunungan dan dapat bertahan hidup mungkin karena kemampuannya memanfaatkan hutan di permukaan yang lebih tinggi. Lambert dan Collar (2002) menyimpulkan bahwa populasi luntur harus dipantau dengan lebih hati-hati, karena bukti yang ada mengungkapkan bahwa mereka lebih rentan terhadap perubahan yang terjadi di hutan-hutan Sunda dibandingkan dengan taxa yang lain. Van Balen (dalam 
O’Brien \& Fimbel 2002) mengidentifikasi empat spesies luntur di MRF. Ke empat spesies tersebut yaitu: Luntur Hutan (Harpactes oreskios), Luntur Diard (H. diardii), Luntur putri ( $H$. duvaucelii), dan Luntur Kasumba $(H$. kasumba). Tiga di antaranya yaitu $H$. diardii, $H$. duvaucelii, dan $H$. kasumba, terbatas penyebarannya pada dataran rendah atau sub-pegunungan yang rendah sehingga lebih rentan terhadap kepunahan lokal (Lambert \& Collar 2002).

\section{Kutilang}

Kutilang (Pycnonotidae) merupakan suku besar dari spesies yang mempunyai preferensi habitat yang beragam. Perbedaan besar badan tidak begitu terlihat, namun spesies dibedakan oleh tipe habitat, ketinggian, dan kemungkinan perbedaan makanan serta perilaku pencarian makanan (lihat MacKinnon \& Phillipps 1993). Sejumlah spesies (Pycnonotus cyaniventris, P. squamatus, P. erythropthalmos, P. eutilotus dan $P$. melanoleucos) terlihat dipengaruhi oleh fragmentasi hutan (Lambert \& Collar 2002). Di lain pihak, sejumlah spesies kutilang mengalami peningkatan kelimpahan setelah penebangan (Hussin 1994; Johns 1989a, 1996; Lambert 1992). Hussin (1996) mengungkapkan bahwa tingginya jumlah spesies kutilang yang diamati memakan buah di hutan bekas tebangan kemungkinan disebabkan berkurangnya persaingan karena rendahnya jumlah spesies pemakan buah hutan primer seperti Sempur-Hujan Rimba (Calyptomena viridis) dan Kacembang Gadung (Irena puella). Sejumlah perubahan bisa juga terjadi akibat perubahan ketinggian pencarian makanan karena banyak spesies kutilang yang umumnya hidup di tepian hutan (forest edges) juga ditemukan pada tajuk pohon di hutan primer (Hussin \& Francis 2001). Namun demikian, faktor utamanya kemungkinan besar karena peningkatan ketersediaan buah-buahan berukuran kecil dari jenis pohon perintis tertentu (banyak jenis pohon perintis tidak menghasilkan buah yang dapat dimakan dan banyak pula yang menghasilkan buah-buah kecil yang disukai burung-burung penyebar biji). Spesies burung pemakan buah/serangga generalis ini memakan buah-buahan dari jenis pohon perintis dan berperan penting dalam penyebaran jenis tumbuhan ini ke daerah tebang pilih (Hussin 1996), meskipun satwa lain seperti kelelawar juga menyebarkan biji tersebut (Hussin \& Francis 2001). Jenis pohon perintis tumbuh dengan cepat dan beberapa menghasilkan buah pada umur yang relatif muda sehingga merupakan sumber makanan tambahan di hutan bekas tebangan. Terakhir adalah Cucak Rawa (Pycnonotus zeylanicus) yang banyak dicari untuk burung peliharaan dalam sangkar (punah secara lokal di wilayah-wilayah hutan Malinau yang dapat diakses dengan mudah). Di samping itu, meningkatnya aksesibilitas hutan serta tingginya harga pasaran burung-burung tersebut menambah tekanan/ancaman terhadap spesies ini.

\section{Kancilan, Berencet, Tepus}

Kancilan/Berencet/Tepus (Timaliidae) terdiri dari spesies-spesies burung kecil yang beragam, dan 27 spesies diantaranya endemik di dataran rendah Sunda (Lambert \& Collar 2002). Biasanya burung-burung ini hidup pada bagian dasar dan tengah hutan. Sembilan spesies berencet Sunda menunjukkan respons yang negatif terhadap 
kegiatan penebangan dan fragmentasi hutan. Empat spesies dalam suku ini (Berencet Loreng (Kenopia striata), Sipinjur Melayu (Eupetes macrocerus), Berencet LeherHitam (Ptilocichla leucogrammica) dan Pelanduk Dada-Putih (Trichastoma rostratum) sangat bergantung pada hutan dataran rendah (Lambert \& Collar 2002). Namun demikian, Hussin dan Francis (2001) berpendapat bahwa spesies-spesies ini relatif langka dan sulit untuk ditemukan, bahkan di hutan primer sekali pun (Hussin 1994; Karr 1977), sehingga sulit untuk mendapatkan hasil survei yang konklusif.

Sejumlah spesies yang hidup di pohon dilaporkan meningkat populasinya akibat terjadinya kegiatan penebangan. Spesies ini antara lain Ciung/Burung Kalaces (Macronous spp.). Sementara spesies yang lain tampak menurun populasinya, meskipun mampu bertahan di hutan bekas tebangan. Hasil penelitian secara kuantitatif untuk individu spesies atau kelompok spesies beragam antar wilayah penelitian. Sebagai contoh, Kancilan Topi Sisik (Malacopteron cinereum) menurun secara drastis kelimpahannya di beberapa lokasi penelitian (Lambert 1992), namun penurunan kelimpahan ini tidak begitu terlihat di tempat lain (Johns 1989a; Hussin 1994). Spesies Malacopteron yang lain masih umum didapati di hutan bekas tebangan, tetapi dalam jumlah yang jauh berkurang di beberapa tempat (Lambert 1992; Nordin \& Hussin 1996) dibandingkan dengan tempat lainnya (Johns 1989a).

Penurunan kelimpahan burung ini, setidaknya sebagian besar, disebabkan oleh hilangnya tumbuhan bawah di bawah naungan yang berada di bagian besar hutan yang ditebang (Hussin \& Francis 2001). Sejumlah kecil spesies seperti berencet menghindari terbang melintasi bagian hutan yang terang atau terbuka lebar (Hussin \& Francis 2001). Hal ini sejalan dengan temuan dari MRF, yaitu dengan tidak ditemukannya spesies berencet ini di areal hutan yang ditebang enam tahun yang lalu (O’Brien \& Fimbel 2002). Burghouts et al. (1992) dan Chung (1993, dalam Hussin \& Francis 2001) menemukan bahwa perubahan iklim mikro terkait dengan perubahan penyebaran serta kelimpahan vertebrata yang menjadi sumber makanan berencet. Di lain pihak, Boer (1998) menemukan bahwa terdapat korelasi yang tidak nyata antara kelimpahan serangga, gangguan habitat, dan keragaman serangga sehingga diperlukan penelitian lebih lanjut mengenai hubungan tersebut. Johns (1989a) menemukan bahwa kelimpahan berencet yang hidup di tumbuhan bawah meningkat enam tahun setelah penebangan dan setelah restorasi penutupan tajuk, meskipun jumlah tersebut masih jauh lebih rendah dibandingkan dengan hutan primer. Namun demikian, Wong (1985) melaporkan bahwa kepadatan dan keragaman pemakan serangga yang hidup pada tumbuhan bawah lebih rendah, bahkan dua puluh lima tahun setelah kegiatan penebangan dibandingkan dengan kepadatan dan keragaman spesies di hutan primer yang berdekatan. Wong (1986) menemukan adanya sedikit perbedaan dalam kelimpahan artropoda di dua lokasi yang berbeda meskipun ketersediaan buah-buahan berkurang frekuensinya di lokasi hutan yang telah tumbuh kembali (regenerating sites).

\section{Sikatan}

Sikatan (Muscicapidae) membentuk kelompok pemakan serangga yang sangat khas (spesialis) yang hidup di beragam habitat (mikro). Spesies sikatan Rhinomyias dan 
Ficedula saling bergantian dalam hal ketinggian tempat hidup, sementara anggota marga Cyornis ditemukan pada tipe habitat yang berbeda di hutan tropis (contohnya, sungai, tajuk bagian tengah, tumbuhan bawah, dan sebagainya). Banyak spesies dari suku ini dipengaruhi secara negatif oleh kegiatan penebangan dan/atau fragmentasi hutan (Lambert \& Collar 2002), meskipun ada satu, yaitu Kehicap Ranting (Hypothymis azurea) meningkat secara nyata setelah penebangan (Hussin 1994). Hal ini bukan merupakan sesuatu yang baru karena spesies ini umumnya dapat ditemui di savana terbuka di Jawa Timur (Meijaard pengamatan pribadi) sehingga dapat dijelaskan bahwa spesies ini dapat beradaptasi dengan baik pada kondisi hutan terbuka. Spesies-spesialis hutan sepanjang sungai, Sikatan Melayu (Cyornis turcosus), mengalami penurunan jumlah di hutan tebangan yang mungkin disebabkan oleh hilangnya vegetasi pelindung yang ada di tepian sungai (O’Brien \& Fimbel 2002).

\section{Burung Kukuk, Kadalan, Bubut, dan Tokhtor}

Data dari Amerika Serikat mengungkapkan bahwa parasit sarang seperti Spizella passerina lebih umum dijumpai hidup di daerah hutan yang rusak dan terfragmentasi, menyebabkan insiden parasitisme sarang bagi sejumlah spesies (Hobson \& Villard 1998; Twedt et al. 2001). Adanya pola yang sama di antara parasit sarang di Asia Tenggara masih belum jelas. Namun demikian, van Balen (in litt. 8 November 2004) menyatakan bahwa kukuk terwakili dengan baik dalam kelompok avifauna yang ada di hutan Jambi, Sumatera, yang ditebang dua tahun sebelumnya. Lebih lanjut, ukuran sampel dianggap terlalu kecil untuk analisis yang memadai.

\section{Burung buas}

Penelitian tentang pengaruh kegiatan penebangan hutan terhadap kelompok raptor (elang, alap-alap) masih belum banyak dilakukan di Asia Tenggara. Thiollay (1998, 1999) menyediakan sejumlah data yang mengungkapkan bahwa khususnya spesies spesialis yang hidup di bagian dalam hutan seperti kelompok Elang Spizaetus tidak toleran terhadap pengaruh pemanenan kayu. Namun demikian, Lambert dan Collar (2002) menekankan bahwa spesies tersebut hidup di fragmen hutan berukuran kecil dan seringkali diamati berada di luar bagian hutan di Jawa dan Sumatera. Lebih jauh, mereka menyatakan bahwa sebagian besar raptor Sunda terlihat mampu bertahan di hutan bekas tebangan. Nijman dan van Balen (2003) mengungkapkan bahwa di antara Elang Jawa (Spizaetus barteli), burung-burung muda diperkirakan akan menyebar di antara fragmen hutan dibandingkan dengan burung-burung yang lebih tua dan dewasa. 


\section{Mamalia}

\section{Umum}

Harrison (1968, 1969) adalah salah seorang peneliti yang mengkaji karakteristik ketergantungan mamalia Asia Tenggara terhadap hutan. Data Harrison mengungkapkan bahwa bila hujan tropis rusak sama sekali, yang akan tersisa hanyalah spesies tikus yang bukan asli. Sejak itulah penelitian jangka pendek dan jangka panjang yang mengungkapkan pengaruh tebang pilih terhadap beragam spesies mamalia dilakukan. Namun demikian, hubungan sebab akibat antara kepadatan spesies dan kegiatan yang berhubungan dengan pemanenan kayu masih belum dapat dipahami dengan jelas.

Salah satu masalah yang berkaitan dengan pengkajian dampak kegiatan penebangan terhadap mamalia adalah penyebaran spesies yang tidak merata bahkan di hutan utuh sekali pun, serta kepadatan antara satu lokasi dengan lokasi lainnya sangat beragam. Daftar yang dibuat oleh Zubaid dan Khairul (1997) menggambarkan keragaman mamalia kecil yang paling umum dijerat oleh sejumlah peneliti pada plot hutan bekas tebangan maupun hutan utuh di Semenanjung Malaya (Tabel 5). Hal ini menunjukkan bahwa membandingkan kepadatan spesies di lokasi hutan bekas tebangan dan hutan utuh kurang bermanfaat bila komposisi dan kepadatan spesies sebelum kegiatan penebangan tidak dikaji. Bila terdapat perbedaan kepadatan sebelum kegiatan penebangan dilakukan, maka pengkajian kepadatan spesies setelah kegiatan penebangan akan lebih sulit dilakukan. Kecuali bila digunakan rancangan sampel yang memadai untuk mempertimbangkan seluruh potensi sumber keragaman. Rancangan seperti ini masih jarang ditemukan. Sayangnya, dalam banyak penelitian tentang pengaruh penebangan, penelitian dasar (baseline studies) sebelum kegiatan penebangan tidak dilakukan. Sejumlah peneliti menggunakan hanya satu atau dua plot perlakuan yang independen (hutan bekas tebangan vs. hutan primer), sehingga sulit untuk menentukan apakah perbedaan yang diamati di luar variasi yang ada di hutan bekas tebangan atau hutan primer dan untuk menentukan apakah perbedaan yang diperoleh tersebut ada hubungannya dengan perbedaan dalam perlakuan (Hurlbert 
1984; Oksanen 2001). Untuk menginvestigasi pengaruh kegiatan penebangan, sebaiknya digunakan rancangan dengan lokasi penelitian ganda serta independen (Augeri 1995; Datta 1998). Tingginya nilai keragaman yang diperoleh dari berbagai hasil kajian tentang pengaruh kegiatan penebangan terhadap kepadatan spesies dapat dijelaskan dengan adanya problema pada saat pengambilan sampel. Namun demikian, kajian kepadatan spesies setelah penebangan yang dikombinasikan dengan informasi biologis dan ekologis spesies yang terkait dapat memberikan gambaran yang bermanfaat.

Tabel 5. Spesies mamalia kecil yang umumnya terjerat dalam sejumlah penelitian di Semenanjung Malaya.

\begin{tabular}{lll}
\hline $\begin{array}{l}\text { Sebagian besar spesies } \\
\text { mamalia kecil di hutan utuh }\end{array}$ & $\begin{array}{l}\text { Sebagian besar spesies mamalia Sumber } \\
\text { kecil di hutan bekas tebangan }\end{array}$ & \\
\hline $\begin{array}{l}\text { Bajing Kelapa (Callosciurus } \\
\text { notatus) dan Tikus Pohon Kelabu } \\
\text { Lenothrix canus }\end{array}$ & $\begin{array}{l}\text { Tikus-raksasa Ekor Panjang } \\
\text { (Leopoldamys sabanus) dan Tikus } \\
\text { Pohon Kelabu C. notatus }\end{array}$ & (Zubaid \& Khairul 1997) \\
\hline $\begin{array}{l}\text { Bajing Akar (Tupaia glis) dan Tikus } \\
\text { Duri Merah/Coklat (Maxomys } \\
\text { surifer/rajah) }\end{array}$ & $\begin{array}{l}\text { (Jum 1987 dalam } \\
\text { Zubaid \& Khairul 1997) }\end{array}$ & (Kemper \& Bell 1985) \\
\hline $\begin{array}{l}\text { Tikus-raksasa Ekor Panjang L. } \\
\text { sabanus dan Bajing Akar (T.glis) }\end{array}$ & $\begin{array}{l}\text { Tikus Belukar (Rattus tiomanicus) } \\
\text { dan Tikus Pohon Kelabu (C. }\end{array}$ & (Harrison 1969) \\
\hline $\begin{array}{l}\text { Tikus Duri Merah/Coklat (M. } \\
\text { surifer/rajah) dan Tikus-raksasa } \\
\text { Ekor Panjang L. sabanus }\end{array}$ & (Langham 1983) \\
\hline $\begin{array}{l}\text { Bajing Akar (T. glis) dan Tikus Duri } \\
\text { Merah/Coklat M. surifer/rajah }\end{array}$ & $\begin{array}{l}\text { Tikus-raksasa Ekor Panjang (L. } \\
\text { sabanus) dan Tikus Duri Merah } \\
\text { (Majomys surifer) }\end{array}$ & (Yasuda et al. 2003) \\
\hline $\begin{array}{l}\text { Bajing Akar (T. glis) dan Tikus- } \\
\text { raksasa Ekor Panjang (L. sabanus) }\end{array}$ & \\
\hline $\begin{array}{l}\text { Tikus-raksasa Ekor Panjang (L. } \\
\text { sabanus) dan Bajing akar (T.glis) }\end{array}$ & & (Kemper \& Bell 1985) \\
\hline
\end{tabular}

\section{Primata}

Primata adalah kelompok mamalia yang paling terkenal yang hidup di hutan tropis dan informasi ekologi spesies primata ini cukup banyak diketahui. Namun demikian, kebanyakan yang diketahui tentang primata Borneo lebih menyangkut perilaku, kondisi populasi, dan pola pergerakannya. Sementara data yang berkaitan dengan respon terhadap gangguan habitat masih sedikit. Meskipun demikian, sejumlah penelitian menyediakan informasi tentang komunitas primata yang hidup di hutan produksi (lihat Johns 1997, Johns \& Skorupa 1987, Plumptre \& Johns 2001, Rijksen 1978). Secara umum, primata yang bersifat generalis, cukup mampu beradaptasi dengan tebang pilih dengan cara mengubah pola jelajah dan makanannya untuk menyesuaikan diri dengan perubahan struktur dan komposisi hutan (Johns 1997).

Johns dan Skorupa (1987) melakukan kajian pustaka yang tersedia dan mengevaluasi hipotesis berikut untuk seluruh spesies primata: kerentanan terhadap gangguan habitat meningkat sejalan dengan peningkatan berat badan dan dengan adanya keragaman makanan, serta kerentanan tersebut menurun dengan meningkatnya 
tingkat konsumsi daun. Hasil analisis Johns dan Skorupa (1987) menunjukkan bahwa secara umum sifatnya sebagai spesies primata pemakan buah menunjukkan korelasi negatif yang kuat dengan kemampuannya untuk bertahan di hutan yang belum lama ditebang, seperti dijelaskan di dalam perbandingan kepadatan populasi di hutan utuh dan hutan bekas tebangan yang berdekatan lokasinya. Sementara keragaman persentasi pemakan buah nyata secara statistik, hal ini masih dianggap tidak cukup untuk digunakan sebagai penduga yang handal bagi kasus-kasus individual (Johns \& Skorupa 1987). Namun demikian, keragaman tipe makanan tidak berpengaruh terhadap kemampuan spesies untuk bertahan setelah kegiatan penebangan terjadi. Faktor yang paling penting yang mempengaruhi ketahanan spesies adalah kemampuan untuk mengubah proporsi berbagai jenis makanan yang berbeda dalam pola makannya, terutama memakan daun-daun muda yang tersedia saat buah-buahan tidak dijumpai ${ }^{1}$. Spesialis pemakan buah kurang mampu melakukan hal ini. Spesies yang paling mampu bertahan adalah spesies pemakan daun, meskipun kadang mereka dianggap sebagai pemakan buah di hutan primer (Johns 1997). Namun demikian, aspek terpenting adalah naiknya tingkat mortalitas primata muda dan bayi primata jika primata dewasa menjadi pemakan daun. Betina yang menyusui menjadi tertekan energinya dan hal ini dapat menyebabkan bayi primata ditinggalkan atau kelaparan. Primata muda tidak mampu untuk mencerna daun-daunan. Risiko kematian karena kelaparan atau pemangsaan meningkat bila satwa tersebut mencari makan sendirian. Sekali lagi, hal ini mengungkapkan bahwa penelitian yang dilakukan di hutan yang telah lama ditebang, yang terpisah dari hutan utuh, dapat membantu kita memahami apa yang sebetulnya terjadi.

Di hutan Asia Tenggara pohon-pohon kayu berasal dari suku Dipterocarpaceae. Pohon-pohon tersebut tidak dikenal sebagai sumber makanan bagi primata. Sebagian besar primata Asia Tenggara bersifat generalis, mampu mengadaptasi pola makannya bergantung dari perubahan ketersediaan makanan di berbagai tipe hutan bekas tebangan yang ditebang dengan cara yang berbeda. Johns (1983) melakukan penelitian tentang pengaruh tebang pilih terhadap primata selama lebih dari dua tahun di Malaysia Barat. Dalam penelitian itu Johns tidak dapat menemukan bukti bahwa tidak satu pun spesies primata biasa bergantung pada hutan dewasa. Johns (1997) menyatakan bahwa keragaman kepadatan lokal yang disebabkan oleh faktor lingkungan atau sejarah (seperti perburuan) bisa lebih tinggi dibandingkan dengan perubahan yang disebabkan oleh kegiatan penebangan kayu. Mungkin pula hal ini disebabkan oleh perbedaan selang waktu, dimana sejumlah spesies primata mampu untuk bertahan di habitat nonhutan untuk periode yang lebih lama dibandingkan dengan dokumentasi yang diperoleh dalam penelitian jangka pendek. Dampak terhadap kepadatan dapat terjadi dalam beberapa tahun. Seringkali pengamatan yang dilakukan secara ekologis sangat singkat, biasanya hanya satu atau dua musim, dan tidak dapat mencatat seluruh pengaruh perubahan dan siklus tahunan yang ada. Johns

\footnotetext{
${ }^{1}$ Keragaman pola makan dan kemampuan untuk mengubah pola makan (spesialisasi makan) bukan hal yang sama. Spesies hewan tertentu bisa memiliki keragaman pola makan yang rendah namun mampu untuk mengganti makanan kesukaannya (contohnya sejumlah Presbytis spp.), atau memiliki keragaman pola makan yang tinggi, namun kemampuan untuk berpindah pada makanan lain terbatas.
} 
dan Skorupa (1987) mengakui bahwa pengamatan kemampuan ketahanan hidup yang dilakukan sesaat atau dalam jangka pendek pada habitat yang terganggu dapat menyebabkan kesalahan pemahaman. Dalam pengambilan sampel di satu titik (point sampling) pada luasan geografis tertentu, Johns dan Skorupa (1987) menyimpulkan bahwa masalah yang sama akan timbul saat menginterpretasikan pengamatan yang berkaitan dengan dampak yang bersifat lokal. Dalam hal ini, primata yang menjauhi daerah yang terganggu, terutama spesies teritorial, akan mengalami laju kematian yang tinggi dan hal ini mungkin tidak teramati pada penelitian yang singkat dan dalam lingkup geografis yang terbatas.

Meskipun habitat terganggu, sejumlah spesies akan tinggal di satu wilayah yang sama karena kesamaan sejarahnya secara teritorial. Sedangkan sejumlah primata lainnya tidak mampu berpindah ke daerah baru karena: a) isolasi bagian-bagian hutan yang dikelilingi oleh lahan yang terjal, b) bukaan tajuk yang besar yang menyebabkan primata harus turun ke tanah (hal ini menjadi masalah, terutama bagi primata yang hidup di pohon), atau c) persaingan yang tertutup serta agresi teritorial antar spesies. Dengan demikian, individu tersebut harus beradaptasi dengan kondisi setempat, yang seringkali mencakup perubahan wilayah jelajah dan perubahan pola makan dari pemakan buah menjadi pemakan daun (Gilbert $\&$ Setz 2001). Bagi sejumlah spesies tertentu, perubahan seperti ini dapat menyebabkan penurunan kondisi kesehatan (Johns 1983; Gilbert 1994; Gilbert \& Setz 2001). Orangutan (Pongo pygmaeus), contohnya, dapat bertahan hidup di hutan yang rusak di Kutai, Kalimantan Timur (Suzuki komunikasi pribadi) dan di perkebunan di Sabah (Ancrenaz komunikasi pribadi), meskipun mungkin hanya bersifat sementara, dan tidak jelas apakah populasi tersebut akan bertahan dalam jangka panjang.

Di Malaysia, Johns (1983) menemukan bahwa hanya dengan laju penebangan kayu sebesar $3.3 \%$, tebang pilih yang ada menyebabkan pengaruh yang serius terhadap primata yang hidup di hutan tersebut. Pengaruh tersebut antara lain adalah penurunan biomassa primata secara drastis, kematian langsung, penurunan tingkat kelahiran, perubahan pola makan selain juga perubahan perilaku bunyi panggilan dari sejumlah spesies (terutama owa), serta tingginya tingkat malnutrisi, penelantaran, dan kematian bayi primata. Bila penelitian hanya dapat mengamati efek perubahan dalam kurun waktu yang relatif singkat atau hanya pada satu lokasi saja, dapat timbul kesalahan persepsi tentang pengaruh minimal terhadap sejumlah spesies tertentu (Johns \& Skorupa 1987, Lovejoy et al. 1986).

Secara umum, kepadatan primata menurun setelah kegiatan penebangan, dan dalam beberapa kasus kepadatan ini sangat rendah, terutama dalam jangka panjang (Davies \& Payne 1982, Gilbert 1994, Gilbert \& Setz 2001, Johns 1983, Lovejoy et al. 1986, Rijksen 1978, Terborgh 1983, Wilson \& Johns 1982, Wilson \& Wilson 1975). Selain itu, kegiatan penebangan pohon menaikkan tingkat kematian bayi, namun laju kelahiran akan kembali normal dengan cepat (Johns \& Johns 1995). Di samping kenaikan kepadatan sementara pada Monyet Ekor Panjang (Macaca fascicularis) (lihat Tabel 6) yang memiliki kecenderungan menginvasi hutan suksesi, tidak ada kecenderungan yang nyata dalam kelimpahan primata biasa hingga delapan belas tahun setelah penebangan (Johns \& Johns 1995). Sebaliknya, Rijksen (1978) menemukan bahwa 3 dari 6 spesies primata (dua spesies owa dan Beruk (Macaca 
nemestrina)) di bagian utara Sumatera lebih sedikit ditemui di hutan dengan gangguan ringan dibandingkan dengan hutan utuh. Spesies tersebut tidak dapat dijumpai sama sekali di hutan yang sedang ditebang dan pada vegetasi sekunder. Salah satu spesies monyet daun (Trachypithecus cristatus) hanya dijumpai di daerah yang paling dipengaruhi kegiatan penebangan.

Marsh et al. (1987) mengungkapkan bahwa karakteristik sekunder yang dapat mempengaruhi kemampuan primata dalam beradaptasi adalah tingkat terestrialnya. Beberapa spesies primata hidup di pohon (arboreal) atau memiliki kemiripan dalam hal tingkatan tajuk-bukaan tajuk dapat memutuskan jalan perlintasan satwa bagi spesies-spesies tersebut. Sebagian besar spesies “Old World” yang mampu mengkoloni hutan sekunder setidaknya memiliki kebiasaan yang semi-terrestrial yang mendukung kemampuannya dalam mempertahankan hidup di fragmen hutan yang kecil. Tetapi, perilaku ini juga yang mempengaruhi mereka untuk merusak tanaman (ladang) penduduk, yang menyebabkan spesies ini sangat rentan terhadap perburuan. Dua spesies kera, yang keduanya bersifat terestrial, sering dianggap sebagai spesies hama. Sementara spesies yang hidup di pohon seperti monyet daun dan owa jarang memasuki daerah pertanian atau menyerang lahan. Orangutan (Pongo pygmaeus) kadang-kadang menyerang tanaman, terutama di daerah yang mengalami deforestasi yang intensif, dan sering mati terbunuh (Meijaard pengamatan pribadi).

Dua spesies yang diteliti secara rinci oleh Johns (1986a), Ungko Lengan Putih (Hylobates lar) dan Lutung (Presbytis femoralis), menunjukkan penurunan tingkat kegiatan setelah penebangan, pengurangan waktu untuk mencari makan dan berpindah tempat, dan lebih banyak beristirahat. Peningkatan waktu istirahat penting untuk mencerna lebih banyak material daun dalam makanannya. Dalam kurun waktu enam bulan setelah selesainya kegiatan penebangan, persentasi waktu makan yang digunakan untuk mencerna daun meningkat dari $23 \%$ menjadi $40 \%$ pada owa, dan dari 40\% menjadi 58\% pada monyet daun (Johns 1986a). Di hutan utuh, owa mengkonsumsi sebagian besar buah-buahan yang kaya akan kandungan gula bebas. Spesies tersebut tidak dapat menemukan jenis buah-buahan ini sesaat setelah penebangan dan mengalami penurunan kapasitas energi sehingga mengurangi jelajah hariannya sampai lebih dari 50\%. Monyet daun juga mengurangi waktu jelajahnya setelah kegiatan penebangan, tetapi perubahan pola jelajahnya lebih mencerminkan perubahan persebaran pohon ketimbang keterbatasan tingkat energi. Monyet ini kemudian lebih banyak mengeksploitasi spesies pohon yang biasa ditemui dibandingkan dengan spesies pohon yang lebih disukai yang lebih tersebar di hutan tua. Dalam hal strategi pencarian makanan yang optimal (lihat Stephens \& Krebs 1986) monyet tersebut meminimalkan waktu ketimbang memaksimalkan energi. Dengan demikian, Johns (1983) menyimpulkan bahwa spesies oportunis lebih baik kondisinya dibandingkan dengan spesies-spesies yang memiliki persyaratan tertentu untuk makanan hariannya, dan tidak tergantung pada sedikit atau banyaknya jenis makanan.

Perubahan perilaku setelah kegiatan penebangan dapat menyebabkan suatu spesies mengalami perubahan organisasi sosial. Kelompok spesies monyet daun, lutung ( $P$. femoralis), yang dipelajari oleh Johns (1986a), terbagi ke dalam unitunit yang lebih kecil dalam mencari makan karena sumber makanan menjadi lebih 
sedikit dan tersebar merata. Monyet daun juga meninggalkan sifat teritorialnya dan menerapkan strategi untuk mencegah perjumpaan dengan kelompok lain sebagai cara untuk mengurangi kompetisi antar kelompok.

Sifat teritorial yang mampu hidup di berbagai kondisi jarang ditemukan (meskipun mungkin bisa juga ditemukan pada primata spesies cercopithecine), dan jenis teritorial biasanya tidak meninggalkan wilayah jelajah sebelumnya, bahkan pada saat penebangan terjadi. Daerah jelajah ditinggalkan jika sumber makanan berkurang secara drastis. Satwa yang sangat teritorial seperti owa kadang-kadang tetap bertahan di wilayah jelajahnya, meskipun penebangan atau kebakaran hutan menghancurkan sebagian besar pohon (Marsh \& Wilson 1981, Marsh et al. 1986, Nijman 1997). Aspek penting dalam sifat teritorial ini adalah serangan terhadap kelompok yang berdekatan: kelompok yang berada di areal tebangan tidak dapat bergerak keluar bahkan dalam keadaan terpaksa (Johns 1983). Johns dan Skorupa (1987) memperkirakan jika jenis teritorial tersebut berusaha keluar dari daerah yang rusak, akan terjadi tingkat mortalitas yang tinggi.

Penelitian Howell mengenai kepadatan primata di Malinau menunjukkan pola yang menarik (Howell 2003). Dari tiga lokasi penelitian di areal bekas tebangan, lokasi yang baru-baru saja ditebang memiliki kepadatan primata yang lebih tinggi dibandingkan dengan plot kontrol yang tidak ditebang, terutama kepadatan Lutung Banggat (P. hosei) dan Kelawat (Owa Kalimantan) (H. muelleri). Namun, pada plot yang sudah lebih lama ditebang (ditebang empat tahun sebelum penelitian dilakukan), lebih dari 60\% kepadatan primata lebih rendah dibandingkan dengan kepadatan di hutan utuh. Howell (2003) mengungkapkan bahwa hal ini menunjukkan bahwa $P$. hosei dan $H$. muelleri pada awalnya tidak mampu berpindah ke tempat lain setelah areal hutannya terpengaruh oleh kegiatan penebangan. Tetapi, lama-kelamaan, spesies ini mampu juga berpindah tempat. Spesies yang memiliki sifat teritorial yang kuat memerlukan waktu beberapa lama untuk keluar dari daerah tebangan. Spesies yang biasanya mudah beradaptasi, $M$. fascicularis, sama sekali tidak dijumpai di hutan bekas tebangan. Demikian juga halnya M. nemestrina. Howell (2003) memperkirakan bahwa kepadatan tumbuhan bawah di hutan bekas tebangan menimbulkan kesulitan bagi $M$. nemestrina, sehingga spesies ini tidak ditemukan pada hutan bekas tebangan di Malinau. Hasil penelitian tersebut harus diinterpretasikan dengan berbagai pertimbangan mengingat sedikitnya jumlah sampel dan lama penelitian yang hanya beberapa bulan saja.

Perubahan kepadatan primata akibat penebangan tertera pada Tabel 6. Data untuk spesies kera (macaque) dan tarsius tidak konklusif, sehingga jelas terdapat keragaman geografis yang cukup besar dalam hal respons akibat penebangan serta pengaruh lainnya yang terkait, dan/atau setidaknya ada ketidaklayakan dalam metodologi penelitian. Akibat penebangan berdampak netral atau negatif pada Owa Kalimantan (H. muelleri). Sementara hampir dari seluruh hasil penelitian menunjukkan bahwa Lutung Banggat (P. hosei) menurun kepadatannya, meskipun hal ini mungkin bukan merupakan reaksi langsung akibat penebangan, tetapi merupakan reaksi akibat peningkatan tekanan perburuan. Lutung Merah (Kelasi) (P. rubicunda) memiliki respons yang relatif netral terhadap penebangan. Ketahanan terhadap gangguan ini mungkin sejalan dengan pengamatan Davis (1962) yaitu bahwa Lutung Banggat 


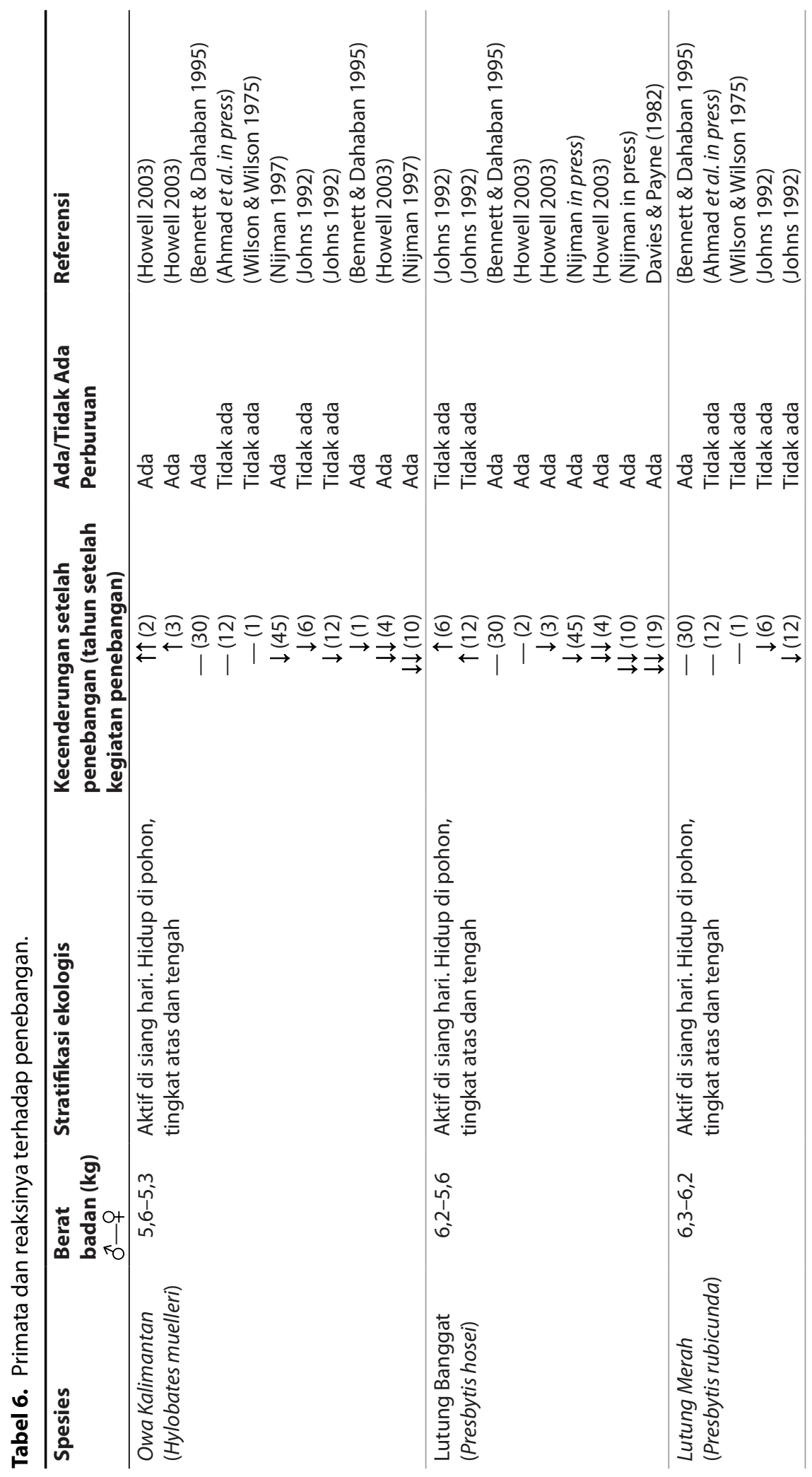




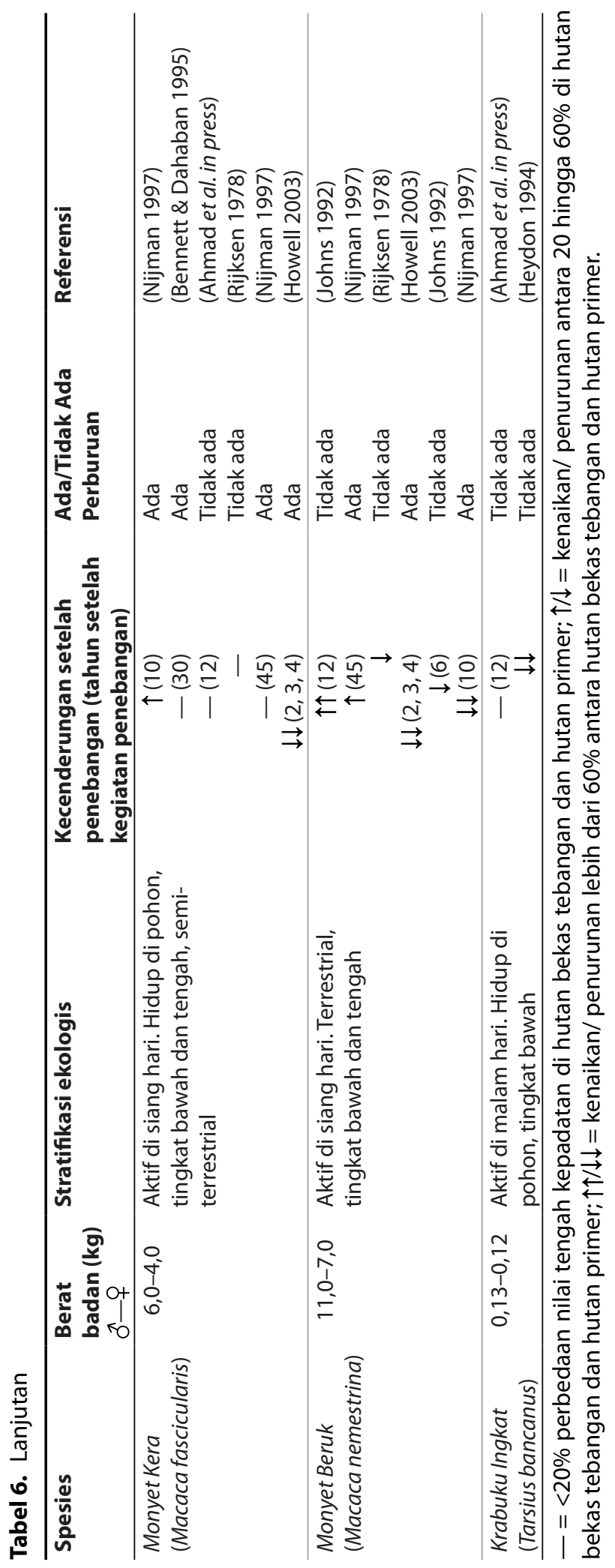


(P. hosei) umumnya diam di tempat sampai saat tertembak, sementara Lutung Merah (Kelasi) (P. rubicunda) akan langsung melarikan diri.

\section{Bajing}

Banyak spesies tupai yang aktif di siang hari (diurnal) sering hidup dalam lingkup geografi yang sama di hutan tropis. MacKinnon (1978) dan Payne (1979) mempelajari pemisahan relung hidup tupai dalam kondisi seperti ini di Semenanjung Malaya. Di Afrika, keragaman spesies tupai hutan dihubungkan dengan keragaman spesies tumbuhan dan kemampuannya dalam memprediksi sumber makanan secara tahunan (Emmons 1980). Sepanjang tahunnya, pemisahan spesies-spesies bajing ditentukan berdasarkan ketinggian tempat pencarian makanan dan ukuran besar badan. Di hutan Asia Tenggara, tupai membagi sumber makanannya berdasarkan waktu kegiatan dan lokasi pencarian makan tersebut (MacKinnon 1978; Payne 1979). Dari 34 spesies tupai yang diketahui hidup di Borneo, 14 spesies aktif di malam hari (nokturnal) dan sisanya merupakan spesies diurnal. Spesies tupai diurnal dapat dikelompokkan menjadi tiga kategori: terestrial, arboreal (hidup di pohon), dan pemanjat, dan masing-masing spesies yang berbeda memanfaatkan strata hutan yang berbeda pula. Di hutan Dipterokarpa di Borneo, pemisahan spesies terjadi saat buah-buahan berlimpah. Saat ketersediaan buah rendah, terjadi tumpang tindih pola makan dan peningkatan persaingan karena seluruh spesies mencari makan pada pohon buah yang hanya sedikit jumlahnya dan mencari makanan alternatif lainnya (Johns 1983).

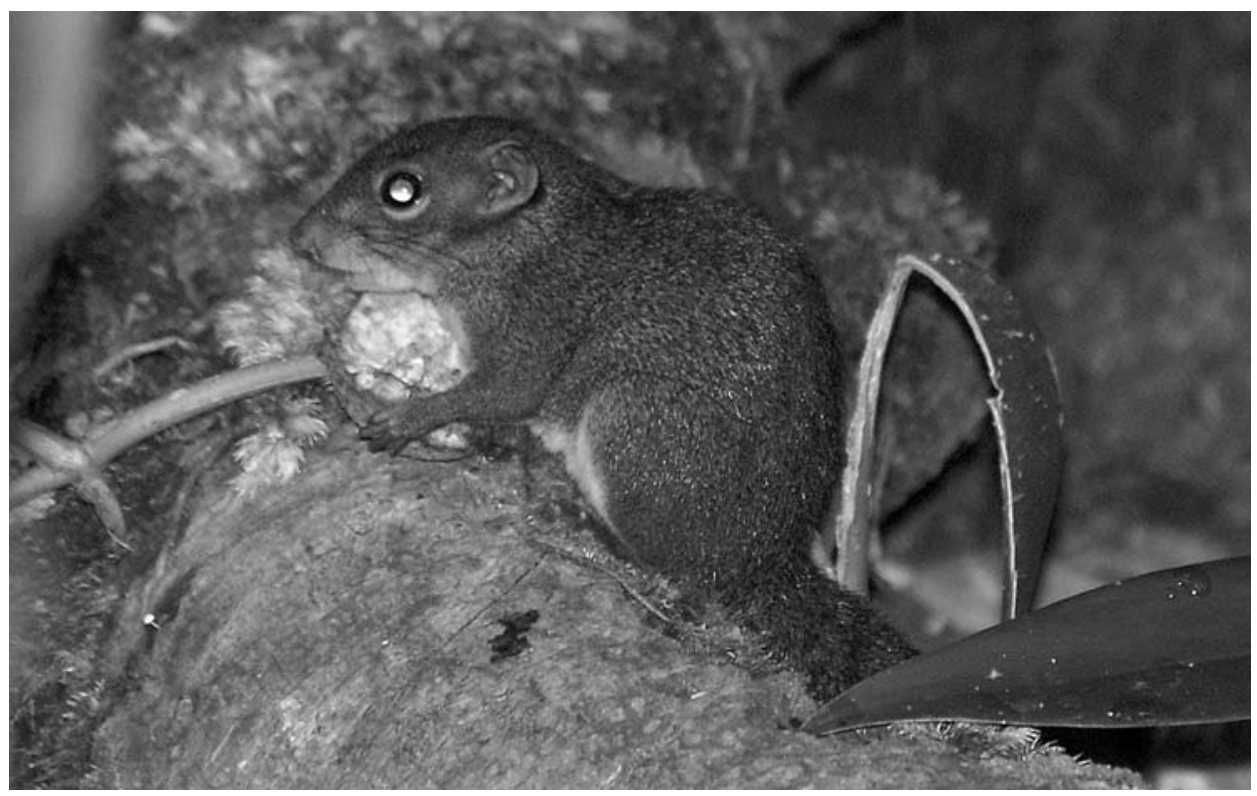

Gambar 9. Sundasciurus lowii, yang terlihat pada gambar sedang memakan buah Nangka (Artocarpus), adalah tupai yang biasa ditemukan di hutan dataran rendah yang utuh maupun yang terganggu. (Foto oleh Kimabajo) 
Respons tupai terhadap kegiatan penebangan tidak mengikuti pola yang jelas (lihat Tabel 7). Terdapat penurunan kepadatan populasi sejumlah spesies tupai, antara lain Ratufa bicolor dan Lariscus insignis. Sementara populasi spesies $R$. affinis, Callosciurus prevostii, C. notatus dan S. tenuis (Gambar 9), di beberapa tempat menunjukkan peningkatan (Johns 1997). Spesies-spesies tersebut, terutama $C$. notatus, ditemukan di Sarawak dengan kepadatan yang lebih tinggi setelah kegiatan penebangan dibandingkan sebelumnya. Namun, kepadatan $R$. affinis menurun sebesar 71\% (Dahaban et al. 1996). Di tempat lain di Sarawak, jumlah $R$ affinis juga menurun setelah kegiatan penebangan untuk ladang berpindah, sementara kepadatan spesies Callosciurus tidak mengalami perubahan yang nyata (Bennett \& Dahaban 1995). Syakirah et al. (2000) mengemukakan bahwa $R$. affinis tidak dapat dijumpai di hutan yang baru saja ditebang dan hutan dataran rendah yang rusak di Semenanjung Malaya. Namun, spesies ini dijumpai dalam plot yang berdekatan dengan hutan yang telah tumbuh kembali (regenerasi) setelah ditebang sekitar dua puluh tahun sebelumnya.

Fredriksson (pengamatan pribadi) seringkali menjumpai spesies ini di hutan bekas tebangan di Kalimantan Timur. Bennett dan Dahaban (1995) dan Dahaban et al. (1996) melaporkan kepadatan spesies tupai Sundasciurus (S. tenuis dan S. lowii) yang lebih tinggi di daerah perladangan berpindah (selama tiga puluh tahun sudah tidak digunakan lagi) dan dibandingkan dengan kepadatan spesies di hutan primer. Hal ini menunjukkan bahwa spesies-spesies tersebut diuntungkan oleh adanya gangguan: S. hippurus tidak dapat dijumpai langsung setelah kegiatan penebangan atau bahkan dua tahun setelah kegiatan penebangan tersebut (Dahaban et al. 1996). Hal ini sejalan dengan temuan dari Semenanjung Malaya (Laidlaw 2000). Laidlaw (200) hanya dapat menjumpai S. hippurus di Cagar Hutan Utuh (Virgin Jungle Reserves), yaitu daerah yang ditetapkan sebagai daerah yang dapat mewakili tipe ekologis kondisi aslinya. $S$. hippurus tidak dapat ditemukan di hutan bekas tebangan yang letaknya berdekatan dengan cagar tersebut. Sementara itu, S. lowii dan S. tenuis dapat dijumpai di hutan bekas tebangan maupun hutan utuh. Di lain pihak, Rijksen (1978) menemukan bahwa $S$. tenuis hidup di semua tipe hutan, dari hutan utuh hingga hutan sekunder, namun kepadatannya sangat menurun akibat penebangan. S. hippurus tidak dapat ditemukan di hutan bekas tebangan dan hutan sekunder, sementara kepadatannya lebih rendah di hutan yang ditebang dengan intensitas rendah dibandingkan dengan kepadatan spesies ini di hutan primer (Rijksen 1978). Spesies yang lain, yaitu $L$. hosei, hanya dapat ditemukan di hutan utuh dan hutan bekas tebangan yang berumur empat tahun (Dahaban et al. 1996), sementara L. insignisi bisa ditemui di hutan yang baru saja ditebang, tetapi tidak dapat dijumpai di hutan sekunder (Syakirah et al. 2000). Selain itu, Bajing Tanah Moncong-Runcing Rhinosciurus laticaudatus tidak dapat ditemukan di hutan yang baru saja ditebang, namun ada di hutan sekunder (Syakirah et al. 2000). Spesies endemik Bajing Tanah Ekor-Tegak (Rheithrosciurus macrotis) tidak banyak dikenal, namun Fredriksson (observasi personal) seringkali menjumpai spesies ini di kawasan hutan bekas tebangan di Kalimantan Timur.

Johns (1997) menyimpulkan bahwa tupai daratan (terestrial) tidak begitu toleran terhadap kondisi hutan bekas tebangan. Temuan ini sejalan dengan penurunan kepadatan Lariscus insignis dan Rhinosciurus laticaudatus yang diamati, dua spesies 


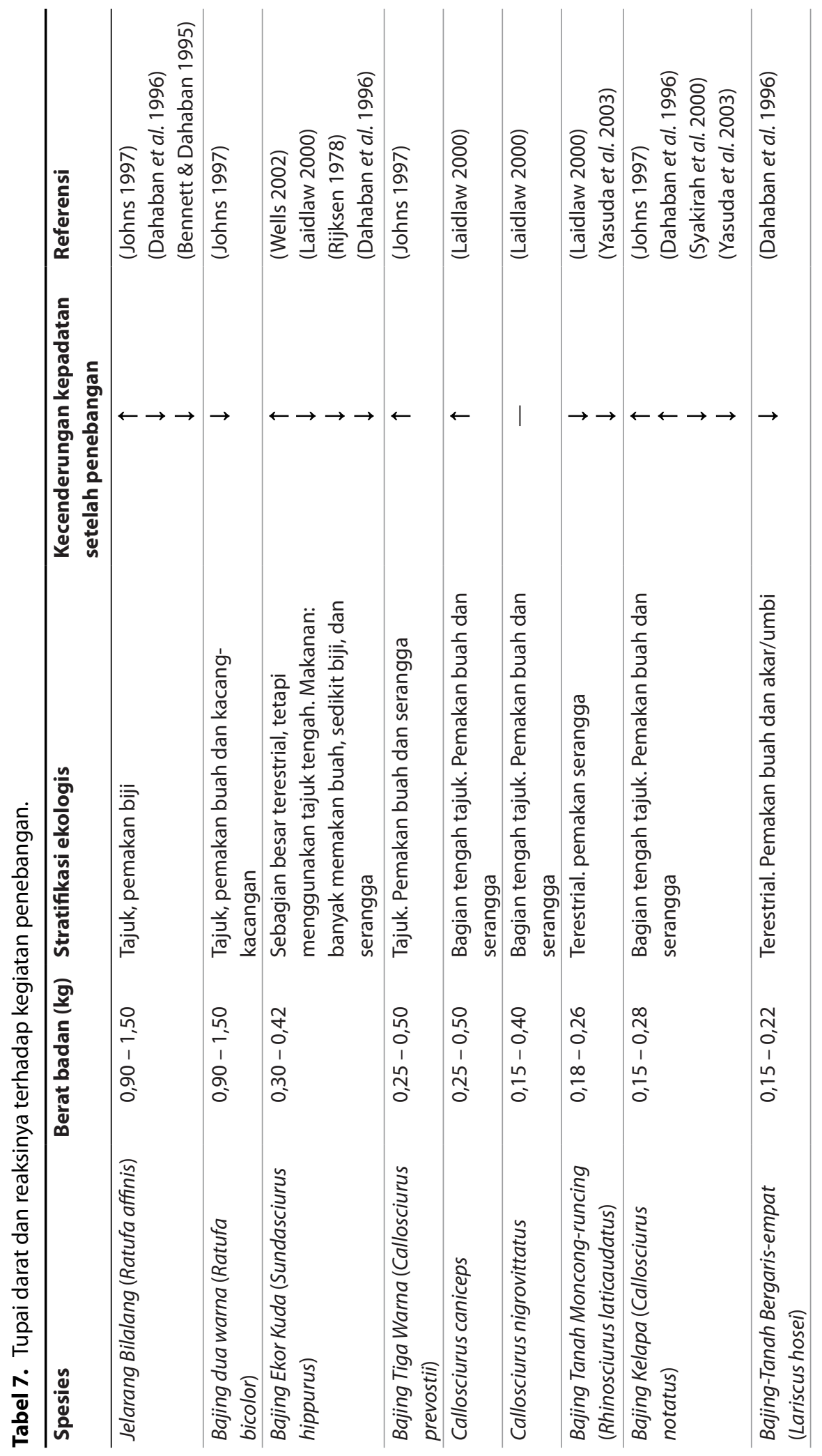


$90 \mid$ Mamalia

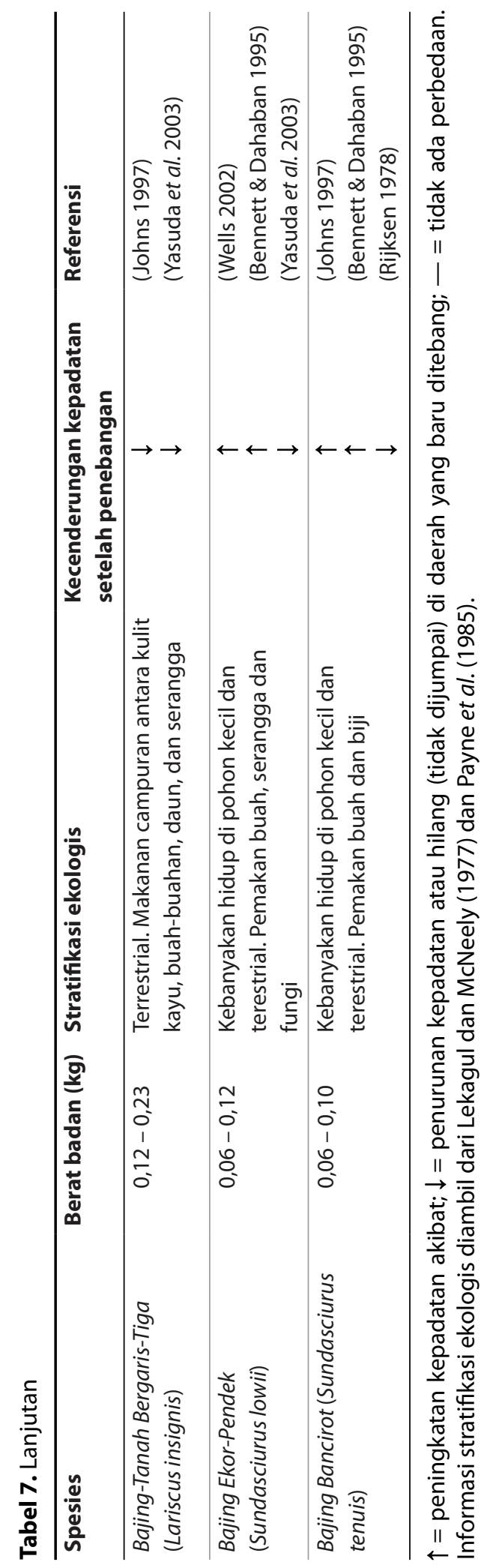


tupai darat pemakan serangga (MacKinnon et al. 1996, p. 217), dan Sundasciurus hippurus, spesies pemakan serangga lainnya yang hidup pada pohon-pohon yang rendah di atas permukaan tanah. Di samping itu, terjadi peningkatan kepadatan Callosciurus prevostii, spesies yang hidup di tajuk bagian atas. Tabel 7 menampilkan gambaran sebenarnya yang lebih rumit karena respons terhadap kegiatan penebangan yang berbeda dikumpulkan dari lokasi yang berbeda. Hal ini ditambah pula dengan kenyataan bahwa berat badan dapat merupakan faktor penting karena spesies yang berukuran lebih besar lebih rentan terhadap kegiatan penebangan (dan perburuan).

Reaksi terhadap penebangan bisa mencerminkan perubahan dalam kelimpahan makanan dan persaingan dengan taxa yang lain. Dwiyahreni (2003) mempelajari pengaruh kebakaran hutan terhadap ketinggian tempat dimana tupai mencari makan. Dwiyahreni (2003) menemukan bahwa tupai yang hidup di tanah berpindah ke strata yang lebih tinggi, sementara tupai yang hidup di tajuk berpindah ke lapisan yang lebih rendah. Hal ini dilakukan sebagai upaya untuk menghindari pemangsa. Perubahan stratifikasi ketinggian ini dapat menyebabkan peningkatan persaingan interspesifik (sesama spesies). Namun demikian, data yang ada masih kurang layak untuk menentukan kapan kompetisi ini menyebabkan pemusnahan spesies.

Makanan utama tupai terbang marga Petaurista dari Asia Tenggara adalah buahbuahan yang empuk dan kaya energi yang ada di hutan tua. Namun demikian, kemampuannya untuk mengkonsumsi daun pada saat paceklik meningkatkan kemampuannya untuk bertahan di hutan tebangan dibandingkan dengan spesies mamalia yang hanya memakan buah. Di Semenanjung Malaya, waktu yang digunakan Bajing-Terbang Raksasa-Merah (Petaurista petaurista) untuk makan daun meningkat dari 51\% menjadi 78\% dalam kurun enam bulan setelah penebangan (Barrett 1984). Namun, sampai sejauh mana hal ini dipengaruhi oleh musim belum diketahui secara pasti. Survei transek mengungkapkan bahwa kepadatan populasi $P$. petaurista tidak berubah banyak enam bulan setelah penebangan (dari 34 menjadi 39 individu/ $/ \mathrm{km}^{2}$ ). Meskipun adaptasi pola makan dapat membantu ketahanan hidupnya, kepadatan spesies menurun di hutan yang telah lama ditebang. Hal ini disebabkan oleh adanya beberapa faktor pembatas lain, seperti ketersediaan tempat berlindung di siang hari atau terjadinya peningkatan pemangsaan dan perburuan. Seperti pada taxa lain yang telah dikemukakan sebelumnya, penelitian jangka pendek ini penuh dengan ketidakpastian.

\section{Spesies-spesies tikus}

Sejumlah penelitian mempelajari bagaimana kepadatan spesies-spesies tikus dipengaruhi oleh kegiatan penebangan di Asia Tenggara. Satu penelitian dari Semenanjung Malaya menemukan bahwa kepadatan Tikus Raksasa Ekor-Panjang (Leopoldamys sabanus) (spesies omnivora-pemakan segala-yang hidup di vegetasi dasar atau bagian bawah) lebih tinggi di hutan yang beregenerasi cukup lama dibandingkan dengan hutan primer ( $\mathrm{p}<0.001$, Yasuda et al. 2003). Zubaid dan Khairul (1997) mengkonfirmasi hasil ini dengan menangkap dua puluh satu spesimen dari hutan rusak dibandingkan hanya dengan satu spesimen dari habitat utuh dengan tipe jerat yang kurang lebih sama. Tikus Belukar (Rattus tiomanicus), spesies omnivora 
yang memanfaatkan seluruh strata vegetasi, adalah spesies yang jarang ditemukan di hutan tua, namun tumbuh subur di pinggir-pinggir belukar. Hal ini merupakan salah satu alasan mengapa spesies ini bisa ditemukan dengan mudah di perkebunan kelapa sawit (see Buckle et al. 1997). Yasuda et al. (2003) menemukan bahwa dua spesies Maxomys, yaitu Tikus Duri Merah (M. rajah_tidak diketahui makanannya) dan Tikus Duri Ekor-Pendek ( $M$. whiteheadi_utamanya pemakan serangga), keduanya bersifat terestrial, menjadi semakin umum (dengan tingkat nyata $\mathrm{p}<0.05$ ) hidup di hutan primer. Sejalan dengan itu, Zubaid dan Khairul (1997) menemukan M. rajah hanya di hutan utuh, sementara $M$. whiteheadi, terlihat lebih umum hidup di hutan rusak (perbedaannya mungkin secara statistik tidak nyata). Tikus Pohon Ekor Polos (Niviven cremoriventer) dan Tikus Pohon Kelabu (Lenothrix canus), keduanya spesies pemakan buah (Yasuma \& Andau 2000) yang hidup di vegetasi bawah dan dasar, hanya dapat ditemukan di hutan yang masih utuh.

Melalui analisis multivariat menggunakan data kelimpahan mamalia darat yang berukuran kecil (terutama Tikus Duri Coklat, Maxomys surifer; Tupai akar, Tupaia glis; Tikus Pohon Ekor Polos, Niviventer cremoriventer; Tikus Duri Ekor-Pendek, Maxomys whiteheadi dan Tupai Tanah, T. tana), Bernard (2004) menemukan bahwa kelimpahan dan keragaman spesies di hutan primer dan hutan yang ditebang 11 hingga 40 tahun sebelumnya tidak berbeda banyak. Kelimpahan mamalia berukuran kecil ditentukan terutama oleh kelimpahan jumlah kayu dan ranting yang jatuh, luas/banyaknya onggokan batu dan daerah yang basah, serta jumlah tunggul-tunggul kayu dan kepadatan vegetasi pada ketinggian yang rendah (1-5m), menengah $(>5 \mathrm{~m})$, dan pada tingkat tajuk. Temuan ini sama dengan temuan Kemper dan Bell (1985). Bernard (2004) mengungkapkan bahwa korelasi antara kehadiran mamalia dan banyaknya onggokan batu, tunggul kayu, dan vegetasi tingkat bawah yang rapat dapat dijelaskan dengan kenyataan bahwa struktur tersebut menyediakan banyak tempat untuk meloloskan dan menyembunyikan diri sehingga meningkatkan kemampuan untuk menghindari hewan pemangsa.

\section{Pemakan serangga}

Informasi kelompok tikus yang terdiri dari Rindil Bulan (Echinosorex gymnurus), munggis dan cucurut ini banyak diketahui, terutama kaitannya dengan pengaruh terhadap penebangan. Seluruh cucurut Borneo sangat bergantung pada hutan bertajuk rapat (Payne et al. 1985) dan sensitif terhadap pengaruh fragmentasi hutan. Hal ini yang menyebabkan tidak ditemukannya spesies cucurut di hampir seluruh pulau-pulau kecil di wilayah Kepulauan Sunda (Tabel 13).

Tikus Bulan adalah spesies yang hidup di hutan dataran rendah yang makanan utamanya adalah cacing dan artropoda. Spesies ini memerlukan kayu yang berongga dan ruang-ruang di antara akar-akar pohon untuk beristirahat dan bersarang. Spesiesspesies tersebut kadang-kadang hidup di perkebunan (Payne et al. 1985). Augeri (unpubl.) menemukan bahwa frekuensi hasil tangkapan foto Rindil Bulan di hutan primer berjumlah dua kali lipat dibandingkan dengan foto tangkapan di hutan bekas tebangan di ekosistem MRF dan Kayan Mentarang, meskipun kajian statistik belum dilakukan. 


\section{Tupai}

Tupai merupakan spesies endemik di wilayah Indomalaya. Spesies ini merupakan suku yang relatif tua yang muncul lebih dari 20 juta tahun yang lalu, kemungkinan pada saat atau sebelum Borneo masa kini (Yasuma 1996). Emmons (2000) mengungkapkan bahwa nama 'tupai' adalah penamaan yang salah karena satwa tersebut bukan cecurut dan jarang yang memanfaatkan pohon. Mengingat bahwa sebagian besar spesies Tupaia merupakan spesies terestrial, sedangkan kegiatan penebangan dikenal berpengaruh terhadap tumbuhan bawah, maka sangat menarik untuk mempelajari pengaruh kegiatan penebangan terhadap spesies-spesies tupai. Emmons (2000) melakukan penelitian ini di Lembah Danum, Sabah, dengan membandingkan hasil tangkapan satwa tersebut di hutan bekas tebangan dan di hutan utuh pada saat yang berbeda-beda. Data lainnya diberikan oleh Stuebing dan Gasis (1989) yang mempelajari populasi tupai di hutan bekas tebangan dan hutan tanaman satu spesies (Eucaplyptus deglupta, Gmelina arborea, Albizia falcataria dan A. falcataria), yang di bawahnya ditanami kakao (Theobroma cacao). Hutan tanaman tersebut ditebang tujuh tahun sebelumnya dan tumbuhan bawahnya berumur sama, kecuali hutan tanaman yang ditanami kakao yang dijaga agar bersih dari tumbuhan bawah. Kedua penelitian itu mengungkapkan bahwa hanya spesies Tupaia yang hidup di pohon (arboreal), yaitu Tupai Kecil (Tupaia minor), menghilang akibat kegiatan penebangan, sedangkan spesies yang lain relatif tidak terganggu. Ketergantungan $T$. minor terhadap liana dan tajuk pohon ( $87 \%$ yang diamati berada pada substrat ini) dapat menjelaskan mengapa spesies ini terpengaruh oleh kegiatan penebangan (dan pemotongan liana). Namun demikian, T. minor dapat ditemukan di ketiga hutan tanaman tersebut, kecuali di hutan tanaman dengan kakao. Selain itu, Bennett dan Dahaban (1995) belum pernah menemukan spesies ini di hutan utuh, meskipun spesies ini dapat dijumpai di hutan yang baru saja ditebang. Hal ini berlawanan dengan temuan Emmons. Tupai Ramping (T. gracilis), tidak dapat ditemukan di semua hutan tanaman tersebut. Tupai Tanah (T. tana) tidak ditemukan di hutan tanaman dengan tumbuhan bawah yang jarang. Tupai Biasa (T. longipes) tidak dapat ditemukan di hutan tanaman tanpa tumbuhan bawah. Spesies ini mengalami peningkatan populasi tiga kali lipat di habitat dengan tumbuhan bawah yang paling padat (Emmons 2000; Stuebing \& Gasis 1989) dan dapat bertahan hidup pada satu habitat dimana spesies-spesies lainnya punah. Spesies arboreal merupakan spesies yang paling terpengaruh oleh tebang pilih, karena kaitannya secara langsung dengan hancurnya tajuk hutan.

Emmons (2000) lebih lanjut memperkirakan respons spesies tupai yang berbedabeda terhadap kegiatan penebangan dan kepadatan tumbuhan bawah. Tupai darat berukuran besar memakan cacing tanah dan invertebrata lain yang mengurai kayu yang ada di atas maupun di bawah serasah. Jika kondisi tumbuhan bawah padat, lapisan serasah permukaan tanah menjadi lembab dan agak gelap sehingga artropoda berlimpah di dekat permukaan. Berbeda dengan di hutan tanaman dengan sedikit lapisan penutup tanah, permukaannya lebih kering, sehingga cacing dan artropoda tidak banyak ditemukan. Lebih jauh, di hutan tanaman ini tidak banyak terjadi proses penguraian (dekomposisi) kayu. Hal ini menjelaskan mengapa Tupai Ramping (T. gracilis) tidak dapat ditemukan di hutan tanaman tersebut. Selain itu, spesies ini 
memiliki wilayah jelajah yang luas, bahkan pada hutan dengan kondisi baik sekalipun. Spesies ini mungkin tidak bisa mendapatkan sumber makanan yang cukup, terutama ulat tumbuhan bawah yang menjadi kesukaannya, yang ada di hutan yang rusak (dengan catatan bahwa Hill et al. 2003 menemukan bahwa kepadatan kupu-kupu dan dengan demikian kepadatan ulat di Sabah lebih ditentukan oleh curah hujan dibandingkan dengan intensitas kegiatan penebangan kayu). Sebaliknya, T. longipes memiliki toleransi habitat yang paling luas di antara seluruh spesies tupai. Emmons mengungkapkan bahwa ini terjadi karena makanan utama spesies tersebut adalah semut, yang sering meningkat ketersediaannya di vegetasi sekunder (contohnya pada penelitian Vasconcelos et al. 2000, yang menemukan bahwa kepadatan semut lebih tinggi di hutan yang baru ditebang dibandingkan dengan hutan yang lebih lama ditebang dan hutan utuh di Amazonia Tengah). Dalam kesimpulannya, Emmons (2000) mengungkapkan bahwa spesies tupai yang paling terancam keberadaannya karena hancurnya hutan adalah spesies yang memiliki relung ekologi yang tersempit serta yang memiliki wilayah jelajah yang terkecil. Seluruh spesies tupai memerlukan hutan, apapun spesiesnya, untuk dapat bertahan hidup. Emmons (2000) juga menyatakan bahwa tupai jarang terlihat melintasi jalan yang lebar. Dengan demikian, spesies ini sangat dirugikan oleh efek fragmentasi dari adanya pembangunan jalan dan pembukaan lahan lainnya.

\section{Kelelawar}

Kelelawar merupakan kelompok vertebrata yang beragam yang hidup di hutan hujan "Old World" dan kontribusinya sampai setengah dari spesies mamalia hutan. Satu kawasan dengan luas $3 \mathrm{~km}^{2}$ di Semenanjung Malaya mampu mendukung kehidupan 51 spesies kelelawar pemakan serangga dan 11 spesies Megachiroptera (Kingston et al. 2003). Belum ada survei tentang kelelawar yang pernah dilakukan di Malinau. Tetapi berdasarkan distribusinya di Borneo (Corbet \& Hill 1992, Meijaard unpubl., Payne et al. 1985, van Strien 2001), dapat diprediksikan bahwa setidaknya ada lima puluh spesies kelelawar yang hidup di daerah tersebut.

Kelelawar sangat rentan terhadap gangguan lingkungan. Kerentanan ini disebabkan oleh karakter sejarah hidup dan sifatnya yang merupakan gabungan dari rendahnya produktivitas, lamanya waktu asuh, dan perkembangan yang lamban; seluruh adaptasi untuk bertahan hidup pada habitat yang stabil dan mudah diprediksi; serta populasi yang dipertahankan untuk tetap berada dalam daya dukung lingkungannya (Kunz \& Peirson 1994, Purvis et al. 2000). Survei Status Global dan Rencana Aksi Konservasi Kelelawar Microchiropteran (The Global Status Survey and Conservation Action Plan for Microchiropteran Bats) menetapkan 22\% spesies sebagai spesies terancam dan $23 \%$ sebagai spesies hampir terancam (Hutson et al. 2001).

Seperti dikemukakan sebelumnya, kelelawar merupakan spesies penyerbuk bagi pohon dan tanaman pangan, serta merupakan penyebar biji yang penting. Kelelawar buah, seperti yang termasuk dalam genera Pteropus dan Cynopterus, menyebarkan beragam spesies tumbuhan seperti Jambu Biji (Psidium guajava), Ganitri (Elaeocarpus sphaericus), Mindi (Melia azedarach), Pisang (Musa spp.), Pepaya (Carica papaya), Kenari (Canarium spp.), Mangga (Mangifera indica), Sirsak/Buah Nona (Annona 
muricata), Sawo (Manilkara achras), Cengkeh dan kerabatnya (Eugenia spp.), Langsat (Lansium domesticum), Sirih Hutan (Piper aduncum), Labu Siam (Sechium edule), berbagai spesies Beringin (Ficus), dan serangkaian spesies palem-paleman seperti Palem Kipas (Livistona spp.), Palem pejibaye (Bactris spp.), Palem merah/kuning/ berwarna (Chrysalidocarpus spp.), Palem ekor ikan (Caryota spp.) dan Nam-nam (Cynometra cauliflora) (nama tumbuhan berubah mengikuti taksonomi oleh Backer \& Bakhuizen-van den Brink (1963-1968)) (catatan: Psidium dan Carica adalah tumbuhan eksotis dari Amerika Selatan). Dalam suatu kajian tentang peran kelelawar dalam propagasi tumbuhan di lima puluh sembilan suku tumbuhan yang berasal dari "Old World", Fujitta dan Tuttle (1991) menemukan bahwa setidaknya 289 spesies tumbuhan memerlukan pteropodids untuk penyerbukan dan penyebaran biji. Suku Moraceae memiliki jumlah spesies yang paling banyak didatangi untuk buahnya (39 spesies), terutama dari marga Ficus, diikuti oleh Sapotaceae (8 spesies), Ancardiaceae (7 spesies), Ebenaceae (6 spesies), Guttiferae (5 spesies) dan Meliaceae (5 spesies). Kelelawar merupakan penyebar biji yang baik karena mampu terbang jauh dari pohon induknya sebelum memproses buah tersebut, dan di banyak kasus, kelelawar hanya menghisap cairan dan daging buah saja kemudian meludahkan sebagian besar biji buah tersebut dalam keadaan utuh (van der Pijl 1935). Alternatif lain yaitu beberapa spesies menyeleksi biji-biji yang baik sehingga meningkatkan daya kecambah biji yang disebarkan (Utzurrum \& Heideman 1991, Utzurrum 1995).

Spesies-spesies dari suku Myrtaceae (59 spesies) di Asia Tenggara merupakan spesies yang umumnya bergantung pada kelelawar untuk proses penyerbukannya. Kelelawar juga melakukan penyerbukan pada beberapa spesies tanaman dari suku Leguminosae (12 spesies), Bignoneaceae (9 spesies), Proteaceae (6 spesies), Bombacaceae (5 spesies), Sonneratiaceae $(5$ spesies) dan Musaceae (4 spesies). Setidaknya ada 448 produk yang dimanfaatkan oleh manusia berasal dari 186 spesies tanaman (Fujita \& Tuttle 1991). Produk ini termasuk buah-buahan, minuman, makanan, hiasan, kayu, serat, pewarna, penyamak, obat-obatan, pakan ternak, dan bahan bakar. Perdagangan durian (Durio spp.) di Asia Tenggara bernilai sebesar 120 juta dollar AS di pertengahan tahun 1980-an (Myers 1985), dan penjualan petai (Parkia speciosa) di Semenanjung Malaya bernilai 15 juta dollar AS per tahunnya (Ng 1980). Di akhir tahun 1990-an penjualan petai di daerah sekeliling Kuala Lumpur, Malaysia, menghasilkan sekitar 2,8 juta dollar AS setiap tahunnya (Chuen et al. 1998). Bukti ini lebih jauh menunjukkan pentingnya tumbuhan tersebut secara ekonomi. Durian tergantung pada kelelawar penghisap madu (terutama yang hidup di dalam gua, Lalai Kembang (Eonycteris spelea), dan Cecadu Pisang-Kecil (Macroglossus minimus)). Saat durian sedang tidak berbunga, kelelawar tersebut bergantung pada spesies pohon lain untuk diambil madunya (diasumsikan spesies ini memerlukan komunitas tumbuhan yang cukup beragam untuk suplai makanan sepanjang tahun). Hilangnya hutan dapat menyebabkan hilangnya kelelawar secara lokal dan kegagalan panen durian (Start \& Marshall 1976).

Banyak spesies kelelawar buah yang hidupnya tidak sepenuhnya bergantung pada hutan tertutup, dan dapat bertahan dengan baik pada lansekap yang didominasi oleh manusia (contohnya, Codot Krawar (Cynopterus brachyotis) dan Codot Horsfield ( $C$. horsfieldii)). Di sebagian besar wilayah Asia Tenggara (termasuk Borneo), hutan hujan 
tropis didominasi oleh spesies-spesies Dipterokarpa yang penyebarannya melalui angin atau gravitasi. Ketersediaan sumberdaya tumbuhan bagi kelelawar buah jumlahnya relatif rendah, dan sangat terpencar dalam ruang dan waktu. Hal ini menguntungkan spesies-spesies yang berukuran besar, mempunyai mobilitas tinggi dan berperilaku makan lebih generalis sehingga membedakan pteropodids dari phyllostomidae, spesies yang biasanya mendatangi tumbuhan yang ada di daerah Neotropis (Fleming 1987, 1993). Sedikitnya jumlah belukar berbuah di wilayah ini juga menunjukkan adanya sejumlah kecil spesies kelelawar yang terbiasa mencari makan pada tumbuhan bawah di hutan (kecuali Codot Krawar (Cynopterus brachyotis) dan Langai-Isiq Totol (Balionycteris maculata)). Namun, lebih banyak spesies kelelawar yang berspesialisasi pada tanaman pohon berumur pendek dengan tajuk lebar yang jumlahnya melimpah, dan sebagai konsekuensinya spesies-spesies tersebut secara morfologis dilengkapi dengan anggota tubuh yang memungkinkan mereka melakukan perjalanan pulang pergi dalam jarak jauh serta terbang di dalam dan di atas tajuk (Hodgkison 2001). Meskipun tidak diragukan lagi beberapa spesies kelelawar buah bergantung pada tegakan pohon hidup di hutan (seperti Langai-Isiq Totol (Balionycteris maculata), Bukal kepala-hitam (Chironax melanocephalus)), spesies lain mungkin mengandalkan kemampuannya terbang pulang dan pergi (bisa melebihi $70 \mathrm{~km}$ setiap malamnya: Start 1974) untuk bertahan hidup di lansekap bekas tebangan atau yang terfragmentasi. Namun demikian, beberapa spesies seperti Pteropus vampyrus memerlukan daerah yang tidak terganggu untuk beristirahat (Gumal 2004).

Sama halnya dengan spesies di atas, kelelawar pemakan serangga yang mencari makan di ruang terbuka di atas hutan dan di bukaan hutan yang besar (contohnya Molossidae, Kubar (Taphozous spp.)), dan spesies yang memanfaatkan tepi hutan dan rumpang karena tumbangnya pohon (vespertilionids dari subfamilia Miniopterinae dan Vespertilionae) cukup dapat beradaptasi dengan lansekap yang lebih terbuka. Adaptasi ekomorfologis untuk pencarian makanan pada habitat yang terbuka dan daerah pinggiran sebenarnya menghalangi banyak spesies untuk memasuki vegetasi yang lebih rapat di interior hutan. Spesies-spesies ini biasanya merupakan spesies yang terbang cepat dengan efisien serta mampu beradaptasi secara ekolokasi (echolocation) untuk mendeteksi serangga dalam jarak menengah dan jarak jauh di lingkungan terbuka. Banyak spesies kelelawar yang dapat bertahan hidup di lingkungan perkotaan (urban), pinggiran kota (sub-urban) dan pedesaan (seperti spesies nighi (Pipistrellus spp.), spesies lasiwen (Myotis spp.), dan spesies pedan (Scotophilus spp.)). Ada beberapa spesies yang tinggal di dalam bangunan dan struktur selain hutan. Spesies lainnya juga ada yang mampu terbang pulang pergi jarak jauh dari sarangnya.

Kelelawar pemakan serangga yang hidup di interior hutan, bisa lebih terpengaruh oleh akibat kegiatan penebangan dan fragmentasi hutan (Kingston et al. 2003). Spesies tersebut tidak hanya dipengaruhi oleh jumlah (luasan) habitat yang hilang saat hutan terfragmentasi dan terdegradasi, tetapi juga mengalami perubahan kualitas habitat karena efek tepi (edge effect) dapat mengubah iklim mikro hutan (Kapos 1989, Saunders et al. 1991) dan kemudian mempengaruhi ketersediaan serangga (Johns 1997).

Kelelawar hutan semakin rentan terhadap gangguan habitat dilihat dari kelengkapan morfologinya yang khas berupa sayap dan ekolokasi, yang memungkinkan 
spesies ini mencari makan pada vegetasi tumbuhan bawah yang rapat, tetapi fleksibilitas ekologisnya menjadi terbatas. Sinyal ekolokasi harus dirancang sedemikian rupa sehingga kelelawar dapat membedakan mangsa/makanan dan tumbuhan yang ada di sekelilingnya. Masalah ini dapat diatasi pada keluarga Hipposideridae dan Rhinolophidae, dan Kerivoulinae serta Murininae (vespertilionid) yang sudah lebih maju dalam kemampuan merespons secara efektif. Respons ini dapat bekerja dengan baik di hutan dengan kepadatan makanan/mangsa yang cukup tinggi. Namun demikian, efisiensi respons ini di habitat yang lebih terbuka dengan kepadatan mangsa yang lebih rendah turun secara drastis. Efektivitas luas jelajah sinyal ekolokasi ini di beberapa spesies sangat terbatas (Kerivoulinae, Murininae, rhinolophoid berfrekuensi tinggi) dan tidak sesuai untuk mendeteksi mangsa/makanan yang kepadatan penyebarannya rendah. Di samping itu, kelelawar yang mampu mencari makan di lingkungan yang "semrawut" harus juga memiliki kemampuan manuver yang tinggi. Kemampuan melakukan manuver dimiliki karena beban sayap yang rendah, ujung sayap yang membulat, dan rasio kemiringan yang rendah (Norberg \& Rayner 1987). Kemampuan melakukan manuver ini memiliki konsekuensi; waktu terbang menjadi lambat dan membutuhkan energi yang besar. Hal ini menghambat penerbangan yang efisien untuk mengeksploitasi mangsa dengan kepadatan rendah pada habitat yang terbuka.

Kombinasi ekolokasi dan kemampuan manuver yang membutuhkan energi tinggi ini yang membatasi banyak spesies kelelawar pemakan serangga untuk hidup di interior hutan hujan. Spesies ini tidak memiliki kemampuan untuk mendeteksi dan/ atau menangkap mangsa di habitat yang lebih terbuka yang cenderung timbul karena adanya gangguan seperti kegiatan penebangan dan fragmentasi. Dengan demikian, spesies ini sangat bergantung pada luasan hutan yang utuh. Selain itu, banyak spesies kelelawar hutan yang hidupnya hanya terbatas pada hutan berkualitas baik, terutama spesies-spesies yang bergantung pada rongga di pohon besar (tegak atau yang tumbang, dan dalam berbagai tingkat pembusukan). Ketersediaan pohon berukuran besar seperti ini sangat bergantung pada jenis dan intensitas kegiatan penebangan. Sebagai contoh, Barong Ridley (Hipposideros ridleyi) adalah spesies langka dan ada dalam daftar merah IUCN dari Malaysia dan Borneo, dan diperkirakan hidup di daerah Malinau. Di Suaka Margasatwa Krau (Krau Wildlife Reserve) di Semenanjung Malaya, sepuluh individu spesies ini dipantau dengan radio dan semuanya memilih pohon besar (dengan $\mathrm{dbh}>70 \mathrm{~cm}$ ) yang tumbang dengan rongga yang dalam (lebih dari $5 \mathrm{~m})$ serta ukuran tempat masuk yang besar $(0,5 \mathrm{~m} \times 1 \mathrm{~m})$ (C. Fletcher unpubl.). Spesies lain dari Borneo yang menggunakan rongga pohon di hutan dan cenderung berisiko tinggi akibat kegiatan penebangan hutan adalah: Pedan Sunda (Nycteris tragata), Vampir Palsu (Megaderma spasma), Prok-bruk Pusang-Ntung (Rhinolophus sedulus), dan Lenawai Besar (Kerivoula papillosa).

Sebagai konsekuensi spesialisasi ekomorfologis dan persyaratan tempat tinggalnya, kelelawar pemakan serangga yang hidup di interior hutan akan mengalami penurunan keragaman secara drastis saat habitat hutan ditebangi dan terfragmentasi. Beberapa penelitian awal menemukan bahwa keragaman spesies kelelawar pemakan serangga memang mengalami penurunan setelah kegiatan penebangan (Danielsen \& Heegaard 1994, Zubaid 1993). Proses urbanisasi yang intensif di Singapura 
menurunkan spesies kelelawar yang hidup di interior hutan hingga berjumlah hanya empat saja, yang semuanya terancam punah secara lokal (Pottie 1996).

\section{Kucing hutan}

Penelitian mengenai kucing hutan kaitannya dengan penebangan di hutan Asia Tenggara sangat sedikit jumlahnya. Santiapillai \& Supraham (1985) memperkirakan bahwa hutan sekunder merupakan habitat yang disukai oleh Kucing Congkok Prionailurus bengalensis. Namun, tidak ada data yang mendukung pernyataan ini secara ilmiah. Hasil tangkapan foto (Augeri unpubl.) mengungkapkan bahwa kepadatan spesies ini di hutan primer lebih tinggi dibandingkan dengan hutan sekunder, tetapi analisis statistik diperlukan untuk melihat apakah perbedaan tersebut nyata.

Rabinowitz et al. (1987) mengungkapkan bahwa deforestasi merupakan ancaman utama terhadap keberadaan Macan Dahan (Clouded Leopard (Neofelis nebulosa)) di Borneo, namun penelitian ini tidak mengulas efek ekologis kegiatan penebangan hutan. Di bagian lain dalam laporan ini diutarakan bahwa spesies Macan Dahan diburu untuk diambil giginya dan kulitnya yang dekoratif, serta untuk perdagangan obat-obatan tradisional Asia. Augeri (unpubl.) mengungkapkan bahwa berdasarkan wawancara dengan penduduk setempat, sejumlah Macan Dahan diburu setiap tahunnya di masing-masing desa di Malinau. Mereka menyatakan bahwa spesies ini langka dan sulit untuk diburu. Bukti bahwa populasi Macan Dahan ini menurun karena diburu sangat sedikit, meskipun Schwaner (1853-1854) menyatakan bahwa spesies ini menjadi sangat langka di kawasan hulu Kahayan (Kalimantan Tengah), padahal jumlahnya sangat berlimpah di masa lalu. Tidak diketahui penyebab penurunan populasi Macan Dahan ini.

Data tentang Kucing Batu (Pardofelis marmorata), menunjukkan bahwakepadatan spesies ini empat kali lebih tinggi di hutan bekas tebangan dibandingkan dengan hutan utuh (Johns 1983). Sayangnya, sampel yang kurang memadai dan pengamatan yang bersifat oportunistik menyebabkan lemahnya penarikan kesimpulan ini. Augeri (in prep) lebih sering menemukan tanda dan jerat foto Marbled Cat di hutan primer ketimbang hutan bekas tebangan di ekosistem MRF dan Kayan Mentarang. Kesimpulan ini juga memerlukan analisis statistik lebih lanjut.

Karnivora tingkat atas diperkirakan memperoleh manfaat dari meningkatnya kepadatan spesies pemakan tumbuhan (herbivora) dan tikus yang biasanya terjadi setelah kegiatan tebang pilih (contohnya Davies et al. 2001, Malcom \& Ray 2000, namun bisa dilihat Wu et al. 1996). Makanan yang berlimpah dapat meningkatkan populasi kucing ini, meskipun masih belum jelas bagaimana hal ini bisa terjadi mengingat spesies ini peka terhadap fragmentasi dan gangguan (lihat ulasan) dan kenyataan bahwa spesies ini sering menjadi sasaran pemburu.

\section{Musang}

Musang, yang terkenal di kawasan tropis Old World, membentuk kelompok karnivora yang beragam. Di Borneo terdapat sembilan spesies musang (Payne et al. 1985). Tujuh spesies dilaporkan ditemukan di MRF, yaitu empat spesies melalui 
pengamatan langsung (Musang Luwak, Paradoxurus hermaphroditus; Musang Galing, Paguma larvata; Binturung, Arctictis binturong, dan Musang Belang, Hemigalus derbyanus) (O’Brien \& Fimbel 2002) dan tiga lainnya melalui jerat kamera (MusangLinsang, Cynogale bennettii; Linsang Linsang, Prionodon linsang; dan Tenggalung Malaya (Viverra tangalunga) (Gambar. 10) (Augeri unpubl.). Spesies kedelapan, yaitu Arctogalidia trivirgata, kemungkinan hidup di daerah itu, namun karena sifatnya arboreal, spesies ini sulit untuk dideteksi.

Spesies ini merupakan spesies arboreal dan terestrial. Meskipun umumnya aktif di malam hari (nokturnal), aspek perilaku mencari makan yang lain mengalami adaptasi yang cukup besar terhadap sinar matahari. Selain itu, meskipun status taksonominya adalah karnivora, ada sejumlah musang yang secara eksklusif pemakan buah, umumnya buah yang berkadar gula tinggi dan berdaging lembut (Heydon \& Bulloh 1996, Rabinowitz 1991). Dengan demikian, musang, terutama spesies yang lebih bersifat pemakan buah, Musang Luwak (P. hermaphroditus) dan Musang Akar (Arctogalidia trivirgata) merupakan penyebar biji yang penting (Medway 1978, Payne 1995).

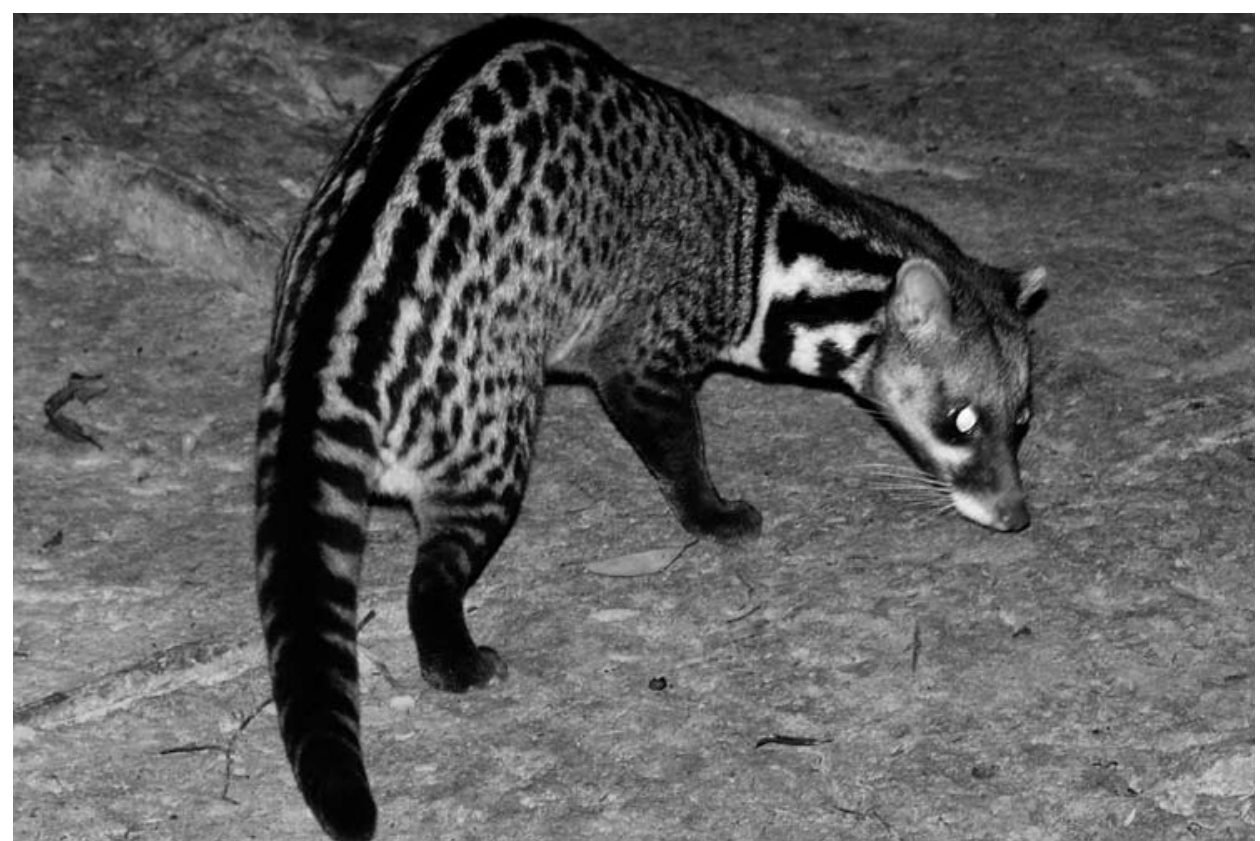

Gambar 10. Tenggalung Malaya (Viverra tangalunga), salah satu spesies musang Borneo yang terpengaruh negatif oleh efek pemanenan kayu. (Foto oleh Kimabajo)

Di Sabah, Heydon dan Bulloh (1996) mencatat terjadinya penurunan kepadatan musang yang tinggi dari 31,5 individu/ $\mathrm{km}^{2}$ di hutan utuh menjadi 6,4 individu/ $\mathrm{km}^{2}$ di hutan bekas tebangan. Spesies musang pemakan serangga, terutama yang mengkonsumsi invertebrata, mengalami penurunan yang lebih tinggi ketimbang spesies musang biasa yang mengkonsumsi lebih banyak buah dalam pakannya. Di Semenanjung Malaya, Johns (1983) mencatat bahwa musang sangat jarang dijumpai di hutan utuh. Tidak lama setelah dimulainya kegiatan penebangan, beberapa 
Tabel 8. Musang dan responsnya terhadap kegiatan penebangan.

\begin{tabular}{|c|c|c|c|}
\hline Spesies & Stratifikasi Ekologis & $\begin{array}{l}\text { Kecenderungan } \\
\text { kepadatan setelah } \\
\text { penebangan }\end{array}$ & Referensi \\
\hline $\begin{array}{l}\text { Paradoxurus } \\
\text { hermaphroditus }\end{array}$ & $\begin{array}{l}\text { Arboreal dan terestrial. } \\
\text { Utamanya memakan } \\
\text { buah }\end{array}$ & $\begin{array}{l}\downarrow \\
\uparrow\end{array}$ & $\begin{array}{l}\text { (Heydon \& Bulloh 1996) } \\
\text { (Stuebing \& Gasis 1989) }\end{array}$ \\
\hline $\begin{array}{l}\text { Arctogalidia } \\
\text { trivirgata }\end{array}$ & $\begin{array}{l}\text { Arboreal. Utamanya } \\
\text { memakan buah }\end{array}$ & $\bar{\downarrow}$ & $\begin{array}{l}\text { (Heydon \& Bulloh 1996) } \\
\text { (Syakirah et al. 2000) }\end{array}$ \\
\hline Arctictis binturong & $\begin{array}{l}\text { Arboreal. Utamanya } \\
\text { memakan buah }\end{array}$ & - & (Heydon \& Bulloh 1996) \\
\hline Paguma larvata & $\begin{array}{l}\text { Arboreal dan terestrial. } \\
\text { Memakan buah dan } \\
\text { serangga }\end{array}$ & Informasi tidak cukup & (Heydon \& Bulloh 1996) \\
\hline $\begin{array}{l}\text { Hemigalus } \\
\text { derbyanus }\end{array}$ & Terestrial. Karnivora & $\downarrow$ & (Heydon \& Bulloh 1996) \\
\hline Cynogale bennettii & $\begin{array}{l}\text { Terestrial/akuatik } \\
\text { (hidup di air). Karnivora }\end{array}$ & Informasi tidak cukup & (Heydon \& Bulloh 1996) \\
\hline $\begin{array}{l}\text { Viverra } \\
\text { tangalunga }\end{array}$ & $\begin{array}{l}\text { Terestrial. Makan } \\
\text { serangga, vertebrata } \\
\text { dan buah }\end{array}$ & $\begin{array}{l}\downarrow \\
\downarrow \\
\downarrow \\
\uparrow\end{array}$ & $\begin{array}{l}\text { (Heydon \& Bulloh 1996) } \\
\text { (Colón 1999) } \\
\text { (Augeri unpubl.) } \\
\text { (Syakirah et al. 2000) }\end{array}$ \\
\hline Prionodon linsang & $\begin{array}{l}\text { Arboreal dan terestrial. } \\
\text { Karnivora }\end{array}$ & $\downarrow$ & (Heydon \& Bulloh 1996) \\
\hline
\end{tabular}

$\uparrow=$ Kepadatan meningkat setelah penebangan; $\downarrow$ = penurunan kepadatan atau hilang dari daerah yang baru ditebang; $-=$ tidak ada perbedaan yang nyata. Informasi stratifikasi ekologi diambil dari Heydon dan Bulloh (1996) dan Payne et al. (1985).

spesies musang yang lain berpindah ke daerah tersebut. Kepadatan spesies musang yang tercatat 12 tahun setelah kegiatan penebangan yaitu sebesar 8 individu/ $/ \mathrm{km}^{2}$. Hasil yang sama juga dilaporkan oleh Syakirah et al. (2000), yang mencatat bahwa Tenggalung Malaya (Viverra tangalunga) hanya ditemukan di hutan yang baru ditebang, tetapi tidak dapat dijumpai di hutan yang ditebang 20 tahun sebelumnya. Sementara Stuebing dan Gasis (1989) menemukan Musang Luwak (Paradoxurus hermaphroditus) di areal hutan tanaman, tetapi tidak di areal hutan bekas tebangan. Berlawanan dengan hasil penelitian sebelumnya serta hasil pengamatan Heyden dan Bulloh (1996), Colón (1999) dalam penelitiannya selama dua tahun menemukan, bahwa kepadatan Tenggalung Malaya (Viverra tangalunga) tercatat sebesar 57\% lebih tinggi di hutan utuh dibandingkan dengan di hutan bekas tebangan. Selain itu, tercatat pula bahwa proporsi buah-buahan yang dikonsumsi oleh spesies ini di hutan yang utuh cukup besar dibandingkan dengan di hutan bekas tebangan. Musang Akar (Arctogalidia trivirgata) hanya dapat ditemui di hutan sekunder dan hutan primer, namun tidak dapat dijumpai di hutan yang baru ditebang (Syakirah et al. 2000). Augeri (unpubl.) menemukan bahwa Tenggalung Malaya ( $V$. tangalunga) setidaknya $50 \%$ lebih sering dijumpai di hutan primer dibandingkan dengan daerah hutan sekunder atau hutan yang rusak di MRF dan Kayan Mentarang. Binturung (Arctictis binturong) juga lebih sering dijumpai di hutan primer, seperti halnya Linsang Linsang 
(Prionodon linsang) serta Musang Belang (Prionodon linsang). Kepadatan populasi musang setelah terjadinya kegiatan penebangan dapat dilihat pada Tabel 8 .

Data pada Tabel 8 mengungkapkan bahwa musangyang hidup di pohon (arboreal) dan pemakan buah tidak terlalu terpengaruh oleh kegiatan penebangan karena lebih bergantung pada tingkat perubahan ketersediaan buah. Spesies darat yang karnivora atau pemakan serangga ternyata lebih sensitif. Penyebab penurunan populasi spesies ini belum diketahui dengan jelas. Colón (1999) tidak menemukan penurunan dalam ketersediaan intervertebrata di hutan bekas tebangan. Seperti yang dikemukakan di atas, menurunnya jumlah buah menjadi penyebab utama menurunnya populasi spesies pemakan buah setelah penebangan. Hasil ini bertentangan dengan terjadinya peningkatan kepadatan spesies musang pemakan buah yang lain, seperti yang terlihat pada Tabel 8.

\section{Beruang madu}

Beruang madu (Ursus (Helarctos) malayanus) perlu dipelajari dan dievaluasi lebih lanjut (Servheen 1999). Di luar beberapa penelitian yang ada, hanya ada empat penelitian lapangan yang berfokus pada beruang madu, sementara yang lain mempelajari perdagangan beruang madu dan ancaman lainnya (Meijaard 1999a, 2001a). Wong (2002) dan Wong et al. (2004) mempelajari ekologi dasar beruang madu di Lembah Danum, Sabah; Nomura (2003) mempelajari pemanfaatan perkebunan kelapa sawit oleh beruang madu, juga di Sabah; Fredriksson (2001) meneliti pemanfaatan hutan terbakar oleh beruang madu dan ekologi pola makannya di Sungai Wain, Kalimantan Timur; sementara Augeri (2003) mempelajari efek penebangan kayu, fragmentasi habitat, dan gangguan oleh manusia kaitannya dengan ekologi dan penggunaan habitat beruang madu di Kalimantan Timur (termasuk Malinau) dan di Sumatera Utara. Penelitian yang kelima yang sedang dilakukan di Thailand (Steinmetz in prep.) yaitu tentang penggunaan habitat secara bersamaan oleh Beruang Madu dan Beruang Hitam Asia. Di Indonesia, ancaman utama bagi beruang madu adalah hilangnya habitat dan gangguan manusia (Augeri 2001, 2003, MacKinnon et al. 1996, Santiapillai \& Santiapillai 1996, Servheen et al. 1999, Whitten et al. 1987).

Ketersediaan dan keragaman buah sangat penting bagi stabilitas nutrisi beruang madu. Wong (2002) mengungkapkan bahwa kondisi fisik yang buruk dan tingkat kematian sejumlah beruang yang diamati dalam penelitiannya disebabkan oleh kelangkaan buah yang berkepanjangan. Fredriksson (2001) juga menduga terjadinya kekurangan nutrisi serta mengungkapkan bahwa beruang madu menumpuk cadangan lemaknya selama periode musim buah untuk mempertahankan hidupnya selama jeda waktu antara musim buah yang lebih panjang, seperti periode paceklik buah dan kekeringan yang ekstrim setelah episode musim buah di tahun 1997-1998 (lihat juga Fredriksson \&Wich in prep.). Namun demikian, selama periode ini, buah yang tidak berbiji (terutama spesies ara) terganggu dan hanya sedikit menghasilkan buah (Harrison 2001), sehingga hal ini berpengaruh terhadap beruang (Fredriksson $\&$ Wich in prep.). Ketersediaan serangga yang merupakan sumber makanan penting lain di luar periode musim buah juga terlihat menurun (Fredriksson pengamatan pribadi). Pada kondisi ketersediaan makanan lain yang cukup, seperti misalnya di 
dekat perkebunan kelapa sawit di Sabah dan di hutan primer yang luas seperti Taman Nasional Kayan Mentarang dan Gunung Leuser, beruang berada dalam kondisi yang baik selama paceklik tahun 1997-1998 dan tahun-tahun berikutnya (Augeri 2002, Nomura 2003, Leuser Management Unit unpubl., Wulfraat pengamatan pribadi).

Saat ketersediaan buah terbatas, spesies seperti Beruang Madu yang makanan utamanya buah-buahan hutan, bergantung pada sumber makanan lainnya, terutama di hutan berukuran kecil dengan ketersediaan sumber makanan yang kurang beragam dan kurang berlimpah. Hal ini menyebabkan beruang mencari makan di luar batas hutan tersebut (2004a; Wulfraat pengamatan pribadi). Sebaliknya, hutan primer berukuran luas memiliki kondisi iklim mikro yang lebih stabil dan ketersediaan sumber makanan yang lebih beragam dan lebih berlimpah di seluruh bentangan alam tersebut.

Augeri (2002, 2003), Fredriksson (2001), dan Wong (2002), ketiganya mengamati bahwa makanan alternatif, seperti koloni rayap yang hidup di atas permukaan tanah, kumbang, sarang lebah, dan sarang semut merupakan sumber makanan yang penting bagi beruang madu, meskipun Augeri $(2002,2003)$ menemukan bahwa makanan alternatif ini tidak begitu berlimpah di daerah yang baru ditebang. Fredriksson (pengamatan pribadi) juga menemukan rendahnya kepadatan koloni lebah tak bersengat dan koloni rayap permukaan tanah di areal yang baru ditebang, meskipun Fredriksson mencatat bahwa koloni rayap yang hidup di dalam tanah merupakan salah satu sumber makanan utama bagi beruang. Penelitian Frederikson di Kalimantan Timur menunjukkan bahwa kurang dari $20 \%$ rayap yang dikonsumsi oleh beruang madu diambil dari gundukan sarang rayap yang terlihat di permukaan (Fredriksson, in litt., 31 August 2004). Namun demikian, efek penebangan terhadap spesies-spesies yang hidup di dalam tanah terlihat negatif, yang menyebabkan turunnya kelimpahan pada tingkat gangguan yang lebih besar (Jones et al. 2003).

Augeri (2003) mencatat bahwa pemanfaatan habitat oleh beruang di hutan primer yang lebih tua dan heterogen lebih tinggi. Secara umum Augeri (2003) menunjukkan adanya hubungan positif yang nyata antara pemanfaatan habitat dan keragaman sumber makanan pada tingkat yang lebih tinggi, tutupan tajuk, tutupan tanah, tempat meloloskan diri, serta jumlah pohon berbuah yang berukuran besar dan dewasa. Spesies-spesies pohon yang ada di ekosistem Malinau dan Kayan Mentarang terutama terdiri dari Dipterocarpaceae, Euphorbiaceae, Fagaceae, Lauraceae, Moraceae, Myrtaceae, dan Sapindaceae dengan diameter setinggi dada (dbh) lebih dari $40-45 \mathrm{~cm}$.

Sejumlah pekerja lapangan mengungkapkan bahwa beruang bisa aktif di lokasi yang relatif dekat dengan gangguan. Sebagai contoh, tidak ditemukan perbedaan yang nyata antara kepadatan spesies di daerah bekas tebangan dan daerah utuh di areal konsesi PT Daisy di Berau, Kalimantan Timur (Eames et al. 2001). Namun demikian, kaitan antara kegiatan beruang dengan umur hutan dan intensitas penebangan masih belum jelas. Lebih jauh lagi, di daerah tersebut, pohon ara pencekik (strangling fig) (sumber makanan penting bagi Beruang Madu) yang sangat rapat masih dipertahankan di kawasan bekas tebangan.

Umur hutan dan waktu serta intensitas gangguan merupakan faktor pertimbangan penting dalam pengamatan kegiatan beruang madu di hutan yang terganggu. Augeri 
(2004a) menemukan bahwa lebih dari 98\% tanda-tanda beruang yang diamati dibuat sebelum kegiatan penebangan atau baru dibuat lebih dari 8-10 tahun setelah kegiatan penebangan yang dilakukan dengan intensitas rendah hingga sedang. Hasil ini mengungkapkan bahwa beruang lebih banyak menggunakan hutan primer ketimbang daerah hutan yang terganggu atau hutan sekunder yang berusia muda serta homogen $(\mathrm{P}<0.00001)$. Pemanfaatan habitat oleh beruang semakin tinggi dengan semakin jauhnya jarak dari gangguan, dan tidak mendekati tingkat yang konsisten sampai 3-4 $\mathrm{km}$ dari daerah yang rusak berat. Sejumlah beruang kadang-kadang menggunakan hutan primer dan sekunder setelah hutan rusak, tetapi umumnya spesies beruang tersebut hidup di hutan regenerasi yang berumur lebih dari 15 hingga 20 tahun. Hutan regenerasi ini memiliki produktivitas makanan yang cukup, habitat dengan gangguan minimal atau tanpa gangguan dalam waktu sepuluh tahun sebelumnya, dan tidak ada gangguan aktivitas manusia atau kalaupun ada hanya dalam level yang rendah. Tidak terdapat kegiatan beruang di daerah yang kegiatan penebangan dan pembersihan kayunya sedang berlangsung. Meskipun makanan merupakan faktor yang sangat penting, hasil penelitian menunjukkan bahwa kegiatan penebangan, pertanian, dan kegiatan manusia secara terus-menerus berkorelasi negatif dengan pemanfaatan habitat oleh beruang, dan hubungan ini nyata secara statistik (Augeri 2002, 2003, 2004a).

Data saat ini menunjukkan bahwa beragam jenis kegiatan penebangan dapat mempengaruhi penggunaan habitat, pola pencarian makan, dan kemampuan bertahan (persistensi) beruang madu, terutama di areal cagar dan bagian-bagian hutan yang berukuran kecil dan terisolasi. Pembukaan hutan berperan penting dan kadangkadang dominan dalam dinamika ekologi komunitas interior hutan dan pinggiran hutan, terutama di "pulau-pulau" hutan berukuran kecil dan hutan-hutan dengan rasio luasan areal pinggiran yang besar (lihat Laurance \& Bierregaard 1997, Lovejoy et al. 1986). Hal ini dapat mempengaruhi beruang madu melalui a) pembatasan akses terhadap daerah sumber makanan yang produktif; b) pengurangan keragaman dan kelimpahan sumber makanan penting; c) peningkatan atau terjadinya efek kekeringan dan perubahan produktivitas, ketersediaan, dan penyebaran buah-buahan pada tingkat lokal maupun regional; dan d) peningkatan akses bagi perburuan (Augeri 2003).

Dari hutan primer utuh yang dihindari atau dimanfaatkan secara minimal oleh beruang madu di Kalimantan Timur dan Sumatera bagian utara, lebih dari $80 \%$ kegiatan manusia berlangsung secara terus-menerus, terutama dalam bentuk perburuan, pengumpulan hasil hutan nonkayu, dan eksplorasi atau penelitian hutan (Augeri 2003). Di hutan primer, pada tingkat yang lebih nyata, Augeri (2003) menemukan bahwa beruang terlihat lebih sensitif, dan menghindari kegiatan manusia serta gangguan habitat yang sifatnya ringan (contohnya, pengumpulan gaharu). Sementara kelimpahan beruang tertinggi didapati di lokasi yang lebih terpencil, dengan sedikit kegiatan manusia atau tidak ada sama sekali (Augeri 2004a). Dari daerah-daerah survei yang dihindari atau digunakan secara minimal oleh beruang madu di Malinau dan Taman Nasional Kayan Mentarang, 90\% (Malinau) dan 80\% (TN Kayan Mentarang) terdapat kegiatan manusia. 
Kejadian bersifat stokastik yang menyebabkan berkurangnya makanan beruang dapat diperburuk oleh adanya kegiatan penebangan, hilangnya hutan, kebakaran hutan, serta gangguan lainnya (Augeri 2004a, Mattson et al. 1996, Merrill et al. 1999). Yang demikian ini terjadi di bagian-bagian hutan yang berukuran kecil. Di hutan primer dengan tutupan yang luas, bahkan kejadian bersifat stokastik seperti tidak terjadinya musim buah dalam jangka waktu yang cukup lama tidak menimbulkan efek gangguan yang nyata seperti yang terjadi pada bagian hutan yang berukuran lebih kecil (Augeri 2004a, Bierregaard et al. 2001, Wulfraat pengamatan pribadi).

Konflik dengan manusia, perburuan, serta perdagangan beruang atau bagianbagian dari beruang secara ilegal merupakan faktor penting yang mengancam kelangsungan hidup beruang madu, terutama di Asia daratan (Mills \& Servheen 1994). Augeri (unpubl.) melakukan wawancara dengan kepala desa, kepala wilayah serta kepala adat di daerah Malinau dan Kayan Mentarang tentang beruang madu yang mati diburu. Hasil yang diperoleh menunjukkan bahwa antara tahun 2000 dan 2003, beruang madu yang diambil untuk obat-obatan dan hiasan mencapai jumlah rata-rata 10 hingga 20 ekor di setiap desa dalam setahun. Kepala desa juga menyatakan bahwa perburuan beruang lebih banyak untuk perdagangan hewan peliharaan atau beruang dibunuh karena dianggap sebagai hama, tetapi tidak termasuk beruang madu. Tingkat pengambilan ini sangat tinggi dibandingkan dengan penelitian mengenai perburuan lainnya di Borneo (lihat Fredriksson \& Wich in press, Puri 1997, Wadley et al. 1997). Hal ini menunjukkan adanya peningkatan pasar bagi perdagangan beruang dan bagian-bagian dari beruang. Bila tingkat perburuan ini mencerminkan pengambilan rata-rata di seluruh wilayah, dalam setahunnya pengambilan ini bisa mencapai ratusan beruang. Dengan peningkatan akses keluar wilayah dan peningkatan pengaruh dari pasar luar dan ekspor, tekanan perburuan ini dapat menyebabkan penurunan jumlah spesies ini secara nyata (Servheen 1999). Penelitian yang dilakukan di tujuh pemukiman masyarakat setempat di Malinau menunjukkan bahwa beruang (bagian empedu, cakar, dan kulitnya) dianggap bernilai penting, baik bagi kepentingan budaya maupun sebagai barang yang diperdagangkan. Kadang-kadang daging beruang tersebut juga dimakan (Sheil et al. in prep.). Menurunnya populasi beruang akibat perburuan dan hilangnya habitat di Borneo bagian Malaysia dan daratan Asia Tenggara bisa memicu perubahan permintaan populasi beruang madu Indonesia yang peruntukannya sebagai satwa peliharaan, dan diambil empedunya serta bagianbagian beruang yang lain untuk obat-obatan dan kosmetik tradisional Asia (Augeri 2004a; Meijaard 2001a). Meskipun beruang madu dilindungi secara internasional, di Indonesia, serta di Malaysia, perburuan dan perdagangan merupakan ancaman yang terus meningkat bagi kelangsungan hidupnya.

\section{Satwa berkuku belah (ungulata)}

Hanya sedikit informasi yang ada tentang ekologi satwa hutan berkuku belah (ungulata) dan responsnya terhadap penebangan. Penelitian mengenai spesies ini, terutama dalam jangka panjang, sangat langka. Ada beberapa hal penting perlunya dilakukan penelitian tentang efek penebangan kayu terhadap populasi ungulata, antara lain karena satwa ini: (1) merupakan sumber protein masyarakat setempat, (2) 
merupakan bagian integral dari berbagai proses ekosistem, dan (3) merupakan faktor penentu utama dalam komposisi dan struktur vegetasi hutan (Davies et al. 2001) Ada dua kelompok satwa hutan berkuku belah yang berbeda yang ditemukan di bagian timur Borneo. Kelompok ini adalah pelanduk (suku Tragulus), dan kijang (suku Muntiacus). Selain itu ada tiga spesies yang berukuran lebih besar yaitu Rusa Sambar (Cervus unicolor), Babi Berjenggot (Sus barbatus), dan Banteng (Bos javanicus).

Suku Muntiacus dan Tragulus diwakili oleh dua spesies yang hidup dalam wilayah geografis yang sama (sympatric) dari masing-masing marganya: Pelanduk Kancil (Tragulus javanicus) (nama spesies ini diubah menjadi T. kanchil oleh Meijaard \& Groves 2004) dan Pelanduk Napu (T. napu), serta Muntiacus atherodes (Kijang Muncak) dan $M$. muntjak (Kijang Kuning). Saat ini, pemisahan antara kedua spesies tersebut sebagian besar berdasarkan perbedaan morfologinya (Groves \& Grubb 1982, Meijaard \& Groves 2004). Payne et al. (1985) dan Augeri (in prep.) mencatat adanya perbedaan rentang ketinggian pada suku Muntiacus dan Tragulus. Namun demikian, pemisahan relung ekologis belum dipelajari secara seksama di kedua marga tersebut. Kijang kuning ( $M$. atherodes) bisa jadi merupakan spesialis dataran rendah, sedangkan Kijang Muncak (M. muntjak) lebih umum dijumpai pada altitude yang lebih tinggi (Augeri unpubl.; Payne et al. 1985). Hal ini juga diindikasikan oleh adanya hiasan kepala satwa hasil buruan (tropi) yang ditemukan oleh Hedges dan Meijaard (1999) di sejumlah desa di daerah hulu Sungai Bahau (ketinggian rata-rata $350 \mathrm{~m} \mathrm{dpl}$ ) di Taman Nasional Kayan Mentarang. Mereka menemukan sebanyak 105 tengkorak $M$. muntjak dan hanya enam $M$. atherodes, namun belum jelas apakah ketinggian merupakan kunci penentu pembedaan kedua spesies ini. Dari bentuk morfologi kaki kedua spesies pelanduk yang diamati, kemungkinan T. napu lebih menyukai habitat yang berawa (Chasen 1940, Smit-van Dort 1989). Hal ini didukung oleh Duckworth (1997a) dan Bennett (komunikasi pribadi dalam Duckworth 1997a) yang mengungkapkan bahwa Pelanduk Kancil (T. javanicus) lebih banyak hidup di daerah perbukitan.

Ungulata dapat dikategorikan berdasarkan perilaku makan dan pemilihan habitat. Kedua spesies pelanduk tersebut sangat bergantung pada buah-buahan yang jatuh dari pohon dan pohon ara pencekik (Ficus spp.) (Heydon \& Bulloh 1997), meskipun material lainnya seperti daun-daun juga dimakan (misalnya Octomeles sumatrana) dan jamur (Russula sp.) (Matsubayashi et al. 2003). Dari seluruh ungulata Borneo, pelanduk terlihat memanfaatkan bahan makanan yang paling kaya nutrisinya. Kedua spesies kijang tersebut lebih banyak memakan buah-buahan dan daun-daunan, dan hanya memilih bagian tertentu dari tumbuhan, serta bertahan sepanjang tahun makan satu atau beberapa jenis vegetasi saja. Rusa Sambar dapat ditemukan di seluruh hutan di Asia Selatan dan Tenggara. Spesies ini hidup di pinggiran hutan, pinggiran sungai, daerah terbuka yang berumput, semak belukar sekunder, dan daerah ladang terbuka (Nowak 1999). Namun spesies ini juga umum ditemukan di hutan yang terbuka mau pun interior hutan yang rapat. Rusa Sambar merupakan spesies pemamah rumput dan pemakan daun yang bersifat generalis, memakan sejumlah jenis rumput dan bagian-bagian tumbuhan.

Intensitas penebangan yang dapat ditoleransi oleh ungulata hutan berukuran kecil bergantung pada seberapa jauh satwa-satwa tersebut memerlukan buah-buahan 
Tabel 9. Perubahan kepadatan suku Cervidae dan Tragulidae setelah kegiatan tebang pilih.

\begin{tabular}{|c|c|c|c|c|}
\hline Spesies & $\begin{array}{l}\text { Berat } \\
\text { badan } \\
(\mathrm{kg}) \\
\end{array}$ & Stratifikasi Ekologis & $\begin{array}{l}\text { Kecenderungan } \\
\text { kepadatan setelah } \\
\text { penebangan }\end{array}$ & Referensi \\
\hline Cervus unicolor & 100 & Terestrial herbivora & $\frac{\uparrow \uparrow}{-}$ & $\begin{array}{l}\text { (Heydon 1994) } \\
\text { (Rijksen 1978) }\end{array}$ \\
\hline $\begin{array}{l}\text { Muntiacus } \\
\text { atherodes }\end{array}$ & 15 & $\begin{array}{l}\text { Terestrial, terutama } \\
\text { pemakan buah }\end{array}$ & $\downarrow$ & (Heydon 1994) \\
\hline $\begin{array}{l}\text { Muntiacus } \\
\text { muntjak }\end{array}$ & 20 & $\begin{array}{l}\text { Terestrial, terutama } \\
\text { pemakan buah }\end{array}$ & $\underset{\uparrow}{\uparrow \uparrow}$ & $\begin{array}{l}\text { (Heydon 1994) } \\
\text { (Duff et al. 1984) }\end{array}$ \\
\hline Tragulus napu & 4 & $\begin{array}{l}\text { Terestrial, terutama } \\
\text { pemakan buah }\end{array}$ & $\downarrow \downarrow$ & (Heydon 1994) \\
\hline Tragulus kanchil & 2 & $\begin{array}{l}\text { Terestrial, terutama } \\
\text { pemakan buah }\end{array}$ & $\downarrow \downarrow$ & (Heydon 1994) \\
\hline Sus barbatus & 125 & $\begin{array}{l}\text { Pemakan segala } \\
\text { (omnivora) }\end{array}$ & $\frac{-}{\downarrow^{*}}$ & $\begin{array}{l}\text { (Davies et al. 2001) } \\
\text { (Linkie \& Sadikin 2003) } \\
\text { (Wilson \& Johns 1982) }\end{array}$ \\
\hline
\end{tabular}

$-=<20 \%$ perbedaan nilai tengah kepadatan di hutan bekas tebangan dan hutan primer; $\uparrow / \downarrow=$ kenaikan/penurunan antara 20 hingga $60 \%$ di hutan bekas tebangan dan hutan primer; $\uparrow \uparrow / \downarrow \downarrow=$ kenaikan/penurunan lebih dari $60 \%$ antara hutan bekas tebangan dan hutan primer.

* Pengaruh akibat perburuan

campuran, tanaman hutan dan nonhutan. Johns (1997) menemukan bahwa Tragulus lebih sering dijumpai di hutan bekas tebangan dibandingkan hutan dewasa di Semenanjung Malaya. Kepadatannya cenderung menurun kembali di hutan bekas tebangan berumur tua. Namun demikian, di Sabah (Heydon (1994) dan Davies et al. (2001) melaporkan bahwa terjadi penurunan kepadatan T. javanicus rata-rata sebesar 55-60\% dan penurunan kepadatan T. napu rata-rata sebesar 71-90\% di hutan tebang pilih dibandingkan dengan hutan utuh (Tabel 9). Sejalan dengan itu, data jerat kamera Augeri mengungkapkan bahwa kedua spesies Tragulus di hutan sekunder memiliki tingkat kepadatan sekitar 65\% lebih rendah dibandingkan dengan kepadatan di hutan primer.

Heydon (1994) menemukan bahwa kepadatan pelanduk berkolerasi positif dengan kelimpahan buah dan selanjutnya mengungkapkan bahwa sifatnya sebagai pemakan buah membatasi kemampuannya berkompensasi pada saat ketersediaan buah menurun. Namun demikian, kemampuan pelanduk untuk beradaptasi secara ekologis diamati oleh Laidlaw (2000) yang secara teratur menjumpai Tragulus spp (tidak diidentifikasi hingga tingkat spesies) di perkebunan dan daerah bersemak belukar di Semenanjung Malaya. Selain itu, Duckworth (pengamatan pribadi) menyatakan bahwa di Indochina, $T$. javanicus merupakan spesies yang hidup di pinggiran hutan. Pemanfaatan habitat yang terganggu oleh T. javanicus juga didukung oleh Matsubayashi et al. (2003) di Sabah, yang menemukan bahwa spesies ini lebih banyak mencari makan di celah hutan akibat pohon tumbang (tree-fall gaps) dan daerah yang didominasi oleh tumbuhan bambu. Kemungkinan spesies tersebut menyukai buah-buahan dan pucuk-pucuk daun tumbuhan perintis yang tumbuh di areal bambu. Bagi satwa pemakan buah, celah karena pohon tumbang tersebut 
merupakan lokasi mencari makan yang baik karena sejumlah jenis tumbuhan celah menghasilkan buah beberapa kali dalam setahun, sementara jenis-jenis tumbuhan klimaks di hutan tua hanya menghasilkan buah sekali dalam setahun atau kurang (Whitmore 1998). Di lain pihak, Matsubayashi et al. (2003) menemukan bahwa $T$. javanicus beristirahat pada malam hari di dasar hutan yang terbuka tanpa tumbuhan bawah. Hal ini mungkin untuk memudahkan mereka mendeteksi pemangsa secara efektif (pada siang hari, satwa ini lebih banyak beristirahat di bawah naungan seperti batang-batang pohonan yang tumbang atau percabangannya). Dasar hutan yang terbuka dan jumlah rongga pohon tumbang yang berlimpah sering ditemukan di hutan primer.

Kijang Kuning biasanya lebih sering dijumpai di hutan utuh dibandingkan dengan Kijang Muncak (meskipun hal ini bisa juga bergantung dari ketinggian lokasi). Heydon (1994) mencatat terjadinya peningkatan jumlah Kijang Muncak sejalan dengan penurunan Kijang Kuning di hutan bekas tebangan (Tabel 9). Duff et al. (1984) juga mengungkapkan terjadinya peningkatan jumlah Kijang Muncak yang ditemukan di hutan bekas tebangan dibandingkan dengan di hutan utuh. Makanan Kijang Muncak diperkirakan mengandung sejumlah besar tumbuhan hijau dibandingkan dengan makanan Kijang Kuning (Barrette 1977), sehingga dapat menjelaskan mengapa mereka mampu bertahan di hutan bekas tebangan.

Pemakan rumput tidak bergantung pada hutan utuh atau dipengaruhi secara negatif oleh kegiatan penebangan (Davies et al. 2001). Rusa Sambar memanfaatkan jalan tebangan untuk makan rumput yang tumbuh di tepi jalan tersebut. Spesies ini terlihat memanfaatkan jalan tebangan sebagai daerah alternatif pencarian makan serta sebagai koridor antara lokasi-lokasi hutan yang disukainya, termasuk hutan bekas tebangan. Jumlah spesies ini berkolerasi positif dengan daerah hutan yang sangat rusak dan berkorelasi negatif dengan daerah hutan primer (Tabel 9) (Heydon 1994). Rijksen (1978) juga mengungkapkan bahwa Rusa Sambar lebih umum hidup di vegetasi sekunder dibandingkan di hutan utuh. Namun demikian, spesies ini diperkirakan menghindari daerah-daerah yang sedang ditebang karena kehadiran manusia dan perburuan. Hasil survei jejak tanda dan jerat kamera di Ekosistem Leuser (Sumatera), MRF, dan Taman Nasional Kayan Mentarang (Kalimantan Timur) sama dengan temuan Rijksen yang mengungkapkan bahwa Rusa Sambar tidak umum ditemukan di daerah yang terganggu yang berumur kurang dari lima tahun dan frekuensi kehadirannya sedikit lebih tinggi di hutan sekunder yang lebih tua dan lebih terbuka (Augeri 2003). Namun demikian, analisis statistik menunjukkan bahwa perbedaan relatif kehadiran spesies ini di daerah hutan utuh dan hutan sekunder tidak nyata (Augeri 2004). Penduduk setempat juga melaporkan bahwa Rusa Sambar tidak terlalu terpengaruh oleh penebangan dibandingkan dengan banyak jenis satwa lain yang menjadi sumber makanan, disamping itu spesies ini merupakan spesies utama yang dibunuh di daerah yang rusak (Sheil pengamatan pribadi). Dengan demikian, Rusa Sambar merupakan spesies yang diuntungkan dengan adanya pemanenan kayu, meskipun perburuan spesies yang dilindungi ini berpotensi mengaburkan efek positif tersebut.

Memelihara populasi Babi Berjenggot (Sus barbatus) merupakan hal yang penting bagi kesejahteraan masyarakat setempat. Babi Berjenggot menyumbang antara 50 
hingga 75\% berat total satwa yang diburu di Borneo (lihat Caldecott 1988, Puri 1997, Bennett et al. 1999). Selain itu, sebagai sumber protein dan lemak hewani yang utama, spesies ini merupakan produk nutrisi dan ekonomi yang penting bagi kehidupan serta adat istiadat penduduk di seluruh pulau ini. Di Malinau, daging babi ternak kurang popular dibandingkan Babi Berjenggot di kalangan penduduk asli, karyawan HPH, dan pendatang baru (Ndan 2003). Di daerah Malinau, penduduk setempat merasakan adanya penurunan jumlah hewan berkuku belah, terutama Babi Berjenggot (Sheil et al. 2003c), sementara kecenderungan serupa juga ditemukan di daerah yang berdekatan dengan Kayan Mentarang (Meijaard 2003a).

MacKinnon et al. (1996) mengungkapkan bahwa Babi Berjenggot mempunyai peran penting sebagai penyebar biji, contohnya dalam penyebaran tumbuhan Rafflesia. Babi juga diperkirakan membantu penyebaran biji durian (Durio spp.) dengan cara memakan buah yang jatuh dan menyebarkan biji yang tidak dapat dicerna melalui kotorannya, meskipun Setyawati (komunikasi pribadi) mengungkapkan bahwa ukuran biji durian mungkin terlalu besar untuk bisa melewati perut babi secara utuh. Analisis feses yang dilakukan Setyawati (unpubl.) dan analisis isi perut yang dilakukan Meijaard dan Wulffraat (unpubl.) juga mengungkapkan bahwa sebagian biji yang berukuran besar dipecahkan terlebih dahulu sebelum ditelan, sehingga kecil kemungkinan bahwa babi mampu menyebarkan biji berukuran besar.

Curran dan Webb (2000) serta Curran dan Leighton (2000) menyelidiki masa berbuah Dipterokarpa yang terjadi secara bersamaan (mass-fruiting), kemampuan hidup anakan dan biji, serta respons vertebrata terhadap kemampuan hidup biji. Babi Berjenggot merupakan pemakan biji yang paling penting. Pada episode kecil massfruiting di tahun 1986, sebanyak 21 spesies pohon Dipterokarpa yang memproduksi 60,000 biji/ha kehilangan seluruh biji berpotensi hidup yang sedang diamati karena vertebrata yang hidup menetap dan nomad, termasuk Babi Berjenggot (Curran \& Leighton 2000). Namun demikian, pada episode 1987 dan 1991, vertebrata yang tinggal di daerah tersebut hanya makan sebagian kecil biji-bijian yang dihasilkan. Vertebrata nomad datang pada akhir periode jatuhnya buah-buahan di masa kedua episode tersebut, sehingga mereka hanya bisa makan biji yang tersebar dalam jangka waktu satu hingga tiga minggu terakhir saat buah jatuh. Biji-bijian yang lolos dan mampu beregenerasi hanya terjadi pada episode reproduksi bersamaan, yaitu saat seluruh spesies Dipterokarpa dari seluruh penjuru daerah berpartisipasi. Berdasarkan pengetahuan yang terbatas tentang ekologi Babi Berjenggot, dapat disimpulkan bahwa dampak kegiatan penebangan terhadap tanaman buah yang penting dapat mempengaruhi pola migrasi, distribusi dan kepadatan satwa ini, dan selanjutnya mempengaruhi penyebaran dan regenerasi spesies-spesies pohon buah lainnya.

Meskipun Banteng (Bosjavanicus) tidak ditemukan selama survei keanekaragaman hayati di Malinau (lihat O’Brien \& Fimbel 1999), Hedges dan Meijaard (1999) menemukan bukti populasi Banteng di bagian barat Sungai Bahau. Kawasan ini mencakup areal padang rumput yang luas. Hoogerwerf (1938, dalam Brookfield 1997) mengungkapkan bahwa Banteng lebih menyukai habitat padang rumput, savana, dan hutan sekunder dibandingkan hutan tropis. Hal ini dilaporkan pula oleh Banks (1931), yang menyatakan bahwa Banteng bergantung pada daerah hutan yang dibuka untuk areal pertanian karena Banteng mencari makan di hutan sekunder dan 
lahan pertanian, serta Banteng tidak banyak menggunakan areal hutan yang rapat. Wharton (1968) membuat pernyataan serupa. Karena Banteng sering ditemukan di sekitar lahan pertanian dan kebun-kebun hutan merusak tanaman, kadang-kadang satwa tersebut diburu dan dianggap sebagai hama, seperti apa yang dilakukan oleh masyarakat Kenyah di daerah hulu Sungai Bahau. Di Kalimantan Timur dan Sarawak terdapat pula permintaan pasar terhadap Banteng untuk hiasan (Hedges \& Meijaard 1999). Banteng diuntungkan dengan terbentuknya rumpang (forest gaps) dan pembukaan lahan hutan, kecuali saat tekanan perburuan yang tinggi membatasi populasinya.

Secara umum, perubahan kelimpahan spesies ungulata ditentukan terutama oleh perburuan. Dampak tersebut dipelajari dengan baik di Sarawak (Bennett et al. 1999, Bennett \& Robinson 2000, Robinson et al. 1999). Sehingga meskipun penebangan memberikan manfaat bagi pemakan rumput karena meningkatnya tanaman makanannya, peningkatan aksesibilitas di wilayah ini (jalan tebangan dan jejaknya) menyebabkan tingginya tekanan perburuan. 



\section{Amfibia dan reptil}

Amfibia mencapai keragaman tertingginya di hutan tropis dunia, dan mewakili sebagian besar fauna vertebrata di hutan tropis. Amfibia merupakan komponen penting dalam jaringan makanan di daerah tropis karena kemungkinan merupakan insektivora terestrial yang utama (Reagan \& Waide 1996). Namun demikian, jumlah makalah yang membahas ekologi satwa yang menjadi komponen hutan tropis Asia Tenggara ini hanya sedikit sekali. Jumlah ini bahkan lebih rendah lagi untuk penelitian yang secara spesifik mempelajari respons herpetofauna terhadap penebangan (misalnya Iskandar 1999a, Iskandar \& Setyanto 1999, lihat juga Iskandar \& Colijn 2000, untuk daftar spesies).

\section{Katak dan kodok}

Amfibia, terutama amfibia hutan tropis, mengalami penurunan dramatis secara global yang disebabkan oleh serangkaian faktor, termasuk hilangnya habitat, perubahan iklim, serta penyakit (Daszak et al. 2001). Namun demikian, proses yang tidak teridentifikasi diperkirakan mengancam $48 \%$ spesies yang populasinya menurun secara cepat, dan mempercepat kepunahannya (Stuart et al. 2004). Penurunan ini secara khusus dilihat dari kecenderungan ekologis spesies, rentang geografis, dan asosiasi taksonomisnya. Kurangnya perangkat konservasi untuk menanggulangi penurunan populasi tersebut menyebabkan ratusan spesies amfibia menghadapi kepunahan (Stuart et al. 2004).

Katak dan kodok (yang disebut sebagai bangsa anura) memiliki keragaman tinggi dalam hal cara reproduksi dengan siklus hidup yang kompleks. Siklus hidup bangsa anura mencakup tahap larva (berudu) yang memerlukan habitat dan sumber makanan yang berbeda dengan tahap dewasa (lihat Inger $\&$ Voris 2001). Aliran sungai dan kolam (genangan air) menyediakan habitat mikro bagi anura dan sebagian besar anura memerlukan habitat akuatik untuk bereproduksi. Spesies katak yang bergantung pada air yang tertahan dalam tumbuhan dan lubang pohon akan dipengaruhi oleh hilangnya lokasi-lokasi yang memiliki mikrohabitat tersebut. Selama perkembangan 
dan metamorfosisnya, larva anura sangat peka terhadap perubahan kimia air dan karakteristik fisik habitat akuatik.

Pada skala global, banyak spesies amfibia yang siklus hidupnya berada pada serasah daun, mengeluarkan telur-telur terestrial yang langsung tumbuh dan berkembang. Di Borneo, hal ini terjadi hanya pada 12 dari 142 spesies yang diketahui (Inger, in litt., 8 Oktober 2003). Spesies lain hanya tinggal pada tajuk yang rendah, memanfaatkan tumbuhan yang dapat menampung air (kebanyakan tumbuhan rambat dan rongga pohon) dan substrat untuk bertelur dan perkembangan tahap berudu. Anura sensitif terhadap berbagai aspek kualitas habitat karena untuk menjalani hidupnya, seringkali spesies ini memerlukan beragam sumberdaya khusus dalam urutan siklus hidupnya yang spesifik.

Ada empat puluh spesies amfibia yang diidentifikasi di MRF, 36 spesies di antaranya terlihat atau dikoleksi, sementara empat spesies lainnya dilaporkan oleh penduduk setempat (Iskandar 2004). Daftar spesies dapat dilihat pada Lampiran 6. Anura dapat dibedakan menjadi dua kelompok—riparian (di sepanjang sungai) dan nonriparian (danau, kolam, dsb.). Dari 40 spesies yang diidentifikasi di Malinau, 24 spesies merupakan kelompok riparian dan 16 spesies merupakan kelompok yang berkembang biak di kolam, meskipun Inger (pengamatan pribadi) mengungkapkan bahwa pemisahan ini tidak selalu jelas. Sebagian besar spesies riparian berkembang biak dan mencari makan di sepanjang sungai sehingga hidupnya terbatas pada jenis lingkungan ini. Spesies lainnya menetas dalam sungai atau kolam batu di sisi sungai, namun kemudian menyebar luas ke seluruh hutan dan menghabiskan masa dewasanya jauh dari air yang mengalir. Di antara katak nonriparian, sebagian besar memerlukan kolam untuk bertelur. Empat spesies memerlukan rongga pohon dan tiga spesies memerlukan rawa atau rembesan air. Spesies Philautus di Borneo biasanya bertelur secara langsung di lantai hutan, tanpa mengalami tahap larva yang bersifat akuatik. Tidak satu pun spesies dari marga ini yang telah diidentifikasi di Malinau, meskipun Philautus hosii dapat ditemukan di hutan nonriparian yang merupakan daerah tebangan ramah lingkungan di Hutan Lindung Ulu Segama sekitar $150 \mathrm{~km}$ dari Malinau (Wong in press $a, b$ ).

Pola makan anuran dewasa umumnya oportunistik dan sedikit sekali yang bersifat spesialis. Kebanyakan mereka memakan beragam invertebrata nonakuatik dan akibatnya banyak terjadi tumpang tindih pola makan. Sebagian spesies merupakan pemakan semut (contoh Microhylidae, Das 1996, Bufonidae, Inger 1969, dan Wong in press a) dan mungkin terjadi korelasi antara ukuran katak dan ukuran mangsa yang dimakan (Inger 1969) yang dapat mengurangi persaingan antara spesies dengan ukuran yang berbeda.

Lingkungan sungai menyediakan beragam habitat bagi larva katak, yang dapat disusun dalam rangkaian berdasarkan aliran air sungai. Ujung tercepat adalah bagian sungai yang berarus deras dan dasarnya terbentuk dari batuan besar dan lempeng batu. Pada ujung yang lambat, bagian-bagian air tenang terbentuk di tepi sungai yang berlekuk atau karena akar-akar yang menjorok ke sungai. Batu kerikil sering mengisolasi kolam-kolam tersebut dari aliran utamanya setelah beberapa hari tanpa hujan. 
Berudu spesies riparian tidak tersebar secara merata di antara habitat sungai. Lebar dan gradien sungai memiliki efek yang nyata terhadap komunitas yang ada (Inger \& Voris 1993). Contoh ekstrim dari efek gradien sungai ditemukan oleh Inger dan Voris (1993), yaitu pada sungai berdasar pasir dan sama sekali tanpa gelombang dan arus, tidak didapati seluruh spesies yang berkembang biak di air yang jernih dan berarus deras. Dengan demikian, peningkatan aliran permukaan dan siltasi yang timbul dari kegiatan penebangan (Douglas et al. 1992, 1993) dapat mempengaruhi spesies yang hidup di air jernih ini.

Komunitas berudu sungai memiliki setidaknya dua karakteristik yang konsisten, yaitu taxa tertentu hidup bersama-sama dan kelompok yang lain hidup dalam habitat mikro yang berbeda. Terdapat pula indikasi stabilitas dalam komposisi spesies di dalam lokasi selama lebih dari satu tahun (Inger et al. 1986). Selain itu, Inger dan Voris (1993) memberikan bukti stabilitas komposisi itu selama periode 22 tahun. Kecenderungan dalam susunan komunitas ini disebabkan oleh tiga faktor sebagai berikut:

1) Perilaku reproduksi anura dewasa: Perilaku bertelur menentukan berbagai kemungkinan habitat berudu spesies-spesies tertentu dapat ditemukan. Pada tingkat yang paling umum, betina bisa bertelur pada aliran sungai atau di hutan yang jauh dari sungai. Tiga dari empat tahap larva Microhyla yang dapat diidentifikasi di MRF ditemukan pada kolam kecil di dasar hutan (Inger 1985).

2) Respons jenis bentuk (morphotypes) terhadap kondisi fisik: Berudu memiliki sifat khas yang sesuai untuk struktur fisik dan kondisi lingkungan habitat tempat tinggalnya. Beberapa contoh jelas karakteristik ini antara lain adalah tahap larva dari Ansonia albomaculata, yang memiliki bentuk badan yang ramping dan bentuk bibir penghisap yang besar (Inger 1985). Bentuk larva Meristogenys memiliki penghisap di perut yang memungkinkannya untuk menempel pada batu dan bertahan pada posisi tertentu dalam arus deras (Inger et al. 1986). Kemungkinan tidak satu pun perangkat penghisap tersebut berfungsi dengan baik dalam substrat berlumpur yang mungkin terjadi akibat tingginya aliran permukaan hutan setelah kegiatan penebangan, sehingga membatasi keberadaan larva A. albomaculata. Bentuk badan larva Leptobrachella mjobergi yang ramping memungkinkan spesies ini untuk menyelinap ke dalam celah-celah dan menghindar dari tekanan gelombang dan arus (Inger 1983). Bentuk badan yang lonjong dan sirip ekor yang dalam pada larva Bufo divergens dan Rhacophorus pardalis menyebabkan kedua spesies ini hidup pada daerah berarus lemah atau tanpa arus sama sekali (Inger 1985). Dengan bentuk morfologis yang membatasi distribusinya, variasi tipe habitat mikro yang ada pada kondisi arus rata-rata bisa diasosiasikan dengan bentuk larva dari beberapa spesies anura.

3) Cara makan: Ada lima cara makan yang dimiliki berudu (Inger 1986): pemakan (hanya) bentik, generalis, pemakan segala dalam jumlah banyak (macrophagous), pemakan renik dalam air, dan pemakan di lapisan permukaan. Di antara spesies yang diidentifikasi di MRF, Ansonia albomaculata menggunakan cara pertama, Bufo divergens dan Rana chalconota cara kedua, Leptobrachium abbotti cara ketiga, 
Microhyla borneensis keempat, dan Megophrys nasuta menggunakan cara kelima. Masing-masing spesies berudu tersebut berfungsi dengan baik dalam habitat yang terbatas.

Pada amfibia nonriparian, terdapat indikasi spesialisasi waktu dan tempat, dibandingkan dengan spesies tepi sungai (lihat Inger 1969). Banjir yang merusak seringkali terjadi pada anak-anak sungai di Borneo. Semua spesies yang hidup di habitat ini harus memiliki ketahanan terhadap peningkatan laju aliran sungai yang cepat. Adaptasi ini dapat membatasi kesempatan membentuk relung ekologisnya. Keragaman spesies dalam kelompok nonriparian jauh lebih tinggi dibandingkan dengan kelompok riparian. Spesies yang menunjukkan kebiasaan/perilaku berbagi sumber daya — makanan dan habitat—yang relatif sedikit, mencerminkan spesialisasi yang lebih besar dalam pemanfaatan waktu dan ruang di lingkungan nonriparian yang lebih stabil (Das 1996).

Kegiatan penebangan dapat mempengaruhi anura secara langsung maupun tidak langsung. Pengaruh penebangan terjadi melalui dampaknya pada kolam dan sungai yang berada di sekitar lokasi kegiatan penebangan, pada daerah aliran sungai (DAS) di seluruh areal, dan pada kondisi habitat mikro berupa serasah daun hutan di habitat nonriparian. Penelitian di Sabah menunjukkan bahwa rusaknya vegetasi bawah dan serasah lantai hutan menyebabkan tingkat erosi yang ekstrim selama hujan diikuti dengan naiknya tingkat sedimentasi yang besar di sungai-sungai. Kegiatan tebang pilih meningkatkan beban sedimen di sungai yang berdekatan dengan lokasi tebangan yaitu sebesar 18 kali lipat dalam waktu 5 bulan setelah kegiatan penebangan tersebut, sementara setahun setelah kegiatan penebangan dilakukan, beban sedimen bulanan yang dihasilkan masih mencapai 4 kali lipat dari beban sedimen di daerah tangkapan yang tidak terganggu; kandungan kimia air juga berubah banyak setelah penebangan (Douglas et al. 1992, 1993). Perubahan komposisi unsur hara, tingkat keasaman $(\mathrm{pH})$, dan suhu dapat menyebabkan cacat bentuk dan kematian larva anura (Feder \& Burggren 1992, Ouellet et al. 1997). Sedimentasi jelas memiliki efek yang merusak reproduksi sejumlah spesies katak yang berkembang biak di sungai, serta sedimentasi ini secara efektif menghambat ketahanan hidup berudu (Inger, in litt., 3 Oktober 2003).

Wong (in press a) mempelajari faktor lingkungan yang berkaitan dengan komposisi spesies komunitas katak di hutan tropis Sabah. Dalam penelitian tersebut Wong menemukan bahwa faktor yang berpengaruh nyata terhadap komunitas katak adalah daya hantar dan tingkat keasaman air sungai, suhu dan kelembaban hutan nonriparian, serta struktur hutan. Selain itu, ketersediaan sumber makanan (contohnya, kepadatan serangga) berkolerasi positif dengan keragaman spesies katak, meskipun korelasi ini lemah dan tidak nyata (Wong in press a, b).

Hampir seluruh siklus hidup anura bergantung pada konsistensi keragaman habitat mikro serasah daun untuk meloloskan diri dari pemangsa, bersarang, berlindung dari kekeringan dan sumber mangsa invertebrata (Scott 1976, Vitt \& Caldwell 1994, 2001). Pembukaan tajuk secara drastis mempengaruhi lingkungan lantai dasar hutan (misalnya, adanya cahaya, suhu, kelembaban, serta laju akumulasi serasah). Hilangnya atau perubahan kualitas serasah daun berpengaruh terhadap anura 
secara langsung maupun tidak langsung (Zou et al. 1995). Di Amazon, keragaman tertinggi artropoda yang hidup di lapisan serasah terdapat di hutan belantara (Vitt \& Caldwell 1994). Pengaruh variasi artropoda serasah daun-yang merupakan makanan utama anuran yang hidup di serasah daun-terhadap pertumbuhan dan reproduksi anuran tidak pernah diteliti di daerah tropis (lihat Vitt \& Caldwell 1994).

Bukti tentang pengaruh negatif kegiatan penebangan dan perubahan-perubahan yang terjadi pada serasah daun disajikan oleh Iskandar (1999a, b), yang meneliti hal ini di Sumatera Utara. Iskandar dalam penelitiannya menemukan bahwa individu yang ditemukan di hutan bekas tebangan hanya 20\% dari jumlah yang ditemukan di hutan utuh pada wilayah yang sama. Kelimpahan spesies ini berkolerasi kuat dengan kelimpahan serasah lantai hutan. Berlawanan dengan temuan ini, Iskandar (2004) melaporkan bahwa di areal MRF yang ditebang pada tahun 1995-1996, kelimpahan relatif amfibia dan reptilia, yaitu sekitar 2,1 spesimen setiap plotnya $(n=21)$. Tetapi, pada hutan utuh di MRF, kelimpahan relatif amfibia hanya mencapai 0,95 spesimen per plot $(\mathrm{n}=51)$. Sampai saat ini, belum ada penjelasan pasti tentang penyebab jumlah spesimen di hutan utuh lebih kecil dibandingkan dengan daerah lain yang dipengaruhi oleh kegiatan penebangan, meskipun komposisi jenis di kedua daerah tersebut kurang lebih sama. Hal-hal yang bisa menjadi alasan kondisi ini terjadi antara lain a) perbedaan habitat yang tidak teramati; b) umur relatif hutan; dan c) kondisi plot di Malinau, baik pembalakan hutan terkendali dan penebangan konvensional, setidaknya masih memiliki tajuk hutan yang tertutup, serta sedikitnya perbedaan antara plot tebangan tersebut dengan hutan utuh. Pada penelitian di Sumatera Utara tersebut, setiap pohon besar di daerah penebangan dipanen. Musim kering yang parah yang terkait dengan El Niño menyebabkan perbedaan yang mencolok pada bukaan tanah. Kekeringan tersebut tidak pernah terjadi di Malinau.

Salah satu temuan yang lebih menonjol dari penelitian yang dilakukan Iskandar (2004) dan rekan-rekannya adalah sebagian besar spesies Limnonectes yang dikumpulkan adalah anuran muda atau hampir dewasa. Di antara 57 spesies, hanya lima spesimen yang ukurannya mendekati ukuran maksimum (empat Limnonectes leporinus (lihat Gambar 11) dan satu L. ibanorum). Iskandar menyelidiki pemanfaatan kedua spesies tersebut oleh masyarakat setempat dan mendapatkan informasi bahwa penduduk setempat hanya kadang-kadang saja mengambil kedua spesies ini. Dengan demikian dapat disimpulkan bahwa tidak ada tekanan terhadap pengambilan satwa tersebut. Kemungkinan bahwa kedua spesies ini secara tidak langsung teracuni oleh kegiatan penangkapan ikan setempat juga belum diketahui. Hutan dan sungai di wilayah tersebut sedikit mengalami kerusakan, dan penggunaan racun dalam penangkapan ikan tidak umum dilakukan di daerah tersebut.

Sama halnya dengan Iskandar, Wong (in press a), yang mempelajari pengaruh pemanenan kayu terhadap amfibia antara Maret 2000 dan Juli 2003, juga menemukan bahwa kegiatan tebang pilih berpengaruh kecil terhadap komunitas katak (Gambar 12). Data dari penelitian di hutan utuh di Sabah, daerah pembalakan hutan terkendali (Reduced Impact Logging-RIL), dan daerah penebangan konvensional (Conventionally Logged-CL) — kedua daerah ini ditebang pada tahun 1993) menunjukkan bahwa di daerah dengan kegiatan tebang pilih ditemukan lebih banyak spesies katak $(n=33)$ dibandingkan dengan plot kontrolnya di hutan utuh $(n=26)$. Namun demikian, di 


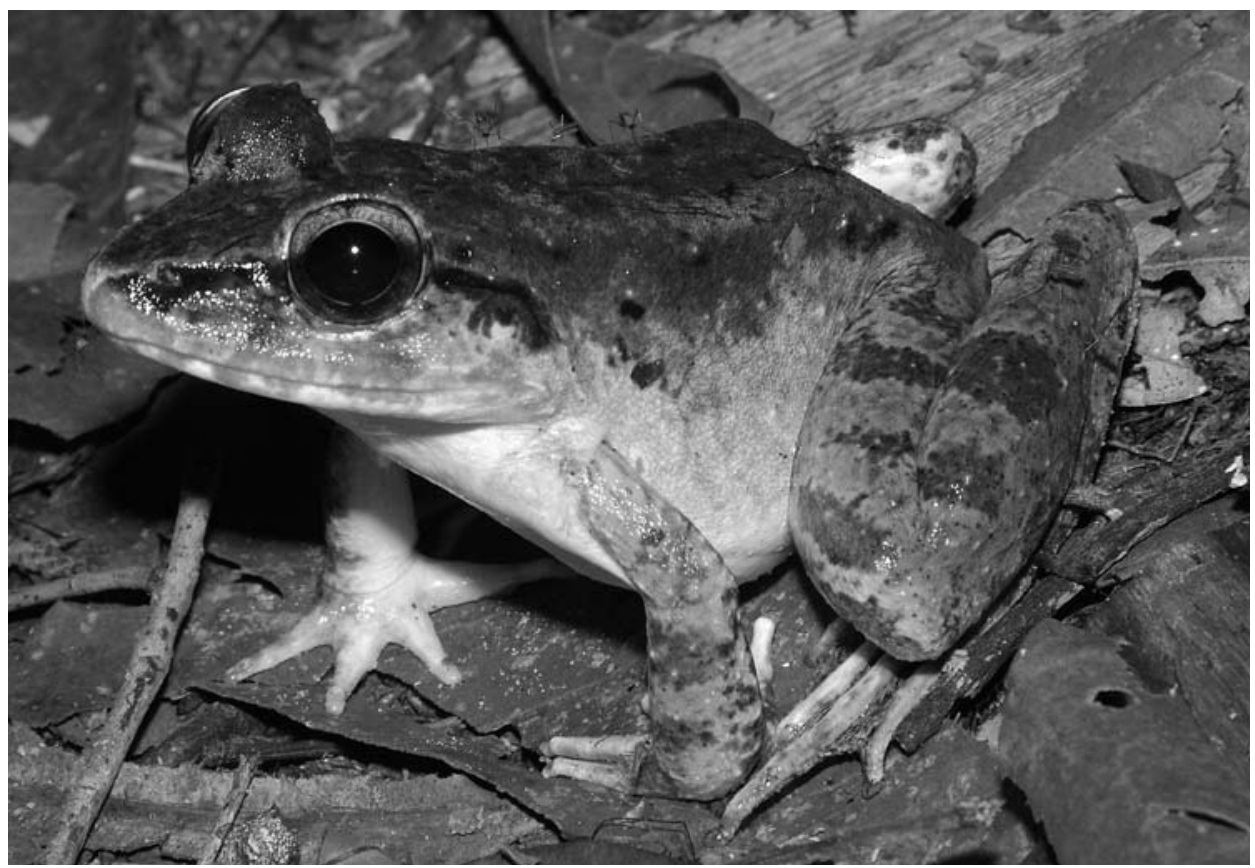

Gambar 11. Limnonectes leporinus, spesies endemik Borneo yang umumnya hidup dekat sungai berukuran besar atau sedang. (Foto oleh Kimabajo)

daerah CL spesies yang ditemukan lebih sedikit $(\mathrm{n}=23)$ (Gambar 12). Tingginya jumlah spesies katak yang ditemukan di daerah RIL dikarenakan ketersediaan habitat mikro yang lebih banyak (kegiatan penebangan menciptakan cekungan pada permukaan tanah yang cocok bagi spesies yang berkembang biak dalam kolam). Hal ini menarik spesies katak yang tidak umum ditemukan di hutan primer (misalnya Rhacophorus pardalis, Polypedates colletti, P. macrotis, Leptobrachium montanum, Rana nicobariensis, dan $R$. signata). Selain itu, sejumlah spesies yang hanya didapati di lokasi RIL adalah spesies yang berkembang biak di kolam, yaitu: Polypedates colletti, P. macrotis, Rhacophorus dulitensis, $R h$. nigropalmatus, dan Rh. pardalis. Dari komposisi spesies yang ada, terlihat bahwa RIL mengundang spesies yang toleran terhadap gangguan selain juga bisa mempertahankan sebagian spesies yang hidup di hutan primer dan hutan bekas tebangan berumur tiga puluh tahun. Penelitian Wong sementara menyimpulkan bahwa hanya sejumlah kecil saja spesies yang rentan terhadap kegiatan penebangan yang dilakukan secara hati-hati, atau setidaknya tidak dilakukan dalam waktu lebih panjang (8-10 tahun setelah penebangan). Meskipun demikian, akibat jangka panjang terhadap spesies yang berkembang biak pada kolam yang lain masih belum diketahui. Di Bolivia, Fredericksen dan Fredericksen (2004) juga menemukan bahwa kepadatan katak di hutan yang ditebang setahun sebelumnya tidak berubah dibandingkan dengan hutan primer. Sejenis kodok yang berukuran lebih besar, Bufo typhonia, meningkat kepadatannya, diperkirakan karena spesies ini merupakan pemakan utama artropoda berukuran besar seperti belalang, ulat, dan laba-laba, yang akhirnya lebih sering ditemukan di rumpang hutan (forest gaps) dibandingkan dengan areal yang tidak ditebang. Selain itu, kodok tidak terlalu 


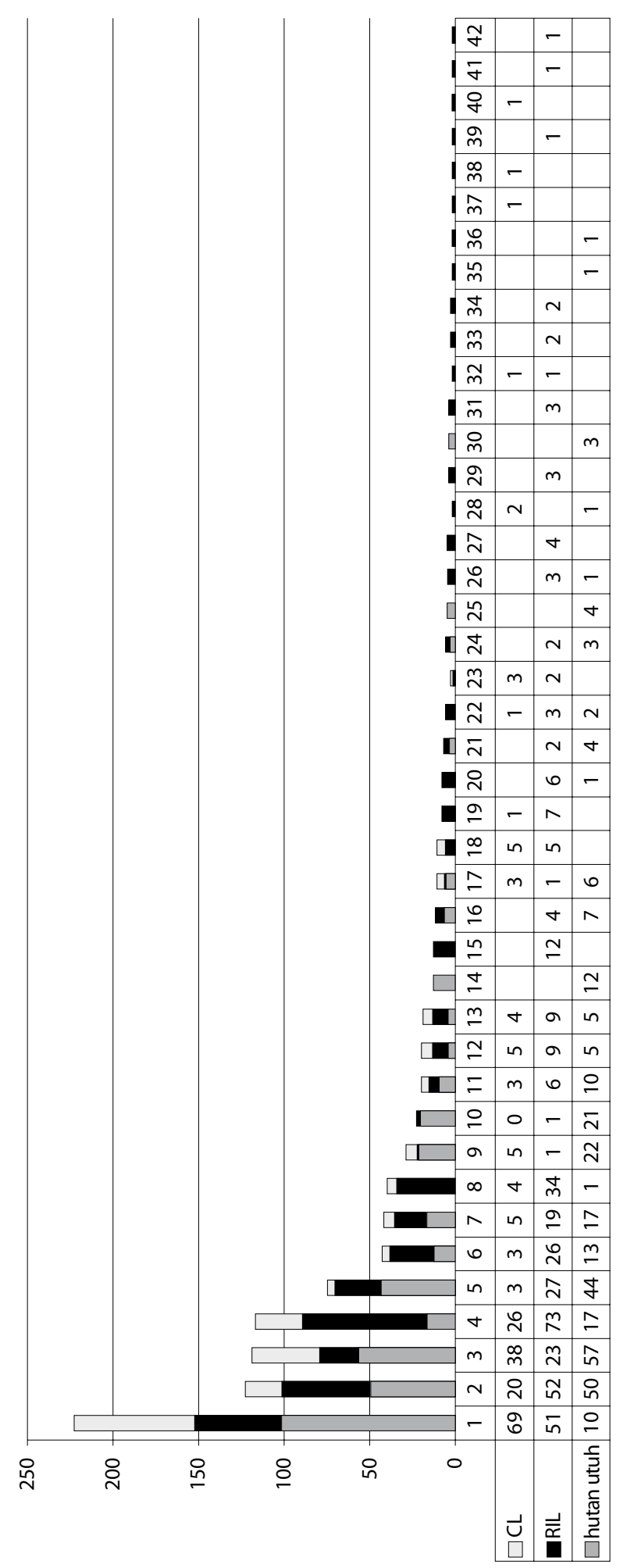

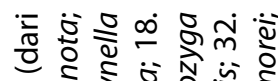

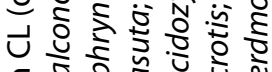

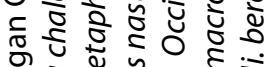

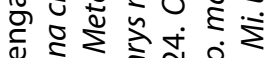
क्ष 菏

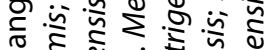

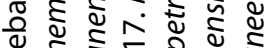

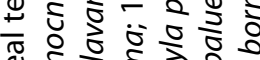

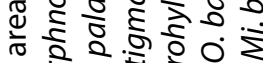

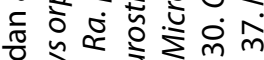
0 ڤ. 혼은

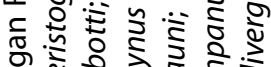

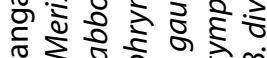
कर

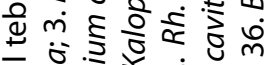

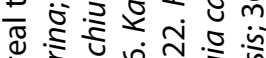

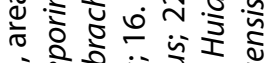

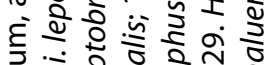

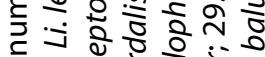
西

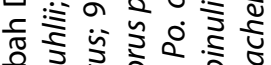

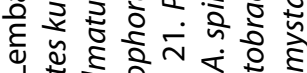
它

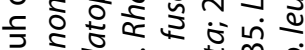
专 है

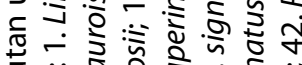
宅讪 ब สั

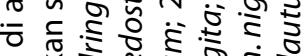

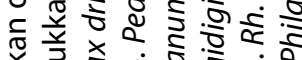

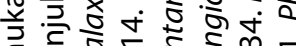
$\varepsilon$ 흥 흐의 ثัँ ช

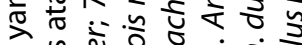

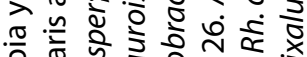
은

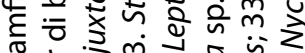
范

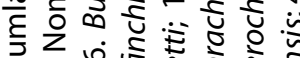

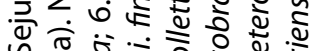
ज.

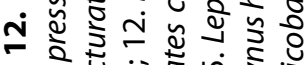

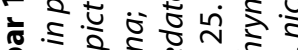
है

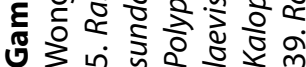


bergantung pada kelembaban seperti halnya katak sehingga memungkinkan spesies ini untuk lebih toleran terhadap suhu yang lebih tinggi di daerah yang terganggu.

Di daerah Malinau, sejumlah spesies katak dimakan atau dimanfaatkan, termasuk Katak Terbang (Rhacophorus spp.), Katak Pohon Polypedates macrotis, Katak Rawa Limnonectes ingeri, empat spesies dari suku Limnonectes (ibanorum, ingeri, leporinus dan kublii), Fejervarya cancrivora dan Hoplobatrachus rugulosus (Iskandar 2004, Puri 2001). Spesies-spesies tersebut secara kebetulan ditangkap oleh masyarakat setempat, namun tidak diperdagangkan maupun tidak bernilai tinggi. Meskipun demikian, efek penebangan terhadap kecenderungan populasi spesies ini belum banyak dipahami. Karena kecil kemungkinan terjadi pemanenan besar-besaran di daerah ini, sehingga tidak dianggap perlu untuk diperhatikan.

Akhirnya, berdasarkan informasi penduduk setempat, baru-baru ini katak eksotis (bukan asli setempat) datang ke wilayah ini. Iskandar (2004) menyatakan bahwa identifikasi spesies eksotis ini perlu dilakukan; meskipun nama lokal spesies ini terkait dengan Hoplobatrachus rugulosus, masih ada kemungkinan bahwa spesies ini adalah Rana catesbeiana (berdasarkan deskripsi lokal). Masuknya spesies eksotis dapat menimbulkan ancaman bagi spesies lokal.

Sebagai kesimpulan, luasnya ragam spesialisasi ekologi katak Borneo menyebabkan sulitnya untuk membuat generalisasi tentang pengaruh kegiatan penebangan terhadap keragaman dan kelimpahan spesies, setidaknya sejumlah spesies banyak terpengaruh sedangkan spesies lainnya lebih banyak terpengaruh. Jelas terlihat, bahwa spesies seperti Fejervarya cancrivora dan Rana nicobariensis dapat bertahan terhadap kegiatan penebangan karena spesies ini dapat hidup bersama-sama dengan manusia. Informasi mengenai spesies-spesies katak hutan yang secara nyata tidak terpengaruh oleh kegiatan tebang pilih masih belum diketahui dengan jelas.

\section{Reptilia}

Penelitian tentang reptilia di Asia Tenggara terutama di Borneo, sejauh ini berfokus pada taksonomi. Penyu dapat diidentifikasi dengan menggunakan Lim \& Das (1999) atau Moll \& Sharma (2000); Iskandar (2004) dalam bukunya juga memasukkan spesies buaya. Stuebing dan Inger (1999) mendeskripsikan ular Borneo, David dan Vogel (1996) mendeskripsikan spesies reptilia di Sumatera, dan Das (2002) menyediakan pengenalan pendahuluan yang berguna tentang amfibia dan reptilia di wilayah ini, sementara Iskandar dan Colijn $(2000,2002)$ membuat daftar pemeriksaan (checklist) reptilia Asia Tenggara. Inger dan Tan (1996) mencatat sejumlah kadal, ular, dan katak yang umum hidup di Sabah, dan buku mereka juga dapat digunakan untuk mengidentifikasi kadal Borneo.

Beberapa spesies reptilia memiliki peran penting dalam ekosistem. Sebagai contoh, penyu memakan bangkai sehingga membantu melepaskan unsur hara yang terkunci. Penyu memakan organisme yang menyebabkan penyakit pada manusia (seperti malaria, penyakit kaki gajah 'schistosomiasis'). Penyu juga memakan dan mencegah penyebaran tumbuhan air eksotik sehingga membantu memelihara kebersihan badan air, serta mengendalikan hama seperti tikus. Reptilia juga merupakan sumber pakan bagi hewan lain, termasuk manusia (Lim \& Das 1999). 
Iskandar (2004) melakukan survei di MRF untuk menyiapkan daftar pemeriksaan awal spesies-spesies amfibia dan reptilia di daerah yang dibatasi oleh Sungai Seturan dan Sungai Rian (lihat Gambar 2). Dalam survei ini, Iskandar juga menambahkan informasi habitat, persyaratan daur hidup, dan kemungkinan kerentanannya terhadap pemanenan kayu dan konversi hutan. Lebih jauh lagi, Iskandar mengidentifikasi keberadaan spesies-spesies yang digunakan, atau memiliki nilai bagi penduduk desa Langap, Loreh, dan Seturan. Informasi ini mencakup latar belakang dan cara pemanfaatannya, serta penggunaannya (lihat Lampiran 7).

Daerah Malinau merupakan daerah yang kaya spesies reptilianya, namun kepadatan populasinya rendah (Iskandar 2004). Sebagaimana dikemukakan di bagian amfibia, Iskandar (2004) menemukan bahwa daerah yang utuh, memiliki jumlah spesimen yang lebih sedikit dibandingkan dengan daerah bekas tebangan. Namun demikian, informasi tambahan mengenai pengaruh penebangan terhadap reptilia sangat sedikit jumlahnya. Komposisi spesies di daerah utuh dan bekas tebangan terlihat kurang lebih sama, meskipun Bennet dan Dahaban (1995) menemukan bahwa Baning Coklat (Geochelone emys) hidup di hutan utuh di Sarawak. Tetapi, spesies ini tidak ditemukan lagi setelah pemanenan kayu. Penurunan kepadatan spesies ini masih belum jelas penyebabnya, apakah sebagai akibat perubahan lingkungan dan perubahan ekologis yang terjadi setelah pemanenan kayu, atau karena spesies ini banyak diambil oleh pekerja penebangan kayu.

Di daerah MRF, sebagian besar penduduk setempat takut ular, meskipun yang berukuran kecil sekalipun. Selain spesies phyton yang mereka makan, penduduk setempat enggan untuk menangkap ular yang lain. Di antara spesies kadal, hanya biawak (Varanus spp.) yang dimakan oleh penduduk setempat. Menurut penduduk, ada tiga spesies yang hidup di daerah tersebut, namun hanya dua yang tercatat oleh survei ( $V$. salvator dan $V$. rudicollis). Kadal berukuran kecil yang berwarna kehitamhitaman jarang dimakan, tetapi Iskandar et al. tidak bisa mendapatkan spesimennya dan tidak bisa memastikan apakah spesies tersebut adalah $V$. heteropholis atau spesies yang belum dideskripsikan. Seluruh spesies kura-kura dimakan oleh penduduk setempat. Perisai penyu sering pula digunakan sebagai hiasan (Sheil pengamatan pribadi). Labi-labi (suku kura-kura yang berperisai lunak), yang berukuran besar, sering ditangkap dengan menggunakan pancing berumpan. Empedu labi-labi memiliki nilai yang sangat tinggi bagi masyarakat setempat karena reputasinya sebagai obat-obatan yang berkhasiat (Sheil pengamatan pribadi). Di tempat-tempat tertentu di Kalimantan (misalnya danau-danau Mahakam, bagian hulu danau-danau Kapuas), kura-kura diambil dengan cara membakar belukar atau bagian hutan dan kemudian satwa yang terlihat diambil (Meijaard pengamatan pribadi).

Schwaner (1853-1854) melaporkan bahwa saat itu buaya hidup di setiap sungai di Borneo, dari hilir hingga hulunya, serta di setiap danau dan rawa. Pada tahun 1930-an, Buaya Muara (Crocodylus porosus) masih ditemukan dalam jumlah besar dekat muara sungai, sementara Buaya Senyulong Tomistoma schlegelii, hidup di daerah Malinau dan Bulungan (Nederlandsch-Indische Vereeniging tot Natuurbescherming 1939). Saat ini buaya sangat jarang ditemukan di wilayah ini, meskipun penduduk setempat menyatakan bahwa buaya dapat ditemukan dalam jumlah besar pada beberapa dekade yang lalu (Sheil unpubl.). Sejumlah masyarakat mengungkapkan bahwa sekelompok 
pemburu pendatang bekerja dengan penduduk setempat 'memanen' buaya dalam jumlah yang besar dan dalam waktu yang singkat. Bila hal ini benar, tentunya masih ada sisa populasi di lokasi yang sulit dijangkau seperti danau dan sungai pegunungan, seperti dinyatakan oleh penduduk asli tersebut. Namun, hal ini masih belum dapat dipastikan. Penduduk asli di Setulang (Malinau hilir) menyatakan bahwa setidaknya ada satu buaya berukuran besar masih hidup di lokasi yang berdekatan dengan Setulang (I. Ramses komunikasi pribadi). Spesies ini masih belum jelas, meskipun rahang dari spesimen besar yang diamati baru-baru ini di Malinau hilir berukuran lebar (dengan tiga orang saksi mata). Hal ini mengungkapkan bahwa Crocodylus porosus atau C. siamensis hidup di daerah ini. Buaya muara (C. porosus) dipastikan hidup di areal mangrove yang berbatasan dengan Sungai Sesayap dekat Tarakan. 


\section{Ikan}

Borneo memiliki sekitar 350 spesies ikan air tawar, 135 di antaranya diperkirakan endemik di pulau ini (Kottelat et al. 1993). Molengraaff dan Weber (1920) mengungkapkan bahwa sungai di daerah timur Borneo diperkirakan memiliki tingkat endemisme ikan yang lebih tinggi dibandingkan dengan sungai-sungai di bagian selatan dan barat. Hal ini disebabkan oleh sungai-sungai di bagian barat dan selatan yang diperkirakan berhubungan dengan sungai di Jawa, Sumatera, dan Semenanjung Malaya pada saat permukaan laut turun, sementara sungai di wilayah timur Borneo terisolasi. Pola ini didukung oleh survei yang dilakukan baru-baru ini, termasuk survei di Malinau (Rachmatika et al. 2005), meskipun karakteristik ikan air tawar di wilayah ini masih banyak yang belum diketahui dan banyak spesies baru yang ditemukan.

Kottelat et al. (1993) membuat daftar ancaman utama terhadap spesies ikan air tawar tropis dan menekankan bahwa hilangnya hutan merupakan ancaman yang paling serius. Empat alasan yang dikemukakannya adalah:

1. Banyak spesies ikan yang bergantung pada materi hewan dan tumbuhan yang jatuh ke dalam air dari tumbuhan yang menggantung. Sebagian besar spesies ikan secara langsung ataupun tidak, bergantung pada materi yang masuk ke dalam air. Membuka vegetasi di tepi sungai mengurangi sumber makanan bagi ikan;

2. Suhu air naik dengan menurunnya naungan bayangan pohon. Hal ini menyebabkan turunnya tingkat oksigen dalam air. Sementara airyang menghangat meningkatkan laju metabolisme ikan sehingga meningkatkan kebutuhan oksigennya. Kurangnya oksigen dapat diperburuk dengan meningkatnya materi yang membusuk yang memasuki badan air sehingga menimbulkan kematian ikan secara massal;

3. Peningkatan kekeruhan dapat membunuh ikan secara langsung karena pasir dan lumpur dapat berakumulasi dalam insang dan menyebabkan kematian. Saat aliran air sungai melambat, lumpur mengendap dan bisa menyekap sumber 
makanan, telur, dan daerah pemijahan, selain juga mengurangi kedalaman dan lebar sungai tersebut. Hal ini dapat mempengaruhi ikan yang hidup di dasar sungai;

4. Hutan (terutama yang tergenang secara musiman) membentuk keragaman dan heterogenitas habitat yang tercermin dalam keragaman ikan dan spesies akuatik yang lain (Iwata et al. 2003).

Martin-Smith (1998c) dalam penelitiannya baru-baru ini di Sabah, menemukan bahwa spesies seperti Garra borneensis, Lobocheilos bo dan Osteochilus chinni adalah spesies yang dipengaruhi oleh kegiatan tebang pilih, meskipun kesimpulan umum yang dihasilkannya menunjukkan bahwa kegiatan tebang pilih memiliki dampak yang rendah terhadap spesies ikan, terutama karena: a) ketahanannya terhadap kegiatan penebangan yang sedang berlangsung atau b) kemampuannya untuk berkoloni kembali beberapa tahun setelah kegiatan penebangan.

Rachmatika et al. (2005) melakukan survei satwa ikan di hulu dan hilir Sungai Seturan di MRF. Dalam penelitiannya, mereka antara lain menyelidiki bagaimana ikan terpengaruh oleh kegiatan penebangan. Upaya ini dilakukan dengan membandingkan lokasi yang ditebang beberapa tahun sebelum atau selama survei dilaksanakan dan lokasi yang belum pernah ditebang kecuali kolam (tidak dianalisis), lokasi yang ditebang lebih dari lima tahun sebelum kegiatan survei serta di habitat-habitat yang spesifik. Sampel-sampel yang diperoleh sebagai berikut:

- Untuk 1999: hutan utuh (32 lokasi), ditebang sebelum atau selama survei tahun 1999 (9 lokasi), kolam (4 lokasi);

- Untuk 2000: hutan utuh (41 lokasi), ditebang sebelum atau selama survei tahun 2000 (10 lokasi), kolam yang terbentuk karena konstruksi jalan yang buruk (3 lokasi), habitat khusus (1 lokasi-daerah rembesan mineral "air asin").

Perbandingan untuk tahun 1999 (Tabel 10) menunjukkan perbedaan yang jelas dalam jumlah spesies yang memiliki potensi rentan (dalam hal kelimpahan dan jumlah dalam lokasi penelitian). Spesies-spesies yang hidup di dasar sungai (Gastromyzon spp., Garra borneensis, dll.) merupakan spesies yang paling terancam, tetapi sejumlah spesies herbivora dan pemakan buah (Lobocheilos bo dan Tor spp.) tidak ditemui di lokasi hutan bekas tebangan. Perbedaan ini kurang nyata untuk tahun 2000, namun hal ini diperkirakan karena enam lokasi penelitian sedang ditebang pada saat survei dilaksanakan sehingga terlalu dini untuk mengkaji dampaknya. Bila daerah hutan utuh di tahun 2000 dibandingkan dengan lokasi survei yang ditebang sebelum survei dilaksanakan, dapat ditemukan pola yang sama dengan tahun 1999, yaitu spesiesspesies yang berpotensi rentan lebih sedikit jumlahnya dan keberadaannya berkurang di daerah yang ditebang. Rachmatika et al. menganggap hasil penelitiannya konsisten dengan apa yang diperkirakan berdasarkan pengetahuan tentang daur hidup spesies yang ada (Martin-Smith 1998a, b).

Kolam-kolam yang terbentuk dari dam-dam dan jalan yang dibuat untuk akses kayu tebangan dicirikan oleh kondisi ikan yang sangat buruk. Dengan menggabungkan dua survei tersebut, ada enam belas spesies yang tercatat dalam lingkungan seperti 
Tabel 10. Perbandingan kelimpahan dan keberadaan ikan antara stasiun penelitian di hutan utuh dan hutan bekas tebangan di Sungai Seturan, Malinau (Rachmatika et al. 2005).

\begin{tabular}{|c|c|c|c|c|c|c|c|c|}
\hline \multirow{3}{*}{ Spesies } & \multicolumn{4}{|c|}{ Daerah hutan utuh } & \multicolumn{4}{|c|}{ Daerah hutan bekas tebangan } \\
\hline & \multicolumn{2}{|l|}{$\begin{array}{l}\text { Jumlah } \\
\text { individu }\end{array}$} & \multicolumn{2}{|l|}{ Keberadaan } & \multicolumn{2}{|l|}{$\begin{array}{l}\text { Jumlah } \\
\text { individu }\end{array}$} & \multicolumn{2}{|c|}{ Keberadaan } \\
\hline & $\mathrm{N}$ & $\%$ & Stasiun & $\%$ & $\mathrm{~N}$ & $\%$ & Stasiun & $\%$ \\
\hline Nematabramis everetti & 127 & 9,6 & 23 & 71,9 & 65 & 35,5 & 9 & 100,0 \\
\hline Osteochilus waandersii & 146 & 11,0 & 22 & 68,8 & 8 & 4,4 & 6 & 66,7 \\
\hline Rasbora elegans & 92 & 6,9 & 17 & 53,1 & 4 & 2,2 & 2 & 22,2 \\
\hline $\begin{array}{l}\text { Hampala } \\
\text { macrolepidota }\end{array}$ & 43 & 3,2 & 16 & 50,0 & 1 & 0,5 & 1 & 11,1 \\
\hline $\begin{array}{l}\text { Hemibagrus cf. } \\
\text { nemurus }\end{array}$ & 26 & 2,0 & 16 & 50,0 & 11 & 6,0 & 7 & 77,8 \\
\hline $\begin{array}{l}\text { Mastacembelus } \\
\text { unicolor }\end{array}$ & 41 & 3,1 & 15 & 46,9 & 0 & 0,0 & 0 & 0,0 \\
\hline Garra borneensis & 247 & 18,6 & 14 & 43,8 & 0 & 0,0 & 0 & 0,0 \\
\hline $\begin{array}{l}\text { Gastromyzon spp. } \\
\text { (nov?) }\end{array}$ & 131 & 9,9 & 14 & 43,8 & 0 & 0,0 & 0 & 0,0 \\
\hline G. cf. lepidogaster & 113 & 8,5 & 14 & 43,8 & 4 & 2,2 & 2 & 22,2 \\
\hline $\begin{array}{l}\text { Nemacheilus } \\
\text { selangoricus }\end{array}$ & 31 & 2,3 & 11 & 34,4 & 2 & 1,1 & 1 & 11,1 \\
\hline Anguilla malgumora & 19 & 1,4 & 11 & 34,4 & 5 & 2,7 & 4 & 44,4 \\
\hline $\begin{array}{l}\text { Rasbora } \\
\text { caudimaculata }\end{array}$ & 21 & 1,6 & 10 & 31,3 & 23 & 12,6 & 7 & 77,8 \\
\hline Puntius spp. (nov?) & 18 & 1,4 & 10 & 31,3 & 2 & 1,1 & 2 & 22,2 \\
\hline $\begin{array}{l}\text { Cyclocheilichthys } \\
\text { armatus }\end{array}$ & 22 & 1,7 & 9 & 28,1 & 2 & 1,1 & 1 & 11,1 \\
\hline C. repasson & 34 & 2,6 & 8 & 25,0 & 1 & 0,5 & 1 & 11,1 \\
\hline Puntius binotatus & 21 & 1,6 & 8 & 25,0 & 12 & 6,6 & 7 & 77,8 \\
\hline Rasbora lateristriata & 17 & 1,3 & 8 & 25,0 & 9 & 4,9 & 4 & 44,4 \\
\hline $\begin{array}{l}\text { Homaloptera } \\
\text { stephensoni }\end{array}$ & 13 & 1,0 & 8 & 25,0 & 0 & 0,0 & 0 & 0,0 \\
\hline Barbodes cf.balleroides & 38 & 2,9 & 7 & 21,9 & 0 & 0,0 & 0 & 0,0 \\
\hline Tor tambra & 17 & 1,3 & 7 & 21,9 & 0 & 0,0 & 0 & 0,0 \\
\hline $\begin{array}{l}\text { Glyptothorax } \\
\text { platypogonoides }\end{array}$ & 10 & 0,8 & 7 & 21,9 & 1 & 0,5 & 1 & 11,1 \\
\hline Parachela ingerkongi & 13 & 1,0 & 6 & 18,8 & 1 & 0,5 & 1 & 11,1 \\
\hline Lobocheilos cf. bo & 12 & 0,9 & 6 & 18,8 & 0 & 0,0 & 0 & 0,0 \\
\hline $\begin{array}{l}\text { Leptobarbus } \\
\text { melanotaenia }\end{array}$ & 9 & 0,7 & 6 & 18,8 & 3 & 1,6 & 1 & 11,1 \\
\hline Ompok cf. bimaculatus & 7 & 0,5 & 6 & 18,8 & 1 & 0,5 & 1 & 11,1 \\
\hline Leiocassis spp. & 7 & 0,5 & 6 & 18,8 & 0 & 0,0 & 0 & 0,0 \\
\hline $\begin{array}{l}\text { Nemacheilus } \\
\text { saravacensis }\end{array}$ & 7 & 0,5 & 5 & 15,6 & 0 & 0,0 & 0 & 0,0 \\
\hline Rasbora argyrotaenia & 6 & 0,5 & 5 & 15,6 & 0 & 0,0 & 0 & 0,0 \\
\hline $\begin{array}{l}\text { Neogastromyzon } \\
\text { nieuwenhuisi }\end{array}$ & 9 & 0,7 & 4 & 12,5 & 0 & 0,0 & 0 & 0,0 \\
\hline $\begin{array}{l}\text { Hemibagrus } \\
\text { baramensis }\end{array}$ & 7 & 0,5 & 4 & 12,5 & 0 & 0,0 & 0 & 0,0 \\
\hline Puntius sealei & 4 & 0,3 & 3 & 9,4 & 8 & 4,4 & 4 & 44,4 \\
\hline
\end{tabular}


Tabel 11. Satwa ikan yang hidup dalam kolam yang terbentuk karena konstruksi jalan yang buruk di Malinau (Rachmatika et al. 2005).

\begin{tabular}{lrrrrrrr}
\hline \multicolumn{1}{c}{ Spesies } & \multicolumn{2}{c}{$\begin{array}{c}\text { Jumlah individu } \\
\text { dalam kolam }\end{array}$} & \multicolumn{2}{c}{$\begin{array}{c}\text { Jumlah individu } \\
\text { dalam sampel }\end{array}$} & \multicolumn{2}{c}{$\%$} \\
\cline { 2 - 9 } & $\mathbf{1 9 9 9}$ & $\mathbf{2 0 0 0}$ & $\mathbf{1 9 9 9}$ & $\mathbf{2 0 0 0}$ & $\mathbf{1 9 9 9}$ & $\mathbf{2 0 0 0}$ \\
\hline Cyclocheilichthys armatus* & 19 & 2 & 43 & 16 & 44,2 & 12,5 \\
\hline Betta unimaculata & 14 & 5 & 30 & 12 & 46,7 & 41,7 \\
\hline Nematabramis everetti & 11 & 1 & 203 & 185 & 5,4 & 0,5 \\
\hline Puntius binotatus & 7 & 6 & 49 & 28 & 14,3 & 21,4 \\
\hline Rasbora elegans & 7 & 4 & 103 & 48 & 6,8 & 8,3 \\
\hline Rasbora caudimaculata & 7 & & 51 & 71 & 13,7 & 0,0 \\
\hline Puntius sealei & 5 & 10 & 17 & 32 & 29,4 & 31,3 \\
\hline Puntius spp. & 5 & & 25 & 17 & 20,0 & 0,0 \\
\hline Nemacheilus saravacensis & 4 & 2 & 11 & 8 & 36,4 & 25,0 \\
\hline Nemacheilus selangoricus & 4 & & 37 & 2 & 10,8 & 0,0 \\
\hline Hemibagrus cf. nemurus & 2 & 1 & 39 & 18 & 5,1 & 5,6 \\
\hline Leptobarbus melanotaenia & 2 & & & & & \\
\hline Nemacheilus spiniferus & 2 & & & & & & \\
\hline Anguilla malgumora & 1 & & & & & & \\
\hline Hampala macrolepidota & 1 & & 31 & 38 & 0,0 & 28,9 \\
\hline Cyclocheilichthys repasson & & 11 & & & & & \\
\hline
\end{tabular}

* Kemungkinan terdapat kerancuan taksonomis antara Cyclocheilichthys armatus dan C. repasson yang dapat menjelaskan variasi yang saling mengisi antar kedua spesies tersebut.

ini (Tabel 11). Seluruh spesies demersal (hidup di/dekat dasar sungai/laut) tidak ditemukan kecuali satu spesimen, yaitu Anguilla malgumora pada jalan keluar kolam. Beberapa spesies ikan yang umum terlihat hidup di kolam adalah:

- Survei pada tahun 1999: Cyclocheilichthys armatus (44\% dari individu ditemukan di kolam), Nemacheilus saravacensis (36\%), Puntius sealei (29\%).

- Survei pada tahun 2000: Cyclocheilichthys armatus (13\% dari individu ditemukan di kolam), C. repasson (29\%), Nemacheilus saravacensis (25\%), Puntius sealei (31\%).

Betta unimaculata tampak memilih hidup di jalan keluar kolam dan tidak atau jarang ditemukan di kolam. Spesies ini merupakan satu-satunya spesies yang dikoleksi dari lokasi rembesan 'air asin' di stasiun penelitian.

Sejumlah spesies ikan yang disurvei memiliki sifat otoekologis atau biologis yang spesifik yang mungkin penting dalam kaitannya dengan kegiatan penebangan atau pertambangan yang ada di wilayah tersebut. Karena spesies demersal memakan organisme bentik, spesies ini bisa dipengaruhi oleh siltasi yang ditimbulkan oleh pembangunan infrastruktur penebangan kayu (penyeberangan sungai dengan perangkat berat, dsb.). Yang termasuk ikan demersal antara lain, Belut (Anguilla spp.), spesies belut lain seperti Mastacembelus spp., Macrognathus spp., lele Bagrid atau Sisorid, dan ikan yang hidup di sungai perbukitan (Gastromyzon spp., Neogastromyzon spp., etc.). 
Di antara spesies demersal, beberapa memiliki perangkat khusus yang memungkinkan untuk menempelkan diri pada subtrat seperti batu, batu besar, kayu tumbang, dan sebagainya, dalam air berarus deras. Spesies ikan ini memiliki bagian permukaan perut yang rata dan mulut yang bergayut yang digunakan untuk merumput (grazing) alga. Biasanya spesies yang tergolong ke dalam kelompok yang disebut "ikan jeram" atau "ikan berperut penghisap" ini tergabung ke dalam tiga suku yaitu:

- Balitoridae (marga Gastromyzon, Homaloptera, Neogastromyzon, Parhomaloptera, Protomyzon). Spesies ini merupakan ikan jeram asli. Sebagaimana terlihat dari namanya, ikan-ikan ini berasal dari sungai dan riam yang berarus deras. Ada banyak spesies yang tersebar hampir di seluruh Asia Tenggara. Spesies ini beradaptasi terhadap air deras dan berpusar dengan mengembangkan mekanisme pengisap pada perut dan siripnya, serta mulut yang bergayut untuk memakan hamparan alga.

- Cyprinidae (marga Garra). Spesies dari marga ini termasuk G. borneensis, salah satu dari spesies yang paling berlimpah dalam survei di Malinau, yang sering disebut 'minnows' penjilat batu karena bibir atas spesies ini berubah menjadi piringan penghisap.

- Sisoridae (suku Sisorid). Satu-satunya spesies yang ditemukan dalam survei kami, yaitu Glyptothorax platypogonoides, memiliki perangkat perekat yang khusus yang terbuat dari kulit halus yang terlipat di bagian depan sirip perut yang rata yang memungkinkannya untuk menempel ke atas permukaan batu.

Karena sifat biologisnya yang khas, spesies ini rentan terhadap peningkatan siltasi (melalui rusaknya hamparan alga dan ketidakmampuannya untuk menempel pada batu).

Spesies lain yang berpotensi terancam adalah ikan yang bersifat bentik pelagis (ikan dasar yang suka berenang/berpindah tempat) yang memakan alga mikro, diatoma (antara lain Lobocheilos bo, beberapa Osteochilus spp., Tor spp.) dan memakan buah-buahan serta tumbuhan hutan (yaitu Leptobarbus melanotaenia, Tor spp.) (Sulastri et al. 1985, Tan 1979). Ikan-ikan tersebut dapat dipengaruhi oleh penurunan ketersediaan makanan yang terjadi setelah kegiatan penebangan.

Pangasius spp. adalah spesies yang bermigrasi yang banyak dicari dan memiliki nilai pasar yang tinggi. Sayangnya, perilaku memijahnya membuat spesies ini mudah tertangkap jaring. Spesies ini hampir hilang dari daerah tengah dan hulu Malinau (Rachmatika et al. 2005). Tor spp. diperkirakan rentan terhadap penangkapan yang berlebih-lebihan dan spesies ini sangat banyak dicari di Malinau (Rachmatika et al. 2005). 



\section{ANALISIS}

\section{Analisis statistik untuk kepekaan spesies}

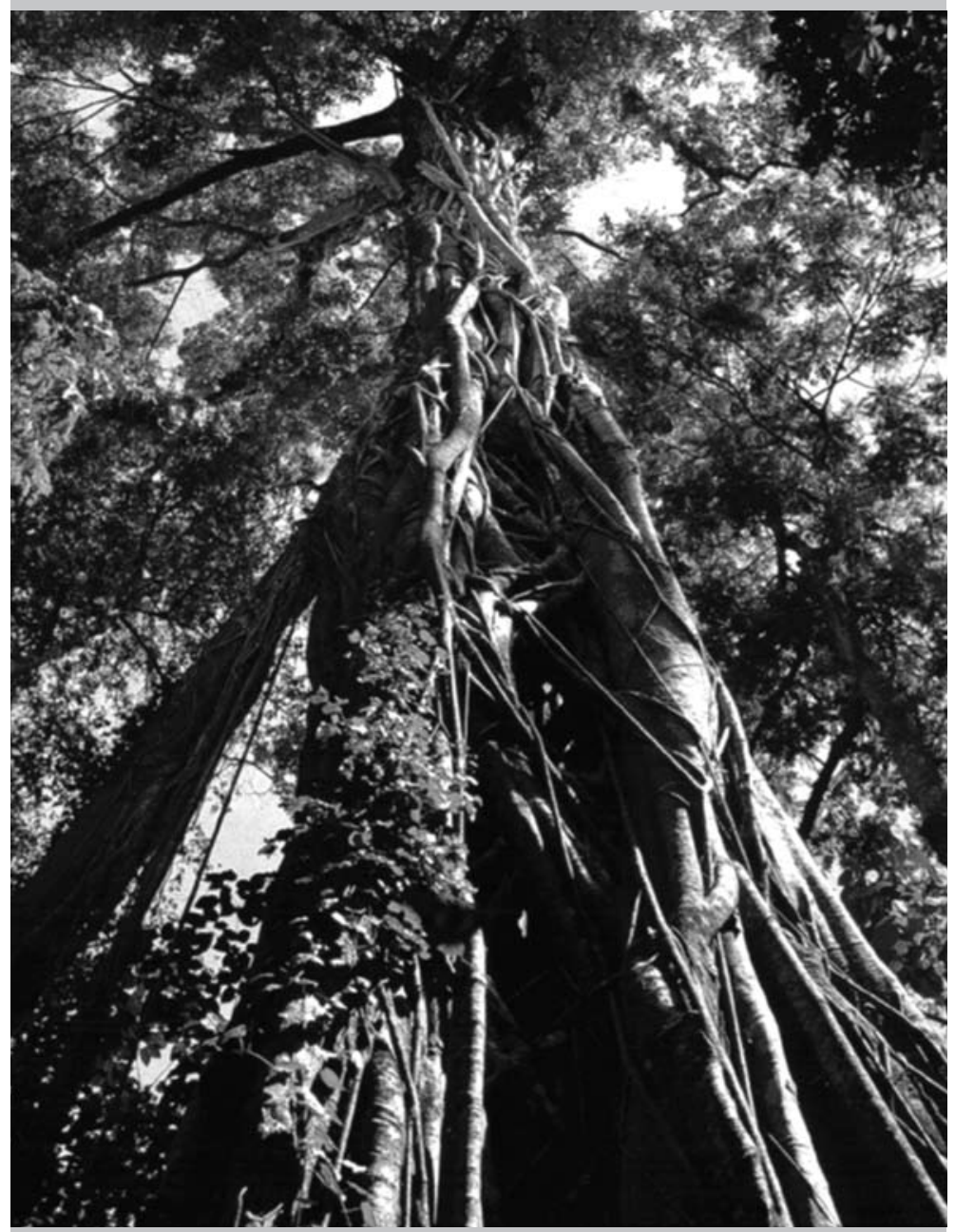

Ara adalah salah satu spesies tanaman yang bermanfaat bagi hidupan liar (Foto oleh Margaret F. Kinnaird). 



\section{Analisis kepekaan spesies}

\section{Pendekatan dan metode}

Kami menggunakan statistik multivariat untuk menganalisis karakteristik spesies kaitannya dengan kepekaannya terhadap kegiatan penebangan dan fragmentasi hutan. Dalam analisis ini, kami memilih 23 spesies burung (6 rangkong, 13 pelatuk, 4 sempidan) dan 27 spesies mamalia (7 primata, 9 bajing, 6 ungulata, dan suku garangan dan musang, serta 1 suku beruang). Pemilihan didasarkan pada respons spesies tersebut terhadap penebangan yang telah diteliti dan diterbitkan dalam jurnal atau buku-buku ilmiah (lihat Lampiran 4 dan 5). Data yang digunakan sebagai variabel penduga (peubah penduga) adalah: taksonomi, distribusi, habitat, siklus hidup, siklus musiman, perilaku jelajah, pertumbuhan dan perkembangan, perilaku perkembangbiakan (reproduksi), dan interaksi ekologis. Kami menggunakan analisis diskriminan, analisis koresponden, dan analisis komponen utama (principal component analyses) untuk menyelidiki korelasi antara kepekaan spesies terhadap kegiatan penebangan dan fragmentasi, serta peubah penduganya. Dasar analisis komponen utama mengasumsikan hubungan linier antar peubah numerik. Karena sebagian besar peubah penduga lebih bersifat kategorik, kami menggunakan prosedur analisis komponen utama kategorik (categorical principal components analysis—CATPCA) (Data Theory Scaling System Group 1999) untuk mengkuantifikasi peubah yang sifatnya kategorik dan bersamaan dengan itu mengurangi sifat dimensionalitas data.

Peubah bebas yang kami gunakan dapat dikategorikan sebagai berikut:

- Jumlah subspesies per spesies (numerik): dari Corbet dan Hill (1992), kecuali bila tersedia kajian taksonomis yang terbaru;

- Usia filogenetik genus (numerik) - Perbedaan umur dalam jutaan tahun dari genus kerabatnya (Meijaard 2003c) — hanya tersedia bagi mamalia;

- Jumlah pulau-pulau kecil tempat hidup spesies di Paparan Sunda (numerik) (Meijaard 2003b); 
- Wilayah jelajah (numerik): rata-rata wilayah jelajah betina yang dilaporkan dalam pustaka;

- Berat badan (numerik): berat badan betina dewasa yang dilaporkan dalam berbagai sumber pustaka;

- Jumlah anak setiap kali melahirkan/per sarang (numerik);

- Umur saat reproduksi pertama (numerik): umur betina pada saat pertama kali bereproduksi (bulan);

- Distribusi (kategorik): (1) endemik di Borneo, (2) endemik di Sub-Wilayah Sunda (3) hidup dalam Sub-Wilayah Sunda dan Indocina;

- Migrasi (kategoris): (1) spesies yang bermigrasi secara teratur diantara bagianbagian hutan, (2) spesies yang tidak bermigrasi secara teratur;

- Ukuran kelompok (kategorik): (1) terdiri dari 1-2 satwa per kelompok, (2) 2 - 5 satwa per kelompok, (3) 5-10 satwa per kelompok, (4) umumnya lebih dari 10 satwa per kelompok;

- Kepadatan (kategorik): Kepadatan rata-rata spesies pada vegetasi utuh, yaitu: (1) $<1$ individu $/ \mathrm{km}^{2} ;(2)>1$ dan $<2$ individu $/ \mathrm{km}^{2}$; (3) $>2$ dan $<5$ individu $/ \mathrm{km}^{2}$; dan (4) $>5$ individu $/ \mathrm{km}^{2}$;

- Kategori makanan (kategorik): 1) >70\% pemakan buah, (2) buah dan daun (bahan hewani $<10 \%$ ), (3) pemakan segala - omnivora (tidak ada kategori $>40 \%$ ), (4) buah dan bahan hewani (bagian tumbuhan yang lain $<10 \%$ ), (5) $>70 \%$ insektivora atau karnivora, (6) >70\% herbivora

- Strata makanan (kategorik): (1) terestrial, (2) tumbuhan bawah di dasar hutan, (3) tingkat bawah hingga menengah, (4) dasar hingga tajuk

Peubah tidak bebas yang digunakan adalah kepekaan terhadap kegiatan penebangan, yang diberi kode sebagai berikut:

- Tidak dapat bertoleransi (intoleran): Spesies yang sangat dirugikan oleh kegiatan tebang pilih, yaitu yang kepadatannya menurun $>20 \%$ dalam tahun pertama setelah kegiatan penebangan dan tidak pulih hingga 5 tahun setelah kegiatan penebangan;

- Netral: Tidak mengalami pengaruh apapun terhadap kegiatan tebang pilih, yaitu tidak ada perubahan yang nyata dalam hal kepadatan yang diukur setelah kegiatan penebangan;

- Toleran: Mengalami pengaruh positif dari kegiatan penebangan, yaitu peningkatan kepadatan $>20 \%$ dalam tahun pertama setelah kegiatan penebangan berlangsung.

Kasus per-spesies kami tidak independen karena adanya hubungan filogenetis. Pada penelitian lainnya (Meijaard et al. in prep.), kami menguji hubungan ini dengan teknik regresi filogenetik dan menemukan bahwa pendekatan yang disederhanakan memberikan hasil yang serupa. Hal ini mengungkapkan bahwa kasus interdependensi di sini bukan merupakan masalah besar dan hasil serupa terjadi di antara kelompok taksonomis yang tidak berhubungan. 


\section{Hasil}

Seperti yang tertera pada Tabel 2-9, dampak kegiatan penebangan terhadap kepadatan populasi spesies yang kami uji seringkali tidak jelas terlihat. Sejumlah peneliti mengungkapkan terjadinya peningkatan kepadatan setelah kegiatan penebangan, dan sejumlah lainnya menunjukkan penurunan. Untuk masing-masing spesies, kami berupaya untuk menggeneralisasikan dampak penebangan, dengan mengamati kecenderungan kepadatan kaitannya dengan umur penebangan dan ada/tidaknya kegiatan perburuan. Hal ini sedikit banyak bergantung pada penilaian pribadi dan kurang memiliki kriteria yang obyektif.

Karena tidak ada data yang dipublikasikan mengenai efek fragmentasi hutan terhadap mamalia di Paparan Sunda, kami menggunakan jumlah pulau di Asia Tenggara tempat hidup masing-masing spesies tersebut (Meijaard 2003b) sebagai ukuran toleransi spesies terhadap fragmentasi hutan dalam jangka panjang. Kami menduga bahwa korelasi antara keberadaan suatu spesies yang berasal dari Paparan Sunda di suatu pulau dengan kepekaannya terhadap fragmentasi hutan belum teruji. Selain itu, kami perkirakan juga bahwa faktor lain dapat mempengaruhi ada atau tidaknya suatu spesies dalam suatu pulau. Kendati demikian, fakta bahwa spesies tertentu dapat bertahan hidup di pulau berukuran kecil mengindikasikan bahwa ukuran wilayah tidak berdampak besar terhadap kemampuan untuk bertahan hidup, meskipun secara jelas ada batas minimal dalam luasannya. Untuk burung, kami juga menggunakan data keberadaan (ada/tidaknya) spesies burung di suatu pulau untuk mengakses kepekaannya terhadap fragmentasi hutan. Namun demikian, analisis awal kami menunjukkan bahwa daftar penyebaran burung di pulau-pulau tidak lengkap dan sering salah (Lammertink pengamatan pribadi), sehingga burung tidak dimasukkan dalam analisis.

Statistik nonparametrik hanya digunakan pada mamalia untuk menguji apakah taxa dengan perbedaan tingkat kepekaan terhadap kegiatan penebangan dapat dibedakan berdasarkan delapan variabel numerik yang berbeda (Tabel 12). Hanya jumlah subspesies per spesies yang berbeda secara nyata dalam tiga kelompok tersebut. 
Karena pada dasarnya kami tertarik pada spesies yang tidak toleran terhadap kegiatan penebangan, kami menyatukan kelompok yang netral dan toleran, dan menguji ulang perbedaan dalam kelompok tersebut untuk kedelapan peubah numerik yang tertera pada Tabel 12. Hasil uji Mann-Whitney menunjukkan bahwa umur spesies dan jumlah subspesies dalam setiap spesies berbeda nyata bagi kedua kelompok tersebut $(p<0.05)$. Hal ini juga diindikasikan pada Gambar 13, yang mengungkapkan bahwa spesies yang toleran terhadap kegiatan penebangan secara umum terpencar dari nenek moyang terdekatnya belakangan ini saja, dibandingkan dengan spesies yang tidak toleran.

Tabel 12. Perbandingan nilai tengah 8 variabel penduga kaitannya dengan kepekaan sejumlah spesies mamalia terhadap kegiatan penebangan.

\begin{tabular}{lcccc}
\hline & Intoleran & Netral & Toleran & Kruskal-Wallis \\
\hline $\begin{array}{lcccc}\text { Umur spesies } \\
\text { (Juta tahun lalu) }\end{array}$ & $\mathrm{SD}=1,7 ; \mathrm{n}=7$ & $\mathrm{SD}=0,6 ; \mathrm{n}=5$ & $\mathrm{SD}=2,2 ; \mathrm{n}=11$ & $\mathrm{~ns}$ \\
\hline Nomor pulau & 7,1 & 15,1 & 16,3 & $\mathrm{~ns}$ \\
& $\mathrm{SD}=8,0 ; \mathrm{n}=15$ & $\mathrm{SD}=16,1 ; \mathrm{n}=12$ & $\mathrm{SD}=15,3 ; \mathrm{n}=13$ & \\
\hline Spesies per & 5,7 & 7,2 & 12,6 & $\mathrm{~ns}$ \\
genus & $\mathrm{SD}=4,4 ; \mathrm{n}=15$ & $\mathrm{SD}=4,5 ; \mathrm{n}=13$ & $\mathrm{SD}=13.8 ; \mathrm{n}=13$ & \\
\hline $\begin{array}{l}\text { Subspesies per } \\
\text { spesies }\end{array}$ & $\mathrm{SD}=3,4 ; \mathrm{n}=15$ & $\mathrm{SD}=11,2 ; \mathrm{n}=12$ & $\mathrm{SD}=13,0 ; \mathrm{n}=13$ & $\mathrm{Chi}^{2}=6,29, \mathrm{df}=2$ \\
\hline $\begin{array}{l}\text { Ukuran } \\
\text { kelompok }\end{array}$ & $\mathrm{SD}=11,4 ; \mathrm{n}=9$ & $\mathrm{SD}=3,2 ; \mathrm{n}=9$ & $\mathrm{SD}=12,3 ; \mathrm{n}=5$ & $\mathrm{~ns}$ \\
\hline Jumlah anak per & 1,6 & 1,9 & 2,1 & $\mathrm{~ns}$ \\
kelahiran & $\mathrm{SD}=0,7 ; \mathrm{n}=13$ & $\mathrm{SD}=1,5 ; \mathrm{n}=8$ & $\mathrm{SD}=1,0 ; \mathrm{n}=11$ & \\
\hline Berat badan & 6,4 & 19,8 & 194,2 & $\mathrm{~ns}$ \\
& $\mathrm{SD}=12,7 ; \mathrm{n}=15$ & $\mathrm{SD}=43,4 ; \mathrm{n}=13$ & $\mathrm{SD}=554,8 ; \mathrm{n}=13$ & \\
\hline $\begin{array}{l}\text { Wilayah jelajah } \\
\text { (ha) }\end{array}$ & 104 & 35 & 651 & $\mathrm{~ns}$ \\
\hline
\end{tabular}

NS = Perbedaan tidak nyata

Analisis diskriminan variabel numerik (jumlah spesies per genus, jumlah subspesies per spesies, jumlah pulau tempat hidup spesies) menunjukkan bahwa ketiga variabel tersebut dapat digunakan untuk menduga kepekaan mamalia terhadap kegiatan penebangan dengan akurasi sebesar 79\%. Untuk analisis ini, kami melakukan transformasi logaritmik terhadap variabel penduga untuk memastikan distribusi yang normal. Untuk hitungan pulau, ditambah dengan nilai satu untuk memastikan bahwa spesies yang tidak dapat hidup di pulau kecil $(n=0)$ dapat memberikan kontribusi titik data yang valid yang sudah ditransformasikan menjadi bentuk $\log _{10}=0$.

Grafik yang dihasilkan (Gambar 14) menunjukkan bahwa tiga kategori terpisah dengan baik. Spesies yang menurun kepadatannya setelah penebangan terutama adalah spesies yang hidup di sejumlah kecil pulau (nilai fungsi 1 yang rendah). Spesies ini juga dibedakan dengan sedikitnya jumlah subspesies per spesies. Namun demikian, karena banyak taxa pulau yang ditetapkan untuk pembeda subspesies, kedua peubah tersebut tidak independen. Spesies yang relatif dapat bertoleransi terhadap kegiatan penebangan adalah spesies yang hidup di pulau-pulau kecil. Hal ini mungkin 


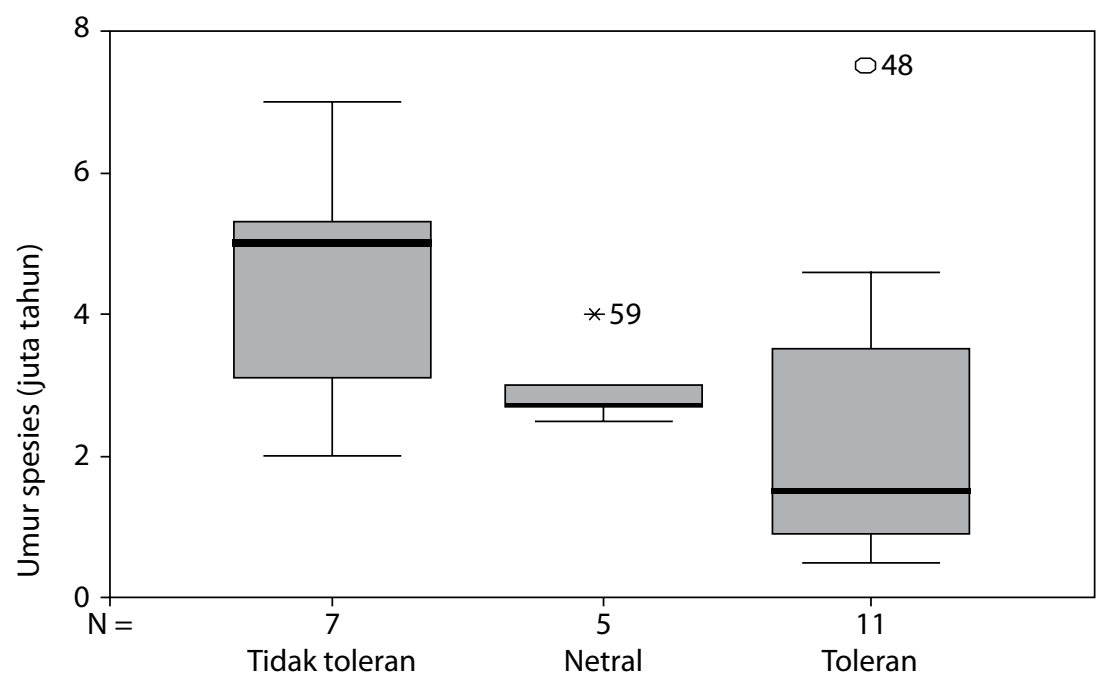

Gambar 13. Plot"box-and-whisker"untuk toleransi spesies terhadap penebangan kaitannya dengan umur spesies. Kotak mewakili rentang interkuartil yang memiliki 50\% nilai. Garis yang membentang dari kotak ke nilai tertinggi dan terendah, kecuali pencilan (outliers). Garis yang melintang di dalam kotak menunjukkan nilai median.

mencerminkan fleksibilitas ekologis dan kemampuannya bertahan hidup pada bagian hutan yang relatif kecil dengan tingkat gangguan yang tinggi dan efek tepi yang nyata. Titik pencilan (outliers) (lihat anak panah pada gambar 12) menunjukkan bahwa Monyet Beruk (Macaca nemestrina), spesies yang dapat ditemui di 10 pulau dan memiliki 15 subspesies, terlihat dipengaruhi secara negatif oleh kegiatan penebangan. Hubungan antara kepekaan terhadap kegiatan penebangan dengan distribusi spesies pada pulau kecil juga terlihat jelas saat hasil analisis ditampilkan dalam plot kotak (box plot) (Gambar 15).

Hasil di atas sangat menarik namun tidak terlalu informatif, karena tidak jelas apakah data kepekaan sebagaimana dilaporkan dari berbagai sumber yang dikutip dalam buku ini mencerminkan pengaruh fragmentasi hutan secara langsung atau tidak langsung. Lebih jauh, indeks taksonomis jarang bersifat obyektif karena sejumlah kelompok taksonomis telah dipelajari lebih rinci sehingga menyebabkan ditetapkannya banyak subspesies. Sementara itu spesies yang lain masih sedikit dikaji dan keragaman geografis masih belum diketahui dan dinamai. Namun demikian, pola yang diamati bermanfaat untuk menduga kepekaan spesies terhadap efek kegiatan penebangan kayu dan fragmentasi hutan yang belum banyak dipelajari. Oleh karena itu, hipotesis berkenaan dengan ini dapat dibangun dan diuji di lapangan.

Eksplorasi lebih lanjut yang dilakukan terhadap variabel penduga kaitannya dengan kepekaan terhadap kegiatan penebangan dan fragmentasi hutan menunjukkan bahwa kepekaan terhadap kegiatan penebangan ini terlihat menurun sejalan dengan jumlah anak per sarang/kelahiran (burung dan mamalia) (Gambar 16). Kami menguji tingkat signifikansi hubungan ini dengan membandingkan titik tengah menggunakan analisis keragaman satu arah (one way analisis of variance-ANOVA), tetapi hasilnya tidak berbeda nyata. Spesies yang peka terhadap kegiatan penebangan 


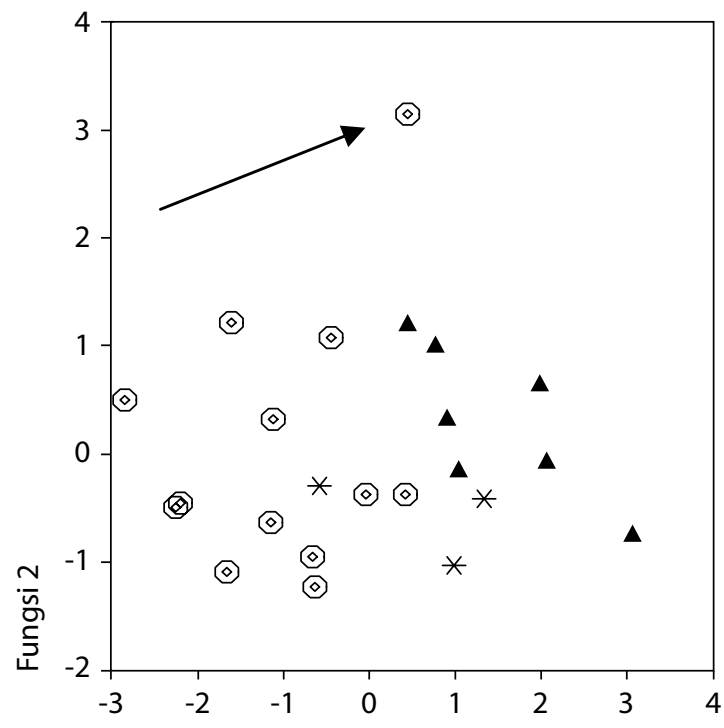

\begin{tabular}{|c|c|c|}
\hline & \multicolumn{2}{|c|}{ Fungsi } \\
\hline & 1 & 2 \\
\hline Jumlah pulau & 0,72 & $-0,67$ \\
\hline $\begin{array}{l}\text { Subspesies per } \\
\text { spesies }\end{array}$ & 0,62 & $-0,69$ \\
\hline Spesies per genus & 0,59 & 0,69 \\
\hline Eigen value & 0,995 & 0,174 \\
\hline $\begin{array}{l}\text { Persentasi } \\
\text { keragaman (varian) }\end{array}$ & 85,1 & 14,9 \\
\hline
\end{tabular}

Fungsi 1

Gambar 14. Analisis diskriminans tiga variabel (jumlah pulau di wilayah Sunda berukuran kecil tempat spesies hidup (Meijaard 2003b), jumlah spesies per genus, dan jumlah subspesies per spesies), serta nilai prediksinya bagi kepekaan spesies mamalia terhadap kegiatan penebangan. Anak panah menunjukkan pencilan Macaca nemestrina (Monyet Beruk)

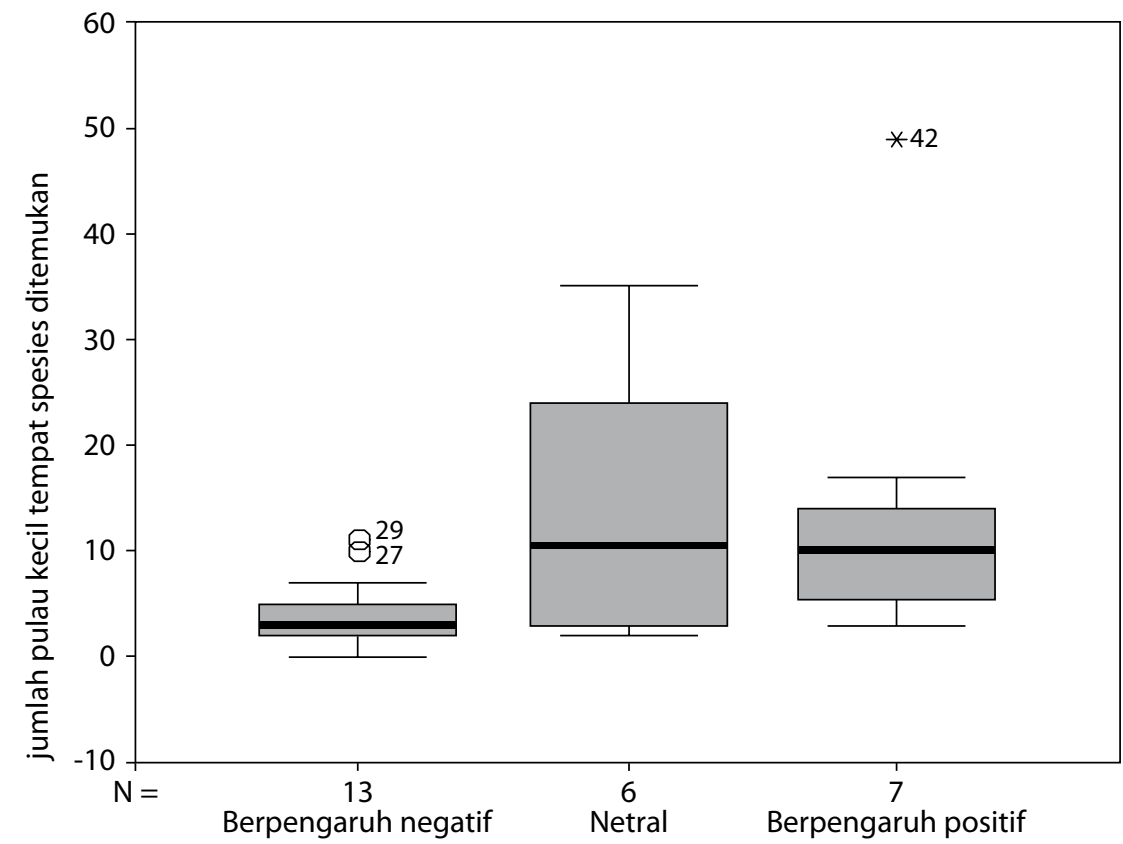

Gambar 15. Plot "kotak dan garis" kategori yang menunjukkan toleransi terhadap kegiatan penebangan kaitannya dengan distribusi spesies di pulau-pulau kecil (hanya mamalia). Kotak mencerminkan rentang interkuartil yang mencakup 50\% dari nilai. Garis memanjang dari kotak ke nilai tertinggi dan terendah, dengan mengecualikan pencilan. Garis yang melintang dalam kotak menunjukkan nilai median. 


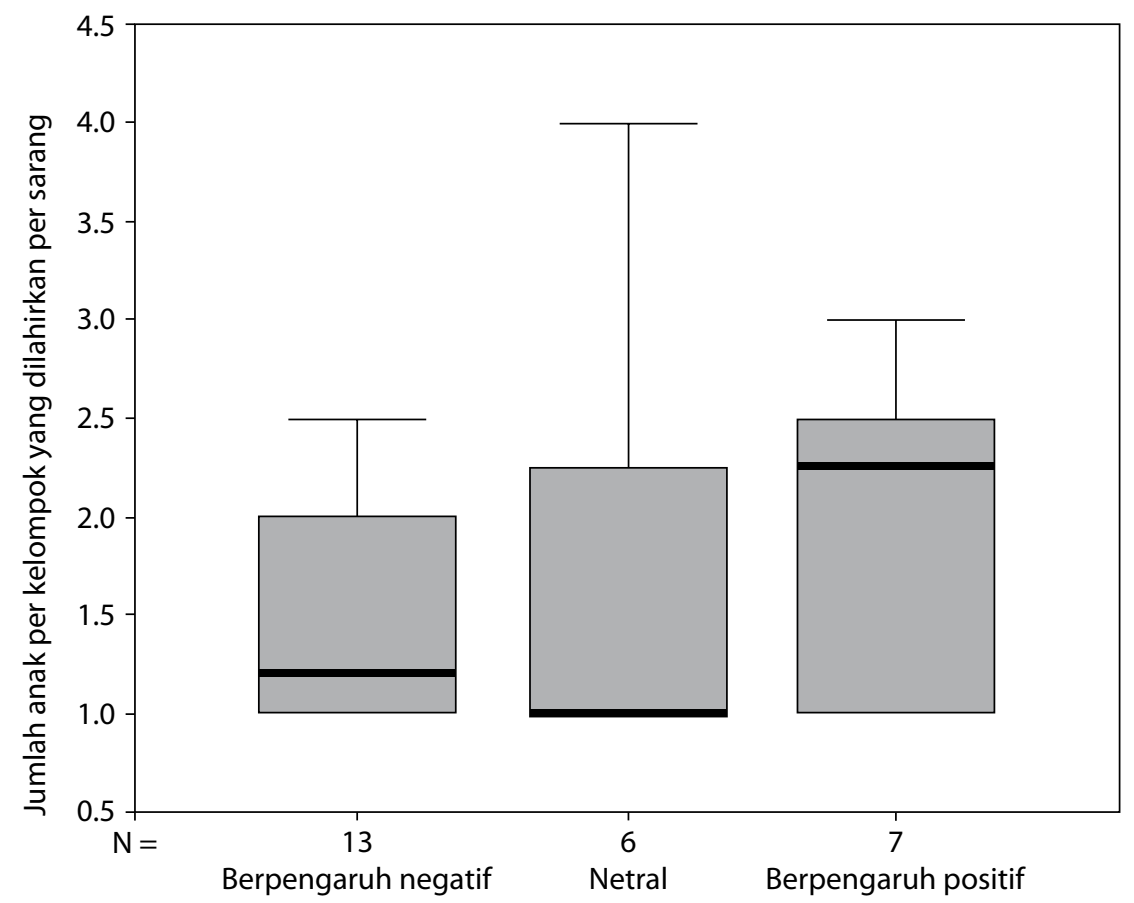

Gambar 16. Plot "kotak dan garis" kategori untuk toleransi terhadap kegiatan penebangan kaitannya dengan jumlah anak per sarang atau kelahiran (burung dan mamalia). Kotak mencerminkan rentang interkuartil yang mencakup 50\% dari nilai. Garis memanjang dari kotak ke nilai tertinggi dan terendah, dengan mengecualikan pencilan. Garis yang melintang dalam kotak menunjukkan nilai median.

memiliki rata-rata $1,57(\mathrm{n}=17)$ anak per kelahiran. Spesies yang netral terhadap penebangan $1,77(\mathrm{n}=11)$, dan spesies yang diuntungkan dari penebangan kayu $1,94(\mathrm{n}=8)$ anak per kelahiran. Meskipun perbedaan ini tidak nyata, hasil tersebut menarik dan diperlukan penelitian lanjutan untuk menyelidiki kekuatan prediksi kesuburan untuk menduga kepekaan terhadap kegiatan penebangan. Untuk sebagian besar spesies, kami kekurangan data reproduksi antara lain: jumlah anak yang lahir per tahun, umur pertama kali bereproduksi, pertambahan jumlah, dan lama hidup. Data tersebut bisa menjadi variabel penduga yang berkorelasi dengan kepekaan terhadap penebangan.

Untuk menjelaskan hubungan antara variabel penduga yang sifatnya kategorik dan variabel tak bebas kami menggunakan analisis koresponden. Hasil analisis menunjukkan bahwa untuk mamalia dan burung, tidak ada hubungan yang nyata antara variabel penduga dan tingkat kepekaan terhadap kegiatan penebangan. Namun demikian, ada kecenderungan yang layak untuk diungkapkan. Spesies yang peka terhadap kegiatan penebangan seringkali endemik di Borneo atau Dataran Sunda, yaitu 5 dari 6 spesies endemik Borneo (= 83\%) dan 19 dari 32 spesies endemik Dataran Sunda sensitif terhadap kegiatan penebangan (Gambar 17). Dari 14 spesies daratan, 7 (50\%) diperkirakan peka terhadap penebangan (5 bereaksi netral dan 2 bereaksi positif). Serupa dengan hal itu, 9 spesies yang hidup di tajuk bagian tengah 
dan atas, 7 (78\%) dipengaruhi secara negatif oleh kegiatan penebangan (1 bereaksi netral dan 1 bereaksi positif terhadap kegiatan penebangan). Di sisi lain, dari 9 spesies yang meningkat kepadatannya setelah penebangan, 56\% hidup di strata vegetasi bagian bawah (Gambar 18). Dari sini dapat terungkap bahwa kegiatan penebangan terutama mempengaruhi spesies yang hidup di dasar hutan atau di strata tajuk. Hasil analisis koresponden juga menunjukkan bahwa dari 26 spesies yang dipengaruhi secara negatif oleh kegiatan penebangan, 18 (69\%) merupakan pemakan buah atau pemakan serangga/pemakan daging (insektivora/karnivora) (Gambar 19).

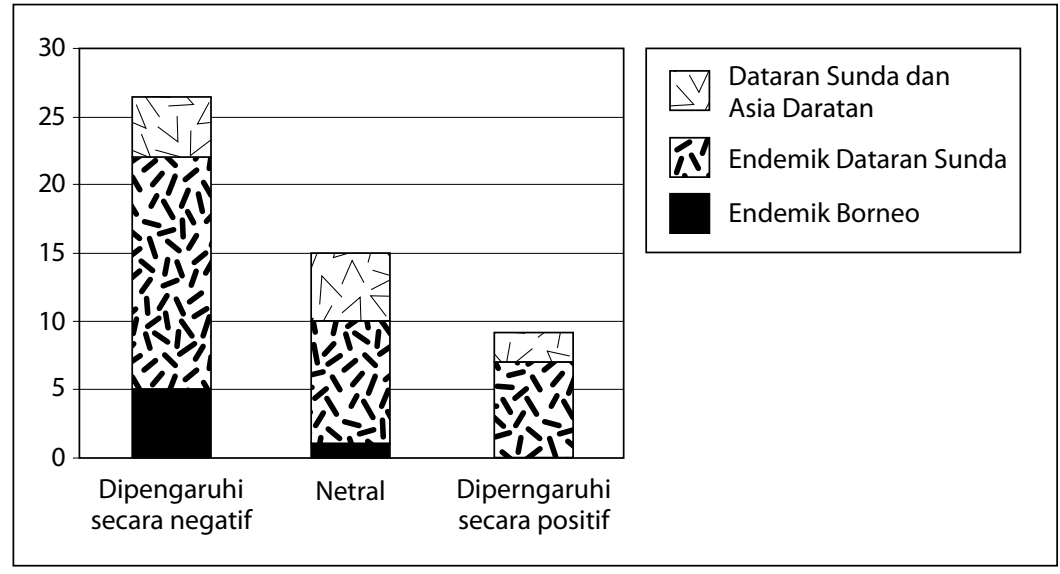

Gambar 17. Grafik kepekaan terhadap kegiatan penebangan kaitannya dengan daerah penyebaran (endemik Borneo vs. endemik Dataran Sunda vs. spesies yang hidup di dataran Sunda dan daratan Asia Tenggara).

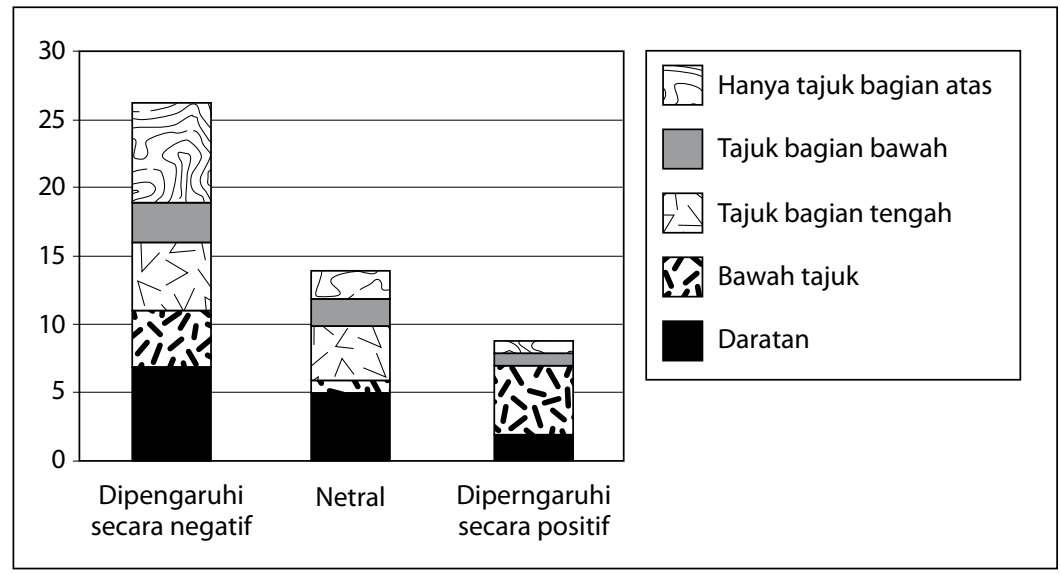

Gambar 18. Grafik kepekaan terhadap kegiatan penebangan kaitannya dengan strata pencarian makan. 


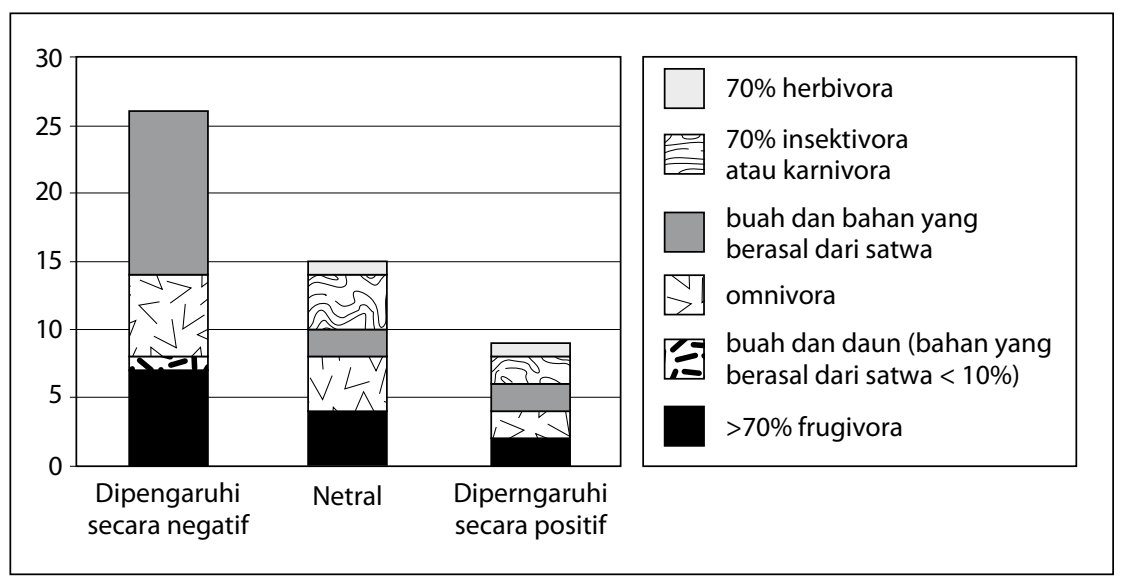

Gambar 19. Grafik kepekaan terhadap kegiatan penebangan kaitannya dengan kategori makanan.

Ada hasil yang menarik dari analisis koresponden untuk mamalia, yaitu bahwa semua spesies insektivora dan karnivora sensitif terhadap penebangan (Bajing Tanah Moncong Runcing, Rhinosciurus laticaudatus; Musang Belang, Hemigalus derbyanus; Musang Akar, Arctogalidia trivirgata; Tenggalung Malaya, Viverra tangalunga; Krabuku Ingkat, Tarsius bancanus). Selain itu, enam dari 10 spesies daratan sensitif terhadap kegiatan penebangan.

Analisis hubungan antara variabel penduga dan kepekaan (burung) terhadap fragmentasi hutan tidak menghasilkan temuan yang bermanfaat karena seluruh spesies yang diuji sensitif terhadap fragmentasi, kecuali dua spesies yaitu Sempidan Biru (Lophura ignita) dan Pelatuk Sayap Merah (Picus puniceus). Dengan demikian dapat disimpulkan bahwa ukuran sampel spesies yang bertoleransi terhadap fragmentasi terlalu kecil jumlahnya. Salah satu variabel penduga, yaitu kategori pencarian makanan, berkoresponden secara nyata dengan kepekaan terhadap fragmentasi hutan, tetapi ini diperkirakan sebagai artefak data. Lambert dan Collar (2002) menganggap seluruh pelatuk sensitif terhadap fragmentasi hutan dan pemakan artropoda, sehingga menyebabkan korelasi kuat antara kedua variabel ini. Namun demikian, kami tidak menganggap hal ini sebagai bukti yang memadai untuk melihat hubungan fungsional yang nyata antara strategi pencarian makanan insektivora dan kepekaan terhadap fragmentasi hutan secara umum.

Karena analisis koresponden menunjukkan pola yang menarik meskipun secara statistik tidak nyata hubungannya, kami menggunakan analisis komponen utama kategorik (CATPCA) untuk menganalisis hubungan antara seluruh variabel kategorik. Kami menggunakan metoda normalisasi objek utama yang dapat mengoptimalkan jarak antara spesies. Gambar 20a-e secara grafis menggambarkan hubungan bivariat (antara 2 variabel) yang kami temukan dalam analisis koresponden. Terjadi pengelompokan pada spesies mamalia yang sensitif terhadap penebangan, terutama ditentukan oleh strata dan kategori pencarian makan (lihat Gambar 20b). Pemeriksaan terhadap dua variabel (dalam Gambar 20d dan 20e) menunjukkan bahwa mamalia 
yang sensitif terhadap kegiatan penebangan sebagian besar adalah spesies pemakan vertebrata dan invertebrata saja (No.5 dalam Gambar 20d) dan spesies pemakan buah saja (no. 6 dalam Gambar 20d). Di lain pihak, jenis herbivora (No. 6 dalam Gambar 20d) dan omnivora (No. 3 dalam Gambar 20d) terlihat lebih bertoleransi terhadap penebangan kayu. Selain itu, spesies yang sensitif terhadap penebangan secara tidak seimbang terwakili oleh jenis daratan (No. 1 dalam Gambar 20e), meskipun tidak eksklusif. Gambar 20e lebih jauh menunjukkan bahwa spesies yang hidup di strata yang lebih rendah (tumbuhan bawah; No. 2 dalam Gambar 20e) relatif toleran terhadap penebangan.

Prosedur serupa yang dilakukan terhadap burung tidak memberikan informasi tambahan. Seperti telah disampaikan sebelumnya, hal ini disebabkan oleh dominasi pelatuk di dalam kelompok yang memiliki strategi dan strata pencarian makan yang serupa, setidaknya dalam tingkat analisis kami.

Hasil analisis statistik menunjukkan bahwa sekalipun ketersediaan informasi relatif sangat terbatas dalam penelitian ini, kami bisa mengidentifikasi pola karakteristik spesies yang sensitif atau toleran terhadap penebangan. Pertama, spesies yang toleran terhadap penebangan umumnya hidup dan ditemukan pada pulau kecil. Namun demikian, hubungannya tidak selalu bersifat dua arah dan sejumlah spesies yang hidup di banyak pulau seperti pelanduk (Tragulus spp.), bisa menjadi sensitif terhadap penebangan. Kemungkinan besar, spesies tersebut hidup di darat seperti pada pelanduk, atau memiliki pola makan yang khusus yang hanya memakan buah saja, daging saja, atau serangga saja. Makin luas relung ekologi suatu spesies, terlihat makin tinggi toleransinya terhadap penebangan. Temuan awal ini bermanfaat untuk mengembangkan hipotesa mengenai spesies lain yang tidak diketahui dengan baik, seperti Kucing Merah (Catopuma badia), dan Kucing Batu (Pardofelis marmorata). 
a
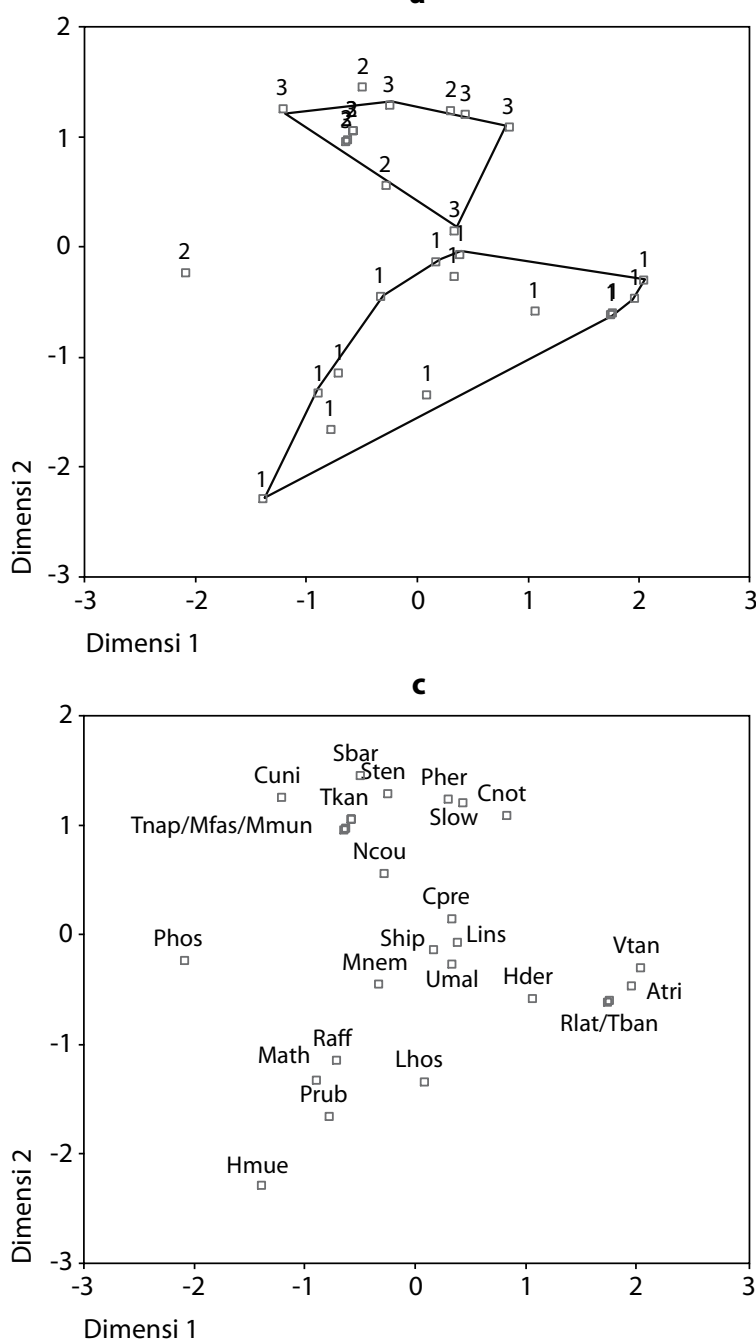

$1=$ sensitif terhadap penebangan $2=$ netral

3 = diuntungkan oleh adanya penebangan

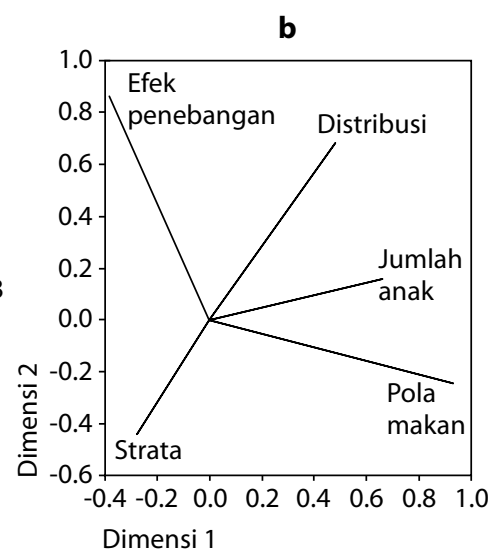

Gambar 20a-c. CATPCA dari 21 spesies mamalia dengan 5 variabel, yaitu: kepekaan terhadap penebangan, strategi pencarian makan, strata pencarian makanan, luas penyebaran, dan jumlah anak. Gambar 20a menunjukkan titik objek dengan label kepekaan terhadap penebangan; Gambar 20b menunjukkan beban komponen untuk masing-masing variabel; Gambar 20c menunjukkan singkatan nama spesies: Atri=Arctogalidia trivirgata; Cnot=Callosciurus notatus; $C p r e=C$. prevostii; Cuni=Cervus unicolor; Hder=Hemigalus derbyanus; Hmue=Hylobates muelleri; Lhos=Lariscus hosei; Lins=L. insignis; Math=Muntiacus atherodes; Mmun=Mu. muntjac; Mfas=Macaca fascicularis; Mnem=Ma. nemestrina; Ncou=Nycticebus coucang; Pher=Paradoxurus hermaphroditus; Phos=Presbytis hosei; Prub $=P$. rubicunda; Raff $=$ Ratufa affinis; Rlat $=$ Rhinosciurus laticaudatus; Sbar $=$ Sus barbatus; Ship=Sundasciurus hippurus; Slow=Sun. lowii; Sten=Sun. tenuis; Tban=Tarsius bancanus; Tkan=Tragulus kanchil; Tnap=Tr. napu; Umal=Ursus malayanus; dan Vtan=Viverra tangalunga. 


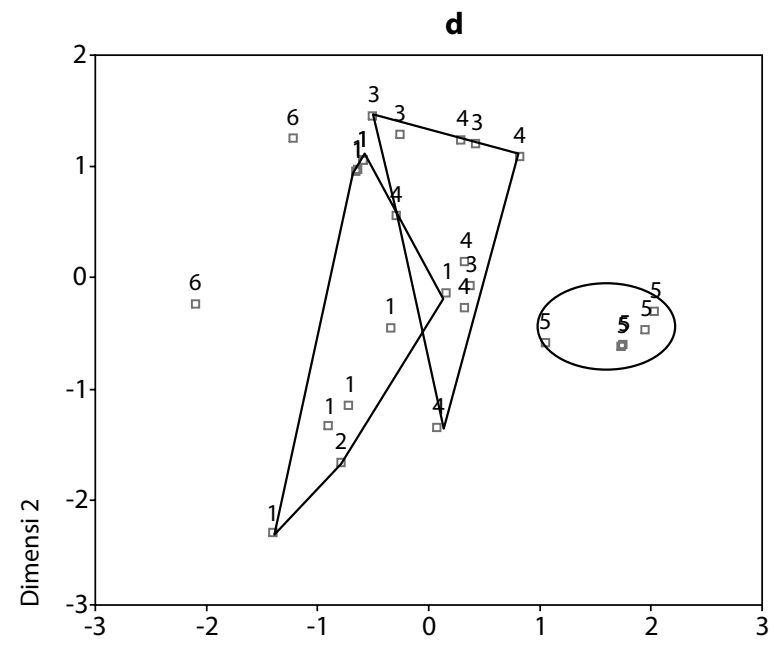

$$
\begin{aligned}
& 1=\text { frugivora } \\
& 2=\text { frugi/herbivora } \\
& 3=\text { omnivora } \\
& 4=\text { frugi/carni/insectivora } \\
& 5=\text { carni/insectivora } \\
& 6=\text { herbivora }
\end{aligned}
$$

Dimensi 1

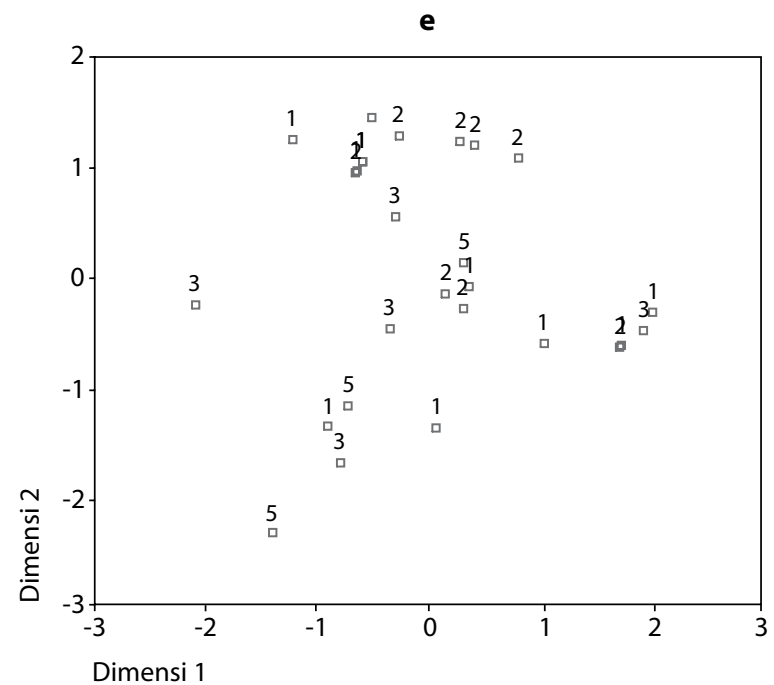

$$
\begin{aligned}
& 1=\text { daratan } \\
& 2=\text { dasar }- \text { bawah tajuk } \\
& 3=\text { bagian bawah }- \text { strata tengah } \\
& 5=\text { bagian tengah }- \text { strata atas }
\end{aligned}
$$

Gambar 20d, e. CATPCA dari 21 spesies mamalia. Gambar 20d menunjukkan titik objek dengan label strategi pencarian makan; Gambar 20e menunjukkan titik objek dengan label strata pencarian makanan. 


\section{Diskusi}

Isi buku ini bertujuan untuk mengidentifikasi dan menjelaskan kemungkinan serta kesempatan untuk memperbaiki praktek kegiatan kehutanan dan peran konsesi kayu bagi perlindungan hidupan liar. Kami tidak menyatakan bahwa hutan bekas tebangan sama dengan hutan primer dari sudut pandang nilai konservasinya, atau bahwa kawasan konservasi yang ketat tidak diperlukan. Kami berasumsi bahwa:

1) Hutan bekas tebangan adalah, dan mungkin akan terus menjadi, pemanfaatan lahan yang penting di Borneo, dan di Dataran Sunda secara umum;

2) Hutan ini (sekunder) memiliki nilai konservasi yang tinggi bila dibandingkan dengan pemanfaatan lahan lainnya seperti perkebunan kelapa sawit atau akasia.

3) Nilai ini dapat ditingkatkan dengan mengubah praktek-praktek kehutanan yang ada; dan

4) Secara ekonomis, perbaikan praktek ini dapat dilaksanakan.

Asumsi yang terakhir ini barangkali merupakan asumsi yang paling problematik, karena upaya yang telah dilakukan untuk memperbaiki pengelolaan memiliki tingkat keberhasilan yang kecil. Namun demikian, ada tiga perkembangan yang bisa memberikan harapan. Pertama adalah skema sertifikasi yang meningkat intensitas kegiatannya dalam kurun waktu beberapa tahun belakangan ini dan pengelola konsesi makin berminat untuk mengembangkan dan menerapkan standar pengelolaan. Kedua, sejumlah organisasi nonpemerintah (Non-Governmental Organization, $N G O$ ) yang bergerak di bidang konservasi sudah memahami pentingnya bekerja sama dengan para pemilik konsesi kayu untuk mencapai tujuan konservasi. Yang ketiga, sejumlah pihak berwenang setempat telah menyadari pentingnya perencanaan sumber daya alam jangka panjang, dan mulai mencari cara bagaimana kehutanan dan konservasi dapat dipadukan dalam proses perencanaan ini. Tujuan kami adalah memberikan informasi yang bermanfaat yang dapat mendukung perkembangan tersebut. 
Diskusi selanjutnya merupakan evaluasi terhadap sejumlah aspek temuan kami dikaitkan dengan kajian-kajian dalam pustaka yang lebih luas. Hal ini karena aspek yang lain telah diulas secara ekstensif dalam kajian pustaka kami di atas.

\section{Pertimbangan metodologi}

Hipotesis nol yang digunakan untuk mengukur penelitian dampak penebangan kayu terhadap kepadatan spesies dilakukan dengan asumsi bahwa tidak ada perubahan. Kajian kami tidak menguji hipotesis nol ini secara formal atau mengukur tingkat kepercayaan untuk mengkaji besarnya penyimpangan—pertanyaan ini memerlukan analisis ulang yang dilakukan secara hati-hati terhadap seluruh kegiatan penelitian. Namun, kami menghitung persentase perubahan yang ada setelah penebangan, tanpa mengkaji kemampuan statistik dari analisis yang dilakukan, atau ketidakpastian setiap penelitian yang berkaitan dengan perubahan ini (lihat Tabel 2-9). Pengaruh penebangan terhadap kepadatan populasi spesies yang kami pilih tidak selalu jelas dan konsisten. Beberapa hasil penelitian menunjukkan terjadinya peningkatan setelah penebangan, sementara yang lain menunjukkan penurunan. Bagi masingmasing spesies kami mencoba membuat generalisasi dengan mengkaji kecenderungan kepadatan dari serangkaian penelitian yang berkaitan dengan umur penebangan kayu, ada dan tidaknya kegiatan perburuan, selain juga mengkaji rancangan penelitian. Namun demikian, interpretasi kami tetap saja bergantung pada kuantitas dan kualitas informasi yang ada tersebut.

Kami memahami potensi masalah dalam mengembangkan rekomendasi berdasarkan data yang sering tidak konklusif (Mangel et al.1996). Namun demikian, karena secara umum kumpulan data tentang kepadatan spesies yang tersedia kurang baik, kami memutuskan untuk berfokus pada mekanisme perubahan (pendugaan parameter) untuk menjelaskan bagaimana suatu respons terkait dengan sebab yang diduga dan bukan pada perubahan itu sendiri. Dalam melakukan hal ini, kami juga memahami bahwa ekosistem Borneo biasanya menunjukkan perubahan besar secara acak yang mengaburkan pengaruh ekologis pemanenan kayu. Kesimpulan yang kami buat, berdasarkan pengkajian beragam hipotesis yang perbedaan skenarionya kami beri bobot berdasarkan validitasnya.

Sebagai contoh, Owa Kalawat (Hylobates muelleri) ditetapkan menurun kepadatannya setelah penebangan dalam enam dari sebelas penelitian yang dilakukan (lihat Tabel 6), sementara dua penelitian (dengan waktu penelitian yang sangat singkat) menyatakan adanya peningkatan. Data lanjutan yang didapat mengungkapkan bahwa faktor penting adalah ketergantungan yang besar terhadap buah-buahan, kesulitan melakukan pergerakan dalam tajuk yang sudah rusak, keengganan untuk melakukan pergerakan di areal yang terbuka, dan kepekaan terhadap perburuan. Dengan demikian kami memutuskan bahwa penurunan kepadatan setelah kegiatan penebangan merupakan respons yang logis dan menolak sejumlah hipotesis yang lain. Sebagai contoh, kami mempertimbangkan bahwa kecil kemungkinan terjadi peningkatan kepadatan spesies setelah kegiatan penebangan, meskipun tersedia lebih banyak buah-buahan pada vegetasi perintis tingkat bawah. Ini disebabkan oleh keberadaan spesies owa ini di luar strata pencarian makan. 
Dalam rekomendasi yang diajukan, kami menekankan perubahan pengelolaan yang mengarah pada keterpaduan prinsip ekologi secara umum dan interpretasi data penebangan. Contohnya, disarankan untuk mempertahankan pohon-pohon buah dan konektivitas tajuk, serta mengurangi efek fragmentasi hutan dan perburuan. $\mathrm{Hal}$ ini bukanlah aturan yang kaku, namun lebih merupakan pendekatan pragmatis dengan adanya keterbatasan informasi dan pengetahuan, namun informasi dan pengetahuan yang kami miliki cukup dapat diandalkan untuk menyarankan perubahan-perubahan yang bermanfaat. Jika ketersediaan data tentang owa memadai dan bisa meningkatkan pemahaman kita, gambaran dan pengetahuan baru tersebut harus dipadukan ke dalam rekomendasi pengelolaan. Pendekatan yang kami ambil ini dapat dibenarkan mengingat sifat ketidakpastian hutan dan ekologi hidupan liar, serta amat mendesaknya kebutuhan pengelolaan konservasi yang lebih baik.

\section{Pengaruh langsung pengambilan kayu}

Sebagaimana telah kami sampaikan, respons vertebrata terhadap pengambilan kayu, fragmentasi habitat, dan perburuan sangat beragam. Respons ini secara simultan mempengaruhi perubahan dan terjadi berbagai macam interaksi, sehingga hampir tidak mungkin untuk bisa mendapatkan pemahaman tentang bagaimana masingmasing individu berkontribusi dalam proses perubahan populasi yang ada. Di sini kami berupaya dan mempertimbangkan implikasi dari masing-masing faktor dengan mengacu pada analisis yang kami lakukan.

Lambert dan Collar (2002) menemukan bahwa bagi sebagian besar spesies burung, pengaruh pemanenan kayu melalui sistem tebang pilih hampir tidak dapat terdeteksi. Biasanya hanya sedikit saja spesies spesialis tertentu yang menurun secara nyata. Dalam kompilasi 34 penelitian mengenai burung dari Afrika, Asia, dan Amerika, disimpulkan bahwa kegiatan tebang pilih di hutan yang tua, tidak menurunkan keragaman spesies secara nyata (Dunn 2004), meskipun ada perubahan di dalam komposisi spesies dan kelimpahan relatifnya. Crome et al. (1996) menemukan bahwa, kalaupun ada, hanya sedikit saja spesies burung dan mamalia berukuran kecil yang dipengaruhi secara negatif oleh kegiatan tebang pilih di daerah tropik Australia. Pengamatan terhadap komunitas mamalia berukuran kecil secara umum menunjukkan peningkatan kelimpahan dan keragaman spesies setelah kegiatan penebangan di Bolivia (Fredericksen \& Fredericksen 2002), Cina (Wu et al. 1996), dan Venezuela (Ochoa 2000).

Generalisasi hasil temuan secara luas didukung oleh ringkasan tentang spesies mamalia yang kami lakukan (lihat dalam bagian analisis multivariat). Dalam temuan kami, 15 dari 41 spesies menurun secara nyata setelah penebangan, 13 menunjukkan sedikit perubahan nyata, dan 13 apesies meningkat kepadatannya. Rangkuman kami mengenai respons apesies burung terlihat tidak terlalu konsisten terhadap pola secara keseluruhan, tetapi terjadi bias akibat ketersediaan pustaka yang umumnya lebih terfokus pada spesies yang sensitif yaitu: lebih dari setengah (12) dari 23 spesies burung yang dianggap menurun secara nyata setelah penebangan. 
Data amfibia dan reptilia sangat terbatas. Amfibia tampaknya tidak terlalu terpengaruh oleh kegiatan penebangan dengan intensitas ringan, paling tidak pada awal kegiatan. Pada kenyataannya, penebangan kayu berdampak minimal (Reduced Impact Logging/RIL) meningkatkan keragaman spesies ini dengan terbentuknya habitat mikro bagi spesies yang biasanya tidak ditemukan di hutan primer. Data kami terlalu sedikit untuk menentukan implikasi yang lebih luas mengenai perubahan tersebut dalam komunitas amfibia. Namun demikian, penelitian lainnya (Inger 1980a, Iskandar 1999a, Iskandar \& Setyanto 1999), menemukan bahwa di Asia Tenggara, hutan yang lebih panas dan lebih kering hanya mampu mendukung kehidupan katak arboreal dan terestrial, dan sejumlah kecil kadal arboreal, tetapi mendukung sejumlah besar kehidupan kadal terestrial yang aktif di siang hari dibandingkan dengan hutan dataran rendah primer. Keragaman iklim makro dan mikro mempengaruhi spesies amfibia dan reptilia secara berbeda-beda, bergantung pada ketahanan spesies-spesies tersebut terhadap kondisi panas dan kering, lokasi bertelur, daur kegiatan hariannya, serta kesempatan untuk berlindung dalam cuaca yang buruk. Karena katak dan kadal terestrial di hutan Borneo merupakan pesaing (kompetitor) sumber makanan dan habitat, penurunan kelimpahan katak mungkin disebabkan oleh meningkatnya kelimpahan kadal. Di sisi lain, pada sejumlah kelompok kadal, kelimpahan dan keanekaragaman spesiesnya menurun. Di antara spesies yang menurun adalah sejenus kadal yang hidup di serasah lantai hutan, spesies bengkarung yang hidup di pohon, dan mungkin beberapa spesies cicak terbang atau cekibar (Draco). Seluruh kadal agamid bertelur pada lantai hutan dengan menggali lubang yang dangkal di tanah dan menutupnya. Keringnya strata tersebut (dasar hutan) setelah penebangan dapat mengurangi kelimpahan kelompok ini. Isu ini harus diklarifikasi ulang.

\section{Filogeni, distribusi, dan taksonomi}

Spesies mamalia endemis dari Borneo atau Dataran Sunda yang berevolusi selama zaman Miosen atau Awal Pliosen terlihat lebih bertoleransi terhadap kegiatan penebangan dibandingkan dengan kelompok lain. Hanya sedikit perbedaan morfologi (bentuk) akibat ragam geografi yang ada dalam kelompok ini (artinya: lebih sedikit jumlah subspesiesnya). Selain itu, satwa dari kelompok ini biasanya langka di pulaupulau kecil, kecuali Jelarang Bilalang (Ratufa affinis), Musang Akar (Arctogalidia trivirgata), dan Tenggalung Malaya (Viverra tangalunga). Spesies tersebut cenderung memiliki relung ekologi yang sempit dan banyak di antaranya memiliki perilaku makan yang terbatas yaitu sebagai spesialis pemakan buah, pemakan daging, atau pemakan serangga. Beberapa memiliki strata pencarian makan yang terbatas hanya di lantai hutan (terestrial), meskipun ada pula yang hidup di bagian pohon yang lebih tinggi dan pada tumbuhan bawah.

Sebaliknya, mamalia yang dapat bertahan dengan baik di hutan bekas tebangan umumnya merupakan spesies yang lebih muda, sebagian besar dari zaman Akhir Pliosen atau Pleistosen. Spesies ini biasanya hidup di pulau-pulau kecil dan sering tersebar di seluruh Asia Tenggara dan menunjukkan keragaman bentuk yang nyata. Spesies yang paling bertoleransi terhadap penebangan adalah herbivora atau omnivora yang mengkonsumsi pucuk-pucuk daun muda atau bahan-bahan tumbuhan. Banyak 
spesies yang hidup pada strata vegetasi bagian bawah (termasuk juga strata terestrial), meskipun sejumlah spesies dapat dijumpai di berbagai tingkat strata hutan.

Dokumentasi dampak ekologis akibat kegiatan penebangan terhadap burung tidak sebaik pada mamalia. Sampel kami didominasi oleh satu kelompok, yaitu pelatuk, yang strata dan strategi pencarian makannya relatif serupa. Lebih jauh, Lambert dan Collar (2002) menganggap seluruh spesies yang kami uji peka terhadap fragmentasi hutan kecuali dua spesies yang tahan terhadap fragmentasi tersebut. Dengan demikian, tidak mungkin untuk melakukan perbandingan untuk mengkaji dan menentukan faktor spesifik yang menyebabkan kepekaan spesies terhadap fragmentasi hutan. Kami tidak menyelidiki hubungan antara umur spesies burung dengan kepekaannya terhadap penebangan karena informasi terkait tidak tersedia. Namun demikian, ada dua makalah ilmiah yang mengulas filogeni Sempidan Asia (Kimball et al. 2001, Randi et al. 2001). Dua spesies sempidan (Lophura spp.) diperkirakan bereaksi secara positif atau netral terhadap efek penebangan (lihat Tabel 4) dan kedua spesies ini "berpisah" dari keluarganya yang masih hidup selama zaman Pliosen akhir atau zaman Pleistosen. Temuan ini sejalan dengan temuan kami mengenai mamalia. Penebangan tampak berpengaruh negatif terhadap Sempidan Kalimantan (Lobiophasis bulweri). Bila $L$. bulweri dikelompokkan dengan tepat ke dalam genus yang hanya memiliki satu spesies (monotypic) (ulasan mengenai hubungan filogenetis L. bulweri dengan Lophura masih belum terselesaikan dengan baik, Randi et al. 2001), kemungkinan pemisahan spesies sempidan terjadi sebelum pemisahan spesies Lophura, sehingga spesies ini mungkin berasal dari jaman awal hingga pertengahan Pliosen. Meskipun terdapat hubungan antara umur spesies sempidan dengan toleransinya terhadap penebangan seperti yang diperkirakan, kesimpulan ini masih belum pasti.

Mekanisme apa yang mendasari pola yang diidentifikasi dalam penelitian ini? Sepanjang pengetahuan kami, buku ini merupakan dokumen pertama yang melaporkan korelasi antara umur spesies mamalia dengan kepekaannya terhadap penebangan, meskipun penelitian lain mengungkapkan bahwa spesies burung yang sudah lama berevolusi dan berasal dari garis keturunan marsupial lebih rentan terhadap kepunahan (lihat Gaston \& Blackburn 1997, Johnson et al. 2002). Garis keturunan yang lebih tua umumnya merupakan spesies yang tersisa dengan luas distribusi dan populasi terbatas (Fisher \& Owens 2004, Gaston \& Blackburn 1997) dan juga umumnya terdiri dari banyak spesies spesialis sehingga dapat meningkatkan risiko kepunahan setelah adanya gangguan seperti penebangan (Johnson et al. 2002, Fisher et al. 2003, Fisher \& Owens 2004). Penjelasan yang kedua dalam analisis kami mendapatkan banyak dukungan, namun kami mengaitkan temuan yang kami hasilkan tersebut dengan kondisi lingkungan-kuno (paleo-environmental) tempat berbagai spesies berevolusi (dari Meijaard 2003c).

Antara 5,5 hingga 4,5 juta tahun yang lalu pada Zaman Awal Pliosen, padang rumput dan jenis vegetasi terbuka lainnya meluas di Asia Tenggara yang menyebabkan, salah satunya, spesiasi spesies secara cepat (Meijaard 2003c, Meijaard \& Groves 2004, Pitra et al. 2004) dan suku Bovidae (kambing, kerbau, sapi) Asia Tenggara (lihat Hassanin \& Ropiquet 2004). Spesies tersebut bisa beradaptasi baik dengan hutan yang lebih terbuka atau dengan kondisi mosaik yang terbentuk karena kegiatan penebangan. Antara 3 dan 4 juta tahun yang lalu, kondisi yang lebih hangat dan 
lebih basah kembali terjadi dan sebagian besar Subregion Sunda ditutupi oleh hutan hujan yang hijau sepanjang musim (evergreen rainforest) (Morley 2000). Dengan demikian kami perkirakan bahwa spesies yang hidup di hutan Asia Tenggara yang berevolusi selama zaman Akhir Miosen (5,3 hingga 11,1 juta tahun yang lalu), berevolusi di lingkungan hutan hujan tropik yang lebih luas dibandingkan dengan masa kini (Morley 2000). Sejak itu, karena fluktuasi iklim zaman Pleistosen dan zaman es, kondisi lingkungan menjadi jauh lebih dingin dan kering. Spesies yang berevolusi selama periode kering zaman Pliosen dan Pleistosen diperkirakan lebih bisa beradaptasi terhadap perubahan kondisi lingkungan, termasuk hutan yang terbuka dan terfragmentasi, sehingga sering bisa bertahan dengan kondisi perubahan vegetasi akibat kegiatan penebangan.

Temuan yang menunjukkan bahwa terdapat jumlah subspesies yang lebih banyak di antara spesies yang bisa bertoleransi terhadap kegiatan penebangan harus dilihat secara hati-hati. Indeks taksonomi bisa bersifat kurang obyektif, karena karakterisasi subspesies lebih banyak bergantung pada sifat dan ruang lingkup penelitian dan keragaman sesama spesies yang ada. Selain itu, dalam taksonomi spesies Asia Tenggara, banyak spesies yang hidup di pulau-pulau di Lempeng Sunda diberi status subspesies, dan kedua variabel tersebut (jumlah subspesies dan jumlah yang hidup di pulau kecil, lihat analisis sebelumnya) berkolerasi secara nyata (korelasi Pearson $=0,84, p<0,001$ ). Namun demikian, ada kecenderungan menarik dalam jumlah pulau tempat spesies hidup dan toleransinya terhadap penebangan yang memerlukan penyelidikan lebih lanjut. Menariknya, kecenderungan ini terlihat lebih bergantung pada pola umur spesies seperti yang diulas sebelumnya. Kemungkinan yang dapat dijelaskan yaitu, spesies yang dapat bertahan hidup di pulau-pulau kecil umumnya mampu beradaptasi dengan fragmentasi habitat-terutama pengaruh ekologis untuk hidup di daerah yang terbatas luasnya dengan gangguan serta efek tepi yang relatif tinggi (Denslow 2003). Dengan mengasumsikan bahwa banyak taxa yang mengkoloni pulau-pulau kecil pada jaman dahulu tidak dapat bertahan di jaman modern, setidaknya secara kasar bisa diasumsikan bahwa populasi pulau kecil bisa memberikan suatu ukuran kemampuan beradaptasi selama terjadinya perubahan iklim, gangguan, dan mungkin juga pengaruh manusia (antropogenik).

\section{Strategi pencarian makanan}

Spesialisasi ekologis dianggap bisa meningkatkan kemungkinan penurunan dan kemungkinan kepunahan suatu spesies di bawah perubahan kondisi lingkungan (Harcourt et al. 2002, Owens \& Bennett 2000). Analisis kami menunjukkan bahwa secara umum, spesies dengan relung ekologi yang lebih luas, yaitu spesies yang mudah beradaptasi dengan kondisi gangguan atau makan jenis makanan yang berbeda-beda, lebih toleran dibandingkan dengan spesies dengan relung ekologis yang lebih sempit. Heydon dan Bulloh (1997) menunjukkan bahwa spesialis karnivora, insektivora, dan frugivora dipengaruhi oleh kegiatan penebangan kayu di Borneo. Lambert dan Collar (2002) juga menemukan bahwa spesies satwa dengan makanan yang spesial akan menderita akibat penebangan. Kemampuan suatu spesies untuk mengganti komponen makanan utamanya yang memudahkan spesies tersebut 
untuk mendapatkan makanan pengganti saat kegiatan penebangan secara langsung mengakibatkan berkurangnya makanan utama mereka. Spesies yang dapat berganti pola makan setelah terjadi gangguan bisa dianggap lebih bertoleransi. Contohnya adalah pelatuk berukuran kecil yaitu Tukik tikus (Sasia abnormis) yang mencari makan pada bambu di hutan bekas tebangan dan pada liana di hutan utuh (Styring $\&$ Hussin 2004a). Sebagai aturan umum, dapat dikatakan bahwa semakin luas relung ekologi suatu spesies, semakin besar toleransinya terhadap kegiatan penebangan.

Hasil penelitian terdahulu secara umum memberikan implikasi bahwa spesies dengan tingkat rantai makanan yang lebih tinggi (karnivora, insektivora) lebih rentan terhadap gangguan dibandingkan dengan spesies dengan tingkat rantai makanan yang lebih rendah (herbivora) (Diamond 1984). Di hutan Venezuela, Ochoa (2000) menemukan bahwa kegiatan penebangan menyederhanakan struktur rantai makanan spesies-spesies yang menetap (nonvolant), dengan pemangsa omnivora yang hidup secara semi-arboreal menjadi kelompok yang dominan, diikuti oleh frugivoraomnivora terestrial. Dalam rantai makanan ini juga terjadi penurunan yang nyata terhadap kelimpahan relatif suatu spesies yang hidup di tajuk. Pola seperti ini lebih mencerminkan spesialisasi spesies dibandingkan dengan hanya tingkat rantai makanan.

Data kami mengungkapkan bahwa penebangan kayu memiliki pengaruh yang lebih besar terhadap spesies yang hidupnya terbatas pada tajuk atau di atas permukaan tanah, dibandingkan dengan spesies yang bisa memanfaatkan berbagai strata vegetasi. Mengapa spesies terestrial atau tajuk yang memiliki strategi pencarian makanan yang khusus (spesialis) tidak bertoleransi terhadap penebangan? Hal ini dapat dijelaskan antara lain sebagai berikut:

1. kegiatan penebangan kayu menyebabkan fragmentasi pada dasar hutan (karena pembukaan jalan dan bekas jalan sarad);

2. sisa dan kotoran akibat kegiatan penebangan dan belukar tumbuhan bawah yang tebal bisa menghambat pergerakan sejumlah satwa;

3. kegiatan penebangan membentuk celah-celah di tajuk yang menyebabkan pergerakan spesies arboreal lebih sulit; dan

4. bukaan tajuk yang lebih besar (pada kasus tertentu penebasan vegetasi tanah) menimbulkan berbagai pengaruh pada vegetasi tumbuhan bawah, yang kemudian mempengaruhi invertebrata dan taxa yang memakan invertebrata tersebut. Contohnya, di Sumatera, keragaman dan kelimpahan spesies rayap menurun secara nyata setelah hutan primer ditebang (Jones et al. 2003). Namun demikian, hubungan antara invertebrata dan penebangan masih belum jelas. Di Sabah, tidak terjadi penurunan spesies secara jelas antara di hutan primer dan dua tipe hutan yang ditebang secara selektif (sistem tebang pilih) (Eggleton et al. 1997).

Penelitian lebih lanjut masih diperlukan untuk menentukan alasan utama mengapa spesies-spesies yang wilayahnya terbatas pada permukaan tanah atau tajuk hutan mengalami penurunan akibat kegiatan penebangan kayu. 


\section{Peran jenis pohon kayu}

Kegiatan penebangan kayu di Borneo terutama diarahkan pada spesies Dipterokarpa. Dapat diramalkan, vertebrata yang hidupnya bergantung pada jenis pohon tersebut (atau bergantung pada jenis kayu komersial lain yang banyak ditebang seperti spesies damar (Agathis)) bisa sangat terpengaruh keberadaannya. Beberapa spesies vertebrata memiliki ketergantungan yang nyata pada spesies dipterocarps (atau pada damar). Pohon Dipterokarpa berukuran besar yang memiliki rongga bisa berfungsi sebagai tempat bersarang spesies burung seperti rangkong (bahwa peran pohon ini bisa digantikan oleh jenis pohon besar lain masih belum jelas). Masih belum jelas apakah ada vertebrata yang bergantung pada daun-daun spesies Dipterokarpa. Sementara beberapa spesies monyet seperti Lutung Merah (Presbytis rubicunda) kadang-kadang memakan sejumlah daun, telah dipahami bahwa pucuk daun dipterokarpa tidak dimakan dan tidak disukai oleh herbivora generalis (Janzen 1974, Waterman et al. 1988). Spesies pemakan biji seperti Beruang Madu, Babi Berjenggot, spesies Muntiacus (rusa), landak, beberapa spesies bajing dan sejumlah rangkong memakan buah Dipterokarpa bila buah-buahan tersebut tersedia, namun di lain musim memakan makanan lain. Meskipun begitu, episode reproduksi (berbuah) yang bersamaan waktunya, termasuk spesies Dipterokarpa, menjadi sangat penting bagi keberadaan sejumlah spesies satwa untuk jangka panjang. Contoh jenis satwa ini adalah babi dan beruang yang menimbun lemak setelah episode reproduksi buah yang bersamaan waktu tersebut.

Meskipun spesies-spesies pohon Dipterokarpa memainkan sejumlah peran dalam kehidupan satwa, kelimpahan vertebrata yang sangat rendah di daerah seperti Malinau bisa disebabkan oleh rendahnya kelimpahan buah dan daun yang disukai vertebrata tersebut (Janzen 1974). Hal ini mengungkapkan bahwa ketersediaan sumber makanan di hutan Dipterokarpa yang ditebang dapat ditingkatkan dengan menanami hutan tersebut dengan pohon yang dapat meningkatkan ketersediaan makanan bagi satwa liar. Idealnya, hal ini mencakup jenis tanaman yang bisa menghasilkan kayu yang bernilai tinggi selain juga buah-buahan. Contoh-contoh spesies tersebut adalah Durian (Durio), Campnosperma, Pometia, Calophyllum, Dialium dan suku seperti Sapotaceae (e.g. Madhuca, Palaquium, Payena, Pouteria spp.), Fagaceae (Castanopsis, Lithocarpus, Quercus) dan Moraceae, atau bahkan meranti yang khas seperti Shorea pinanga yang dikenal menghasilkan biji dan buah-buahan bernilai tinggi.

\section{Perubahan karakteristik struktur hutan}

Pohon yang memiliki dahan dan percabangan yang besar menyediakan ronggarongga untuk sarang dan persediaan makanan bagi bermacam-macam satwa. Praktek penebangan yang menghilangkan pohon berongga dan cabang-cabang mati merupakan salah satu penyebab mengapa spesies burung rangkong, terutama Rangkong Gading (Rhinoplax vigil) yang bersarang di pohon dipterokarpa berukuran besar (lihat ulasan mengenai burung di Bagian 1) dirugikan oleh kegiatan penebangan. Spesies musang dan bajing tertentu yang memanfaatkan lubang, terutama Jelarang Bilalang (Ratufa affinis), dapat terpengaruh secara negatif akibat hilangnya pohonpohon bergerowong/berongga setelah kegiatan penebangan. 


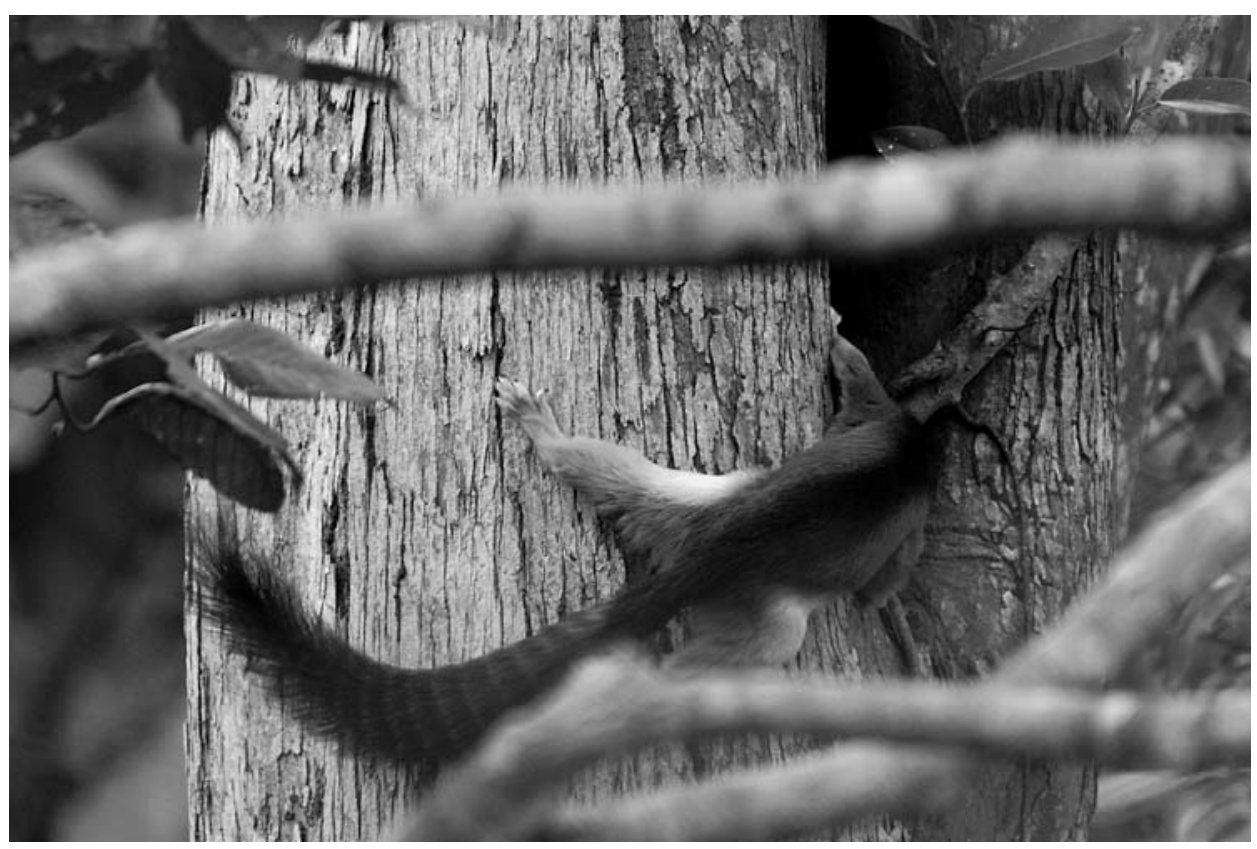

Gambar 21. Pohon berongga merupakan komponen ekologi yang penting pada hutan yang sehat. Di sini Jelarang Bilalang (Ratufa affinis) sedang memasuki rongga pohon. (Foto oleh Kimabajo)

Informasi yang tersedia menyangkut penyebaran, penentu, dan karakter rongga pohon di hutan Dipterokarpa sangat sedikit. Sebagai contoh, suatu kajian menyeluruh yang dipublikasikan baru-baru ini tentang spesies-spesies pohon Dipterokarpa (Appanah \& Turnbull 1998) tidak mengulas faktor penyebab terjadinya rongga pada pohon selain hanya secara singkat menjelaskan mengenai busuk gubal. Rongga pohon tersebut lebih banyak terjadi pada jenis pohon berdahan besar yang berinti kayu dan kayunya relatif ringan. Awalnya, setelah pohon kayu ditebang dalam jumlah yang terbatas, pohon-pohon berukuran besar yang rusak membuka peluang terjadinya pembentukan rongga. Namun kesempatan ini hilang bila pohon berukuran besar ditebang habis dalam beberapa daur penebangan. Sejumlah spesies pohon hutan Asia Tenggara seperti Dyera spp. tidak menghasilkan kayu gubal (Ng 1986) dan kecil kemungkinannya untuk bisa membentuk rongga berukuran besar, namun topik ini jarang dipelajari. Tegakan hutan regenerasi mungkin tidak memiliki jumlah busuk gubal yang cukup banyak dan tidak dapat membentuk rongga pohon yang besar yang digunakan oleh spesies burung seperti rangkong (McClure 1968). Selain itu, bentuk dan struktur rongga pohon serta kemungkinannya menampung air ditentukan oleh karakteristik sudut antara batang utama dan percabangan pohon tersebut, kemampuannya dalam memangkas, dan respons aktif serta pasif terhadap kerusakan tegakan (Loehle 1988)—suatu topik yang, sekali lagi, jarang diteliti.

Berbagai perubahan iklim mikro terjadi di hutan yang dipanen kayunya. Cahaya, kelembaban, angin, suhu, dan karakteristik iklim mikro lainnya berubah-ubah dan selanjutnya dapat mengubah parameter lingkungan yang terbatas secara fisiologis 
yang dibutuhkan oleh sejumlah spesies satwa untuk bersarang, berinkubasi, tumbuh, menyusui, dan sebagainya. Faktor iklim mikro secara umum jarang diidentifikasi untuk menentukan perubahan hewani (faunistik). Padahal, bagi kelompok tertentu seperti anura yang bersarang di tanah dan kadal dari suku Agamidae, faktor iklim mikro merupakan hal yang sangat penting.

Vertebrata tertentu bergantung pada struktur tertentu untuk hinggap, mencari makanan, berkembang biak atau beristirahat (contohnya, owa adalah penghuni tajuk yang memerlukan struktur tajuk yang utuh dan rapat, bajing lebih menyukai bagian atas tajuk, binturong segan untuk berpindah tempat melalui darat (tanah), dan rangkong bergantung pada percabangan pohon untuk mencari serangga makanannya), namun hanya pelatuk yang banyak diteliti dengan baik. Sebagai contoh, pelatuk yang hanya mencari makan pada pohon mati berukuran besar mengalami kesulitan bertahan pada tegakan pohon berumur tua di Semenanjung Malaya dimana habitat tersebut jarang ditemukan (Styring \& Hussin 2004a). Sebagian spesies mendapat manfaat dari terbentuknya rumpang (misalnya rusa) sedangkan spesies lain tidak bisa mendapatkan makanan dalam rumpang hutan yang sama (contohnya kelelawar barong (Hipposideros spp.) dan kelelawar-ladam (Rhinolophus spp.)). Sejumlah spesies (misalnya beberapa spesies tikus berukuran kecil) mendapat manfaat dari kondisi tumbuhan bawah yang lebih rapat dan kompleks yang biasanya muncul setelah kegiatan penebangan, sementara yang lain memerlukan struktur hutan primer yang lebih terbuka dan teratur (misalnya spesies burung hantu seperti Otus rufescens dan spesies paruh kodok Batrachostomus spp.). Sekali lagi, semakin tinggi kemampuan adaptasi perilaku suatu spesies, semakin besar kemungkinannya untuk bertahan terhadap kegiatan penebangan.

\section{Pengaruh yang terkait dengan ekstraksi kayu}

Setelah mengulas sejumlah pola umum menyangkut toleransi spesies terhadap pemanenan kayu, kami menyelidiki bagaimana dampak langsung secara ekologi jika dibandingkan dengan pengaruh yang terkait seperti fragmentasi hutan dan peningkatan tekanan perburuan.

\section{Fragmentasi hutan}

Sejumlah penelitian mengungkapkan bahwa fragmentasi hutan lebih berpengaruh terhadap spesies burung di lingkup yang lebih luas seperti omnivora, insektivora, dan pemakan madu dibandingkan dengan kegiatan tebang pilih, meskipun beragam generalis dan sejumlah spesies nonhutan meningkat kepadatannya (Lambert \& Collar 2002). Tidak ada penelitian yang rinci untuk mempelajari efek fragmentasi terhadap mamalia Dataran Sunda, meskipun beberapa penelitian berupaya mengaitkan hubungan evolusi di antara spesies-spesies yang ada dengan kepekaan relatifnya terhadap fragmentasi hutan (Harcourt \& Schwartz 2001, Ruedi \& Fumagalli 1996). Penelitian yang dilakukan oleh Brook et al. (2003) mengaitkan kepunahan mamalia di Pulau Singapura dengan pengurangan jumlah habitat yang tersedia (lihat juga Kinnaird et al. 2003 untuk beberapa ulasan mengenai kawasan lindung di Sumatera). 
Meijaard (2003b) meneliti mamalia di pulau-pulau Lempeng Sunda yang terisolasi setelah zaman es dahulu kala, maksimum sekitar 14.000 tahun yang lalu. Penelitian ini menghasilkan model yang dapat digunakan untuk mengkaji efek fragmentasi habitat, karena pulau-pulau ini dikelilingi oleh kawasan hutan yang jauh lebih luas sebelum pulau-pulau tersebut terisolasi oleh naiknya muka air laut. Namun demikian, harus disadari bahwa tidak semua pulau di hutan hujan tropik yang hijau sepanjang musim ditutupi oleh vegetasi (lihat Heaney 1986, Meijaard 2003b, Bird in prep.). Lebih tepatnya, satwa pulau tersebut adalah hasil kombinasi dari fragmentasi, perburuan, dan perubahan habitat, karena sebagian besar pulau yang ada telah dihuni oleh manusia selama beratus-ratus tahun lamanya. Data dari penelitian Meijaard (2003b) menunjukkan bahwa empat spesies karnivora besar, yaitu Panthera tigris (Harimau), P. pardus (Macan Tutul), Neofelis nebulosa (Macan Dahan) dan Ursus malayanus (Beruang Madu), yang sejauh ini bisa kita sebut sebagai karnivora, hidup di pulau yang besar atau berjarak dekat dengan Semenanjung Malaya, Sumatera, Borneo, atau Jawa (lihat Tabel 13). Pengamatan ini mengungkapkan bahwa kawasan hutan yang lebih kecil dari $5,000 \mathrm{~km}^{2}$ tidak dapat mendukung kehidupan populasi karnivora, kecuali terjadi perpindahan satwa dari luar kawasan dan tingkat perburuan yang rendah.

Hal yang serupa dilaporkan oleh Crooks (2002) dan Laidlaw (2000) dari Kalifornia dan Semenanjung Malaya tentang adanya hubungan antara jumlah karnivora yang ditemui, berat badannya, areal fragmen, dan tingkat isolasi. Di wilayah ini, karnivora terbesar hanya dapat bertahan di bagian hutan yang paling besar dan relatif dekat dengan daerah sumbernya. Sebagaimana telah diperkirakan, karnivora yang lebih besar tidak dapat mempertahankan hidupnya di pulau berukuran kecil, namun di luar dugaan, karnivora dan insektivora yang lebih kecil (Herpestidae, Soricidae, Tarsiidae dan Mustelidae) juga terbatas pada kawasan hutan yang lebih luas (Tabel 13). Hal ini mungkin berkaitan dengan keberadaan spesies bersangkutan pada tingkat jaring makanan yang paling tinggi. Jika dikombinasikan dengan wilayah jelajah yang terbatas, faktor ini bisa meningkatkan kemungkinan kepunahan secara nyata (Purvis et al. 2000). Dengan demikian, kerentanan spesies ini bisa dikaitkan dengan tingkat jaring makanan.

Dalam beberapa hal, satwa yang hidup di pulau berbeda dengan satwa yang hidup di bagian kecil (kantung hutan). Di bagian-bagian hutan ini biasanya berpeluang besar terjadinya dispersal (fauna dan flora) ke areal hutan lainnya dibandingkan dengan yang ada di sebagian besar pulau-pulau. Penelitian yang dilakukan baru-baru ini menunjukkan bahwa matriks habitat (yang terbentuk karena fragmentasi) sangat mempengaruhi dinamika di dalam fragmen-fragmen habitat (Jules \& Shahani 2003). Namun demikian, data tentang satwa yang hidup di pulau masih belum konklusif. Spesies garangan terestrial yang bersifat karnivora/insektivora dan munggis hanya hidup di beberapa pulau besar saja. Di sisi lain, ungulata (hewan berkuku belah seperti babi, rusa, dan pelanduk) hidup di banyak pulau, termasuk pulau berukuran kecil. Kubung Malaya (Cynocephalus variegatus) yang merupakan jenis herbivora juga dapat bertahan hidup di daerah yang kecil termasuk Pulau Perhentian dengan luas hanya $2 \mathrm{~km}^{2}$. 
Tabel 13. Jumlah dan titik tengah ukuran pulau-pulau di kawasan Indo-Malaya yang menjadi tempat tinggal spesies mamalia dari berbagai suku. Kami tidak memasukkan seluruh spesies yang dianggap eksotis. Analisis dibangun berdasarkan data yang dibuat oleh Meijaard (2003b).

\begin{tabular}{lcccc}
\hline Suku & $\begin{array}{l}\text { jumlah spesies } \\
\text { dalam suku } \\
\text { yang hidup di } \\
\text { pulau kecil }\end{array}$ & $\begin{array}{l}\text { jumlah rata-rata } \\
\text { pulau tempat } \\
\text { tinggal spesies }\end{array}$ & $\begin{array}{l}\text { ukuran } \\
\text { rata-rata } \\
\text { pulau (km }{ }^{2} \text { ) }\end{array}$ & $\begin{array}{l}\text { ukuran } \\
\text { terkecil } \\
\text { pulau (km }{ }^{2} \text { ) }\end{array}$ \\
\hline $\begin{array}{l}\text { Mustelidae (musang, biul } \\
\text { dan berang-berang) }\end{array}$ & 5 & 5,0 & 4.564 & 1 \\
\hline Herpestidae (garangan) & 2 & 2,0 & 4.519 & 1 \\
\hline Tarsiidae (tarsius) & 1 & 4,0 & 4.109 & 54 \\
\hline Ursidae (beruang) & 1 & 4,0 & 3.735 & 929 \\
\hline $\begin{array}{l}\text { Soricidae (cucurut dan } \\
\text { munggis) }\end{array}$ & 2 & 2,7 & 3.594 & 228 \\
\hline Felidae (kucing) & 4 & 4,8 & 2.613 & 17 \\
\hline Viverridae (musang) & 8 & 7,3 & 2.536 & 1 \\
\hline Muridae (tikus dan mencit) & 26 & 8,2 & 2.350 & 2 \\
\hline Suidae (babi) & 2 & 10,5 & 2.163 & 1 \\
\hline Tupaiidae (tupai) & 10 & 8,4 & 2.096 & 1 \\
\hline Sciuridae (bajing) & 17 & 8,8 & 1.933 & 2 \\
\hline Hystricidae (landak) & 4 & 2,8 & 1.825 & 10 \\
\hline $\begin{array}{l}\text { Pteromyidae (bajing } \\
\text { terbang) }\end{array}$ & 14 & 2,9 & 1.634 & 24 \\
\hline Manidae (trenggiling) & 1 & 23,0 & 1.565 & 7 \\
\hline Hylobatidae (owa) & 1 & 4,0 & 1.487 & 530 \\
\hline Loridae (kukang) & 1 & 18,0 & 1.038 & 20 \\
\hline Cervidae (rusa) & 2 & 8,5 & 1.018 & 1 \\
\hline Cercopithecidae (monyet) & 7 & 6,1 & 871 & 1 \\
\hline Tragulidae (pelanduk) & 2 & 39,0 & 781 & 1 \\
\hline $\begin{array}{l}\text { Erinaceidae (cucurut babi } \\
\text { dan rindil bulan) }\end{array}$ & 2 & 1,5 & 630 & 6 \\
\hline Cynocephalidae (Kubung) & 1 & 37,0 & 614 & 2 \\
\hline & & & & \\
\hline
\end{tabular}

Meskipun kesimpulan ini masih belum pasti, korelasi sederhana antara berat badan dan risiko kepunahan di dalam kantung habitat (Belovsky 1987) belum cukup untuk menjelaskan pola yang diamati. Contohnya, babi merupakan jenis satwa berukuran besar seperti halnya harimau, beruang, dan macan tutul. Tetapi, babi bisa bertahan hidup di pulau kecil yang terisolasi, sementara harimau, beruang, dan macan tutul hanya bisa bertahan hidup di pulau yang besar dan tidak terisolasi. Biedermann (2003) mengungkapkan bahwa hubungan langsung antara luas habitat, berat badan, dan risiko kepunahan hanya bisa diterapkan pada spesies yang bersifat spesialis secara ekologis, tetapi tidak untuk generalis. Selain itu, tingkatan dalam jaring makanan perlu dipertimbangkan karena pemangsa tertinggi membutuhkan mangsa yang cukup banyak. Swihart et al. (2003) melaporkan bahwa ada korelasi negatif antara luas relung ekologi dan risiko kepunahan di kawasan hutan yang terfragmentasi untuk sejumlah spesies mamalia dan amfibia di Amerika Serikat. Pola 
ini sejalan dengan data mamalia berukuran kecil dari daerah tropik Australia. Di daerah ini spesies spesialis tepi dan spesies yang bisa menggunakan matriks di antara kantung-kantung hutan meningkat kepadatannya setelah penebangan, sementara spesies spesialis hutan menurun (Harrington et al. 2001). Kemungkinan kepunahan meningkat saat wilayah jelajah satwa lebih besar dibandingkan kantung habitat yang ada (Harrington et al. 2001). Dengan demikian, ukuran fragmen merupakan faktor penting bagi jumlah populasi spesies spesialis yang hidup di pedalaman hutan di dalam bagian (kantung) tersebut (Kinnaird et al. 2003).

Penebangan kayu dan fragmentasi hutan yang mempengaruhi spesies dengan cara yang berbeda-beda bukan merupakan hal yang baru. Pengambilan kayu mengubah lingkungan fisik seperti tempat bersarang, perlindungan, tempat bernaung, kebutuhan wilayah jelajah, atau serasah daun serta tumbuhan bawah yang lembab, sehingga mempengaruhi spesies-spesies yang hidupnya bergantung pada lingkungan tersebut. Di pihak lain, fragmentasi dalam skala besar mempengaruhi karakteristik populasi seperti demografi dan proses penyebaran spesies karena fragmentasi menurunkan ukuran efektif populasi. Fragmentasi juga mempengaruhi spesies di tingkat individu atau tingkat hubungan dalam spesies (autecology), termasuk laju ketahanan untuk hidup dalam kantung hutan yang lebih kecil. Hal ini selanjutnya mempengaruhi laju perkembangbiakan, pertambahan jumlah, dan rasio demografis.

Di daerah Neotropik, fragmentasi menurunkan keragaman spesies pada banyak taxa, meskipun beberapa spesies seperti herbivora berukuran sedang diuntungkan (mendapat manfaat) dengan hilangnya karnivora berukuran besar (Terborgh 1992). "Manfaat" seperti ini dapat menyebabkan kelimpahan yang berlebih yang menyebabkan, salah satunya, peningkatan kerusakan anakan pohon dan pemakan biji, dan persaingan dengan spesies yang lebih rentan (Asquith et al. 1997). Soulé et al. (1988) mengungkapkan bahwa jenis satwa omnivora yang berukuran kecil menjadi sangat berlimpah dalam fragmen hutan, suatu masalah yang mereka sebut sebagai "pelepasan predator tengah" (the mesopredator release). Bagaimana hal ini mempengaruhi populasi spesies mangsa tidak banyak diketahui. Namun demikian, Laurance (1997) berhipotesis bahwa spesies mangsa yang berukuran besar mendapat manfaat dari hilangnya karnivora (mungkin hal ini dapat digunakan untuk menjelaskan mengapa pelanduk (Tragulus spp.) sangat umum dijumpai di sejumlah besar pulau), sementara tekanan terhadap vertebrata yang lebih kecil meningkat.

Efek tepi dan kemampuan spesies yang berbeda-beda untuk bergerak melalui matriks atau habitat hutan yang rusak di Asia Tenggara, tidak banyak diketahui. Padahal, informasi ini penting untuk memahami tingkat ketahanan satwa dalam bentang alam yang sangat terfragmentasi.

\section{Perburuan}

Selain fragmentasi hutan, perburuan merupakan faktor penting dalam penurunan jumlah satwa liar di berbagai konsesi hutan dan juga di hutan utuh (Robinson \& Bennett 1999, Fimbel et al. 2001). Tidak adanya penjelasan tentang dampak perburuan terhadap kepadatan spesies setelah penebangan kayu disebabkan oleh kurangnya informasi menyangkut tekanan perburuan dalam penelitian mengenai 
penebangan, meskipun untuk sejumlah kelompok spesies kami bisa menyimpulkan dampaknya (lihat contohnya Tabel 6). Namun demikian, sejumlah penelitian telah membuka peluang bagi kami untuk menyimpulkan bahwa kegiatan perburuan dapat menurunkan atau bahkan memusnahkan spesies dari hutan dengan luasan yang cukup besar (Bennett \& Gumal 2001, Bennett et al. 1999, Nijman in press, Walter 2000). Kegiatan perburuan mempengaruhi jenis satwa yang dicari untuk makanan atau perdagangan, misalnya, babi, rusa, kijang, pelanduk, dan kura-kura. Meskipun demikian, cara yang digunakan seperti jerat tidak membeda-bedakan spesies hewan yang diburu dan bisa menimbulkan dampak yang lebih luas. Perburuan dengan intensitas sedang di suatu wilayah dengan kepadatan manusia yang rendah sekalipun dapat mengubah populasi satwa liar. Pengambilan satwa untuk perdagangan satwa hidup juga merupakan masalah yang penting diperhatikan bagi sejumlah taxa burung.

Karena analisis yang kami lakukan tidak terlalu banyak menambah ketersediaan pustaka yang ada dalam topik perburuan ini, kami tidak akan mengulang argumentasi yang telah disimpulkan dengan baik di sini. Namun, fokus ditujukan pada rekomendasi bagi pengelolaan yang dapat mengurangi tekanan kegiatan perburuan di dalam konsesi perkayuan. Membatasi kegiatan perburuan terhadap spesies-spesies yang rentan, terutama kegiatan perburuan komersial, sulit untuk dilaksanakan, tetapi merupakan tujuan pengelolaan yang penting dalam mengembangkan nilai konservasi hidupan liar di kawasan konsesi hutan. 


\section{PENGELOLAAN}

\section{Implikasi bagi pengelolaan kehutanan dan konsesi}

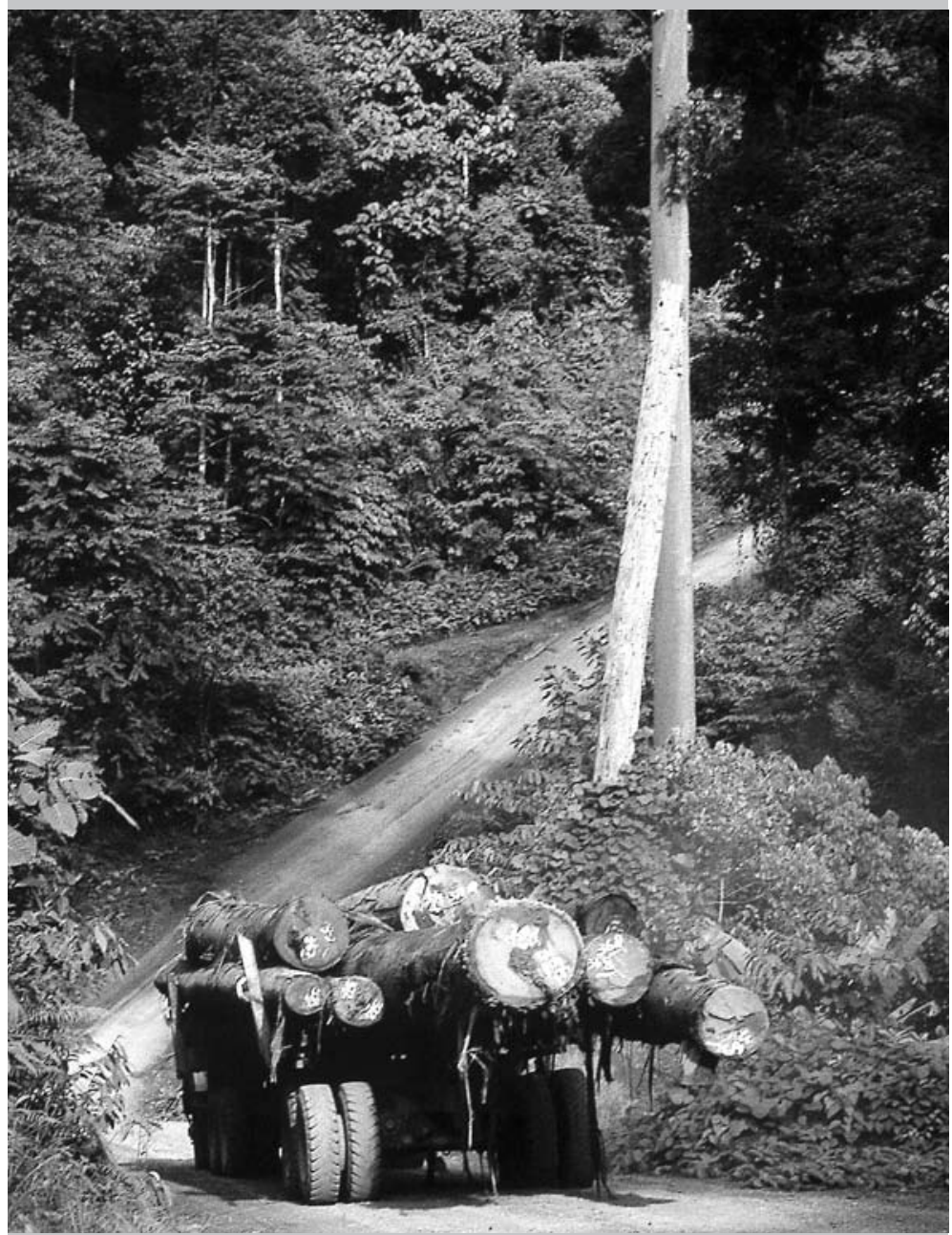

Kayu gelondongan menuju Kota Malinau. Kegiatan pengelolaan yang beragam dapat meningkatkan nilai hutan bekas tebangan untuk konservasi satwa liar (Foto oleh Charlie Pye-Smith). 



\section{Kesimpulan}

Kajian kami menunjukkan bahwa kegiatan tebang pilih, dalam konteks konsesi perkayuan, bisa berdampak sangat negatif terhadap vertebrata Borneo. Meskipun sejumlah efek ini merupakan konsekuensi langsung dari penebangan dan pengambilan kayu, atau pembangunan jalan, namun beberapa dampak tersebut terkait dengan perubahan yang biasanya terjadi di daerah konsesi, seperti fragmentasi habitat dan peningkatan kegiatan perburuan. Keseluruhan pengaruh ini dapat dikurangi dengan pengelolaan yang sesuai dan efektif.

Pengelolaan hutan lestari merupakan perangkat yang secara politis paling praktis untuk mempertahankan tutupan hutan di sebagian besar wilayah Borneo. Konservasi spesies yang berjelajah luas dan berkepadatan rendah membutuhkan bentang alam hutan yang luas. Data terbaru menunjukkan bahwa hutan Kalimantan di kawasan lindung (yang ada dan yang diusulkan) menghilang dengan laju yang secara jelas lebih cepat dibandingkan dengan hutan yang berada di luar kawasan lindung (Fuller et al. 2003). Jaringan kawasan lindung di Kalimantan yang dirancang sebagai tempat perlindungan terakhir bagi spesies-spesies tersebut gagal dalam mencapai tujuan utamanya, yaitu untuk melestarikan keragaman spesies tumbuhan dan satwa (Departemen Kehutanan 1990, Bagian 1 Pasal 1.13). Selain itu, jaringan kawasan lindung di Kalimantan terlalu kecil dan terfragmentasi untuk dapat memastikan keberlangsungan seluruh elemen keanekaragaman hayati, terutama spesies dengan wilayah jelajah yang luas atau yang bermigrasi (Jepson et al. 2002). Dengan demikian, konservasi keanekaragaman hayati di luar "kawasan lindung" menjadi semakin penting. Hal ini ditunjukkan oleh meningkatnya perhatian dari organisasi nonpemerintah yang bergerak di bidang konservasi seperti The Nature Conservancy (TNC), World Wide Fund for Nature (WWF) dan Wildlife Conservation Society (WCS), untuk bekerja di areal hutan yang telah dimanfaatkan (ada sejumlah kritik untuk upaya ini, contohnya dalam Gullison (2003), meskipun contoh ini tidak mengacu secara khusus ke Borneo). Dalam pandangan kami, bila keanekaragaman hayati vertebrata Borneo secara sungguh-sungguh ingin terjaga, pemahaman nilai konsesi 
hutan bagi konservasi keanekaragaman hayati menjadi hal yang amat penting. Lebih jauh, para pemilik konsesi secara hukum bertanggung jawab untuk memastikan bahwa spesies-spesies yang dilindungi dapat bertahan hidup di dalam hutan. Hal ini termasuk perlindungan habitat yang diperlukan spesies tersebut untuk bertahan hidup (meskipun hal ini tidak dinyatakan secara eksplisit dalam hukum konservasi di Indonesia).

Pada Bagian II buku ini kami mengulas dan menganalisis sejumlah spesies yang telah dipelajari dengan lebih baik kaitannya dengan toleransi spesies tersebut terhadap pengaruh penebangan dan tekanan yang ditimbulkannya. Faktor yang berkaitan dengan kerentanan terhadap penebangan adalah spesialisasi pola makanan, strata pencarian makanan yang terbatas, endemisme, usia evolusi (spesies yang berevolusi pada jaman Miosen atau Awal Pliosen) dan ketidakhadiran suatu spesies di pulau-pulau kecil. Insektivora dan frugivora terestrial tampak sangat peka terhadap kegiatan penebangan, sementara herbivora dan omnivora lebih toleransi atau bahkan mendapat manfaat dari kegiatan penebangan. Di luar gambaran yang di dapat, kami menemukan kurangnya panduan pengelolaan yang dihasilkan dari penelitian sebelumnya. Banyak areal hutan yang dikelola secara kurang efektif terutama dalam hal perlindungan keanekaragaman hayatinya karena kurangnya pengetahuan dan informasi.

Pada Bagian III buku ini, kami menyajikan rekomendasi bagi pengelolaan konsesi hutan yang ramah terhadap hidupan liar. Pada Bagian IV kami menitikberatkan peran penelitian dan menyarankan sejumlah cara yang dapat meningkatkan efisiensi penelitian tentang hidupan liar serta meningkatkan kemungkinan penerapannya untuk mengatasi permasalahan umum dalam konservasi biologi. Dalam tabel 14 kami menyusun daftar spesies yang mendapatkan manfaat dari pengelolaan konsesi penebangan yang lebih baik. Daftar ini masih belum sempurna karena terbatasnya pengetahuan kami tentang vertebrata Borneo dan ancaman keberadaannya.

Tabel 14. Daftar spesies Borneo yang paling mendapatkan manfaat dari pengelolaan konsesi hutan yang lebih mendukung keberadaan hidupan liar. LR/nr = Risiko Rendah/ hampir terancam (Lower Risk/near threatened).

\begin{tabular}{|c|c|c|}
\hline Spesies (nama umum) & Ancaman utama & Catatan \\
\hline $\begin{array}{l}\text { Sus barbatus (Babi } \\
\text { Berjenggot) }\end{array}$ & Perburuan & Tidak terancam di Borneo \\
\hline $\begin{array}{l}\text { Ursus malayanus } \\
\text { (Beruang Madu) }\end{array}$ & $\begin{array}{l}\text { Efek ekologis kegiatan } \\
\text { penebangan, perburuan, } \\
\text { gangguan, dan fragmentasi hutan }\end{array}$ & $\begin{array}{l}\text { Data tidak cukup (Data } \\
\text { Deficient), diusulkan menjadi } \\
\text { Rentan (Vulnerable) (IUCN 2003); } \\
\text { dilindungi oleh Undang-undang }\end{array}$ \\
\hline $\begin{array}{l}\text { Muntiacus atherodes } \\
\text { (Kijang Kuning) }\end{array}$ & $\begin{array}{l}\text { Penebangan dan perburuan } \\
\text { (terutama di dataran rendah) }\end{array}$ & Tidak terdaftar oleh IUCN \\
\hline $\begin{array}{l}\text { Presbytis spp. (monyet } \\
\text { daun/lutung) }\end{array}$ & $\begin{array}{l}\text { Perburuan yang terkait dengan } \\
\text { penebangan dan sasaran } \\
\text { pengambilan batu empedu }\end{array}$ & $\begin{array}{l}\text { P. hosei dan P. frontata terdaftar } \\
\text { sebagai Data Deficient (IUCN } \\
\text { 2003) }\end{array}$ \\
\hline $\begin{array}{l}\text { Tragulus spp. } \\
\text { (pelanduk) }\end{array}$ & $\begin{array}{l}\text { Efek ekologis akibat penebangan; } \\
\text { perburuan }\end{array}$ & $\begin{array}{l}\text { Tidak terdaftar oleh IUCN; } \\
\text { dilindungi Undang-undang }\end{array}$ \\
\hline
\end{tabular}


Tabel 14. Lanjutan

\begin{tabular}{|c|c|c|}
\hline Spesies (nama umum) & Ancaman utama & Catatan \\
\hline $\begin{array}{l}\text { Hylobates muelleri } \\
\text { (Owa Kalawat) }\end{array}$ & $\begin{array}{l}\text { Efek ekologis akibat penebangan; } \\
\text { perburuan }\end{array}$ & $\begin{array}{l}\text { Terdaftar sebagai LR/nr; } \\
\text { dilindungi Undang-undang }\end{array}$ \\
\hline $\begin{array}{l}\text { Pongo pygmaeus } \\
\text { (Orangutan } \\
\text { Kalimantan) } \\
\end{array}$ & $\begin{array}{l}\text { Perburuan dan perdagangan } \\
\text { satwa peliharaan }\end{array}$ & $\begin{array}{l}\text { Terdaftar sebagai Rawan Punah } \\
\text { (Endangered) oleh IUCN (2003); } \\
\text { dilindungi Undang-undang }\end{array}$ \\
\hline $\begin{array}{l}\text { Cervus unicolor (Rusa } \\
\text { Sambar) }\end{array}$ & $\begin{array}{l}\text { Meskipun mendapatkan } \\
\text { manfaat ekologis dari kegiatan } \\
\text { penebangan, dipengaruhi secara } \\
\text { negatif oleh perburuan }\end{array}$ & Dilindungi Undang-undang \\
\hline $\begin{array}{l}\text { Neofelis nebulosa } \\
\text { (Macan Dahan) }\end{array}$ & $\begin{array}{l}\text { Kurang informasi/kurang dikenal; } \\
\text { kemungkinan karena ketersediaan } \\
\text { hewan mangsa yang terbatas; } \\
\text { juga menjadi sasaran perburuan }\end{array}$ & $\begin{array}{l}\text { Terdaftar sebagai Rawan } \\
\text { (Vulnerable) oleh IUCN (2003); } \\
\text { dilindungi Undang-undang }\end{array}$ \\
\hline $\begin{array}{l}\text { Sebagian besar } \\
\text { karnivora kecil (kucing, } \\
\text { garangan dan musang) }\end{array}$ & $\begin{array}{l}\text { Kemungkinan dipengaruhi oleh } \\
\text { fragmentasi hutan }\end{array}$ & $\begin{array}{l}\text { Musang Air (Cynogale bennettii) } \\
\text { dan Kucing Merah (Catopuma } \\
\text { badia) terdaftar sebagai Rawan } \\
\text { Punah }\end{array}$ \\
\hline $\begin{array}{l}\text { Ratufa affinis (Jelarang } \\
\text { Bilalang) }\end{array}$ & $\begin{array}{l}\text { Efek ekologis akibat penebangan; } \\
\text { perburuan }\end{array}$ & Tidak terdaftar oleh IUCN \\
\hline $\begin{array}{l}\text { Sundasciurus hippurus } \\
\text { (Bajing Ekor-Kuda) }\end{array}$ & Efek ekologis akibat penebangan & Tidak terdaftar oleh IUCN \\
\hline $\begin{array}{l}\text { Rhinosciurus } \\
\text { laticaudatus (Bajing } \\
\text { Tanah Moncong- } \\
\text { Runcing) }\end{array}$ & Efek ekologis akibat penebangan & Tidak terdaftar oleh IUCN \\
\hline $\begin{array}{l}\text { Lariscus hosei (Bajing- } \\
\text { Tanah Bergaris-Empat) }\end{array}$ & Efek ekologis akibat penebangan & $\begin{array}{l}\text { Terdaftar sebagai Rawan } \\
\text { (Vulnerable) (IUCN 2003) }\end{array}$ \\
\hline $\begin{array}{l}\text { Lariscus insignis (Bajing- } \\
\text { Tanah Bergaris-Tiga) }\end{array}$ & Efek ekologis akibat penebangan & Tidak terdaftar oleh IUCN \\
\hline $\begin{array}{l}\text { Sebagian besar bajing } \\
\text { terbang }\end{array}$ & $\begin{array}{l}\text { Kemungkinan banyak } \\
\text { dipengaruhi oleh fragmentasi } \\
\text { hutan; secara ekologis tidak } \\
\text { banyak diketahui }\end{array}$ & Tidak terdaftar oleh IUCN \\
\hline $\begin{array}{l}\text { Seluruh spesies } \\
\text { rangkong }\end{array}$ & $\begin{array}{l}\text { Efek ekologis akibat penebangan, } \\
\text { terutama fragmentasi hutan; } \\
\text { perburuan untuk makanan, bulu, } \\
\text { dan hiasan }\end{array}$ & $\begin{array}{l}\text { Kangkareng Hitam } \\
\text { (Anthracoceros malayanus), } \\
\text { Rangkong Badak (Buceros } \\
\text { rhinoceros) dan Rangkong } \\
\text { Gading (Rhinoplax vigil) terdaftar } \\
\text { sebagai LR/nr }\end{array}$ \\
\hline $\begin{array}{l}\text { Sebagian besar spesies } \\
\text { pelatuk }\end{array}$ & Efek ekologis akibat penebangan & $\begin{array}{l}\text { Pelatuk Raffles (Dinopium } \\
\text { rafflesii) dan Caladi Badok } \\
\text { (Meiglyptes tukki) terdaftar } \\
\text { sebagai LR/nr tetapi tidak } \\
\text { banyak terpengaruh oleh } \\
\text { penebangan. Spesies lain yang } \\
\text { tidak terdaftar namun lebih } \\
\text { terpengaruh oleh penebangan. }\end{array}$ \\
\hline $\begin{array}{l}\text { Sebagian besar luntur } \\
\text { dan sempur-hujan }\end{array}$ & $\begin{array}{l}\text { Dipengaruhi oleh penebangan } \\
\text { dan terutama fragmentasi hutan }\end{array}$ & $\begin{array}{l}4 \text { spesies luntur dan } 2 \text { spesies } \\
\text { sempur-hujan terdaftar sebagai } \\
\text { LR/nr }\end{array}$ \\
\hline
\end{tabular}


Tabel 14. Lanjutan

\begin{tabular}{|c|c|c|}
\hline Spesies (nama umum) & Ancaman utama & Catatan \\
\hline $\begin{array}{l}\text { Seluruh spesies } \\
\text { sempidan/ayam hutan }\end{array}$ & Perburuan & $\begin{array}{l}\text { Meskipun sempidan cukup } \\
\text { toleran terhadap efek } \\
\text { penebangan, spesies ini } \\
\text { dipengaruhi oleh kegiatan } \\
\text { perburuan }\end{array}$ \\
\hline $\begin{array}{l}\text { Beberapa spesies } \\
\text { burung hantu, paruh- } \\
\text { kodok, dan raptor }\end{array}$ & $\begin{array}{l}\text { Dipengaruhi oleh fragmentasi } \\
\text { hutan terutama spesies spesialis } \\
\text { pedalaman hutan, meskipun } \\
\text { sebagian besar spesies ini juga } \\
\text { mencari makan di luar hutan }\end{array}$ & $\begin{array}{l}\text { Banyak spesies ini yang } \\
\text { dilindungi dan terdaftar oleh } \\
\text { IUCN }\end{array}$ \\
\hline $\begin{array}{l}\text { Gracula religiosa (Tiong } \\
\text { Emas) }\end{array}$ & Jerat & $\begin{array}{l}\text { Tidak terdaftar oleh IUCN, tidak } \\
\text { dilindungi Undang-undang }\end{array}$ \\
\hline $\begin{array}{l}\text { Irena puella } \\
\text { (Kacembang Gadung) }\end{array}$ & $\begin{array}{l}\text { Efek ekologis akibat penebangan } \\
\text { dan fragmentasi hutan }\end{array}$ & Tidak terdaftar oleh IUCN \\
\hline $\begin{array}{l}\text { Beberapa spesies tepus } \\
\text { Malacopteron }\end{array}$ & Efek ekologis akibat penebangan & $\begin{array}{l}\text { Spesies yang tidak toleran } \\
\text { terhadap penebangan tidak } \\
\text { terdaftar oleh IUCN }\end{array}$ \\
\hline $\begin{array}{l}\text { Alcedo euryzona (Raja } \\
\text { Udang Kalung-Biru) } \\
\text { dan Lacedo pulchella } \\
\text { (Cekakak Batu) }\end{array}$ & $\begin{array}{l}\text { Keduanya dipengaruhi oleh efek } \\
\text { ekologis akibat penebangan }\end{array}$ & $\begin{array}{l}\text { Tidak terdaftar oleh IUCN, tetapi } \\
\text { keduanya dilindungi Undang- } \\
\text { undang }\end{array}$ \\
\hline Merpati & $\begin{array}{l}\text { Peka terhadap efek ekologis } \\
\text { penebangan, terutama spesialis } \\
\text { pemakan buah; Banyak spesies } \\
\text { merpati yang menjadi sasaran } \\
\text { perburuan }\end{array}$ & $\begin{array}{l}\text { Punai Bakau (Treron fulvicollis) } \\
\text { adalah LR/nr; Ducula pickeringii } \\
\text { dan Treron capellei terdaftar } \\
\text { sebagai Rawan (Vulnerable) }\end{array}$ \\
\hline Seluruh spesies buaya & Diburu dan diambil & $\begin{array}{l}\text { Tidak dilindungi Undang- } \\
\text { undang di Indonesia }\end{array}$ \\
\hline $\begin{array}{l}\text { Seluruh spesies kura- } \\
\text { kura }\end{array}$ & Diburu dan diambil & $\begin{array}{l}\text { Sebagian besar terdaftar } \\
\text { sebagai Kritis Punah (Critically } \\
\text { Endangered), Rawan Punah, atau } \\
\text { Rawan; tidak satupun dilindungi } \\
\text { Undang-undang di Indonesia }\end{array}$ \\
\hline $\begin{array}{l}\text { Spesies ikan tertentu, } \\
\text { seperti Tor tambra }\end{array}$ & $\begin{array}{l}\text { Efek ekologis akibat penebangan; } \\
\text { penangkapan berlebih }\end{array}$ & Tidak terdaftar oleh IUCN \\
\hline
\end{tabular}




\section{Implikasi bagi pengelolaan kehutanan dan konsesi}

Kajian dalam Bagian I dan analisis dalam Bagian II menunjukkan bahwa berbagai spesies satwa liar secara ekologis dan tidak langsung dipengaruhi oleh kegiatan tebang pilih dan kegiatan lain yang langsung terkait. Demikian juga halnya dengan fragmentasi hutan, perburuan, dan tekanan-tekanan lainnya yang secara nyata/serius dapat merupakan ancaman. Walaupun kegiatan pemanenan kayu dapat diperbaiki melalui berbagai cara, memelihara konektivitas hutan, mengatur pola perburuan, dan menyelesaikan masalah yang berkaitan dengan ancaman terhadap satwa liar yang lebih luas merupakan tantangan dan kewajiban baru. Buku ini mungkin tidak akan dapat memberikan solusi yang optimum, namun paling tidak, buku ini dapat memberikan indikasi bagian mana dan bidang apa yang dapat dibenahi. Meskipun kami telah menjelaskan dasar perubahan yang dapat dilakukan pada bagian awal buku ini, kami juga memberikan gambaran singkat alasan-alasan penting dari usulan-usulan yang dikemukakan (disarankan). Hal yang demikian tidak hanya membuka peluang untuk memberi kritik pada usulan-usulan yang kurang tepat pada kondisi/situasi tertentu, atau ketika pemikiran dan pemahaman berubah, bahkan yang terpenting adalah memastikan bahwa pihak yang berupaya membenahi aspek tertentu dari pengelolaan dapat dengan mudah mendapatkan arahan yang diperlukan ini tanpa harus membaca seluruh isi dokumen.

Ada sejumlah tantangan dalam pengembangan peraturan yang dapat menjembatani antara kegiatan pemanenan kayu dan konservasi. Sebagai contoh, kita dapat memahami bahwa diperlukan suatu kendali dan batasan yang jelas. Namun, apa pun definisi dan istilah yang diusulkan sering mencerminkan adanya kompromi, yaitu ambang batas suatu rentang trade off. Contohnya mengapa kegiatan penebangan dilakukan pada pohon dengan diameter lebih dari $60 \mathrm{~cm}$ (bukan $65 \mathrm{~cm}$ atau $55 \mathrm{~cm}$ )? Atau hanya membatasi penebangan kayu di sungai dengan lebar lebih dari $1 \mathrm{~m}$, atau pada kelerengan lebih dari 50\%. Peraturan memang harus jelas, namun dalam jangka panjang, yang lebih penting adalah pemahaman dan makna peraturan tersebut bagi yang akan menjalankannya. Hal penting lainnya adalah memastikan bahwa peraturan 
tersebut tercermin dalam perencanaan dan pelaksanaannya. Banyak kriteria yang kami ajukan dikembangkan dari pemikiran penulis dengan mempertimbangkan hasil diskusi dan konsultasi dengan para praktisi dan pakar dalam pengelolaan kehutanan.

Sebagian pembaca buku ini mungkin menganggap usulan-usulan kami hanya sebagai daftar usulan yang diinginkan saja. Memang betul daftar ini merupakan sesuatu yang diidamkan, tetapi daftar ini merupakan daftar usulan yang bersifat pragmatis. Kajian dan melanjutkan pengumpulan data selalu diperlukan, peraturan akan dapat diperbaiki atau disesuaikan, dan rincian dari perubahan apa saja dapat menjadi bahan diskusi yang tak habis-habisnya. Namun bila kita sudah memiliki pengetahuan apa yang buruk bagi keberadaan hidupan liar dan apa yang harus dilakukan untuk memperbaikinya, mengapa harus menunggu?

Lebih jauh lagi, apa yang terlihat janggal dan tidak praktis bisa jadi menjadi lebih mudah untuk dilaksanakan dan lebih bermanfaat dari yang diperkirakan. Sebagai contoh, usulan bahwa pihak konsesi/perusahaan harus mempertimbangkan dan memperbanyak rongga pohon untuk bersarang bagi rangkong sepertinya sesuatu yang sulit untuk dilakukan. Namun laporan terbaru dari Thailand mengungkapkan bahwa kegiatan ini dapat dilaksanakan dan upaya ini bermanfaat untuk memperbaiki kehidupan rangkong (Poonswad et al. 2004).

Kami berasumsi bahwa kewenangan dan batas-batas hukum dapat diperjelas, misalnya antara Departemen Kehutanan dan kewenangan daerah (Dinas Kehutanan) di tingkat kabupaten. Panduan dan peraturan harus secara konsisten dilaksanakan. Untuk itu, panduan dan peraturan ini harus dapat dilaksanakan meskipun kelihatannya sederhana, hal ini sering sulit untuk dilakukan. Contohnya, penerapan batas kelerengan untuk memanen kayu dalam peraturan yang berlaku dapat membuat sebagian besar hutan Kalimantan yang tersisa secara ekonomi tidak dapat dipanen. Meskipun baik untuk tujuan konservasi dalam jangka pendek, tetapi hal ini tidak dapat diterima oleh pihak-pihak yang menginginkan lahan hutan produksi untuk kayu. Kami juga mencatat perlunya penyelarasan peraturan yang berlaku dengan petunjuk teknis. Misalnya definisi daerah perlindungan di sekitar sungai berbeda dalam peraturan TPTI (Tebang Pilih Tanam Indonesia), dalam Kode Etik Kegiatan Pemanenan Hutan di Asia Pasifik yang dikeluarkan FAO (FAO Code of Practice for Forest Harvesting in Asia-Pacific) dimana Indonesia ikut menandatangani, serta dalam panduan penebangan yang berdampak minimum (Reduced Impact Logging - RIL) yang disahkan oleh Departemen Kehutanan (Elias et. al. 2001). Upaya menyelaraskan peraturan dan panduan ini merupakan tugas pemerintah dan mekanisme pasar (misalnya, melalui standar sertifikasi). Namun demikian, yang lebih penting bagi pengelola hutan serta pakar biologi adalah ikut berperan aktif dalam membantu proses ini untuk mencapai tujuan akhir secara birokratis, tetapi juga dapat dikerjakan dan bermanfaat bagi tujuan-tujuan konservasi.

Tidak semua hal dapat ditetapkan oleh peraturan dan perundangan karena pengelolaan selalu dihadapkan pada penetapan prioritas yang bertentangan satu sama lain, pemahaman masyarakat setempat dan adanya inovasi baru. Dengan demikian diperlukan visi yang jelas. Tujuan utama kami adalah: 1) untuk mempertahankan bentang alam hutan yang cukup luas dan saling terkait (termasuk areal yang 
tidak ditebang) yang mengandung tipe-tipe hutan asli seutuh mungkin dan memelihara elemen-elemen bentang alam yang penting dan satwa liar yang ada di dalamnya; 2) mengidentifikasi ancaman-ancaman utama terhadap kehidupansatwa liar dalam bentang alam tersebut dan mengambil langkah-langkah untuk mengatasi ancaman tersebut.

Bagaimana temuan kami dapat diterjemahkan ke dalam usulan-usulan praktis bagi pihak yang sehari-harinya berhubungan dengan kegiatan kehutanan dan masalah hidupan liar? Ada tiga kelompok utama stakeholders yang kami soroti:

1. Pengelola konsesi hutan $(\mathrm{HPH})$

2. Pemerintah dan badan yang berwenang dalam pengaturan

3. Peneliti dan ahli biologi konservasi

\section{Rekomendasi bagi para pengelola hutan}

Pengelola hutan memiliki serangkaian hak untuk memanen kayu. Namun pihak pengelola memiliki juga tanggung jawab terhadap hak pengelolaan, termasuk di dalamnya menangani dan menghadapi ancaman terhadap hutan dan hidupan liarnya. Hal ini bukanlah tanggung jawab yang ringan dan para pengelola tersebut sering merasa tidak mempunyai fasilitas untuk melakukannya. Panduan untuk dapat mengidentifikasi dan melaksanakan prioritas tersebut tidak mudah di dapat.

Kami mulai dengan mengusulkan kegiatan yang dapat dilakukan dalam perencanaan dan pelaksanaan penebangan. Keanekaragaman struktur dan heterogenitas merupakan faktor yang sangat penting dalam menentukan kekayaan spesies suatu komunitas dalam lingkungan hutan alam, sehingga memelihara habitat dan keragaman struktur hutan tersebut merupakan hal yang penting. Upaya tersebut dapat juga diarahkan langsung untuk melindungi sumberdaya alam tertentu atau karakteristik bentang alam yang khusus (seperti pohon yang menjadi sumber makanan, liana, gua, rembesan mata air mineral/tempat pengasinan - salt licks, sungai yang jernih) yang diperlukan oleh sejumlah taxa tertentu. Kegiatan-kegiatan tersebut relevan/dapat dilaksanakan dalam identifikasi wilayah yang lebih luas yang memungkinkan untuk dikeluarkan dari kegiatan penebangan serta dalam penetapan batas wilayah pemanenan. Kami tidak menjelaskan konsep dan prosedur umum RIL seperti perencanaan jalan sarad dan arah rebah pohon (lihat Elias et al. 2001 untuk panduan yang lebih rinci dan praktis). Rekomendasi kami hendaknya dipandang sebagai tambahan dan dukungan bagi prosedur RIL yang baik untuk keragaman hayati.

Kami mengelompokkan masing-masing rekomendasi pengelolaan tersebut sebagai 'wajib/ harus dilakukan', 'sangat dianjurkan', atau 'dianjurkan'. Kategori yang keempat yaitu 'Wajib/harus dilakukan dan memerlukan perbaikan aturan' merupakan rekomendasi yang sangat penting yang memerlukan amendemen terhadap peraturan yang ada atau pembentukan peraturan yang baru. Secara umum, kami mendukung sebagian besar rekomendasi dalam TPTI (dengan beberapa pengecualian khusus), dan penyempurnaan pustaka dari Elias et al. (2001) sebagai konsensus yang terbaik dalam RIL saat ini dan praktek penebangan yang baik. 


\section{Perencanaan yang matang sebelum kegiatan penebangan}

- Setiap kegiatan penebangan harus didahului oleh kegiatan survei yang dirancang secara hati-hati dan perencanaan yang mempertimbangkan silvikultur dan aturan penebangan, metoda pengumpulan/analisa data, penetapan batas wilayah produksi dan wilayah perlindungan, hydrographic, dan jaringan jalan (sebagai yang harus dilakukan);

\section{Perencanaan untuk tujuan khusus}

Tujuan kami adalah untuk meningkatkan keberadaan satwa yang peka terhadap penebangan dan fragmentasi hutan pada areal yang telah ditebang. Banyak pustaka yang mengulas pemantauan bentang alam melalui perhitungan berbagai indeks menggunakan penginderaan jauh dan Sistem Informasi Geografis (SIG). Hal ini terlihat dalam perangkat untuk menentukan kriteria dan indikator (C\&I, e.g., Stork et al. 1997). Manfaat SIG berbeda-beda bagi tiap pengelola. Kami lebih menekankan perencanaan ruang yang dapat memperlihatkan perbedaan jaringan jalan dan kemungkinan fragmentasi yang dapat diantisipasi dengan jelas, sehingga dampak kegiatan penebangan dapat diketahui dan dipertimbangkan dengan seksama.

Perencanaan hendaknya mempertimbangkan upaya perbaikan areal yang rusak dan melibatkan kajian yang menyeluruh dari lahan-lahan yang ada di sekelilingnya serta ancaman yang mungkin timbul. Sebagai contoh, di beberapa tempat, jalur penahan api (frebreaks) lebih penting dibandingkan dengan efek tepi (ekoton) yang dapat ditimbulkan oleh jalur penahan api tersebut. Dalam beberapa hal, tepian hutan diidentifikasi sebagai relung yang disukai oleh beberapa spesies spesifik tertentu. Seluruh faktor tersebut harus menjadi bahan pertimbangan dan dipertimbangkan. Perencanaan kemudian dapat dianggap sebagai perencanaan yang memiliki keseimbangan integritas spasial yang mempertimbangkan keseluruhan aspek, termasuk pemangku kepentingan yang lebih luas. Begitu disetujui, rencana tersebut menjadi dokumen mengenai hal-hal yang perlu/dapat diverifikasi. Dengan demikian indeks-indeks yang sifatnya abstrak tidak diperlukan lagi.

Paling tidak proses perencanaan tersebut harus memastikan bahwa habitat dan spesies langka, tidak umum, maupun peka harus mendapatkan perhatian yang selayaknya. Kajian sebaiknya dapat mengidentifikasi penyumbang informasi yang bermanfaat, termasuk kearifan lokal yang selama ini terabaikan. Tujuan lain dari pengelolaan adalah untuk menyeimbangkan dengan kebutuhan lain yang mungkin dapat berupa kegiatan yang diarahkan untuk mempertahankan konektivitas hutan, meminimalkan lebar dan panjang jalan, menghindari pembentukan ekosistem tepi/ pinggir hutan (ekoton) yang tidak diinginkan, dan mempertahankan areal-areal yang merupakan perwakilan dari keseluruhan habitat alami. Pengkajian yang dilakukan sebaiknya juga diarahkan bagi pencarian bukti bahwa pertimbangan pengelolaan maupun pertimbangan terhadap hidupan liar akan mempengaruhi penentuan pilihan (contohnya, pilihan-pilihan $A, B$, dan $C, C$ dipilih karena,...). Ketentuan yang khusus dan terkait dengan kondisi setempat tersebut mengarah pada pengkajian langsung, seperti yang telah dilakukan dalam tingkat operasional di beberapa juta hektar hutan di DAS Kongo (Nasi \& Forni 2003). 
Dalam hal pewilayahan (zonasi), Elias et al. (2001) mencatat perlunya daerah yang dikhususkan, seperti daerah cagar budaya, aliran air, badan air dan tepian air, daerah longsor, zona konservasi dan perlindungan, daerah hutan masyarakat dan masyarakat setempat, zona konservasi keanekaragaman hayati, zona konservasi kehidupan satwa liar, zona bagi penelitian ilmiah, dan daerah penyangga. Daerahdaerah tersebut dapat direncanakan dan dipetakan.

\section{Pengkajian dampak lingkungan dan inventarisasi}

Di Indonesia, seluruh kegiatan yang berkaitan dengan penebangan kayu harus diawali dengan pengkajian dampak lingkungan sebagaimana tercantum dalam Bagian Dua, Pasal 13, Undang-undang Kehutanan (1999):

(1) Inventarisasi hutan harus dilaksanakan untuk mengetahui dan mengumpulkan data dan informasi yang berkaitan dengan sumberdaya, kekayaan alam hutan dan lingkungannya secara menyeluruh.

(2) Inventarisasi hutan seperti tercantum, dalam ayat (1) harus dilaksanakan melalui survei status dan kondisi fisik hutan, flora dan fauna, sumberdaya manusia, dan kondisi sosial masyarakat yang hidup di dalam dan di sekitar hutan.

(3) Inventarisasi hutan seperti tercantum dalam ayat (2) harus mencakup inventarisasi hutan di tingkat nasional, inventarisasi hutan di tingkat regional, inventarisasi butan di tingkat daerah aliran sungai, dan inventarisasi hutan pada tingkat unit pengelolaan.

Hasil dari kegiatan inventarisasi hutan seperti tercantum, dalam ayat (1), ayat (2), dan ayat (3) harus digunakan oleh para pihak sebagai dasar untuk menentukan batas wilayah hutan, pengaturan keseimbangan sumberdaya hutan, persiapan perencanaan hutan dan sistem informasi kehutanan.

Bila dilaksanakan dengan standar teknis yang layak dan digunakan sebagai masukan baru dalam menetapkan pilihan-pilihan pengelolaan, kami yakin bahwa kegiatan ini dapat mendukung kegiatan dan tujuan-tujuan konservasi. Kami rekomendasikan bahwa inventarisasi diarahkan secara khusus kepada status dari spesies lokal yang penting. Perhatian khususnya harus diarahkan pada distribusi spesies dan ancaman terhadap spesies yang tercakup dalam kategori sebagai berikut:

- Dilindungi oleh Undang-undang nasional (lihat contoh dalam Noerdjito \& Maryanto 2001) (wajib);

- Memiliki status konservasi yang tinggi oleh lembaga konservasi dunia (World Conservation Union) (lihat IUCN 2002, 2003) (wajib);

- Sangat dipengaruhi keberadaannya oleh kegiatan penebangan dan efek-efeknya. Sebagai contoh, spesies yang hanya dapat dijumpai (hidup) dalam hutan primer atau aliran sungai yang tanpa gangguan (lihat Tabel 14) (sangat dianjurkan);

- Banyak digunakan oleh, atau memiliki nilai manfaat yang tinggi bagi masyarakat setempat (lihat Tabel 15) (wajib/perlu perubahan peraturan). 
Kami sangat menganjurkan adanya kaitan yang jelas antara kegiatan pengambilan data dan penggunaan data tersebut dalam kegiatan pengelolaan. Sebaiknya data inventarisasi ini ditampilkan dalam format SIG. Saat ini, sebagian besar data dikumpulkan sebagai salah satu kegiatan yang sifatnya memenuhi kebutuhan birokrasi dan laporan serta catatannya dibuat hanya untuk memenuhi persyaratan saja, sehingga data yang terkumpul tersebut tidak selalu dianggap penting sebagai masukan bagi perencanaan dan seringkali diabaikan saja.

- Areal dengan rencana pemanfaatan yang berbeda harus tergambar dengan jelas dalam peta (wajib) dan batas fisiknya di lapangan harus ditetapkan (wajib). Elias et al. (2001) menganjurkan penandaan keliling zona penyangga dengan "hurufT terbalik" (misalnya, dengan cat) setinggi mungkin pada sisi pohon yang menghadap ke daerah penebangan (sangat dianjurkan). Selain itu, tanda-tanda yang secara jelas menunjukkan status dari blok-blok hutan tertentu serta kegiatan-kegiatan yang diijinkan atau tidak diijinkan harus ditetapkan (sangat dianjurkan).

\section{Perencanaan untuk kegiatan konservasi}

- Setiap kawasan lindung harus digambarkan batas-batasnya secara jelas dalam peta penebangan hutan untuk setiap areal konsesi dan batas-batas tersebut harus terlihat secara jelas di lapangan (wajib). Hal ini sangat penting dilakukan untuk mencegah terjadinya pergeseran batas dan perubahan luas kawasan lindung di sekitar areal konsesi dan terjadinya penebangan, sementara di atas kertas kawasan tersebut masih dalam status dilindungi (hal ini terjadi dalam kawasan lindung di Kalimantan Timur dan di Virgin Jungle Reserve di Semenanjung Malaysia (Wildlife Conservation Society (WCS) \& Departemen Kehutanan Sarawak (Sarawak Forest Department) 1996, Rijksen \& Meijaard 1999);

- Habitat untuk spesies yang dilindungi harus dikelola sedemikian rupa dengan mencegah kegiatan-kegiatan yang merugikan bagi keberadaan dan kemampuannya untuk bertahan. Hal ini secara jelas memerlukan pendekatan yang seimbang, yaitu dengan prosedur perencanaan yang mengkaji spesies mana yang menjadi prioritas dalam wilayah konsesi tertentu, dan bagaimana keberadaan spesies tersebut dapat dilindungi dalam jangka panjang. Prosedur ini harus dievaluasi secara teratur dan menambahkan informasi baru serta melakukan pendugaan faktor risiko bagi spesies tertentu. (sangat dianjurkan);

- Untuk beberapa konsesi mungkin perlu ditetapkan untuk mencapai tujuan keanekaragaman hayati berhubungan dengan nilai-nilai khusus lokasi-lokasi tertentu di dalam areal konsesi Contohnya kawasan konsesi tertentu memiliki jumlah spesies langka yang tinggi, dan pengelolaannya mensyaratkan perlindungan habitat serta mengurangi ancaman yang terkait terhadap spesies tersebut (dianjurkan);

- Jika direncanakan konservasi untuk spesies-spesies tertentu, maka sebelum kegiatan penebangan dilakukan harus dipertimbangkan bersama pengelolaan khusus untuk spesies tersebut, bimbingan/arahan ahli, pengetahuan lokal dan penelitian ekologis kaitannya dengan perlindungan dari spesies yang lain (sangat dianjurkan); 
- Membangun dan memelihara basis data dalam bentuk catatan atau SIG untuk memantau keberadaan spesies prioritas (lihat bagian yang menjelaskan pengelolaan yang spesifik bagi spesies tertentu di bawah ini) dan persyaratan ekologisnya yang penting (wilayah penggembalaan ternak, mata air mineral, dan sebagainya) (dianjurkan);

- Setidaknya $10 \%$ dari luasan daerah hutan komersial harus dilindungi sebagai penghubung antara kelompok-kelompok hutan yang tidak ditebang sehingga dapat berfungsi sebagai daerah perlindungan sementara, yang kemudian akan menjadi tempat bagi spesies untuk menempati kembali daerah di sekelilingnya (Fimbel et al. 1998) (sangat dianjurkan). Harus pula diperhatikan bahwa meskipun hutan dataran rendah sering merupakan sumber kayu komersial bernilai tinggi, daerah ini juga merupakan habitat satwa liar yang sangat penting dan sebagian dari wilayah ini harus disisakan sebagai wilayah yang tidak ditebang (sangat dianjurkan);

- Daerah bebatuan (umumnya kapur) dan gua merupakan daerah yang rentan terutama bila digunakan untuk bahan pembuatan jalan dan penggalian/ penambangan. Di Malinau, beberapa daerah perbukitan kapur dan gua telah rusak karena adanya pembangunan jalan. Identifikasi daerah penting yang rentan ini untuk dilindungi harus memberikan dasar yang kuat bagi pengembangan daerah perlindungan dalam bentang alam hutan luas serta identifikasi ini harus dilakukan sebelum kegiatan penebangan dilakukan (sangat dianjurkan);

- Areal-areal tebangan tahunan yang tersebar di seluruh hutan dapat membantu regenerasi hutan dan migrasi satwa liar yang terganggu oleh kegiatan penebangan (DFID 1999), meskipun upaya ini akan mempersulit perencanaan jalan dan pengawasan (dianjurkan).

\section{Memelihara kesinambungan (konektivitas) bentang alam dan perlindungan daerah aliran sungai}

Memelihara koridor di bagian dalam hutan dapat memberikan efek positif bagi satwa vertebrata (Marcot et al. 2001). Banyak spesies yang memberikan respons yang negatif terhadap fragmentasi terutama yang biasanya hidup di hutan primer, sehingga koridor dapat bermanfaat baginya (Lovejoy et al. 1986, Laurance 1991, Stouffer \& Bierregaard 1995, Bierregaard \& Stouffer 1997). Sebaiknya, celah dalam koridor hutan harus dihindari. Burung (Bierregaard et al. 1992) dan mamalia (Laurance 1990, Goosem 1997) yang hidupnya bergantung pada hutan terlihat menghindari areal terbuka walaupun tidak begitu lebar (50-100m) (Stouffer \& Bierregaard 1995, Malcolm \& Ray 2000). Kami menyarankan untuk mempertahankan suatu areal hutan berdasarkan dua faktor, yaitu areal perlindungan dan koridor penghubungnya. Areal perlindungan ditetapkan dan dilindungi berdasarkan karakteristik keberadaan dan fungsinya (contohnya, perlindungan daerah aliran sungai, daerah perburuan, kuburan, habitat yang penting bagi spesies tertentu). Hal ini mencakup daerah resapan, lahan dengan kemiringan yang curam, daerah sempadan sungai, daerah di sekeliling tempat pemijahan/perkembangbiakan spesies yang terancam punah, dan sebagainya koridor hutan merupakan bagian dari hutan yang diperlukan untuk mempertahankan konektivitas daerah-daerah perlindungan tersebut. Meskipun 
sebagian areal ini berukuran kecil (misalnya, kuburan atau areal perlindungan mata air mineral), dalam jaringan koridor hutan yang lebih luas, termasuk sempadan sungai dan hutan di lereng yang curam sejauh mungkin harus direncanakan sebagai penghubung areal perlindungan.

Kami mencatat ketidakkonsistenan dalam sejumlah panduan tentang daerah penyangga sempadan sungai/sungai besar dan pelaksanaannya. Dalam hal ini baik penjelasan dalam TPTI dan Elias et al. (2001) sama-sama kurang jelas. Contohnya, TPTI mensyaratkan $100 \mathrm{~m}$ daerah penyangga pada setiap sisi sungai yang besar dan $50 \mathrm{~m}$ di masing-masing sisi anak sungai, tetapi tidak dijelaskan bagaimana membedakan atau menentukan ukuran "sungai besar". Demikian pula dalam Elias et al. 2001, "sungai kelas $1=30 \mathrm{~m}$ di masing-masing sisi, sungai kelas $2=20 \mathrm{~m}$ di masing-masing sisi, dan kelas 3 di masing-masing sisi”, tanpa ada penjelasan besar sungai kelas 1, kelas 2, dan kelas 3 .

- Peraturan yang ada mensyaratkan penetapan zona bebas penebangan untuk melindungi sungai yang besar, sungai dan badan air lainnya untuk mempertahankan koridor hutan yang dilindungi di sepanjang badan air yang lebih besar (wajib).

Bagaimana peraturan seharusnya dilaksanakan untuk sungai dan aliran air tidak begitu jelas.

- Kami menganjurkan untuk mengikuti Sist et al. (1998a), yaitu berdasarkan lebar maksimum sungai (dua kali atau lebih) (sangat dianjurkan), kecuali untuk jalan yang memotong sungai/penyeberangan;

\begin{tabular}{cc}
\hline Lebar sungai $(\mathbf{m})$ & Perlindungan $(\mathbf{m})$ di setiap sisinya \\
\hline$>40$ & 100 \\
\hline $21-40$ & 40 \\
\hline $11-20$ & 25 \\
\hline $1-10$ & 10 \\
\hline$<1$ & tidak perlu \\
\hline
\end{tabular}

- Perlindungan sungai mencakup penandaan zona areal yang tidak ditebang sepanjang aliran sungai sebelum pembangunan jalan dan kegiatan penebangan berlangsung. Penandaan ini harus dilakukan baik dalam peta kerja dan di lapangan (sangat dianjurkan). Selain itu diperlukan pemeriksaan yang teratur agar kegiatan penebangan dan pengeluaran kayu tidak terjadi di dalam areal tersebut (sangat dianjurkan). Areal perlindungan berupa hutan penyangga dalam jumlah yang layak pada setiap sisi sungai merupakan jaringan hutan yang relatif masih baik yang sangat berharga untuk mempertahankan kesinambungan keseluruhan bentang alam;

- HTI dan THPB (lihat keterangan singkatan), yaitu daerah yang didominasi oleh hutan tanaman industri dengan keragaman yang rendah, perkebunan, atau hutan 
rakyat (baik spesies eksotis ataupun asli) memiliki nilai yang rendah bagi satwa liar dibandingkan dengan hutan campuran asli. Namun demikian, beberapa spesies menggunakan areal ini sebagai koridor penghubung antara daerah yang berhutan alam (Laidlaw 2000). Kami anjurkan untuk memilih kegiatan perkebunan pada lokasi yang bisa menghubungkan bagian dan areal hutan yang terputus (dianjurkan);

- Seluruh daerah koridor dan daerah lindung ini harus dipetakan dan dipertahankan (sangat dianjurkan);

- Kesinambungan tajuk pohon harus dipelihara pada tempat-tempat tertentu (sangat dianjurkan). WWF Malaysia merekomendasikan lokasi-lokasi penyeberangan pada setiap $100 \mathrm{~m}$ panjang jalan (Muziol et al. 2000). Pemeliharaan dan pembersihan jalan secara manual sangat dianjurkan dibanding penggunaan alat berat dan membatasi pergerakan buldoser akan memperkecil kerusakan tegakan tinggal dan memperkecil pembukaan tajuk (gap). Tajuk atas yang berkaitan juga dapat mengurangi tekanan hujan terhadap badan jalan sehingga mengurangi jumlah aliran permukaan, pemadatan, dan kerusakan badan jalan.

\section{Meminimalkan kerusakan selama kegiatan penebangan dan kegiatan lain yang terkait}

\section{Sarana dan Prasarana Jalan}

- Basecamp penebangan harus ditempatkan secara strategis, sejauh mungkin dari zona hutan yang tidak ditebang, terutama zona-zona yang ditujukan untuk manfaat bagi satwa liar (sangat dianjurkan);

- Jalan harus ditempatkan setidaknya $100 \mathrm{~m}$ dari sungai (Elias et al. 2001) (sangat dianjurkan);

- Jalan dan jalan sarad harus direncanakan secara detail dengan tujuan meminimalkan kerusakan tajuk (DFID 1999) (wajib). Di Sabah, perencanaan seperti ini secara nyata meningkatkan efisiensi dan menurunkan biaya pemanenan, dari 4,51 dollar US per $\mathrm{m}^{3}$ dalam kegiatan penebangan konvensional menjadi 1,98 dollar US per $\mathrm{m}^{3}$ dalam kegiatan RIL (Tay 1999);

- Tanjakan jalan secara umum harus kurang dari 10\% (kurang dari $6^{\circ}$ ). Apabila tidak dapat dihindari, dengan tanjakan hingga 20\% (kurang dari $12^{\circ}$ ) dengan panjang jalan dapat ditoleransi dengan jarak tidak lebih dari $500 \mathrm{~m}$ (maksimum). Namun batas ini tidak boleh dilampaui (Lihat Elias et al. 2001 untuk panduan yang lebih rinci dari setiap jenis jalan) (sangat dianjurkan);

- Ada pertentangan agar jalan harus selurus mungkin untuk mengurangi biaya pembangunan jalan dan luas daerah yang terpengaruhi, atau menghindari pohon yang tinggi yang tidak akan ditebang untuk meminimalkan kerusakan tajuk. Pada umumnya pembangunan jalan yang lurus akan menebang pohon besar penghalang tanpa pertimbangan dan akan menyebabkan kerusakan tajuk yang berat (Malcolm \& Ray 2000). Namun demikian, jalan yang lurus dianggap memiliki manfaat secara ekologis dan finansial, karena dapat meminimalkan luasan total daerah yang rusak dan mengurangi waktu penyaradan kayu. Manfaat 
ekologis dan ekonomi ini harus seimbang dalam proses perencanaannya (sangat dianjurkan);

- Jaringan jalan dan jalan sarad yang berbentuk "tulang ikan” dan pengumpulan kayu hasil tebangan secara teratur dapat mengurangi kerusakan tegakan tinggal yang tersisa dan meningkatkan efisiensi penebangan (Johns et al. 1996) (dianjurkan)

- Menghentikan praktek "tebangan matahari" yang menebang seluruh pohon tepi untuk mengeringkan permukaan jalan dengan sinar matahari (sangat dianjurkan). Kegiatan ini sering menghasilkan bukaan dengan lebar keseluruhan lebih dari 50 m. Bukaan ini memberikan dampak yang besar terhadap tingkat sedimentasi dan erosi (Gambar 22) dan bila jalan dibangun dengan baik, hal ini tidak perlu terjadi. DFID (1999) merekomendasikan lebar keseluruhan sebesar $4 \mathrm{~m}$ (juga Elias et al. 2001), sementara Dykstra dan Jeinrich (1996) dan Mason dan Thiollay (2001a) menyarankan bukaan maksimum untuk jalan utama selebar 7,5 m dan $5 \mathrm{~m}$ untuk jalan kecil;

- Pembangunan jalan dan jalan sarad utama harus dilaksanakan dalam cuaca yang kering dan sesaat sebelum penebangan dilakukan (DFID 1999, Elias et al. 2001) (sangat dianjurkan);

- Jalan sarad harus direncanakan sebelum kegiatan penebangan (DFID 1999, Elias et al. 2001) (wajib);

- Jalan sarad harus dirancang sependek mungkin dengan mengikuti kontur lahan (sangat dianjurkan). Jalan sarad ini harus dibangun dengan menghindari daerah yang curam, lembah yang sempit, rawa, dan tanah yang tidak stabil dan meminimalkan jumlah penyeberangan sungai (sangat dianjurkan) (Elias et al. 2001);

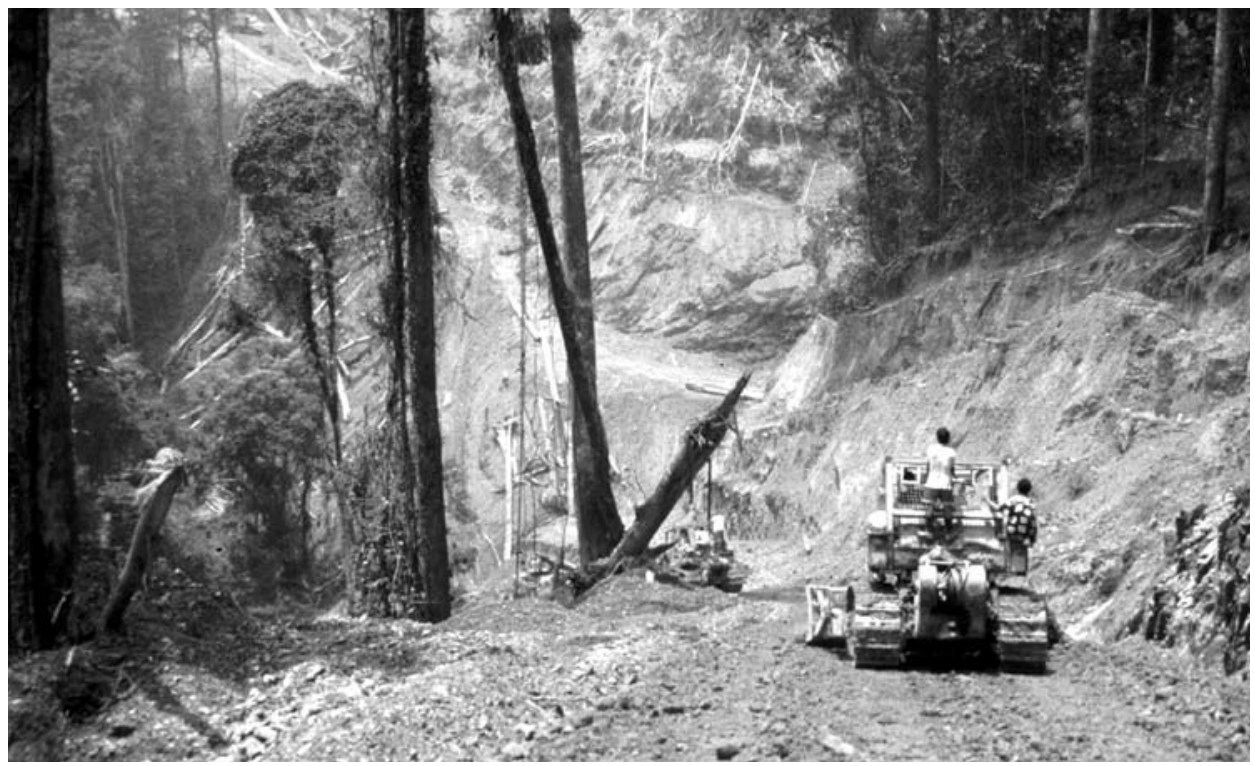

Gambar 22. Jalan untuk kegiatan penebangan sering kali memiliki lebar yang berlebihan, meningkatkan efek fragmentasi hutan dengan membatasi pergerakan satwa dan meningkatkan tingkat sedimentasi dan erosi. (Foto oleh Rob Fimbel) 
- Akar, cabang, dan vegetasi pada jalan sarad sedapat mungkin harus dipertahankan (DFID 1999). Pemanfaatan sisa penebangan tersebut pada areal yang dilalui alat berat dengan intensitas tinggi akan mengurangi pemadatan tanah dan membantu regenerasi hutan (Brearley et al. 2003) (sangat dianjurkan);

- Tempat pengumpulan kayu harus ditempatkan pada daerah yang datar dengan kemiringan maksimum $10 \%$ (kurang dari $6^{\circ}$ ) atau puncak bukit, jauh dari sungai dan badan air, dan di luar zona perlindungan (wajib).

Banyak spesies amfibia, ikan, beberapa spesies reptilia, burung, dan kemungkinan juga berang-berang dan Musang Air (Cynogale bennettii) tergantung pada air jernih untuk berkembang biak dan mencari makan. Sistem drainase yang baik yang mengalirkan air ke daerah yang bervegetasi, jembatan serta kolam genangan yang dibangun dan dirawat dengan baik, sangat penting untuk mempertahankan kejernihan sungai. Kualitas air juga merupakan masalah besar bagi manusia dan satwa liar yang tinggal di bagian hilir sungai. Beberapa saran di bawah ini banyak didasari oleh penelitian DFID (1999).

- Jembatan harus dibangun dengan baik sehingga luapan air dapat lewat tanpa merusak struktur jembatan tersebut (wajib), pondasi ujung jembatan harus terpancang dengan baik sehingga tidak hanyut terbawa air, dan penyangga di atas dan di bawah jembatan harus distabilkan dengan kayu yang kuat (seperti Dialium indum-keranji, Cotylelobium spp. (giam, resak gagil), Dipterocarpus spp. (keruing), Dryobalanops spp. (kapur), beberapa spesies yang lebih berat seperti Hopea spp. (merawan) dan Vatica spp. (resak)), batu atau beton. Lapisan sejenis "geotextile" atau polythene dipasang antara kayu pendukung utama dan tanah yang melapisi kayu tersebut (terpal sejenis ini harus dibuang dengan hati-hati dan tidak dibolehkan hanyut atau tercuci ke sungai). Kayu penghalang diletakkan di setiap sisi jembatan untuk mencegah agar tanah dari jalan tidak jatuh ke dalam badan air. Celah-celah yang ada di antara kayu pendukung utama (gelagar) harus diisi dengan kayu-kayu berukuran kecil, benih kayu spesies nonkomersial, potonganpotongan sisa penggergajian, atau bahan-bahan sejenis, sebelum lapisan terpal tersebut di pasang (lihat Elias et al. 2001);

- Genangan air yang disebabkan oleh pembangunan jalan atau persimpangan jalan, atau kegiatan pembangunan jalan yang mempunyai pengaruh terhadap drainase secara lokal (meskipun umumnya belum diteliti) harus dihindari (dianjurkan);

- Pembentukan badan jalan dan tempat pengumpulan kayu sementara (TPn) harus dilakukan sedemikian rupa sehingga aliran air diarahkan ke daerah yang bervegetasi dan tidak langsung ke sungai. Hal ini bisa dilakukan dengan membelokkan aliran ke luar ke arah vegetasi di sekelilingnya setidaknya $50 \mathrm{~m}$ sebelum mencapai badan air (Elias et al. 2001) (sangat dianjurkan);

- Gunakan jerat/penahan lumpur bila diperlukan (sangat dianjurkan);

- Gorong-gorong harus dibangun (dianjurkan) untuk memperlancar aliran air dan membantu perpindahan spesies mamalia, reptilia, dan amfibia (Clevenger et al. 2001); 
- Gorong-gorong dan saluran drainase harus dipelihara secara teratur (sangat dianjurkan);

- Seluruh jalan angkutan dan jalan sarad harus dikonstruksi dengan baik sehingga proses pengeringan badan jalan dapat lebih efektif. Hindari gundukan pada tepi jalan angkutan dan jalan sarad, tersebut karena dapat mencegah aliran air keluar jalur jalan untuk menuju lantai hutan (sangat dianjurkan).

\section{Daerah lindung}

- Daerah perlindungan dan koridor penghubung harus dikelola dengan cara sebagai berikut (berdasarkan Elias et al. 2001):

a) Tidak dibolehkan melakukan penebangan pohon dalam daerah lindung dan daerah penyangganya (wajib);

b) Akses bagi alat berat dilarang, kecuali bila jalan yang direncanakan melintasi daerah tersebut. Seluruh jalan dan penyeberangan badan air harus dirancang dengan baik dan sungai dilindungi secara hati-hati (sangat dianjurkan);

c) Tidak ada penggalian atau sisa penggalian jatuh/terbuang ke dalam daerah lindung (sangat dianjurkan);

d) Tidak ada limbah penebangan yang dibuang ke arah daerah lindung, terutama ke arah badan air (sangat dianjurkan);

e) Pohon harus ditumbangkan tidak ke arah daerah penyangga dan sungai (sangat dianjurkan);

- Penambahan rotasi penebangan tidak kurang dari 40 tahun (sangat dianjurkan). Rotasi penebangan di Indonesia umumnya 35 tahun, tapi saat ini sedang dalam pengkajian ulang. Berbagai penelitian menunjukkan bahwa memperpanjang daur penebangan tidak hanya memperbaiki kondisi konservasi keanekaragaman hayati tetapi juga memperbaiki keberlanjutan produksi kayu (Muziol et al. 2000, van Gardingen et al. 2003, Sist et al. 2003a, b).

\section{Meminimalkan kerusakan di daerah produksi}

Mengurangi kerusakan-kerusakan kecil yang biasanya ada di sepanjang jalan sarad dan tempat pengumpulan kayu umumnya dapat mengurangi dampak kegiatan penebangan terhadap vertebrata. Daerah yang terbuka biasanya ditumbuhi oleh tanaman merambat dan kemudian oleh spesies pionir. Umumnya, spesies pionir ini bukan sumber makanan yang baik bagi satwa pemakan buah. Sebagian besar mamalia pohon (arboreal) dipengaruhi oleh lebarnya rumpang antara tajuk (Putz et al. 2001b) sehingga mempertahankan tajuk/tajuk bagian tengah yang relatif utuh dan saling terkait dapat memberikan manfaat yang besar bagi spesies-spesies tersebut. Sist et al. (2003b) menganjurkan untuk memastikan jarak minimum antara tunggak pohon yang ditebang dengan tujuan untuk mengurangi intensitas penebangan maupun ukuran rumpang. Kegiatan penelitian di Kalimantan Timur menunjukkan bahwa kerusakan akibat penebangan hanya dapat dikurangi secara nyata bila teknik RIL diterapkan dengan intensitas penebangan di bawah 10 pohon/ha. Jarak antara pohonpohon yang ditebang sedikitnya $35 \mathrm{~m}$ yang secara teori dapat mencapai intensitas penebangan tersebut. Namun demikian, penelitian lebih lanjut diperlukan untuk menentukan apakah aturan tersebut dapat diterapkan di lapangan. 
- Dianjurkan untuk mengidentifikasi habitat penting dan kondisi habitat yang harus dilindungi sebelum kegiatan penebangan (idealnya dilakukan oleh staf yang memiliki kemampuan dalam menentukan apa yang menjadi prioritas di tempat tersebut dan bagaimana mengenalinya serta memastikan bahwa sedapat mungkin habitat tersebut terlindungi) (sangat dianjurkan). Untuk mencegah kegiatan ini menjadi beban bagi konsesi, dapat ditetapkan bahwa hanya sejumlah lokasi dan tegakan yang dilindungi per petak tebangan (misalnya paling banyak 5 batang dan 2 lokasi per ha);

- Dianjurkan untuk membatasi penebangan pohon komersial dengan kisaran diameter setinggi dada (dbh) $60-100 \mathrm{~cm}$, sehingga memungkinkan penggunaan mesin yang lebih ringan dan pembatasan ini tidak harus menjadi kendala produksi (Sist et al. 2003a) (sangat dianjurkan). Untuk mengurangi besarnya rumpang, diupayakan tidak menebang pohon dengan diameter dbh lebih dari $100 \mathrm{~cm}$. Kebanyakan pohon-pohon tersebut sering kali sulit untuk ditebang dengan aman yang biasanya pecah dan akan merusak pohon lainnya, biasanya pohon-pohon tersebut masih dapat bereproduksi dan dapat berfungsi sebagai pohon benih, serta biasanya membusuk atau berlubang;

- Memastikan bahwa pohon komersial yang ditebang ke arah yang tidak merusak tegakan tinggal (DFID 1999) (sangat dianjurkan). Menentukan konfigurasi yang terbaik bagi arah penebangan untuk memudahkan penyaradan dan winching untuk mengurangi kerusakan tegakan tinggal, dan pilihan yang diputuskan masih diperdebatkan. Rumpang yang tersebar bermanfaat karena pohon yang ditebang tidak akan tersangkut (Johns et al. 1996), dan bukaan rumpang yang dihasilkan relatif kecil. Penebangan pohon yang sedemikian rupa agar tajuk saling bertindihan (atau ke arah celah yang ada) dapat mengurangi kerusakan tajuk secara total (Malcolm \& Ray 2000), meskipun celah-celah besar antara pohon biasanya tidak baik. Keputusan arah penebangan harus diambil berdasarkan kasus per kasus, tergantung tujuan konservasi setempat dan tujuan pengelolaannya;

- Pada daerah dengan lapisan tanah yang sangat tipis atau bagian hutan dengan tanah berpasir putih, disarankan untuk tidak menebang pohon meskipun keuntungan ekonominya mungkin tinggi, karena lahan ini umumnya tidak mampu menumbuhkan kembali vegetasi apa pun (Chunkao 1978) (sangat dianjurkan). Di Kalimantan daerah seperti ini umumnya ditemukan di daerahdaerah hutan Kerangas;

- Bila terdapat spesies penting yang langka dan sensitif terhadap gangguan, teknik pengangkutan kayu dengan kabel yang dilakukan di atas pohon dapat dipertimbangkan (dianjurkan). Teknik ini umumnya digunakan pada kondisi topografi yang terjal yang memerlukan biaya lebih mahal dibandingkan dengan penyaradan dengan menggunakan buldoser (Aulerich et al. 1974 dalam Pinard et al. 2000). Selain itu biaya dan potensi manfaatnya bagi hidupan liar harus dikaji secara seksama (dengan membuka daerah yang mestinya tetap utuh, nilai konservasinya masih belum jelas);

- Merencanakan daerah kerja yang berbeda pada musim kering dan musim hujan untuk meminimalkan erosi dan pemadatan tanah (sangat dianjurkan). Pengambilan kayu tidak boleh dilakukan di daerah yang peka terhadap gangguan 
selama musim hujan (Pringle \& Benstead 2001). Penyaradan dengan buldoser pada lereng yang curam harus dihindari selama musim dengan curah hujan tinggi (Mason \& Putz 2001) (sangat dianjurkan);

- Menjaga agar gangguan terhadap tanah dan lantai hutan seminimum mungkin, karena banyak invertebrata, reptilia, dan amfibia memanfaatkan tanah tersebut sebagai tempat berlindung (Fimbel et al. 2001) (sangat dianjurkan);

- Jalan sarad tidak boleh terkeruk, yaitu pada saat menyeret kayu. Buldoser yang menyeretnya harus bergerak dengan pisau yang terangkat, sehingga tidak ada gundukan bekas pisau traktor yang terbentuk dan gangguan terhadap lantai hutan dapat diminimalkan (Malcolm \& Ray 2000) (sangat dianjurkan);

- Pengupasan tanah dengan buldoser harus dibatasi hanya pada kemiringan kurang dari 45\% (kurang dari 24\%) dimana diperlukan untuk meningkatkan kestabilan dan pengendalian (Stuart \& Carr 1991 dalam Pinard et al. 2000) (sangat dianjurkan);

- Hanya buldoser dengan mata pisau yang pendek dapat digunakan (DFID 1999) (sangat dianjurkan);

- Batas kemiringan idealnya mencerminkan kondisi setempat. Para ahli menyarankan kemiringan topografi maksimum sebesar 50\% (kurang dari $27^{\circ}$ ) untuk kegiatan penebangan (sangat dianjurkan) dan kemiringan jalan sarad maksimum disarankan kurang dari $35 \%$ atau kurang dari $20^{\circ}$, atau hanya untuk kondisi tanah yang sangat baik maksimum 40\% (kurang dari 22\%) (sangat dianjurkan);

- Penggalian atau pemindahan tanah dengan menggunakan buldoser hanya boleh dilakukan untuk jarak pendek saja. Untuk jarak jauh, gunakan truk pengangkut dan loader, meskipun menggunakan cara ini harus juga diminimalkan untuk mencegah kerusakan berat terhadap vegetasi dan pemadatan tanah lebih lanjut (sangat dianjurkan);

- Proses winching harus digunakan sebanyak mungkin untuk menyarad kayu ke arah jalan sarad yang kemudian akan diangkut oleh penyarad (buldoser) (sangat dianjurkan);

- Alat penyarad (buldoser) harus bergerak mundur pada saat menyarad dan tim yang melakukan penebangan harus mencari rute penarikan dengan berjalan kaki (sangat dianjurkan);

- Metode pemanenan yang berdampak rendah lainnya harus diujicoba. Hal ini termasuk penyaradan dengan hewan, perangkat mesin yang lebih ringan, dan mesin serta perangkat angkut dengan ban karet yang lebar (dianjurkan). Penggunaan alat ini akan mengurangi pemadatan tanah, erosi, dan kerusakan terhadap tegakan tinggal.

\section{Mempertahankan kompleksitas dan keragaman habitat}

- Pohon gerowong harus dipertahankan sebanyak mungkin karena pohon ini menyediakan lubang yang penting bagi vertebrata untuk berkembang biak, bersarang, dan menyimpan makanan (wajib);

- Air yang ada di pohon (arboreal) sangat penting bagi sejumlah spesies tertentu. Tandanya adalah tanaman berkantong (pitcher plants) (Gambar 23) dan rongga dalam beberapa jenis pohon. Hal ini memang sulit untuk direncanakan 
dalam penebangan karena karakteristiknya yang merupakan habitat mikro. Mempertahankan pohon dengan batang yang besar dan penandaan tumbuhan berkantong bisa dilakukan untuk menghindari kerusakan tersebut (dianjurkan). Bila habitat tumbuhan berkantong ini dapat diidentifikasi, maka habitat yang lebih luas harus dipertimbangkan secara khusus (dianjurkan);

- Memelihara struktur tegakan yang mendukung keberadaan kayu-kayu mati dalam berbagai ukuran. Hal ini terutama dengan membiarkan tegakan pohon tua atau mati yang berukuran besar (diameter lebih dari $100 \mathrm{~cm}$ ) agar kayu mati selalu tersedia dan menyediakan tempat yang baik berupa lubang dan celah bagi burung dan mamalia bersarang (e.g., Styring \& Hussin 2004a) (sangat dianjurkan);

- Tunggak kayu yang busuk sering digunakan oleh spesies-spesies satwa seperti tupai, Beruang Madu (Ursus malayanus), luntur, cekakak hutan, dan kirik-kirik hutan (sangat dianjurkan);

- Penyiapan lokasi untuk regenerasi hutan dengan pembakaran harus dihindarkan (sangat dianjurkan) karena hal ini dapat menurunkan heterogenitas habitat dan menghancurkan banyak sumberdaya dan habitat mikro yang digunakan oleh satwa invertebrata (Ghazoul \& Hill 2001);

- Daerah dengan batuan terjal merupakan tempat bersarang dan beristirahat berbagai jenis satwa, termasuk reptilia, burung (raptor, walet/kapinis) dan mamalia berukuran kecil, selain itu daerah ini juga merupakan tempat berlindung dari satwa pemangsa (Bernard 2004). Pada areal berbatu kapur, penambangan kapur di daerah terjal sedapat mungkin harus dihindarkan, dan apabila terpaksa

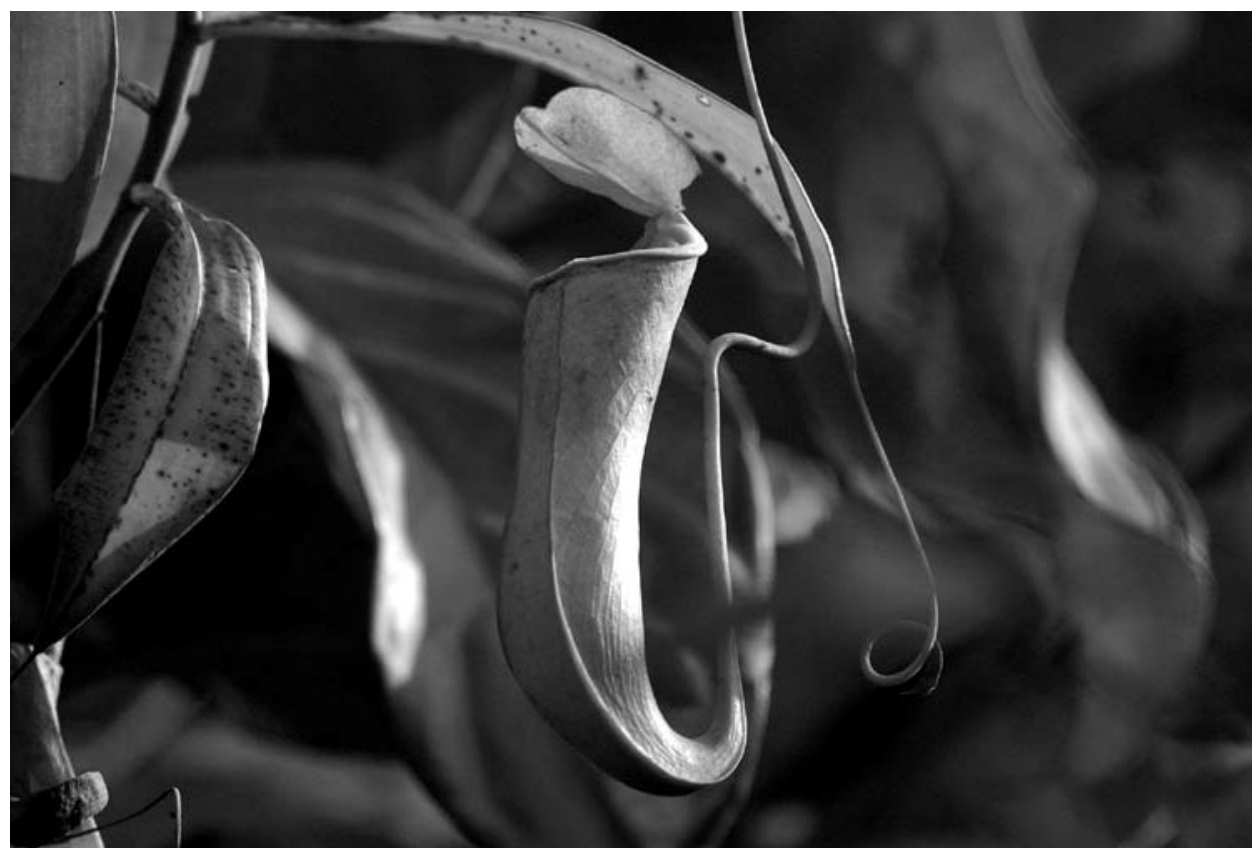

Gambar 23. Nepenthes gracilis, tumbuhan kantung semar yang dapat ditemukan di hutan dataran rendah. Tumbuhan ini merupakan habitat yang penting bagi serangga dan vertebrata kecil. (Foto oleh Kimabajo) 
penambangan kapur ini harus dilakukan berdasarkan peraturan yang dibuat dengan hati-hati (sangat dianjurkan);

- Bila gua tertentu merupakan habitat bagi spesies langka serta terancam punah dan/atau dilindungi, harus dipertimbangkan pelarangan untuk memasuki gua tersebut dan meniadakan pembangunan jalan dan sarad di daerah sekitarnya. Bila ada gua yang merupakan sumber sarang burung misalnya, bekerja sama dengan stakeholders setempat, gua-gua tersebut harus dilindungi sebagai zona yang tidak boleh ditebang (sangat dianjurkan);

- Tempat berkubang dan kolam/genangan air yang lebarnya lebih dari $1 \mathrm{~m}$ serta genangan air yang permanen atau hampir permanen, harus terlindung dari jalan sarad (dianjurkan);

- Mata air mineral (salt spring), tanah bergaram (salt earth) dan tempat dengan lempung yang biasa dimakan oleh hewan, areal tersebut harus diidentifikasi dan dimasukkan dalam perencanaan (masyarakat setempat biasanya bisa membantu mencari lokasi-lokasi tersebut). Tempat-tempat ini umumnya tidak boleh diganggu (sangat dianjurkan);

- Pemotongan liana harus dilakukan dengan pertimbangan berdasarkan pohon per pohon. Keuntungannya (memperkecil kerusakan) harus dipertimbangkan dengan kemungkinan kerugiannya (turunnya keragaman vegetasi dan buah-buahan) (dianjurkan);

- Kayu bulat sedapat mungkin harus dikupas di tempat penebangan (in situ) sebelum kegiatan penyaradan kayu dilakukan untuk mempertahankan unsur hara yang ada dalam sistem (Nykvist et al. 1994) (dianjurkan). Prosedur praktisnya memerlukan pengembangan lebih lanjut.

\section{Mempertahankan sumberdaya yang penting}

- Mempertahankan sebanyak mungkin pohon-pohon buah, terutama pohon yang berbuah sepanjang tahun yang sangat penting bagi satwa pemakan buah yang hidup di tajuk selama periode tidak ada buah (Leighton \& Leighton 1983; Lambert 1991) (sangat dianjurkan). Sumber buah yang sangat penting ini termasuk beringin, palem, Anacardiaceae (Dracontomelon spp., Koordersiondendron spp.), Euphorbiaceae (terutama Baccaurea spp, Menteng), famili Guttiferae (Garcinia spp. - Mundu), Sapindaceae (Dimocarpus spp., Nephelium spp. - kapulasan), Tiliaceae (Microros spp.), berbagai famili Fagaceae dan Jambu (Myrtaceae), serta berbagai jenis tumbuhan pemanjat, terutama Annonaceae dan jenis tumbuhan buah bukan musiman seperti tumbuhan bawah Rubiaceae, jahe, dan kerapkali vegetasi daerah rawa. Mempertahankan tajuk bagian tengah dengan meminimalkan kerusakan kecil pada pohon merupakan strategi yang baik untuk melestarikan seluruh tumbuhan palem, Annonaceae, Myristicaceae, dan Lauraceae (sangat dianjurkan);

- Beringin (Ficus spp.) sangat penting bagi satwa liar karena pohon ini menyediakan buah-buahan sepanjang tahun dan memenuhi kebutuhan nutrisi (lihat O'Brien et al. 1998a). Harus dilakukan upaya untuk melestarikan sebanyak mungkin bangsa beringin ini, berapa pun umurnya (wajib/perlu perubahan peraturan);

- Daerah pohon buah, kebun buah yang sudah tua, dan desa yang ditinggalkan 
penduduknya dikenal oleh masyarakat setempat sebagai lokasi perburuan yang baik dan sumber makanan bagi pemakan buah. Tempat-tempat seperti ini harus dilindungi dari kegiatan penebangan kayu dan pembangunan jalan (sangat dianjurkan);

- Banyak pengetahuan penduduk asli yang ditemukan berkaitan dengan spesiesspesies pohon yang penting untuk memelihara populasi satwa liar. Kearifan lokal ini harus dievaluasi dan sebanyak mungkin dimasukkan ke dalam pengelolaan konsesi (sangat dianjurkan).

\section{Kegiatan pasca penebangan}

- Setelah petak tebangan selesai, beberapa jalan angkutan harus ditutup (meskipun hanya sementara saja), sehingga satwa dapat bermigrasi tanpa gangguan dan mengurangi tekanan perburuan (sangat dianjurkan). Hal ini dapat dicapai dengan memutuskan lintasan sungai (jembatan dan gorong-gorong) atau dengan memasang pintu (gerbang). Apabila jalan sudah tidak lagi digunakan, jalan harus ditutup (diblokade atau dibongkar (Mason \& Thiollay 2001a) (sangat dianjurkan).

TPTI menyarankan pembersihan vegetasi yang tumbuh di atas tanah untuk mempercepat regenerasi. Kami berpendapat bahwa kegiatan pembersihan lebih buruk dari penebangan itu sendiri, mengingat lahan di Malinau sangat terjal maka kegiatan penebangannya terpisah-pisah. Dengan demikian, tim di lapangan melakukan dengan berjalan kaki dan menebas banyak vegetasi yang ada di hutan. Pebebasan oleh masyarakat setempat dianggap sebagai kegiatan yang sangat merusak terutama bagi banyak sumberdaya non-kayu (Sheil et al. 2003a, b). Hal ini tentu saja dapat berdampak negatif bagi banyak jenis terestrial (contohnya lihat Bernard 2004). Pada prakteknya kegiatan ini diabaikan di banyak areal konsesi.

- Kegiatan penebasan harus dikaji secara seksama dan ditinggalkan sama sekali saat tidak disyaratkan secara spesifik (wajib/perlu perubahan peraturan).

Rehabilitasi daerah yang dipanen bisa menjadi bagian dari kegiatan yang ditujukan untuk a) mengurangi erosi tanah dan sedimentasi dan b) memelihara/ meningkatkan keragaman vegetasi bagi tujuan konservasi satwa liar. DFID (1999) mencatat bahwa hal ini belum pernah dilakukan secara efektif di Indonesia. Selain itu, melaksanakan rehabilitasi hutan masih dianggap oleh banyak pihak sebagai yang tidak diperlukan di wilayah konsesi hutan dataran rendah dan hutan pegunungan. Bila hutan dikelola dengan baik, penanaman kembali hutan dalam skala luas (reforestasi) sebetulnya tidak diperlukan. Namun demikian, melindungi lokasi tertentu dari erosi masih merupakan hal yang penting.

Kegiatan rehabilitasi yang diperlukan adalah (berdasarkan DFID 1999):

- Membangun drainase yang baik melewati areal yang tanahnya padat di lokasilokasi tertentu seperti tempat pengumpulan kayu dan jalan tebangan (wajib/ perlu perubahan peraturan); 
- Lapisan tanah bagian atas pada daerah penebangan dan tempat pengumpulan kayu harus disebarkan ke seluruh daerah (sangat dianjurkan);

- Harus ada rehabilitasi sistematis pasca penebangan untuk tempat pengumpulan kayu serta penyeberangan sungai, terutama untuk mengurangi erosi tanah. Bilamana jalan atau tempat pengumpulan kayu tidak lagi digunakan dalam daur panen yang akan datang harus ada upaya untuk menghutankan kembali daerah tersebut (wajib/perlu perubahan peraturan);

- Bila perlu, rehabilitasi dengan penanaman kembali harus dilakukan setelah setiap petak tebangan selesai dikerjakan dan tidak perlu menunggu hingga seluruh bagian selesai dikerjakan (sangat dianjurkan).

Rehabilitasi areal bekas tebangan atau lahan yang sangat rusak merupakan upaya konservasi yang bermanfaat (Dunn 2004, Goosem \& Tucker 1995). Hal ini dimungkinkan bila rehabilitasi tersebut menggunakan beragam spesies pohon asli yang memiliki nilai tinggi bagi industri kayu dan bagi hidupan liar serta meningkatkan koridor antara daerah hutan asli, atau berfungsi sebagai penyangga tepi hutan.

- Daerah tanpa sisa tutupan pohon harus ditanam kembali dengan spesiesspesies pionir yang tumbuh cepat (dianjurkan). Di Malinau, penanaman ini bisa menggunakan spesies seperti Trema yang mampu bertahan dan tumbuh dalam kondisi terbuka dengan cahaya penuh/tanpa naungan. Pohon ini dapat mendukung penanaman dan pertumbuhan jenis pohon yang tahan naungan;

- Saat penanaman kembali, spesies pohon asli yang penting seperti berikut ini harus disertakan:

a) untuk hidupan liar, spesies-spesies non-meranti seperti Petai (Parkia speciosa), P. javanica, Baccaurea spp. (menteng), spesies kapulasan/rambutan (Nephelium spp.), spesies beringin (Ficus spp.), spesies mangga (Mangifera spp.), dan spesies asam (Pithecellobium spp.) atau

b) Untuk diambil kayunya dan untuk hidupan liar, misalnya Tetramarista glabra, Meliosma sumatrana, beberapa spesies nangka (Artocarpus), Pacar (Aglaia) dan spesies Dysoxylum (kayu kualitas baik), Santiria oblongifolia, Durian (Durio zibethinus) dan D. oxleyanus (untuk keperluan kayu secara umum), dan Dracontomelon dao (Keßler \& Sidiyasa 1994).

\section{Meminimalkan dampak dan ancaman tak langsung}

\section{Perburuan dan ekstraksi}

Seperti halnya di sebagian besar hutan tropis, produktivitas hutan di Borneo terbatas untuk kelangsungan kegiatan eksploitasi. Perburuan yang dikaitkan dengan pembalakan, memberikan tekanan tambahan terhadap hidupan liar dan komponen keanekaragaman hayati yang lain. Diperlukan serangkaian peraturan yang tegas dan jelas mengenai perburuan dan perdagangan satwa liar di wilayah konsesi hutan. Batas wilayah dan tanda-tandanya harus diidentifikasi dengan jelas di lapangan dan dikenal serta dipahami bagi seluruh pelaku setempat. Demikian pula halnya dengan peraturan 
setempat dan kesepakatan yang berkaitan dengan pemanfaatan dan perlindungan spesies atau lokasi, harus diketahui oleh seluruh pengguna sumberdaya yang harus diberi arahan untuk mentaati peraturan tersebut. Saran kami (dimodifikasi dari Robinson 2000 dan Fimbel et al. 2001) untuk mengurangi perburuan di wilayah konsesi hutan adalah sebagai berikut:

- Larangan bagi perburuan spesies yang dilindungi (lihat Tabel 1) (wajib);

- Larangan bagi perburuan komersial di seluruh daerah konsesi. Bila masyarakat asli telah memiliki hak untuk berburu, diperlukan negosiasi untuk menetapkan batas perburuan tersebut (wajib/perlu perubahan peraturan). Peraturan biasanya akan sulit dilaksanakan, tetapi kita bisa melihat contoh dari Sarawak yang menggambarkan berbagai hal yang dapat dilakukan dengan kemauan politik yang memadai dan mendukung (WCS 1998);

- Melarang dan menerapkan larangan pedagang segala spesies satwa liar dan bagianbagian tubuh satwa baik di dalam, keluar dari, atau yang menuju daerah konsesi, terutama bagi spesies yang dilindungi, langka, terancam punah, terancam, rentan, atau spesies yang berkembangbiaknya lambat (wajib/perlu perubahan peraturan);

- Memastikan adanya mekanisme hukum dan mekanisme praktis bagi masyarakat setempat untuk terlibat dalam pengambilan keputusan dan pengelolaan yang berkaitan dengan sumberdaya serta perburuan satwa liar di wilayahnya (wajib/ perlu perubahan peraturan). Hal ini harus dilakukan demi kepentingan pengawasan dan pengendalian untuk mencegah terjadinya pemanenan berlebih. Mekasnisme hukum dan kegiatan praktis ini dapat dicapai dengan kemitraan pengelolaan kolaboratif antara masyarakat setempat dan ahli teknis/ilmiah (dari pihak pemerintah mau pun nonpemerintah);

- Apabila perburuan untuk nafkah sehari-hari akan terus dilakukan, prosedur dan pemeriksaan yang tegas dan jelas diperlukan untuk memastikan bahwa proses ini tidak disalahgunakan (wajib/perlu perubahan peraturan);

- Zona konservasi dalam daerah konsesi yang terdapat larangan perburuan perlu ditetapkan (wajib/perlu perubahan peraturan);

- Menutup jalan yang tidak diperlukan lagi setelah kegiatan penebangan selesai (seperti yang telah dianjurkan di muka) (wajib/perlu perubahan peraturan);

- Penggunaan kejutan listrik, bom, dan racun dalam penangkapan ikan menyebabkan kerusakan berbagai komponen ekosistem akuatik. Penggunaan cara ini menyebabkan lebih banyak satwa yang mati dibandingkan dengan yang benar-benar bisa dimanfaatkan. Penggunaan alat berburu yang umum ini harus dihentikan (wajib/perlu perubahan peraturan). Penangkapan ikan bisa diizinkan bagi daerah di luar daerah lindung, dan hanya diijinkan dengan teknik dan alat yang khusus dan selektif (jaring, kail);

- Penetapan hak perburuan yang eksklusif bagi penduduk asli di wilayah tertentu akan membatasi dampak perburuan yang dilakukan oleh pendatang. Pengendalian seperti ini dapat didasari oleh peraturan dan dewan adat, serta ditambah dengan dokumen tertulis dengan hak dan kewajiban yang dinyatakan secara jelas dan tegas. (sangat dianjurkan); 
- Melarang dan memastikan bahwa kendaraan perusahaan penebangan tidak digunakan untuk mengangkut serta memperdagangkan daging satwa liar (wajib). Pos pemeriksaan di titik keluar masuk daerah konsesi penebangan dapat memastikan larangan ini ditaati serta meningkatkan keamanan dan mencegah terjadinya pencurian kayu;

- Larangan bagi perburuan dengan jerat karena alat perburuan ini tidak selektif dan banyak yang terbuang percuma (Fa et al. 2004) (sangat dianjurkan);

- Mengaitkan pembayaran upah karyawan konsesi dengan kualitas pekerjaan dan produktivitasnya sebagai upaya untuk mengurangi penggunaan waktu karyawan untuk berburu (sangat dianjurkan);

- Gunakan klausul kontrak/perjanjian yang menyatakan bahwa pelanggaran peraturan dapat mengakibatkan hukuman dan pemecatan (sangat dianjurkan);

- Karyawan konsesi harus diberi instruksi mengenai pemanfaatan sumberdaya satwa di wilayah konsesi. Karyawan tidak dapat dibebaskan untuk mengambil apa saja yang disukainya dari wilayah konsesi dan pengambilan satwa liar harus diatur dengan ketat (sangat dianjurkan);

- Pembuatan materi informasi publik dan peningkatan kesadaran masyarakat secara sederhana dan tepat harus dipertimbangkan. Materi informasi publik ini dapat disebarkan melalui jalur pemerintahan, sekolah, pedagang, dan sebagainya Namun demikian kami mencatat bahwa banyak Undang-undang dan peraturan yang diabaikan, tidak dipahami, bahkan disalahgunakan karena ketidakjelasan peraturan dan perundangan tersebut (sangat dianjurkan).

Bennet (2002) dan Lee (2000) berpendapat bahwa pengurangan tekanan perburuan satwa liar tropis mungkin dapat dicapai bila masyarakat memiliki sumber protein yang lain. Mereka menyarankan bahwa pihak konsesi/perusahaan sebaiknya diharuskan untuk memberi subsidi dan mengimpor daging dari luar daerah tersebut dan/atau mendorong peternakan skala kecil setempat (ayam, babi, kambing, atau ikan). Konsesi/Perusahaan penebangan kayu dapat membantu pengembangan program peternakan, meskipun di banyak tempat masih belum bisa menerima budaya hewan ternak sebagai sumber protein pengganti dari satwa liar. Kami mencatat pula adanya ancaman terhadap jenis-jenis satwa liar oleh hewan ternak, terutama penyakit dan perkawinan silang. Upaya peternakan harus dilakukan dengan hati-hati dengan tidak melepaskan hewan ternak, terutama babi yang telah diternakkan dan sapi Bali (banteng yang telah diternakkan), yang mungkin bercampur dengan populasi satwa liar di alam.

- Mensyaratkan perusahaan penebangan untuk menyediakan pasokan protein yang memadai bagi seluruh staf dan karyawan, dan dengan demikian dapat menghapus kebutuhan untuk berburu (sangat dianjurkan);

- Pilihan utama kami adalah bahwa perusahaan diharuskan untuk mengimpor dan memberikan subsidi daging dan ikan dari sumber di luar hutan (sangat dianjurkan). Kemudahan dan dukungan pengembangan teknologi penyimpanan daging (pendinginan dan pembekuan) akan membantu menurunkan jumlah 
daging yang terbuang atau busuk (namun hal ini akan berpotensi untuk meningkatkan risiko pemanfaatan penyimpanan untuk tujuan komersial).

\section{Kebakaran}

Kebakaran yang terjadi pada tahun 1997 dan 1998 yang telah merusak wilayah hutan yang sangat luas di Kalimantan Timur (Siegert et al. 2001) menunjukkan bahwa api dapat menyebabkan kerusakan hebat pada hutan dan hidupan liar, terutama bila dikaitkan dengan praktek penebangan hutan yang buruk (Gambar 24). Asap juga memberikan dampak yang buruk bagi manusia dan lingkungannya. Hal ini terutama di wilayah Borneo yang lebih kering karena di wilayah seperti ini api mampu menghancurkan daerah hutan produksi yang luas (Leighton \& Wirawan 1986, Woods 1989). Hal yang penting adalah adanya strategi pengelolaan kebakaran di lokasi dan tersedia apabila diperlukan dengan segera. Pada tingkat pemantauan, sistem peringatan dini yang dapat mendeteksi kebakaran (hot spots) berdasarkan citra satelit serta indeks kekeringan dapat memberikan informasi yang sangat penting bagi pengelola kehutanan (Hoffmann et al. 1999). Sejumlah sistem peringatan dini sudah ada dan berjalan dengan baik di Indonesia (Dennis 1999). Secara teoritis, sistem tersebut dapat memberikan informasi yang diperlukan bagi para pengelola kehutanan untuk pengurangan dan penanganan bencana kebakaran, pembangunan sekat bakar untuk melindungi sumberdaya yang bernilai tinggi, dan menyediakan informasi terbaru mengenai kebakaran selama dalam situasi kebakaran genting.

- Diperlukan pelatihan bagi pemadam kebakaran di unit pengelola hutan di lapangan, konsesi di tingkat kabupaten yang selalu siaga. Selain itu diperlukan pula

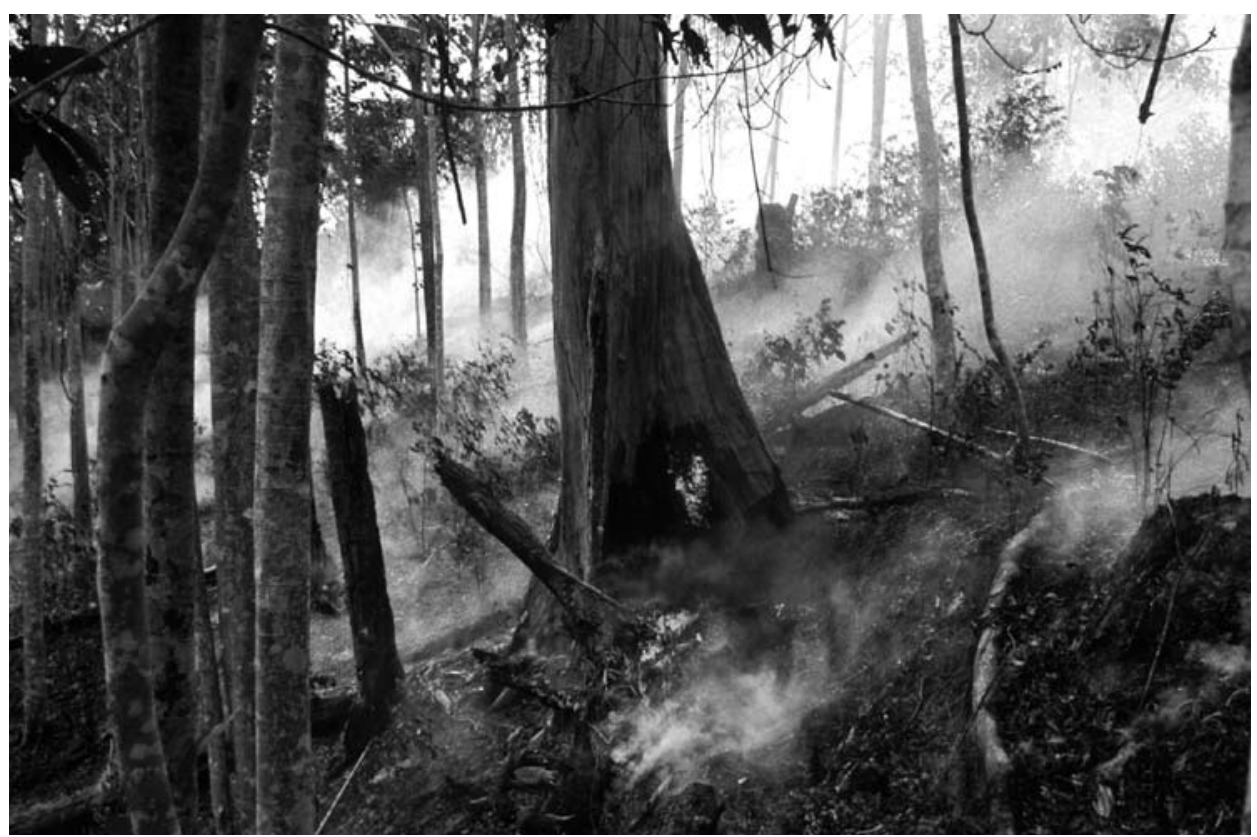

Gambar 24. Sisa-sisa hutan di Kalimantan Timur setelah kebakaran hutan yang berulang. (Foto oleh Gabriella Fredriksson) 
setidaknya seorang pengelola yang memantau kebakaran dan mengkoordinasikan pemadaman api serta tindakan pencegahan selama periode kritis di setiap wilayah konsesi (sangat dianjurkan);

- Membangun hubungan kerja dengan masyarakat setempat yang secara tradisional menggunakan api untuk kegiatan pertanian atau untuk menarik perhatian hidupan liar di sekitar konsesi hutan (Dennis et al. in prep.). upaya ini dapat membantu mengurangi risiko terjadinya kebakaran yang tidak diinginkan di hutan (sangat dianjurkan);

- Van Nieuwstadt et al. $(2001,2002)$ mengungkapkan bahwa praktek pemanenan yang tidak terencana harus diperbaiki (direvisi). Di Indonesia, pemegang konsesi hutan biasanya tidak bisa menebang lagi di daerah hutan tanpa menunggu periode yang ditetapkan Undang-undang (biasanya daur penebangan adalah 35 tahun). Namun demikian, dengan adanya kebakaran hutan, batasan ini terhapuskan, dan penebangan lebih lanjut dengan biaya murah menjadi mungkin. Sistem insentif mendorong pemicu kebakaran dan harus dihindarkan (wajib/perlu perubahan peraturan).

\section{Spesies eksotik dan invasif}

- Konsesi penebangan hutan harus memantau spesies eksotik yang ada di wilayahnya dan harus secara aktif menyingkirkan spesies-spesies tersebut sebelum menimbulkan masalah bagi hidupan liar dan regenerasi hutan. Spesies dan genera yang dikenal sebagai penyebab masalah ini harus dicegah secara aktif (sangat dianjurkan);

- Program penghutanan kembali (reforestasi) harus sedapat mungkin menghindari penanaman spesies eksotik. Apabila tidak bisa dihindari, spesies eksotik ini harus dipilih dengan hati-hati dan hasilnya harus dipantau dengan seksama (sangat dianjurkan);

- Beberapa lembaga atau kegiatan kerjasama harus mempublikasikan dan selalu memperbaharui daftar spesies asing yang invasif, cara mengidentifikasi, dan cara memberantasnya (sangat dianjurkan). Rejmanek (1999) memberikan informasi mengenai skema/mekanisme untuk menyaring spesies tumbuhan berkayu yang berisiko tinggi;

- Diperlukan kegiatan yang dapat meminimalkan pertukaran tanah dan bahan yang berpotensi untuk menyebarkan penyakit di antara lokasi. Saran umum yang dapat diberikan adalah mencari daerah untuk kontrol yang berkaitan dengan impor dan perpindahan tanah, tumbuhan, dan satwa hidup, serta peraturan yang berkaitan dengan kesehatan yang bersangkutan. Banyak contoh peraturan yang berkaitan dengan hal ini, salah satunya adalah yang dibuat dan dilaksanakan secara rinci dan seksama oleh Australia (sangat dianjurkan);

- Tentu saja, implementasi saran serta anjuran ini membutuhkan peningkatan kesadartahuan mengenai isu tersebut di tingkat masyarakat, pemerintah setempat, dan tingkat perusahaan (penebangan). Pembuatan materi penyuluhan yang ditujukan secara tepat dapat memberikan kontribusi yang penting bagi pengelolaan isu ini (sangat dianjurkan). 


\section{Hewan peliharaan/ternak}

Hewan peliharaan seperti sapi, anjing, dan kucing bisa menjadi ancaman besar atau sumber penyakit bagi satwa liar yang asli, baik secara langsung (contoh Clarke \& Pacin 2002, May \& Norton 1996) atau tidak langsung. Knapen (1997) melaporkan adanya penyakit menular mulut dan kuku yang membunuh sebagian besar populasi sapi di Borneo Tenggara antara 1871 dan 1872 sebelum kemudian penyakit ini menyebar ke populasi Babi Berjenggot. Penyakit ini menyebar hingga mencapai Kahayan Hulu dan Sungai Kapuas di Kalimantan Tengah. Pada tahun 1878, penyakit ini menyerang kembali, dan pada awalnya menyerang populasi sapi dan kemudian membunuh populasi babi dalam jumlah yang besar. Epidemi yang lain dilaporkan oleh Nieuwenhuis (1907, Vol 1, p.196), yang mengungkapkan bahwa selama perjalanannya ke Borneo bagian tengah di tahun 1894, babi jarang ditemui, karena baik populasi liarnya di alam dan populasi yang diternakkan mati oleh penyakit menular di Borneo bagian tengah di tahun 1888 dan 1889. Penularan rabies dan penyakit kurap dari anjing peliharaan ke satwa liar begitu juga halnya dengan sejumlah penyakit burung yang ditularkan oleh ayam peliharaan merupakan ancaman yang lain terhadap spesies-spesies asli (lihat Butler et al. 2004).

- Melarang hewan peliharaan dan ternak yang bebas berkeliaran di daerah konsesi (dianjurkan). Sapi, kambing, babi, dan ayam ternak harus terpisah dan sebaiknya dikandangi ditempat khusus dan tidak diperbolehkan berkeliaran. Hal ini dilakukan untuk meminimalkan penyebaran penyakit dari dan ke spesies asli (dianjurkan);

- Anjing peliharaan yang menjadi liar harus dikendalikan (dianjurkan). Selain itu, meskipun kita belum mengetahui dampak kucing peliharaan terhadap satwa liar asli, hal ini memiliki potensi dampak yang serius. Di Amerika Utara, sekitar akhir 1990-an, diperkirakan sekitar 40 juta burung berkicau (bernyanyi) tiap tahun mati dibunuh kucing peliharaan. Di daerah konsesi penebangan, kucing peliharaan juga harus dikendalikan (dianjurkan).

\section{Lalu lintas}

- Kami menganjurkan peraturan penggunaan jalan yang juga membatasi perburuan dan penebangan kayu ilegal (sangat dianjurkan). Peraturan ini harus mencakup penutupan jalan untuk lalu lintas pada malam hari yang tidak terlalu penting, penyediaan pos-pos pemeriksaan di jalan perusahaan/konsesi untuk memonitor perdagangan satwa liar dan kayu, pelarangan lalu lintas pejalan kaki di jalan, larangan mengangkut senjata perburuan, jerat, perangkap, dan sebagainya;

- Lalu lintas perlu diatur. Batas kecepatan kendaraan tidak hanya mengurangi jumlah satwa yang tergilas kendaraan tetapi juga jumlah terjadinya kecelakaan (dianjurkan);

- Setiap kendaraan yang masuk daerah konsesi harus dicuci untuk membuang bibit dan potongan-potongan spesies eksotis (dianjurkan). 


\section{Polusi}

- Seluruh buangan (sampah) di daerah camp dan bengkel harus dibersihkan dan seluruh sampah padat harus dibuang ke dalam lubang dan dibakar (Elias et al. 2001). Sampah tidak boleh dibuang ke badan air. Seluruh buangan, termasuk sampah, sampah padat, minyak, dan bahan-bahan kimia, bila tidak bisa lagi digunakan kembali harus dibuang secara ramah lingkungan di luar lokasi (sangat dianjurkan).

\section{Penebangan kayu dan konservasi bagi masyarakat setempat}

Banyak penelitian yang dilakukan di Malinau hingga saat ini bertujuan untuk mencari landasan bersama dengan masyarakat setempat sebagai dasar bagi pengembangan kegiatan konservasi di luar kawasan perlindungan (Sheil 2003a, b). Sebagian dari pemikiran ini telah diungkapkan di beberapa bagian lain (contohnya melindungi mata air mineral—salt licks, perlindungan sumber air bersih dan hidupan liar yang bernilai tinggi). Berikut ini adalah beberapa tambahan pemikiran bagi upaya konservasi:

- Diperlukan serangkaian konsultasi dengan masyarakat yang memiliki akses ke daerah konsesi untuk memberikan panduan dan informasi kepada pihak pengelola (wajib);

- Meskipun pihak konsesi penebangan memiliki hak secara hukum terhadap wilayah hutan yang cukup luas, masih banyak hal yang dapat dicapai dengan mengidentifikasi dan melindungi lokasi-lokasi yang memiliki nilai budaya tinggi atau tempat-tempat yang penting bagi masyarakat setempat (seperti kuburan, desa tua, tempat keramat, mata air mineral, dan sebagainya) (sangat dianjurkan);

- Selain itu, daerah dengan kelimpahan sumberdaya yang penting (meskipun hak hukumnya belum jelas) seperti gaharu, rotan, dan pohon yang mengandung getah untuk merekatkan perahu (lateks), harus diidentifikasi dan dilindungi (sangat dianjurkan). Panduan yang sifatnya lokal/setempat harus dicari untuk mengenali dan menemukan lokasi-lokasi tersebut;

- Koompassia spp. adalah spesies yang dilindungi oleh peraturan pengambilan dan oleh kebiasaan masyarakat setempat. Perlindungan ini dilakukan karena pohon tersebut merupakan tempat bersarang lebah (Apis spp.) yang dianggap penting bagi produksi madu dan bagi fungsi penyerbukannya. Pohon tersebut juga tidak boleh ditebang (sesuai dengan peraturan yang ada: wajib);

- Kayu Ulin (Eusideroxylon zwageri) juga memiliki status khusus dan berdasarkan peraturan pemerintah tidak bisa ditebang karena dilindungi bagi pemanfaatan oleh masyarakat setempat. Spesies ini dianggap bernilai paling tinggi oleh penduduk setempat (Sheil et al. unpubl.). Pelanggaran peraturan tersebut saat ini sangat banyak terjadi;

- Sejumlah spesies rotan diambil dan dimanfaatkan secara lokal untuk berbagai kerajinan tangan dan kegiatan konstruksi. Di beberapa daerah, spesies-spesies ini dibudidayakan. Beberapa spesies tersebut sangat berkurang jumlahnya, terutama yang berada dekat pemukiman-meskipun secara umum rotan terlihat dapat tumbuh dengan baik pada hutan yang terganggu. Ancaman utama bagi rotan adalah peraturan yang mewajibkan pembersihan tumbuhan bawah sesaat 
setelah penebangan kayu. Seperti telah kami anjurkan di muka, pembersihan ini sedapat mungkin harus dihentikan atau diminimalkan (wajib/perlu perubahan peraturan)

- Lokasi desa lama dan daerah pohon buah harus dilindungi terhadap penebangan dan sumber kerusakan lainnya (sangat dianjurkan). Lokasi desa lama memiliki nilai sejarah dan budaya yang tinggi bagi penduduk yang pernah tinggal di desa tersebut. Namun faktor yang lebih nyata terlihat adalah berlimpahnya spesies pohon buah-buahan yang tersebar di lokasi seperti ini. Di desa lama dan di daerah tepian sungai secara umum banyak tumbuh pohon seperti durian (Durio spp.), kelapa (Cocos nucifera), spesies nangka (Artocarpus spp.), dan spesies mangga (Mangifera spp.), dan sebagainya. Pohon buah ini menjadi sumber makanan bagi berbagai satwa pemakan buah;

- Palem Eugeissona ulitis, umumnya tumbuh di puncak bukit dan rentan terhadap jalan sarad. Spesies palem tersebut (setidaknya di Malinau) merupakan bahan makanan penduduk setempat saat paceklik dan harus dilindungi dengan perencanaan jalan sarad yang baik (sangat dianjurkan);

- Batuan kapur dan gua merupakan karakter yang sangat khusus di daerah hutan tropis seperti yang telah dinyatakan sebelumnya. Daerah ini merupakan tempat tinggal burung walet (terutama Collocalia spp.) yang sarangnya memiliki nilai budaya dan nilai komersial yang sangat tinggi dan dapat menjadi dasar pembentukan kawasan perlindungan dengan radius satu kilometer dari wilayah yang tidak boleh ditebang (sebagai zona pengecualian di Malinau) (sangat dianjurkan);

- Budaya dan kebiasaan masyarakat setempat harus dikaji dan dimasukkan ke dalam rencana pengelolaan satwa liar, seperti kebutuhan bulu burung rangkong atau kebutuhan satwa liar untuk obat-obatan (Sheil et al. 2003c) (sangat dianjurkan). Ada kebutuhan untuk melindungi spesies yang penting bagi budaya setempat. Masyarakat pasti tidak menginginkan punahnya rangkong akibat pengambilan yang berlebihan. Hal ini bisa dicapai dengan menerapkan pengawasan dan persetujuan yang sesuai. Selain itu sepanjang kebutuhan dan permintaan ini hanya datang dari masyarakat setempat saja dan tidak melayani kebutuhan dan permintaan dari luar daerah, pengambilan satwa liar tidak akan mengancam keberadaan suatu spesies.

\section{Implementasi dan pengawasan}

\section{Pemantauan}

Sheil et al. (2004) menyarankan penekanan awal pada kesepakatan, hukum, dan peraturan yang dirundingkan secara lokal. Tujuan program pemantauan ini adalah untuk melihat apakah peraturan tersebut dapat diterima dan dapat diterapkan. Halhal yang dapat digunakan sebagai dasar-dasar pemeriksaan lokal ini:

1) Apa yang menjadi ancaman besar di lingkungan sekitar saat ini? Apa yang diperkirakan dapat menjadi ancaman ke depan? Apakah hal ini tercermin dalam pemantauan yang diperkirakan? 
2) Seberapa banyak pihak yang terlibat dan bertanggung jawab memahami peraturan dan tugas serta tanggung jawab yang telah disepakati?

3) Berapa kali peraturan diterapkan sejauh ini? Bagaimana hasilnya?

4) Berapa kira-kira jumlah hasil perburuan liar yang ditemukan dalam uji petik di daerah tersebut (jumlah satwa atau kg yang ditemukan per hari)?

5) Berapa persentasi pekerja konsesi hutan yang memiliki kemudahan untuk membeli sumber protein alternatif?

6) Berapa banyak peralatan, hiasan, atau barang lain yang terkait dengan kegiatan perburuan liar untuk setiap populasi yang ditemukan di lokasi yang tidak selayaknya?

Kami menganggap pemeriksaan yang sifatnya kualitatif (yaitu uji petik) kerap kali cukup untuk mengidentifikasi masalah yang serius dalam perburuan komersial. Pertanyaan dan tolok ukur atau bukti yang tersedia harus sejalan dengan pemahaman tentang peraturan dan kesepakatan/perjanjian, kemampuan dan upaya untuk menerapkan aturan dan kesepakatan tersebut, dan pencarian bukti dalam pelaksanaannya.

Seperti banyak dianjurkan, banyak alasan untuk memonitor populasi hidupan liar tertentu secara langsung (misal, Stork et al. 1997). Namun pemantauan langsung ini harus dilakukan berdasarkan pertimbangan yang matang. Pemantauan secara tidak langsung sering kali lebih efisien.

- Kami merekomendasikan pemantauan keterlibatan pengelolaan dalam hubungannya dengan perubahan kelimpahan hidupan liar apabila bisa menjadi panduan dalam pengelolaan - Barangkali bantuan dari pihak luar (arahan dan evaluasi pakar) akan dapat memastikannya. Kriteria khusus bagi kegiatan pemantauan ini dapat dimulai melalui rencana pengelolaan dan panduan pelaksanaan (code-of-practice), yaitu apa yang akan dilaksanakan dan caranya. Kami yakin bahwa pendekatan dua arah ini dapat memberikan dasar yang kuat untuk memperbaiki praktek penebangan dan membuatnya sejalan dengan konservasi hidupan liar (Sheil et al. 2004) (sangat dianjurkan);

- Setiap daerah yang belum ditebang (tidak sama dengan 'daerah lindung' atau 'zona lindung' karena areal penebangan ditentukan oleh berbagai faktor yang lain) harus dipantau dan dicatat pada peta penebangan di setiap daerah konsesi (sangat dianjurkan).

\section{Aspek hukum, pelaksanaan dan pengawasan}

- Seluruh karyawan dan pelaku yang bekerja pada daerah konsesi harus mengenal dan memahami seluruh peraturan yang berhubungan dengan kegiatan mereka (wajib). Hal ini harus menjadi dasar pemeriksaan dan uji petik (sangat dianjurkan);

- Dampak lingkungan yang tidak diinginkan akibat praktek kegiatan penebangan yang buruk, dapat menjadi lebih parah akibat adanya penebangan berintensitas tinggi untuk spesies kayu komersial yang diinginkan serta sistem pembayaran karyawan berdasarkan jumlah tebangan dengan pengawasan yang minimal (DIFD 1999). Kegiatan penebangan harus diawasi terus menerus di tingkat kegiatan yang berbeda (sangat dianjurkan). Kegiatan pengawasan ini mencakup pengawasan 
produksi, pemeriksaan blok tebangan, dan pengawasan karyawan yang melakukan penebangan dan penyaradan (Elias et al. 2001);

- Menutup jalan yang tidak terlalu diperlukan secepatnya kegiatan operasional penebangan selesai. Hal ini dapat mencegah pemburu dalam memanfaatkan jalan tersebut dan juga mengurangi kesempatan kegiatan penebangan ilegal/liar untuk memasuki daerah tersebut (Bennett \& Robinson 2000) serta kegiatan yang tidak diinginkan lainnya, seperti: kegiatan pertanian atau risiko kebakaran hutan. Pencegahan ini dapat dilakukan dengan meruntuhkan jembatan, membongkar permukaan jalan, atau menutup jalan akses (sangat dianjurkan);

- Untuk meminimalkan tindak korupsi dan memaksimalkan efisiensi, konsesi penebangan tidak boleh membayar/menggaji secara langsung petugas pemerintah yang bekerja di bidang hidupan liar. Pembayaran ini harus dilakukan melalui sistem yang mengharuskan perusahaan penebangan menyimpan dana yang proporsional terhadap luas daerah rencana tebangan pada tahun berjalan dan membayarkannya kepada departemen pemerintah yang bersangkutan (Wilkie et al. 2001) (wajib/ perlu perubahan peraturan);

- Penegakan peraturan serta mekanismenya harus dimasukkan ke dalam panduan (sangat dianjurkan). Karena Departemen Kehutanan dan pemerintah setempat mengawasi kegiatan penebangan dan pihak konsesi penebangan mengawasi keamanan, panduan ini harus merupakan kombinasi kegiatan yang sifatnya pengawasan melekat dengan uji petik oleh KSDA dan perwakilan pihak pemerintah yang telah ditetapkan. Idealnya, wakil pemerintah tersebut sebaiknya ahli biologi yang terlatih baik dan memiliki wewenang yang cukup. Stakeholders (perwakilan masyarakat setempat, LSM, dan sebagainya) harus mendapat kesempatan untuk terlibat kegiatan pengawasan dan verifikasi ini (sangat dianjurkan);

- Kami menganjurkan suatu audit sertifikasi hutan yang dilakukan oleh lembaga yang terakreditasi, yang apabila terlaksana merupakan alat untuk mengukur keberhasilan (sangat dianjurkan);

- Kami menganjurkan bahwa panduan sertifikasi kayu yang dibuat oleh Dewan Penyantun Hutan (Forest Stewardship Council, ITTO), dan lembaga lain yang terkait dan sejenis yang secara langsung memasukkan prinsip-prinsip penanganan isu konservasi keanekaan hayati dan terutama masalah hidupan liar (sangat dianjurkan). Prinsip ini harus jelas dan tegas dan harus mengutamakan ancaman yang secara khusus dihadapi oleh hidupan liar didalam konsesi penebangan (Bennett \& Gumal 2001);

- Seorang ahli biologi independen yang diberi wewenang secara formal harus diijinkan memasuki seluruh lokasi penebangan sebelum, selama, dan setelah kegiatan penebangan. Selain itu, ahli biologi ini harus dapat bekerja sama dengan erat dengan pengelola konsesi penebangan. Aturan untuk kewenangan dan kerjasama ini harus ditetapkan dalam kerangka kerja yang lebih luas, seperti misalnya dalam program sertifikasi (sangat dianjurkan);

- Menetapkan dan melaksanakan Undang-undang dan/atau peraturan yang menuntut perusahaan penebangan yang beroperasi di Indonesia untuk bertanggung jawab dalam melakukan tindak pencegahan perburuan yang dilakukan oleh karyawannya. Hal ini dapat dilakukan dengan menyediakan sumber protein satwa 
domestik yang segar, dan dengan melarang kendaraan operasional digunakan untuk mengangkut pemburu dan daging satwa liar (sangat dianjurkan). Tindakan ini harus disertai dengan program pendidikan yang ditujukan bagi penebang kayu dan masyarakat setempat, yang menjelaskan mengapa perusahaan kayu tidak lagi dapat memberikan satwa liar bagi penduduk desa. Undangundang/peraturan tersebut harus dikaitkan dengan tindakan yang memastikan pentaatan oleh pihak perusahaan. Idealnya hukuman bagi pelanggaran peraturan tersebut berupa pencabutan ijin penebangan kayu. Perusahaan penebangan kayu diharuskan untuk membayar pelaksanaan peraturan tentang hidupan liar di lokasi penebangan mereka. Hal ini dapat dilakukan oleh karyawan pihak perusahaan penebangan, pemerintah, atau lembaga lain (Bennett \& Robinson 2000);

- Pada areal yang tidak boleh ditebang dan menghadapi ancaman tebangan liar yang tinggi, kegiatan penandaan pohon yang didukung dan diawasi secara hukum dapat menjadi cara yang efektif dan murah untuk menghentikan pemanenan kayu liar (Foreman \& Haywood 1989, Meijaard 2001b, Fredriksson et al. unpubl.). Proyek percontohan kegiatan ini dilakukan di daerah hutan Sungai Wain dekat Balikpapan, Kalimantan Timur. Kegiatan ini berhasil mengurangi jumlah kegiatan penebangan liar. Kunci utama keberhasilan ini adalah dukungan politik setempat, pelaksanaan/penegakan hukum yang terkoordinasikan, partisipasi berbagai pihak, serta perhatian media masa yang cukup besar (Fredriksson et al. unpubl.). Kami menganjurkan suatu kegiatan pengkajian untuk melihat dimana dan kapan penandaan pohon ini dapat dilakukan (sangat dianjurkan);

- Pos dengan karyawan keamanannya harus didirikan di pintu masuk utama, yaitu jalan utama yang digunakan kendaraan untuk memasuki wilayah konsesi. Bila ada kendaraan yang masuk tanpa ijin dari pihak yang berwenang setempat, (1) minta untuk segera meninggalkan tempat, (2) peringatan kepada petugas penjaga, dan (3) laporkan kepada pihak pengelola yang berwenang (Muziol et al. 2000) (rekomendasi ini tergantung pada status hukumnya: wajib atau sangat dianjurkan).

\section{Kesadaran dan pelatihan}

Praktek penebangan dan pembangunan jalan yang kurang baik yang berlangsung saat ini, antara lain disebabkan oleh kurangnya pemahaman/pengetahuan tentang pengawasan dan insentif. Peningkatan kesadaran dan pemahaman RIL dan kaitannya dengan pengelolaan hutan yang berkelanjutan bagi seluruh personel yang terlibat dalam penebangan dan pembangunan jalan adalah hal yang sangat penting. Personel ini terutama operator chainsaw, tim inventarisasi dan penandaan pohon, pengawas penebangan dan pembangunan jalan, tim penebang dan pembangun jalan, operator alat berat, dan pengupas kayu. Pelatihan yang teratur dan terstruktur dengan baik dalam topik di bawah ini akan sangat bermanfaat (berdasarkan DFID 1999) (sangat dianjurkan):

- Pengoperasian chainsaw;

- Penebangan yang terarah;

- Pemotongan kayu;

- Pemangkasan tumbuhan merambat; 
- Perencanaan jalan, tempat pengumpulan kayu sementara, dan jalan sarad;

- Pengawasan;

- Konstruksi jalan, perlintasan air, tempat pengumpulan kayu sementara, dan jalan sarad;

- Rehabilitasi jalan, perlintasan air, tempat pengumpulan kayu sementara, dan jalan sarad yang telah dibuldoser.

Selain itu, pelatihan tersebut harus mengulas:

- Status perlindungan spesies dan aspek hukum lainnya yang berkaitan dengan perburuan dan perdagangan satwa liar (termasuk kesadaran dan pemahaman pihak penegak hukum dan mekanismenya);

- Apa yang harus dilakukan bila spesies yang dilindungi berada di sekitar lokasi penebangan pohon.

\section{Saran-saran khusus}

\section{Permintaan, kepentingan bagi masyarakat setempat, dan status perlindungan spesies satwa liar}

Dalam bagian sebelumnya kami memberikan rekomendasi pengelolaan yang secara umum bermanfaat bagi berlangsungnya fungsi ekosistem dalam wilayah konsesi penebangan kayu. Beberapa spesies satwa liar diuntungkan dari tindakan-tindakan yang diusulkan tersebut. Secara umum, rekomendasi kami menitikberatkan pada jenis hutan yang lebih peka/sensitif, sementara implementasi rekomendasi kami tersebut dapat memperbaiki regenerasi hutan dan mempertahankan sebagian besar tingkat produksi dan jasa hutan.

Yang kami belum masukkan dalam rekomendasi tersebut sejauh ini adalah saran yang khusus tentang bagaimana melindungi spesies satwa liar setempat yang penting. Kepentingan spesies ini sangat tergantung dari pandangan stakeholders dan dengan demikian sulit untuk didefinisikan secara umum. Salah satu pendekatan yang dapat dilakukan adalah dengan mempertimbangkan perlindungan dan status konservasi di tingkat nasional dan internasional, tingkat pemanfaatannya serta nilai budayanya bagi masyarakat setempat, dan wilayah jelajah dan tempat tinggalnya (sebagai contoh, spesies endemik Borneo lebih penting dibandingkan dengan spesies yang hidupnya lebih tersebar luas). Karena itu, kami menggunakan status IUCN untuk spesies-spesies yang hidup di Malinau (Lihat Lampiran 2), status perlindungannya dalam Undang-undang/peraturan di Indonesia (lihat Tabel 1), dan kepentingannya bagi masyarakat setempat (lihat Lampiran 3).

Tabel 15 menunjukkan spesies yang terancam punah dan relatif memiliki tingkat permintaan yang tinggi di masyarakat lokal. Tabel ini juga menunjukkan bahwa spesies yang terdaftar dalam IUCN ini tidak (selalu) dilindungi oleh Undang-undang di Indonesia. Sebagai contoh, Cucak Rawa (Pycnonotus zeylanicus) dan Sempidan Merah (Lophura erythrophthalma) (BirdLife International 2001), meskipun dilindungi di negara-negara lain, di Indonesia kedua spesies ini masih boleh diburu di alam (meskipun ijin bagi kuota pengambilan spesies tersebut ditetapkan, lihat Lampiran 
Tabel 15. Tiga puluh spesies utama yang dimanfaatkan oleh masyarakat setempat (berdasarkan Sheil et al. 2003c), dan yang terdaftar dalam Daftar Merah Spesies yang Terancam IUCN (IUCN Red List of Threatened Species) (IUCN 2002). Status perlindungannya dalam Undang-undang di Indonesia juga tertera pada tabel ini.

\begin{tabular}{llll}
\hline \multicolumn{2}{c}{ Nama spesies } & Status IUCN & $\begin{array}{l}\text { Status } \\
\text { perlindungan }\end{array}$ \\
\hline Neofelis nebulosa & Macan Dahan & Rentan & ya \\
\hline Lophura erythrophthalma & Sempidan Merah & Rentan & tidak \\
\hline Pycnonotus zeylanicus & Cucak Rawa & Rentan & tidak \\
\hline Anthracoceros malayanus & Kangkareng Hitam & $\begin{array}{l}\text { Risiko rendah/hampir } \\
\text { terancam }\end{array}$ & ya \\
\hline Macaca fascicularis & Monyet Kra & $\begin{array}{l}\text { Risiko rendah/hampir } \\
\text { terancam }\end{array}$ & tidak \\
\hline Manis javanica & Trenggiling Peusing & $\begin{array}{l}\text { Risiko rendah/hampir } \\
\text { terancam }\end{array}$ & ya \\
\hline Argusianus argus & Kuau Raja & $\begin{array}{l}\text { Risiko rendah/hampir } \\
\text { terancam }\end{array}$ & ya \\
\hline Presbytis hosei & Lutung Banggat & Data kurang & ya \\
\hline Buceros rhinoceros & Rangkong Badak & $\begin{array}{l}\text { Risiko rendah/hampir } \\
\text { terancam }\end{array}$ & ya \\
\hline Ursus malayanus & Beruang Madu & Rentan/Data kurang & ya \\
\hline
\end{tabular}

12). Hal ini mengungkap kondisi sistem hukum di Indonesia yang masih banyak celah dan kekurangannya.

Kecuali Kangkareng Hitam (Anthracoceros malayanus), Kuau Raja (Argusianus argus) dan Beruang Madu Sun Bear (Ursus malayanus), tidak satu pun spesies yang ada dalam Tabel 15 tersebut, dianggap terpengaruh oleh kegiatan tebang pilih. Gangguan (kerusakan) yang timbul setelah penebangan menyebabkan kepindahan sementara spesies-spesies tersebut. Mengurangi tekanan perburuan atau penebangan sangat penting untuk mencegah terjadinya kelangkaan atau bahkan kepunahannya. Pihak konsesi penebangan dan lembaga pemerintah harus berupaya untuk melindungi Neofelis nebulosa (Macan Dahan), Anthracoceros malayanus (Kangkareng Hitam), Manis javanica (Trenggiling Peusing), Argusianus argus (Kuau Raja), Buceros rhinoceros (Rangkong Badak), dan Ursus malayanus (Beruang Madu). Tidak satu pun dari spesies yang dilindungi tersebut boleh diburu atau diambil untuk makanan. Kegunaannya sebagai obat-obatan, perdagangan, dan budaya, lebih penting ketimbang untuk gizi (Puri 2001). Namun demikian, karena sangat dicari oleh masyarakat setempat, larangan perburuan dan penangkapan spesies tersebut harus dikombinasikan dengan kampanye penyebaran informasi. Selain itu perdagangan dan perburuannya harus dihentikan secara bertahap.

Kategori yang lain adalah spesies yang terdaftar sebagai Terancam Punah atau Rentan oleh IUCN, namun tidak termasuk dalam 30 spesies yang utama yang dimanfaatkan oleh penduduk setempat (Tabel 16). Sekali lagi, dapat terlihat bahwa spesies yang berstatus Terancam Punah atau Rentan oleh IUCN (2002) tidak seluruhnya dilindungi oleh Undang-undang di Indonesia. Meskipun di luar fokus buku ini, diperlukan suatu tindakan perbaikan perundangan yang menyeluruh bagi spesies-spesies yang dilindungi. 
Tabel 16. Spesies yang terdaftar sebagai Terancam Punah atau Rentan oleh IUCN (2002), tetapi tidak begitu dicari oleh masyarakat lokal. Status perlindungan oleh Undang-undang di Indonesia juga ditampilkan.

\begin{tabular}{llll}
\hline & Nama spesies & Status IUCN & $\begin{array}{l}\text { Status } \\
\text { perlindungan }\end{array}$ \\
\hline Bos javanicus & Banteng & Terancam Punah & ya \\
\hline Nasalis larvatus & Bekantan Kahau & Terancam Punah & ya \\
\hline Ciconia stormi & Bangau Storm & Terancam Punah & ya \\
\hline Manouria emys & Baning Coklat & Terancam Punah & tidak \\
\hline Orlitia borneensis & Bajuku & Terancam Punah & tidak \\
\hline Pelochelys cantorii & Labi Labi Bintang & Terancam Punah & tidak \\
\hline Alcedo euryzona & Raja Udang Kalung Biru & Rentan & ya \\
\hline Cynogale bennettii & Musang Air & Terancam Punah & ya \\
\hline Lobiophasis bulweri & Sempidan Kalimantan & Rentan & ya \\
\hline Nycticebus coucang & Kukang Bukang & Rentan & ya \\
\hline Ptilocichla leucogrammica & Berencet Kalimantan & Rentan & tidak \\
\hline Rollulus rouloul & Puyuh Sengayan & Rentan & tidak \\
\hline Spilornis kinabaluensis & Elang Ular Kinibalu & Rentan & tidak \\
\hline Treron capellei & Punai Besar & Rentan & tidak \\
\hline Macaca nemestrina & Monyet Beruk & Rentan & tidak \\
\hline Amyda cartilaginea & Bulus & Rentan & tidak \\
\hline Notochelys platynota & Beiyogo & Rentan & tidak \\
\hline
\end{tabular}

Dari spesies yang tercantum dalam Tabel 16, sempidan, berencet, dan punai merupakan spesies-spesies yang dipengaruhi secara langsung oleh kegiatan penebangan. Sempidan Kalimantan (Lobiophasis bulweri) adalah spesies endemik Borneo yang hidup di pegunungan bawah dan daerah yang berbukit-bukit dan mungkin bersifat nomad. Sebagai pemicu perkembangbiakannya, spesies ini bergantung pada musim buah yang panjang di hutan Dipterokarpa dataran rendah. Sempidan Merah jarang ditemui di hutan terbuka dan mungkin memerlukan daerah hutan utuh yang luas (BirdLife International 2001). Berencet Kalimantan (Ptilocichla leucogrammica) hidupnya terbatas pada hutan dataran rendah di Borneo bagian utara (BirdLife International 2001). Spesies ini lebih jarang ditemukan di daerah tebangan dibandingkan dengan di daerah hutan utuh (Lambert 1992). Dengan demikian, spesies ini sangat bergantung pada hutan dataran rendah yang utuh bagi keberlangsungan hidupnya. Luasan hutan di kawasan Malinau cocok bagi habitat spesies ini. Punai Besar (Treron capellei) adalah spesies khusus pemakan buah ara (Ficus) yang hidup di hutan dataran rendah (BirdLife International 2001). Hilangnya pohon yang merupakan sumber makanannya akan menyebabkan turunnya populasi spesies ini. Ketiga spesies tersebut bisa mendapatkan manfaat dari rekomendasi pengelolaan yang secara rinci kami sampaikan di muka.

Pengaruh kegiatan penebangan terhadap penyu, kura-kura darat dan kura-kura air tawar belum banyak diketahui. Namun demikian dapat diperkirakan bahwa populasi terutama dipengaruhi oleh pengambilan spesies tersebut untuk makanan dan obatobatan, dibandingkan dengan akibat kegiatan tebang pilih. Kura-kura air tawar lebih banyak dicari di Kalimantan. Sebagai contoh, Dudgeon (2000) melaporkan bahwa 
13,5 juta kg kura-kura hidup yang diimpor ke Hongkong di tahun 1998, sebagian besar berasal dari Indonesia dan Thailand. Dari seluruh spesies kura-kura air tawar yang dikonsumsi (terutama di Cina dan Taiwan), suku Labi Labi (Trionychidae) dianggap yang terbaik karena rasio berat tulang terhadap berat badan yang rendah, serta spesiesspesies dari suku ini memiliki proporsi tulang rawan dan kulit lunak yang tinggi. Beberapa peneliti/penulis menyatakan bahwa setidaknya setengah dari perdagangan kura-kura darat dan kura-kura air tawar adalah spesies yang berperisai lunak (suku Labi Labi), terutama Bulus (Amyda cartilaginea) (Walter 2000). Kemungkinan, spesies ini juga diincar di sebagian besar daerah MRF, meskipun data kuantitatifnya sangat kurang. Walter (2000) melaporkan bahwa sekitar $35.000 \mathrm{~kg}$ kura-kura darat/kurakura air tawar diperdagangkan setiap tahunnya di Taman Nasional Danau Sentarum di Kalimantan Barat. Perdagangan ini menghasilkan antara 50.000 hingga 75.000 dollar AS per tahun bagi para pemburu lokal, atau sekitar 4,5\% dari penghasilan kotor penduduk di Taman Nasional tersebut. Data serupa tidak ada di MRF, namun perdagangan kura-kura/kura-kura air tawar memiliki potensi ekonomi lokal yang tinggi. Karena tidak satu pun spesies kura-kura, kura-kura darat, maupun kura-kura air tawar yang dilindungi, kami hanya dapat menganjurkan strategi pengambilan yang lebih lestari di MRF. Indonesia menetapkan kuota ekspor untuk spesies seperti Labi Labi Raksasa (Pelochelys cantorii) sebanyak 100 ekor/tahun dan Baning Coklat (Manouria emys) sebanyak 500 ekor per tahun (lihat situs web CITES://www.cites. org/index.html), meskipun tidak jelas apakah kuota ini ditegakkan atau tidak. Lokakarya perdagangan kura-kura/kura-kura air tawar Asia yang diselenggarakan baru-baru ini (van Dijk et al. 2000) merekomendasikan bahwa seluruh spesies kurakura air tawar Asia harus dipertimbangkan untuk masuk ke dalam daftar CITES setidaknya Appendix II. Ini berarti bahwa perdagangan spesies tersebut akan sangat terbatas.

Spesies lain yang ada dalam Tabel 16 seperti Banteng dan Bekantan Kahau langka di MRF. Hal ini antara lain karena kedua spesies ini terlindungi dengan baik di habitat utamanya, yaitu padang rumput di Taman Nasional Kayan Mentarang untuk Banteng (lihat Hedges \& Meijaard 1999), dan di wilayah hutan mangrove dan hutan di tepian sungai dekat pantai bagi Bekantan Kahau (lihat Meijaard \& Nijman 2000).

Akhirnya, diperlukan pula suatu pembatasan pengambilan spesies yang tidak dilindungi atau tidak terdaftar oleh IUCN, tetapi sangat dicari oleh masyarakat setempat (lihat Lampiran 3). Perlindungan ini terutama bagi Babi Berjenggot (Sus barbatus), sementara spesies yang secara formal sudah dilidungi adalah Rusa Sambar (Cervus unicolor) dan spesies-spesies pelanduk (Tragulus spp.). Namun demikian, perburuan spesies ini biasa terjadi dan Undang-undang yang melindunginya jarang atau bahkan tidak pernah ditegakkan. Landak Raya (Hystrix brachyura) terdaftar sebagai Rentan (Vulnerable) dalam daftar IUCN dan dilindungi di Indonesia, meskipun spesies ini banyak didapati hidup di wilayah ini (common) dan banyak dicari untuk diambil dagingnya. Penelitian sangat diperlukan untuk melihat statusnya sebagai spesies yang dilindungi.

Babi Berjenggot (Sus barbatus) merupakan spesies penting sebagai sumber protein hewani di wilayah MRF. Puri (1997) melaporkan bahwa Babi Berjenggot mencapai 
$79,8 \%$ dari seluruh satwa tangkapan dan $91 \%$ dari seluruh daging yang dapat dimakan di Taman Nasional Kayan Mentarang. Hal ini sejalan dengan temuan Chin (2001) di Sarawak yang menemukan bahwa persentasi daging Babi Berjenggot dalam biomassa hasil buruan berkisar antara 67,4\% hingga 97\%. Perburuan yang berlebihan ini menyebabkan kepunahan Babi Berjenggot secara lokal di banyak tempat di Borneo (Bennett \& Dahaban 1995, Bennett et al. 1999). Sementara menurut Davies et al. (2001) spesies ini telah punah di Semenanjung Malaya. Analisis tentang jumlah total daging Babi Berjenggot yang dikonsumsi di Taman Nasional Kayan Mentarang yang dilakukan baru-baru ini memperkirakan jumlah yang nilainya kira-kira sejumlah 3.500.000 dollar AS. Perhitungan ini berdasarkan populasi manusia yang berjumlah 16.645 pada tahun 2001, konsumsi bulanan sebanyak $10 \mathrm{~kg}$ daging per bulan (yang tinggi), dan harga daging sebesar (12.000 rupiah/kg) (Effendi et al. 2002). Babi Berjenggot dengan demikian dapat dianggap sebagai spesies yang memiliki kepentingan bagi gizi dan ekonomi yang tinggi. Saat spesies ini hilang, masyarakat setempat tidak hanya akan kehilangan sumber protein yang penting yang akan menyebabkan tingginya biaya hidup karena daging harus dibeli, tetapi diperkirakan juga bahwa akan ada pergeseran permintaan terhadap spesies yang sebelumnya tidak begitu dicari. Perburuan babi di bagian Borneo ini sangat boros, karena hanya sedikit saja bagian-bagian dari hewan ini yang dimanfaatkan dan sisanya dibuang begitu saja (Augeri pengamatan pribadi, Meijaard pengamatan pribadi, R. Puri komunikasi pribadi). Banyak penduduk desa di Malinau yang mengamati terjadinya penurunan ketersediaan babi liar. Bila metode perburuan yang lebih lestari (misalnya tidak memburu betina yang sedang hamil, hewan yang kurus, atau muda), pengangkutan, dan penyimpanan dikembangkan, tekanan perburuan dapat dikurangi. Selain itu, pengembangan ternak babi, rusa, dan sapi juga akan mengurangi tekanan perburuan terhadap populasi spesies-spesies ini.

Upaya peningkatan penegakan hukum dapat mengurangi tekanan dari kegiatan perburuan bagi sejumlah spesies yang dilindungi seperti (Rusa (Cervus), Pelanduk (Tragulus), dan Landak (Hystrix). Dengan pertimbangan bahwa jarang sekali peraturan-peraturan tersebut diterapkan dan bahwa spesies tersebut dianggap banyak pihak sebagai sumberdaya penting yang cuma-cuma (gratis), diperlukan pemantauan yang lebih detail dalam hal kecenderungan pengambilan dan jumlah populasi, serta pengembangan strategi pengambilan spesies tersebut secara lestari. Rusa Sambar (C. unicolor) mendapatkan manfaat dari peningkatan jumlah rumput setelah kegiatan penebangan. Untuk spesies ini, strategi pengelolaan yang memasukkan pemikiran pengembangan zona tanpa perburuan atau zona perburuan terbatas dapat menguntungkan Rusa Sambar sehingga spesies ini dapat dimanfaatkan. Untuk melaksanakan zona pengelolaan bagi perburuan spesies yang dilindungi diperlukan persetujuan dari pihak pemerintah yang berwenang. Karena hal ini dapat berlawanan dengan status perlindungan spesies tersebut. Perbaikan (revisi) status perlindungan hukum yang mempertimbangkan peran satwa liar dalam pemenuhan kebutuhan protein bagi penduduk setempat dapat dilakukan. 


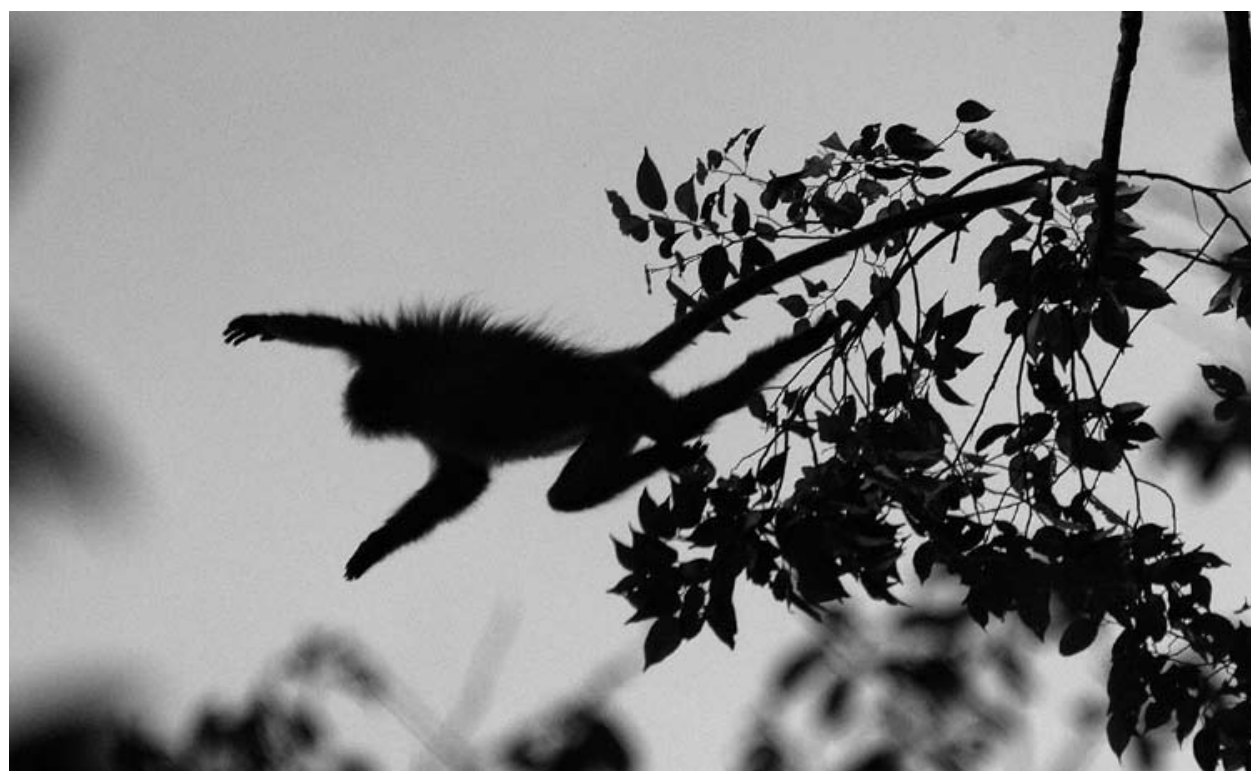

Gambar 25. Lutung Merah (Presbytis rubicunda) memerlukan konektivitas tajuk untuk keberlangsungan hidupnya di atas pohon. (Foto oleh Kimabajo)

\section{Primata}

Ancaman utama bagi Owa Kalawat (Hylobates muelleri), Lutung Banggat (Presbytis hosei), Lutung Merah (P. rubicunda) (Gambar 25), Bekantan Kahau (Nasalis larvatus), Kukang Bukang (Nycticebus coucang), Monyet Beruk (Macaca nemestrina) dan Monyet $\mathrm{Kra}$ (M. fascicularis) adalah perburuan dan hilang/rusaknya habitat. Malinau adalah salah satu daerah yang kaya akan spesies primata (Meijaard \& Nijman 2003). Karena di wilayah ini tidak ada hutan dataran rendah yang dilindungi, pengelolaan spesies primata di konsesi penebangan hutan merupakan hal yang sangat penting.

Owa Kalawat (Hylobates muelleri), Bekantan Kahau (Nasalis larvatus), Kukang Bukang (Nycticebus coucang), dan Lutung Merah (P. rubicunda) dilindungi Undangundang di Indonesia dan tidak boleh diburu. Informasi mengenai larangan ini harus disebarkan bagi karyawan perusahaan penebangan dan patroli untuk menegakkan peraturan ini harus dilakukan (wajib). Lutung Banggat (Presbytis hosei) dan spesiesspesies monyet diburu dengan alasan yang berbeda-beda. Pengaruh perburuan terhadap spesies-spesies ini harus dilakukan untuk mengarah kepada tingkat perburuan yang lestari (sangat dianjurkan), Lutung Banggat harus dilindungi (sangat dianjurkan) karena subspesies lokal (Brandon-Jones 1996) memiliki kemungkinan untuk ditingkatkan menjadi spesies (Meijaard \& Groves unpubl.). Selain itu spesies ini memiliki wilayah distribusi yang sangat terbatas.

\section{Mamalia yang lain}

1. Macan Dahan (Neofelis nebulosa). Deforestasi merupakan ancaman yang terburuk bagi spesies ini (Rabinowitz et al. 1987). Macan Dahan juga banyak diburu untuk diambil gigi dan kulitnya, serta untuk diambil tulangnya bagi perdagangan obat-obatan tradisional Asia (Nowell \& Jackson 1996). Kulitnya 
bisa didapati pada pakaian upacara adat di banyak desa di wilayah Malinau (Sheil pengamatan pribadi).

1a. Macan Dahan merupakan spesies penting yang dimanfaatkan untuk kegiatan budaya (Puri 2001) dan spesies ini makin jarang terlihat di alam. Bila prioritas konservasi secara global tidak diberikan, pemanfaatan lokalnya akan menyebabkan spesies ini mengalami nasib yang sama dengan harimau (Jawa) (Panthera tigris javanensis) yang mengalami kepunahan. Macan Dahan dilindungi oleh hukum di Indonesia dan di tingkat internasional dan tidak boleh diburu. Informasi mengenai larangan ini harus disebarkan kepada karyawan perusahaan penebangan dan staf perusahaan konsesi harus memahami dan menegakkan hukum tersebut (wajib).

1b. Tujuan utama pengelolaan Macan Dahan harus dikembangkan bila spesies ini hidup di daerah konsesi penebangan. Temuan dan tanda-tanda keberadaannya harus dilaporkan kepada para ahli biologi yang memantau dan harus ditetapkan jenis hutan dimana spesies ini dapat ditemui. Radio telemetri dan jerat kamera merupakan cara terbaik untuk menetapkan wilayah jelajah spesies dan jumlah individu yang ada di wilayah konsesi. Hal lain yang penting adalah pencatatan dan perlindungan terhadap mangsa Macan Dahan dan habitat spesies mangsa tersebut (sangat dianjurkan).

2. Keberadaan Beruang Madu (Ursus malayanus) dipengaruhi secara negatif oleh penebangan dan perburuan. Sementara fragmentasi hutan menyebabkan habitatnya menjadi terlalu kecil untuk keberlangsungan hidupnya dalam jangka panjang (Augeri 2004a, b). Selain itu, bagian-bagian hewan tersebut, seperti empedu dan cakarnya, banyak diminati terutama di Asia Timur. Karena populasi Beruang di Asia Timur menurun dengan cepat (Servheen et al. 1999), permintaan terhadap produk-produk tersebut dari Kalimantan akan meningkat.

2a. Beruang Madu dilindungi oleh Undang-undang di Indonesia dan di tingkat internasional dan tidak boleh diburu. Informasi mengenai larangan ini harus disebarkan kepada karyawan perusahaan penebangan dan staf perusahaan konsesi ini harus memahami dan menegakkan hukum tersebut (wajib)

2b. Hal yang penting dilakukan adalah mencatat dan melindungi sumber makanan Beruang Madu (sangat dianjurkan) seperti pohon buah, pohon yang memiliki sarang lebah dan koloni rayap (lihat Lampiran 5).

3. Trenggiling Peusing (Manis javanica) diburu secara lokal untuk dimanfaatkan sebagai makanan, obat-obatan, dan hewan peliharaan (Puri 2001). Di akhir tahun 1970-an dan awal 1980-an spesies ini merupakan barang yang penting bagi perdagangan internasional. Sekitar 30.000 kulit Trenggiling Peusing yang diperdagangkan ke Amerika Serikat berasal dari Indonesia dan Malaysia (Anonymous 1981). Trenggiling Peusing masih diperdagangkan di Asia Tenggara, terutama ke Cina. Baru-baru ini ditangkap pengiriman sebanyak 88 pon (sekitar $35 \mathrm{~kg}$ ) sisik trenggiling ke Australia (Reuters 2003) yang mengungkapkan bahwa perdagangan di Indonesia masih berlanjut. Manis javanica saat ini tercatat pada Appendix II CITES dan spesies ini dilindungi oleh Undang-undang di Indonesia. Spesies ini tidak boleh diburu. Informasi mengenai larangan ini harus disebarkan kepada karyawan perusahaan penebangan dan staf perusahaan konsesi ini harus 
memahami dan menegakkan hukum tersebut (wajib). Lebih jauh, sumber makanan utamanya seperti koloni semut dan rayap harus dipelihara (sangat dianjurkan).

\section{Burung}

4. Rangkong (Rangkong Gading (Rhinoplax vigil), Rangkong Badak (B. rhinoceros), Kangkareng Hitam (Anthracoceros malayanus) dan Julang Jambul-Hitam ( $A$. corrugatus)) terancam oleh perburuan, hilangnya tempat untuk berkembang biak, dan hilangnya sumber makanan.

4a. Spesies rangkong dilindungi oleh Undang-undang di Indonesia dan tidak boleh diburu, kecuali ada ijin berburu burung untuk keperluan budaya. Informasi mengenai larangan ini harus disebarkan kepada karyawan perusahaan penebangan. Tanda dan rambu yang menjelaskan status perlindungannya harus dipasang dan perusahaan konsesi ini harus memahami dan menegakkan hukum tersebut (wajib).

4b. Penggunaan kotak untuk sarang harus dipertimbangkan (dianjurkan). Julang Emas (Aceros undulatus) dan Kangkareng Perut-Putih (Anthracoceros albirostris) dapat berkembang biak dalam kotak sarang biasa $\left(50 \mathrm{~cm}^{2}\right.$ dengan tinggi $1 \mathrm{~m}$ ) dan batang yang dilubangi. Namun belum diketahui apakah spesies prioritas yang ada di Malinau dapat berkembang biak dalam kotak sarang tersebut. Sejumlah rancangan kotak sarang harus diuji untuk melihat keberhasilan perkembangbiakannya. Perlu dicatat bahwa Mckenney \& Lindenmayer (1994) mengungkapkan bahwa sebagian besar rancangan kotak sarang ini lebih mahal dibandingkan dengan tanda larangan penebangan kayu, bahkan dengan berbagai potongan harga sekali pun.

4c. Rangkong tidak membuat lubang, tapi spesies ini bisa memperbesar rongga yang dibuat oleh pelatuk atau spesies lainnya. Rangkong memerlukan pohon yang besar untuk bersarang, sehingga pohon dengan dbh minimum $50 \mathrm{~cm}$ harus tidak boleh ditebang (sangat dianjurkan). Rangkong Gading (Rhinoplax vigil) memerlukan pohon meranti berdiameter sangat besar (dbh lebih dari $105 \mathrm{~cm}$ ) untuk bersarang dan pohon seperti ini harus dipertahankan (seperti telah disampaikan di muka) (sangat dianjurkan).

4d. Saat sarang rangkong ditemukan pada pohon yang dipilih untuk ditebang, hal ini dapat menjadi indikasi bahwa pohon tersebut memiliki busuk gubal dan tidak boleh ditebang karena rangkong cenderung untuk memanfaatkan rongga tersebut selama bertahun-tahun (sangat dianjurkan).

4e. Di daerah-daerah tertentu, pohon yang buahnya kaya akan lipid, seperti suku kemuning (Aglaia) dan pala (Myristica), buah-buahan berdaging/berair seperti alpukat (dari famili Lauraceae) dan sirsak (Annonaceae), dan buahbuahan yang mengandung kadar gula tinggi seperti beringin tidak boleh ditebang karena spesies-spesies pohon tersebut merupakan sumber makanan bagi burung-burung ini (sangat dianjurkan). Hal ini dapat dicapai dengan meminimalkan kerusakan pohon yang bukan target penebangan.

4f. Spesies rangkong cenderung berkembang biak pada masa ketersediaan buah yang tinggi. Bila mungkin, penebangan harus ditangguhkan pada masa- 
masa ini, terutama bila penebangan tersebut berdekatan dengan pohon buah yang penting (sangat dianjurkan). Menetapkan daerah bersarang yang penting (sementara) hingga musim kawin selesai dapat dipertimbangkan dalam pengelolaan penebangan (sangat dianjurkan). Untuk memastikan bahwa rangkong tidak diburu pada musim kawinnya, diperlukan perhatian dan kehati-hatian yang tinggi (Datta 1998).

5. Sempidan (Sempindan Kalimantan (Lobiophasis bulweri), Sempidan Merah (Lophura erythrophthalma), Sempidan Biru (Lophura ignita) dan Kuau Raja (Argusianus argus)), adalah spesies-spesies yang terancam oleh perburuan, hilangnya sumber makanan, dan gangguan manusia.

5a. Sempidan Kalimantan dan Kuau Raja adalah spesies yang dilindungi oleh Undang-undang di Indonesia dan tidak boleh diburu. Informasi tentang larangan ini harus disebarkan kepada karyawan konsesi penebangan dan karyawan ini harus memahami dan menegakkan/menerapkan Undangundang tersebut (wajib).

5b. Cara yang terbaik untuk menangani akibat rusaknya habitat, hilangnya sumber makanan (buah-buahan yang jatuh dan invertebrata yang hidup pada daun yang luruh) serta gangguan yang ditimbulkan manusia terhadap spesies ini adalah dengan mengalihkan daerah hutan yang cukup luas bagi perlindungan populasi burung-burung tersebut. Sempidan Merah diperkirakan merupakan spesialis yang hidup di dasar lembah (McGowan \& Garson 1995 in BirdLife International 2001), terutama bila Sempidan Biru (Lophura ignita) tidak ditemui. Namun demikian, Sempidan Merah bisa hidup di hutan perbukitan. Sempidan Kalimantan dapat hidup terutama di hutan yang utuh di daerah perbukitan. Bila kawasan hutan dalam konsesi penebangan dilindungi untuk mendukung spesies-spesies sempidan tersebut, areal hutan ini harus cukup luas dan mencakup bagianbagian hutan perbukitan yang utuh serta lembah-lembah alluvial (sangat dianjurkan).

6. Spesies Cucak Rawa (Pycnonotus zeylanicus) dicari untuk dijadikan burung peliharaan dalam sangkar (Holden 1997 dalam BirdLife International 2001). Populasinya menurun drastis dan sebagai burung liar, spesies ini hampir tidak dapat ditemukan di alam (Holmes 1995 dalam BirdLife International 2001). Populasi yang ada di Kalimantan Timur menjadi sangat penting untuk melestarikan Cucak Rawa karena populasi tersebut berfungsi sebagai sumber kolonisasi kembali. Untuk itu diperlukan perlindungan hukum bagi spesies tersebut yang dapat diatur melalui pemerintah dan perbaikan sistem perlindungan serta penegakan hukum di daerah konsesi penebangan (sangat dianjurkan).

7. Raptor Elang Ular Kinibalu (Spilornis kinabaluensis) dan Elang-Alap Jambul (Accipiter trivirgatus).

7a. Elang-Ular Kinibalu adalah spesies yang sangat terpengaruh oleh adanya kerusakan habitat subpegunungan (Collar \& Andrew 1988 dalam BirdLife International 2001). Elang-Ular Kinibalu merupakan satu-satunya spesies di Indonesia yang ditemukan di Kalimantan Timur dan penelitian mengenai spesies ini harus ditujukan terutama untuk memantau populasinya 
(menetapkan jumlah populasi, wilayah jelajah, penggunaan habitat, dan sebagainya) (dianjurkan).

7b. Elang-Alap Jambul dilindungi oleh Undang-undang di Indonesia dan dengan demikian tidak boleh diburu serta habitatnya harus dilindungi (wajib).

8. Raja Udang Kalung-Biru (Alcedo euryzona) hidup di aliran sungai berukuran sedang, jernih dan berbatu serta terjal di kawasan hutan tropis dataran rendah atau hutan tropis di kaki pegunungan (BirdLife International 2001). Raja Udang Kalung-Biru sangat terpengaruh oleh rusaknya habitat hutan tepian sungai, pendangkalan sungai, dan peningkatan lalu lintas sungai.

8a. Diperlukan survei untuk menentukan tempat hidup spesies ini di daerah Malinau. Pendangkalan sungai di tempat hidup burung ini harus dicegah (sangat dianjurkan).

8b. Wells (1999) menganjurkan adanya evaluasi pengaruh penebangan hutan terhadap spesies ini. Evaluasi ini dapat dilakukan dalam kondisi yang terkendali di konsesi penebangan di Malinau (dianjurkan).

9. Punai Besar (Treron capellei) hidup di hutan primer dataran rendah yang relatif rata dan hutan primer di kaki perbukitan, dan merupakan spesies spesialis buah ara. Spesies ini sangat dipengaruhi oleh degradasi hutan mengingat bahwa kelimpahannya di daerah tebangan hanya setengah dari di hutan primer (Lambert 1992). Spesies ini kemungkinan banyak diburu untuk dimakan (BirdLife International 2001).

9a. Mempertahankan spesies beringin berukuran besar dalam jumlah yang cukup (contoh Ficus drupacea) (Lambert 1989c, Wells 1999), untuk sumber makanan yang memadai sepanjang tahunnya, merupakan upaya penting bagi keberadaan spesies burung ini (Wells 1999) (sangat dianjurkan).

9b. Perburuan Punai Besar harus diteliti dan tingkat perburuan yang berkelanjutan harus diupayakan. Perburuan di hutan tebangan harus dihentikan (sangat dianjurkan).

10. Pelatuk Kelabu-Besar (Mulleripicus pulverulentus). Seperti halnya Punai Besar, burung ini hidup di hutan dataran rendah yang rata dan kepadatan populasinya di hutan tebangan berkurang hingga lebih dari 80\% dibandingkan dengan di hutan primer (Lammertink 2004). Spesies ini membutuhkan pohon hidup dengan diameter besar untuk tempat makanannya yang berupa sarang lebah tak bersengat, semut, dan sarang rayap yang biasanya ada di rongga alami pada cabang pohon atau batang pohon yang besar. Mempertahankan pohon meranti atau spesies lain berukuran besar di hutan dataran rendah yang landai, dapat membantu menghambat penurunan populasi spesies ini setelah kegiatan penebangan (sangat dianjurkan).

\section{Kura-kura, kura-kura darat, dan kura-kura air tawar}

Beiyogo (Notochelys platynota), Baning Coklat (Manouria emys), dan mungkin Bulus (Amyda cartilaginea) terancam oleh kegiatan pemanenan yang berlebihan dan tidak dilindungi oleh Undang-undang di Indonesia. Penduduk setempat menangkap hewan tersebut untuk dimakan dan empedunya digunakan untuk obat-obatan 
(Sheil pengamatan pribadi). Untuk mencapai tingkat pemanfaatan yang lestari, perlu penelitian untuk menetapkan kepadatan spesies dan jumlah dari berbagai spesies kura-kura tersebut (sangat dianjurkan).

\section{Ikan}

Ikan mas (Tor spp.) dan ikan patin (Pangasius spp.) merupakan spesies yang paling dicari di MRF (lihat lampiran 3). Pangasius adalah spesies yang bermigrasi dan mudah ditangkap karena berkumpul di tempat-tempat yang mudah diduga. Ada sejumlah rekomendasi bersifat umum yang berkaitan dengan ikan Tor spp. Ikan ini sangat disukai oleh penduduk desa (berdasarkan wawancara di tiga desa) dan selain itu memiliki nilai budaya yang penting. Ikan Tor spp. dewasa hidup di lubuk yang dalam dan jernih di dalam hutan sementara anaknya hidup di anak sungai yang lebih dangkal. Spesies ini merupakan pemakan buah dan alga, dan diyakini berkaitan dengan keberadaan Dipterocarpus dan Ficus yang tumbuh di sepanjang tanggul sungai. Ikan ini harus dipandang sebagai spesies yang rentan karena memerlukan air yang jernih dan bergantung pada vegetasi hutan serta endapan sungai, mudah ditangkap, memiliki tingkat reproduksi yang relatif rendah, serta banyak dicari. Tentu saja, ikan-ikan ini tidak dapat ditemukan di daerah yang sungai yang bersiltasi, akibat penebangan hutan atau pembangunan jalan, dan umumnya tidak dapat hidup di daerah yang lebih terbuka. Untuk mencapai tingkat pemanfaatan yang lestari, perlu penelitian untuk menetapkan kepadatan spesies dan jumlah dari berbagai spesies ikan tersebut (sangat dianjurkan). Lebih jauh lagi, pengelolaan aliran sungai secara hatihati (lihat pula berbagai rekomendasi bagi pembangunan jalan dan infrastruktur di muka) dapat memastikan aliran air dan kolam-kolam yang jernih. Populasi spesies ikan tersebut tidak dipengaruhi secara negatif oleh kegiatan penebangan kayu (Rachmatika et al. 2005) (sangat dianjurkan). 



\section{Rekomendasi bagi perencana pemerintah}

Misi ITTO ke Indonesia belum lama ini (Yeom \& Chandrasekharan 2001) menyatakan bahwa kehutanan di Indonesia berada pada persimpangan jalan. Ada dua pilihan, yaitu melanjutkan ekstraksi hutan yang menyebabkan penurunan tajam kontribusi sektor ini pada kesejahteraan ekonomi, sosial, dan lingkungan, atau beralih ke kontribusi yang berkelanjutan untuk jangka panjang. Tidak diragukan lagi, pilihan pertama menimbulkan biaya jangka panjang yang lebih besar dibandingkan dengan pilihan kedua. Disini kami menyajikan bagaimana perbaikan perencanaan oleh pemerintah dan implementasinya dapat memperbaiki kelangsungan hidup hutan dan hidupan liar di Kalimantan Timur dan langkah apa saja yang dianggap akan bermanfaat.

\section{Perlunya rencana induk (masterplan) bagi hidupan liar}

Berdasarkan Undang-undang konservasi dan pemanfaatan hutan di Indonesia, konsesi penebangan kayu memiliki serangkaian kewajiban konservasi yang harus menjadi bagian dari prosedur perencanaannya. Namun demikian, kewajiban ini seringkali tidak tegas dan tidak jelas. Meskipun secara seksama setidaknya ada beberapa aspek dituangkan dalam peraturan, sebagian besar biasanya diabaikan dalam penerapannya. Contohnya, Pasal 5 Undang-undang No. 5 tahun 1990 (Departemen Kehutanan 1990) yang menyatakan: "konservasi sumberdaya hayati dan ekosistemnya harus dilakukan melalui kegiatan: a) perlindungan sistem penyangga kehidupan; b) pengawetan keanekaragaman spesies tumbuhan dan satwa beserta ekosistemnya; c) pemanfaatan secara lestari sumberdaya alam hayati dan ekosistemnya". Sejalan dengan itu, Peraturan Pemerintah No. 34 tahun 2002 tentang Tata Hutan dan Penyusunan Rencana Pengelolaan Hutan, Pemanfaatan Hutan dan Penggunaan Kawasan Hutan mencakup peraturan yang berkaitan dengan hidupan liar di wilayah konsesi penebangan. Maksud pernyataan tersebut memang baik, tetapi panduan pelaksanaan yang berkaitan dengan pencapaian peraturan sangatlah kurang. Panduan dan petunjuk yang lebih jelas dengan tujuan, peraturan, hak, serta kewajiban yang 
lebih tegas yang harus ditetapkan secara pragmatis dan lebih operasional merupakan hal yang sangat dibutuhkan. Dokumen tunggal yang mencakup ke semua itu, atau suatu rencana induk bagi hidupan liar, akan menjadi sangat penting (Bennett et al. 1996).

Lembaga pemerintah seharusnya bertanggung jawab untuk memastikan bahwa ancaman dikenali dengan baik dan upaya pencegahan dilakukan secara memadai. Contoh-contoh upaya ini antara lain adalah mengembangkan pendekatan bagi pencegahan dan pemantauan kebakaran hutan, mengidentifikasi spesies-spesies asing (eksotik) yang agresif, dan mengembangkan skema konservasi nasional yang mempertimbangkan perubahan iklim.

\section{Kesepakatan kepemilikan lahan}

Pengelolaan hutan dalam jangka panjang akan mendapat manfaat dengan adanya kesepakatan tentang hak lahan dan hak sipil. Tanpa mempertimbangkan hak penduduk asli yang telah lama tinggal di hutan dan hak-hak adat lainnya, konflik mungkin akan selalu terjadi. Ada peraturan adat tradisional yang jarang memiliki kekuatan hukum di Indonesia. Sejalan dengan itu, ada pula hak yang diberikan kepada konsesi hutan atau lembaga pemerintah di masa pemerintahan yang lalu (C. Colfer, in litt., 17 Oktober 2003). Undang-undang No. 41 tahun 1999 tentang Kehutanan Pasal 67 mengakui hukum adat dan hal ini sejalan dengan Surat Keputusan Menteri Kehutanan dan Perkebunan Tentang Hutan Kemasyarakatan 677/KptsII/1998. Namun demikian, petunjuk mengenai mekanisme hukum untuk dapat menterjemahkan dan menerapkan hukum dan peraturan tersebut sangatlah kurang. Isu ini merupakan hal yang rumit karena pertentangan hak seringkali timbul dari isi peraturan-peraturan yang saling berkontradiksi (lihat Lynch \& Harwell 2002).

Pertimbangan yang seksama harus diberikan agar hak lahan tradisional dapat ditetapkan dan diselesaikan secara adil. Lebih lanjut, diperlukan suatu prosedur dan mekanisme untuk menyelesaikan pertentangan yang ada. Perundingan serta kejelasan hukum juga diperlukan. Meskipun kami memahami pentingnya kepemilikan lahan, kami menyadari bahwa kami tidak dapat memberikan pemikiran yang memadai bagi isu yang rumit serta cara terbaik bagi penyelesaiannya. Pihak yang berminat pada topik yang penting ini dapat mengacu pada sumber-sumber pustaka seperti Lynch dan Harwell (2002), yang menjelaskan sejarah hak kepemilikan lahan hutan di Indonesia. Colfer dan Resosudarmo (2002), mengulas hambatan dalam penyelesaian isu kepemilikan lahan serta isu lain yang terkait, sementara Wollenberg et al. (2001), mengulas bagaimana stakeholders yang beragam, dapat diakomodasikan (terutama masyarakat) dalam pengelolaan hutan. Jika para stakeholders dalam suatu konsesi penebangan hutan mencapai kesepakatan kepemilikan lahan, perundingan mengenai tata batas pada daerah konsesi tersebut harus dilakukan di setiap desa:

- Wilayah, topografi, sungai, dan pola daerah resapan air;

- Fungsi hutan;

- Lokasi khusus (kuburan, desa tua, lokasi warisan, dan sebagainya) 
- Sejarah desa, penduduk desa, dan hak kepemilikan dan hak pemanfaatan lahannya;

- Pemanfaatan tradisional sumberdaya hutan (contohnya rotan, satwa liar);

- Pemanfaatan dan hal yang menjadi perhatian saat ini dalam bentang alam sekeliling hutan;

- Jumlah keluarga dan populasinya;

- Sumber mata pencaharian (terutama siapa yang memanfaatkan hutan, dan untuk apa);

- Prasarana, terutama akses ke dalam hutan melalui jalan dan sungai;

- Lokasi: apakah suatu desa terletak di luar, di perbatasan atau sebagian berada di dalam, atau berada di dalam daerah konsesi.

\section{Perencanaan berskala besar}

Perencanaan berskala besar harus dilakukan oleh pemerintah pada skala ruang yang lebih luas. Merancang dan melaksanakan rencana tata ruang pada skala bentang alam untuk tata guna lahan di Malinau diperlukan untuk memastikan bahwa fragmentasi hutan sedapat mungkin diminimalkan dan kesinambungan (konektivitas) antara hutan produksi dan hutan lindung dimaksimalkan. Rencana Konservasi Nasional Indonesia (FAO 1981) mengusulkan suatu jaringan kawasan hutan yang mencakup hutan dataran rendah Sebuku dan Sembakung di sebelah utara Malinau, daerah dataran rendah dan pesisir (Muara Kayan dan Gunung Berau), dan daerah hilir Taman Nasional Kayan Mentarang serta daerah aliran sungai dari sungai-sungai utama yang mengalir dari timur ke barat, antara pesisir dan pegunungan. Hal lain yang masih perlu dilakukan adalah menciptakan jaringan hutan yang terwakili dan dilindungi di Kalimantan Timur dengan mengusulkan daerah konservasi dan menerapkan upaya konservasi yang memadai bagi Hutan Lindung. Isu penting lainnya adalah bahwa tidak ada perluasan kegiatan pertanian dengan mengorbankan hutan di daerah yang tanahnya miskin serta daerah yang sangat terjal yang menghambat kelayakan pengembangan secara ekonomi.

Sebagaimana telah kami sampaikan, fragmentasi habitat merupakan faktor utama yang mengancam kelangsungan hidup spesies burung dan mamalia hutan. Jepson et al. (2002) belum lama ini mengungkapkan bahwa jaringan kawasan perlindungan di Kalimantan Timur masih harus dibangun. Hal ini terjadi meskipun pada tahun 1982 pemerintah Republik Indonesia telah mengadopsi kebijakan perencanaan tingkat bentang alam bagi kawasan hutan terkait. Pengembangan perencanaan dan prosedur pelaksanaan yang lebih efektif yang melibatkan departemen dan lembaga (di tingkat nasional dan kabupaten/provinsi) serta stakeholders lain yang terkait jelas sangat diperlukan. Dalam UU No. 24/1992 tentang Penataan Ruang, provinsi dan kabupaten diharuskan untuk menyiapkan rencana tata ruang (dikenal sebagai Rencana Tata Ruang Wilayah Propinsi/Kabupaten = RTRWP/K). Tetapi di Kalimantan Timur rencana ini tidak menggambarkan penetapan hutan dengan luasan yang memadai untuk keberlangsungan hidup satwa liar dalam jangka panjang (Jepson et al. 2002). Selain itu, rencana ini mengabaikan kawasan hutan untuk perlindungan daerah aliran sungai (DAS) dan daerah-daerah lindung yang diusulkan dalam Rencana Konservasi 
Nasional Indonesia di tahun 1981/1982 (FAO 1981). Namun, peta daerah hutan yang dibuat oleh Departemen Kehutanan belum lama ini masih menunjukkan adanya kawasan hutan yang luas di Kalimantan Timur bagian utara. Tantangannya adalah bagaimana mempertahankan keutuhan daerah tutupan hutan ini, terutama hutan dataran rendah, tanpa mengabaikan kepentingan pembangunan ekonomi setempat. Provinsi Kalimantan Timur telah merevisi rencana tata ruangnya di tahun 1999 menjadi yang disebut sebagai rencana tata ruang padu serasi. Rencana tata ruang ini bertujuan untuk memadukan tata guna lahan kehutanan dan yang lainnya. Namun demikian, rencana yang telah direvisi ini belum disepakati oleh seluruh pihak karena adanya rencana yang dianggap bertentangan di tingkat kabupaten/kota.

Pengembangan dan pemeliharaan jaringan daerah lindung dan wilayah hutan produksi harus dipadukan dengan tujuan pembangunan yang lain (seperti jalan, jembatan, kehutanan, dan sebagainya). Sedapat mungkin, daerah hutan produksi harus dipertahankan untuk tetap berkesinambungan dengan hutan yang dilindungi sehingga satwa dapat bergerak bebas di kedua tipe hutan tersebut. Hal ini untuk memastikan perlindungan seluruh spesies dan pasokan makanan yang terus menerus bagi para pemburu yang pemenuhan kebutuhan protein hewaninya bergantung pada satwa liar. Daerah tersebut bisa mencakup hutan produksi dan hutan lindung yang dikelola untuk memelihara tutupan hutan dan keanekaragaman hayati selain juga untuk mencapai tujuan-tujuan produksinya. Meskipun saran kami terlihat tidak realistis, kami mencatat ada banyak contoh keberhasilan dari tindakan dan upaya ini di Sarawak (WCS 1998).

Secara khusus menetapkan sistem tata guna lahan yang terdiri dari jaringan kawasan hutan lindung dan kawasan hutan produksi kayu yang utuh merupakan tindakan yang sangat penting dilakukan. Kawasan dalam jaringan ini mencakup daerah yang dilindungi yang melarang atau sangat membatasi kegiatan perburuan. Ada dua tipe daerah lindung yang dibutuhkan, yaitu:

- Wilayah yang luas (lebih dari $100 \mathrm{~km}^{2}$ ), yang memadai untuk melindungi populasi spesies satwa liar yang layak, yang berfungsi sebagai "sumber (sources)" yang dapat mengisi kembali tempat-tempat penurunan (sink) populasi karena perburuan;

- Daerah yang lebih kecil atau daerah penghubung untuk melindungi daerah yang rentan bagi spesies tertentu. Daerah seperti ini mencakup daerah tempat bersarang yang umum, mata air asin - salt licks, koridor, daerah yang kaya akan tumbuhan yang menjadi sumber makanan, atau daerah yang dikenal sebagai tempat berkembang biak.

\section{Perburuan dan penangkapan ikan}

Pemerintah Indonesia memiliki peran yang penting dalam mendorong tercapainya perburuan yang lestari dan berkelanjutan. Kerangka hukum bagi perburuan ini telah dinyatakan dalam Peraturan Pemerintah No. 13 tahun 1994 tentang Perburuan Satwa Buru. Panduan hukum lebih lanjut tercantum dalam peraturan berikut ini: 
- Peraturan Pemerintah No. 8 tahun 1999 tentang Pemanfaatan Spesies Tumbuhan dan Satwa liar;

- Surat Keputusan Menteri Kehutanan No. 447447/Kpts-II/2003 tentang Administrasi Pengambilan atau Penangkapan dan Penyebaran Tumbuhan dan Satwa;

- Surat Keputusan Direktur Jenderal Perlindungan Hutan dan Konservasi Alam No. 158/KPTS/DJ-IV/2003 tentang Kuota Pengambilan Vegetasi Alami dan Penangkapan Satwa untuk tahun 2004.

Peraturan dan perundangan tersebut menyatakan bahwa kuota maksimum bagi pengambilan seluruh satwa liar di alam-dilindungi atau tidak dilindungiharus ditetapkan (lihat Lampiran 12). Umumnya, pengambilan spesies yang tidak dilindungi (dan spesies yang dilindungi, pada sejumlah kasus) tidak diatur. Lagi-lagi, petunjuk yang jelas dan tegas yang dikembangkan secara praktis dan operasional sangat diperlukan. Rencana Induk hidupan liar di Sarawak (Sarawak Wildlife Masterplan) memberikan panduan yang bermanfaat bagi hal ini. Berdasarkan Rencana Induk ini (dimodifikasi berdasarkan Bennett \& Robinson 2000), kami menggarisbawahi halhal sebagai berikut:

- Penetapan daerah-daerah dimana kegiatan perburuan dibatasi atau dilarang;

- Mengawasi akses perburuan dan penangkapan ikan di daerah-daerah yang penting (dengan melarang pendatang untuk memasuki daerah perburuan dan penangkapan ikan tradisional);

- Mengawasi atau melarang perdagangan satwa liar, termasuk pengangkutan dan penjualannya;

- Menetapkan dan menegakkan hukum untuk melindungi spesies yang rentan;

- Penetapan dan menegakkan peraturan yang membatasi atau melarang perburuan dan penangkapan ikan dari spesies yang secara musiman rentan;

- Menetapkan dan menegakkan hukum tentang penggunaan berbagai alat perburuan dan penangkapan ikan yang merusak;

- Membangun mekanisme dan kondisi yang mendorong program pendidikan dan kesadaran tentang konservasi hidupan liar serta tentang pentingnya upaya pengurangan kegiatan perburuan dan penangkapan ikan yang berlebih, di setiap tingkat: pengambil keputusan, sekolah, dan masyarakat setempat.

Selain itu, pemerintah dapat berupaya untuk mengurangi kebutuhan daging satwa liar dengan mengembangkan, mensubsidi, atau setidaknya mendorong program yang menyediakan sumber protein hewani alternatif bagi kebutuhan penduduk setempat. Program ini bisa mencakup produksi hewan ternak, tambak ikan, atau perkebunan. Hal ini harus dilakukan sebagai bagian dari perencanaan tata guna lahan yang utuh. Jika tidak dikaitkan dengan skema yang lebih besar, upaya ini tidak akan dapat mengurangi perburuan yang dilakukan secara berlebihan. Untuk itu upaya ini harus menjadi bagian dari pendekatan yang utuh untuk mencapai sistem pengawasan dan pengendalian perburuan yang berjalan dengan baik. 
Lee (2000) menyarankan agar pemerintah juga berupaya untuk mengembangkan sistem denda dan hukuman bagi perburuan liar. Sebagaimana dinyatakan dalam Undang-undang No. 5 Tahun 1990, denda maksimum bagi perburuan spesies yang dilindungi adalah Rp. 100.000.000 (atau 45,454 dollar AS) dan/atau hukuman penjara maksimum 5 tahun. Dengan pertimbangan penghasilan perkapita ratarata di Indonesia kurang dari sepersepuluh jumlah denda ini, dan hanya sedikit saja pelanggar hukum yang dapat membayar denda tersebut, diperlukan kajian ulang untuk pelaksanaan Undang-undang ini. Clayton dan Milner-Gulland (2000) menyarankan agar penerapan denda bagi pedagang daging satwa liar merupakan cara yang lebih efektif untuk mengurangi tekanan perburuan komersial.

\section{Penegakan hukum dan tata kelola kehutanan}

Ada kebutuhan yang mendesak bagi pemerintah provinsi dan kabupaten/kota di Indonesia untuk melaksanakan hukum dan peraturan yang melindungi hutan serta menjadikan prinsip pengelolaan hutan lestari sebagai panduan utama. Banyak peraturan dan perundangan yang ada di Indonesia yang terkait dengan rekomendasi kami dapat diperkuat atau setidaknya diterapkan secara lebih baik. Peraturan dan perundangan ini diterjemahkan secara terburu-buru dengan data ilmiah atau pemahaman teknis yang kurang baik, tidak menyediakan ruang bagi keterlibatan publik, dan tidak memasukkan acuan antar sektoral (pertambangan, pertanian, dan kebijakan tata guna lahan). Dinamika reformasi yang ada saat ini telah menghasilkan ribuan produk hukum baru dalam beberapa tahun belakangan ini. Dengan demikian, Undang-undang (seperti Undang-undang No. 41 Tahun 1999, lihat Lampiran 10) yang ada masih berada dalam transformasi, sehingga menyulitkan kami untuk mengusulkan perubahan hukum secara spesifik. Contohnya, Keputusan Menteri Kehutanan No. 162/kpts-ii/2003 yang bertujuan untuk mempercepat pengembangan HTI untuk memenuhi kebutuhan industri kertas dan pulp, menyatakan bahwa tebang habis dapat dilakukan di areal hutan alam yang menjadi lokasi implementasi sistem pemanfaatan lestari dari hutan perkebunan. Peraturan ini bertolak belakang dengan peraturan yang melarang kegiatan tebang habis di wilayah hutan alam. Perubahan hukum yang kami usulkan adalah sebagai berikut:

- Hukum yang mengatur batas maksimum diameter pohon yang boleh ditebang;

- Menyatakan dengan tegas bahwa melestarikan 'spesies yang dilindungi' mensyaratkan perlindungan habitatnya. Selain itu, petunjuk pelaksanaannya perlu diadakan, karena kerangka hukum yang ada saat ini tidak menerangkan cara untuk melindungi habitat spesies yang dilindungi, meskipun kriteria untuk melestarikan spesies yang dilindungi tersebut telah ditetapkan, baik di dalam maupun di luar cagar alam (lihat Rijksen \& Meijaard 1999, p. 321);

- Pembatalan peraturan yang mengharuskan pemangkasan tumbuhan rambat dan vegetasi tanah yang dinyatakan dalam persyaratan pengelolaan hutan (TPTI);

- Rehabilitasi tempat pengumpulan kayu dan perlintasan sungai setelah kegiatan penebangan secara sistematis; 
- Penutupan jalan yang tidak terlalu diperlukan pada saat kegiatan penebangan selesai. Hal ini dapat mencegah pemburu untuk menggunakan jalan tersebut serta menurunkan kesempatan masuknya kembali kegiatan penebangan liar, pertanian, dan kebakaran hutan;

- Melarang perburuan dan pengambilan satwa liar komersial di wilayah konsesi penebangan kayu (untuk penjelasan rinci lihat bagian Rekomendasi bagi Para Pengelola, mengawasi perburuan dan pengambilan);

- Pelaksanaan dan penegakan larangan perdagangan satwa liar dan bagian-bagian tubuh satwa di wilayah konsesi;

- Perlu dikembangkan mekanisme hukum dan mekanisme pelaksanaan bagi keterlibatan masyarakat setempat dalam pengambilan keputusan dan pengelolaan sumberdaya hidupan liar serta perburuan di wilayahnya;

- Penetapan zona konservasi dalam wilayah konsesi penebangan yang melarang kegiatan perburuan;

- Larangan penggunaan alat kejut listrik, bom, dan racun dalam penangkapan ikan;

- Kebakaran hutan menghilangkan pembatasan bagi pemegang konsesi hutan untuk tidak melakukan penebangan di daerah hutan yang telah dipanen sebelum berakhirnya periode konsesi tersebut secara legal. Perubahan hukum diperlukan untuk melarang penebangan kembali sebelum masa konsesi berakhir;

- Peraturan bagi perusahaan penebangan untuk menyediakan dana untuk dibayarkan kepada lembaga pemerintah terkait yang berwenang, yang jumlahnya dihitung berdasarkan proporsi hutan yang akan dieksploitasi pada tahun tersebut dan digunakan untuk penegakan hukum yang berkaitan dengan hidupan liar;

- Pengajian kembali status perlindungan spesies yang terancam punah (menurut IUCN) atau spesies yang berada dalam tekanan perburuan/pengambilan yang sangat tinggi (lihat daftar di bawah ini).

Masalah-masalah lain yang timbul karena upaya pemerintah pusat dalam desentralisasi lembaga pemerintahan adalah wewenang kabupaten yang dapat menerbitkan peraturannya sendiri. Hal yang sangat penting untuk dilakukan adalah menegaskan status hukum peraturan yang diterbitkan di tingkat nasional dan tingkat provinsi/kabupaten-kota.

Ada indikasi bahwa saat ini pemerintah pusat berupaya untuk menerapkan Undang-undang kehutanan dan konservasi di tingkat kabupaten. Contohnya, kesepakatan pembangunan jalan di dalam Taman Nasional Kayan Mentarang di Kalimantan Timur, antara Sabah Forest Industries dan Yayasan Pendidikan Pembangunan Perbatasan Kalimantan Timur dianggap ilegal oleh Direktur Konservasi Kawasan, yang menyatakan bahwa "seluruh taman nasional di Indonesia berada di bawah wewenang Direktur Jenderal Perlindungan Hutan dan Konservasi Alam Departemen Kehutanan, dan bukan di bawah wewenang Pemerintah Kabupaten Nunukan atau Malinau atau Pemerintah Provinsi Kalimantan Timur (Francis 2003). Hal ini dengan jelas dinyatakan dalam Undang-undang No. 22/1999 bahwa wilayah konservasi masih berada di bawah kendali pemerintah pusat. 
Kami menganggap penegakan hukum adalah elemen kunci bagi perbaikan pengelolaan hutan, meskipun praktek kegiatan kehutanan hanya akan menjadi lebih baik bila kondisi sistem pemerintahannya ditingkatkan. Kami menyampaikan rekomendasi ini dengan pemahaman bahwa perbaikan sistem ini tengah berlangsung dalam proses sistem perundangan di Indonesia.

Banyak rekomendasi kami yang telah dimasukkan ke dalam sistem hukum di Indonesia. Contohnya, Peraturan Pemerintah No. 13 tahun 1994 tentang Perburuan Satwa Buru. Peraturan ini antara lain melarang penggunaan alat buru ilegal, seperti bahan kimia, jerat dan perangkap lubang. Namun, peraturan ini jarang sekali diterapkan, di lain pihak seperti telah disampaikan di bagian lain buku ini, ada ketimpangan yang menyolok antara status perlindungan spesies dan upaya perlindungan yang seharusnya dilakukan untuk spesies tersebut. Untuk itu ada sejumlah spesies yang sangat langka masih dapat diburu atau ditangkap karena tidak termasuk dalam daftar spesies yang dilindungi di Indonesia (lihat daftar di bawah ini, mohon dicatat bahwa spesies yang tidak dilindungi juga memerlukan kuota untuk penangkapan secara legal-lihat Lampiran 12). Dengan demikian penanganan isu ini dilakukan dengan cara meneliti kembali spesies yang terdaftar oleh IUCN dan mengkaji spesies-spesies yang belum dilindungi di Indonesia. Puslitbang Biologi LIPI saat ini sedang melakukan pengkajian kembali daftar spesies yang dilindungi Undangundang di Indonesia yang diterbitkan tahun 2001 (Noerdjito \& Maryanto 2001). Berkaitan dengan spesies yang hidup di Malinau, kandidat utama untuk dimasukkan dalam daftar adalah:

- Bangau Storm Ciconia stormi (terdaftar sebagai terancam punah (Endangered) oleh IUCN)

- Baning Coklat Manouria emys (terdaftar sebagai terancam punah (Endangered) oleh IUCN)

- Bajuku Orlitia borneensis (terdaftar sebagai terancam punah (Endangered) oleh IUCN)

- Labi Labi Raksasa Pelochelys cantorii (terdaftar sebagai terancam punah (Endangered) oleh IUCN)

- Sempidan Merah Lophura erythrophthalma (terdaftar sebagai rentan (Vulnerable) oleh IUCN)

- Cucak Rawa Pycnonotus zeylanicus (terdaftar sebagai rentan (Vulnerable) oleh IUCN)

- Berencet Kalimantan Ptilocichla leucogrammica (terdaftar sebagai rentan (Vulnerable) oleh IUCN)

- Puyuh Sengayan Rollulus rouloul (terdaftar sebagai rentan (Vulnerable) oleh IUCN)

- Elang-Ular Kinibalu Spilornis kinabaluensis (terdaftar sebagai rentan (Vulnerable) oleh IUCN)

- Punai Besar Treron capellei (terdaftar sebagai rentan (Vulnerable) oleh IUCN)

- Bulus Amyda cartilaginea (terdaftar sebagai rentan (Vulnerable) oleh IUCN)

- Beiyogo Turtle Notochelys platynota ((terdaftar sebagai rentan (Vulnerable) oleh IUCN) 
- Monyet Beruk Macaca nemestrina (terdaftar sebagai rentan (Vulnerable) oleh IUCN)

- Lutung Banggat Presbytis hosei (terdaftar sebagai Data Kurang (Data Deficient) oleh IUCN).

Pemerintah harus mengkaji kembali apakah sejumlah spesies yang saat ini dilindungi secara legal dapat diburu untuk kebutuhan sehari-hari. Spesies ini termasuk antara lain Rusa Sambar (Cervus unicolor), Kijang Muncak (Muntiacus muntjak), Pelanduk Kancil (Tragulus javanicus), Pelanduk Napu (T. napu), dan Landak Raya (Hystrix brachyura). Untuk itu diperlukan adanya perubahan status perlindungan secara hukum terhadap spesies-spesies tersebut. Sebelum perubahan status ini dilakukan, pemerintah harus mempertimbangkan spesies yang bergantung pada hutan, seperti pelanduk (Tragulus spp.) yang membutuhkan daerah hutan yang luas. Dengan demikian diperlukan perlindungan daerah hutan yang luas dan bebas dari kegiatan permukiman dan fragmentasi sebelum memperkirakan potensi kegiatan perburuan secara lestari.

Akhirnya, penegakan hukum seharusnya didukung oleh perangkat canggih yang dapat mendeteksi kegiatan ilegal seperti penebangan dan tebang habis liar atau penggunaan api secara ilegal. Teknik penginderaan jauh memungkinkan pemantauan pembangunan jalan, degradasi dan deforestasi hutan, serta kebakaran hutan secara rinci. Pengembangan sistem pemantauan jarak jauh dan pemanfaatan data yang dihasilkannya harus dipertimbangkan ke dalam sistem penegakan hukum, meskipun teknik tersebut hanya bisa efektif bila reformasi kelembagaan telah berhasil membangun penegakan hukum yang efektif di lapangan. Selama pihak yang berkuasa dan pihak yang memiliki uang banyak berhasil menghindari proses hukum, harapan untuk memberantas penebangan dan perburuan ilegal, serta memberantas kegiatan lain yang dapat menimbulkan efek negatif bagi populasi kehidupan di Indonesia sangat rendah. Hal ini banyak terkait dengan tindak korupsi, baik di sektor publik maupun swasta. Lebih lanjut hal ini menekankan perlunya perencanaan sektor kehutanan yang transparan, keterlibatan stakeholders yang terkait-mulai dari tahap perencanaan hingga pelaksanaan, dan sistem pemantauan yang efektif yang dilaksanakan oleh lembaga pemerintah dan nonpemerintah.

\section{Pelaksanaan yang efektif}

Selain penegakan hukum, praktek kehutanan harus didukung oleh konteks pengelolaan, kemampuan/kapasitas dan kesempatan. Mungkinkah para pengelola konsesi hutan menemukan paradigma pengelolaan yang baru? Kebijakan kehutanan di Indonesia terutama didorong oleh pertimbangan ekonomi. Terlepas dari pendekatan yang lebih diarahkan pada upaya konservasi dan konversi, degradasi hutan terus berlangsung dengan laju yang mengkhawatirkan (lihat Holmes 2000, Jepson et al. 2001). Bahkan kawasan konservasi tidak terhindar dari tebang habis, seperti contohnya di Taman Nasional Kutai di Kalimantan Timur dengan hutan sisa yang sangat sedikit (Soehartono \& Mardiastuti 2001). Kondisi seperti ini banyak terjadi di tempat lain di Indonesia. Di provinsi Sumatera Selatan yang memiliki 
enam buah kawasan konservasi (dengan luas total $2.580 \mathrm{~km}^{2}$ ), tidak lagi memiliki tutupan hutan sama sekali (Holmes 2000). Di daerah Malinau, sejumlah proyek pembangunan jalan direncanakan dan sebagian sudah dilaksanakan. Pembangunan ini akan menyebabkan fragmentasi lebih lanjut di daerah hutan dataran rendah utuh yang masih luas, meningkatkan tekanan terhadap populasi satwa liar dan produk hutan nonkayu lainnya, serta meningkatkan risiko kebakaran hutan. Dalam konteks ini, kami masih belum yakin tentang bentuk rekomendasi yang diperlukan untuk pengelolaan konsesi hutan yang lebih baik agar berhasil dilaksanakan sesuai rencana.

Spektrum kebijakan yang dapat membantu implementasi rekomendasi disarankan untuk dimulai dari pendekatan top-down, penegakan hukum oleh pemerintah, hingga pendekatan strategi berbasis masyarakat yang sifatnya bottom-up. Di antara pendekatan tersebut, ada pula kesempatan yang lebih bersifat pendekatan pasar seperti sertifikasi hutan. Belum lama ini, sejarah kebijakan kehutanan di Indonesia menunjukkan adanya masalah yang berkaitan dengan pelaksanaan kebijakan pemerintah tentang kehutanan dan konservasi, terutama pada saat ini dimana wewenang pemerintah didesentralisasikan (Colfer \& Resosudarmo 2002). Selain itu tidak ada kejelasan hubungan antara hukum di tingkat nasional, regional, dan kabupaten tentang rencana tata guna lahan. Sistem hukum di tingkat nasional harus dimasukkan dalam rencana pengelolaan konsesi, contohnya, yang berkaitan dengan larangan perburuan spesies yang dilindungi, atau pembentukan daerah perlindungan yang baru. Namun dengan pertimbangan kurangnya penegakan hukum, pendekatan yang dapat menunjukkan manfaat hutan yang dikelola secara lestari kepada stakeholders setempat memiliki kemungkinan sukses yang lebih baik. Kami yakin bahwa sertifikasi hutan dan pengelolaan hutan yang partisipatif merupakan strategi yang paling menjanjikan untuk memastikan agar hutan di Malinau dikelola secara lestari.

Kami tidak menyarankan agar seluruh tanggung jawab langsung diserahkan pada masyarakat setempat. Strategi sertifikasi dan pengelolaan partisipatif harus diperkenalkan dengan hati-hati dan dikombinasikan dengan kebijakan pemerintah yang mudah dipahami oleh pemangku kepentingan setempat.

Selain itu, harus ada pemantauan kemajuan strategi tersebut secara ketat dan independen. Bagaimana pemantauan tersebut dapat menjadi alat umpan balik yang efektif terhadap pengelolaan yang lebih baik merupakan hal yang sulit dijawab. Bila ada keterlibatan investasi asing, kelompok pengawas (pressure group) dapat menggunakan pengaruhnya untuk memastikan bahwa investasi tersebut diarahkan pada proyek kehutanan yang dikelola dengan baik. Upaya ini telah berhasil dilaksanakan di beberapa proyek sertifikasi kayu di sejumlah tempat di dunia. Contohnya, dalam industri minyak kelapa, penyandang dana utama telah menyetujui prosedur pelaksanaan mengacu pada hukum nasional dan terbuka bagi pemeriksaan independen (lihat http://www. rabobank.com/repository/position/palmoilcode_rabobank.pdf). Meskipun belum diterapkan di Malinau atau di tempat lain di Indonesia, hal ini merupakan pertanda yang baik dan sertifikasi kayu dari hutan alam akhirnya terealisasi. 


\section{Persyaratan sertifikasi}

Buku ini tidak bermaksud untuk menganalisis kriteria dan indikator secara rinci. Namun kami ingin membandingkan secara singkat temuan yang kami dapatkan dengan kriteria rekomendasi pengelolaan kehutanan lestari yang telah dikenal secara luas. Umumnya, banyak rekomendasi kami yang tumpang tindih, atau setidaknya tujuan yang ada di belakangnya, dengan rekomendasi yang dinyatakan dalam prinsip-prinsip Forest Stewardship Council (FSC). Contohnya, Prinsip FSC 6.2 menekankan 'perlunya pengawasan bagi perburuan, penangkapan ikan, penjeratan, dan pengambilan yang tidak benar', sementara Prinsip 1.1 menyatakan bahwa 'pengelolaan hutan akan mematuhi seluruh hukum nasional dan hukum setempat serta persyaratan administratifnya'. Prinsip ke-9 menyatakan bahwa 'kegiatan pengelolaan dalam hutan dengan nilai konservasi tinggi akan memelihara atau memperkuat karakteristik yang membentuk hutan tersebut'. Lebih lanjut, Prinsip 10 mengulas kebutuhan untuk mempertahankan konektivitas hutan alam, meskipun hal ini terkait dengan perencanaan perkebunan, dimana peran konsesi hutan tampaknya sangat kecil (lihat Prinsip 6.10). Tetapi upaya untuk mempertahankan integritas ekologis dan konektivitas di hutan produksi tidak dibahas dan dinyatakan dengan memadai dalam kriteria FSC.

Kajian kami menunjukkan bahwa fragmentasi hutan merupakan salah satu faktor yang paling penting dalam penurunan populasi satwa liar. Karenanya, upaya untuk memastikan bahwa hutan di daerah konsesi sedapat mungkin masih memiliki keterkaitan sementara pada skala bentang alam dan dengan daerah hutan yang dilindungi. Solusi terbaik bergantung pada konteks dan pilihan-pilihan yang ada, yaitu dengan memperhitungkan pilihan yang pragmatis dan seimbang. Hal ini tidak mudah untuk disederhanakan menjadi serangkaian kriteria dasar. Upaya perencanaan yang seksama sangat diperlukan untuk mempertimbangkan perangkat terbaik untuk mempertahankan konektivitas tersebut (Sheil et al. 2004). 
Kriteria FSC tentang perburuan, penangkapan ikan, penjeratan, dan pengambilan (lihat bagian sebelumnya) tidak bisa memberikan panduan yang tegas mengenai bagaimana pihak yang memiliki konsesi hutan harus menangani masalah ini di wilayahnya. Istilah 'tidak benar' dalam Prinsip 6.2 memberikan ruang interpretasi yang luas bagi pengelola kawasan konsesi. Kami kira akan lebih tepat bila prinsipprinsip FSC memberikan penekanan pada perlunya upaya kajian daftar spesies prioritas dalam wilayah konsesi (yang sejenis dengan kajian yang disajikan dalam buku ini). Kajian ini dapat dikumpulkan sebagai dasar rencana tindakan khusus bagi masing-masing spesies dengan prioritas tinggi. Kajian ini mencakup penelitian mengenai habitat dan wilayah jelajah, sumberdaya yang penting bagi spesies tertentu (pohon tertentu, mata air mineral, gua, dan sebagainya), strategi penebangan yang mendorong keberadaan spesies tersebut, dan rekomendasi mengenai tingkat perburuan yang lestari atau mengenai larangan perburuan. Kami juga menganggap kriteria FSC tidak memberikan rincian yang cukup tentang bagaimana menangani kondisi sehari-hari dimana spesies yang dilindungi secara langsung kerap terancam oleh kegiatan penebangan. Contohnya, pohon tempat bersarang rangkong yang dijadwalkan untuk ditebang.

Lebih jauh lagi, tidak terlihat kriteria tentang bagaimana mengatur pemanfaatan/ pemanenan daging satwa liar (selain yang dinyatakan dalam hukum nasional). Sekali lagi, panduan yang tegas dan jelas sangat diperlukan antara lain karena banyak spesies yang diburu memiliki peran yang penting bagi keberlanjutan hutan produksi dalam jangka panjang. Akhirnya, seperti telah kami kemukakan, kayu mati merupakan komponen yang sangat penting bagi keberlanjutan hutan. Cara terbaik untuk memastikan keberadaan kayu/pohon mati yang cukup, setidaknya dalam jangka menengah, adalah mempertahankan pohon yang produktif berukuran besar dan memfokuskan kegiatan penebangan kayu pada pohon berukuran menengah.

Kesimpulannya, kriteria sertifikasi dan prosedur serta panduan yang terkait dapat dibuat lebih bermanfaat dengan memasukkan pengelolaan hidupan liar yang lestari didalam kegiatan kehutanan. Hal ini untuk memastikan kelangsungan hidup populasi satwa liar yang layak di daerah konsesi penebangan. Meskipun diupayakan perlindungan hutan dengan nilai konservasi tinggi serta perlindungan bagi spesies tertentu, kriteria FSC tidak memberikan panduan yang cukup rinci mengenai bagaimana menangani permasalahan sehari-hari yang problematis. Contoh masalah ini antara lain perburuan spesies yang dilindungi seperti Rusa Sambar (Cervus unicolor), menebang pohon yang digunakan oleh spesies langka atau dilindungi. Dengan demikian, kami menganjurkan revisi proses sertifikasi yang ada dengan memasukkan contoh-contoh yang jelas-dalam perencanaan, operasional, dalam kesiapan terhadap ancaman, serta seluruh aspek pengelolaan-yang mencerminkan prioritas konservasi hidupan liar, masalah dan tujuan bagi setiap konsesi penebangan secara jelas dan eksplisit (Sheil et al. 2004). 


\section{B A A N D PENELITIAN}

\section{Rekomendasi bagi penelitian dan para peneliti}

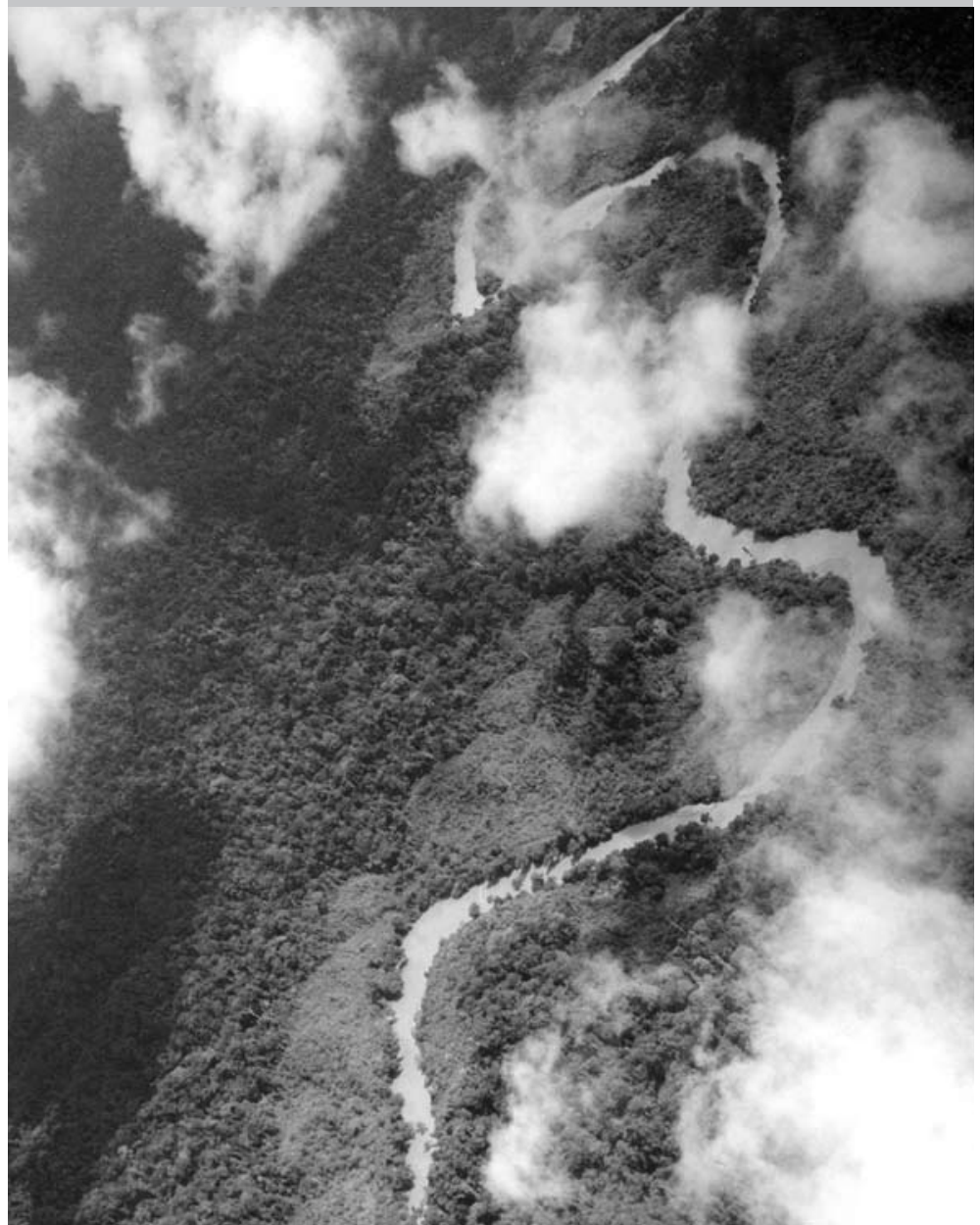

Pemandangan percabangan Sungai Malinau yang mencakup kawasan hutan regenerasi. Konsesi penebangan kayu harus dimanfaatkan sebagai bagian dari proses perencanaan dan pemeliharaan bentang alam hutan yang utuh dan saling berkaitan (Foto oleh Sven Wunder). 



\section{Rekomendasi bagi penelitian dan para peneliti}

Kajian kami menunjukkan bahwa satwa liar di Borneo-kecuali beberapa spesies saja-kurang dikenal. Selain itu penelitian tentang ancaman terhadap satwa liar tersebut kurang banyak dilakukan. Penelitian serupa lebih banyak dilakukan di Sarawak dan Danum Valley Field Center, Sabah (sebagai contoh, Heydon \& Bulloh 1997, Colón 1999). Di Sarawak para peneliti berupaya mengungkap pengaruh perburuan (termasuk di dalamnya yang terkait dengan kegiatan di konsesi penebangan kayu) terhadap burung dan mamalia (Bennett et al. 1997, Bennett et al. 1999, Bennett \& Gumal 2001), dan di Danum Valley Field Center, Sabah (e.g., Heydon \& Bulloh 1997, Colón 1999). Di Kalimantan, penelitian tentang ancaman terhadap primata (terutama Orangutan, Pongo pygmaeus) lebih banyak mendapatkan perhatian. Beberapa penelitian yang dilakukan belum lama ini berfokus pada Beruang Madu (Ursus malayanus) dan Babi Berjenggot (Sus barbatus) (Curran et al. 1999, Meijaard 2003a, Hancock et al. in press).

Mengingat belum banyak penelitian terhadap spesies lain yang kurang dikenal, diperlukan penelitian yang bersifat pragmatis yang dapat mengklarifikasi secara langsung kebutuhan dan/atau peluang konservasi, serta penelitian tentang satwa liar yang lebih bersifat terapan. Penelitian yang dilakukan diharapkan tidak terlalu terfokus pada pemantauan kepadatan spesies tertentu, namun lebih terfokus pada pengaruh langsung ancaman tertentu dan cara penanganannya.

Kurangnya kajian tentang ancaman terhadap fauna Borneo sangat nyata terlihat. Pada umumnya tidak ada kesulitan dalam mengidentifikasi ancaman terhadap keanekaragaman hayati, yang mencakup hilangnya habitat (terutama hilangnya tutupan hutan alam), perambahan, eksploitasi yang tidak diatur, dan berbagai bentuk degradasi lingkungan. Hal yang sangat penting adalah diperlukannya informasi mengenai distribusi, persyaratan pakan, persyaratan sarang, dan bahkan morfologi, sifat genetik, dan taksonomi dari spesies yang menjadi target. Namun informasi tersebut jarang bisa secara langsung memperbaiki pengelolaan konservasi. Penyebabnya antara lain adalah ketidakjelasan implikasi pengelolaan dari kegiatan penelitian yang telah dilakukan. 
Mengapa jarang sekali peneliti melakukan atau mempublikasikan pengamatan tentang respons spesies terhadap gangguan dan ancamannya? Sejumlah penelitian mungkin memiliki tujuan yang berbeda. Memperoleh informasi ekologis secara rinci mengenai spesies dan interaksinya dengan lingkungan (yang rusak) tempat tinggalnya membutuhkan waktu yang lebih lama ketimbang waktu pengamatan yang tersedia bagi seorang peneliti. Meskipun demikian, dengan upaya yang relatif terbatas, kegiatan penelitian di Borneo bisa membangun suatu data yang ekstensif tentang bagaimana spesies bereaksi terhadap ancaman tertentu. Data tersebut bisa diambil dari pengamatan sederhana (contohnya, informasi mengenai spesies yang melintasi jalan tebangan selebar $3 \mathrm{~m}$ pada jam 15.30) yang dilakukan secara rutin sebagai bagian dari pengamatan yang sedang dilakukan. Bila seluruh data yang tersedia dikompilasi secara konsisten, banyak pertanyaan penting yang mungkin bisa terjawab. Kesimpulan seperti ini secara retrospeksi mudah dilakukan. Tidak ada pihak manapun yang bersalah dalam hal ini, namun kami ingin menekankan bahwa pendekatan penelitian yang lebih baik adalah bagaimana penelitian tersebut lebih relevan dan bisa memberikan informasi tentang apa saja yang diperlukan. Kami harap, upaya penelitian ke depan bisa lebih memberikan penekanan pada pengumpulan dan pelaporan informasi yang lebih baik. Tujuan ini harus menjadi bagian yang tak terpisahkan dari kegiatan penelitian satwa liar, dan mungkin akan lebih baik bila informasi ini bisa dipadukan dalam suatu basis data untuk seluruh Borneo.

Berdasarkan relevansi kebutuhan penelitian dan beragam isu prioritas yang tercatat dalam kajian ini, kami dapat membuat rekomendasi secara garis besar tentang penelitian yang diperlukan bagi spesies-spesies satwa liar di wilayah penebangan. Di samping penelitian mengenai jenis satwa dan interaksinya dengan vegetasi dan spesies

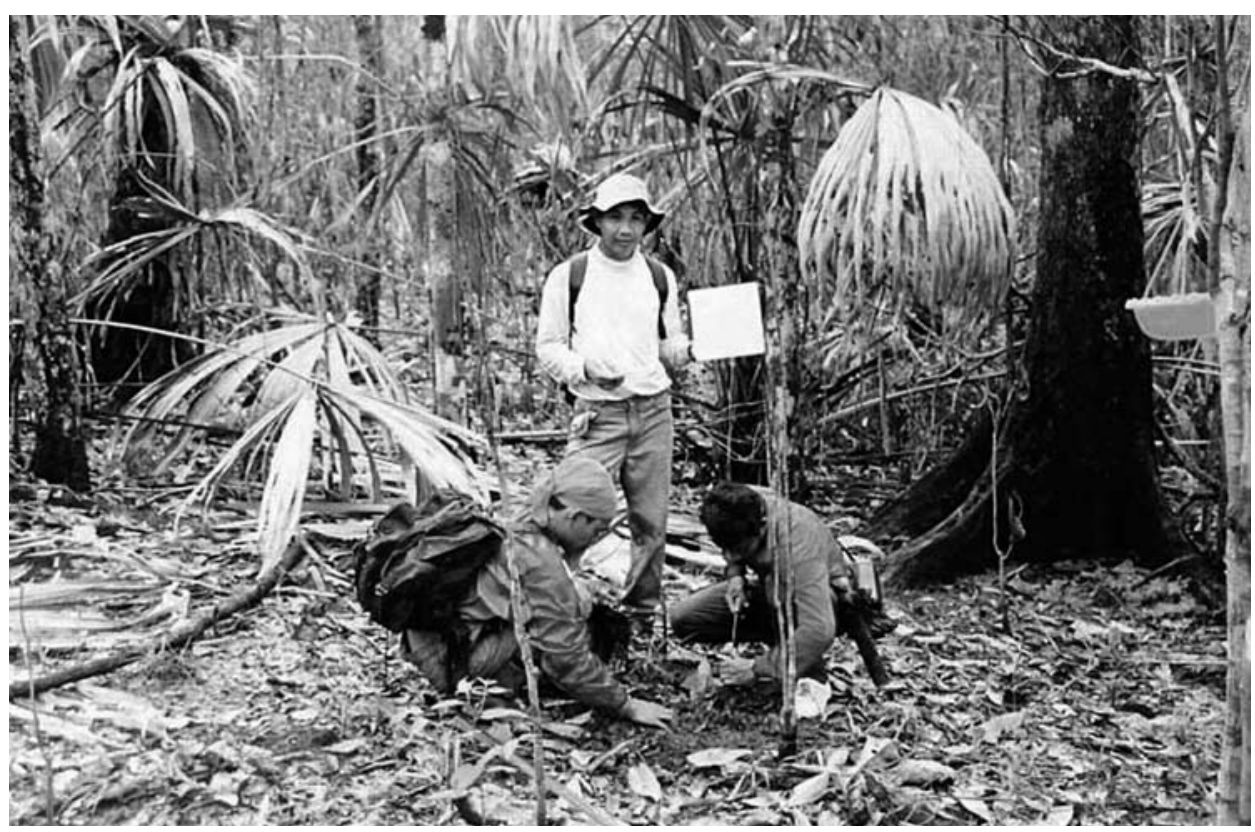

Gambar 26. Peneliti lokal sedang mengkaji kerusakan akibat kebakaran hutan di Kalimantan Timur. (Foto oleh Gabriella Fredriksson) 
lainnya, diperlukan pula penelitian lebih lanjut mengenai sosial ekonomi. Penelitian tersebut harus dapat mengulas isu seperti tingkat pengambilan spesies satwa liar yang tidak dilindungi secara lestari. Selain itu, harus dipertimbangkan pula penelitian yang dapat melihat kelayakan pengembangan fasilitas konsesi penebangan kayu yang dapat digunakan oleh pengunjung yang berminat melihat/mengunjungi daerah penebangan kayu yang dikelola secara lestari, spesies-spesies hidupan liarnya, serta nilai-nilai budayanya.

Salah satu kelemahan yang ada yaitu usulan-usulan yang dikemukakan disini tidak menyeluruh. Keterbatasan rekomendasi ini karena keterbatasan pemahaman, asumsi, dan imajinasi yang kami miliki. Pergeseran cara berpikir tentang konservasi seperti apa yang kami harapkan dapat membuat penelitian dapat lebih bermanfaat. Sebagai contoh: di Puerto Rico, kegiatan kehutanan dibatasi berdasarkan musim untuk mengurangi gangguan terhadap perkembangbiakan Amazona vittata sejenis burung yang terancam punah (Caribbean National Forest 1997, Scatena 2001, Snyder et al. 1987). Melakukan hal yang sama di Borneo akan terlihat sebagai mimpi yang sulit tercapai, namun ke depan, situasinya mungkin akan berubah. Saat ini, rekomendasi kami berfokus pada pengkajian prioritas secara pragmatis, yaitu apa yang kita perlu ketahui untuk memperbaiki nilai konservasi dari konsesi penebangan kayu bagi hidupan liar?

\section{Rekomendasi bagi para peneliti}

Rekomendasi konseptual bagi peneliti dalam merancang program terkait mencakup hal-hal sebagai berikut:

- Mempertimbangkan bagaimana peraturan dan kegiatan kehutanan dapat dimodifikasi dengan mudah sehingga dapat bermanfaat bagi hidupan liar (contohnya, pemangkasan/pembersihan tumbuhan bawah tidak diperdebatkan dalam pustaka);

- Mengenali dan memahami konteks hukum dan pengelolaan. Perhatian harus ditujukan pada proses perbaikan dan pelaksanaan peraturan dan prosedur yang ada;

- Memastikan intervensi pengelolaan yang diusulkan layak dan dipahami. Rekomendasi tersebut harus dikaji ulang kaitannya dengan konsesi penebangan, masyarakat, pemerintahan, dan pelaku-pelaku lainnya;

- Memastikan seluruh kendali/pengawasan berdasarkan peraturan memiliki definisi operasional yang jelas dan tegas yang dapat mengesampingkan interpretasi yang bertolak belakang. Sebagai contoh, bagaimana kita bisa menentukan bahwa suatu daerah terlalu curam untuk kegiatan penebangan? Bila suatu batas telah ditentukan pada X derajat, bagaimana kita dapat menunjukkan bahwa suatu daerah memiliki kemiringan yang lebih dari X derajat? Pengalaman di Indonesia menunjukkan bahwa menetapkan sudut kemiringan saja tanpa menyatakan bagaimana cara pengukuran yang terkait dengan keterjalan setempat dan peta konsesi tidak cukup (Sheil pengamatan pribadi). Hal yang sama terungkap dalam konteks yang berbeda, misalnya bagaimana menentukan sungai yang memerlukan perlindungan?; 
- Tetap pragmatis. Penelitian yang dapat memberikan perbaikan dalam waktu singkat dan praktis dalam pengelolaan hutan harus mendapatkan prioritas yang lebih tinggi dibandingkan penelitian akademis jangka panjang yang memerlukan biaya yang lebih mahal dan memberikan sumbangan yang kecil saja bagi konservasi;

- Upaya yang dilakukan harus menitikberatkan pada penyelesaian masalah konservasi dibandingkan dengan hanya mengamati perkembangan masalah tersebut (Sheil 2001b);

- Sedapat mungkin membuat rekomendasi yang jelas. Makalah penelitian yang menyatakan bahwa penelitian tersebut "bermanfaat bagi konservasi", harus menjelaskan apa manfaat tersebut dengan cara yang spesifik dan pragmatis. Penelitian yang bertujuan memberi rekomendasi praktis bagi perbaikan pengelolaan harus menyediakan rekomendasi yang dimaksudkan. Idealnya, rekomendasi tersebut harus didiskusikan dengan para pengguna untuk memastikan bahwa rekomendasi tersebut jelas dan realistis;

- Memeriksa ekologi spesies kaitannya dengan penggunaan habitat dan perubahan kondisi hutan, serta mengaitkan pada pilihan-pilihan pengelolaan. Pengamatan yang menyatakan bahwa suatu spesies "menurun setelah penebangan" merupakan informasi dasar yang lemah untuk mengembangkan praktek kehutanan yang lebih baik;

- Melakukan inventarisasi spesies menggunakan strategi yang jelas untuk pemanfaatan hasilnya. Inventarisasi spesies yang mendasar dapat dibenarkan di wilayah yang kurang dikenal/diketahui seperti Malinau bila sumberdaya dan tenaga ahlinya tersedia. Penelitian yang dilakukan di Malinau belum lama ini telah mencatat sejumlah taxa vertebrata yang belum dideskripsikan (Iskandar pengamatan pribadi, Rachmatika et al. 2005), dan kita harus mengantisipasi bahwa masih banyak spesies yang harus dicatat. Penyebaran spesies yang terbatas ini bisa memiliki implikasi konservasi secara luas. Informasi penyebaran spesies yang lebih baik dan statusnya di Borneo dan wilayah Dataran Sunda dapat memperbaiki proses perencanaan konservasi. Namun demikian, respons dan pemanfaatan data tersebut harus dapat dipastikan bila penelitian yang dilakukan telah ditetapkan sebagai kegiatan prioritas. Pertanyaan selanjutnya adalah siapa yang harus mendanai kegiatan penelitian ini dan apakah mungkin pihak konsesi penebangan dapat melakukan kegiatan inventarisasi ini;

- Menentukan cara yang efektif untuk menjembatani prioritas dan pandangan dari stakeholders setempat dan antara pengguna sumberdaya dengan prioritas konservasi internasional. Selain itu, mengembangkan prioritas yang memandu proses perencanaan konservasi yang dapat dipadukan dengan pengelolaan serta pengambilan keputusan lokal;

- Melakukan penelitian dan kajian terhadap hambatan dalam pelaksanaan kegiatan pengelolaan yang efektif serta peraturan dan kendalanya;

- Menjelaskan dan mempromosikan hasil penelitian kepada pihak-pihak setempat (seperti pengguna sumberdaya dan pengambil keputusan);

- Memberikan perhatian yang khusus terhadap efek yang berbeda-beda dari penebangan kayu, pembangunan jalan, fragmentasi, perburuan, dan dampak 
lainnya, bagaimana kegiatan tersebut saling mempengaruhi, dan bagaimana kegiatan tadi berinteraksi;

- Melakukan (atau mengkoordinasikan) penelitian dengan waktu yang cukup panjang dengan lingkup geografis yang cukup luas, serta lokasi dengan karakter yang beragam, terutama yang bisa mencakup variasi kepadatan spesies-spesies yang bersifat annual dan supra-annual;

- Melakukan koordinasi dengan lembaga dan peneliti yang berbeda. Penelitian jangka panjang berskala besar dan perbandingan antar lokasi bisa mendapatkan manfaat dari kerjasama seperti ini. Hasilnya dapat memberikan informasi yang komprehensif dan rinci tentang kepekaan spesies serta teknik pengelolaan yang efisien serta memadai secara ekologis;

- Merancang seluruh bidang penelitian dengan penekanan pada skala, konteks, proses ekologis, dan pengaruh yang ditimbulkannya (serta spesies parameter dasar yang diperlukan untuk melaksanakan meta-analisis yang lebih kuat);

- Melakukan identifikasi spesies-spesies yang peka terhadap spesies intervensi (atau kombinasi beberapa intervensi) dan evaluasi trade-off yang lebih jelas antara tujuan konservasi dan tujuan pengelolaan yang lain;

- Mengembangkan panduan untuk menentukan prioritas spesies yang paling membutuhkan intervensi pengelolaan tertentu, dan bagaimana hal ini dapat disesuaikan dengan konsesi tertentu;

- Melakukan evaluasi dan perbaikan hipotesis yang telah dikembangkan dalam kajian ini (identifikasi kesamaan dan pengecualiannya) dan meneliti sejauh mana rekomendasi praktis dapat diambil dari upaya ini (untuk mengidentifikasi spesies yang peka, tipe intervensi yang paling merusak, dan tindakan apa yang harus diambil untuk memperbaikinya);

- Meneruskan upaya kaji ulang dan sintesis informasi yang ada untuk mengembangkan dan menguji hipotesis yang belum terungkap dengan baik (misalnya, pemikiran bahwa perilaku diurnal (aktif di siang hari) dan/atau sifat teritorial yang kuat menyebabkan kepekaan yang lebih tinggi terhadap fragmentasi hutan dan pembukaan habitat).

Meskipun isu kelembagaan tidak menjadi fokus upaya kajian kami, kami menyarankan para peneliti di bidang konservasi juga mempertimbangkan beberapa tambahan peran dan tanggung jawab (Bennett \& Robinson 2000). Di antaranya adalah:

- Bertindak sebagai penengah bagi lembaga pemerintahan dan lembaga internasional, masyarakat setempat, dan perusahaan penebangan kayu untuk meningkatkan manfaat upaya konservasi bagi masyarakat setempat;

- Mempromosikan sistem pemantauan yang dapat dibantu atau dilaksanakan oleh stakeholders setempat sehingga mereka bisa mendapatkan "rasa kepemilikan' dan tanggung jawab bagi rekomendasi pengelolaan;

- Mempromosikan dan melaksanakan kegiatan pendidikan dan kesadaran yang ditujukan bagi seluruh stakeholders lokal; 
- Menyediakan pelatihan untuk meningkatkan kapasitas pengelolaan yang tersedia untuk menangani kebutuhan pemanfaatan sumberdaya hayati serta pembangunan setempat.

Saran penelitian yang berorientasi pada topik, termasuk:

\section{Pemanenan kayu}

Pemanenan kayu dapat dilaksanakan dengan cara yang berbeda dengan pembatasan dan pengawasan yang berbeda pula. Diperlukan upaya untuk mengevaluasi bagaimana perbedaan ini dapat diterjemahkan menjadi sesuatu yang bermanfaat bagi konservasi hidupan liar. Salah satu alasan diperbolehkannya penebangan kayu dengan intensitas yang lebih tinggi di lokasi tertentu adalah karena kegiatan ini dapat meringankan tekanan di tempat lain. Dasar pemikiran bagi alasan tersebut (secara khusus atau umum) saat ini belum ada dan hal ini harus menjadi pertimbangan tujuan penelitian jangka panjang.

Kegiatan kehutanan yang harus "diteliti" dari sudut pandang hidupan liar adalah sebagai berikut:

- Implikasi penebangan kayu di areal bekas tebangan (penebangan kedua, ketiga, dan sebagainya). Sebagian besar penelitian biasanya difokuskan pada hutan utuh versus hutan bekas tebangan. Ke depan, pilihan-pilihan tersebut akan lebih terkait pada kapan dan bagaimana menebang kayu di daerah yang telah dieksploitasi.;

- Standar pembangunan dan pemeliharaan jalan dan jembatan;

- Jenis peralatan mesin dan pengoperasiannya;

- Drainase lahan/tapak;

- Informasi yang dikembangkan dari survei kegiatan sebelum penebangan dilakukan dan bagaimana hal ini dapat diadaptasikan secara lokal ;

- Rencana petak tebangan;

- Pemangkasan tumbuhan memanjat/merambat;

- Identifikasi dan pemeliharaan pohon benih;

- Perlindungan bagi regenerasi lanjut;

- Perlindungan daerah lereng, badan air, dan karakter bentang alam lainnya;

- Optimasi tutupan jalan sarad;

- Pengurangan kerusakan (penumbangan yang terarah, penyaradan dengan pisau digantung (blade-up), pembatasan ukuran batang, dsb.)

- Rotasi penebangan;

- Intensitas penumbangan (ukuran batang, kontrol dan pembatasan yang lain);

- Penanaman kembali (jenis dan metode);

- Kebutuhan pemupukan/penyuburan (fertilisasi) di hutan tropis setelah kegiatan penebangan (lihat Nykvist 1998 untuk argumentasinya);

- Pemakuan pohon (tree spiking) sebagai perangkat perlindungan wilayah konsesi penebangan hutan. Penelitian lebih lanjut diperlukan untuk mengidentifikasi situasi khusus dimana teknik ini dapat diterapkan dan pada kondisi apa (contohnya pada daerah yang berbatasan dengan daerah lindung). 


\section{Kegiatan operasional konsesi penebangan kayu}

- Mencari pemahaman yang lebih baik tentang bagaimana karyawan perusahaan konsesi penebangan dan kegiatannya berpengaruh pada lingkungan setempat. Upaya evaluasi dapat diarahkan pada tingkat pengetahuan karyawan dan pemahaman akan pengawasan dan pengaturan di tingkat nasional, lokal, dan wilayah konsesi penebangan, serta bagaimana hal tersebut dapat ditingkatkan. Evaluasi mengenai perilaku dan pemahaman konservasi dan bagaimana hal ini bisa dikembangkan akan menjadi informasi yang sangat berharga;

- Mengkaji ulang seluruh aspek pembangunan di konsesi penebangan (pembangunan dan pemeliharaan jalan, pemakaian air, lokasi pengumpulan kayu, banjir yang disebabkan oleh jalan, dsb.), kegiatan operasional (lalu lintas, penyimpanan bahan bakar, kebutuhan daging lokal dan produk lainnya, patroli), dan penutupan (penutupan jalan, pemeliharaan jembatan) untuk mengidentifikasi dampak lingkungan yang sebenarnya, pengaruhnya terhadap ancaman, dan tindakan apa yang dapat diambil;

- Pemanfaatan sisa penebangan di daerah yang menggunakan alat berat dapat mengurangi pemadatan tanah dan membantu regenerasi hutan. Dalam kaitan ini, diperlukan penelitian tentang ketebalan lapisan sisa tebangan yang dibutuhkan untuk memaksimalkan manfaatnya bagi regenerasi hutan (Hutchings et al. 2002);

- Menentukan dampak terbentuknya kolam oleh jalan dan sebagainya terhadap fauna akuatik dan terestrial;

- Klarifikasi jenis pengawasan di lapangan dan skema insentif yang paling efektif bagi upaya konservasi serta bisa diterima oleh perusahaan komersial;

- Mengkaji untung-rugi kegiatan operasional penebangan yang sifatnya terkumpul (lokalisasi) atau tersebar. Kegiatan operasional yang menyebar dapat mengurangi dampak keseluruhan, tetapi biayanya tinggi dan pengawasannya lebih sulit dilakukan. Isu seperti ini memerlukan pertimbangan yang jelas dan seksama.

\section{Karakteristik bentang alam (lansekap)}

- Menyelidiki diperlukan atau tidaknya karakter bentang alam yang khas oleh spesies hidupan liar atau kelompoknya (seperti sumber air asin, gua, tepi sungai yang berpasir). Bagaimana lokasi khusus tersebut dapat dipetakan secara efektif dan nilainya dijaga dengan baik?

- Mengkaji sifat dan pentingnya kolam/genangan air dan kubangan yang ada di seluruh hutan. Bagaimana cara terbentuknya? Apakah perannya bagi ekologi setempat? Bagaimana kolam dan kubangan ini dipengaruhi oleh kegiatan penebangan dan oleh perubahan kelimpahan satwa?

- Mengklarifikasi spesies-spesies yang bergantung pada suatu habitat dan untuk kebutuhan apa. Dimana satwa pemakan buah mencari makan saat kelimpahan buah rendah? Dimana spesies-spesies kelelawar beristirahat?

- Mengevaluasi apakah suatu karakter bentang alam bisa diganti secara buatan (misalnya salt licks). 


\section{Buah}

- Mengkaji ekologi spesies Ficus spp. di hutan bekas tebangan dan bagaimana ketersediaan buah dapat berubah setelah kegiatan intervensi. Penelitian yang ada dapat menetapkan faktor yang membatasi tumbuhnya spesies beringin ini di bawah tajuk dan cara yang dapat meningkatkan kelimpahan buah ara ini dengan rekayasa ekologis ((Laman 1995a, b, 1996a, b, Leighton \& Leighton 1983). Diperlukan penelitian lebih lanjut tentang pengaruh penebangan terhadap sumber buah ara yang penting;

- Mengevaluasi ekologi dan pentingnya jenis pohon berbuah lainnya, dan apa yang mempengaruhi keberadaan serta proses berbuahnya. Sebagai contoh, liana dari suku Annonaceae dikenal sebagai sumberdaya yang mungkin penting bagi sejumlah vertebrata. Liana ini dapat dengan mudah tumbuh dalam rumpang yang terbentuk karena penebangan kayu. Penelitian lebih lanjut diperlukan untuk menentukan sejauh mana tumbuhan ini (dan mungkin juga beragam spesies lain yang masih perlu diidentifikasi) berpengaruh pada pemulihan kembali hutan dengan menarik satwa pemakan buah ke daerah penebangan;

- Melakukan kajian terhadap spesies perintis yang berbuah yang menyediakan makanan bagi satwa pemakan buah. Menarik satwa pemakan buah ke jenis hutan perintis dapat mempercepat proses regenerasi hutan melalui peningkatan jumlah buah-buahan hutan primer yang dijatuhkan di daerah yang beregenerasi;

- Melakukan kajian tentang bagaimana spesies-spesies pohon buah dan ketersediaan pohon buah dipengaruhi oleh aspek pengelolaan hutan yang berbeda dan bagaimana hal ini mempengaruhi satwa pemakan buah. (literatur yang kami acu mencatat beberapa kontradiksi tentang ketersediaan buah setelah kegiatan penebangan);

- Mengkaji pilihan-pilihan untuk melakukan kegiatan penanaman kembali hutan dengan pohon kayu yang selain memiliki nilai yang tinggi sebagai sumber kayu juga bernilai tinggi bagi sumberdaya hidupan liar. Bekerja bersama dengan masyarakat setempat adalah salah satu cara untuk mengidentifikasi spesies yang berfungsi ganda. Karenanya diperlukan penelitian tentang spesies pohon yang dapat memenuhi kriteria pengelolaan hutan dan kriteria ekologis.

\section{Ketergantungan spesies}

- Melakukan penelitian tentang pemakaian spesies pohon kayu oleh satwa liar, baik yang berkaitan dengan makanan atau strukturnya, serta bagaimana satwa tersebut dipengaruhi oleh penebangan spesies pohon tersebut secara selektif. Kami mencatat sangat sedikit spesies vertebrata yang dengan jelas bergantung pada dipterocarps atau spesies pohon kayu lainnya (contoh Agathis borneensis, Eusideroxylon zwageri).

\section{Struktur habitat}

- Melakukan penelitian tentang pengaruh perubahan struktur hutan terhadap fauna yang rentan. Satwa tertentu membutuhkan pohon yang tinggi dan berukuran 
besar untuk tempat bersarangnya (seperti rangkong, lebah, beberapa raptor tertentu, dan kelelawar (lihat Harrison 1962b));

- Melakukan penelitian tentang fauna yang bergantung pada pohon berdiameter besar yang sudah tua dan berpenyakit;

- Melakukan kajian tentang ketersediaan rongga pohon dari berbagai spesies pohon kayu komersial dan nonkomersial. Program pemantauan sederhana untuk rongga tersebut dapat dikembangkan dengan memeriksa pohon-pohon yang ditebang;

- Menyelidiki peran rongga pohon (pada pohon yang hidup atau mati, yang tegak maupun yang telah tumbang) untuk tempat bersarang atau berkembang biak, beristirahat, sebagai sumber air pada pohon (arboreal) di dalam hutan (pemijahan amfibia) dan penyimpanan makanan, dan bagaimana ketersediaan habitat tersebut berkaitan dengan pengelolaan kehutanan;

- Melakukan kajian untung-rugi teknik silvikultur (untuk memberantas jamur busuk gubal) yang menebang pohon-pohon yang sekarat mati dan membakarnya (Elouard 1998);

- Trockenbrodt et al. (2002) melaporkan bahwa selama kegiatan penebangan di Deramakot, Sabah, hingga 50\% pohon-pohon yang ditandai untuk ditebang berongga. Namun mereka menganggap tingkat pengenalan/pengujian rongganya tidak memadai. Diperlukan upaya untuk mengembangkan pengujian yang dapat mendeteksi rongga pohon ;

- Tumpukan kayu secara langsung dapat menjadi habitat bagi beragam spesies satwa liar (Lindenmayer \& Hobbs 2004). Perlu diselidiki apakah tumpukan kayu sisa bisa bermanfaat bagi hidupan liar di daerah hutan tropis yang dikelola;

- Mempertimbangkan peran vegetasitumbuhan bawah. Penekanan terhadap kegiatan penebangan yang mengubah vegetasi, dan dengan demikian mengubah makanan dan habitat vertebrata, kerapkali berfokus pada pohon. Banyak spesies tumbuhan bawah, termasuk tumbuhan semak herba (seperti jahe-jahean (Zingiberaceae), Marantaceae, pisang-pisangan (Musaceae), Poaceae) yang berfungsi sebagai sumberdaya hayati yang penting bagi banyak spesies satwa (seperti untuk Babi Berjenggot, Sus barbatus) dan menghasilkan sejumlah besar buah-buahan dan sari bunga. Peran tumbuhan tersebut harus diperhatikan (spesies mana yang penting, dimana tumbuhnya, dan bagaimana reaksinya terhadap berbagai aspek pengelolaan hutan, dan bagaimana spesies-spesies ini dapat dipertahankan);

- Melakukan kajian tentang dampak pemangkasan spesies terestrial dan spesies penggali tanah serta melakukan analisis tentang efektivitas biaya penerapan teknik tersebut.

\section{Konektivitas, ruang dan pergerakan}

- Melakukan kajian tentang pengaruh jaringan jalan dan jalan setapak terhadap pergerakan hidupan liar, termasuk aspek-aspek seperti lebar jalan, bahan pembuat jalan, selokan, penggunaan jalan, vegetasi tepi jalan, pengalihan lahan, dan kontak tajuk. Penelitian ini sebaiknya dilakukan dengan menggunakan pos pengamatan yang melihat ke arah jalan atau dengan rangkaian jerat kamera. Pilihan lain adalah menandai teknik tangkap dan tangkap ulang (capture-recapture) yang diterapkan 
pada kedua sisi hambatan tertentu (McDonald \& St Clair 2004) dapat memberikan pandangan mengenai spesies mana yang dibatasi oleh hambatan tertentu.;

- Lakukan pengujian terhadap kemampuan spesies untuk bergerak melalui (atau di atas) berbagai areal hutan bekas tebangan kaitannya dengan peran hutanhutan cagar yang berukuran kecil. Hal ini termasuk pula fenomena source-sink, peran pengkolonisasian kembali, dan nilai pemeliharaan pada bentang alam yang dikelola;

- Menyelidiki distribusi spasial dan luas daerah sumber dan penurunan (source \& sink) hidupan liar; apa yang menghambat dan mendorong pergerakan spesies tertentu ke dalam hutan setelah kegiatan penebangan;

- Melakukan kajian menyangkut konektivitas hutan, koridor hutan, dan peluang/ kesempatan yang tersedia karena teknik-teknik rehabilitasi hutan;

- Evaluasi pengaruh efek tepian hutan hubungannya dengan skala dan sifat matriks hutan tersebut;

- Melakukan identifikasi dan pengenalan tentang peran habitat yang penting atau menghambat bagi hidupan liar dalam musim tertentu atau dalam tahapan daur hidupnya;

- Melakukan kajian terhadap kondisi lingkungan apa saja yang sangat penting untuk dipertahankan dalam tutupan hutan yang berkesinambungan dan bagaimana hal ini dapat dicapai;

- Melakukan kajian penggantian zona penebangan bebas yang optimum dari sudut pandang ekologis maupun operasional.

\section{Perburuan}

- Melakukan kajian variasi geografis menyangkut intensitas perburuan dan tekanan perburuan bagi spesies yang spesifik. Pemahaman pola spasial perburuan dalam skala regional dan skala lokal dapat memberikan masukan yang penting bagi perbaikan pengelolaan konservasi;

- Melakukan identifikasi teknik perburuan yang paling tidak merusak satwa liar dan hasil perburuan optimal yang lestari bagi masing-masing spesies;

- Melakukan evaluasi dinamika sumber-penurunan (source-sink) perburuan dan bagaimana konektivitas habitat ditentukan. Hal ini terutama bagi spesies yang berjelajah luas, bermigrasi, dan bergerak;

- Melakukan pengujian apakah zona perburuan bebas menyebabkan peningkatan atau penurunan hasil di wilayah yang berdekatan;

- Melakukan kajian tentang kebutuhan nutrisi, budaya, dan sosial masyarakat setempat yang melakukan perburuan dan menentukan bagaimana kebutuhan ini dapat digantikan. Penelitian ini juga mencakup kelayakan pengembangan industri ternak lokal atau kelayakan mengganti bulu rangkong yang digunakan dalam upacara tradisional (Gambar 27) dengan bulu kalkun, dan sebagainya;

- Melakukan kajian tentang pengaruh metode perburuan dan penangkapan ikan yang berbeda terhadap komunitas satwa;

- Melakukan penelitian tentang musim tertentu saat spesies kurang atau lebih rentan terhadap dampak perburuan. Hal ini terkait dengan perkembangbiakan, migrasi, atau ketersediaan makanan; 


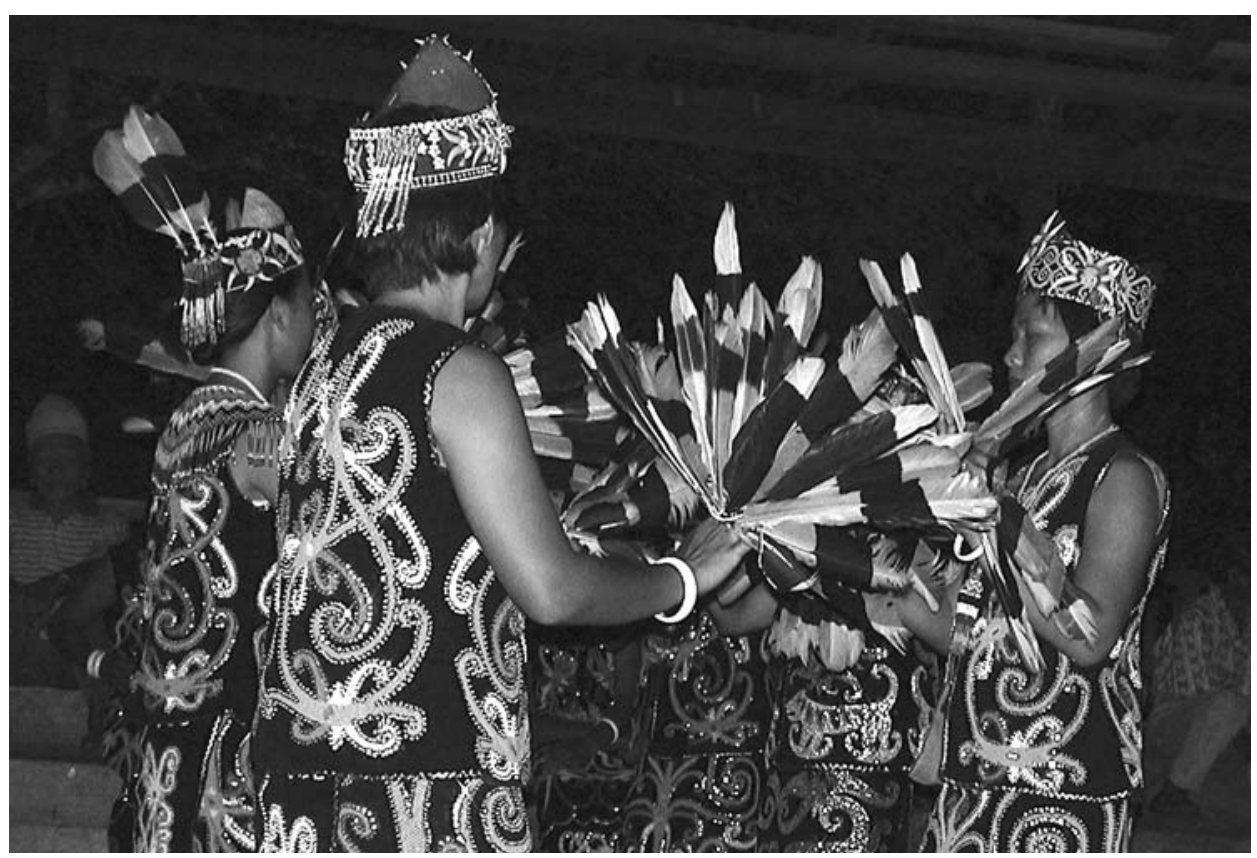

Gambar 27. Kulit Beruang Madu dan bulu rangkong yang digunakan dalam upacara tradisional. (Foto oleh Dave Augeri)

- Melakukan kajian tentang pengaturan atau pengurangan perburuan bagi kehidupan sehari-hari (untuk makan): jenis pengendalian dan insentif apa yang efektif? Upaya penelitian diperlukan untuk penegakan hukum perburuan. Contohnya efektivitas patroli, pos pengamanan, pendaftaran senjata, ijin berburu, dan pemanfaatan larangan dan batasan tradisional berburu spesies-spesies tertentu.

\section{Ancaman lainnya}

- Mengembangkan metode operasional untuk mengenali dan memonitor seluruh hal yang dianggap sebagai ancaman dan merencanakan sistem cepat tanggap (kesiagaan);

- Mengembangkan cara praktis untuk mencegah introduksi spesies invasif;

- Bila telah terintroduksi, maka dikembangkan cara untuk membantu identifikasi, mengendalikan, dan kemungkinan pemusnahan spesies invasif;

- Mengembangkan cara untuk membantu identifikasi dan mengendalikan kebakaran hutan di daerah yang berisiko tinggi;

- Melakukan identifikasi spesies-spesies asli yang noninvasif dan tahan api serta menyelidiki apakah spesies tersebut dapat ditanam sebagai sekat bakar (firebreaks) di sekeliling hutan yang rentan, terutama bila batas hutan tersebut merupakan daerah yang sering terbakar (misalnya daerah ladang berpindah);

- Melakukan kajian atau membuat model tentang pengaruh perubahan iklim terhadap populasi satwa liar. Bagaimana spesies dapat dipengaruhi oleh perubahan suhu, pola musiman atau pola curah hujan? Apa implikasinya? 
Isu yang memiliki prioritas lebih rendah namun menuntut pertimbangan yang seksama tercakup sebagai berikut:

- Memeriksa dampak dari anjing. Anjing umumnya dianggap sebagai ancaman bagi satwa liar asli di banyak tempat di dunia (Butler et al. 2004). Namun belum ada penelitian tentang pengaruh anjing pemburu terhadap satwa liar di Borneo. Anjing tersebut membantu perburuan dan memakan sebagian daging hasilnya. Anjing juga mempengaruhi populasi satwa liar bila anjing peliharaan ini kembali menjadi liar (gelandangan). Hal ini karena pemangsaan langsung atau karena perpindahan penyakit seperti rabies dan distemper anjing;

- Periksa dampak satwa peliharaan yang menggelandang (liar). Ada penelitian yang menyatakan bahwa penyebaran anjing dan kucing peliharaan yang menjadi liar serta dampaknya terhadap satwa asli hutan dapat berkolerasi positif dengan kepadatan jalan ((May \& Norton 1996). Hal ini perlu diselidiki di Borneo;

- Penelitian tentang bagaimana praktek kehutanan dapat berpengaruh pada reservoir atau menjadi perantara penyakit atau hama. Contohnya, intervensi kehutanan biasanya menyebabkan perubahan pada komunitas spesies nyamuk dan mengubah terjadinya penyakit seperti malaria dan dengue (Chang et al. 1997. Overgaard et al. 2003). Sifat perubahan tersebut tergantung pada kondisi tanah setempat dan karakter ekologi jenis-jenis perantara tadi. Di beberapa kasus, penebangan kayu dengan mesin menyebabkan terbentuknya genangan air pada bentang alamnya, yang meningkatkan kepadatan jumlah nyamuk setempat. Perubahan seperti ini berpotensi mempengaruhi populasi manusia dan satwa secara nyata;

- Melakukan survei tentang hewan yang mati terlindas di dalam konsesi penebangan hutan (kapan terjadinya, apa spesies yang terkena, jenis kelaminnya, kondisi, dan musim) dan meneliti bagaimana hewan terlindas ini dapat dikurangi jumlahnya;

- Mempertimbangkan pengembangan batas antara areal hutan dan pertanian, dampaknya terhadap satwa liar, dan bagaimana pandangan manusia dan tanggapannya terhadap satwa liar. Banyak mamalia dan burung yang memasuki kebun yang bersebelahan letaknya dengan hutan untuk memakan tanaman kebun. Spesies ini terutama Babi Berjenggot (Sus barbatus), Rusa Sambar (Cervus unicolor), kijang (Muntiacus spp.), monyet (Macaca spp.), Banteng (Bos javanicus), Beruang Madu (Ursus malayanus) dan bondol (Lonchura spp.) (Meijaard pengamatan pribadi). Satwa tersebut banyak diburu dan kemudian dibunuh. Diperlukan penelitian tentang sejauh mana hal ini menyebabkan penurunan jumlah satwa liar. Selain itu penelitian menyangkut tipe pengendalian sederhana yang digunakan untuk mengurangi dampak perambahan tanaman kebun oleh hidupan liar;

- Klarifikasi pilihan pengelolaan yang terbaik bagi daerah yang hutannya telah terbakar.

\section{Penelitian mengenai burung}

Kegiatan penebangan yang menyebabkan pembukaan hutan dan perubahan habitat bisa menguntungkan bagi sejumlah spesies tertentu namun merugikan bagi spesies yang lain. Pembukaan hutan meningkatkan akses bagi semua tipe perburuan, 
penjeratan, dan pemangsaan. Sayangnya, data yang tersedia tentang dampak penebangan terhadap burung sangat terbatas. Beberapa hal yang perlu dilakukan antara lain:

- Melakukan penelitian tentang dampak perburuan, penangkapan burung, peningkatan pemangsaan, dan perdagangan burung hidup terhadap populasi satwa liar. Diperlukan survei yang rinci bagi spesies yang berpotensi terkena dampak, mencakup identifikasi habitat inti dan lokasi bersarang. Disamping itu penelitian ekologis harus dapat mengklarifikasi kerapatan populasi, keberhasilan perkembangbiakan, pola pencarian makan, penyebaran, dan keberlangsungan hidupnya (Collar et al. 1994);

- Melakukan penelitian avifauna di areal hutan bekas tebangan yang terisolasi dari sumber rekolonisasi untuk menentukan kemampuan sesungguhnya untuk mempertahankan spesies burung tersebut (Lambert \& Collar 2002). Banyak penelitian yang mengabaikan efek hutan utuh yang berdekatan lokasinya. Pulau lepas pantai yang dikenal sebagai tempat avifauna sebelum kegiatan penebangan hutan dilakukan, setelah penebangan kayu dilakukan bisa menjadi kasus uji yang sesuai untuk penelitian seperti ini. Penelitian ini dapat dibandingkan dengan penelitian avifauna di kantung hutan yang relatif terlindungi dan terisolasi di daratan (misalnya Hutan Lindung Sungai Wain dekat Balikpapan);

- Melakukan kajian faktor-faktor yang mengatur dinamika komposisi spesies burung tropis. Hal ini rumit dan sulit untuk dimengerti tanpa pemahaman ekologi dari masing-masing spesies dan tidak bisa didapat dari penelitian dengan sampel populasi dalam satu waktu saja. Perangkap jaring (mist netting) untuk burung harus dilakukan dalam waktu yang lama untuk memperoleh data tentang kecepatan pemulihan populasi, kegiatan reproduksi, rekrutmen, keandalan dan kelanggengan lokasi di hutan bekas tebangan dan hutan utuh. (n.b. meskipun perangkap jaring paling efektif bagi komunitas tumbuhan bawah, mungkin juga dipasang lebih tinggi-jaring dan tiangnya harus berada pada katrol setinggi terbang burung yang akan ditangkap, Roy Dennis komunikasi pribadi);

- Melakukan klarifikasi pola pergerakan spesies burung pemakan biji dan penyebar biji pada tingkat bentang alam. Diperlukan penelitian tentang pola jelajah spesiesspesies tersebut. Mengikuti jejak spesies burung berukuran besar menggunakan satelit (berat badan lebih dari $1 \mathrm{~kg}$, Roy Dennis komunikasi pribadi) mungkin dilakukan dan dapat memberikan informasi tentang faktor yang menentukan pola jelajah burung tersebut;

- Melakukan klarifikasi terhadap spesies yang paling peka terhadap hilangnya habitat dan lokasi keberadaannya. Spesies yang hidup di dataran rendah dan lereng dataran rendah paling rentan terhadap deforestasi. Pengkajian rentang ketinggian dan penentu distribusi burung lainnya diperlukan bagi pengelolaan;

- Menentukan kebutuhan habitat. Penelitian tentang perilaku pencarian makan harus dimasukkan dalam data survei. Hal ini diperlukan untuk menentukan apakah spesies tersebut peka terhadap kerusakan komponen yang spesifik dalam habitatnya; 
- Melakukan pengkajian tentang dampak perubahan habitat bagi spesies sempidan. Meskipun sebagian besar spesies dapat ditemukan di hutan tebang pilih, batas toleransinya terhadap perubahan habitat tidak diketahui. Selain itu, sedikit saja hal yang diketahui tentang interaksi kompetisi antar spesies sempidan. Kami menyarankan penelitian spesies ini menggunakan jerat kamera untuk menghubungkan kerapatan spesies dengan karakteristik bentang alam setempat dan tekanan perburuan;

- Van Balen (dalam O’Brien \& Fimbel 2002) mengamati adanya tiga jenis kelompok yang terdiri dari berbagai spesies di Malinau, tanpa atau sedikit saja tumpang tindih spesies di antara ketiganya. Spesies campuran tersebut adalah 1) kumpulan burung yang tinggal di tajuk yang spesies intinya adalah Cipoh Kacat (Aegithina tiphia), Cica-Daun Sayap-Biru (Chloropsis cochinchinensis), Jinjing Batu (Hemipus hirundinaceus), Kepudang-Sungu Kecil (Coracina fimbriata) dan spesies sepah (Pericrocotus spp.); 2) kumpulan burung yang tinggal di tingkat lebih bawah dengan spesies inti dari Asi (Malacopteron) dan Tepus (Stachyris); dan 3) kumpulan burung pelatuk. Data kumpulan burung beragam spesies ini harus dikumpulkan untuk mengklarifikasi reaksi kumpulan burung yang berbeda tersebut terhadap fragmentasi dan degradasi hutan;

- Melakukan evaluasi pemangsaan burung dan pemangsaan sarang yang berkaitan dengan habitat hutan sebelum dan setelah penebangan yang berbeda-beda;

- Melakukan penelitian tentang parasitisme sarang yang berkaitan dengan habitat hutan sebelum dan setelah penebangan yang berbeda-beda;

- Melakukan penelitian tentang perilaku pencarian makan spesies burung pemangsa (raptor dan burung hantu) yang berkaitan dengan habitat hutan sebelum dan setelah penebangan yang berbeda-beda dan evaluasi dampaknya terhadap spesies pemangsa tersebut;

- Melakukan klarifikasi pilihan-pilihan dan manfaat intervensi yang sifatnya spesifik bagi spesies tertentu dan mengembangkan panduannya. Saat kebutuhan spesifik dari spesies burung dapat diidentifikasikan, intervensi upaya konservasi harus dikembangkan untuk memenuhi kebutuhan spesies tersebut (contohnya lokasi sarang tiruan yang dapat dikembangkan bagi spesies yang rentan).

\section{Penelitian tentang mamalia}

- Sebagian besar penelitian tentang efek penebangan kayu terhadap spesies mamalia difokuskan pada kajian kerapatan spesies sebelum dan setelah kegiatan penebangan kayu. Bagi spesies yang berumur panjang, penelitian tersebut mungkin tidak bisa mengungkapkan efek sesungguhnya dari penebangan tersebut, terutama bila spesies tersebut mampu bertahan hidup pada sumberdaya yang rusak namun tidak mampu untuk bereproduksi, hal ini tidak dapat ditampilkan dalam penurunan kepadatan dalam jangka pendek. Dengan demikian, diperlukan penelitian tentang demografi, habitat, dan kelompok spesies tertentu dan bagaimana spesies tersebut saling berinteraksi, terutama bagi mamalia berukuran besar dengan perkembangbiakan yang lambat. Termasuk dalam spesies ini adalah Beruang Madu (Ursus malayanus), Macan Dahan (Neofelis nebulosa), Kucing Merah (Catopuma 
badia), Kucing Batu (Pardofelis marmorata), dan spesies Owa (Hylobates spp.);

- Melakukan penelitian jangka panjang tentang efek isolasi dan fragmentasi spesies yang memiliki pola jelajah luas, berteritori luas, dan memiliki preferensi habitat yang beragam (contohnya Beruang Madu, Macan Dahan, Kucing Merah, Kuning Batu, Rusa Sambar (Cervus unicolor), Orangutan (Pongo pygmaeus), dsb.). Selain itu penelitian sebaiknya dilakukan untuk spesies dengan perilaku migrasi penuh atau sebagian (semi-migratory) (contohnya Babi Berjenggot (Sus barbatus));

- Merancang dan melakukan penelitian yang membedakan efek perubahan habitat dan perburuan terhadap binatang berkuku belah (ungulata);

- Melakukan penelitian tentang kecenderungan (perubahan populasi) dalam jangka panjang. Diperlukan penelitian jangka panjang tentang dinamika populasi spesies babi dan rusa, serta bagaimana dinamika populasi ini dipengaruhi oleh fragmentasi dan perubahan habitat (pembukaan hutan dapat menguntungkan sejumlah spesies), dan oleh perburuan;

- Melakukan penyelidikan tentang bagaimana mamalia arboreal (yang hidup di pepohonan) yang tidak terbang (non-volant) dipengaruhi oleh tajuk yang terputus yang disebabkan oleh kegiatan penebangan kayu serta kaitannya dengan distribusi dan kelimpahan makanan, selain kerentanannya terhadap pemangsaan (Putz et al. 2001);

- Melakukan klarifikasi faktor kunci bagi dinamika populasi Babi Berjenggot dan pergerakannya di hutan. Ada kebutuhan yang mendesak dalam mengembangkan pendekatan pengelolaan jangka panjang yang lestari serta perlindungan ekosistem

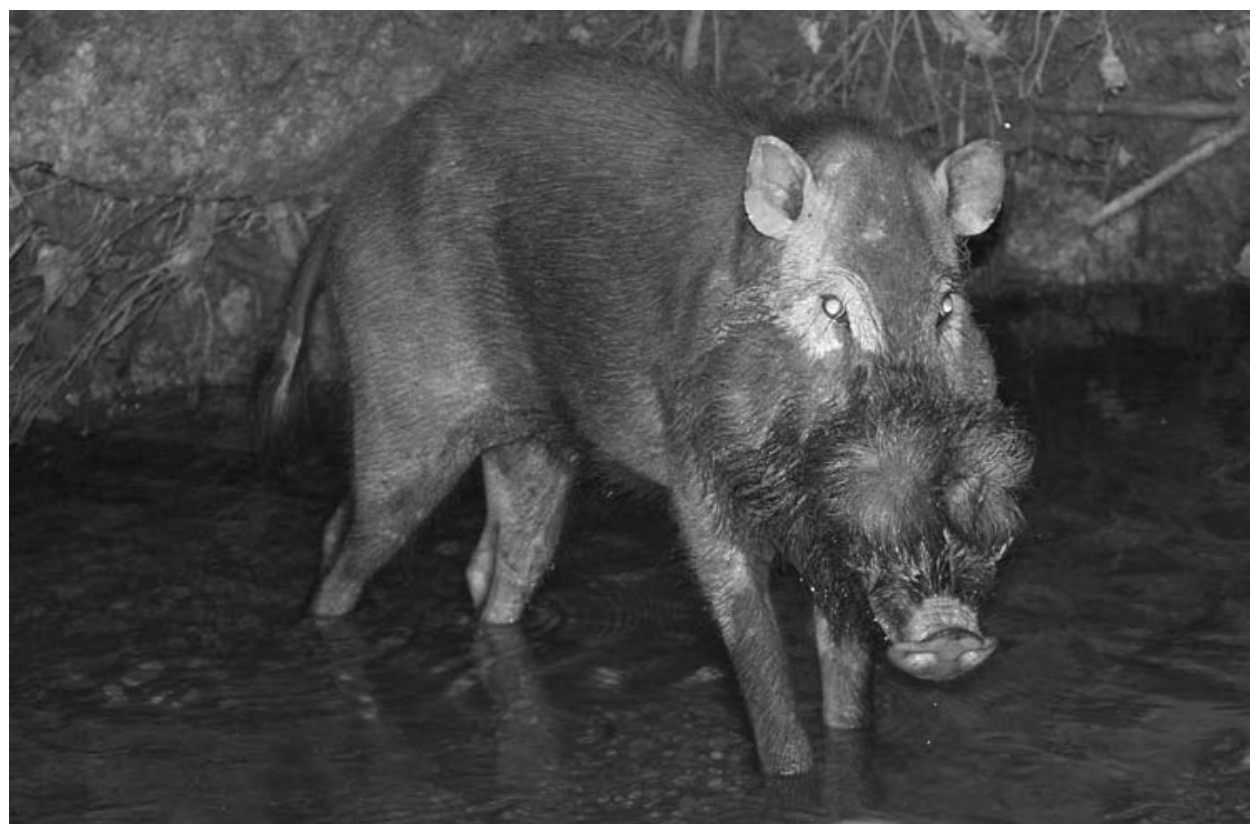

Gambar 28. Babi Berjenggot (Sus barbatus) yang kurang dikenal merupakan perekayasa ekosistem yang penting dan merupakan sumber utama protein hewani bagi masyarakat pedalaman. (Foto oleh Kimabajo) 
Borneo. Selain itu diperlukan pula perancangan panduan kebijakan yang efektif bagi pengambilan dan perdagangan daging satwa liar;

- Melakukan klarifikasi tentang ancaman terhadap lutung, terutama Lutung Banggat, Lutung Merah, dan Lutung Dahi-Putih (Presbytis spp.), yang umumnya diburu untuk diambil empedu dan dagingnya. Spesies Lutung Merah dilindungi Undangundang, tetapi Lutung Dahi-Putih dan Lutung Banggat tidak. Harus dilakukan suatu kajian untuk melihat bagaimana spesies-spesies ini dipengaruhi oleh efek kombinasi dari hilangnya habitat dan perburuan. Panduan pengelolaan spesies ini harus dikembangkan bagi pengambilan yang lestari atau bagi perlindungannya;

- Melakukan penelitian lebih lanjut tentang fauna yang hidup pada 'pulau' yang terisolasi untuk memberikan pemahaman yang lebih baik tentang efek jangka panjang fragmentasi hutan;

- Melakukan penelitian tentang efek degradasi dan fragmentasi hutan terhadap spesies kelelawar hutan seperti Barong (Hipposideridae), Kelelawar-ladam (Rhinolophidae) dan Lenawai (Kerivoulinae) dan Ripo (Murininae);

- Melakukan klarifikasi hubungan antara Babi Berjenggot dengan pemangsa biji dan anakan, masa reproduksi spesies yang bersamaan, dan regenerasi hutan, perubahan hubungan tersebut akibat deforestasi, fragmentasi bentang alam hutan, dan perburuan Babi Berjenggot (Gambar 28).

\section{Penelitian mengenai amfibia dan reptilia}

Katak adalah satwa yang mudah untuk dijadikan sampel (meskipun identifikasinya sering kali sulit) dan peka terhadap gangguan habitat. Namun demikian hanya sedikit saja data mengenai kelimpahan dan keragaman katak di hutan Borneo. Penelitian lanjutan tentang amfibia dan populasi kadal pada hutan utuh dan hutan bekas tebangan direkomendasikan dalam kajian ini:

- Melakukan kajian efek ragam artropoda yang hidup pada daun yang gugur terhadap pertumbuhan dan reproduksi spesies anura yang hidup pada media yang sama;

- Melakukan klarifikasi implikasi jangka panjang akibat peningkatan kerapatan spesies amfibia yang memijah di kolam di hutan tebang pilih. Banyak spesies ini tidak biasa ditemukan di hutan primer dan mungkin berkompetisi dengan spesies hutan primer yang lain;

- Melakukan klarifikasi tentang kepekaan spesies pemakan serangga terhadap perubahan habitat. Penebangan kayu mungkin berdampak terhadap kelimpahan relatif dan jumlah spesies serangga secara langsung maupun tidak langsung. Hal ini kemudian menyebabkan perubahan komposisi spesies dan jumlah pemangsa hewan pemakan serangga seperti amfibia (dan burung). Diperlukan penelitian untuk melihat hubungan ini secara rinci dalam kurun waktu yang panjang;

- Melakukan kajian terhadap ancaman yang disebabkan oleh perdagangan spesies kura-kura/kura-kura air tawar seperti Bajuku (Orlitia borneensis) dan Baning Coklat (Manouria emys). Menyelidiki penggunaan habitat, tempat bertelur dan demografinya, dan berikan rekomendasi penghentian pengambilan (moratorium) 
atau pengambilan spesies-spesies tersebut secara lestari. Karena spesies-spesies tersebut tidak dilindungi di Indonesia, kegiatan pengelolaan spesies berbasis masyarakat tampaknya akan berhasil. Penelitian serupa diperlukan bagi spesies penting yang diperdagangkan seperti Buaya Muara (Crocodylus porosus) dan ular piton (Python spp.);

- Melakukan kajian dampak pemanenan kayu dan bagaimana hal ini lebih lanjut dipengaruhi oleh kondisi yang berubah-ubah. Masyarakat setempat mengungkapkan bahwa sungai berpasir di lokasi-lokasi tertentu merupakan tempat yang baik bagi perburuan kura-kura/kura-kura air tawar dan pengambilan telurnya. Pentingnya peran ekologis lokasi tersebut, ancamannya, dan perlunya daerah tersebut dilindungi di dalam areal konsesi penebangan perlu perhatian yang lebih baik;

- Melakukan klarifikasi perubahan iklim mikro tumbuhan bawah yang terkait dengan penebangan kayu yang mempengaruhi kelangsungan hidup dan pemijahan spesies katak yang bertelur di tanah dan kadal agamid;

- Melakukan identifikasi dan kajian sifat dan kondisi ancaman yang disebabkan oleh spesies eksotis;

- Melakukan kajian tentang populasi buaya yang tersisa. Spesies mana yang masih ada, apakah populasinya layak, apa yang dapat dilakukan untuk melindunginya?

\section{Penelitian mengenai ikan}

- Melakukan kajian tentang penetapan, perlindungan, pengelolaan perikanan yang lestari pada sistem sungai dan daerah tangkapan air;

- Melakukan kajian tentang dampak langsung kegiatan penebangan terhadap populasi ikan di hutan. Topik penelitian ini antara lain dampak penutupan aliran sungai dan pembentukan kolam/genangan air akibat kegiatan operasional jalan dan penebangan; dampak kekeruhan dan siltasi terhadap kualitas habitat dan lokasi pemijahan; dan dampak perubahan rejim suhu air karena turunnya tutupan tajuk;

- Melakukan kajian tentang pentingnya vegetasi tepi sungai (habitat dan spesies). Tajuk hutan di atas aliran dan tepi sungai memberikan naungan dan sumber makanan bagi ikan. Namun demikian, peran materi tumbuhan seperti bunga dan buah vegetasi di daerah sungai (spesies meranti (Dipterocarpus spp.), beringin (Ficus spp.), dan sebagainya,) terhadap pola makan ikan (cyprinidae) harus lebih banyak diteliti untuk mengamati peran langsung spesies pohon tersebut terhadap ikan;

- Melakukan identifikasi lokasi yang penting di sungai yang memungkinkan kelangsungan hidup spesies. Mulut anak sungai memberikan lokasi perlindungan bagi ikan saat sungai utamanya banjir dan menjadi keruh. Sejumlah spesies ikan berukuran besar seperti Tor spp. dan Barbodes spp. berlindung di lokasi yang memiliki air yang jernih, dan identifikasi spesies habitat ini sangat penting untuk melindungi populasi spesies tersebut. Dibutuhkan penelitian tentang hubungan antara kekeruhan dan aspek biokimia air sungai dan spesies yang hidup di tempat tersebut (occurrence); 
- Melakukan kajian mengenai pemeliharaan spesies ikan asli seperti Tor spp., tawes (Barbodes spp.) dan Leptobarbus spp. Aspek teknis dan ekonomis apa yang menentukan keberhasilannya? Hal ini dapat memberikan sumber protein hewani yang teratur dan potensi penghasilan bagi masyarakat, dan dapat meringankan tekanan terhadap satwa liar;

- Melakukan klarifikasi ekologis (dan identitas taksonomis) spesies ikan bermigrasi yang rentan seperti Pangasius spp. Spesies-spesies ini membutuhkan luasan yang cukup besar dalam sistem sungai, termasuk bagian dari MRF dan Taman Nasional Kayan Mentarang (Hartyono 1992) pada waktu yang berbeda dalam daur hidupnya. Saat ini, spesies-spesies ini ditangkap secara berlebihan karena lokasi berkumpul untuk memijah berada di tempat yang telah dikenali oleh masyarakat. Hanya sedikit yang diketahui tentang pola migrasinya. Melakukan penjejakan (tracking) ikan serta mengkaji pengetahuan masyarakat setempat mungkin dapat membantu untuk mengidentifikasi lokasi habitat yang penting. 


\title{
Lampiran 1 \\ Data spesies
}

\author{
Taksonomi \\ Nama umum \\ Nama ilmiah \\ Jumlah spesies \\ Jumlah subspesies
}

\section{Penyebaran}

Dunia

Kalimantan

Keberadaan umum suatu taxa

\section{Habitat}

Rentang ketinggian

Topografi

Vegetasi

Kesesuaian habitat (subtrat, ketinggian di atas permukaan laut -elevasi, tutupan tanah, dsb.)

- Subtrat

- Ketinggian (altitude) penyebaran

- Tutupan tanah

- Tipe hutan

- Karakteristik struktural

- Kebiasaan migrasi

- Akses pada air yang mengalir (Kemampuan menyeberangi sungai ?)

- Kebutuhan akan kualitas air

\section{Kondisi/sejarah alami}

Pola/spesies makanan

- Umum 
- Komposisi secara kualitatif

- Komposisi secara kuantitatif

- Ragam musiman

- Perubahan kedewasaan

\section{Perilaku makan (ketergantungan dan penyebaran, pengaruh perubahan habitat}

- Komposisi makanan

- Pola pencarian pakan

- Jenis-jenis makanan

\section{Siklus musiman}

- Musim reproduksi

- Siklus birahi

- Usia awal reproduksi (jantan dan betina)

- Masa hamil

- Jumlah anak (per kelahiran)

- Masa menyusui

Ketergantungan terhadap bentang alam khusus, sumberdaya, dan substrat tertentu

- Tanah liat untuk bersarang

- Gua untuk berlindung

- Mosaik hutan/padang rumput untuk makan

- Danau

- Spesialis tepian hutan (ekoton)

\section{Perilaku Jelajah}

- Pola umum

- Kepadatan

- Kepekaan terhadap perubahan habitat

- Ukuran wilayah jelajah

- Sifat teritorialitas

- Pola pergerakan harian vs. bulanan, vs musiman

- Perilaku migrasi (ketergantungan dan gangguan)

- Kemampuan mobilitas

- Perilaku penyebaran dan kemampuan adaptasi

\section{Pertumbuhan dan perkembangan}

- Usia penyapihan

- Perilaku bersarang

- Perawatan oleh induk

- Kurva pertumbuhan

- Tingkat kematian (mortalitas) 
- Tingkat Survival

- Panjang Usia (liar dan dalam penangkaran)

\section{Aspek reproduksi}

- Sistem reproduksi

- Waktu reproduksi

- Usia subur

- Jarak antara kelahiran

- Parasit

- Jumlah anak pada setiap upaya reproduksi

- Keberhasilan reproduksi

- Perbedaan masing-masing spesies (inra-specific)

- Karakteristik tempat pemijahan/perkembangbiakan (tentukan karakteristik, musim, ketergantungan)

- Karakteristik tempat bersarang/memijah/rongga, dsb. (dengan kriteria sespesifik mungkin)

\section{Perilaku}

- Bersuara (vokalisasi)

- Sensitivitas indera

- Sosial

- Perilaku agonistik

- Kepekaan terhadap manusia

\section{Peran ekologis}

- Hubungan antar spesies

- Pemangsaan

- Penyakit

\section{Hal yang lain}

- Status komersial dan pemanfaatannya (jenis ancaman dan dampaknya bagi populasi spesies)

- Potensi penyebab penurunan/kematian/pengurangan ketahanan

- Catatan khusus dalam panduan RIL yang seharusnya dinyatakan dengan jelas

- Hal-hal lain yang belum diketahui mengenai taxon yang sangat perlu dipertimbangkan dalam kegiatan pengelolaan hutan yang baik

- Status konservasi (Indonesia, IUCN) 


\section{Lampiran 2 Status IUCN}

Spesies vertebrata di daerah Malinau yang penting untuk di konservasi dan status konservasinya berdasarkan kriteria IUCN (2002). Untuk kriteria IUCN, lihat keterangan di bawah ini, dan informasi yang lebih rinci dapat dilihat di IUCN (2002).

\begin{tabular}{lll}
\hline \multicolumn{2}{l}{ Spesies } & $\begin{array}{l}\text { Status konservasi } \\
\text { internasional }\end{array}$ \\
\hline Burung & Bangau Storm & Terancam Punah (Endangered) \\
\hline Ciconia stormi & Sempidan Kalimantan & Rentan (Vulnerable) \\
\hline Lobiophasis bulweri & Sempidan Merah & Rentan (Vulnerable) \\
\hline Lophura erythrophthalma & Puyuh Sengayan & Rentan (Vulnerable) \\
\hline Rollulus rouloul & Elang-Ular Kinibalu & Rentan (Vulnerable) \\
\hline Spilornis kinabaluensis & Punai Besar & Rentan (Vulnerable) \\
\hline Treron capellei & Raja Udang Kalung Biru & Rentan (Vulnerable) \\
\hline Alcedo euryzona & Cucak Rawa & Rentan (Vulnerable) \\
\hline Pycnonotus zeylanicus & Berencet Kalimantan & Rentan (Vulnerable) \\
\hline Ptilocichla leucogrammica & Rangkong Gading & $\begin{array}{l}\text { Risiko Rendah/Hampir Terancam } \\
\text { (Lower Risk/near threatened) }\end{array}$ \\
\hline Rhinoplax vigil & Kuau Raja & $\begin{array}{l}\text { Risiko Rendah/Hampir Terancam } \\
\text { (Lower Risk/near threatened) }\end{array}$ \\
\hline Argusianus argus & Elang -lkan Kepala Kelabu & $\begin{array}{l}\text { Risiko Rendah/Hampir Terancam } \\
\text { (Lower Risk/near threatened) }\end{array}$ \\
\hline Ichthyophaga humilis & Cekakak-Hutan Melayu & $\begin{array}{l}\text { Risiko Rendah/Hampir Terancam } \\
\text { (Lower Risk/near threatened) }\end{array}$ \\
\hline Actenoides concretus & &
\end{tabular}




\begin{tabular}{|c|c|c|}
\hline \multicolumn{2}{|c|}{ Spesies } & \multirow{2}{*}{$\begin{array}{l}\text { Status konservasi } \\
\text { internasional }\end{array}$} \\
\hline Anthracoceros malayanus & Kangkareng Hitam & \\
\hline Buceros rhinoceros & Rangkong Badak & $\begin{array}{l}\text { Risiko Rendah/Hampir Terancam } \\
\text { (Lower Risk/near threatened) }\end{array}$ \\
\hline Calyptomena hosii & Madi-Hijau Perut Biru & $\begin{array}{l}\text { Risiko Rendah/Hampir Terancam } \\
\text { (Lower Risk/near threatened) }\end{array}$ \\
\hline Pycnonotus melanoleucos & Cucak Hitam & $\begin{array}{l}\text { Risiko Rendah/Hampir Terancam } \\
\text { (Lower Risk/near threatened) }\end{array}$ \\
\hline Pycnonotus squamatus & Cucak Bersisik & $\begin{array}{l}\text { Risiko Rendah/Hampir Terancam } \\
\text { (Lower Risk/near threatened) }\end{array}$ \\
\hline Cuculus vagans & Kangkok Kumis & $\begin{array}{l}\text { Risiko Rendah/Hampir Terancam } \\
\text { (Lower Risk/near threatened) }\end{array}$ \\
\hline Enicurus ruficapillus & Meninting Cegar & $\begin{array}{l}\text { Risiko Rendah/Hampir Terancam } \\
\text { (Lower Risk/near threatened) }\end{array}$ \\
\hline Calyptomena viridis & Madi-Hijau Kecil & $\begin{array}{l}\text { Risiko Rendah/Hampir Terancam } \\
\text { (Lower Risk/near threatened) }\end{array}$ \\
\hline Eurylaimus ochromalus & Sempur-Hujan Darat & $\begin{array}{l}\text { Risiko Rendah/Hampir Terancam } \\
\text { (Lower Risk/near threatened) }\end{array}$ \\
\hline Harpactes diardii & Luntur Diard & $\begin{array}{l}\text { Risiko Rendah/Hampir Terancam } \\
\text { (Lower Risk/near threatened) }\end{array}$ \\
\hline Harpactes duvaucelii & Luntur Putri & $\begin{array}{l}\text { Risiko Rendah/Hampir Terancam } \\
\text { (Lower Risk/near threatened) }\end{array}$ \\
\hline Harpactes kasumba & Luntur Kasumba & $\begin{array}{l}\text { Risiko Rendah/Hampir Terancam } \\
\text { (Lower Risk/near threatened) }\end{array}$ \\
\hline Kenopia striata & Berencet Loreng & $\begin{array}{l}\text { Risiko Rendah/Hampir Terancam } \\
\text { (Lower Risk/near threatened) }\end{array}$ \\
\hline Macronous ptilosus & Ciung -Air Pongpong & $\begin{array}{l}\text { Risiko Rendah/Hampir Terancam } \\
\text { (Lower Risk/near threatened) }\end{array}$ \\
\hline Malacopteron affine & Asi Topi-Jelaga & $\begin{array}{l}\text { Risiko Rendah/Hampir Terancam } \\
\text { (Lower Risk/near threatened) }\end{array}$ \\
\hline Malacopteron magnum & Asi Besar & $\begin{array}{l}\text { Risiko Rendah/Hampir Terancam } \\
\text { (Lower Risk/near threatened) }\end{array}$ \\
\hline Stachyris maculata & Tepus Tunggir-Merah & $\begin{array}{l}\text { Risiko Rendah/Hampir Terancam } \\
\text { (Lower Risk/near threatened) }\end{array}$ \\
\hline Stachyris nigricollis & Tepus Kaban & $\begin{array}{l}\text { Risiko Rendah/Hampir Terancam } \\
\text { (Lower Risk/near threatened) }\end{array}$ \\
\hline Trichastoma rostratum & Pelanduk Dada-Putih & $\begin{array}{l}\text { Risiko Rendah/Hampir Terancam } \\
\text { (Lower Risk/near threatened) }\end{array}$ \\
\hline Alcippe brunneicauda & Wergan Coklat & $\begin{array}{l}\text { Risiko Rendah/Hampir Terancam } \\
\text { (Lower Risk/near threatened) }\end{array}$ \\
\hline Megalaima henricii & Takur Topi-Emas & $\begin{array}{l}\text { Risiko Rendah/Hampir Terancam } \\
\text { (Lower Risk/near threatened) }\end{array}$ \\
\hline
\end{tabular}




\begin{tabular}{|c|c|c|}
\hline \multicolumn{2}{|c|}{ Spesies } & \multirow{2}{*}{$\begin{array}{l}\text { Status konservasi } \\
\text { internasional }\end{array}$} \\
\hline Megalaima mystacophanos & Takur Warna-Warni & \\
\hline Megalaima rafflesii & Takur Tutut & $\begin{array}{l}\text { Risiko Rendah/Hampir Terancam } \\
\text { (Lower Risk/near threatened) }\end{array}$ \\
\hline Meiglyptes tukki & Caladi Badok & $\begin{array}{l}\text { Risiko Rendah/Hampir Terancam } \\
\text { (Lower Risk/near threatened) }\end{array}$ \\
\hline Oriolus xanthonotus & Kepudang Hutan & $\begin{array}{l}\text { Risiko Rendah/Hampir Terancam } \\
\text { (Lower Risk/near threatened) }\end{array}$ \\
\hline Philentoma velatum & Philentoma kerudung & $\begin{array}{l}\text { Risiko Rendah/Hampir Terancam } \\
\text { (Lower Risk/near threatened) }\end{array}$ \\
\hline Cyornis turcosus & Sikatan Melayu & $\begin{array}{l}\text { Risiko Rendah/Hampir Terancam } \\
\text { (Lower Risk/near threatened) }\end{array}$ \\
\hline Anthreptes rhodolaema & Burung Madu Leher-Merah & $\begin{array}{l}\text { Risiko Rendah/Hampir Terancam } \\
\text { (Lower Risk/near threatened) }\end{array}$ \\
\hline Pitta caerulea & Paok Sintau & $\begin{array}{l}\text { Risiko Rendah/Hampir Terancam } \\
\text { (Lower Risk/near threatened) }\end{array}$ \\
\hline Pitta granatina & Paok Delima & $\begin{array}{l}\text { Risiko Rendah/Hampir Terancam } \\
\text { (Lower Risk/near threatened) }\end{array}$ \\
\hline \multicolumn{3}{|l|}{ Mamalia } \\
\hline Bos javanicus & Banteng & Terancam Punah (Endangered) \\
\hline Nasalis larvatus & Bekantan Kahau & Terancam Punah (Endangered) \\
\hline Macaca nemestrina & Monyet Beruk & Rentan (Vulnerable) \\
\hline Nycticebus coucang & Kukang, Bukang & Rentan (Vulnerable) \\
\hline Neofelis nebulosa & Macan Dahan & Rentan (Vulnerable) \\
\hline Ursus malayanus & Beruang Madu & $\begin{array}{l}\text { Data Kurang (Rentan) -Data } \\
\text { Deficient (Vulnerable) }\end{array}$ \\
\hline Presbytis hosei & Lutung Banggat & Data Kurang (Data Deficient) \\
\hline Presbytis rubicunda & Lutung Merah & Data Kurang (Data Deficient) \\
\hline Tarsius bancanus & Krabuku Ingkat (Tarsius) & Data Kurang (Data Deficient) \\
\hline Pardofelis marmorata & Kucing Batu & Data Kurang (Data Deficient) \\
\hline Lutra spp. & Berang-berang & Data Kurang (Data Deficient) \\
\hline Hylobates muelleri & Owa Kalawat & $\begin{array}{l}\text { Risiko Rendah/Hampir Terancam } \\
\text { (Lower Risk/near threatened) }\end{array}$ \\
\hline Macaca fascicularis & Monyet Kra & $\begin{array}{l}\text { Risiko Rendah/Hampir Terancam } \\
\text { (Lower Risk/near threatened) }\end{array}$ \\
\hline Manis javanica & Trenggiling, Peusing & $\begin{array}{l}\text { Risiko Rendah/Hampir Terancam } \\
\text { (Lower Risk/near threatened) }\end{array}$ \\
\hline
\end{tabular}




\begin{tabular}{lll}
\hline & Spesies & $\begin{array}{l}\text { Status konservasi } \\
\text { internasional }\end{array}$ \\
\hline Reptil & Baning Coklat & Terancam Punah (Endangered) \\
\hline Manouria emys & Bajuku & Terancam Punah (Endangered) \\
\hline Orlitia borneensis & Labi Labi Raksasa & Terancam Punah (Endangered) \\
\hline Pelochelys cantorii & Bulus & Rentan (Vulnerable) \\
\hline Amyda cartilaginea & Beiyogo & Rentan (Vulnerable) \\
\hline Notochelys platynota & &
\end{tabular}

\section{Kritis Punah (Critically Endangered (CR))}

Suatu taxon termasuk dalam kategori Kritis Punah (Critically Endangered-CR) apabila bukti paling lengkap mengenai taxon tersebut menunjukkan bahwa taxon ini memenuhi salah satu kriteria Kritis Punah, A hingga E. Dengan demikian, taxon tersebut dianggap memiliki risiko kepunahan di alam yang nyata dan sangat tinggi.

\section{Terancam Punah (Endangered (EN))}

Suatu taxon termasuk dalam kategori Terancam Punah (Endangered-EN) apabila bukti paling lengkap menunjukkan bahwa taxon ini memenuhi salah satu kriteria Terancam Punah, A hingga E. Taxon ini dianggap memiliki risiko kepunahan yang sangat tinggi di alam

\section{Rentan (Vulnerable (VU))}

Suatu taxon termasuk dalam kategori Rentan (Vulnerable—VU) apabila bukti paling lengkap menunjukkan bahwa taxon ini memenuhi salah satu kriteria Rentan. Taxon ini dianggap memiliki risiko kepunahan yang tinggi di alam.

\section{Hampir Terancam (Near Threatened (NT))}

Suatu taxon termasuk dalam kategori Hampir Terancam (Near Threatened-NT) apabila telah dievaluasi berdasarkan kriteria tetapi saat ini tidak bisa memenuhi kualifikasi Kritis Punah (Critically Endangered), Terancam Punah (Endangered) atau Rentan (Vulnerable). Namun kualifikasi kriterianya sangat dekat atau hampir memenuhi kualifikasi terancam dalam waktu dekat.

\section{Belum Terancam (Least Concern (LC))}

Suatu taxon termasuk dalam kategori Belum Terancam (Least Concern - LC) apabila taxon ini setelah dievaluasi tidak bisa memenuhi kriteria Kritis Punah (Critically Endangered), Terancam Punah (Endangered), Rentan (Vulnerable) atau Hampir Terancam (Near Threatened). Taxa yang tersebar luas dan berlimpah termasuk dalam kategori ini.

\section{Data Kurang (Data Deficient (DD))}

Suatu taxon termasuk dalam kategori Data Kurang (Data Deficient—DD) apabila informasi untuk melakukan kajian risiko kepunahan secara langsung maupun tidak 
langsung berdasarkan distribusi dan/atau status populasi tidak ada. Taxon dalam kategori ini mungkin saja banyak diteliti, dan sifat biologisnya banyak dikenal. Namun data yang memadai tentang kelimpahan dan/atau penyebarannya sangat kurang. Dengan demikian DD bukan merupakan kategori keterancaman. Taxa yang ada dalam kategori ini menunjukkan bahwa diperlukan informasi yang lebih banyak dan lebih baik. Kelayakan klasifikasi status keterancaman taxon tergantung dari penelitian lanjutan yang dilakukan. Pada berbagai informasi, yang tersedia hanyalah status DD dan tingkat keterancaman. Jika serangkaian taxon diperkirakan memiliki keterbatasan dan waktu pencatatan yang cukup panjang, maka status terancam dapat diterapkan. 


\section{Lampiran 3}

\section{Kajian kepentingan spesies-spesies vertebrata bagi masyarakat lokal di MRF}

Daftar vertebrata di daerah Malinau yang dikaji oleh masyarakat di sekitar daerah MRF, dalam urutan menurun dari yang terpenting. Rincian diberikan oleh Sheil et al. (2003c).

\begin{tabular}{llrl}
\hline Nama Ilmiah & Nama Indonesia & Skor & Pemanfaatan untuk \\
\hline Cervus unicolor & Rusa Sambar & 30,1 & $\begin{array}{l}\text { makanan, hiasan, } \\
\text { diperdagangkan, peralatan }\end{array}$ \\
\hline Sus barbatus & Babi Berjenggot & 25,2 & $\begin{array}{l}\text { makanan, diperdagangkan, obat- } \\
\text { obatan }\end{array}$ \\
\hline Ursus malayanus & Beruang Madu & 14,8 & makanan, obat-obatan, hiasan \\
\hline Hystrix brachyura & Landak Raya & 13,7 & makanan, obat-obatan \\
\hline Tragulus napu & Pelanduk Napu & 12,6 & $\begin{array}{l}\text { diperdagangkan, obat-obatan, } \\
\text { makanan, hiasan }\end{array}$ \\
\hline Buceros vigil & Rangkong Gading & 11,7 & $\begin{array}{l}\text { hiasan, diperdagangkan, obat- } \\
\text { obatan }\end{array}$ \\
\hline Buceros rhinoceros & Rangkong Badak & 10,1 & hiasan, diperdagangkan \\
\hline Gracula religiosa & Beo & 9,8 & diperdagangkan, hiasan \\
\hline Muntiacus muntjak & Kijang Muncak & 9,8 & $\begin{array}{l}\text { makanan, diperdagangkan, } \\
\text { hiasan }\end{array}$ \\
\hline Presbytis hosei & Lutung Banggat & 9,1 & $\begin{array}{l}\text { makanan, peralatan, obat- } \\
\text { obatan, diperdagangkan }\end{array}$ \\
\hline Fish/Tor tambra* & Ikan Mas & 8,9 & diperdagangkan \\
\hline Pycnonotus zeylanicus & Cucak Rawa & 8,8 & diperdagangkan \\
\hline Python reticulatus & Ular Sanca & 8,7 & obat-obatan, hiasan \\
\hline Copsychus malabaricus & Kucica Hutan & 8,2 & diperdagangkan \\
\hline Cyclemys dentata & Kura-kura Bergerigi & 6,5 & hiasan, makanan, obat-obatan \\
\hline Collocalia fuciphaga & Walet Sarang-Putih & 6,4 & diperdagangkan, obat-obatan \\
\hline Argusianus argus & Kuau Raja & 6,3 & hiasan, makanan \\
\hline Mustela nudipes & Musang Kepala Putih & 6,1 & obat-obatan \\
\hline Manis javanica & Trenggiling Peusing & 4,9 & hiasan, obat-obatan \\
\hline & & & \\
\hline & & &
\end{tabular}




\begin{tabular}{llrl}
\hline Nama Ilmiah & Nama Indonesia & Skor & Pemanfaatan untuk \\
\hline Arctictis binturong & Binturong & 4,4 & obat-obatan, makanan \\
\hline Aceros corrugatus & Julang Jambul-Hitam & 4,1 & hiasan, diperdagangkan \\
\hline Macaca fascicularis & Monyet Kra & 4,1 & makanan \\
\hline Lophura ignita & Sempidan Biru & 3,6 & makanan, diperdagangkan \\
\hline $\begin{array}{l}\text { Paradoxurus } \\
\text { hermaphroditus }\end{array}$ & Musang Luwak & 3,3 & makanan, hiasan \\
\hline Apis dorsata & Lebah Madu & 3,0 & obat-obatan \\
\hline Anorrhinus galeritus & Enggang Klihingan & 3,0 & hiasan, diperdagangkan \\
\hline Hylobates muelleri & Owa Kalawat & 2,9 & diperdagangkan \\
\hline Anthracoceros & Kangkareng Hitam & 2,9 & diperdagangkan, hiasan \\
malayanus & & & \\
\hline Neofelis nebulosa & Macan Dahan & 2,5 & hiasan \\
\hline Loriculus galgulus & Serindit Melayu & 2,0 & diperdagangkan \\
\hline Formicidae & Semut & 1,9 & obat-obatan \\
\hline Trichys fasciculata & Angkis Ekor Panjang & 1,5 & obat-obatan \\
\hline Gallus spp. & Ayam peliharaan & 0,9 & makanan \\
\hline Nycticebus coucang & Kukang Bukang & 0,8 & obat-obatan \\
\hline Ophiophagus hannah & Ular Kobra & 0,8 & bahan berburu \\
\hline Treron curvirostra & Punai Lengguak & 0,7 & hiasan \\
\hline Dogania subplana & Labi Labi Hutan & 0,6 & makanan \\
\hline Pardofelis marmorata & Kucing Batu & 0,6 & hiasan \\
\hline Pteropus vampyrus & Kalong Besar & 0,5 & hiasan, obat-obatan \\
\hline Haliastur indus & Elang Bondol & 0,2 & diperdagangkan \\
\hline Rattus tiomanicus & Tikus Belukar & 0,2 & obat-obatan \\
\hline Varanus rudicollis & Biawak Leher Kasar & 0,1 & makanan \\
\hline Ada & & &
\end{tabular}

* Ada ketidakpastian spesies yang spesifik versus ikan secara umum saat pengkajian ini dilakukan

** Ayam biasanya tidak dimasukkan ke dalam satwa hutan, tetapi dua kelompok masyarakat di daerah hilir (Gong Solok dan Seturan) menyebutkannya 


\section{Lampiran 4 Rangkuman spesies burung}

\section{Elang Klihingan Anorrhinus galeritus}

Taksonomi Ada dua spesies dalam genus ini dan tidak ada subspesies dalam Anorrbinus galeritus.

Penyebaran global Borneo, Sumatera, Thai/Semenanjung Malaya dan Tenasserim (daerah Myanmar yang berbatasan dengan Thailand).

Status populasi di Borneo Tersebar luas di seluruh hutan yang ada, termasuk daerah tebang pilih, meskipun tidak didapati di beberapa daerah pesisir seperti Tanjung Putting. Wilayah jelajah: 1,2-5,6 km²/kelompok tergantung dari kualitas habitat (Kemp \& Kemp 1975, Leighton 1982, Johns 1987).

Keberadaan pada pulau kecil di Asia Tenggara Bunguran $(\mathrm{n}=1)$.

Habitat Umum, dengan kelompok terbesar di dalam hutan pada ketinggian sedang hingga rendah dengan populasi spesies ara/beringin yang baik, termasuk daerah hutan rawa gambut (Kemp 1995). Hutan tropis dataran rendah yang sedang sampai padat, yang tua dan tumbuh dengan baik dari permukaan laut hingga 1.600 (Gunung Lunjut, Taman Nasional Kayan Mentarang), dan hingga 1,600m di Sumatera (van Marle \& Voous 1988). Umumnya bisa hidup di antara pohon-pohon yang lebih rendah dibandingkan dengan spesies rangkong yang lain (van Marle \& Voous 1988).

Ekologi pencarian makan Bergerak secara sistematis di antara rimbunan daun sambil mengambil buah, dan berpindah-pindah, tidak pernah di tajuk yang rapat. seringkali turun ke lantai hutan,. Makanan yang di bawa ke sarang umumnya buah-buahan, namun juga artropoda, kadal, dan katak (Kemp 1995). Makanannya beragam jenis buah (Kemp 1995), dan tidak sepenuhnya bergantung pada buah ara. Di antara buah selain ara, buah pala sering pula menjadi makanannya (Wells 1999). Buah-buahan yang bersifat kapsular, berbiji besar, berdaging buah tebal dan berserat yang kaya akan lipid merupakan makanan yang sangat penting (terutama sejenis mahoni-Meliaceae-dan suku pala-Myristicacea) (Leighton \& Leighton 1983, Hadiprakarsa \& Kinnaird 2001). Spesies ini akan mengupas kulit kayu menggali 
di antara epifit, dan membelah tempurung buah dan kapsulnya, terutama pada saat buah tidak banyak didapati (paceklik) Kemp 1995).

Organisasi sosial Bersifat teritorial, dalam kelompok yang berjumlah rata-rata tujuh ekor di hutan primer (kelompok ini lebih besar saat musim buah berlimpah, lebih kecil saat buah langka). Memiliki tempat beristirahat yang tetap, biasanya pada pohon-pohon dekat aliran sungai (Kemp \& Kemp 1975, Leighton 1982). Kelompok yang lebih besar bergabung untuk mengusir spesies lain yang berada pada pepohonan yang berbuah (Leighton 1986).

Ekologi perkembangbiakan Bersifat monogamus, membesarkan anak bersamasama dalam kelompok yang jumlahnya tujuh hingga sepuluh ekor; daur bertelur 75 hari (30 hari mengerami; 60 hari masa tinggal dalam sarang). Bertelur antara bulan Januari dan Maret; anakan menetas dan mulai tumbuh bulu selama puncak musim buah (Leighton \& Leighton 1983), namun tidak ada musim berkembang biak yang jelas (Madge 1969). Biasanya dua atau tiga anak dibesarkan sekali bersarang (Leighton 1986). Lubang sarang pada $10-25 \mathrm{~m}$ di atas batang pohon yang hidup atau yang mati (Kemp 1995). Akan bertelur lagi segera setelah anak dewasa dan bila makanan tersedia (Leighton 1986).

Pengaruh dari perubahan habitat Tidak terlalu tertekan akibat penebangan seperti spesies rangkong lainnya karena mampu mencari makan pada vegetasi bagian bawah dan tengah (Wells 1999); di hutan yang ditebang 5-6 tahun sebelumnya ukuran kelompok tidak terganggu (Johns 1989a).

Status konservasi Dilindungi oleh Undang-undang di Indonesia dan termasuk dalam CITES Appendix II. Tidak terdaftar dalam IUCN.

\section{Enggang Jambul Berenicornis comatus}

Taxonomi Satu spesies dalam genus dan tidak ada subspesies

Penyebaran global Thailand Selatan dan Tenasserim bagian selatan, Malaysia, Sumatera, dan Borneo

Status populasi dan kepadatannya di Borneo Tidak ada catatan yang terakhir dari Borneo (Holmes \& Burton 1987), namun ditemukan pada lima dari delapan daerah yang disurvei dengan baik walaupun dalam jumlah yang sedikit (van Balen 1999a). Kepadatan: satu kelompok/10 km² di Sabah (Johns 1988); 6,3 kelompok/ $10 \mathrm{~km}^{2}$ di Sarawak (Kemp \& Kemp 1975).

Keberadaan di pulau kecil di Asia Tenggara Tidak ditemukan di pulau lepas pantai $(\mathrm{n}=0)$

Habitat Terutama hidup di hutan tropis dataran rendah hingga ketinggian 600 $\mathrm{m}$ dpl. Menyukai hutan di sepanjang sungai, rawa pasang surut, hutan campuran, dan bahkan hutan sekunder yang berpohon tinggi dan areal hutan tebang pilih (Kemp 1995). 70\% dari pengamatan mencatat burung ini menyukai hidup di bawah tajuk yang rendah (Leighton 1986, Johns 1987). Menyukai daerah dengan tumbuhan bawah yang rapat.

Ekologi pencarian makan Mencari makan pada seluruh lapisan tajuk pohon, dari tajuk yang paling tinggi di hutan primer, hingga tajuk tingkat bawah di hutan bekas tebangan (Kemp \& Kemp 1975, Johns 1987, Kemp 1995). Memakan artropoda 
yang berlimpah dan vertebrata berukuran kecil, termasuk ular berukuran kecil, kadal, dan burung-burung kecil yang ditemukan di serasah perkebunan kelapa sawit, atau memakan serangga pengebor kayu dan larva yang digali dari sampah sisa penebangan (Johns 1987); selain juga banyak memakan buah-buahan. Di Kalimantan, buahbuahan yang kaya lipid dan berdaging merupakan sumber buah-buahan penting dalam makanannya; buah ara yang kaya akan gula tidak terlalu banyak dimakan (Kemp 1995).

Ekologi perkembangbiakan Bersarang pada lubang pohon yang terletak 10-30 $\mathrm{m}$ di atas tanah; rongga yang sama selalu digunakan pada tahun-tahun berikutnya. Didapati berkembang biak di lubang-lubang alami pada pohon di hutan bekas tebangan maupun hutan yang utuh (Johns 1987). Daur bersarang sekitar 130 hari. Betinanya meninggalkan sarang setelah anaknya bisa terbang (setelah kurang lebih 3 bulan). Biasanya hanya ada satu anak dalam sarang, tetapi burung ini bisa membesarkan dua anakan sekaligus (\& Douglas 1978, Smythies 1981).

Organisasi sosial Hidup berkelompok atau dalam kelompok keluarga (Johns 1987); biasanya berpasang-pasangan atau dalam kelompok 3-4 ekor burung atau 78 ekor meskipun jarang terjadi. Sebagian besar kelompok terdiri dari satu pasang dengan 1-3 ekor pengiring dan sejumlah anak (Kemp 1995); Kelompok menjadi lebih banyak saat buah-buahan berlimpah, seluruh atau sebagian pengiring memisahkan diri saat ketersediaan buah terbatas (Leighton 1982).

Hubungan antar spesies Saat hidup bersamaan dengan spesies rangkong lainnya pada wilayah yang sama, rangkong yang lebih besar menghabiskan waktu yang lebih banyak pada setiap sumber makanan dan hanya mengambil buah yang paling matang/masak, sementara rangkong yang lebih kecil hanya dalam waktu singkat dan tidak terlalu memilih buah yang dimakannya. Hubungan antar spesies antara Enggang Jambul dan spesies rangkong yang lain tidak diketahui.

Pengaruh dari perubahan habitat Spesies ini dapat bertahan hidup dalam bagian hutan yang kecil yang terlindungi dengan baik, dan menjelajah ke hutan sekunder di sekelilingnya (Kemp 1995). Namun demikian, ukuran bagian-bagian hutan yang minimum bagi kelangsungan hidup serta pengaruh vegetasi di sekelilingnya untuk mempertahankan hidupnya belum diketahui. Kemampuan spesies ini untuk bertahan pada ketinggian yang lebih tinggi, yaitu daerah dengan kerusakan hutan yang tidak terlalu parah, menunjukkan bahwa penurunan jumlah spesiesnya tidak terlalu cepat (BirdLife International 2001).

Status konservasi Dilindungi oleh Undang-undang di Indonesia dan termasuk dalam Lampiran II CITES. Tidak ada dalam daftar IUCN.

\section{Julang Emas Rhyticeros undulatus}

Taxonomi Dikenal ada lima spesies dalam genus. Sanft (1960) mengungkapkan ada tiga subspesies, termasuk $R$. $u$. aequabilis Borneo yang berukuran lebih kecil dan lekuk di sepanjang cakarnya tidak terlalu berkembang. Namun demikian, validitas subspesies Borneo, masih diragukan (Kemp 1995).

Penyebaran global India Timur hingga India Barat Daya, Kepulauan Andaman, Asia Tenggara, Sumatera, Borneo, Jawa, dan Bali. 
Status populasi dan kepadatannya di Borneo Tersebar luas, namun secara umum tidak biasa hidup di wilayah ini (uncommon) (Kemp 1995); Kepadatan yang diukur berdasarkan luas dalam wilayah jelajah sekitar $1,3 \mathrm{~km}^{2} /$ ekor di Malaysia Barat (Johns 1987); 0,2 $\mathrm{km}^{2} /$ ekor di hutan utuh, dan $0,15 \mathrm{~km}^{2} /$ ekor di hutan yang ditebang di Sabah (Johns 1988).

Keberadaan di pulau kecil di Asia Tenggara Kepulauan Batu Kepulauan Laut Lingga, Musala, dan Panaitan $(\mathrm{n}=5)$.

Habitat Menyukai hutan primer yang hijau sepanjang musim, terutama di daerah kaki dan lereng gunung, hingga ketinggian $1.800 \mathrm{~m}$ di Borneo (Smythies 1981).

Ekologi pencarian makan Pemakan segala dan merupakan spesies pemakan yang umum (generalized feeder). Mencari makan di tajuk atas hingga hutan bagian bawah. Buah-buahan berdaging yang kaya lipid (Lauraceae, Burseraceae) merupakan makanan pokoknya di Kalimantan (Leighton 1986) dan Sumatera (Hadiprakarsa \& Kinnaird 2001), tetapi ketersediaanya buah-buahan ini lebih bersifat musiman dibandingkan dengan buah-buahan yang berbentuk kapsular (Leighton 1986). Dilihat dari jumlah, buah ara yang kaya akan gula hanya $10 \%$ dari konsumsi pakan, dan komponen satwa dalam pakan leboh sedikit lagi (Leighton 1986). Kunjugan dalam waktu singkat secara bergantian pada pohon-pohon yang sedang berbuah hanya untuk berburu hewan (Kemp 1995). Di Thailand, saat berkembang biak, (berdasarkan berat) makanannya terdiri dari 57\% ara, 29\% nonara, dan 5\% hewan. Buah-buahan yang dimakan mencakup 26 spp. dalam 12 suku, dan 19 genera (Poonswad et al. 1983, 1988). Burung ini biasa berkumpul pada pohon yang sedang berbuah.

Perilaku migrasi Wilayah jelajah jantan rata-rata adalah $10 \mathrm{~km}^{2}$ pada masa berkembang biak, dan $28 \mathrm{~km}^{2}$ saat tidak berkembang biak (Poonswad \& Tsuji 1994). Pergi saat persediaan buah menurun tetapi kembali lagi saat pohon kembali produktif (meskipun hanya satu spesies pohon saja yang berbuah), menandakan kemampuan mencari buah yang baik (Leighton \& Leighton 1983).

Ekologi perkembangbiakan Daur bersarang 113-137 hari; betina dan anaknya keluar pada saat yang bersamaan. Di Kalimantan, berkembang biak di bulan Januari hingga Mei, saat buah berlimpah tetapi tidak berkembang biak lagi selama dua tahun berikutnya (Leighton \& Leighton 1983). Biasanya menghasilkan dua atau tiga (jarang) butir telur, namun paling banyak hanya seekor anak yang hidup dan mampu terbang (Kemp 1995). Bersarang di lubang pada pohon hutan, seringkali pada pohon yang besar dengan tinggi 18 hingga 26 meter di atas tanah (Bartels \& Bartels 1937).

Organisasi sosial Terpisah atau bergabung, spesies yang nonteritorial dan hidup berpasang-pasangan atau dalam kelompok yang terdiri dari 4-14 ekor. Kelompok ini bisa lebih besar jumlah anggotanya saat beristirahat (lihat bagian selanjutnya). Dibandingkan dengan spesies territorial, spesies ini tidak terlalu dominant pada pohon-pohon hutan, bahkan dibandingkan dengan spesies yang berukuran lebih kecil (Leighton 1986).

Pergerakan dan migrasi harian Nomadik, bisa menjelajah lebih dari 100 $\mathrm{km}^{2}$ setiap harinya. Burung yang dipasangi radio-tracking meninggalkan tempat berlindungnya untuk mencari makan di lembah di daerah seluas 6 hingga $8 \mathrm{~km}^{2}$ 
(Tsuji et al. 1987). Burung yang belum dewasa hidup dalam kelompok burung yang terpisah. Tidur di pohon-pohon tempat beristirahat di hutan dalam jumlah 400 bahkan sampai 1000 ekor burung.

Pengaruh dari perubahan habitat Hidup dan berkembang biak secara ekstensif di hutan tebang pilih (Kemp 1995); sarangnya biasanya rusak saat kegiatan penebangan (Kemp \& Kemp 1975).

Status konservasi Dilindungi oleh Undang-undang di Indonesia dan termasuk dalam Appendix II CITES. Tidak terdaftar dalam IUCN.

\section{Kangkareng Hitam Anthracoceros malayanus}

Taxonomi Ada lima spesies yang dideskripsikan dalam genus ini dan dua subspesies: A. m. albirostris dan $A$. m. convexus.

Penyebaran global Semenanjung Thailand bagian selatan, Malaysia, Borneo, dan Sumatera.

Status populasi dan kepadatannya di Borneo Salah satu dari tiga spesies rangkong yang umum hidup di dataran rendah (Holmes \& Burton 1987). Kepadatan yang diukur dalam luasan wilayah jelajah: $1 \mathrm{~km}^{2} /$ pasang di Kalimantan Timur (Leighton 1986); 0,5-5 pasang $/ \mathrm{km}^{2}$ di Sabah (Johns 1988); 3,40 individu/ $\mathrm{km}^{2}$ (Galetti \& McConkey 1998), dan 0,6 km²/pasang di Sarawak (Kemp \& Kemp 1975).

\section{Keberadaan di pulau kecil di Asia Tenggara Bangka, Belitung dan Lingga (n $=3)$.}

Habitat Hutan primer dataran rendah yang hijau sepanjang musim, pada ketinggian hingga $600 \mathrm{~m}$, meskipun jarang ditemui di atas ketinggian $200 \mathrm{~m}$. Merupakan spesies spesialis dataran rendah. Dapat ditemukan di bagian tengah hutan, namun bisa menempati hutan sepanjang sungai, rawa pasang surut, hutan campuran, dan bahkan hutan sekunder yang berpohon tinggi (Kemp 1995). Menyukai tegakan pohon besar dengan tumbuhan bawah dan tumbuhan merambat. Menempati tajuk bagian atas dan tengah. Jarang terlihat di luar daerah hutan (Bartels \& Bartels 1937).

Ekologi pencarian makan Pemakan buah yang oportunistis. Pola makannya beragam, seringkali berupa buah-buahan besar, terutama buah-buahan berbiji besar dan pecah dari famili Meliaceae dan Myristicaceae (Leighton \& Leighton 1983). Secara teratur memakan buah ara, termasuk buah Ficus auranticacea yang berukuran sangat besar dan 17 spesies ara lainnya (Lambert 1989b). 40\% menu makannya terdiri dari buah-buahan yang kaya akan gula. Buah-buahan yang kaya lipid sangat penting saat buah-buahan lain terbatas jumlahnya. Kadang-kadang, hewan yang diburu dalam waktu singkat juga dimakannya (Leighton 1986). Mencari makanan terutama pada tumbuhan pelilit yang lebat, dengan cara melompat serta merayap ke sana kemari di lantai hutan (Kemp 1995). Hanya sebagian kecil saja yang mencari makan di tajuk saat mengambil buah ara dan buah-buahan lainnya (Kemp 1995).

Ekologi perkembangbiakan Tidak banyak diketahui (Kemp 1995). Bersifat monogamus dalam pasangan yang terpisah tanpa pengiring (Kemp 1995). Memiliki daur sedikitnya 80 hari. Di Kalimantan, anak dipelihara dan mampu terbang 
pada saat ketersediaan buah melimpah (Leighton \& Leighton 1983). Jumlah anak yang dipelihara: 2-3, namun kerapkali hanya satu anak saja yang dibesarkan. Di Kalimantan, hanya satu saja anak dibesarkan selama 2 tahun (Leighton \& Leighton 1983). Ada satu sarang yang ditemukan pada ketinggian 4,5 m di atas tanah pada pohon hutan hidup yang berukuran sedang (Bartels \& Bartels 1937).

Organisasi sosial Hidup dalam suatu teritori sepanjang tahun, berpasangpasangan, dan kadang-kadang bergabung dengan kelompok lain yang anggotanya 5-6 ekor, dan jarang sekali hingga 33 ekor bersama-sama (Johns 1987, Medway \& Wells 1976)

Hubungan antar spesies Merupakan penyebar biji yang utama bagi spesies petai cina, Aglaia spp. (Meliaceae), dengan buah-buahan berbentuk kapsul (Becker \& Wong 1985). Kurang dominan dibandingkan dengan spesies rangkong lainnya yang hidup pada pohon yang berbuah; cenderung datang pada saat-saat terakhir pohon berbuah (Leighton 1986). Sering terusir oleh sejumlah spesies tupai (Becker \& Wong 1985).

Degradasi dan hilangnya habitat Bertoleransi terhadap sejumlah gangguan habitat. Namun terbatas hidupnya di hutan dataran rendah sehingga terancam oleh kerusakan hutan.

Status konservasi Dilindungi oleh Undang-undang di Indonesia dan termasuk Appendix II CITES. Terdaftar dalam kategori Risiko Rendah/hampir terancam (Lower risk/near threatened) pada Buku Data Merah Burung-burung Asia yang terancam (Red Data Book of threatened birds of Asia (BirdLife International 2001)) dan oleh IUCN (2002).

\section{Rangkong Badak Buceros rhinoceros}

Taxonomi Ada tiga spesies yang dideskripsi pada genus ini, dan diketahui ada 3-4 subspesies. Ras Borneo B. r. borneoensis (Gambar. 29) dibedakan oleh ukurannya yang kecil, lebih pendek, serta tanduk jengger yang lebih lebar menggulung ke bawah dengan tajam pada bagian punggungnya.

Penyebaran global Semenanjung Thailand bagian selatan, Malaysia, Sumatera, Borneo, dan Jawa.

Status populasi dan kepadatannya di Borneo Merupakan salah satu dari tiga spesies rangkong yang umum hidup di dataran rendah di Kalimantan (Holmes \& Burton 1987). Kepadatan yang diukur dalam luasan dalam wilayah jelajah: 0,3-1,6 $\mathrm{km}^{2} /$ pasang, hingga $0,1 \mathrm{~km}^{2} /$ pasang di Sabah (Johns 1988); hingga $1,2 \mathrm{~km}^{2} /$ pasang di Sarawak (Kemp \& Kemp 1975); 2-3 km²/pasang di Kalimantan Timur (Leighton 1986). Populasinya kemungkinan kurang dari 2.500 di Borneo (Worth et al. 1994), atau kurang dari 1.200 menurut Robson (2000).

Keberadaan di pulau kecil di Asia Tenggara Laut $(\mathrm{n}=1)$.

Habitat Hutan tropis dataran rendah yang lebat, terutama hutan rawa, hutan Dipterokarpa di perbukitan, dengan ketinggian hingga $1.200 \mathrm{~m}$ dpl. Hidup dan berkembang biak di hutan tebang pilih (Johns 1987).

Ekologi pencarian makan Cenderung terbang jarak jauh untuk mencari makanannya. Mempelajari lokasi pohon berbuah di wilayah teritorinya melalui 


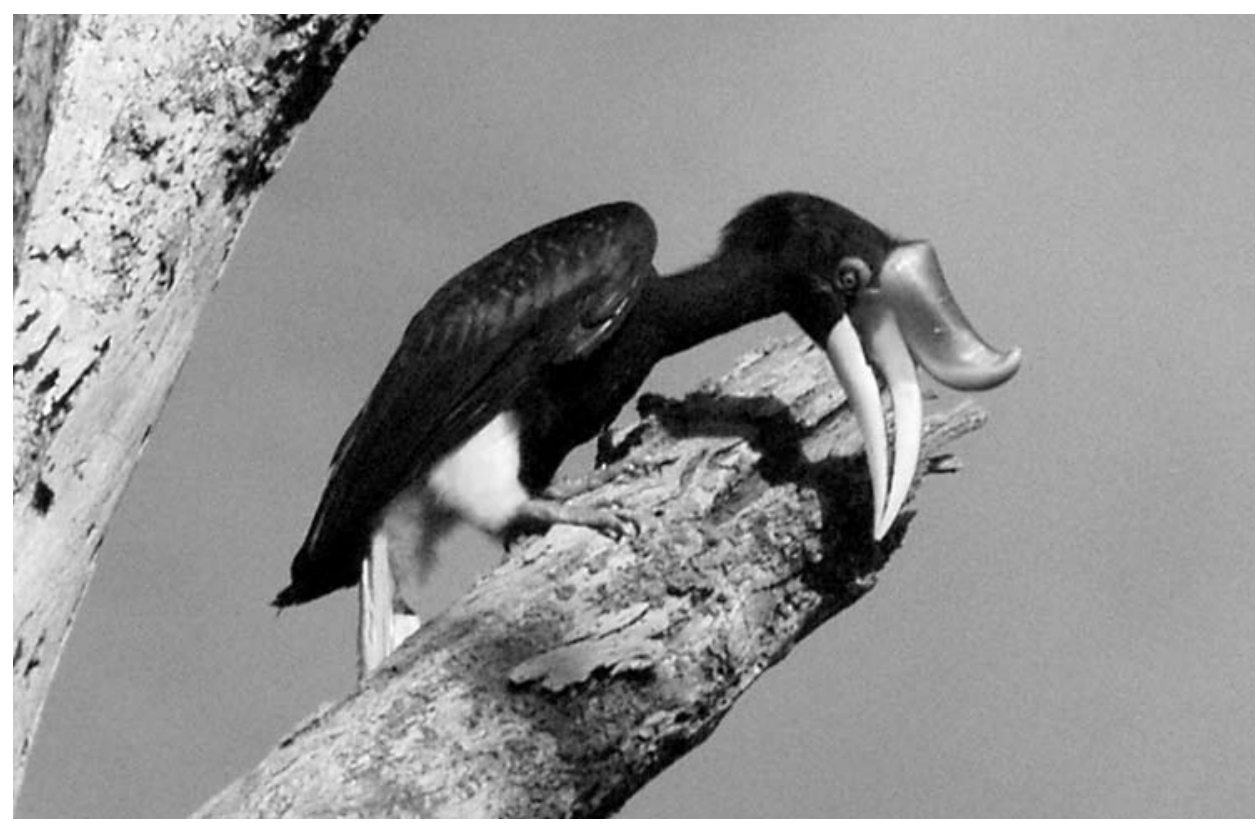

Gambar 29. Tegakan pohon yang mati sangat diperlukan oleh banyak spesies. Tempat Rangkong Badak (Buceros rhinoceros) mencari serangga. (Foto oleh Kimabajo)

penglihatannya. Banyak energi yang dikeluarkan dalam mencari sumber buahbuahan makanannya. Sumber makanan dari hewan tersebar secara merata namun sedikit dibandingkan dengan buah-buahan-energi yang digunakan untuk mencari makanan ini lebih sedikit, namun lebih banyak energi yang digunakan untuk memprosesnya. Secara umum, rangkong harus meluangkan waktu yang lebih besar untuk mencari makanan yang berbentuk hewan untuk mendapatkan hasil yang seimbang (Leighton 1986). 40 hingga 60\% makanannya terdiri dari buah-buahan yang kaya akan kandungan gula. Berburu hewan secara aktif hingga 50\% dari waktunya. Makanan hewaninya termasuk kadal, katak pohon, serangga, dan telur burung (Bartels \& Bartels 1937), atau 23,1\% terdiri dari makanan hewani dan buahbuahan nonara, dan 76,9\% buah ara (Hadiprakarsa \& Kinnaird 2001). Makanan dari buah-buahan termasuk spesies ara, Santiria laevigata, Sterculia parvifolis, Meliaceae, pala liar, dan kelapa sawit (McClure 1966). Memanfaatkan setidaknya 13 spesies ara di Malaysia (Lambert 1989a). Mampu membelah Shorea xanthophylla berdiameter $2 \mathrm{~cm}$, tetapi tidak bisa membelah buah-buahan yang lebih besar dari lima spesies meranti yang lain (Gould \& Andau 1989). Selain itu mencari makanan yang ada di bawah kulit kayu batang pohon yang mati (Bartels \& Bartels 1937).

Ekologi perkembangbiakan Merupakan pasangan yang monogamus. Bersarang di dalam lubang alami pada pohon yang besar dan tinggi (Bartels \& Bartels 1937). Dua dari tujuh sarang yang ditemukan (Johns 1982) atau satu dari empat sarang (Bartels \& Bartels 1937) berada pada pohon yang mati. Spesies ini memilih jalan masuk yang memanjang dan sempit, hanya cukup untuk burung betina masuk. Waktu bersarang bersamaan dengan musim buah dalam hutan (Johns 1982). Daur bersarangnya adalah 105-126 hari. Tanggal bertelurnya di Borneo adalah: Januari, 
Mei-Juni, September. Menetaskan 1 hingga 2 anakan, tetapi biasanya hanya satu saja yang mampu terbang. Kemungkinan tidak kawin beranak setiap tahun, namun kadang-kadang memakai kembali lubang sarangnya secara tahunan (Bartels \& Bartels 1937).

Organisasi sosial Kebanyakan hidup menetap dan berpasangan secara teritorial. Kumpulan burung muda dan burung dewasa yang tidak berkembang biak menjelajah seluas lebih dari ratusan $\mathrm{km}^{2}$ (Wells 1974. Leighton 1986). Hidup monogamus dan kadang-kadang dengan burung pengiring.

Hubungan antar spesies Mempertahankan teritorinya hanya terhadap jenisnya sendiri, sehingga dapat hidup bersama-sama dengan spesies rangkong yang lain. Sering kali datang paling akhir di pohon ara dan mengusir spesies rangkong yang lebih kecil. Bisa merupakan penyebar biji yang efektif.

Degradasi dan hilangnya habitat Bisa bertoleransi terhadap serangkaian kegiatan penebangan (Johns 1987), namun spesies ini rentan terhadap kepunahan jika hidup dalam bagian hutan yang berukuran lebih kecil (Lambert \& Collar 2002).

Status konservasi Dilindungi oleh Undang-undang di Indonesia dan termasuk dalam Appendix II CITES. Bulu ekornya banyak dicari untuk digunakan sebagai hiasan kepala. Kepala dan tanduk jengger yang diawetkan kerap kali digunakan sebagai hiasan (Kemp 1995). Terdaftar dalam kategori Risiko Rendah/hampir terancam (Lower risk/near threatened) dalam Buku Data Merah Burung-burung Asia yang terancam (Red Data Book of threatened birds of Asia (BirdLife International 2001)) serta dalam IUCN (2002).

\section{Rangkong Gading Rhinoplax vigil}

Taxonomi Spesies. Merupakan spesies tunggal dalam genus ini (genus monotipik) dan tidak memiliki subspesies.

Penyebaran global Semenanjung Thailand, Malaysia, Sumatera, dan Borneo.

Status populasi dan kepadatannya di Borneo: $1,8 \mathrm{~km}^{2} /$ pasang dalam hutan tebangan; hingga $0,9 \mathrm{~km}^{2} /$ pasang dan $0,5 \mathrm{~km}^{2} /$ pasang dalam hutan sekunder berumur 6 tahun dan hutan-hutan yang terisolasi di Sabah (Johns 1988);0,12 km²/pasang dalam hutan primer di kaki gunung di Sarawak (Kemp \& Kemp 1975); 7-8 km²/ pasang di Kalimantan Timur (Leighton 1986).

Keberadaan di pulau kecil di Asia Tenggara Tidak dikenal hidup di pulau lepas pantai $(\mathrm{n}=0)$.

Habitat Hutan hijau sepanjang musim yang lembab pada ketinggian hingga $1.100 \mathrm{~m}$, tidak ditemukan di hutan rawa gambut di daerah pesisir (Smythies 1957). Sangat berlimpah di antara kaki bukit pada puncak pepohonan yang besar.

Ekologi pencarian makan Menurut Leighton (1986) makanannya terdiri dari buah-buahan (Ficus spp., Parkia speciosa, Urostigma spp.), dan separuh waktunya dihabiskan untuk mencari makanan dari sumber hewani, termasuk tupai dan burung. Namun demikian, Hadiprakarsa dan Kinnaird (2001), mengungkapkan bahwa makanan spesies burung ini 98,6\% terdiri dari buah ara dan hanya sebagian kecil memakan hewan (1.4\%).

Ekologi perkembangbiakan Tidak banyak dipelajari. Tidak memiliki musim 
yang jelas, bisa menetaskan 1 hingga 2 ekor anak, tetapi biasanya hanya satu yang tercatat bersama burung dewasa. Lubang sarang terdapat di pepohonan hutan yang terisolasi (van Marle \& Voous 1988); Di Thailand, mayoritas pepohonan yang digunakan untuk bersarang adalah suku Meranti, terutama Hopea spp. dan Shorea spp., dengan diameter antara 105 hingga 216,6 cm (dbh) (Thiensongrusamee et al. 2001). Betinanya keluar dari sarang sebelum anaknya. Kawin pada puncak musim buah dan selang setahun sesudahnya (Leighton 1986). Wilayah jelajahnya mencapai 770 ha (Leighton 1982).

Organisasi sosial Hidup menetap secara teritorial dalam pasangan yang monogamus, terpisah dari kelompok-kelompok burung yang hampir yang nomadis (Leighton \& Leighton 1983). Berkelompok secara sendiri-sendiri atau berpasangan; berkelompok dengan jumlah delapan ekor, yang terdiri dari burung muda, hampir dewasa, dan burung dewasa yang tidak berkembang biak dan mencari makanan secara teratur pada tajuk (Leighton 1986).

Degradasi dan hilangnya habitat Menyebar ke hutan tebang pilih tetapi tidak di hutan sekunder (Kemp 1995). Rentan terhadap kepunahan dalam fragmen hutan yang berukuran kecil (Lambert \& Collar 2002), dan dianggap sebagai spesies yang akan dirugikan oleh kegiatan penebangan, karena merupakan spesies yang hanya memakan ara (spesialis ara).

Status konservasi Dilindungi oleh Undang-undang di Indonesia dan termasuk dalam Appendix II CITES. Dipengaruhi oleh hilangnya habitat utama karena ladang berpindah dan deforestasi, serta diburu gadingnya untuk ukiran dan obat-obatan. Bulu ekornya bernilai tinggi untuk hiasan pelindung kepala dalam perang. Terdaftar dalam kategori Risiko Rendah/hampir terancam (Lower risk/near threatened) dalam Buku Data Merah Burung-burung Asia yang terancam (Red Data Book of threatened birds of Asia IUCN (2002) (BirdLife International 2001)).

\section{Sempidan Merah Lophura erythrophthalma}

Taxonomi Ada sepuluh spesies dalam genus. Dua subspesies telah deskripsikan. Di Borneo, spesies ini diwakili oleh suku pyronota yang endemis.

Penyebaran global Semenanjung Malaysia, Sumatera, dan Borneo.

Status populasi dan kepadatannya di Borneo Hanya sedikit catatan mutakhir dari Kalimantan, yaitu seekor yang dikurung di Sukamandang (Holmes \& Burton 1987), di hulu Barito pada ketinggian $200 \mathrm{~m}$ (Wilkinson et al. 1991); Tanjung Puting (Holmes 1997); Gunung Palung (Laman et al. 1996); dan belum lama ini betina dengan anaknya sepanjang Sungai Tubu pada bulan November 1997).

Keberadaan di pulau kecil di Asia Tenggara Tidak hidup di pulau lepas pantai $(\mathrm{n}=0)$.

Habitat Hutan primer di dataran rendah, namun di Malaysia ditemukan pada ketinggian $300 \mathrm{~m}$, yang mungkin bisa bertoleransi terhadap hutan tebangan (Lambert dalam Holmes 1989, del Hoyo et al. 1997). Diperkirakan merupakan spesies spesialis dasar lembah (McGowan \& Garson 1995).

Ekologi pencarian makan Tidak banyak diketahui dan dikenal sebagai spesies yang memakan buah yang jatuh. Dalam perutnya ditemukan proporsi hewan dan 
tumbuhan yang sama (del Hoyo et al. 1997). Pernah terlihat sepasang yang mematuki buah Knema yang jatuh (del Hoyo et al. 1997); kelompok yang mencari invertebrata; bekerja sendirian atau dalam kelompok (pada waktu yang berbeda dalam suatu tahun) dalam waktu singkat sebelum berpindah pada kegiatan lain yang lebih luas (Davison 1981b). Pada temboloknya didapati materi tumbuhan dan hewan dalam jumlah yang relatif sama banyak. Rayap banyak dimakan, sedangkan kutu dan larva lebih jarang. Buah berbiji keras ditemukan pada perut dua ekor jantan (Beebe 1918-1922).

Pergerakan Tidak ada informasi.

Ekologi perkembangbiakan Sempidan Merah kerap ditemukan dalam kelompok (pernah ditemui sebanyak 22 ekor, mungkin terdiri dari beberapa keluarga yang bergabung setelah berkembang biak) dengan penyebaran jenis kelamin yang merata (Beebe 1918-1922) atau biasanya dengan satu jantan (Robinson \& Chasen 1936). Pada kasus ini, spesies terlihat bersifat polygynous (berpasangan banyak) (BirdLife International 2001). Sarangnya berupa cekungan dalam lapisan bawah (dedaunan yang gugur) di antara pepohonan, atau di atas tanah yang memiliki rayap. Empat hingga enam butir ditelurkan pada bulan Maret hingga Juni. Pengeraman dan pemeliharaan anak oleh betina. Sempidan yang dikandang mulai bertelur pada tahun ke tiga (Wells 1999). Sarang yang terbuat dari ranting ditemukan antara akar pohon hampir mati yang terlindung (del Hoyo et al. 1997).

Interaksi antar spesies Saat hidup berdampingan dengan Sempidan Biru (Lophura ignita) burung ini menghindari habitat yang disukai Sempidan Biru, yaitu habitat di dasar lembah (Davison 1981b). Terlihat kompetisi eksklusif di antar dua spesies ini, sehingga wilayah jelajahnya bisa bertumpang tindih atau tidak sama sekali (setidaknya di Semenanjung Malaysia). L. ignita biasanya menempati hutan sepanjang sungai dan L. erythrophthalma menempati hutan sepanjang sungai dan hutan di perbukitan, hanya bila L. ignita tidak hidup di daerah tersebut (Davison 1981b, BirdLife International 2001).

Degradasi dan hilangnya habitat Yatim (1993) menyatakan bahwa spesies ini sering dijumpai dekat tepian hutan, di ladang, dan sepanjang sungai di hutan meranti dataran rendah (BirdLifeInternational 2002, mengevaluasi hal ini dan menyatakan bahwa keberadaan di ladang hampir tidak mungkin terjadi). Ada bukti mengenai toleransi spesies ini di habitat yang rusak, namun sebagian besar terjadi di Semenanjung Malaysia. Di daerah ini tercatat kepadatan spesies yang tertinggi $\left(6 \mathrm{ekor} / \mathrm{km}^{2}\right) \mathrm{di}$ wilayah hutan yang ditebang pada tanah yang berbukit-bukit dengan tumbuhan bawah palem yang lebat. Kepadatan yang lebih rendah $\left(3 / \mathrm{km}^{2}\right)$ ada di hutan dataran rendah yang rata dengan tanah yang kering dan berawa, dan yang terendah (0.6/ $\mathrm{km}^{2}$ ) adalah di hutan daratan rendah yang rata dalam lahan teras alluvial campuran yang kering dan berawa (Davison \& Scriven, naskah tulisan tidak bertanggal dalam BirdLife International 2001). Di Borneo, tidak terlalu banyak bukti bahwa spesies ini menggunakan hutan yang rusak. Beebe (1918-1922) memperkirakan bahwa spesies di Borneo tidak terlalu toleran terhadap keberadaan manusia (dalam bentuk pemukiman) dibandingkan dengan di Semenanjung Malaysia (BirdLife International 2001). Namun demikian, hal ini bisa disebabkan oleh tekanan perburuan yang berbeda.

Status konservasi Rentan secara global (Collar et al. 1994); terancam punah 
((McGowan \& Garson 1995). Spesies yang hidup di hutan dan dataran saja terutama memiliki risiko akibat hilangnya habitat (Wells 1999). Terancam karena degradasi dan hilangnya habitat karena pertanian. Terdaftar sebagai Rentan (Vulnerable) oleh IUCN (2002).

\section{Sempidan Biru Lophura ignita}

Taxonomi Ada 10 spesies dalam genus. Dari empat subspesies yang dikenal, dua hidup di Borneo. Subspesies ignita di Kalimantan (dan Pulau Bangka) dan nobilis yang lebih besar, endemik di Sabah dan Sarawak. Pfeffer (1960) mengidentifikasi burung yang dikoleksi di Taman Nasional Kayan Mentarang sebagai nobilis, dan mungkin populasi di Malinau juga termasuk dalam subspesies ini.

Penyebaran global Semenanjung Malaysia, Sumatera ( $r u f a)$, Sumatera bagian Tenggara (macartneyi), Bangka, Kalimantan (ignita), dan Borneo bagian utara (nobilis)

Status populasi dan kepadatannya di Borneo Tercatat di seluruh hutan dataran rendah Borneo.Tadinya merupakan burung yang umum didapati di lantai hutan tetapi sekarang terpecah-pecah dan jarang terlihat karena kerusakan habitat dan perburuan (MacKinnon \& Phillipps 1993).

Keberadaan di pulau kecil di Asia Tenggara Tidak dikenal sebagai burung yang hidup di pulau lepas pantai $(n=0)$.

Habitat Di Sumatera dan Kalimantan dianggap sebagai spesialis hutan dataran rendah (del Hoyo et al. 1997); di Malaysia, hidup di lantai hutan dataran rendah yang tajuknya rapat dan tinggi dari permukaan laut $1.200 \mathrm{~m}$ pada hutan pegunungan dataran rendah. Kadang-kadang juga terdapat di habitat dasar lembah yang tergenang, terutama pada daerah yang dekat dengan sungai di daerah yang kadang tergenang, tetapi bukan rawa yang permanen (Wells 1999). Tercatat di hutan tebangan dan hutan sekunder tetapi tidak jumpai di hutan rawa (del Hoyo et al. 1997).

Ekologi pencarian makan Tidak ada informasi yang jelas selain isi perut berupa daun dan biji-bijian, serta sejumlah serangga. Spesies ini terlihat memakan buah ara yang jatuh.

Pergerakan Tidak ada informasi. Spesies ini dijumpai secara acak di seluruh habitat yang cocok (del Hoyo et al. 1997). Banyak melakukan pergerakan dan memanfaatkan ruang yang berbeda dalam beberapa hari.

Ekologi perkembangbiakan Sedikit sekali informasi yang ada mengenai musim berkembang biak. Pada bulan Juli ada empat anak yang baru menetas di Borneo (del Hoyo et al. 1997). Sarang terdiri dari daun-daun mati, rumput, dan bambu yang dibangun di bawah semak belukar yang tebal (Robinson \& Chasen 1936). Menetaskan 4-8 telur.

Degradasi dan hilangnya habitat BirdLife International (2001) melaporkan bahwa spesies ini dapat bertahan hidup di hutan tebangan, rusak, dan hutan sekunder, namun tidak jelas apakah kepadatannya menurun setelah kegiatan penebangan.

Status konservasi Terancam oleh rusaknya habitat karena pertanian dan kemungkinan punah di daerah hutan dataran rendah yang ditebang habis. Tercatat di hutan sekunder dan hutan tebangan, namun batas toleransinya terhadap perubahan 
habitat tidak diketahui. Terdaftar sebagai Risiko Rendah/Hampir terancam oleh IUCN (2002).

Kepraktisan sensus Vokal sangat mirip dengan Sempidan Merah dan tidak bermanfaat banyak bagi tujuan sensus.

\section{Sempidan Kalimantan Lobiophasis bulweri}

Taxonomi Sempidan Kalimantan adalah spesies monotypic yang endemik di Borneo. Kadang-kadang dikelompokkan kedalam genus Lophura.

Penyebaran global Endemik di Borneo.

Status populasi dan kepadatannya di Borneo Penyebarannya lokal dan terpecah-pecah secara berkelompok. Di Kalimantan, tidak ditemui $200 \mathrm{~km}$ ke arah timur dan selatan pantai. Umum hidup di beberapa tempat, tetapi sukar untuk dilihat (BirdLife International 2001).

Keberadaan di pulau kecil di Asia Tenggara Tidak diketahui hidup di pulau lepas pantai $(\mathrm{n}=0)$.

Habitat Di hutan pegunungan primer yang tua, dengan ketinggian hingga $1.500 \mathrm{~m} \mathrm{dpl}$., terutama pada lereng yang landai. Beebe (1918-1922) menyatakan bahwa spesies ini umumnya menempati puncak berhutan sekitar hulu sungai. Beebe (1918-1922) selalu menemukan spesies ini di sepanjang sungai (biasanya sungai yang lebih besar) dan anak sungai pada musim kemarau. Sementara pada awal musim penghujan, spesies ini lebih jarang datang ke tepian sungai, kemungkinan karena kelembaban yang cukup di genangan air (kolam) di hutan (BirdLife International 2001). Habitat intinya mungkin di antara ketinggian 500 hingga $1000 \mathrm{~m}$.

Ekologi pencarian makan Proporsi serangga dan buah-buahan dalam makanannya sama (Smythies 1981). Sering diasosiasikan dengan babi liar yang juga sering berada di daerah dataran tinggi Kelabit (Smythies 1981).

Pergerakan Dari beberapa bagian bukti yang ada, burung ini bersifat nomadik dan kadang bergerak dalam kelompok untuk mencari lokasi dengan pohon yang sedang berbuah (BirdLife International 2001).

Ekologi perkembangbiakan Mungkin lima butir ditelurkan, tetapi sarang dan pengeramannya tidak diketahui (Smythies 1981). Sedikit sekali informasi mengenai sistem perkawinannya, tetapi diperkirakan sebagai spesies yang berpasangan ganda (polygynous) dengan kemungkinan monogami (Johnsgard 1999).

Degradasi dan hilangnya habitat Spesies ini menghindari daerah perladangan dan daerah yang ditebang habis. Hidup hanya pada hutan primer sehingga dapat dianggap rentan terhadap kegiatan penebangan kayu.

Status konservasi Sempidan ini diklasifikasikan sebagai Rentan (Vulnerable) oleh IUCN (2002) karena dianggap menurun jumlahnya secara cepat dengan hilangnya habitat secara ekstensif yang sampai saat ini masih berlangsung, ditambah dengan kegiatan perburuan. Spesies ini diasumsikan memiliki jumlah populasi yang kecil, sehingga diperkirakan akan terpengaruhi oleh fragmentasi hutan yang semakin meningkat. Penyebab lainnya adalah keberadaan spesies yang bersifat nomadis di daerah dataran rendah (BirdLife International 2001). Spesies ini dilindungi oleh Undang-undang di Indonesia. 


\section{Kuau Raja Argusianus argus}

Taxonomi Genus ini merupakan monotypic, meskipun spesies yang ada di Pulau Jawa bisa juga merupakan spesies yang berbeda. Dikenal ada dua subspesies. Di Borneo, spesies ini diwakili oleh subspesies yang endemik $A$. a. grayi, yang dibedakan dari induk spesiesnya karena ukurannya yang lebih kecil, titik-titik putih di bagian atasnya, dan jingga (oranye) pada dada bagian atas dan punggung merah muda pada jantan.

Penyebaran global Semenanjung Malaysia, Sumatera dan Borneo.

Status populasi dan kepadatannya di Borneo Semakin jarang ditemukan di daerah bagian tengah dan bawah sungai (bagian hilir) karena banyaknya jumlah senapan dan jerat (Smythies 1981). Jumlah di kawasan Borneo menurun (Smythies 1981). Hidup di seluruh hutan dataran rendah dan perbukitan, tetapi dalam jangka panjang spesies ini hanya bisa dianggap aman dalam cagar-cagar hutan dan hutan produksi yang dikelola dengan baik (Holmes 1989). Umumnya hidup dan ditemukan di Taliyasan, Kalimantan Timur pada tahun 1985 (Holmes \& Burton 1987). Di Malaysia, kepadatan sebesar 1,5-2,25 petak sampel jantan per $\mathrm{km}^{2}$ di lahan berbukit versus $0,15-0,54$ di hutan yang rata pada tahun yang sama. Petak berjarak rata-rata 375 dan 435 m (Davison 1981a), tetapi ditemukan pula jarak yang lebih pendek sepanjang 40-140 m (n = 4) (Hernowo 1989). Nijman (1998) menemukan jantan yang bersuara 0,25 (hutan sepanjang sungai) hingga hampir 2,0 (hutan primer) per $\mathrm{km}^{2}$ di Taman Nasional Kayan Mentarang, Kalimantan Timur. Kawanishi (2002) menemukan kepadatan antara 0,15 dan 0,79 individu/ $\mathrm{km}^{2}$ di Taman Nasional Taman Negara, di Semenanjung Malaysia. Sözer et al. (1997) melaporkan kepadatan populasi sebesar 2-8 individu $/ \mathrm{km}^{2}$ di Kalimantan.

Keberadaan di pulau kecil di Asia Tenggara Tidak ketahui hidup di pulau lepas pantai $(\mathrm{n}=0)$.

Habitat Hutan tropisdi pesisir hingga hutan campuran yang hijau sepanjang musim, termasuk lokasi tebang pilih (Wells 1999). Biasanya hidup di ketinggian hingga $1.000 \mathrm{~m} \mathrm{dpl}$, namun kadang-kadang bisa mencapai ketinggian $1.500 \mathrm{~m}$ dpl. (Mjöberg 1929, p. 52). Langka hingga tidak ada sama sekali di hutan dataran rendah rawa gambut dan hutan kerangas pasir putih (Davison \& Scriven 1987; Wells 1999). Nijman (1998) menemukan bahwa Kuau Raja berkorelasi secara positif dengan diameter pohon, tinggi pohon, tinggi percabangan pertama dan tutupan tajuk, jarak dari sungai besar dan jarak dari habitat yang lebih tinggi. Tetapi korelasi tersebut tidak selalu menunjukkan hubungan sebab akibat.

Ekologi pencarian makan Tidak seperti spesies sempidan lain yang lebih sosial, Kuau Raja tidak pernah mengais lapisan di lantai hutan untuk mencari invertebrata. Kuau Raja mencari spesies yang lebih langka dan lebih besar saat berjalan perlahan di antara hutan (Wells 1999). Utamanya, semut raksasa (Camponotus gigas), dan artropoda berukuran besar lainnya yang dipilih, selain juga bahan dedaunan dan buah-buahan (Wells 1999). Buah-buahan dari tumbuhan memanjat dan palem yang hidup di bagian bawah merupakan makanan favorit, selain pula buah-buah jatuhan yang kaya akan gula. Makanan yang lebih kaya tetapi lebih jarang didapat ini membuat Kuau Raja lebih rentan terhadap keterbatasan makanan dibandingkan dengan spesies yang bersifat generalis (memakan segala) (Davison 1981a). 
Ekologi perkembangbiakan Dua (jarang sekali tiga) butir telur dalam lubang di atas lantai hutan, dilapisi dengan ranting, serat akar, rumput, daun, dan bulu (Davison \& Scriven 1987, Wells 1999). Tidak ada musim kawin yang jelas (Davison \& Scriven, 1987), dan waktu bertelur akan tergantung pada musim reproduksi spesies pohon yang bersamaan waktunya (Wells 1999). Berpasangan banyak dan secara bebas (promiscuous). Panggilan kawin dilakukan dari suatu arena yang telah dibersihkan secara seksama, biasanya di sepanjang puncak bukit. Betina memilih jantannya dari bunyi yang keras dan terus menerus dari arena yang telah dipersiapkan tersebut (Wells 1999). Jantan dan betina hidup menyendiri, dengan wilayah jelajahnya antara 7 hingga 32 ha (Winarni 2002).

Degradasi dan hilangnya habitat Spesies ini mungkin tidak menurun jumlahnya secara cepat karena hidup di lokasi yang tinggi dengan tingkat kerusakan hutan yang tidak terlalu parah dan dapat hidup di lokasi tebang pilih (Wells 1999). Namun Winarni (2002) melaporkan bahwa hutan utuh dengan pohon-pohon yang besar merupakan habitat penting bagi Kuau Raja jantan dalam wilayah jelajahnya.

Status konservasi Dianggap sebagai Rentan (McGowan \& Garson 1995), karena tingginya laju deforestasi. Dilindungi Undang-undang di Indonesia dan termasuk dalam Appendix II CITES. Terdaftar sebagai Risiko Rendah/Hampir Terancam oleh IUCN (2002). Saat ini tidak terancam, meskipun hal ini agak mengherankan untuk spesies burung berukuran besar dan mudah ditangkap ini (Wells 1999). Spesies ini toleran terhadap sejumlah gangguan hutan, namun laju penebangan hutan yang cepat, fragmentasi hutan, serta tekanan penebangan bisa menjadi ancaman yang serius dalam waktu yang akan datang (Nijman 1998).

\section{Pelatuk Sayap-Merah Picus puniceus}

Taxonomi Genus Picus menyebar di seluruh Eurasia dan memiliki 14 spesies, tiga di antaranya hidup di Borneo. Populasi P. puniceus di Borneo termasuk dalam subspesies observandus yang menempati seluruh daerah penyebarannya (lihat bagian selanjutnya) kecuali di pulau Jawa dan Nias (Winkler et al. 1995).

Penyebaran global Semenanjung Thailand dan Tenaserrim, ke arah selatan melalui Malaya, Sumatera, Borneo, Pulau Bangka, Pulau Nias, dan Jawa (Short 1982). Merupakan spesies endemik di Dataran Sunda.

Status populasi dan kepadatannya di Borneo Hidup dalam kepadatan yang rendah di Borneo. Merupakan salah satu dari empat spesies pelatuk yang terlangka (dari 14 spesies yang ada) di hutan dataran rendah primer. Namun spesies ini tersebar luas di seluruh pulau. Kepadatan rata-rata di hutan dataran rendah $(0,78$ individu/ $\left.\mathrm{km}^{2}\right)$ lebih tinggi dibandingkan dengan di hutan perbukitan $\left(0,45\right.$ individu/ $\left.\mathrm{km}^{2}\right)$ (Lammertink 2004). Kepadatan rata-rata di hutan dataran rendah (0,81 individu/ $\mathrm{km}^{2}$ ) hampir sama dengan uang didapati di hutan dataran rendah yang ditebang $\left(0,76\right.$ individu $\left./ \mathrm{km}^{2}\right)$.

Keberadaan di pulau kecil di Asia Tenggara Bangka dan Nias ( $\mathrm{n}=2)$.

Habitat Mungkin paling umum hidup pada lokasi diantara hutan primer dan sekunder yang tinggi (Short 1982). Menjelajah hingga kaki bukit tetapi jarang lebih dari $560 \mathrm{~m}$ di daratan utama. Di Borneo, dimana P. chlorophus dalam genus yang 
sama tidak dapat ditemukan, spesies ini menjelajah hingga $1.500 \mathrm{~m}$ (Harrisson dalam Short 1982). Menjelajah hingga hutan sekunder yang memiliki sisa pohon besar yang cukup (Short 1982). Di hutan tebangan, spesies ini kerapkali hidup di bagian hutan primer dibandingkan dengan bagian hutan yang ditebang (Lammertink 1999).

Pergerakan dan migrasi harian Kadangkala bergerak sepanjang $0,5 \mathrm{~km}$ atau lebih ke daerah terbuka untuk mendatangi pohon yang disukainya (Short 1978). Hidup dalam bagian hutan seluas 150 ha yang dipisahkan oleh rumpang selebar 1 km dari hutan utuh di Taman Nasional Gunung Palung (Lammertink 1999).

Ekologi pencarian makan Metode pencarian makannya terutama dengan menotok (26\% dari total waktu mencari makan) dan mematuk (16\%) sehingga Pelatuk Sayap Merah ini termasuk spesies pelatuk yang menotok dibandingkan dengan spesies dalam genus yang sama yang hidup di Borneo ( $P$. mentalis dan $P$. miniaceus). Pelatuk Sayap-Merah berbeda dari spesies yang lain dalam hal mencari makan di tempat yang sedikit lebih tinggi (rata-rata $2 \mathrm{~m}$ lebih tinggi) dan mencari makan di percabangan yang menghadap ke dasar hutan (15\% waktu pencarian makan). Tidak seperti spesies dalam satu genus lainnya, Pelatuk Sayap-Merah jarang mencari makan di liana atau epifit. 12\% waktunya dihabiskan untuk mencari makan di percabangan yang mati tetapi tidak pernah pada pohon yang telah mati; hal ini mirip dengan saudara segenusnya. Ketinggian pencarian makan adalah 15,6 \pm 7,3 m pada pohon dengan ketinggian $20,8 \pm 7,5 \mathrm{~m}$, yaitu pada $75 \%$ dari tinggi pohon total. Pohon tempat mencari makan memiliki dbh 21,8 $\pm 10,5 \mathrm{~cm}$. Diameter substrat pencarian makanan adalah 9,3 \pm 7,9 cm (Lammertink unpubl.).

Pencarian makanan terutama pada tajuk dengan batang dan cabang yang besar, terutama spesies pepohonan yang menjulang tinggi dan pohon-pohon yang berbatasan dengan (pohon dipinggir) daerah yang ditebang habis. Spesies ini hanya memakan semut (Short 1982). Asosiasi pencarian makanan: 38\% sendirian; 25\% dengan Pelatuk Sayap-Merah yang lain (biasanya berpasangan); 38\% dalam kelompok campuran (Lammertink unpubl.). Mencari makan secara soliter (sendirian) atau berpasangan (Lagendijk 2000, Short 1982, Winkler et al. 1995). Nilai tengah (mean) individu yang dijumpai adalah 1,22 (Lammertink 2004).

Ekologi perkembangbiakan Berkembang biak pada musim kering (Short 1982). Tempat bersarang dan beristirahat cenderung di batang kecil yang telah mati, setinggi $20 \mathrm{~m}$ atau lebih di pepohonan besar (Short 1978, 1982). Tempat bersarang mungkin dikembangkan dari rongga tempat beristirahat (hinggap) jantan (Short 1982).

Interaksi antar spesies Tercatat dalam kelompok campuran dengan beragam spesies burung yang lain, seperti: Pelatuk Kumis Kelabu (Picus mentalis), Caladi Batu (Meiglyptes tristis), Caladi Badok (M. tukki), Pelatuk Pangkas (Blythipicus rubiginosus), Pelatuk Rafles (Dinopium rafflesii), Caladi Tikotok (Hemicircus concretus), Kadalan Birah (Phaenicophaeus curvirostris), Kadalan Selaya (P. chlorophaeus), Srigunting Batu (Dicrurus paradiseus), Empuloh Paruh-Kait (Setornis criniger), Kipasan Mutiara (Rhipidura perlata), Takur Gedang (Megalaima chrysopogon), Tepus Merbah-Sampah (Stachyris erythroptera), Tepus Tunggir-Merah ( $S$. maculata), Tepus Kaban ( $S$. nigricollis), dan Ciung Air-Coreng (Macronous gularis) (Lammertink unpubl.); lihat juga (Winkler et al. 1995, Lagendijk 2000, Styring \& Ickes 2001a). 
Status konservasi Tidak terancam secara global. Telah hilang dari hutan dataran rendah Borneo yang ditebang habis. Namun kelimpahan yang sama ditemukan di hutan primer maupun hutan yang telah ditebang. Keberadaannya di hutan perbukitan menunjukkan bahwa sebagian besar populasi yang relatif terlindungi masih ada di Borneo. Tidak terdaftar dalam IUCN (2002).

\section{Pelatuk Kumis-Kelabu Picus mentalis}

Taxonomi Terdiri dari dua subspesies, yaitu: mentalis yang endemik di pulau Jawa dan kini hanya hidup di Jawa Barat saja dan langka. Yang lain adalah humii yang menempati daerah sebaran lainnya, termasuk Borneo (Winkler et al. 1995).

Penyebaran global Semenanjung Thailand dan Tenaserrim, ke arah selatan melalui Malaya, Sumatera, Borneo, Pulau Bangka, Pulau Nias, dan Jawa (Short 1982). Merupakan spesies endemik di Dataran Sunda, namun sebarannya sedikit meluas ke arah utara dari Istmus Kra, suatu garis batas fauna antara Subregion Sunda dan Indocina.

Status populasi dan kepadatannya di Borneo Merupakan salah satu (dari dua spesies) pelatuk Borneo yang sangat sensitif terhadap gangguan akibat kegiatan penebangan (spesies sensitif lainnya adalah Pelatuk Kelabu Besar Mulleripicus pulverulentus). Kepadatan Pelatuk Kumis Kelabu menurun dengan nilai tengah (mean) $85 \%$ di delapan lokasi dataran rendah yang mencakup rentang dari hutan primer hingga hutan tebang pilih di Borneo Barat (Lammertink 2004). Kepadatan pelatuk ini juga sangat menurun di hutan yang terbakar (Balen pengamatan pribadi). Di Borneo, spesies menyebar hingga ketinggian $1.600 \mathrm{~m}$ (Winkler et al. 1995), tetapi kepadatannya di hutan perbukitan primer lebih rendah $\left(2,16\right.$ individu/ $\left.\mathrm{km}^{2}\right)$ dibandingkan dengan kepadatan di hutan dataran rendah primer $(4,18$ individu/ $\mathrm{km}^{2}$ ) (Lammertink 2004).

Keberadaan di pulau kecil di Asia Tenggara Bangka $(n=1)$.

Habitat Dalam bentang alam yang ditebang, spesies ini lebih banyak hidup di bagian hutan primer dibandingkan dengan dibagian hutan yang ditebang (Lammertink 1999). Pelatuk ini lebih menyukai hutan primer dengan tumbuhan bawah yang relatif terbuka, karena hutan terbuka tersebut memungkinkan Pelatuk Kumis-Kelabu untuk bergerak cepat saat mencari makan di atas dan di antara substrat (Lammertink 1999). Hutan yang telah ditebang memiliki tumbuhan bawah yang lebih rapat yang dihindari oleh pelatuk ini. Namun demikian, di hutan sekunder yang telah ditebang 40 tahun yang lalu di Semenanjung Malaysia dan telah mendapatkan tindakan pengelolaan (tumbuhan bawahnya ditipiskan dan liana serta tumbuhan rambatnya telah di buang) serta memiliki tumbuhan bawah yang lebih terbuka dibandingkan dengan hutan primer, Pelatuk Kumis-Kelabu ini lebih berlimpah dibandingkan dengan di hutan primer (Styring \& Ickes 2001b).

Pergerakan dan migrasi harian Hidup di bagian hutan seluas 150 ha dan 1.500 ha yang dipisahkan oleh rumpang hutan selebar $1 \mathrm{~km}$ dari hutan utuh di Taman Nasional Gunung Palung (Lammertink 1999).

Ekologi pencarian makan Teknik pencarian makannya adalah dengan memanjat dan menelusur ( $42 \%$ dari waktu pencarian makan), mencari $(21 \%)$, dan 
mengumpulkan (16\%). Spesies ini lebih banyak memanjat dan menelusur serta memangsa dibandingkan spesies lain dalam satu genus. Burung ini menghabiskan $13 \%$ waktunya pada liana dan $12 \%$ pada kayu mati. Ketinggian pencarian makan adalah $13,6 \pm 8,2 \mathrm{~m}$ pada pohon dengan tinggi $21,0 \pm 9,7 \mathrm{~m}$, yaitu sama dengan $65 \%$ tinggi pohon total. Pohon tempatnya mencari makan memiliki dbh $26,8 \pm 16,5 \mathrm{~cm}$. Diameter substrat pencarian makan adalah 12,6 \pm 12,0 cm (Lammertink unpubl.).

Mencari makanan di hutan tingkat bawah dan tengah (3-15m). Memakan semut, rayap, larva, kumbang, belalang, kecoa, dan serangga lainnya, dan kadang-kadang memakan buah-buahan kecil berbiji (Winkler et al. 1995). Asosiasi pencarian makan: 12\% sendirian; 35\% bersama Pelatuk Kumis-Kelabu lainnya; 53\% dalam kelompok campuran (Lammertink unpubl.). Nilai tengah jumlah individu yang ditemui adalah 1,38 (Lammertink 2004).

Ekologi perkembangbiakan Di Borneo, reproduksi tercatat di bulan Februari hingga Juni. Sarang digali dalam tunggul pohon yang mati. Menetaskan dua atau tiga telur (Winkler et al. 1995).

Interaksi antar spesies Tercatat dalam kelompok campuran yang terdiri dari Pelatuk Sayap-Merah (Picus puniceus), Pelatuk Merah (P. miniaceus), Caladi Badok (Meiglyptes tukki), Pelatuk Pangkas (Blythipicus rubiginosus), Pelatuk Rafles (Dinopium rafflesii), Caladi Tikotok (Hemicircus concretus), Pelatuk Kijang (Celeus brachyurus), Pelatuk Kundang (Reinwardtipicus validus), Tukik Tikus (Sasia abnormis), Kadalan Selaya (Phaenicophaeus chlorophaeus), Srigunting Batu (Dicrurus paradiseus), Empuloh Irang (Alophoixus phaeocephalus), Asi Topi-Sisik (Malacopteron cinereum), Luntur Putri (Harpactes duvaucelii), dan Ciung Air-Coreng (Macronous gularis) (Lammertink unpubl.).

Status konservasi Tidak terancam secara global. Populasi di dataran rendah di seluruh Subregion Sunda berkurang secara cepat karena tebang habis, penebangan, dan terbakarnya hutan dataran rendah. Namun spesies pelatuk ini masih hidup dalam kepadatan sedang di daerah hutan perbukitan yang luas. Tidak masuk dalam daftar IUCN (2002).

\section{Pelatuk Merah Picus miniaceus}

Taxonomi Populasi di Borneo termasuk dalam subspesies malaccensis (Gambar 30) yang juga ditemukan di Semenanjung Malaysian dan Sumatera. Subspesies yang lain adalah perlutus di Semenanjung Myanmar dan Thailand; niasensis dari Pulau Nias; dan miniaceus dan Jawa (Winkler et al. 1995).

Penyebaran global Asia Tenggara, mulai dari Semenanjung Thailand dan Tenasserim, ke selatan melalui Malaysia ke Sumatera, Pulau Nias, Borneo, dan Jawa. Burung ini endemik di Dataran Sunda.

Status populasi dan kepadatannya di Borneo Di antara burung pelatuk Borneo, Pelatuk Merah adalah spesies yang paling toleran terhadap gangguan hutan. Kepadatan rata-rata di hutan yang ditebang adalah 0,60 individu/ $\mathrm{km}^{2}$, lebih tinggi dari kepadatan di hutan dataran rendah primer $\left(0,05\right.$ individu $\left./ \mathrm{km}^{2}\right)$. Kepadatan yang tertinggi mungkin berada pada areal yang banyak perkebunan dan pohon kelapa (Lammertink 2004). 


\section{Keberadaan di pulau kecil di Asia Tenggara Bangka, Belitung dan Nias ( $\mathrm{n}=$ 3).}

Habitat Umumnya hidup di hutan dataran rendah dan hutan pegunungan dengan ketinggian hingga $1.400 \mathrm{~m}$ (MacKinnon \& Phillipps 1993). Namun di Taman Nasional Gunung Palung di Kalimantan Barat, spesies ini hanya ditemui pada ketinggian kurang dari 200 m (Laman et al. 1996, Lammertink 2004). Jarang mencapai ketinggian $1.000 \mathrm{~m}$ di dataran utama dan Sumatera, tetapi bisa hidup pada ketinggian hingga $1.500 \mathrm{~m}$ di Jawa, dan $1.700 \mathrm{~m}$ di Borneo (Short 1982). Hidup dengan kepadatan yang tinggi di daerah pedesaan yang ada perkebunan kelapa (Lammertink unpubl.).

Pergerakan dan migrasi harian Informasi tidak tersedia.

Ekologi pencarian makan Teknik pencarian makan yang utama adalah dengan memanjat dan menelusur (27\% waktu pencarian makan), mematuk (19\%), mengumpulkan makanan (17\%), dan mencari (14\%). Spesies ini terutama memakan semut, tetapi kadang kala burung ini memakan serangga yang lain dan buah-buahan. Dalam hal kegiatan memanjat dan menelusur, Pelatuk Merah merupakan spesies yang berada di pertengahan-intermediate, antara spesies dalam satu genus $P$. puniceus dan P. mentalis. Hal ini bertentangan dengan Short (1978) yang melaporkan bahwa Pelatuk Merah merupakan pencari makan yang paling pasif di antara tiga spesies

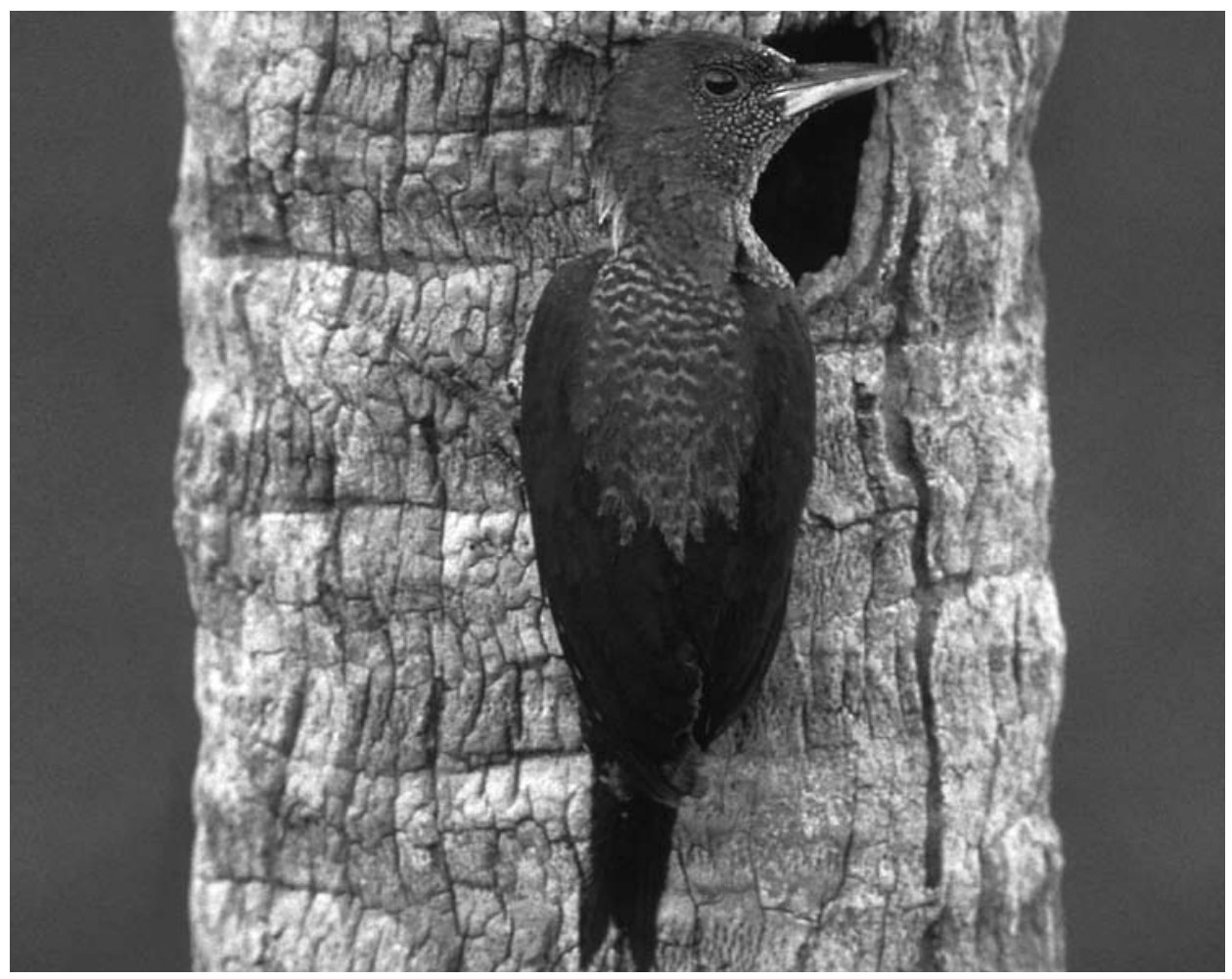

Gambar 30. Pelatuk Merah Betina (Picus miniaceus); pelatuk ini hidup dengan kepadatan yang lebih tinggi di hutan yang terganggu dan daerah pedesaan dibandingkan dengan hutan primer. (Foto oleh Martjan Lammertink) 
tersebut. Pelatuk Merah menghabiskan 20\% waktunya mencari makan pada liana yang padat ketimbang spesies lain yang segenus. $10 \%$ waktunya dihabiskan pada kayu mati. Ketinggian pencarian makan yaitu 13,2 $\pm 5,5 \mathrm{~m}$ pada pohon dengan ketinggian 19,2 $\pm 9,4$ m, yaitu 60\% dari tinggi pohon total. Pohon-pohon tempat mencari makan memiliki dbh 20,1 $\pm 10,0 \mathrm{~cm}$. Diameter substrat tempat pencarian makan adalah $8,1 \pm 9,5 \mathrm{~cm}$ (Lammertink unpubl.).

Pelatuk Merah mencari makan di semua tingkat pada tumbuhan merambat, balak yang tumbang, tunggul, batang pohon, epifit, dan cabang pohon hutan (Short 1982). Hanya kadang-kadang saja mencapai tajuk saat burung ini terbang di sepanjang tumbuhan merambat, pohon tumbang, dan anakan pohon yang ditutupi tumbuhan rambat (Short 1978). Asosiasi pencarian makan: 30\% mencari makan secara soliter; $50 \%$ dari pencarian makannya bersama satu atau dua ekor Pelatuk Merah lain; dalam 20\% pengamatan mencari makanan dalam kelompok campuran (Lammertink unpubl.). Mencari makan secara soliter atau kerap kali berpasangan (Short 1978). Nilai tengah dari jumlah yang ditemui adalah 1,33 (Lammertink 2004).

Ekologi perkembangbiakan Bersifat monogamus (berpasangan tunggal). Sarangnya digali pada tunggul pohon yang sekarat atau pohon mati pada ketinggian yang beragam (Short 1978). Jantan dan betinanya bersama-sama menggali sarang ini namun jantan lebih sering dibandingkan dengan betinanya (Short 1982). Jantannya beristirahat dalam rongga sarang (Short 1982). Pemberian makan atau perawatan bagi anaknya tidak diketahui. Musim berkembang biak dimulai pada bulan Februari atau Maret dan berlangsung hingga Juni (di Malaya), anak pelatuk ini ditemukan di Borneo sekitar bulan Agustus (Short 1982). Menetaskan dua atau tiga telur (Short 1982), meskipun banyak upaya bersarang yang gagal (Short 1982). Sarang dibangun dari tunggul pohon mati setinggi 4,5 - $20 \mathrm{~m}$ (Short 1982). Di daerah pedesaan di bagian barat Borneo, burung ini sering bersarang pada pohon kelapa mati yang bagian atasnya patah. Perkembangbiakannya diamati di Borneo bagian barat pada Januari, Juni, Juli, dan Oktober (Lammertink unpubl.).

Interaksi antar spesies Tercatat dalam kelompok campuran dengan Pelatuk Kumis Kelabu ((Picus mentalis), Tukik Tikus (Sasia abnormis), Caladi Badok (Meiglyptes tukki), dan Empuloh Irang (Alophoixus phaeocephalus) (Lammertink unpubl.).

Status konservasi Kelimpahannya meningkat di daerah dataran rendah Borneo sejalan dengan pembukaan hutan primer, sehingga perhatian konservasi hanya sedikit (Lammertink 2004). Tidak terdaftar dalam IUCN (2002).

\section{Pelatuk Pangkas Blythipicus rubiginosus}

Taxonomi Berhubungan erat dengan Blythipicus pyrrhotis yang hidup di dataran tinggi di beberapa bagian Semenanjung Malaya dan seluruh Asia Tenggara. Tidak ada pemisahan subspesies yang diketahui (Winkler et al. 1995).

Penyebaran global Hidup menyebar dari Myanmar bagian selatan dan Semenanjung Thailand ke Malaya serta Sumatera dan Borneo (Short 1982). Merupakan spesies endemik Dataran Sunda.

Status populasi dan kepadatannya di Borneo Sekitar 2 pasang $/ \mathrm{km}^{2}$ (4 individu $/ \mathrm{km}^{2}$ ) di Semenanjung Malaysia (sampel yang diambil sedikit) (Short 1978). 
Di Borneo bagian barat, kepadatannya 2,14 individu/ $\mathrm{km}^{2}$ di dataran rendah tetapi hanya 0,69 individu $/ \mathrm{km}^{2}$ di hutan perbukitan dengan ketinggian lebih dari $200 \mathrm{~m}$ (Lammertink 2004).

Keberadaan di pulau kecil di Asia Tenggara Tidak hidup di pulau lepas pantai $(\mathrm{n}=0)$.

Habitat Umumnya kelimpahannya lebih rendah di hutan dataran rendah yang ditebang $\left(1,85\right.$ individu $\left./ \mathrm{km}^{2}\right)$ dibandingkan dengan hutan dataran rendah primer $\left(2,62\right.$ individu $\left./ \mathrm{km}^{2}\right)$. Namun demikian, ragam kepadatan dalam kedua habitat tersebut sangat tinggi dan tidak ada korelasi yang nyata antara kepadatan spesies dan gangguan oleh kegiatan penebangan (Lammertink 2004). Spesies ini menyukai bagian hutan primer dalam bentang alam bekas tebangan (Lammertink 1999). Habitatnya di hutan dataran rendah yang lebat, biasanya hutan primer, tetapi ada pula yang hidup dalam hutan sekunder yang lebat (Short 1978), dengan ketinggian hingga $1.000 \mathrm{~m}$. Di Borneo, kepadatannya rendah di dataran tinggi dengan ketinggian hingga 2.200 m (Winkler et al. 1995). Daerah ini lebih tinggi dibandingkan dengan bagian-bagian sebarannya dan tumpang tindih dengan saudaranya di dataran tinggi $B$. pyrrhotis.

Pergerakan dan migrasi harian Tidak ada informasi.

Ekologi pencarian makan Kecuali Tukik Tikus (Sasia abnormis), spesies ini mencari makan di vegetasi yang lebih rendah dibandingkan spesies pelatuk Borneo yang lain. Ketinggian pencarian makan adalah 5,0 \pm 5,1 $\mathrm{m}$ pada pohon dengan tinggi $12,6 \pm 7,7 \mathrm{~m}$, yaitu pada 39\% tinggi total pohon. Metode pencarian makanan adalah menotok (62\% waktu pencarian makanan) dan memanjat, serta menelusur (13\%) Spesies ini mencari makan pada kayu mati sebanyak 21\%, dan $9 \%$ pada cabang dan batang yang sakit. Dengan demikian, pencarian makanan pada kayu mati tidak sebanyak yang diungkapkan oleh Short (1978). Namun mencari makan pada kayu mati lebih nyata terlihat pada Pelatuk Pangkas dibandingkan dengan pada spesies pelatuk berukuran sedang atau kecil di Borneo. Pelatuk yang lebih besar Pelatuk Kundang (Reinwardtipicus validus) dan Pelatuk Ayam (Dryocopus javensis) mencari makan hanya pada pohon mati (spesialis pohon mati) dengan waktu mencari makan sebesar 58\% bagi Pelatuk Kundang dan 97\% bagi Pelatuk Ayam. Kedua spesies ini mencari makan di ketinggian yang lebih tinggi pada vegetasi dibandingkan dengan Pelatuk Pangakas. Kadang-kadang, Pelatuk Pangkas mencari makan di liana dan epifit. Asosiasi pencarian makan: 33\% soliter; 61\% berpasangan atau berkelompok dalam satu spesies yang sama dengan 3 individual; dan $6 \%$ kelompok campuran. Pohon tempat mencari makan memiliki nilai tengah dbh 17,3 $\pm 12,8 \mathrm{~cm}$. Diameter substrat tempat mencari makan adalah 11,4 $\pm 10,5 \mathrm{~cm}$ (Lammertink unpubl.).

Kumbang dan larva pelobang/penggerek kayu lain yang tidak dikenal merupakan makanan utama spesies ini (Short 1978). Mencari makanan secara soliter atau berpasangan secara bebas, memelihara kontak suaranya dengan menggunakan pepohonan yang berbeda dalam mencari makan (Short 1978). Nilai tengah jumlah pelatuk yang ditemui $=1$ (Lammertink 2004).

Ekologi perkembangbiakan Berkembang biak selama musim kering (Short 1982). Tempat bersarang dan beristirahat biasanya pada dahan yang agak kecil, dengan ketinggian dari tanah $20 \mathrm{~m}$ atau lebih pada pohon yang besar (Short 1982).

Interaksi antar spesies Jarang berada dalam kelompok campuran dengan 
Pelatuk Kumis-Kelabu (Picus mentalis) dan/atau Kadalan Selaya (Phaenicophaeus chlorophaeus).

Status konservasi Spesies ini dapat bertahan hidup dengan kepadatan sedang di hutan tebangan. Keberadaannya dalam sejumlah pecahan hutan menunjukkan bahwa pelatuk ini bisa bertahan hidup dalam jangka pandang di bentang alam bekas tebangan. Selain itu, spesies ini hidup pada hutan perbukitan sehingga tidak berada dalam ancaman yang langsung di Borneo, meskipun laju hilangnya habitat dataran rendah amat cepat. Tidak terdaftar oleh IUCN (2002).

\section{Pelatuk Kijang Celeus brachyurus}

Taxonomi Merupakan perwakilan tunggal Asia dari genus Neotropis (Short 1982, tapi hal ini harus diperiksa dengan teknik molekular); dengan sejumlah subspesies. Subspesies badiosus adalah spesies endemik Borneo dan satu-satunya di pulau ini.

Penyebaran global Asia Selatan, dari Himalaya di bagian India, Cina bagian selatan hingga Sri Lanka, Myanmar, Thailand, Vietnam, Hainan, Malaya, Jawa, Sumatera, dan Borneo.

Status populasi dan kepadatannya di Borneo Di hutan dataran rendah dengan ketinggian di bawah $200 \mathrm{~m}$ lebih umum $\left(1,80\right.$ individu/ $\left.\mathrm{km}^{2}\right)$ ditemui dibandingkan di hutan pegunungan (1,13 individu/ $\mathrm{km}^{2}$ ) (Lammertink 2004). Kepadatan populasi di Semenanjung Malaysia bisa jadi lebih tinggi hingga 2,3 pasang $/ \mathrm{km}^{2}$ (Short 1982), namun data ini berdasarkan daerah sampel yang kecil dan teknik pendugaan kepadatan yang tidak dijelaskan secara spesifik.

Keberadaan di pulau kecil di Asia Tenggara Bangka, Belitung dan Nias ( $\mathrm{n}=3$ ).

Habitat Lebih berlimpah di hutan dataran rendah primer $\left(2,77\right.$ individu/ $\left.\mathrm{km}^{2}\right)$ dibandingkan dengan hutan dataran rendah yang ditebang $\left(1,22\right.$ individu/ $\left./ \mathrm{km}^{2}\right)$, namun tidak ada kolerasi yang nyata antara kepadatan spesies dengan gangguan akibat kegiatan penebangan karena adanya pencilan nilai (outliers) kepadatan yang tinggi pada salah satu hutan bekas tebangan (Lammertink 2004). Selain itu, spesies ini hidup di hutan sekunder, kebun kelapa, kebun, pohon budidaya, dan mangrove (Short 1982, Lammertink unpubl.); di Borneo, spesies ini ditemukan di ketinggian hingga $1.900 \mathrm{~m}$ (Smythies 1981). Hidup dalam tiga dari empat fragmen hutan yang berukuran 90 hingga 1.500 ha yang berdekatan dengan Taman Nasional Gunung Palung (Lammertink unpubl.).

Ekologi pencarian makan Metode pencarian makanan adalah mengumpulkan bahan makanan (33\%) dan menotok (24\%). 14\% waktu mencari makannya dihabiskan pada tumbuhan epifit. Nilai tinggi ini disamai hanya oleh Caladi Badok $(M$. tukki) (lihat bawah). Pelatuk Kijang merupakan pencari makan aktif, yang memiliki nilai tengah jarak terbang pada setiap menit waktu mencari makan lebih tinggi dari seluruh pelatuk Borneo yang ada. Pergerakan memanjatnya hanya dilampaui oleh Pelatuk Sayap-Merah dan Pelatuk Kumis Kelabu. Ketinggian pencarian makannya adalah $12,7 \pm 9,1 \mathrm{~m}$ pada pohon setinggi 24,7 $\pm 11,5 \mathrm{~m}$ (atau sama dengan $51 \%$ tinggi pohon total). Diameter substrat rata-ratanya adalah $10,5 \pm 7,8 \mathrm{~cm}$ pada pohon dengan dbh $21,6 \pm 18,3 \mathrm{~cm}$. Hanya $2 \%$ dari upaya pencarian makanan ini dihabiskan di pohon mati (Lammertink unpubl.). 
Berbagai semut, terutama dari genera Crematogaster dan Phidole, merupakan makanan utamanya, namun rayap dan serangga yang lain juga mungkin ikut dimakan (Short 1978). Buah ara dan mungkin buah-buahan lain dimakannya (Ali 1953). Spesies ini juga memanfaatkan sari dari berbagai bunga. Burung ini mencari makan di lokasi yang beragam, mulai dari gundukan kotoran hewan, sarang semut dan rayap di atas tanah hingga pada daun-daun pohon yang tinggi. Sarang rayap dan semut yang besar dipatuki dan dirusak oleh Pelatuk Kijang yang sedang mencari makan ini (Short 1978). Asosiasi pencarian makanan: Jarang mencari makan sendiri (4\%), sebagian besar berpasangan atau dalam kelompok yang terdiri dari empat individu, dan 26\% mencari makan secara berkelompok. Nilai tengah jumlah yang dapat ditemui adalah 1,86 (Lammertink 2004).

Ekologi perkembangbiakan Musim berkembang biak pada bulan Februari hingga April di Malaya dan Sumatera. Sarang biasanya dibangun dari sarang semut (terutama genus Crematogaster) pada pohon yang tingginya 3-15 m, meskipun kadang-kadang spesies ini menggali lubang pada batang pohon. Biasanya menetaskan dua butir telur. Periode pengeramannya biasanya 12-14 hari, jantan dan betinanya mengerami telur tersebut. Anakan yang baru menetas diberi makan melalui makanan yang dikeluarkan kembali dari perut dewasa, yang berisi semut, larva, kepompong, dan telur semut. Perilaku anak yang telah mampu terbang tidak diketahui (Short 1978).

Interaksi antar spesies Memiliki hubungan erat dengan semut Crematogaster. Di sebagian besar penyebarannya, sarang pelatuk ini berada pada lubang yang digali dalam sarang yang digunakan oleh semut. Semut dan pelatuk ini menempati sarang pada waktu yang bersamaan. Kebiasaan bersarang pada sarang semut dan rayap ini secara efektif menyingkirkan persaingan Pelatuk Kijang dalam lokasi bersarang dan beristirahat dengan pelatuk yang lain (Short 1982).

Bergabung secara longgar dalam kelompok campuran dalam mencari makan dengan Pelatuk Kumis Kelabu (Picus mentalis), Pelatuk Sayap-Merah (P. puniceus), dan Caladi Belacan (Dendrocopus canicapillus).

Status konservasi Bukan merupakan spesies yang memerlukan perhatian konservasi di Borneo, karena kemampuannya dalam bertahan hidup di daerah bekas tebangan, hutan sekunder, dan daerah pedesaan, lebih jauh lagi, ditemukan pula di hutan perbukitan. Tidak terdaftar dalam IUCN (2002).

\section{Caladi Badok Meiglyptes tukki}

Taxonomi Genus Meiglyptes terbatas hidupnya di Asia Tenggara dan terdiri dari tiga spesies. $M$ tukki memiliki 5 subspesies, dua di antaranya berada di Borneo: tukki di Borneo utara (juga di Sumatera dan Bangka) dan percnerpes yang merupakan spesies endemik di Borneo bagian selatan (Winkler et al. 1995).

Penyebaran global Asia Tenggara dari Tenasserim dan Semenanjung Thailand hingga Malaya ke Borneo dan Sumatera: sehingga spesies ini endemik bagi Dataran Sunda.

Status populasi dan kepadatannya di Borneo Biasa hidup di hutan dataran rendah Borneo $\left(2,62\right.$ individu $\left./ \mathrm{km}^{2}\right)$ dan hutan perbukitan $\left(2,27\right.$ individu/ $\left./ \mathrm{km}^{2}\right)$. 
Di Semenanjung Malaysia, dilaporkan memiliki kelimpahan dua kali lipat: 0,32,7 pasang $/ \mathrm{km}^{2}$, namun daerah sampel dan teknik pendugaan kepadatannya tidak dijelaskan (Short 1978).

Keberadaan di pulau kecil di Asia Tenggara Kepulauan Bangka, Banyak, Batu, Belitung, Bunguran dan Nias $(n=6)$.

Habitat Hampir sama kelimpahannya di hutan yang ditebang (2,58 individu/ $\left.\mathrm{km}^{2}\right)$ dengan kelimpahan di hutan dataran rendah primer $\left(2,69\right.$ individu/ $\left.\mathrm{km}^{2}\right)$ (Lammertink 2004). Hidup di hutan dataran rendah dan perbukitan, sering menempati hutan primer dan hutan sekunder yang lebat (Short 1982). Spesies ini menyukai daerah dengan tumbuhan bawah yang lebat, menghindari daerah tebangan dan tepian hutan yang disukai oleh spesies lain dalam genus yang sama (Short 1982). Jarang dijumpai di ketinggian di atas $625 \mathrm{~m}$, namun secara sporadis bisa mencapai $1.200 \mathrm{~m}$ di pegunungan di Malaya (Short 1982) dan $1.000 \mathrm{~m}$ di Borneo (Winkler et al. 1995).

Ekologi pencarian makan Kegiatan mencari makannya terutama menotok (27\% waktu pencarian makan), memanjat dan menelusur (25\%) dan mengumpulkan makanan (25\%). Sangat berbeda dengan spesies segenusnya yang tinggal dalam wilayah yang sama $M$. tritis di Borneo. Spesies ini menghabiskan 14\% waktu mencari makannya dengan mencari epifit (bandingkan dengan $0 \%$ pada $M$. tritis), dan kurang banyak mencari makan pada liana (11\%, dibandingkan dengan 25\% pada $M$. tritis). Parameter perilaku pencarian makanan lain dari ke dua spesies yang segenus ini sangat mirip. Caladi Badok menghabiskan 7\% waktunya mencari makan pada struktur sarang semut pohon dan rayap. Hal ini lebih banyak dibandingkan dengan spesies pelatuk Borneo yang lain: 3\% waktu mencari makan Pelatuk SayapMerah dihabiskan pada struktur tersebut, sementara spesies pelatuk yang lain $0 \%$ (Lammertink unpubl.). Namun demikian, Styring (2002a) melaporkan bahwa pelatuk di Semenanjung Malaya lebih sering mencari makan pada sarang semut dan rayap, termasuk 42\% Caladi badok, 25\% Pelatuk Merah, 18\% Pelatuk Pangkas, dan 16\% Caladi Batu, tetapi 0\% untuk Pelatuk Sayap Merah. Ketinggian pencarian makan Caladi Badok pada 12,2 \pm 8,9 m pada pohon dengan ketinggian 23,4 $\pm 18,9$ (atau $52 \%$ tinggi pohon). Diameter substrat rata-ratanya adalah $12,6 \pm 21,9 \mathrm{~cm}$, pada pohon dengan dbh 29,9 $\pm 25,6 \mathrm{~cm}$. Perhatikan juga standar penyimpangan (deviasi) diameter substrat dan dbh. Hal ini menunjukkan bahwa spesies pelatuk ini mencari makan pada substrat dan diameter pohon yang sangat beragam. 7\% upaya pencarian makan dilakukan pada kayu mati (Lammertink unpubl.).

Hampir seluruh makanannya terdiri dari semut dan rayap (Smythies 1986), kayu yang membusuk, tunggul, ranting, dan anakan (Short 1982). Mencari makan pada ketinggian yang beragam, namun kesukaannya mencari makan pada tumbuhan bawah yang lebat menunjukkan bahwa makanan pada ketinggian yang rendah merupakan hal yang penting (Short 1982). Namun demikian menurut Short (1982) pergerakan yang cepat di antara substrat di Kalimantan Barat berada dalam urutan ke 7 dalam pergerakan memanjat, dan urutan ke 4 dalam pergerakan terbang. Sehingga dalam hal pergerakan, spesies ini merupakan pelatuk yang rata-rata (Lammertink unpubl.). Sebagian besar pencarian makan dilakukan berpasangan atau dalam kelompok campuran (Winkler et al. 1995). Di Borneo, asosiasi pencarian makanan 
adalah sebagai berikut: 18\% secara soliter, 38\% dengan Caladi Badok yang lain, dan $46 \%$ dalam kelompok campuran. Nilai tengah jumlah individu yang ditemui adalah 1,59 (Lammertink 2004).

Ekologi perkembangbiakan Jantan dan betinanya mengurus anaknya. Memberi makanan dengan cara dimuntahkan dari temboloknya dan membuang kantong fesesnya. Diketahui ada dua burung dalam satu sarang (Ogilivie 1954 dalam Short 1982). Menggali dalam dahan pohon hidup tetapi lebih sering pada dahan yang telah membusuk dengan ketinggian 1-5 m di atas tanah (Short 1982). Dua buah sarang ditemukan di Kalimantan Barat pada bulan Juni dan Juli, keduanya pada dahan yang membusuk, 6,5 dan 1,2 m dari lantai hutan (Lammertink unpubl.).

Interaksi antar spesies Bergabung dalam kelompok campuran bersama-sama Caladi Batu, Pelatuk Kumi-Kelabu, Pelatuk Sayap-Merah, Pelatuk Rafles (Dinopium rafflesii), Pelatuk Kundang (Reinwardtipicus validus), Srigunting Batu (Dicrurus paradiseus), Kipasan Mutiara (Rhipidura perlata), Luntur Putri (Harpactes duvaucelii) dan Kadalan Selaya (Phaenicophaeus chlorophaeus). Saat ikut serta dalam kelompok pencarian makan, spesies ini menyebar ke arah tajuk yang lebih tinggi (Short 1978).

Status konservasi Terdaftar dalam kategori Risiko Rendah/Hampir Terancam (Lower Risk/near threatened) oleh IUCN (2002). Lammertink (2004a) mengusulkan perubahan status ke Tidak Terancam (Not Threatened) karena tidak terlihat adanya penurunan kepadatan jumlah setelah kegiatan penebangan dan keberadaannya dapat dijumpai di daerah pedesaan, pecahan hutan, dan hutan perbukitan.

\section{Caladi Batu Meiglyptes tristis}

Taxonomi Ditemukan subspesies grammithorax hampir di seluruh wilayah penyebarannya, termasuk Borneo. Merupakan subspesies endemik di Pulau Jawa dan mungkin sudah punah karena tidak ada catatan terbaru tentang subspesies ini (Winkler et al. 1995).

Penyebaran global Myanmar bagian tenggara di Tenasserim, Thailand bagian selatan, semenanjung Malaysia, Sumatera, Borneo, dan Jawa. Endemik di Dataran Sunda.

Status populasi dan kepadatannya di Borneo Umumnya hidup di hutan dataran rendah $\left(1,32\right.$ individu/ $\left.\mathrm{km}^{2}\right)$ dibanding dengan hutan perbukitan $(0,72$ individu/ $\mathrm{km}^{2}$ ), dengan ketinggian antara 200 hingga $400 \mathrm{~m} \mathrm{dpl}$. Kepadatan serupa didapati di hutan dataran rendah Semenanjung Malaysia (0.77 pasang $/ \mathrm{km}^{2}$ (Short 1978).

Keberadaan di pulau kecil di Asia Tenggara Bangka dan Nias ( $\mathrm{n}=2)$.

Habitat Kelimpahannya di hutan dataran rendah bekas tebangan (1,31 individu $/ \mathrm{km}^{2}$ ) hampir sama dengan kelimpahan di hutan dataran rendah primer (1,34 individu/ $\mathrm{km}^{2}$ ) (Lammertink 2004). Tersebar pada ketinggian sekitar $625 \mathrm{~m}$ di daratan utama, hingga 1,100 m di Borneo (Winkler et al. 1995).

Ekologi pencarian makan Metode pencarian makan yang utama adalah memanjat dan menelusur (35\%), mengumpulkan (30\%), dan menotok (20\%). 5\% waktu pencarian makan Caladi Batu dilakukan di dedaunan. Jumlah ini lebih banyak dibandingkan dengan pelatuk Borneo yang lain. Caladi Tikotok (Hemicircus 
concretus) menghabiskan 3\% waktu pencarian makannya di struktur yang sama (Lammertink unpubl.). Spesies ini lebih banyak mencari makan pada kayu mati dibandingkan dengan spesies segenusnya M.tukki (17\% dalam tristis, versus $7 \%$ dalam tukki). Untuk perbedaan lain dengan $M$. tukki, lihat keterangan di atas. Diameter substratnya $11,0 \pm 22,5 \mathrm{~cm}$ dan dbh $27,1 \pm 27,9 \mathrm{~cm}$, dengan catatan bahwa standar deviasi diameternya besar karena menunjukkan ragam pohon yang tinggi. Mencari makan pada ketinggian $11,5 \pm 9,0 \mathrm{~m}$ pada pohon dengan tinggi 17,5 $\pm 15,2 \mathrm{~m}$, yaitu 68\% tinggi pohon (Lammertink unpubl.). Spesies ini adalah pemakan serangga, sering terlihat pada tajuk yang tinggi (Short 1982). Memiliki spesialisasi terhadap semut yang berhubungan dengan pohon Macaranga spp., yang dominan pada hutan regenerasi (Styring \& Hussin 2004b). Asosiasi pencarian makanan: 3\% mencari makan secara soliter, $73 \%$ bersama dengan Caladi Batu yang lain (dalam kelompok yang terdiri dari 5 individu), 25\% dalam kelompok campuran (Lammertink unpubl.). Hampir selalu dalam pasangan atau kelompok campuran (Winkler et al. 1995). Nilai tengah jumlah individu yang ditemui adalah 1,64 (Lammertink 2004).

Ekologi perkembangbiakan Di Malaya, spesies ini membangun sarangnya pada bulan April; ditemukan sarang dengan dua butir telur pada akhir bulan Maret di Malaya (Short 1982). Spesimen burung muda dari Borneo bagian selatan di ambil pada bulan Juli, dari Borneo bagian utara selama bulan Agustus, dan dari Pulau Jawa pada bulan Maret (Short 1982). Bersarang pada dahan pohon mati atau hidup (Short 1978). Menggali lubang pada ketinggian $8 \mathrm{~m}$ pada pohon selebar $17 \mathrm{~cm}$ yang patah, $12 \mathrm{~m}$ di atas permukaan tanah (Short 1982). Bersarang pada tunggul yang tingginya $2 \mathrm{~m}$ (Short 1982).

Interaksi antar spesies Kecepatannya yang tinggi dan kecenderungannya untuk mencari makan pada pohon yang tinggi, membedakan spesies ini dari M. tukki (Short 1978). Namun demikian tidak ada perbedaan mobilitas pencarian makan yang jelas di Borneo bagian Barat (Lammertink unpubl.). Secara teratur spesies ini berasosiasi dengan kelompok campuran yang terdiri dari Caladi Badok, Pelatuk Kumis Kelabu, Pelatuk Sayap-Merah, Seriwang Asia ((Terpsiphone paradisi), Srigunting Batu (Dicrurus paradiseus), Kehicap Ranting (Hypothymis azurea), Philentoma SayapMerah (Philentoma pyrhopterum), dan Tepus Tunggir-Merah (Stachyris maculata) (Lammertink unpubl.).

Status konservasi Tidak terdaftar dalam IUCN (2002).

\section{Tukik Tikus Sasia abnormis}

Taxonomi Tukik genus Sasia terdiri dari 3 spesies, dua di antaranya hidup di Asia Tenggara dan satu di Afrika. Populasi di Borneo termasuk dalam subspesies abnormis yang mencakup seluruh wilayah sebaran spesies ini kecuali di Pulau Nias. Di P. Nias, ditemukan magnirostris (Winkler et al. 1995).

Penyebaran global Tenasserim (?), Semenanjung Thailand ke selatan melalui Malaya, Sumatera, Borneo, Jawa bagian barat, Nias. Merupakan spesies endemik di Dataran Sunda.

Status populasi dan kepadatannya di Borneo Umum hidup di hutan dataran rendah primer dan bekas tebangan dengan nilai tengah kepadatan 3,30 individu/ 
$\mathrm{km}^{2}$. Lebih rendah kelimpahannya pada hutan perbukitan dengan kelimpahan 0,12 individu/ $\mathrm{km}^{2}$ (Lammertink 2004).

Keberadaan di pulau kecil di Asia Tenggara Belitung, Bunguran, Laut dan Nias $(\mathrm{n}=4)$.

Habitat Lebih berlimpah di hutan dataran rendah yang ditebang (3,79 individu $/ \mathrm{km}^{2}$ ) dibandingkan dengan kelimpahan di hutan dataran rendah primer (2,50 individu $/ \mathrm{km}^{2}$ ) (Lammertink 2004). Hidup pada tumbuhan bawah yang lebat di hutan primer atau hutan sekunder yang rapat, terutama di sekitar rumpun bambu, tumbuhan menjalar, dan tumbuhan bawah di tepian sungai. Menjelajah sampai ke perbukitan hingga $800 \mathrm{~m} \mathrm{dpl} \mathrm{di} \mathrm{Borneo} \mathrm{(Winkler} \mathrm{et} \mathrm{al.} \mathrm{1995).}$

Ekologi pencarian makan Metode pencarian makan yang utama adalah menotok (59\%) dan memanjat dan menelusur (17\%). 28\% waktu mencari makannya dihabiskan pada kayu mati, $7 \%$ pada ranting gugur yang masih tergantung pada vegetasi, 15\% pada liana, dan 3\% pada rotan berduri. Memiliki relung yang berbeda dibandingkan dengan seluruh pelatuk Borneo yang lain dalam komunitas pelatuk: terkecil diameter substratnya $(1,0 \pm 0,6 \mathrm{~cm})$, terkecil dbh-nya $(5,6 \pm 6,1 \mathrm{~cm})$, terendah tingginya $(3,3 \pm 2,0 \mathrm{~m})$ dan terendah pohonnya $(6,2 \pm 4,6 \mathrm{~m})$. Makananya terdiri dari semut, telur semut, dan larva dari berbagai serangga. Secara teratur mengambil larva dengan ukuran $2,5 \times 0,4 \mathrm{~cm}$ dari kayu mati atau rotan. Untuk memakan mangsa ini, Tukik Tikus terbang ke lantai hutan dan perlu waktu beberapa menit untuk menelan mangsa tersebut (Lammertink unpubl.). Nilai tengah jumlah individu yang ditemui adalah 1,02 (Lammertink 2004).

Ekologi perkembangbiakan Hampir tidak diketahui. Periode bersarang diperkirakan bulan April hingga Juli. Kelompok keluarganya tetap utuh selama periode setelah berkembang biak. Sarangnya digali pada dahan yang kecil.

Interaksi antar spesies Bergabung dalam kelompok campuran yang terdiri dari Asi Topi-Sisik (Malacopteron cinereum), Kipasan Mutiara (Rhipidura perlata), Pelatuk Kumis-Kelabu, Pelatuk Merah, dan Srigunting Batu (Dicrurus paradiseus) (Lammertink unpubl.).

Status konservasi Berlimpah di hutan bekas tebangan, tetapi perilakunya menyukai hutan dengan ketinggian rendah menunjukkan bahwa populasinya akan menurun drastis apabila seluruh hutan dataran rendah di Dataran Sunda hilang. Tidak terdaftar pada IUCN (2002).

\section{Luntur Diard Harpactes diardii}

Taxonomi Terdiri dari dua subspesies, yaitu $H$. d. diardii dan $H$. d. sumatranus.

Penyebaran global Semenanjung Malaya dan Thailand bagian selatan, Sumatera, dan Borneo, serta dulu di Singapura (Robson 2000).

Status populasi dan kepadatannya di Borneo Termasuk tidak umum karena spesies ini jarang ditemui (Johnsgard 2000). Ditemukan hingga dua pasang dalam petak seluas 15 ha (Wells 1998). Merupakan spesies yang menyendiri (soliter) dan tidak ada interaksi (Johnsgard 2000).

Keberadaan di pulau kecil di Asia Tenggara Kepulauan Bangka dan Lingga (n $=2+)$. 
Habitat Terbatas pada hutan primer dataran rendah yang hijau sepanjang musim dan semi-hijau (Johnsgard 2000). Dapat hidup di hutan sekunder yang lebat (Johnsgard 2000). Hidup di strata menengah dan bawah, namun tetap di pepohonan (arboreal). Sering hinggap tidak bergerak dan tidak bersuara untuk waktu yang lama (Johnsgard 2000). Menjelajah hingga $950 \mathrm{~m} \mathrm{dpl} \mathrm{(Johnsgard} \mathrm{2000).}$

Pergerakan dan migrasi Tidak ada informasi.

Ekologi pencarian makan Berburu dari posisi hinggapnya dan terbang dalam waktu singkat untuk menangkap mangsanya dari dedaunan atau vegetasi yang lain. Memakan ulat, serangga ranting, spesies belalang, dan buah (ara yang besar) (Smythies 1986).

Ekologi perkembangbiakan Jantannya terlihat merawat sarangnya (Wells 1998); bertelur pada bulan Februari hingga setidaknya pertengahan Mei (Johnsgard 2000). Telurnya ditemukan pada bulan Mei dan Juni (Johnsgard 2000). Anaknya yang sudah mampu terbang ditemukan pada bulan Maret (Johnsgard 2000). Memelihara hingga dua anak (Johnsgard 2000). Sarangnya terletak pada kayu tua yang membusuk pada ketinggian 1,2 - 2,5 $\mathrm{m}$ di atas tanah (Wells 1998, Johnsgard 2000). Diameter bukaan sarangnya $11 \mathrm{~cm}$ (Johnsgard 2000).

Degradasi dan hilangnya habitat Spesies ini terlihat dapat bertahan pada hutan di lereng bukit dan hutan bekas tebangan, dengan syarat tajuknya tidak terlalu parah kerusakannya (Pearson 1975).

Kompetisi antar spesies Tidak tersedia informasi

Status konservasi Terdaftar dalam kategori Risiko Rendah/Hampir Terancam (Lower Risk/near threatened) oleh IUCN (2002). Dilindungi Undang-undang di Indonesia.

\section{Luntur Kasumba Harpactes kasumba}

Taxonomi Terdiri dari dua subspesies: H. k. impavidus dan H. k. kasumba.

Penyebaran global Semenanjung Malaya, Sumatera dan Borneo.

Status populasi dan kepadatannya di Borneo Merupakan spesies yang tidak umum karena jarang dijumpai (Johnsgard 2000).

Keberadaan di pulau kecil di Asia Tenggara Tidak diketahui hidup di pulau lepas pantai $(\mathrm{n}=0)$.

Habitat Hidup di hutan dataran rendah primer, kadang-kadang pada hutan bekas tebangan (Johnsgard 2000). Ditemui pula pada hutan rawa gambut yang tajuknya telah tertutup rapat (Wells 1998 dalam Johnsgard 2000). Menjelajah hingga ketinggian $625 \mathrm{~m} \mathrm{dpl} \mathrm{(Johnsgard} \mathrm{2000).}$

Pergerakan dan migrasi Tidak ada informasi.

Struktur Sosial Sedikit sekali informasi yang ada (Johnsgard 2000). Merupakan spesies yang relatif soliter.

Ekologi pencarian makan Berburu dari tempat hinggapnya dan tiba-tiba terbang singkat untuk menangkap mangsanya di dedaunan atau vegetasi yang lain

Ekologi perkembangbiakan Monogamus dan pengeraman dilakukan oleh jantan (Wells 1998). Tidak ada informasi mengenai kronologi perkembangbiakan (Johnsgard 2000). Pola peluruhan bulunya menunjukkan bahwa spesies ini 
berkembang biak selama musim keding (Johnsgard 2000). Satu anakan yang aktif terpantau selama tanggal 30 Juli hingga 30 Agustus. Ada dua telur dalam sarang ada sebuah sarang ditemukan pada ketinggian 1,2 $\mathrm{m}$ dari tanah pada dahan setinggi 1,6 dan dengan diameter $18 \mathrm{~cm}$ yang membusuk sebagian (Wells 1998).

Degradasi dan hilangnya habitat Mampu untuk berkoloni dalam hutan sekunder yang dewasa (Johnsgard 2000). Meskipun tidak bisa bertoleransi terhadap rusaknya tutupan tajuk, spesies ini mampu memanfaatkan hutan regenerasi, dan keberadaannya pada lereng menunjukkan bahwa spesies ini tidak terlalu terancam (Wells 1999).

Status konservasi Terdaftar pada kategori Risiko Rendah/Hampir Terancam (Lower Risk/near threatened) oleh IUCN (2002). Dilindungi Undang-undang di Indonesia.

\section{Luntur Harimau Harpactes oreskios}

Taxonomi Secara umum dikenal ada 5 subspesies: H. o. dulitensis, H. o. nias, $H$. $o$. oreskios, $H$. o. stellae, dan $H$. o. uniformis.

Penyebaran global Cina Selatan, Thailand, Laos, Vietnam, Kambodia, Myanmar, Semenanjung Malaya, Nias, Sumatera, Borneo, dan Jawa.

Status populasi dan kepadatannya di Borneo Tidak tersedia informasi

Keberadaan di pulau kecil di Asia Tenggara Nias $(\mathrm{n}=1)$.

Habitat Selain ditemukan pada hutan rawa yang dewasa dan hutan rawa yang rusak serta hutan pegunungan bawah, kebanyakan spesies ini ditemukan di hutan dataran rendah yang hijau sepanjang musim atau semi-hijau (Wells 1998). Hidup pada strata tajuk tengah dan bawah (Johnsgard 2000). Diperkirakan suka hinggap pada pohon yang lebih pendek, terutama pepohonan yang ditumbuhi vegetasi epifit dan parasit yang lebat (Johnsgard 2000). Di Borneo, seringkali didapati di sepanjang pegunungan bagian tengah dengan ketinggian antara 300 hingga $900 \mathrm{~m}$ dpl, meskipun di dataran tinggi Kelabit, umum ditemukan di atas $900 \mathrm{~m}$ (Smythies 1986). Menjelajah pada 625 hingga $1.250 \mathrm{~m}$ di Semenanjung Malaysia.

Pergerakan dan migrasi Tidak ada informasi.

Ekologi pencarian makan Sedikit sekali informasi mengenai perilaku spesies ini. Tidak ada informasi rinci mengenai makanan (Johnsgard 2000). Memakan kumbang, jangkrik, spesies lokus, belalang, kadal, semut, buah-buahan, dan campuran material dedaunan (Smythies 1986).

Ekologi perkembangbiakan Sedikit sekali informasi mengenai perilaku perkembangbiakannya; monogamus; di Tenasserim, musim kawin terjadi sepanjang pertengahan bulan Februari hingga akhir April (Johnsgard 2000). Menelurkan dua atau tiga butir telur, tetapi empat butir pernah tercatat meskipun jarang terjadi (dilaporkan dalam Johnsgard 2000). Beristirahat pada vegetasi tumbuhan bawah (Johnsgard 2000). Di Tenasserim, biasanya spesies ini beristirahat di tunggul yang berongga yang tingginya kurang dari satu meter di atas tanah, tetapi ada pula yang beristirahat di pohon bambu yang mati (Johnsgard 2000). Dua buah sarang dilaporkan di Semenanjung Malaya berada pada 1,5 $\mathrm{m}$ dan 2,0 $\mathrm{m}$ di atas tanah pada tunggul atau pohon yang membusuk (Wells 1998). 
Degradasi dan hilangnya habitat Tidak ada informasi.

Kompetisi antar spesies Menjadi bagian dari kelompok pencari makan dengan spesies campuran (Wells 1998).

Status konservasi Dilindungi Undang-undang di Indonesia. Tidak terdaftar dalam IUCN (2002).

\section{Luntur Putri Harpactes duvaucelii}

Taxonomi Tidak ada subspesies yang pernah ditelakan dari taxon ini.

Penyebaran global Semenanjung Malaya, Thailand bagian utara dan barat daya, Sumatera, Borneo, Kepulauan Riau, Pulau Banyak (di lepas pantai Sumatera bagian barat), Bangka, Belitung, dan Natuna.

Status populasi dan kepadatannya di Borneo Informasi tidak tersedia.

Keberadaan di pulau kecil di Asia Tenggara Bangka, Batu Islands, Belitung, Pulau Natuna dan Kepulauan Riau ( $n=5+$ ).

Habitat Terutama di hutan dataran rendah primer (Wells 1998, Johnsgard 2000). Ada beberapa yang hidup di hutan sekunder tetapi tidak hidup di hutan mangrove, daerah ladang, dan daerah terbuka (Wells 1998, Johnsgard 2000). Menempati strata hutan tengah, dan kadang-kadang di strata bawah (Wells 1998). Tercatat hingga setinggi $1.100 \mathrm{~m}$ dpl. (Johnsgard 2000). Spesies ini senang hinggap pada cabang yang rendah di hutan belantara, terutama di daerah lembah sungai yang teduh, kadang sepanjang tumbuhan yang merambat (Robinson 1927 dalam Johnsgard 2000).

Pergerakan dan migrasi Tidak ada informasi.

Ekologi pencarian makan Burung ini meluncur dari hutan strata menengah ke bawah untuk menangkap mangsanya dari permukaan tumbuhan dan kadang-kadang dari udara (Wells 1998). Makanannya berupa ngengat, serangga ranting, ulat, dan sebangsa lokus, termasuk dalam masih dalam bentuk larva (Wells 1998, Johnsgard 2000).

Struktur Sosial Burung ini biasanya soliter, namun kadang kala berpasangan (Johnsgard 2000).

Ekologi perkembangbiakan Monogamus, dengan kedua spesies (jantan dan betina) menjaga anaknya dan menyediakan makanan anaknya hingga 17 minggu (Fogden 1972 dalam Johnsgard 2000). Telurnya ditemukan selama bulan Mei di Perak, Malaysia (Johnsgard 2000). Anakan yang menetas ditemukan pada pertengahan bulan Maret dan Mei (1998). Ada catatan yang masih diragukan tentang menetasnya dua telur (Johnsgard 2000). Bersarang pada tunggul tua di hutan yang hijau sepanjang musim, meskipun Wells (1998) meragukannya.

Degradasi dan hilangnya habitat BirdLife International (2001) mengacu pada Wells (1999) menyatakan bahwa meskipun tidak dapat bertoleransi terhadap rusaknya tutupan tajuk, kemampuan spesies ini dalam memanfaatkan hutan regenerasi dan keberadaannya secara luas di lereng menunjukkan bahwa burung ini tidak terlalu terancam.

Kompetisi antar spesies Terlihat mengikuti kumpulan burung pelanduk/asi yang sedang mencari makan. 
Status konservasi Termasuk dalam kategori Risiko Rendah/Hampir Terancam oleh IUCN (2002). Dilindungi Undang-undang di Indonesia.

\section{Luntur Tunggir-Coklat Harpactes orrhophaeus}

Taxonomi Ada dua subspesies yang telah ditelakan: H. o. orrhophaeus dan H. $o$. vidua.

Penyebaran global Semenanjung Malaysia, Sumatera, Borneo bagian utara dan tengah (Johnsgard 2000).

Status populasi dan kepadatannya di Borneo Tidak umum hingga langka (Johnsgard 2000). Ditemukan empat pasang dalam petak seluas 15 ha (Wells 1998)

Keberadaan di pulau kecil di Asia Tenggara Tidak dikenal hidup pada pulau lepas pantai $(\mathrm{n}=0)$.

Habitat Hutan dataran rendah yang tinggi di Malaysia (Johnsgard 2000). Hutan pegunungan bagian tengah hingga $1500 \mathrm{~m}$ di Sumatera dan Borneo (Johnsgard 2000). Langka atau tidak ditemukan di hutan yang lebih bersifat musiman seperti hutan keranggas atau hutan tropis yang menggugurkan daun atau semi-hijau sepanjang musim (Johnsgard 2000). Biasanya didapati di ketinggian 2-3 m di atas tanah (Wells 1998).

Pergerakan dan migrasi Tidak ada bukti mengenai pergerakan (Johnsgard 2000). Dua dari 14 ekor burung yang diberi cincin pelacak di suatu daerah, hadir pada 109 dan 115 bulan kemudian. Bukti yang lain adalah burung yang lain terperangkap kembali pada lokasi yang sama 156 bulan setelah penandaan dengan cincin (Wells 1998).

Ekologi pencarian makan Tidak diketahui secara khusus. Memakan serangga dan buah-buahan (Johnsgard 2000). Berburu diam pada cabang dalam vegetasi tumbuhan bawah yang cukup lebat.

Struktur Sosial Spesies yang soliter.

Ekologi perkembangbiakan Sedikit saja informasi yang diketahui. Jantan dan betina dikenal mengerami dan merawat anaknya (Wells 1998). Telurnya ditemukan pada awal bulan Mei dan pertengahan bulan Juni (Wells 1998). Anaknya terlihat pada pertengahan bulan April (Wells 198). Ada dua telur sekali bertelur (Wells 1998). Ditemukan 3 buah sarang, semuanya berada dalam rongga setinggi 1-1,5 $\mathrm{m}$ di atas tanah dalam batang pohon yang membusuk (Wells 1998). Satu rongga dalamnya 10 cm (Wells 1998).

Degradasi dan hilangnya habitat Di Thailand bagian selatan dan Semenanjung Malaysia, ketergantungannya akan hutan yang datar dengan tajuk tertutup membuatnya berisiko tinggi bila dibandingkan dengan spesies dalam genus yang sama (Wells 1999 dalam BirdLife International 2001). Namun demikian, di Borneo spesies ini ditemui di hutan yang relatif kurang terancam pada lahan yang berlereng (Johnsgard 2000). 
Kompetisi antar spesies Terbatas pada daerah (sub)pegunungan di Borneo. Hal ini bertentangan dengan keberadaannya di Thailand bagian selatan dan Semenanjung Malaysia, yaitu di dataran rendah (Wells 1999). Hal ini bisa menunjukkan bahwa keterbatasan habitat di Borneo disebabkan oleh kompetisi.

Status konservasi Terdaftar dalam kategori Risiko Rendah/Hampir Terancam (Lower Risk/near threatened) IUCN (2002). Dilindungi oleh Undang-undang di Indonesia. 


\section{Lampiran 5}

\section{Rangkuman spesies mamalia}

\section{Kukang/Bukang Nycticebus coucang}

Taksonomi Terdapat 3 spesies dalam genus ini dan ada 3 subspesies dalam spesies (Groves 1998, 2001).

Penyebaran global Semenanjung Malaysia dari tanah Genting Kra ke arah selatan, Sumatera, Jawa, Borneo, pulau-pulau yang lebih kecil yaitu Tioman, Penang, Singapura, Batam, Galang (Kepulauan Riau), Bangka, Bunguran, Siminul, Sanga Sanga dan Bongao (Kepulauan Sulu) (Corbet \& Hill 1992, Groves 1998).

Populasi dan statusnya di Borneo Umum.

Keberadaan di pulau kecil di Asia Tenggara Banggi, Bangka, Batam, Bunguran, Galang, Karimata, King, Letong, Panaitan, Pangkor, Penang, Siantan, Singapura, Tebing Tinggi dan Tioman ( $\mathrm{n}=15)$ (Meijaard 2003b).

Umur Genus/spesies Sekitar 6 Jt (Juta tahun) (lihat Lu et al. 2001)/2,7 Jt.

Habitat Hutan hujan tropis hingga ketinggian 1.300 m. Kebanyakan hidup pada pohon berukuran kecil hingga sedang (Payne et al. 1985). Menyukai daerah pinggir/hutan dimana banyak serangga sebagai mangsanya (Johns 1986a), Kukang/ Bukang biasanya dijumpai di sepanjang jalan tebangan kayu dan pinggir hutan.

Aktivitas Nokturnal (aktif di malam hari) dan biasanya hidup di pohon (arboreal) (Payne et al. 1985). Memanfaatkan tumbuhan merambat untuk lokasi tidurnya.

Pergerakan dan migrasi Tidak diketahui.

Ekologi pencarian makan Memakan hewan kecil, sebagian besar serangga, dan buah-buahan berdaging dan berair (Payne et al. 1985), selain juga moluska yang besar, burung, mamalia kecil, dan kadal (Lekagul \& McNeely 1977). Makanannya terdiri dari 50\% buah, hewan 30\%, getah 10\% (Bearder 1987).

Ekologi perkembangbiakan Kebanyakan menyendiri/soliter (solitary) (Payne et al. 1985), namun pada musim kawin kadang-kadang ditemukan dalam kelompok hingga 6 individu (Lekagul \& McNeely 1977). Masa kehamilan antara 90 hingga 193 hari (Lekagul \& McNeely 1977). Daur birahi antara 37-54 hari (Lekagul \& McNeely 1977). Anak yang lahir biasanya satu, atau kadang-kadang dua (Lekagul \& McNeely 1977). 
Degradasi dan hilangnya habitat Spesies ini ditemui pula hidup di hutan sekunder, terutama pada pohon berukuran kecil hingga sedang. Sering memasuki kebun dan perkebunan (Payne et al. 1985, Yasuma \& Andau 2000), sehingga menunjukkan bahwa spesies ini bisa mengatasi gangguan habitat akibat penebangan kayu.

Hubungan antar spesies Tidak diteliti secara memadai.

Status konservasi Dilindungi oleh Undang-undang di Indonesia dan termasuk dalam Appendix II CITES. Tidak terdaftar dalam IUCN (2002). Hanya subspesies Jawa yang dianggap sebagai spesies yang lengkap oleh IUCN, terdaftar dalam kategori Data Kurang (Data Deficient).

\section{Krabuku Ingkat Tarsius bancanus}

Taksonomi Genus tunggal ini diperkirakan memiliki 3 atau 4 spesies (contoh Hill 1955), namun penelitian berdasarkan vokal yang belum lama ini dilakukan menunjukkan bahwa spesies ini mungkin bisa mencapai 13 spesies (Shekelle in press).

Penyebaran global Borneo, Sumatera (hanya bagian paling selatan), Sulawesi, Filipina, dan beberapa pulau yang lebih kecil.

Populasi dan statusnya di Borneo MacKinnon (1986) memperkirakan secara konservatif (sederhana) bahwa terdapat 9.912.500 individu $T$. bancanus yang menempati $198.250 \mathrm{~km}^{2}$ habitat yang tersisa di Indonesia dengan kepadatan ratarata sebesar $50 \mathrm{ind} / \mathrm{km}^{2}$.

Keberadaan di pulau kecil di Asia Tenggara Tidak ada informasi.

Umur Genus/spesies 20,0 Jt/7,5 Jt.

Habitat Spesies ini bisa hidup hutan primer dan sekunder. Selain itu, spesies ini bisa hidup di hutan sepanjang pesisir atau di tepi hutan yang berbatasan dengan perkebunan (Niemitz 1984).

Aktivitas Nokturnal. Krabuku Ingkat tidur sendirian pada siang hari di tumbuhan merambat pada ketinggian 3,5-5 m (Crompton \& Andau 1986). Spesies ini senang tidur pada cabang yang memiliki sudut sekitar $85^{\circ}$ (Niemitz 1984).

Pergerakan dan migrasi Niemitz (1984) melaporkan bahwa pasangan dewasa T.bancanus menempati wilayah jelajah seluas 1-2 ha. Fogden (1974) yang juga bekerja di Borneo, menemukan wilayah jelajah seluas 2-3 ha, lebih besar bagi jantan dibandingkan dengan betina. Wilayah jelajah individu dengan jenis kelamin yang sama kebanyakan eksklusif, namun ada tumpang tindih yang luas antara wilayah jelajah jantan dan betina. Meskipun dilaporkan bahwa tarsius biasanya ditemukan berpasangan, Fogden melihat dua ekor secara bersamaan hanya delapan kali selama waktu penelitiannya. Fogden mencatat bahwa jantan yang belum dewasa dijumpai di hutan primer, yang dianggapnya bukan sebagai habitat yang baik. Fogden kemudian mengungkapkan bahwa hewan muda ini disapih ke tempat lain untuk meraih kebebasannya. Namun untuk betina, wilayah jelajahnya tetap berada dekat wilayah jelajah induknya. Krabuku Ingkat dapat ditemukan dari permukaan tanah hingga ketinggian $8 \mathrm{~m}$ di bawah tajuk (Fogden 1974). Individu bergerak melalui tumbuhan bawah dan mencari makan secara soliter dan jantannya cenderung untuk bergerak 
lebih jauh pada malam hari dibandingkan dengan betinanya (Crompton \& Andau 1987).

Ekologi pencarian makan Mangsa tarsius terutama adalah serangga dan dalam kandang, bisa pula memakan kadal kecil dan krustasea, seperti udang. Spesies ini kadang-kadang memangsa burung atau ular kecil. Seekor tarsius akan mengawasi mangsanya yang bergerak, menyesuaikan posisinya dan memusatkan perhatian, dan tiba-tiba melompat ke depan dan menangkap mangsanya dengan kedua tangannya. Mangsanya dikunyah dengan pergerakan rahang dari samping ke samping sambil duduk tegak. Primata ini minum air dengan cara menjilat.

Ekologi perkembangbiakan Fogden (1974) melaporkan bahwa T. bancanus memiliki musim berkembang biak yang sangat teratur. Musim kawin pada bulan Oktober-Desember dan lahir pada bulan Januari -Maret. Namun demikian, Van Horn dan Eaton (1979) mempertanyakan data Fogden dan mengungkapkan bahwa penelitian yang dilakukan sebelumnya menemukan betina yang mengandung pada setiap bulan dalam setahun di Pulau Bangka. Masa kehamilan in T. bancanus adalah sekitar 178 hari, yang dianggap panjang untuk spesies mamalia kecil. Masa suburnya antara 18 hingga 27 hari, dengan masa birahi selama 1 hingga 3 hari (Izard et al. 1985, Wright et al. 1986). Anaknya lahir dalam kondisi yang cukup berkembang-berbulu lebat, matanya terbuka, dan mampu memanjat dan melompat (jarak pendek) pada permukaan yang rata. Anak yang berumur hingga 1 bulan tidak bisa melompat jauh. Berat kelahirannya sekitar 20-31 gram. Fogden (1974) menyatakan bahwa berat badan dewasa dicapai pada umur 15-18 bulan.

Degradasi dan hilangnya habitat Tarsius umumnya menyukai hutan sekunder, belukar, dan daerah terbuka dengan vegetasi yang tebal, tetapi spesies ini juga ditemukan pada hutan primer dan mangrove. Bersifat arboreal, namun kadangkadang menghabiskan waktunya di atas tanah untuk mencari makan (Fogden (1974). Tarsius tidur pada siang hari pada vegetasi yang lebat dan di ranting yang vertikal, namun jarang pada pohon yang berongga. Krabuku Ingkat dengan demikian dapat diperkirakan tidak terlalu terancam akibat kegiatan tebang pilih.

Status konservasi. Dilindungi oleh Undang-undang di Indonesia dan termasuk dalam Appendix II CITES. Terdaftar dalam kategori Data Kurang (Data Deficient) oleh IUCN (2003).

\section{Monyet Kra Macaca fascicularis}

Taksonomi Dalam 4 kelompok Monyet (Macaque) terdapat 14-19 spesies. $M$. fascicularis termasuk salah satu dari 3 spesies Macaca dengan 10 sub-spesies (Groves 2001).

Penyebaran global Indocina Selatan dan Semenanjung Thai/Malaya, Sumatera, Jawa, Borneo, Koh Pennan, Koh Samui, Kepulauan Redang Besar, Tioman, Tinggi, Anamba, Tambelan, Bunguran, Subi Besar, Serasan, Simalur, Lasia, Nias, Bali, Mata Siri, Bawean (dan lebih banyak lagi di Filipina, Nicobar dan Kepulauan Megui, Kepulauan Sunda Kecil) (Chasen 1940, Corbet \& Hill 1992).

Populasi dan statusnya di Borneo Umum.

Keberadaan di pulau kecil di Asia Tenggara Pulau Aroa, Pulau Babi, 
Balembangan, Banggi, Bangka, Bawal, Bengkalis, Bruit, Con Son, Datuk, Dua, Durian, Jambongan, Jemur, Karimum Jawa, Ketam, Kissaraing, Kram, Kundur, Lamukotan, Lan, Langkawi, Lasia, Laut, Linapacan, Malawali, Maratua, Mataha, Matak, Mendanau, Merah, Mohea, Molleangen, N. Pagai, Nias, Nusa Barung, Padang, Palawan, Panau, Payong, Pemanggil, Penang, Phuket, Pipidon, Sangalan, Sebatik, Sebesi, Setoko, Siantan, Simeulue, Singapura, Sir John Malcolm, Sirhassen, Siumat, Sribuat, St Barbe, Tambelan Besar, Tambelan, Tampel, Tao, Tavoy, Teibeian besar, Telibon, Tinggi, Wai dan Weh $(\mathrm{n}=66+)$ (Meijaard 2003b).

Umur Genus/spesies 7,5 Jt/3,0 Jt.

Habitat Ditemukan di seluruh habitat kecuali hutan pegunungan (hingga $2000 \mathrm{~m}$ ) (Wrangham et al. 1983, Rowe 1996). Biasanya berhubungan dengan hutan sepanjang sungai dan hutan rusak atau daerah tepi. Menurut Rodman (1991) spesies ini menyukai habitat yang lebat dengan tajuk yang rapat untuk mendukung pergerakan arborealnya. Namun spesies ini sering terlihat pula di pantai dan lahan terbuka, dan mungkin lebih umum di daerah terbuka. Untuk tidur mereka kembali ke pohon yang berada di tepian sungai.

Aktivitas Diurnal (aktif di siang hari). Biasanya pada ketinggian 0 hingga $22 \mathrm{~m}$ dari permukaan tanah (Ungar 1995) dan kontak dengan permukaan tanah kurang dari 10\% (MacKinnon \& MacKinnon 1980), meskipun di beberapa tempat (seperti hutan pesisir di Jawa, Meijaard pengamatan pribadi) sering berada di atas tanah.

Pergerakan dan migrasi Wilayah jelajahnya 25-200 ha (Wolfheim 1983); dengan jelajah harian 150 hingga $1500 \mathrm{~m}$ (Payne et al. 1985). Seluruh jantan mudanya beremigrasi pada umur 7 tahun dan sebagian besar pada umur 4 hingga 5 tahun (van Noordwijk et al. 1993).

Ekologi pencarian makan Makanan utamanya adalah buah, tetapi sangat fleksibel. Sebagai contoh, Berenstain (1986) melaporkan bahwa Monyet Kra yang pemakan buah setelah kebakaran besar menghancurkan sumber makannya, spesies ini kemudian beralih memakan serangga, batang daun, daun, dan biji meranti. Yeager (1996) melaporkan bahwa makanannya terdiri dari buah-buahan (66,7\%), daun $(17,2 \%)$, bunga $(8,9 \%)$, serangga $(4,1 \%)$ dan 3,2\% tidak diketahui. Laporan lain yang serupa juga mengungkapkan dominasi buah dalam makanannya. Aldrich-Blake (1980) melaporkan: buah (62\%), daun (25\%), invertebrata (3\%), dan yang lainnya (11\%); Sterck (1995): 98\% buah, 0,3\% daun, dan 2\% yang lain. Monyet Kra terlihat selektif dalam memilih spesies buah yang dimakannya; spesies ini memakan jumlah tanaman lebih banyak dari yang diperkirakan (Yeager 1996). Mengkonsumsi buahbuahan matang yang relatif kecil, dan hanya menghabiskan 20\% waktunya untuk memakan ara (Ungar 1995).

Perilaku sosial Berkelompok bersama-sama sejumlah jantan, betina, dan anakanaknya (Yeager 1996). Subkelompok bersifat Fission-fusion ${ }^{2}$. Ukuran kelompok rata-rata: 10-48, dapat mencapai 100 ekor (Aldrich-Blake 1980, Wolfheim 1983); dalam kelompok rata-rata 2,5 betina untuk satu jantan (Roonwal \& Mohnot 1977).

\footnotetext{
${ }^{2}$ Fission-fusion adalah bentuk organisasi sosial yang terus berubah. Kelompok yang besar berpisah menjadi unit yang lebih kecil dan unit yang kecil bergabung menjadi kelompok yang lebih besar. Perilaku ini merupakan respons dari kegiatan dalam kelompok dan musim dalam setahun.
} 
Ekologi perkembangbiakan Polygynous (berpasangan ganda). Umur rata-rata betina saat pertama kali bereproduksi sekitar 3,9 tahun (Hadidan \& Bernstein 1979) dan 51,6 bulan (Harvey et al. 1987). Umur jantan saat pertama kali bereproduksi sekitar 50,4 bulan (Harvey et al. 1987). Jarak antara kelahiran 13 bulan (Hadidan \& Bernstein 1979; Ross 1992).

Degradasi dan hilangnya habitat Spesies ini terlihat bisa beradaptasi dalam hutan yang rusak (Wilson \& Wilson 1975), yang juga dikonfirmasikan oleh Nijman (1997) yang menemukan kepadatan tertinggi spesies ini pada hutan sepanjang sungai dan hutan sekunder muda, serta terendah di hutan primer dan hutan sekunder tua.

Hubungan antar spesies Bersaing untuk makanan dengan Bekantan Kahau (Nasalis larvatus). Hampir dua per tiga dari tumbuhan sumber pakan yang dimanfaatkan oleh Monyet Kra juga digunakan oleh Bekantan Kahau (Yeager 1996). Namun demikian perbedaan fisiologis kedua spesies ini mencerminkan pilihan makanan dan mengurangi persaingan.

Bisa merupakan penyebar biji yang penting, meskipun tidak seefektif pemakan buah lainnya dalam wilayah jelajah yang sama. Lebih dari $70 \%$ biji-bijian yang besarnya/ukurannya lebih dari 2,3 mm dan panjangnya kurang dari $30 \mathrm{~mm}$ diludahkan oleh Monyet Kra. Biji-bijian yang besarnya/ukurannya kurang dari 2,3 mm selalu ditelan. Sejumlah biji-bijian dibawa dalam kantong pipinya. Spesies ini juga membawa buah-buahan dari pohon asalnya untuk menghindari persaingan antara individu sejenis (Lucas \& Corlett 1998). Biji dari buah-buahan kering selalu dihancurkan (Lucas \& Corlett 1998).

Status konservasi Tidak dilindungi oleh Undang-undang di Indonesia. Termasuk dalam Appendix II CITES. Terdaftar dalam Risiko Rendah/Hampir Terancam (Lower Risk/near threatened) oleh IUCN (2002)

\section{Monyet Beruk Macaca nemestrina}

Taksonomi Ada 14-19 spesies dalam 4 kelompok spesies monyet. M. nemestrina termasuk dalam kelompok silenus-sylvanus bersama-sama dengan 6 spesies yang lain. Tidak ada subspesies pada nemestrina.

Penyebaran global Di beberapa bagian Indocina, Sumatera, Borneo, Bangka, pulau yang lebih kecil di Chance, Sullivan, Phuket, Penang, Tioman, Siberut, Sipura, Pagai Utara dan Pagai Selatan (Chasen 1940, Corbet \& Hill 1992).

Status populasi dan kepadatan di Borneo Umum; antara 250.000 dan 375.000 individu (Nijman \& Meijaard unpubl.); kepadatan: 52,8 ind $/ \mathrm{km}^{2}$ atau 0.94 kelompok $/ \mathrm{km}^{2}$ (Oi 1990).

Keberadaan di pulau kecil di Asia Tenggara Alange, Bangka, Bedung, Iyan, Kangean, Klum, Lingung Nias, Payong dan Si Chang $(\mathrm{n}=10+)$ (Meijaard 2003b).

Umur Genus/spesies 7.5 Jt/5.0 Jt.

Habitat Menyukai hutan meranti dataran rendah dan hutan sekunder. Kelimpahannya tinggi di hutan sekunder tua, tetapi tidak ditemui pada hutan sekunder muda atau hutan sungai (riverine) (Nijman 1997). Kadang-kadang dijumpai di perkebunan (Yasuma \& Andau 2000). Ditemukan pada ketinggian 
hingga 1,700 m (Caldecott 1986). Juga dijumpai di hutan pesisir, rawa, aluvial, dan hutan pegunungan (Caldecott 1986).

Aktivitas Hidup di darat (terestrial) dan hidup di pohon (arboreal). Meskipun demikian, tidak terlalu bersifat terestrial bila dibandingkan dengan $M$. fascicularis (Whitten et al. 1987), dan kemungkinan ini tergantung pada tipe hutannya. 50\% waktunya dihabiskan di permukaan tanah, dan 50\% di atas pohon setinggi hingga 30 m (Nijman 1997). Namun Caldecott (1986) menemukan spesies ini memanfaatkan kegiatan di tanah 8,4\%, tajuk bawah 33,8\%, tajuk tengah $47,4 \%$, tajuk atas $10,4 \%$ (Caldecott 1986)

Pergerakan dan migrasi Wilayah jelajahnya 62 -828 ha (Caldecott 1986), dengan jelajah harian $2.000 \mathrm{~m}$ (Wrangham et al. 1983). Jantan disapih/keluar dari kelompok pada umur 5 tahun dan tetap menyendiri atau di pinggir wilayah suatu kelompok.

Ekologi pencarian makan Makanan utamanya buah. Makanan terdiri dari buah-buahan sebanyak 88\%, dedaunan 22\% (Rodman 1978); 73.8\% buah-buahan dan biji-bijian, 12,2\% memangsa hewan (termasuk serangga, burung kecil, telur dan larva rayap, dan kepiting sungai), 5,4 daun, 3\% pucuk, dan 1,1\% bunga (Caldecott 1986).

Perilaku sosial Berkelompok yang terdiri dari sejumlah jantan dan betina dengan hirarki yang didominasi oleh garis matrilineal. Kelompok fission/fusion (lihat catatan kaki di bagian Monyet Kra). Besar kelompok rata-rata 36 ekor (kisaran 6-81) (Oi 1990), 15-40 (Caldecott 1986), tetapi kadang-kadang terlihat di kelompok yang lebih besar (lebih dari 100) yang berpecah ke dalam sub kelompok yang tidak terikat dalam mencari makan (Duckworth pengamatan pribadi). Rasio 1 jantan bagi 5-8 betina (Caldecott 1986).

Ekologi perkembangbiakan Poligami. Umur betina saat pertama kali bereproduksi kira-kira 3,6 tahun (Hadidan \& Bernstein 1979) atau 35 bulan (Caldecott 1986). Jarak antar kelahiran kira-kira 1,1 tahun (Hadidan \& Bernstein 1979).

Degradasi dan hilangnya habitat Nijman (1997) melaporkan terdapat perbedaan kecil dalam hal kepadatan spesies antara hutan primer dan hutan sekunder (yang ditebang 40 tahun yang lalu) di Kalimantan Timur. Perbedaannya tidak nyata secara statistik. Spesies ini mungkin terpengaruh oleh deforestasi.

Hubungan antar spesies Tidak ada informasi.

Status konservasi Tidak dilindungi oleh Undang-undang di Indonesia. Termasuk dalam Appendix II CITES. Terdaftar dalam kategori Rentan (Vulnerable) oleh IUCN (2002).

\section{Owa Kalawat Hylobates muelleri}

Taksonomi Dua spesies Hylobates hidup di Borneo, yaitu albibarbis/agilis? di daerah barat Sungai Barito dan bagian selatan Sungai Kapuas, serta muelleri di bagian lain di Borneo. Tiga subspesies dari H. muelleri hidup di Borneo, spesies muelleri hidup di tenggara Borneo, H. m. funereus di Sabah, Kalimantan Timur, sebelah utara Sungai 
Mahakan dan mungkin bagian utara Sarawak, dan H. m. abbotti di bagian barat Borneo, sebelah utara Sungai Kapuas, dan ke timur sejauh Distrik Saribas di Sarawak (Groves 2001).

Penyebaran global Borneo, kecuali di daerah barat daya.

Status populasi dan kepadatan di Borneo Relatif umum; antara 250.000 hingga 375.000 individu (Nijman \& Meijaard unpubl.). Kepadatannya beragam antara 2 dan 2,6 kelompok/ $\mathrm{km}^{2}$ di Taman Nasional Kayan Mentarang (Nijman 1997). Di hutan yang mengalami degradasi parah dan hutan yang terfragmentasi di Hutan Pendidikan Bukit Soeharto di Kalimantan Timur, hidup sekitar 20 individu dalam daerah seluas $2,5 \mathrm{~km}^{2}$, yang menunjukkan kepadatan yang sangat tinggi (8 individu/ $\mathrm{km}^{2}$ ) (Oka et al. 2000). Dalam petak-petak kecil di hutan rusak yang berada di dalam matriks lahan pertanian dengan ukuran beragam antara 16 hingga 25 ha, tiap petaknya terdapat tiga hingga 5 individu (Oka et al. 2000).

Keberadaan di pulau kecil di Asia Tenggara tidak diketahui hidup di pulau lepas pantai $(\mathrm{n}=0)$ (Meijaard 2003b).

Umur Genus/spesies 6,0 Jt/3,5 Jt.

Habitat, Menyukai hutan dataran rendah, primer dan sekunder yang tua, bukan sekunder yang muda (Nijman 1997). Banyak mengunjungi habitat daerah sungai tetapi tidak menetap di sana (Nijman 1997). Ditemukan hingga $1.500 \mathrm{~m}$ (Leighton 1987) atau $1.700 \mathrm{~m}$ di Sabah (Yasuma \& Andau 2000).

Aktivitas Diurnal, menggunakan tajuk tengah dan atas $(20-50 \mathrm{~m})$ (Nijman 1997). Meskipun sangat jarang, spesies ini dapat turun ke permukaan tanah untuk berpindah.

Pergerakan dan migrasi Dalam penelitian selama 15 bulan, Leighton (1987) menemukan wilayah jelajah rata-ratanya berukuran 36 ha (kisaran 33-43 ha, $\mathrm{n}=4$ ). Jantan dan betina yang dewasa secara seksual keluar/disapih dari kelompok kelahirannya pada umur 8-10 tahun untuk membentuk kelompok baru (MacKinnon 1977).

Ekologi pencarian makan Pemakan buah. Makanannya terdiri dari buah-buahan 78\% (Ungar 1995), 58\% buah, 42\% daun (Rodman 1978), 60\% buah dan bunga, 29\% daun, 2\% invertebrata (Chivers 1992). Spesies ini menyukai buah-buahan kecil yang manis, terutama buah ara (Ficus), yang mendominasi hampir separuh kegiatan makannya (Ungar 1995). Sebagian besar buah-buahan makanannya matang, buah yang berbiji lunak dengan daging yang asam dan berserat (Ungar 1995).

Perilaku sosial Monogami, ukuran kelompok rata-rata 3,5 (berkisar antara 25 individu) (Mitani 1992). Kelompoknya terdiri dari satu jantan dan satu betina dengan anak-anaknya. Spesies yang bersifat teritorial.

Ekologi perkembangbiakan Monogami. Betinanya pertama kali mengalami menstruasi pada Umur 8 tahun, dan mengandung anak pertamanya pada umur 9 tahun (Carpenter 1940 dalam Oka et al. 2000). Masa kehamilannya 7 bulan. Jarak antar kelahiran setiap dua tahun atau lebih (Oka et al. 2000). Dari data yang terbatas yang ada, tidak terlihat adanya musim kelahiran atau puncak kelahiran dalam populasi owa kalawat. Biasanya melahirkan anak satu ekor saja.

Degradasi dan hilangnya habitat Di Kalimantan Timur, spesies owa diamati memiliki kepadatan yang sama di hutan sekunder yang tua (yang ditebang sekitar 45 
tahun yang lalu) dan hutan primer. Tetapi spesies ini jarang hidup di hutan sekunder muda (yang ditebang sekitar 10-20 tahun yang lalu. Di bagian-bagian Kalimantan Timur yang lain, Oka et al. (2000)menemukan bahwa owa dapat bertahan hidup dalam kepadatan yang tinggi di bagian hutan yang kecil, setelah sebagian dari daerah tersebut dikonversikan menjadi kegiatan pertanian dan setelah adanya kebakaran besar yang singkat. Hal ini menunjukkan bahwa owa dapat bertahan pada habitat yang terganggu dan terfragmentasi.

Hubungan antar spesies Mungkin berkompetisi dengan pemakan buah lainnya seperti binturong (Nettelbeck 1998).

Status konservasi Dilindungi oleh Undang-undang di Indonesia. Tercantum dalam Appendix II CITES. Terdaftar dalam kategori Risiko Rendah/Hampir (Lower Risk/near threatened) terancam oleh IUCN (2002).

\section{Lutung Banggat Presbytis hosei}

Taksonomi Ada sekitar 11 spesies dalam genus ini. Groves (2001) mengungkapkan bahwa $P$. hosei seharusnya dibagi menjadi tiga spesies dengan meningkatkan $P$. $h$. cancricus dan $P$. h. sabana menjadi spesies. Analisis kraniometri (craniometry, yaitu pengukuran tengkorak hewan kering setelah seluruh selaput dibuang) awal yang dilakukan oleh Meijaard \& Groves (unpubl.) menegaskan bahwa ada perbedaan yang nyata antara subspesies ini.

Penyebaran global Borneo bagian timur laut.

Status populasi dan kepadatannya di Borneo Umum dijumpai; antara 250.000 dan 375.000 individu (Nijman \& Meijaard unpubl.) Kepadatan yang lebih tinggi dan ukuran kelompok yang lebih besar didapati di hutan primer dibandingkan dengan kepadatan di hutan sekunder (Nijman 1997). Kepadatan dalam hutan primer 2,3 kelompok $/ \mathrm{km}^{2}$, di hutan sungai $1,13 \mathrm{kelompok} / \mathrm{km}^{2}$, hutan sekunder tua 0,96 kelompok $/ \mathrm{km}^{2}$, hutan sekunder muda $0,78 \mathrm{kelompok} / \mathrm{km}^{2}$ (Nijman 1997). Di dataran rendah didapati kepadatan 4,25 kelompok $/ \mathrm{km}^{2}$ di dataran rendah dan 3,6 kelompok $/ \mathrm{km}^{2}$ di dataran tinggi, dan $1,3 \mathrm{kelompok} / \mathrm{km}^{2}$ di hutan yang ditebang (Davies \& Payne 1982).

Keberadaan di pulau kecil di Asia Tenggara tidak diketahui hidup di pulau lepas pantai $(\mathrm{n}=0)$ (Meijaard 2003b).

Umur Genus/spesies $5.0 \mathrm{Jt} / 2.7 \mathrm{Jt}$.

Habitat Hutan Dipterokarpa dataran rendah dan perbukitan, kepadatan yang lebih tinggi dan ukuran kelompok yang lebih besar di hutan primer dibandingkan dengan hutan sekunder, sesekali memasuki daerah perkebunan (Payne et al. 1985). Ditemui pada ketinggian hingga $1.000 \mathrm{~m} \mathrm{dpl}$. (MacKinnon 1986) dan kadangkala hingga $4.000 \mathrm{~m} \mathrm{dpl}$.(Medway 1969).

Aktivitas Diurnal. Mayoritas kegiatan berada pada ketinggian 10-30 m dari atas permukaan tanah (Mitchell 1994).

Pergerakan dan migrasi Wilayah jelajah rata-ratanya seluas 34,5 ha dalam hutan yang utuh dan 44,8 ha di hutan tebangan (Mitchell 1994). Namun menurut Suzuki (1991), wilayah jelajahnya 120 ha di Taman Nasional Kutai. Jelajah hariannya di 
hutan primer rata-rata $691 \mathrm{~m}$ (Mitchell 1994). Jelajah harian di hutan yang ditebang rata-rata $794 \mathrm{~m}$ (Mitchell 1994).

Ekologi pencarian makan Pemakan daun. Di hutan primer, spesies ini memilih/ makan $77,8 \%$ daun, 16,7\% biji-bijian, 19,4\% buah-buahan, dan 2,8\% bunga menurut Mitchell (1994). Rodman (1978) menemukan bahwa pemilihan makanan oleh Lutung Banggat di hutan primer: 68\% daun, 29\% buah, dan 3\% yang lain (Rodman 1978); sementara di hutan yang ditebang memakan 59.7\% daun/ $21.3 \%$ biji/ $40.1 \%$ buah/ $0.2 \%$ bunga (Mitchell 1994). Tercatat memakan sejumlah besar biji-bijian di Kutai, Borneo bagian timur (Leighton \& Leighton 1983).

Perilaku sosial Kelompok dengan satu jantan dominan. Di hutan primer ditemui 2,3 kelompok $/ \mathrm{km}^{2}$; hutan tepi sungai 1,13 kelompok $/ \mathrm{km}^{2}$, hutan sekunder tua 01.96 kelompok $/ \mathrm{km}^{2}$, hutan sekunder muda $0,78 \mathrm{kelompok} / \mathrm{km}^{2}$ (Nijman 1997); 4,25 kelompok di dataran rendah dan 3,6 kelompok $/ \mathrm{km}^{2}$ di dataran tinggi (Davies \& Payne 1982); 1,3 kelompok $/ \mathrm{km}^{2}$ hutan yang ditebang (Davies \& Payne 1982). Di hutan yang utuh ukuran kelompok rata-rata adalah 9,0 ekor (Mitchell 1994), 7,0 ekor di hutan bekas tebangan (Mitchell 1994), 6-8 ekor (Payne et al. 1985; Bennett \& Davies 1994), ukuran kelompok: 8,2 ekor di hutan primer, 7,5 ekor di hutan sekunder, perbedaannya tidak signifikan (Nijman 1997).

Ekologi perkembangbiakan (Berpasangan ganda) Poligami.

Degradasi dan hilangnya habitat Di Taman Nasional Kayan Mentarang, Kalimantan Timur Nijman (1997) menemukan bahwa P. hosei mencapai kepadatan tertingginya dalam hutan primer, sementara kepadatan yang nyata-nyata lebih rendah di hutan tepian sungai, hutan sekunder tua dan muda. Namun demikian, apakah kepadatan ini disebabkan oleh gangguan terhadap habitat, atau lebih disebabkan oleh perburuan masih belum jelas (lihat Nijman in press). Davies dan Payne (1982) menemukan kepadatan sebesar 1,3 kelompok $/ \mathrm{km}^{2}$ di hutan yang ditebang (berumur 19 tahun), dibandingkan dengan 3,6-4,3 kelompok/ $\mathrm{km}^{2}$ dalam hutan utuh yang berbatasan. Mitchell (1994) melaporkan bahwa $P$. hosei tidak ditemui di hutan yang ditebang habis.

Hubungan antar spesies Dapat hidup dalam wilayah yang sama dengan Lutung Merah (Presbytis rubicunda). Kedua spesies ini memiliki persyaratan ekologis yang serupa. Namun Lutung Banggat lebih sering dijumpai di tajuk atas dan pohon yang tinggi di dalam hutan sementara Lutung Merah lebih sering dijumpai di bagian tajuk yang lebih bawah (dilaporkan dalam Mitchell 1994).

Status konservasi Tidak dilindungi oleh Undang-undang di Indonesia. Termasuk dalam Appendix II CITES. Terdaftar sebagai Data Kurang (Data Deficient) oleh IUCN (2002).

\section{Lutung Merah Presbytis rubicunda}

Taksonomi Ada sekitar 11 spesies dalam genus dan 5 subspesies dalam spesies ini (Groves 2001).

Penyebaran global Borneo dan Pulau Karimata.

Populasi dan kepadatannya di Borneo Sangat umum. Diperkirakan oleh Nijman dan Meijaard (unpubl.) ada lebih dari 1,000,000 individu. Kepadatan: 18,9 
individu/ $\mathrm{km}^{2}$ (Davies 1984). Kepadatan rata-rata dari 3 penelitian adalah 20.7 (van Schaik et al. 1992); kepadatan kelompok rata-rata adalah 2,4 kelompok $/ \mathrm{km}^{2}$ (van Schaik et al. 1992). Ukuran rata-rata kelompok 7,0 (kisaran 3-10) (Davies 1984); 6,1 (kisaran 3-8) (Supriatna et al. 1986). Ukuran rata-rata kelompok dalam 3 penelitian adalah 8,0 (van Schaik et al. 1992). 2003b).

Keberadaan di pulau kecil di Asia Tenggara Karimata $(n=1)$ (Meijaard

Umur Genus/spesies 5,0 Jt/2,0 Jt.

Habitat Hutan meranti dataran rendah, primer, dan sekunder (MacKinnon 1986). Dapat hidup pada perkebunan tertentu dan keluar dari hutan masuk ke dalam kebun untuk memakan daun muda (Payne et al. 1985). Hidup pada ketinggian kurang dari 1,500 m dpl. (MacKinnon 1986).

Aktivitas (Yasuma \& Andau 2000). Diurnal. Bersifat arboreal (umumnya selalu di atas pohon), tetapi kadang-kadang turun ke tanah (Yasuma \& Andau 2000).

Pergerakan dan migrasi Ukuran wilayah jelajah: 70-84,8 ha (Davies 1984); $0,71 \mathrm{~km}^{2}$ (Supriatna et al. 1986). Rata-rata dari tiga penelitian 64,5 ha (van Schaik et al. 1992). Wilayah jelajah hariannya $890 \mathrm{~m}$ (Davies 1984), wilayah jelajah rata-rata dari 2 penelitian adalah $819 \mathrm{~m}$ (van Schaik et al. 1992).

Ekologi pencarian makan Pemakan biji, buah/daun. 37,6\% memakan daun, 30,1\% biji, 49,3\% buah, 11,1\% bunga, dan 1,1\% yanglain (Davies 1984), makanannya terdiri dari 61\% buah dan biji (van Schaik et al. 1992). Memakan biji-bijian dari 48 spesies pohon dan liana serta memakan buah utuh dari 24 spesies tumbuhan. Suku leguminosae merupakan tumbuhan yang paling banyak dimakan (Davies et al. 1988). Secara umum, primata tidak memiliki kecenderungan untuk menjajagi pohon Dipterokarpa untuk makanannya. Namun di Sepilok, P. rubicunda terlihat memakan biji dan/atau daun dari 6 spesies Dipterokarpa, termasuk Shorea xanthophylla sebanyak 7,8\% pada bulan Agustus 1981 (Davies et al. 1988). Kebanyakan buah-buahan yang dimakannya (72\%) memiliki daging buah yang tebal; hanya sekitar setengah buah yang dimakan tidak memiliki daging buah. Daun muda (umbut) dan kecambah juga dimakannya. Setengah sisanya memiliki daging buah yang berserat, baik berair atau kering. Tumbuhan juga dicari untuk dimakan bijinya (Davies 1991). Sejumlah analisis mengungkapkan bahwa Lutung Merah memilih daun yang tinggi proteinnya dan rendah serat yang menghambat pencernaannya (Davies et al. 1988). Biji-bijian yang dimakannya memiliki tanin pekat yang sangat rendah dan serat asam detergent yang rendah yang berkaitan dengan kemudahan mencerna yang tinggi (Davies 1991). Ara hanya $1 \%$ saja dari makananya (Davies 1991). Makanan yang dimakan dalam jumlah sangat kecil (kurang dari 1\%) termasuk tanah dari sarang rayap, lapisan bagian dalam bambu, dan serangga (umumnya rayap) (Bennett \& Davies 1994; Davies 1991).

Struktur sosial Harem dengan satu jantan/kelompok dengan jantan ekstra (Davies 1984), 88,9\% kelompok dengan satu jantan, 11,1\% monogami (Supriatna et al. 1986). Ukuran kelompok rata-rata: 7,0 (kisaran 3-10) (Davies 1984); 6,1 (kisaran 3-8) (Supriatna et al. 1986); Rata-rata dari tiga penelitian 8,0 (van Schaik et al. 1992).

Ekologi perkembangbiakan Sistem sosial dengan jantan tunggal dan polyginous (berpasangan ganda) (Davies 1987; Supriatna et al. 1986). Kelompok terdiri dari satu 
jantan dewasa, satu atau lebih betina dewasa, muda, anak, dan bayi (Supriatna et al. 1986).

Degradasi dan hilangnya habitat $P$. rubicunda terlihat lebih menyukai hutan primer (V. Nijman unpubl.).

Hubungan antar spesies Tidak ada informasi

Status konservasi Tidak dilindungi oleh Undang-undang di Indonesia. Termasuk dalam Apendix II CITES. Tidak terdaftar dalam IUCN (2002).

\section{Bajing Kelapa Callosciurus notatus}

Taksonomi Ada 14 spesies dalam genus (Corbet \& Hill 1992). Maryanto et al. mengkaji ulang 49 subspesies Indonesia dari C. notatus. Berdasarkan analisis pengukuran tegkorak dan penelitian mengenai kulit, Maryanto et al. (2002) menyimpulkan bahwa dalam karakteristik tengkorak dan gigi hanya terdapat sedikit ragam di antara populasi dari Jawa dan Kalimantan, dan banyak subspesies ini yang dapat digabungkan.

Penyebaran global Semenanjung Malaya dan pulau-pulau di sekitarnya. Kepulauan Riau, Sumatera, Pulau Bangka, Jawa, Borneo, Bali dan Lombok.

Status populasi dan kepadatannya di Borneo Tersebar luas di dataran rendah dan daerah perbukitan. Ketinggian sampai 1,700 m dpl(Yasuma \& Andau 2000). Kepadatan di Ule Mudah Forest Reserve, Kedah, Semenanjung Malaysia tercatat 5,35 individu $/ \mathrm{km}^{2}$ (Saiful \& Nordin 2004). Kepadatan di Taman Nasional Kayan Mentarang, Kalimantan Timur diperkirakan sebesar 8,1 individu/ $\mathrm{km}^{2}$ (Yeager 1999).

Keberadaan di pulau kecil di Asia Tenggara Arends, Banggi, Bangka, Bangkaru, Basilan, Bawal, Bengkalis, Bintan, Bulan, Con Dao, Datuk, Dua, High, Jarak, Johore, Kaban, Krakatau, Kram, Lang Tengah, Lang, Mak, Malawali, Mapor, Mataha, Mendol, Merah, Mesan, Miang Besar, Midai, Mohea, Pagai Utara, Nias, Nusa Barung, Padang, Panaitan, Panau, Panebangan, Pangkor, Payong, Pengiki, Pipidon, Redang, Samui, Sangalan, Setoko, Siantan, Siminul, Singapura, Sir John Malcolm, Siumat, Sribuat, Sullivan, Tana Bala, Tana Masa, Tebing Tinggi, Telibon, Temaju, Tinggi, Weh dan Perhentian Barat $(n=60+)$ (Meijaard 2003b).

Umur Genus/spesies 7,5 Jt/4,0 Jt.

Habitat Sangat berlimpah di sekitar pinggiran hutan atau dalam bagian hutan sekunder yang memiliki vegetasi rendah yang cukup rapat (MacKinnon 1978). Umumnya hidup secara arboreal dengan ketinggian yang tidak lebih dari $15 \mathrm{~m}$ (63\%) (Whitten 1981). Jarang didapati pada hutan Dipterokarpa yang tinggi (Yasuma \& Andau 2000).

Aktivitas Diurnal, paling aktif pada pagi hari (matahari terbit) dan akhir sore (menjelang malam) (Yasuma \& Andau 2000).

Pergerakan dan migrasi Di Semenanjung Malaysia, wilayah jelajahnya beragam antara $0,7 \pm 0,19$ ha untuk 4 jantan dewasa hingga $1,85 \pm 0,47$ ha bagi 6 betina dewasa (Saiful et al. 2001).

Ekologi pencarian makan Pemakan segala. Memakan sejumlah besar serangga yang diambil dari batang pohon yang berlumut (20\%), kulit kayu (5\%), sejumlah 
dedaunan (15\%), bunga (30\%), beragam buah-buahan lunak (40\%) (MacKinnon 1978). Spesies ini terutama mencari makan pada ketinggian antara 5 hingga 20 meter (nilai tengah $=13,5)$ (MacKinnon 1978).

Ekologi perkembangbiakan Bersarang pada pohon berongga atau membangun sarangnya dengan daun dan ranting pada cabang pohon atau semak yang besar; sarangnya terletak pada 25-30 m (MacKinnon 1978). Ada tiga betina yang bunting masing-masing dengan tiga embrio (janin) yang diambil pada bulan Juli (Davis 1962).

Degradasi dan hilangnya habitat Spesies ini terlihat lebih umum hidup di habitat yang rusak. Masyarakat Punan di Taman Nasional Kayan Mentarang menyebut spesies ini sebagai puan bokken, yang artinya bajing hutan sekunder (Puri 1997). Spesies ini mendapatkan manfaat dari gangguan hutan dan berkembang secara baik dalam kebun dan perkebunan.

Hubungan antar spesies Spesies bajing berukuran sedang ini memanfaatkan pohon besar, sementara spesies yang lebih besar $C$. caniceps mencari makan pada pepohonan yang lebih kecil. Spesies C.caniceps lebih umum hidup di daerah bersemak belukar (Tamura 1995; Saiful et al. 2001).

Status konservasi Tidak terdaftar oleh IUCN (2002). Tidak dilindungi (tidak memerlukan perhatian) di Indonesia (PHPA 1996b).

\section{Bajing Tiga-Warna Callosciurus prevostii}

Taksonomi Corbet dan Hill (1992) mencatat ada 17 subspesies Callosciurus prevostii, namun validitasnya perlu diteliti lebih lanjut.

Penyebaran global Semenanjung Malaya, Kepulauan Riau, Sumatera, Borneo dan Sulawesi (mungkin melalui introduksi manusia).

Status populasi dan kepadatannya di Borneo Kepadatannya di Mudah Forest Reserve, Kedah, Semenanjung Malaysia adalah 3,29 individu $/ \mathrm{km}^{2}$ (Saiful \& Nordin 2004). Terutama hidup di dataran rendah dengan catatan tertinggi pada Gunung Kinibalu pada ketinggian 550 m (Yasuma \& Andau 2000).

Keberadaan di pulau kecil di Asia Tenggara Balembangan, Banggi, Bangka, Bangkaru, Dua, Kompei, Labuan, Lamukotan, Lang, Matak, Mohea, Nusa Barung, Padang, Palawan, Pemanggil, Sedanau, Serutu, Siantan, Sirhassen, Subi Kecil dan Tampel ( $\mathrm{n}=21)$ (Meijaard 2003b).

Umur Genus/spesies Tidak diketahui/tidak diketahui.

Habitat Tinggal di tajuk bagian atas. Menghabiskan sebagian besar waktunya pada tajuk utama antara 25 dan 30 m (MacKinnon 1978). Hidup di hutan Dipterokarpa dataran rendah, baik tegakan primer maupun sekunder. Kadang-kadang memasuki kebun dan perkebunan (Yasuma \& Andau 2000).

Aktivitas Diurnal.

Pergerakan dan migrasi Tidak ada informasi.

Ekologi pencarian makan Pemakan segala; memakan daun muda dari pohon polong-polongan seperti spesies-spesies merbau (Instia spp.) dan spesies-spesies tualang (Koompassia spp.) (MacKinnon 1978), Anacardiaceae (sebangsa manggajambu), Annonaceae (sebangsa sirsak), Burseraceae (sebangsa kenari), Euphorbiaceae 
(termasuk jarak, kaliki, ubi kayu), Lauraceae (termasuk kayu manis), Meliaceae (sebangsa kecapi monyet, duku, culan), Myristicaceae (sebangsa pala), Oxalidaceae (keluarga belimbing), Rosaceae (keluarga mawar), Sapindaceae (termasuk paria, lerak, kelayu, kapulasan), Leguminosae (keluarga polong-polongan), dan Simaroubaceae (termasuk belilik dan bitterbout)(Becker \& Wong 1985). Juga terlihat memakan buah ara di Semenanjung Malaysia, dan dikenal pula memakan telur, kuncup, bunga, bahan vegetasi lainnya, serta serangga, termasuk semut, rayap, larva kumbang, meskipun bukan merupakan makanan utamanya (Heaney 1978).

Ekologi perkembangbiakan Ditemukan betina yang mengandung dua atau tiga embrio pada bulan Juni dan Agustus (Davis 1962). Tingkat kehamilan di Semenanjung Malaysia secara umum terkait dengan jumlah curah hujan (Wang 1964 dalam Hoffmann 2003).

Degradasi dan hilangnya habitat Bisa mendapatkan manfaat dari gangguan terhadap hutan yang ringan, namun rentan terhadap deforestasi. Bisa mendukung regenerasi hutan karena spesies ini menjatuhkan biji-bijian dari sejumlah jenis pohon setelah memakan daging buahnya. Spesies ini menyebarkan biji tersebut dengan membawa biji tersebut dari pohon induknya. Dengan demikian mengurangi risiko biji tersebut termakan dibandingkan dengan bila biji tersebut ditemukan pada pohon induk (Becker et al. 1985).

Hubungan antar spesies Pemisahan ekologis Bajing Tiga-Warna dan Jelarang Bilalang (Ratufa affinis, lihat bagian selanjutnya) adalah oleh parameter makanannya (Jelarang Bilalang lebih bisa memakan buah-buahan keras dan tidak memakan ara).

Status konservasi Tidak terdaftar dalam IUCN (2002). Tidak dilindungi di Indonesia (PHPA 1996b).

\section{Bajing Tanah Bergaris-Tiga Lariscus insignis}

Taksonomi Ada sepuluh subspesies yang telah dideskripsi, namun hanya sedikit saja yang dapat dianggap benar (Corbet $\&$ Hill 1992). Di Borneo, hidup spesies $L$. insignis diversus

Penyebaran global Semenanjung Malaya dan pulau-pulau di sekitarnya. Kepulauan Riau, Sumatera, Jawa, Borneo (Nowak 1999); tersebar luas dan umum.

Status populasi dan kepadatannya di Borneo 0,6-1,9 individu/ha (Harrison 1969); tersebar luas dan umum.

Keberadaan di pulau kecil di Asia Tenggara Bintan, Pagai Utara, Penang, Siantan, Singapura, Tana Bala dan Tioman ( $\mathrm{n}=7$ ) (Meijaard 2003b).

Umur Genus/spesies 7,5 Jt/Tidak diketahui tidak diketahui.

Habitat Hutan sekunder yang tinggi (Payne et al. 1985). Menggunakan lubang dalam tanah untuk melarikan diri saat terancam (Lekagul \& McNeely 1977). Kebanyakan hidup pada ketinggian 910-1.510 m dpl. (Nowak 1999). Namun hal ini mungkin tidak tepat karena yang lain menganggapnya sebagai spesies dataran rendah (Yasuma \& Andau 2000).

Aktivitas Hanya di daratan saja (terestrial) (Whitten 1981); didapati pada tanah atau pada pohon tumbang di tanah (MacKinnon 1978).

Pergerakan dan migrasi Di Semenanjung Malaysia, wilayah jelajah L. insignis 
beragam antara 0,13 ha untuk 1 betina dewasa hingga 4,18 untuk jantan dewasa (Saiful et al. 2001).

Ekologi pencarian makan Memakan buah, tumbuhan dan serangga (MacKinnon 1978, Payne et al. 1985, Whitten 1981).

Ekologi perkembangbiakan Membangun sarangnya pada kayu yang tumbang (Nowak 1999). Ditemukan betina yang mengandung dua embrio pada bulan Juli (Davis 1962).

Degradasi dan hilangnya habitat Terlihat sensitif terhadap gangguan hutan akibat penebangan, terutama terhadap perubahan habitat terestrial. Mekanisme hal ini masih belum dipahami dengan baik.

Hubungan antar spesies Tidak ada informasi yang tersedia

Status konservasi Tidak terdaftar oleh IUCN (2002). Dilindungi di Indonesia (PHPA 1996b).

\section{Bajing-Tanah Bergaris-Empat Lariscus hosei}

Taksonomi 3 spesies dalam genus, tidak ada subspesies dalam L. hosei (Corbet \& Hill 1992).

Penyebaran global Spesies endemik Borneo.

Status populasi dan kepadatannya di Borneo Tidak ada informasi

Keberadaan di pulau kecil di Asia Tenggara Tidak dikenal hidup pada pulau lepas pantai $(\mathrm{n}=0)$ (Meijaard 2003b).

Umur Genus/spesies 7.5 Jt/ Tidak diketahui.

Habitat pada kelompok-kelompok kecil Hutan primer dan sekunder (Payne et al. 1985).

Aktivitas Melakukan aktivitasnya di daratan dan aktif pada siang hari (Payne et al. 1985). Spesies ini jarang ditemukan pada pepohonan dan membangun sarangnya pada kayu yang tumbang/jatuh. L. hosei sering mengunjungi tebing sungai di pedalaman hutan (Nowak 1999).

Pergerakan dan migrasi Tidak ada informasi

Ekologi pencarian makan Makanannya mencakup buah dan serangga (Payne et al. 1985).

Ekologi perkembangbiakan Ditemukan L. hosei betina yang mengandung dua embrio pada tanggal Juli di Borneo bagian utara (Davis 1962).

Degradasi dan hilangnya habitat Spesies ini sensitif terhadap gangguan akibat penebangan. Ditemukan dalam hutan yang utuh, tidak didapati pada hutan yang baru ditebang atau hutan yang telah ditebang 2 hingga 4 tahun yang lalu.

Hubungan antar spesies Tidak ada informasi

Status konservasi Terdaftar sebagai Rentan (Vulnerable) oleh IUCN (2002).

\section{Bajing Terbang Raksasa-Merah Petaurista petaurista}

Taksonomi Ada 10 subspesies yang telah ditelakan dalam spesies ini (Corbet \& Hill 1992), tiga diantaranya hidup di Borneo, yaitu P. p. rajah di Sabah dan Sarawak, 
tetapi tidak hidup di sekitar Teluk Sandakan tempat hidup P. p. nigrescens, dan P. $p$. lumholtzi hidup di daerah lainnya di Borneo (Payne et al. 1985).

Penyebaran global Afganistan bagian utara dan Kasmir melalui kaki Himalaya hingga Yunan, ke Selatan melalui Myanmar dan Thailand ke Semenanjung Malaya, Kepulauan Riau, Sumatera, Jawa, Borneo, dan Kepulauan Natuna.

Status populasi dan kepadatannya di Borneo Umumnya hidup berpasangan (Medway 1978).

Keberadaan di pulau kecil di Asia Tenggara Bunguran, Nusa Kambangan dan Rupat ( $\mathrm{n}=3$ ) (Meijaard 2003b).

Umur Genus/spesies Tidak diketahui/Tidak diketahui.

Habitat Hidup di hutan primer dan sekunder, dan ditemukan juga di daerah terbuka dengan sedikit pohon, kebun, dan perkebunan (Payne et al. 1985).

Aktivitas Nokturnal dan arboreal. Terbang melayang untuk berpindah dari satu pohon ke pohon lain. Menggunakan tajuk atas pada ketinggian 15-30 m (Nowak 1999). Beristirahat pada rongga pohon di siang hari.

Pergerakan dan migrasi Sebagian besar Petaurista hidup pada ketinggian di atas $900 \mathrm{~m}$, namun pada musim semi spesies ini diamati berada pada ketinggian yang lebih rendah. Kemungkinan bermigrasi dalam jangka pendek saat pohon dapat menyediakan pilihan daun muda dan kuncup bunga yang belum tersedia di ketinggian yang lebih tinggi.

Ekologi pencarian makan Pemakan daun.

Ekologi perkembangbiakan Sarangnya ditempati secara permanen oleh pasangan yang kawin (Nowak 1999). Biasanya melahirkan satu anak, kadang-kadang dua (Mitchell 1979). Betina yang menyusui ditemukan pada bulan Juni (Davis 1962). Banyaknya anak dalam satu kali melahirkan $=1$; jarang berkembang biak dan seekor Petaurista muda memerlukan waktu yang lama untuk tumbuh dewasa (3-4 bulan atau lebih).

Degradasi dan hilangnya habitat Kepadatan yang tinggi bisa didapati di daerah dengan penebangan yang parah (Meijaard pengamatan pribadi), namun tingginya perkiraan kepadatan di daerah tersebut bisa disebabkan oleh peningkatan visibilitas (jadi mudah terlihat), terutama saat hewan ini melayang di antara pepohonan sesaat sebelum petang. Di India bagian selatan, spesies ini terlihat meningkat kepadatannya sejalan dengan peningkatan gangguan terhadap hutan (Umapathy \& Kumar 2000), meskipun hal ini bisa jadi karena pengaruh penurunan kepadatan spesies arboreal yang lain pada fragmen hutan tersebut. Muul dan Lim (1978) serta Syakirah et al. (2000) menemukan bahwa bajing terbang ini dapat berkembang biak dengan baik walaupun terjadi perubahan habitat, dengan catatan pepohonan yang tinggi tempat bersarangnya tidak ditebang.

Hubungan antar spesies Digantikan keberadaannya oleh Petaurista elegans pada elevasi yang lebih tinggi dan pada hutan primer.

Status konservasi Tidak terdaftar oleh IUCN (2002). Tidak terdaftar dalam CITES (ARCBD 2002). Tidak dilindungi di Indonesia (PHPA 1996b). 


\section{Jelarang Bilalang Ratufa affinis}

Taksonomi Ada 11 subspesies yang telah ditelakan dalam spesies ini (Corbet \& Hill 1992).

Penyebaran global Semenanjung Malaya, Kepulauan Riau, Sumatera, pulau di sebelah barat Sumatera, Borneo.

Status populasi dan kepadatannya di Borneo 11 individu $/ \mathrm{km}^{2}$ (MacKinnon et al. 1996). Kepadatan di Ule Mudah Forest Reserve, Kedah, Semenanjung Malaysia 1,3 individu $/ \mathrm{km}^{2}$ (Saiful \& Nordin 2004).

Keberadaan di pulau kecil di Asia Tenggara Banggi, Bangka, Batam, Belitung, Bintan, Bulan, Bunguran, Karimata, Karimon, Kundur, Labuan, Laut (Kepulauan Natuna), Laut (Borneo bagian tenggara), Lingga, Musala, Panebangan, Pinie, Sebuku, Singapura, Singkep, Sirhassen, Sugi, Talang, Tana Bala, Tana Masa dan Tuangku (n = 26) (Meijaard 2003b).

Umur Genus/spesies 30,0 Jt/Tidak diketahui.

Habitat Berpindah secara ekstensif di tajuk atas, juga sering bergerak di tajuk yang lebih rendah. Jarang terlihat di atas tanah (MacKinnon 1978). Bergerak ke tanah hanya untuk mengejar bajing lain atau mengikuti betina selama musim kawin (Nowak 1999), atau melintasi rumpang yang lebar pada tajuk pohon (Payne et al. 1985). Nilai tengah ketinggian yang digunakannya 23 meter (MacKinnon 1978).

Aktivitas Diurnal; menggunakan lubang pada pohon untuk tempat berlindung (Nowak 1999).

Pergerakan dan migrasi Tidak ada informasi.

Ekologi pencarian makan Pemakan buah. Memiliki spesialisasi buah dengan biji yang relatif besar dan berkulit biji keras (Leighton \& Leighton 1983). Memakan buah-buahan, kacang-kacangan, kulit sejumlah spesies kayu, serangga, dan telur burung (Nowak 1999). Memakan buah-buahan yang lembut dan keras, serta sejumlah daun (MacKinnon 1978). Tidak ditemui memakan buah ara, tetapi memakan buah berserat Grewia latifolia, yang tidak dimakan oleh bajing yang lain, tetapi sangat disukai oleh primata (MacKinnon 1978). Tercatat makan buah-buahan Dipterokarpa (Dipterocarpus confertus dan Shorea beccarianna) (Gould \& Andau 1989).

Ekologi perkembangbiakan Sarang yang berbentuk membulat kira-kira sebesar sarang burung elang dibangun di atas cabang pohon (Nowak 1999). Anaknya dilahirkan dan dibesarkan dalam sarang tersebut (Nowak 1999). 1-2 anak dengan berat sekitar $77 \mathrm{~g}$ (Nowak 1999).

Degradasi dan hilangnya habitat Selama survei mamalia di beberapa tempat di Semenanjung Malaysia spesies ini hanya didapati pada daerah hutan dengan tajuk yang tinggi dan rapat (Syakirah et al. 2000). Selain itu (Banks (1949) melaporkan bahwa spesies ini hanya ditemukan di hutan tua, tidak pernah ditemukan di hutan sekunder, perkebunan, dan sebagian besar penelitian mengungkapkan bahwa spesies ini dipengaruhi secara negatif oleh kegiatan penebangan.

Hubungan antar spesies Tidak ada informasi.

Status konservasi Tidak terdaftar oleh IUCN (2002). Terdaftar pada Appendix II CITES (ARCBD 2002). Tidak dilindungi di Indonesia (PHPA 1996b). 


\section{Bajing Ekor Kuda Sundasciurus hippurus}

Taksonomi Ada 9 spesies dalam genus dan 3-5 subspesies dalam spesies ini (Corbet \& Hill 1992).

Penyebaran global Semenanjung Malaya, Kepulauan Riau, Sumatera, dan Borneo.

Status populasi dan kepadatannya di Borneo Kepadatan di Ule Mudah Forest Reserve, Kedah, Semenanjung Malaysia adalah 3,93 individu/ $\mathrm{km}^{2}$ (Saiful \& Nordin 2004).

Keberadaan di pulau kecil di Asia Tenggara Tidak diketahui hidup di pulau lepas pantai $(\mathrm{n}=0)$ (Meijaard 2003b).

Umur Genus/spesies 11.0 Jt/Tidak diketahui.

Habitat Hutan dataran rendah primer. Spesies ini hidup di lantai hutan, tajuk bawah/tengah, dan tajuk atas (MacKinnon 1978).

Aktivitas Diurnal. Umumnya terlihat di dalam hutan pada ketinggian 3-12 m (Davis 1962). Menunjukkan kemampuan pemanfaatan yang merata pada tingkat tajuk dan permukaan tanah dibanding dengan bajing lain yang hidup bersama dalam satu wilayah (sympatric) (MacKinnon 1978).

Pergerakan dan migrasi Tidak ada informasi.

Ekologi pencarian makan Sebagian besar memakan buah yang keras yang diambil di tajuk bagian atas, tetapi dibawa di mulutnya dalam jarak yang cukup jauh dan sering di atas tanah; mungkin membuat kantong makanan (di mulutnya) (MacKinnon 1978).

Ekologi perkembangbiakan Tidak ada informasi.

Degradasi dan hilangnya habitat Tidak dijumpai di hutan yang baru ditebang dan hutan yang telah ditebang 2 tahun, tetapi hadir di hutan yang telah ditebang empat tahun sebelumnya (Dahaban et al. 1996). Yeager (1999) melaporkan bahwa di daerah hulu Sungai Kapuas dan Mahakam spesies ini berlimpah (41 individu/ $\mathrm{km}^{2}$, berdasarkan Istiadi et al. 1994), tetapi spesies ini tidak dijumpai di sekitar pusat penelitian di Taman Nasional Kayan Mentarang. Rijksen (1978) mencatat penurunan sebesar 50\% di hutan yang terganggu ringan dibandingkan dengan hutan utuh. Selain itu, Baks (1949) melaporkan bahwa spesies ini ditemukan hanya pada hutan yang tua, tidak pernah ditemui di hutan sekunder, kebun, atau perkebunan.

Hubungan antar spesies Tidak ada informasi.

Status konservasi Tidak terdaftar pada IUCN (2002). Tidak terdaftar dalam CITES (ARCBD 2002). Tidak dilindungi di Indonesia (PHPA 1996b).

\section{Bajing Ekor-Pendek Sundasciurus lowii}

Taksonomi Ada 9 spesies dalam genus, dan 4 subspesies dalam spesies ini (Corbet \& Hill 1992).

Penyebaran global Ditemukan di Malaya, Sumatera, dan Borneo (Corbet \& Hill 1992).

Status populasi dan kepadatannya di Borneo Tercatat di seluruh dataran rendah dan perbukitan hingga ketinggian $1.400 \mathrm{~m} \mathrm{dpl}$., namun biasanya di bawah 900 m, juga di sejumlah pulau (Payne et al. 1985). Kepadatan di Ule Mudah Forest 
Reserve, Kedah, Semenanjung Malaysia dengan jumlah 13 individu/km² (Saiful \& Nordin 2004).

Keberadaan di pulau kecil di Asia Tenggara Balembangan, Banggi, Bunguran, Kundur, Labuan, Lagong, Laut, Lingung, Pagai Utara, Pinie, Pagai Selatan, Siberut, Sipura, Sirhassen dan Tana Bala $(\mathrm{n}=15)$ (Meijaard 2003b).

Umur Genus/spesies 11,0 Jt/Tidak diketahui.

Habitat Ditemukan pada hutan dengan pohon-pohon tinggi atau dekat permukaan tanah, jarang terlihat berada di atas pohon (Medway 1969, Lekagul \& McNeely 1977). Menyukai hutan primer campuran (Whitten 1981). Sangat aktif pada batang pohon bagian bawah hutan (MacKinnon 1978).

Aktivitas Diurnal, sangat aktif pada pagi hari dan petang (Payne et al. 1985). Mencari makan di daratan dan strata yang lebih rendah hingga $5 \mathrm{~m}$. Davis (1962) melaporkan bahwa spesies ini tidak pernah ditemui $3 \mathrm{~m}$ di atas permukaan tanah. MacKinnon (1978) yang melakukan penelitian di Malaya melaporkan bahwa seluruh catatan spesies ini ditemukan pada ketinggian di bawah $15 \mathrm{~m}$, dengan 65\% dibawah $7,5 \mathrm{~m}$, dan $5 \%$ di atas tanah. Spesies ini jarang berpindah melalui tajuk antara pohon namun melalui anak pohon, tumbuhan bawah, tanah, atau dari tanah, atau melompat di antara batang pohon $=7 \mathrm{~m}$ di atas tanah (Whitten $\&$ Whitten 1987).

Ekologi pencarian makan Memakan serangga dan buah (Davis 1962, Harrison 1962a); kulit (49\%), lumut, jamur dan alga (lichen), dan serangga (39\%) (Whitten 1981). Memakan kulit pohon dengan preferensi tertentu. Jumlah famili yang paling umum dimanfaatkan berbeda secara nyata dari prediksi jika pola pakan menyebar merata di antara famili yang ada di Pulau Siberut (Whitten \& Whitten 1987). Makanan dan jumlah lichen serta tumbuhan rambat terhadap pohon berkorelasi secara negatif. Adanya tumbuhan merambat yang hampir menutup kulit kayu bisa menurunkan keinginan untuk makan (Whitten \& Whitten 1987).

Ekologi perkembangbiakan Betina yang hamil atau menyusui ditemui di Borneo pada bulan Juni dan Agustus. Jumlah anak biasanya $2-3$.

Degradasi dan hilangnya habitat Terlihat mendapatkan manfaat dari kegiatan tebang pilih (Dahaban et al. 1996, Wells 2002).

Status konservasi Tidak terdaftar dalam IUCN (2002). Tidak terdaftar dalam CITES (ARCBD 2002). Tidak dilindungi di Indonesia (PHPA 1996b).

\section{Bajing Bancirot Sundasciurus tenuis}

Taksonomi Ada 9 spesies dalam genus dan 7 subspesies dalam spesies ini (Corbet $\&$ Hill 1992).

Penyebaran global Semenanjung Thailand dan Malaya, Sumatera, dan Borneo (Endemik dataran Sunda)(Corbet \& Hill 1992).

Status populasi dan kepadatannya di Borneo tersebar luas di Borneo; tidak ada informasi kepadatan.

Keberadaan di pulau kecil di Asia Tenggara Bangkaru, Batam, Jimaja, Labuan, Lingga, MoburMusala, Redang, Siantan, Singapura, Tana Bala, Tana Masa dan Tioman ( $=13)$ (Meijaard 2003b).

Umur Genus/spesies 11,0 Jt/Tidak diketahui. 
Habitat Hidup dalam hutan sekunder yang tinggi di dataran rendah dan pegunungan bagian bawah hingga $1.650 \mathrm{~m}$. Terutama aktif pada pohon berukuran kecil (Payne et al. 1985).

Aktivitas Dilakukan pada siang hari/aktif pada siang hari diurnal (Meijaard pengamatan pribadi; Yasuma \& Andau 2000).

Pergerakan dan migrasi Tidak ada informasi.

Ekologi pencarian makan Pemakan kulit kayu dan getah, selain itu serangga, buah-buahan dan biji-bijian (Payne et al. 1985, MacKinnon et al. 1996).

Ekologi perkembangbiakan Tidak ada informasi.

Degradasi dan hilangnya habitat Bisa jadi mendapatkan manfaat dari sejumlah gangguan habitat (Bennett \& Dahaban 1995).

Hubungan antar spesies Bajing Bancirot terlihat digantikan secara ekologi oleh Bajing Jentink, S. jentinki di pegunungan bagian utara dan bagian tengah pulau Borneo (Payne et al. 1985).

\section{Bajing-Tanah Moncong Kuning Rhinosciurus laticaudatus}

Taksonomi Genus monotypic dengan 3 subspesies (Corbet \& Hill 1992).

Penyebaran global Semenanjung Malaysia, Sumatera, Borneo, dan beberapa pulau kecil (Corbet \& Hill 1992).

Status populasi dan kepadatannya di Borneo Tidak ada informasi

Keberadaan di pulau kecil di Asia Tenggara Batam, Batan, Bintan, Bunguran, Karimon, Kundur, Lingga, Siantan, Singapura, Sirhassen, Tioman dan Tuangku ( $\mathrm{n}=12$ ) (Meijaard 2003b).

Umur Genus/spesies 9,0 Jt/7,0 Jt.

Habitat Di darat.

Aktivitas Melakukan aktivitas pada siang hari - diurnal (Yasuma \& Andau 2000).

Pergerakan dan migrasi Tidak ada informasi.

Ekologi pencarian makan Terutama memakan serangga pada kayu tumbang (MacKinnon 1978). Serangga ini terutama adalah semut besar, rayap, dan kumbang; namun spesies ini juga memakan buah (Yasuma \& Andau 2000).

Ekologi perkembangbiakan Tidak ada informasi.

Degradasi dan hilangnya habitat Terlihat terpengaruh secara negatif oleh kegiatan penebangan dan akan sangat dirugikan oleh kegiatan penebangan.

Hubungan antar spesies Tidak ada informasi.

Status konservasi Tidak tercatat dalam IUCN (2002).

\section{Binturong Arctictis binturong}

Taksonomi Spesies tunggal dengan 2 atau 3 subspesies yang dikenal. Subspesies yang hidup di Borneo: A. binturong.

Penyebaran global Mulai dari Sikkim hingga Indochina dan Semenanjung Malaya, Kepulauan Riau, Sumatera, Bangka, Jawa, Borneo dan Palawan.

Status populasi dan kepadatannya di Borneo Sering terlihat pada hutan primer 
dengan 1,7 individu/km perjalanan. Populasi tidak berlimpah (Nowak 1999). Hidup sendirian atau dalam kelompok kecil dewasa dengan anak yang belum dewasa.

Keberadaan di pulau kecil di Asia Tenggara Bangka, Batam, Bintan, Kundur, Nias, Palawan, Payong, Tebing Tinggi dan Tioman $(\mathrm{n}=9)$ (Meijaard 2003b).

Umur Genus/spesies 10.8 Jt/Tidak diketahui.

Habitat Hutan lebat. Di Thailand, tercatat ada dua ekor spesies ini menghabiskan $100 \%$ waktunya pada hutan kerangas, hutan semi tropis yang hijau sepanjang musim/ campuran yang menggugurkan daun (Austin \& Tewes 1999).

Aktivitas nokturnal, arboreal, namun kadangkala bersifat terestrial, cathemeral (yaitu aktif di siang dan malam hari) atau nokturnal (aktif di malam hari).

Pergerakan dan migrasi Di Thailand, betinanya menggunakan wilayah jelajah sekitar $6 \mathrm{~km}^{2}$, dengan daerah inti (85\% lokasi) hanya $1,5 \mathrm{~km}^{2}$. Jantannya menggunakan wilayah jelajah seluas kira-kira 9,5 km² (Austin \& Tewes 1999).

Ekologi pencarian makan Pemakan buah (Heydon \& Bulloh 1996), namun juga memakan burung, bangkai, daun, dan pucuk daun (Nowak 1999). Di Thailand, kotorannya ditemukan berisi hanya biji buah pohon beringin (Ficus sp.) (Austin \& Tewes 1999), serupa dengan isi perut binturong dalam Rozhnov (1974 dalam Austin \& Tewes 1999). Lihat juga Nettelbeck (1997) untuk keterangan mengenai pemanfaat pepohonan ara.

Ekologi perkembangbiakan Perkembangbiakannya terjadi sepanjang tahun (Lekagul \& McNeely 1977). Dalam kandang, betinanya memiliki lebih dari sekali masa subur (polyestrous) dan bisa melahirkan dua anak dalam setahunnya (Nowak 1999). Dalam kandang, daur masa subur rata-ratanya 81,8 hari. Rata-rata masa kehamilan $=91,1$ hari. Jumlah anak rata-rata 1,98. Masa sapih pada umur 6-8 minggu. Dewasa secara seksual pada umur 30,4 bulan bagi betina dan 27,7 bagi jantan. Aktif secara seksual setidaknya selama 15 tahun (Nowak 1999).

Degradasi dan hilangnya habitat Lebih sering terlihat di hutan bekas tebangan dibandingkan di hutan primer (2,4 individu/km jejak), tetapi perbedaan ini tidak nyata (Heydon \& Bulloh 1996).

Hubungan antar spesies Bisa bersaing dengan spesies owa untuk mendapatkan buah (Nettelbeck 1998).

Status konservasi Tidak terdaftar dalam IUCN (2002). Terdaftar dalam Appendix III CITES (ARCBD 2002). Dilindungi Undang-undang di Indonesia (PHPA 1996b).

\section{Musang Belang Hemigalus derbyanus}

Taksonomi Terdiri dari dua spesies dalam genus, meskipun Musang Gunung Diplogale hosei sering dimasukkan dalam Hemigalus (Corbet \& Hill 1992, cf. Payne et al. 1985), dan Musang Belang Owston (Chrotogale owstoni) biasanya dipisahkan. Dengan demikian genus sering dianggap sebagai monospescific (berjenis tunggal). Dikenal ada 3 subspesies, tetapi subspesies yang ada di Malaya, Sumatera, dan Borneo terlihat tidak dapat dipisahkan (Corbet \& Hill 1992).

Penyebaran global Tenasserim, Semenanjung Malaya, southern Thailand, Sumatera, Kepulauan Mentawai, dan Borneo. 
Status populasi dan kepadatannya di Borneo Tercatat di banyak tempat di dataran rendah dan perbukitan (Payne et al. 1985).

Keberadaan di pulau kecil di Asia Tenggara Pagai Selatan dan Sipura $(\mathrm{n}=2)$ (Meijaard 2003b); bentuk Musang Belang yang ada di pulau-pulau ini kemungkinan merupakan spesies yang berbeda (Screiber et al. 1989).

Umur Genus/spesies 11,5 Jt/Tidak diketahui.

Habitat Hidup di hutan sekunder dan hutan yang berpohon tinggi (Payne et al. 1985).

Aktivitas Nokturnal (Davis 1962, Heydon \& Bulloh 1996); kebanyakan terestrial (Medway 1978); kadang-kadang bersifat arboreal dan dapat memanjat dengan baik (Lekagul \& McNeely 1977).

Pergerakan dan migrasi Berpindah tempat dan makan sebagian besar dilakukan di tanah, tetapi tidur di lubang, di atas tanah atau pada pohon (Payne et al. 1985).

Ekologi pencarian makan Karnivora (pemakan daging) dengan bahan makan hewani lebih dari 95\% (Heydon \& Bulloh 1996). Makanannya termasuk: orthoptera (serangga sejenis belalang) dan cacing (80\%), dan 20\% sisanya terdiri dari invertebrata yang lain (Nowak 1999). Memakan juga Tikus Duri-Coklat (Maxomys rajah), bijibijian, Brachyura, Chilopoda, Annelida, Coleoptera, Araneae, dan sebangsa bunga matahari (Colón 1999).

Ekologi perkembangbiakan Di Borneo, ditemukan betina yang mengandung satu embrio pada bulan Februari (Nowak 1999). Dalam kandang, matanya membuka pada umur 8-12 hari. Memakan makanan padat pertama pada umur 70 hari (Ewer 1973).

Degradasi dan hilangnya habitat Sering dijumpai di hutan bekas tebangan 6 tahun yang lalu dan hanya $15 \%$ dari perjumpaan pada hutan primer (Heydon $\&$ Bulloh 1996).

Hubungan antar spesies Tidak ada informasi.

Status konservasi Appendix II CITES. Tidak dikenal dengan baik, namun kemungkinan sangat dipengaruhi oleh kegiatan penebangan kayu dan dibunuh secara langsung oleh masyarakat yang menganggap spesies ini adalah pemangsa ayam peliharaan (Nowak 1999). Tidak terdaftar dalam IUCN (2002). Tidak dilindungi Undang-undang di Indonesia (PHPA 1996b).

\section{Musang Galing Paguma larvata}

Taksonomi Hanya ada satu spesies dalam genusnya dengan 13 subspesies yang telah ditelakan. Salah satu subspesies ini (P. l. leucocephala) hidup di Borneo (Corbet \& Hill 1992).

Penyebaran global Pakistan bagian utara dan Kasmir hingga Indochina dan Semenanjung Malaya, sebagian besar bagian selatan dan timur Cina, Pulau Andaman, Taiwan, Hainan, Sumatera, dan Borneo.

Status populasi dan kepadatannya di Borneo Payne et al. (1985) melaporkan bahwa spesies ini sebagian besar hidup di bagian utara Borneo, catatan lain terdapat juga di bagian yang paling selatannya dari Gunung Liang Kubung di Kalimantan Barat sampai daerah hulu Sungai Mahakam di Kalimantan Timur. Namun demikian 
spesimen dari Sungai Barito (van Strien 2001) mengungkapkan bahwa Borneo bagian selatan merupakan daerah sebarannya. Selain itu ada catatan dari bagian selatan Sungai Mahakam (G. Frederiksson in litt pada Meijaard), dan Danau Mahakam (Gönner 1997); mungkin juga di seluruh Kalimantan Barat (Blundell 1996, Jeanes \& Meijaard 2000, Simons 1987).

Keberadaan di pulau kecil di Asia Tenggara Tidak diketahui hidup di pulau lepas pantai $(\mathrm{n}=0)$ (Meijaard 2003b).

Umur Genus/spesies Tidak diketahui/Tidak diketahui.

Habitat Hidup di hutan meranti dataran rendah dan hutan pegunungan bagian bawah, baik tegakan primer maupun sekunder (Azlan 2003, Yasuma \& Andau 2000). Kadang-kadang masuk ke perkebunan untuk makan (Yasuma \& Andau 2000).

Aktivitas Semi-arboreal (aktivitas dilakukan di atas pohon dan kadang-kadang di permukaan tanah). Jarang mencari makan dan berpindah di atas tanah. Nokturnal, dan puncak kegiatannya antara jam 19.30 dan 22.30 (Rabinowitz 1991). Bersarang di tajuk atas (Rabinowitz 1991). Tidak ada tanda spesies ini menggunakan sarang hewan yang lain (Rabinowitz 1991). Tidak selalu kembali pada tempat tidurnya yang sama di siang hari (Rabinowitz 1991). Tempat tidur siangnya sering berada dekat sungai/aliran air (Rabinowitz 1991). Saat ditemukan beristirahat di atas tanah pada daerah yang 80-90\% terbuka (Rabinowitz 1991).

Pergerakan dan migrasi Rata-rata wilayah jelajah $=0,93 \mathrm{~km}^{2}$ (Rabinowitz 1991). Luas wilayah jelajah betina lebih dari $3,7 \mathrm{~km}^{2}$ (Rabinowitz 1991), bervariasi tergantung pada ketersediaan makanan (Joshi et al. 1995, Rabinowitz 1991). Memiliki wilayah jelajah yang tumpang tindih dengan spesies lain dari genus yang sama (Joshi et al. 1995). Secara umum wilayah jelajah bulanan, pusat wilayah jelajahnya bergeser, dan menunjukkan peningkatan linier antara radius kegiatan dengan berat dan ukuran individu (Rabinowitz 1991). Meskipun wilayah jelajah secara umum bertumpang tindih, wilayah jelajah bulanannya lebih tetap dan tidak bertumpang tindih (Rabinowitz 1991). Bukti mengungkapkan bahwa musang mungkin memusatkan pergerakannya di sekitar tempat makannya selama musim buah berlimpah (Rabinowitz 1991). Rata-rata pergerakan harian adalah $620 \mathrm{~m}$ (Rabinowitz 1991). Rata-rata radius aktivitas bulanan adalah $484 \mathrm{~m}$ (Rabinowitz 1991). Rata-rata pergeseran wilayah jelajah adalah 320 m (Rabinowitz 1991).

Ekologi pencarian makan 60-90\% makananya terdiri dari makanan hewani (Heydon \& Bulloh 1996), terutama hewan pengerat dan ada pula bukti bahwa spesies ini memakan serangga, spesies pemakan serangga, ular, kadal, burung, dan rumput. Spesies juga memakan buah. Dari survei transek, empat spesies pohon buah paling sering didapati dalam kotoran musang (60\%) namun hanya 22\% dari spesies pohon tersebut yang ditemui dalam transek (Rabinowitz 1991).

Ekologi perkembangbiakan Di Nepal, spesies ini terlihat membesarkan anaknya dalam lubang pohon (Nowak 1999). Di Thailand, musim kawin berkaitan dengan dua musim hujan yang lebih panjang (Lekagul \& McNeely 1977), namun hal ini mungkin tidak relevan terhadap Borneo. Jumlah anak 1-1 (Nowak 1999). Mencapai ukuran dewasa pada umur sekitar 3 bulan (Lekagul \& McNeely 1977).

Degradasi dan hilangnya habitat Data tidak memadai. Hidup di hutan yang ditebang mau pun hutan utuh, tetapi frekuensi terlihatnya spesies ini terlalu rendah 
untuk dapat mengevaluasi efeknya (Heydon \& Bulloh 1996).

Hubungan antar spesies Spesies ini dilaporkan menyebarkan biji-bijian berbagai spesies tumbuhan (Payne et al. 1985).

Status konservasi Status konservasi Tidak terdaftar dalam IUCN (2002). Terdaftar pada Appendix III CITES (ARCBD 2002). Tidak dilindungi Undangundang di Indonesia (PHPA 1996b).

\section{Musang Luwak Paradoxurus hermaphroditus}

Taksonomi. Ada empat spesies dalam genus. P. hermaphroditus merupakan spesies yang paling tersebar luas dari keempat spesies ini. Spesies yang lain memiliki penyebaran di Kepulauan Mentawai, India barat daya, dan Sri Lanka. Corbet dan Hill (1992) mengenali ada 23 subspesies dan dua di antaranya, P. h. baritensis dan P. h. sabanus, hidup di Borneo. Spesies ini memerlukan kaji ulang taksonomis.

Penyebaran global Seluruh daratan utama Asia Tenggara, Semenanjung Malaya, Hainan, Sumatera, Jawa, Borneo, dan Palawan.

Status populasi dan kepadatannya di Borneo Secara umum tersebar luas dan bisa hidup dalam jarak yang dekat dengan pemukiman penduduk.

Keberadaan di pulau kecil di Asia Tenggara Alange, Pulau Babi, Balabac, Banggi, Bangka, Bawean, Bedung, Belitung, Clara, Datuk, Iyan, Karimata, Kateman, Ketam, Kissaraing, Klum, Kram, Kundur, Lagong, Lang, Lingga, Lingung, Mohea, Nias, Padang, Palawan, Payong, Phuket, Pipidon, Redang, Simeulue, Singkep, Sirhassen, St Barbe, Tambelan, Tavoy, Teibeian besar, Terutau, Tinggi dan Wai ( $\mathrm{n}=$ 40+) (Meijaard 2003b).

Umur Genus/spesies 4,9 Jt/Tidak diketahui.

Habitat Di Borneo, spesies ini hidup di hutan sekunder, perkebunan, dan kebun. Jarang dijumpai di hutan primer (Payne et al. 1985), meskipun di tempat lain seperti Laos spesies ini menggunakan hutan primer.

Aktivitas Nokturnal, arboreal dan terestrial (Duckworth 1997b). Menggunakan rongga dan cekungan yang tersembunyi (Nowak 1999). Di Nepal, aktivitas dimulai sekitar jam 18.00 dan berakhir sekitar jam 04.00 (Joshi et al. 1995). Di Nepal, spesies ini lebih aktif pada malam yang gelap dibandingkan dengan malam yang terang karena cahaya bulan (Joshi et al. 1995). Pada siang hari beristirahat di pohon-pohon yang tertutup oleh tanaman merambat yang lebat (63\%), juga dalam rongga pohon (21\%) tetapi frekuensinya lebih rendah dibandingkan dengan dalam tumbuhan rambat atau lubang (16\%). Tumbuhan rambat yang sangat lebat bisa melindunginya terhadap pemangsa yang arboreal dan spesies raptor (Joshi et al. 1995). Tempat tidur di siang harinya biasanya pada pohon (86\%) dan biasanya dekat dengan air (Rabinowitz 1991). Lokasi tempat istirahat tersebar merata di seluruh daerah penelitian, sehingga tidak jelas apakah keberadaan lokasi istirahat ini berpengaruh besar terhadap pola pencarian makan. Spesies ini mencari makan sesaat sebelum matahari terbit dan mencari makan dekat dengan lokasi istirahatnya (Joshi et al. 1995). Puncak kegiatannya antara jam 19.30 dan 01.30 (Rabinowitz 1991).

Pergerakan dan migrasi Di Thailand, pergerakan dan migrasinya bervariasi tergantung pada ketersediaan makanan (Joshi et al. 1995, Rabinowitz 1991). Di 
Nepal, ukuran wilayah jelajahnya beragam tergantung pada ketersediaan makanan (Joshi et al. 1995), dan ada tumpang tindih yang besar dengan spesies dalam satu genus (Joshi et al. 1995). Memiliki wilayah jelajah yang bertumpang tindih dengan spesies lain dari genus yang sama (Joshi et al. 1995). Secara umum, wilayah jelajah bulanan, pusat wilayah jelajahnya bergeser, dan radius kegiatan menunjukkan peningkatan linier dengan berat dan ukuran individu (Rabinowitz 1991). Di Nepal nilai tengah total wilayah jelajahnya adalah 14,1 ha (Joshi et al. 1995). Ukuran wilayah jelajah dalam hutan campuran, meranggas dan kering, berdaun jarum di Thailand luasnya 21 kali lebih besar dibandingkan luas jelajah di Nepal (Rabinowitz 1991). Meskipun wilayah jelajah keseluruhan menunjukkan adanya tumpang tindih yang besar, wilayah jelajah bulanannya lebih terbatas dan tidak bertumpang tindih (Rabinowitz 1991). Ada bukti yang mengungkapkan bahwa musang ini memusatkan pergerakannya di sekitar daerah pencarian makanan tertentu saat buah berlimpah (Rabinowitz 1991). Rata-rata wilayah jelajah bulanan adalah $0,72 \mathrm{~km}^{2}$ (Rabinowitz 1991). Selama buah berlimpah, aktivitas yang tinggi terjadi di daerah yang sempit (Rabinowitz 1991).

Ekologi pencarian makan Pemakan buah yang oportunistik, memakan beragam spesies tumbuhan dan hewan (Joshi et al. 1995). Di Nepal, 84,5\% kotorannya mengandung bijian buah (Joshi et al. 1995). Di Nepal, terjadi pergeseran makanan dari buah-buahan ke vertebrata dan invertebrata apabila buah-buahan tidak tersedia (Joshi et al. 1995). Di Nepal spesies ini juga memakan sari bunga Kapuk (Bombax ceiba) dan getah Vallaris solanacea (Joshi et al. 1995). Di Sabah, 45\% makanannya terdiri dari buah (Heydon \& Bulloh 1996). Transek spesies pohon buah menunjukkan bahwa keempat spesies pohon yang paling sering didapati dalam kotoran musang $(60 \%)$ hanya $22 \%$ saja termasuk dalam pohon yang ditemui dalam transek (Rabinowitz 1991). Secara umum spesies memakan buah yang kaya akan gula dan lembut dagingnya (Rabinowitz 1991). Di Sabah, spesies ini memakan buah (Connarus spp.), buah, biji, daun Annelida, Chilopoda, Araneae, Brachyura, dan jaringan daging dan lemak hewan (Colón 1999). Di Thailand, musang (tidak diidentifikasi hingga tingkat spesiesnya, bisa Paguma atau Paradoxurus) terutama memakan buah pohon Beringin (Ficus sp. (24\%), Rambusa (Passiflora foetida) (20\%), dan Polyalthia spp. (18\%)), dengan 17\% fesesnya mengandung sisa serangga (Grassman 1998).

Ekologi perkembangbiakan Masa kehamilan: 60 hari (Hayssen et al. 1993). Kedewasaan seksual dicapai pada umur 11-12 bulan (dilaporkan dalam Nowak 1999).

Degradasi dan hilangnya habitat $30 \%$ penurunan kepadatan populasi di hutan bekas tebangan yang berumur 6 tahun ( $\&$ Bulloh 1996), namun Stuebing dan Gassis (1989) menemukan spesies ini hanya pada daerah perkebunan dan tidak pada pohon yang ditebang.

Hubungan antar spesies Spesies ini dilaporkan menyebarkan biji berbagai spesies tumbuhan (Payne et al. 1985). Di Nepal, spesies ini dimangsa oleh karnivora yang besar (Joshi et al. 1995). Pemangsaan tertinggi terjadi saat mencari makan di tanah, sampai individu kembali bersembunyi dalam tajuk segera setelah selesai makan (Joshi et al. 1995).

Status konservasi Tidak tercatat dalam IUCN (2002). Tercatat pada Appendix III CITES. Tidak dilindungi di Indonesia (ARCBD 2002). 


\section{Musang Akar Arctogalidia trivirgata}

Taksonomi Genus ini monospecific dan ada 7 subspesies yang telah ditelakan berdasarkan pada karakter bulu dan ukurannya (Corbet \& Hill 1992).

Penyebaran global Spesies ini hidup mulai dari Assam, Yunnan dan Indochina hingga Malaya, Sumatera, Borneo dan berbagai pulau kecil. Populasi di Jawa bagian barat harus ditetapkan menjadi spesies yang berbeda (Schreiber et al. 1989).

Status populasi dan kepadatannya di Borneo Heydon dan Bulloh (1996) melaporkan frekuensi terlihatnya spesies ini sebesar $2,1 \pm 2,1$ hewan/100 km jalur pengamatan di hutan primer, tetapi jumlah ini terlalu rendah untuk menduga kepadatan spesies ini.

Keberadaan di pulau kecil di Asia Tenggara Banggi, Bangka, Batam, Belitung, Bintan, Bulan, Bunguran, Galang, Kundur, Langkawi, Lingga, Pinie, Singapura, Singkep, Sugi, Tebing Tinggi, Terutau dan Tioman. ( $\mathrm{n}=18)$ (Meijaard 2003b) (dengan catatan bahwa spesies yang jarang diamati ini bisa jadi banyak yang tidak terlaporkan).

Umur Genus/spesies 4,9 Jt/Tidak diketahui.

Habitat Hutan tropis, tidak ada catatan dari hutan kerangas (Duckworth 1997b, Rabinowitz 1991). Ada catatan dari 1,500 m dpl di Borneo (Payne et al. 1985).

Aktivitas Spesies ini bersifat arboreal penuh. Di Laos spesies ini tidak pernah terlihat berada di tanah dan hanya sekali terlihat pada tajuk (Duckworth 1997b). Spesies ini terlihat nokturnal (Duckworth 1997b, Lekagul \& McNeely 1977, Payne et al. 1985, Walston \& Duckworth 2003). Di Laos, ditemui 6 kelompok yang beranggotakan 2 ekor (Duckworth 1997b).

Pergerakan dan migrasi Spesies ini merupakan pemanjat yang aktif dan melompat dari cabang ke cabang dengan sangat baik.

Ekologi pencarian makan Makanannya terdiri dari buah-buahan dan hewan kecil (Payne et al. 1985). Lekagul dan McNeely (1977) menjelaskan spesies ini sebagai pemakan segala, pemangsa seperti bajing dan burung, tetapi juga memakan berbagai spesies buah, serangga, kumbang, dan katak.

Ekologi perkembangbiakan Anaknya dibesarkan dalam rongga pohon. Jumlah anak biasanya 2 atau 3 dan mungkin ada 2 kali kelahiran dalam setahun (Yasuma $\&$ Andau 2000).

Degradasi dan hilangnya habitat $\mathrm{Di}$ Thailand, spesies ini paling banyak ditemui di hutan primer jauh dari pedesaan (Lekagul \& McNeely 1977), tetapi Duckworth (1997b) melaporkan bahwa hal ini tidak sama dengan di Laos, dimana spesies ini juga ditemukan di hutan yang rusak parah. Data yang dibuat oleh Heydon \& Bulloh (1996) dan Syakirah et al. (2000) mengungkapkan bahwa di Borneo, spesies ini sedikit menurun setelah kegiatan penebangan. Menurut Yasuma \& Andau (2000), spesies ini sering memasuki perkebunan untuk makan buah.

Hubungan antar spesies Tidak ada informasi.

Status konservasi Mungkin agak terancam oleh perburuan dan penjeratan karena perilaku arboreal penuh dan nokturnal (Walston \& Duckworth 2003). 


\section{Tenggalung Malaya Viverra tangalunga}

Taksonomi Ada dua subgenera dan empat spesies dengan sedikit variasi pada $V$. tangalunga sendiri.

Penyebaran global Borneo, Filipina, Sumatera, Kepulauan Riau (Nowak 1999).

Status populasi dan kepadatannya di Borneo Status populasi dan kepadatannya di Borneo 24,4 individu/100 km di hutan primer (Heydon \& Bulloh 1996).

Keberadaan di pulau kecil di Asia Tenggara Banggi, Bangka, Belitung, Bintan, Bunguran, Karimata, Kundur, Langkawi, Laut (Kepulauan Natuna), Laut (Borneo Tenggara), Lingga, Palawan, Panebangan, Penang, Rupat dan Singapura $(\mathrm{n}=16)$ (Meijaard 2003b).

Umur Genus/spesies 13,3 Jt/5,6 Jt.

Habitat Hutan primer yang tinggi namun mampu bertahan di hutan yang rusak. Lebih menyukai tumbuhan merambat yang padat sebagai tempat tidur di siang hari.

Aktivitas Terestrial; nokturnal, Biasanya menyendiri (soliter). Tempat tidur pada siang hari berlokasi hanya pada tanah yang penyerapan yang baik (berpori) (Colón 1999). Bisa hidup dalam lubang di tanah yang digali oleh satwa yang lain (Nowak 1999). Tempat tidur siangnya berlokasi di bawah pohon-pohon yang tumbang, pada tumbuhan merambat yang padat atau di dekat pinggir hutan yang mempunyai vegetasi yang rapat.

Pergerakan dan migrasi Sebagian besar wilayah jelajahnya digunakan untuk mencari makan dan beristirahat (Colón 1999). Jelajah siang hari (daerah beristirahat) dan jelajah malam hari (daerah mencari makan) tidak berbeda secara nyata (Colón 1999). Tingkat kegiatan harian mencapai 52\%. Nilai tengah kegiatan nokturnal adalah $80,9 \%$. Nilai tengah kegiatan diurnal adalah 21,2\% (Colón 1999) Kegiatan di malam hari tidak berlangsung terus-menerus, terpotong oleh kegiatan yang lebih rendah seperti beristirahat (Colón 1999). Wilayah jelajah: 1103 ha (Colón 1999). Wilayah jelajah jantan secara statistik tidak berbeda nyata dengan wilayah jelajah betina (Colón 1999). Bersifat teritorial: tumpang tindih wilayah jelajahnya besar antar individu di hutan utuh dan hutan bekas tebangan (Colón 1999). Jantannya menunjukkan tumpang tindih yang lebih kecil dibandingkan dengan wilayah jelajah betina, dan tumpang tindih dalam gender lebih kecil dibandingkan dengan tumpang tindih antar gender (Colón 1999). Tidak mengawasi batas wilayah jelajahnya dan dengan demikian mungkin tidak teritorial. Namun demikian, individu spesies ini lebih luas tersebar daripada yang diduga, menunjukkan bahwa saat memilih tempat tidur siangnya spesies ini secara aktif menghindari pertemuan satu sama lain (Colón 1999). Pola pergerakan harian vs. bulanan vs. musiman: pergeseran musiman terjadi dalam ukuran dan lokasi wilayah jelajah selama curah hujan tinggi dan rendah yang mencerminkan perubahan musiman dalam hal ketersediaan sumber makanan di hutan musiman (Rabinowitz 1991); di hutan yang tidak terpengaruh musim, ukuran dan lokasi wilayah jelajah tidak berkorelasi dengan curah hujan (Colón 1999); tidak ada perbedaan yang nyata antar gender, meskipun nilai tengah wilayah jelajah ini lebih besar bagi jantan di hutan bekas tebangan dan hutan utuh Colón 1999); tidak 
ada perbedaan yang nyata dalam hal jarak harian yang ditempuh antar gender atau di hutan bekas tebangan dan hutan utuh (wilayah jelajah $=1,0 \mathrm{~km}$ dalam 13 jam 9,7 km dalam 6 jam) (Colón 1999). Jantannya melintasi daerah yang jauh lebih luas di sebagian besar wilayah jelajahnya dalam semalam dibandingkan betina (Colón 1999). Menggunakan jalan (hutan bekas tebangan) dan jalan setapak (hutan utuh) (Colón 1999).

Ekologi pencarian makan Dianggap sebagai karnivora dan insektivora (Payne et al. 1985). Dilaporkan memakan daun, buah, dan bahkan sisa makanan (MacDonald \& Wise 1979). Spesies invertebrata merupakan bahan yang sering dimakannya, diikuti dengan buah (Colón 1999). Makanan yang paling sering dijumpai adalah kumbang (Coleoptera), kepiting (Brachyura), kalajengking (Palamneus sulpides), dan kaki seribu (Sphaeropieus spp.) (Colón 1999). Buah-buahan didapati 12\% dari total keseluruhan makanannya (Davis 1962). Buah-buahan adalah makanan kedua yang paling sering dijumpai setelah serangga. Setidaknya ada 20 spesies buah dari 18 genera. Biji-bijian spesies beringin (Ficus spp.), spesies Connarus spp. dan spesies nangka belanda, srikaya, dan buah nona (Annona spp.) merupakan spesies yang sering diidentifikasi (Colón 1999). Di hutan yang utuh proporsi spesies pohon buah-buahan sumber pakan lebih besar dibandingkan dengan hutan bekas tebangan (Colón 1999). Jenis vertebrata yang dimakan termasuk jenis pengerat, pemakan serangga, burung kecil, ular, dan kadal (Colón 1999). Kelelawar dilaporkan juga dimakan di Sarawak (MacDonald \& Wise 1979). Pola makannya menunjukkan perbedaan yang besar dilihat dari frekuensi ditemukannya hewan darat kecil. Hal ini menunjukkan adanya preferensi pemangsaan (Colón 1999).

Ekologi perkembangbiakan Berkembang biak sepanjang tahun (Nowak 1999). Hewan mudanya sering didapati pada bulan Maret hingga Mei (Colón 1999). Hewan yang hampir dewasa lebih sering ditemui pada bulan September - April (Colón 1999). Anaknya membuka mata setelah 10 hari dan mulai disapih setelah satu bulan (Nowak 1999). Ada satu hingga empat anak, meski biasanya dua atau tiga (Nowak 1999). Anaknya lahir di lubang dalam tanah atau pada kondisi vegetasi yang rapat (Nowak 1999).

Degradasi dan hilangnya habitat Terdapat penurunan sebanyak $60 \%$ pada hutan bekas tebangan berumur 6 tahun (Heydon \& Bulloh 1996). 95\% nilai tengah MCP ada di hutan utuh $=88,5$ (kisaran $=56-111$ ha) vs. 132,0 ha (kisaran 70-284 ha) di hutan bekas tebangan. Namun perbedaannya secara statistik (ANOVA)_tidak nyata (Colón 1999). Tidak ada pola aktivitas yang berbeda secara statistik antara kegiatan di hutan bekas tebangan dan hutan utuh (Colón 1999). Dari invertebrata yang dikenal dimakan oleh musang, hanya Scorpianidae dan Isoptera yang populasinya secara nyata lebih berlimpah di hutan primer, dan Coleoptera dan Hymenoptera lebih umum dijumpai di hutan bekas tebangan (Burghouts et al. 1992). Azlan (2003) menemukan bahwa spesies ini adalah karnivora kecil yang paling umum hidup di hutan sekunder berumur 30 tahun di Semenanjung Malaysia.

Hubungan antar spesies Memanfaatkan jauh lebih banyak intervertebrata dibandingkan dengan spesies musang lainnya dan memungkinkan terjadinya pembagian sumber makanan (Colón 1999). Musang bisa menjadi penyebar spesies utama bagi sejumlah genera pohon-pohon Asia (Corlett 1988). 68\% dari kotoran 
yang dianalisis mengandung parasit atau telur dari 26 kelompok yang berbeda (Colón 1999). Ada 5 spesies kutu yang diidentifikasi, yang paling umum adalah Haemaphysalis asiaticus (Colón 1999).

Status konservasi Tidak terdaftar dalam IUCN (2002). Tidak terdaftar dalam CITES (ARCBD 2002). Tidak dilindungi di Indonesia (PHPA 1996b).

\section{Pelanduk Kancil Tragulus kanchil}

Taksonomi Belum lama ini dipisahkan dari T. javanicus oleh Meijaard dan Groves (2004). Banyak subspesies yang telah dideskripsikan, meskipun hanya sebagian kecil saja yang mungkin valid. Meijaard dan Groves (2004) mengungkapkan bahwa 2 subspesies hidup di Borneo, yaitu T. k. klossi di Sabah bagian timur dan tengah dan Kalimantan Timur bagian utara, dan T. k. hosei di Sarawak, Kalimantan Tengah dan Barat, dan seluruh Kalimantan Timur. T. k. klossi bisa menjadi spesies tersendiri.

Penyebaran global Yunnan Selatan, Thailand, Indochina, Semenanjung Malaya dan pulau-pulau di dekatnya, Sumatera, dan Borneo (Meijaard \& Groves 2004).

Status populasi dan kepadatannya di Borneo 21-39 individu/ $\mathrm{km}^{2}$ (Heydon \& Bulloh 1997. Kepadatannya berkolerasi positif dengan masa buah 1-5 g, dengan masa biji 0,01-0,5 g, dan total buah (Heydon \& Bulloh 1997). Kepadatan spesies ini berkolerasi negatif dengan pohon pionir dan rumput serta herba (Heydon \& Bulloh 1997).

Keberadaan di pulau kecil di Asia Tenggara Bangka, Bangkaru, Batam, Bengkalis, Bintan, Bunguran, Bunoa, Karimata, Karimon Kecil, Karimon, King, Kissaraing, Labuan, Langkawi, Laut (Kepulauan Natuna), Laut (Borneo Tenggara), Lingga, Matak, Mendanau, Padang, Panaitan, Panebangan, Penang, Penjalei, Penuba, Phuket, Pinie, Pipidon, Ransang, Rawi, Redang, Rupat, Siantan, Singapura, Singkep, Sullivan, Tambelan Besar, Tana Bala, Tana Masa, Tebing Tinggi dam Tuangku (n = 41) (Meijaard 2003b).

Umur Genus/spesies 18,0 Jt/Tidak diketahui.

Habitat Hutan berpohon tinggi di dataran rendah (Nowak 1999). Duckworth (1997a) dan Bennett (komunikasi pribadi dalam Duckworth 1997a) mengungkapkan bahwa T. javanicus hidup terutama di daerah yang berbukit, tetapi Caldecott (1988) menyatakan bahwa T. javanicus dilaporkan tidak ditemui di daerah dengan ketinggian lebih dari $250 \mathrm{~m}$ di Sarawak, sedangkan T. napu hidup di daerah yang jauh lebih tinggi.

Aktivitas Diurnal hingga cathemeral (aktif di siang dan di malam hari). Tunggal atau berpasangan, atau dalam kelompok dengan satu betina dan satu atau dua anaknya (Ahmad 1994 dalam Davison 1980, Matsubayashi et al. 2003).

Pergerakan dan migrasi Tidak teritorial. Wilayah jelajah dan daerah inti yang tumpang-tindih dan pengawasan batasnya terbatas (Ahmad 1994). Jantannya bersifat sangat menetap (philopatric = selalu kembali ke tempat yang sama) namun betinanya membangun wilayah jelajah yang baru setelah melahirkan anaknya (Ahmad 1994). Wilayah jelajah dan daerah intinya tidak berbeda berdasarkan jenis kelamin, namun ditentukan oleh ukuran badan (Ahmad 1994). Matsubayashi et al. (2003) menduga ukuran wilayah jelajah betina adalah 4,4 ha dan jantan 5,9 ha dengan menggunakan 
metode minimum poligon cembung, tetapi perbedaan antara jantan dan betina tidak nyata. Nilai tengah jarak harian yang ditempuh bagi jantan adalah 519,1 $\pm 88,8 \mathrm{~m}$ dan bagi betina adalah 573,8 $\pm 219,7 \mathrm{~m}$.

Ekologi pencarian makan Pemakan buah. Spesies ini memakan pucuk, daun muda, dan buah-buahan yang jatuh (Medway 1978 dalam Davison 1980). Massa buah 1-5 g dan massa bijinya 0,01-0,5 g(Heydon \& Bulloh 1997).

Ekologi perkembangbiakan Polygynous/Poligami; masa birahi terjadi setelah melahirkan (post-partum estrus), betina hampir selalu dalam keadaan hamil (Cadigan 1972 dalam Davison 1980); lama kehamilan = 140-177 hari (Boonsong \& McNeely 1977 dalam Davison 1980); 2-3 anak per tahun (dalam Davison 1980); anaknya selalu disembunyikan (Ahmad 1994).

Degradasi dan hilangnya habitat Lebih jarang ditemukan di hutan bekas tebangan, dengan kepadatan berkisar antara 10 dan $15 \mathrm{ekor} / \mathrm{km}^{2}$. Keseluruhan kepadatan dan biomassanya di hutan tebang pilih secara nyata lebih rendah dibandingkan dengan hutan utuh. Penurunan kepadatan rata-rata 60\% (Heydon 1994). Kepekaannya mungkin akibat keterbatasan makanan yang membatasi kemampuannya untuk mengkompensasi penurunan kelimpahan buah-buahan pilihannya di hutan yang rusak dengan cara memanfaatkan tumbuhan merambat.

Hubungan antar spesies Kompetisi dengan T. napu tidak nyata, tetapi aktivitas hariannya cenderung mengurangi kompetisi dengan jenis satwa yang lain. Di hutan utuh, T. napu lebih umum ditemui dibandingkan dengan T. javanicus. Namun demikian, setelah kegiatan penebangan, jumlah T.napu menurun dan di hutan yang berumur 2 hingga 5 tahun, T. javanicus merupakan spesies yang paling umum ditemukan. Di hutan bekas tebangan berumur 12 tahun, T. napu kembali mendominasi (Heydon 1994).

Status konservasi Tidak terdaftar dalam IUCN (2002). Tidak terdaftar dalam CITES (ARCBD 2002). Dilindungi di Indonesia (PHPA 1996b).

\section{Pelanduk Napu Tragulus napu}

Taksonomi Meijaard dan Groves (2004) mengenal ada 7 subspesies T. napu, tetapi lebih banyak lagi yang telah dideskripsikan dan penelitian lebih lanjut diperlukan untuk memeriksa keabsahannya. Hanya 1 subspesies yang hidup di Borneo, sama dengan yang hidup di Sumatera, Semenanjung Malaya/Thai dan Myanmar bagian selatan (Meijaard \& Groves 2004).

Penyebaran global Thailand bagian selatan dan Myanmar, Semenanjung Malaya dan pulau-pulau di sekitarnya, Sumatera, dan Borneo (Nowak 1999).

Status populasi dan kepadatannya di Borneo Kepadatannya berkorelasi positif dengan keberadaan pohon ara/beringin (figs) dan berkorelasi secara negatif dengan rumput dan herba serta tumbuhan merambat (Heydon \& Bulloh 1997). Hidup di hutan primer dengan 37-72 individu $/ \mathrm{km}^{2}$ (Heydon \& Bulloh 1997). Di Pulau Tioman, kepadatannya berkisar antara 27,8 - 312,5 individu/ $\mathrm{km}^{2}$ (Miura \& Idris 1999). Wilayah jelajah di hutan primer: 7 ha (Ahmad 1994). Kebanyakan menyendiri dan nilai tengah ukuran kelompok: 1,37 (Miura \& Hidris 1999), dengan catatan bahwa data tersebut diambil dari satu pulau dan tidak jelas sejauh mana data ini relevan di wilayah daratan. 
Keberadaan di pulau kecil di Asia Tenggara Bakong, Balabak, Balembangan, Banggi, Bangka, Batam, Belitung, Bintan, Bulan, Bunguran, Durian, Galang, Iyan, Jimaja, Karimon Kecil, Karimun, Kundur, Langkawi, Laut (Borneo Tenggara), Lingga, Matak, Moro Kecil, Musala, Nias, Penuba, Sebangka, Sebatik, Sebuku, Setoko, Siantan, Singkep, Sirhassen, Subi, Sugi Bawa, Sugi, Tana Bala, Tana Masa dan Tioman ( $\mathrm{n}=38$ ) (Meijaard 2003b).

Umur Genus/spesies 18.0 Jt/Tidak diketahui.

Habitat Hutan primer. Berdasarkan morfologi kaki, T. napu menunjukkan preferensi terhadap habitat berawa dibandingkan dengan T. javanicus (Chasen 1940, Smit-van Dort 1989).

Aktivitas Cathemeral (=aktif di siang dan malam hari).

Pergerakan dan migrasi Tidak teritorial, tetapi jantan dan betinanya tidak bertoleransi terhadap jenis kelamin yang sama (Ahmad 1994). Luas wilayah jelajah dan daerah intinya tidak berbeda menurut jenis kelamin, tetapi ditentukan oleh ukuran badan individu (Ahmad 1994).

Ekologi pencarian makan Pemakan buah. Hose (1893, dalam Caldecott 1988) menyatakan bahwa T.napu juga memakan ayam, namun tidak ada bukti yang mendukung pernyataan ini.

Ekologi perkembangbiakan Mungkin polygynous (berpasangan ganda). Tidak ada perbedaan musim kawin dan betinanya melahirkan anak sepanjang tahun di Semenanjung Malaysia (Miura \& Idris 1999). Biasanya melahirkan satu atau jarang sekali dua anak (Yasuma \& Andau 2000).

Degradasi dan hilangnya habitat Lebih jarang dijumpai di hutan bekas tebangan, dengan kepadatan berkisar antara 6 hingga 16 hewan $/ \mathrm{km}^{2}$ (Heydon \& Bulloh 1997). Wilayah jelajah harian lebih luas di hutan sekunder. Keseluruhan biomassa dan kepadatannya di hutan tebang pilih secara nyata lebih rendah dibandingkan dengan hutan utuh. Penurunan kepadatan rata-rata 86\% (Heydon 1994). Kepekaannya mungkin sebagai konsekuensi kemampuannya untuk mengganti jenis makanan karena keterbatasan makanan akibat penurunan kelimpahan buah-buahan pilihannya dalam hutan yang rusak dengan memanfaatkan jenis rumput-rumputan (Heydon \& Bulloh 1997). Di hutan bekas tebangan berumur 12 tahun, jumlah pohon yang termasuk dalam genera yang dimakan oleh T.napu lebih sedikit (Heydon \& Bulloh 1997). Di Pulau Tioman, kepadatannya meningkat sejalan dengan jarak dari pemukiman. Hal ini mungkin berhubungan langsung dengan tekanan perburuan. Selain itu, 83\% dari pengamatan di pulau ini dilakukan di hutan primer dan hanya $17 \%$ saja di hutan sekunder dan perkebunan karet 9 (Miura \& Idris 1999).

Hubungan antar spesies Jumlahnya terlihat lebih berlimpah dibandingkan T. javanicus yang hidup di wilayah yang sama (sympatric) di hutan primer. Tetapi di hutan sekunder, dominasi ini terbalik dan T. napu kelimpahannya kurang dari kelimpahan T. javanicus. Setelah 12 tahun setelah (pasca) penebangan, T. napu kembali mendominasi (Heydon 1994).

Status konservasi Tidak terdaftar dalam IUCN (2002). Tidak terdaftar dalam CITES (ARCBD 2002). Dilindungi di Indonesia (PHPA 1996b). 


\section{Kijang Kuning Muntiacus atherodes}

Taksonomi). Jumlah spesies dalam genus ini antara 8 hingga 10, sementara tidak ada subspesies yang telah dideskripsikan.

Penyebaran global Endemik Borneo (Groves \& Grubb 1982

Status populasi dan kepadatannya di Borneo Ukuran kelompok 1,60 individu/ kelompok (Groves \& Grubb 1982).

Keberadaan di pulau kecil di Asia Tenggara Tidak diketahui hidup di pulau lepas pantai $(\mathrm{n}=0)$ (Meijaard 2003b).

Umur Genus/spesies 6,0 Jt/5,0 Jt.

Habitat (Payne et al. 1985). Lebih mendominasi hutan pegunungan bawah dan daerah pesisir dibandingkan dengan M. muntjak (Payne et al. 1985).

Aktivitas Diurnal dan nokturnal. Aktivitas di siang hari dan malam hari di alam telah dilaporkan (Nowak 1999). Utamanya aktif pada siang hari, dan berkurang sesaat sebelum matahari terbit (yang terdingin) (Heydon 1994). Betinanya berpasangan sebanyak 59,9\% dari waktunya, dan kijang yang menyendiri terhitung 29,1\% waktunya (Heydon 1994), terutama yang jantan dan yang betina berpasangan (Heydon 1994).

Pergerakan dan migrasi Ukuran wilayah jelajah antara jantan dan betina dewasa sama, dan tumpang tindih antara keduanya (Heydon 1994). Perkiraan jarak harian yang ditempuh oleh jantan dewasa adalah 6,47 $\mathrm{km}$ dan betina 5,92 km (Heydon 1994).

Ekologi pencarian makan Pemakan buah yang generalis/browser, mengandalkan buah yang jatuh (Ahmad 1994. Heydon 1994). Sering terlihat memakan buah yang dijatuhkan oleh pemakan buah arboreal (Heydon 1994). Diduga sebagai pemakan biji-bijian (Heydon 1994). Mempunyai jelajah yang luas, memakan "buah-buahan primata' 'buah-buahan burung', 'buah-buahan kelelawar' dan buah yang disebarkan oleh angin (Heydon 1994). Memakan buah dari 17 famili tumbuhan (Heydon 1994). Juga memakan biji Dipterokarpa (Heydon 1994).

Ekologi perkembangbiakan Hidup dalam pasangan stabil dan monogami (Heydon 1994). Geist (1998) mengungkapkan bahwa dibandingkan dengan $M$. muntjak, $M$. atherodes lebih memilih sistem pertahanan teritori yang lebih primitif di daerah yang produktif dan lebih menyendiri, agresif, dengan tanduk yang lebih kecil yang lebih berguna untuk menusuk dibandingkan untuk berkelahi.

Degradasi dan hilangnya habitat Tebang pilih terlihat memberikan sedikit pengaruh negatif terhadap kepadatan populasi kijang ini (Heydon 1994).

Hubungan antar spesies Meskipun $M$. atherodes hidup berdampingan dalam wilayah yang sama dengan $M$. muntjak (sympatric) di hutan dataran rendah, spesies ini merupakan spesies yang lebih umum ditemui $(83,1 \%)$. Namun demikian, perbedaan kelimpahan kedua spesies ini tidak terlalu nyata di hutan tebang pilih (53,1\%) (Heydon 1994).

Status konservasi Tidak terdaftar dalam IUCN (2002). Tidak terdaftar dalam CITES (ARCBD 2002). Meskipun dinyatakan endemik namun tidak dilindungi di Indonesia, tidak seperti M. muntjac yang populasinya lebih tersebar (PHPA 1996b). 


\section{Kijang Muncak Muntiacus muntjak}

Taksonomi Jumlah spesies dalam genus ini adalah antara 8 dan 10 .

Penyebaran global Pakistan bagian timur laut, India dan Nepal hingga Cina bagian selatan, Lao, Thai, Myanmar, Kambodia dan Vietnam, Semenanjung Malaya dan sejumlah pulau kecil di dekatnya, Kepulauan Riau, Sri Lanka, Hainan, Sumatera dan Kepulauan Nias ke arah barat, Bangka, Belitung, Jawa, Bali, dan Borneo (Nowak 1999).

Status populasi dan kepadatannya di Borneo Rata-rata ukuran kelompok 1,35 individu (Heydon 1994).

Keberadaan di pulau kecil di Asia Tenggara Bangka, Bintan, Lingga, Belitung, Galang, Nias, Panaitan, Singapura, Bali, Bawal, Chang, Kangean, Karimum Jawa, Mata Siri, Mesan dan Pangkor $(\mathrm{n}=16)$ (Meijaard 2003b).

Umur Genus/spesies $6.0 \mathrm{Jt} / 1.0 \mathrm{Jt}$.

Habitat. Hutan primer. Tetapi di luar Borneo dapat juga hidup di tipe hutan yang lebih terbuka dan padang rumput.

Aktivitas Paling sering diamati sebagai individu yang menyendiri $(50,6 \%$ dari pengamatan). Pasangan betina dewasa terhitung hanya $43,0 \%$ dari pengamatan (Heydon 1994).

Pergerakan dan migrasi Pendugaan sementara berdasarkan betina di Jawa mengungkapkan bahwa wilayah jelajahnya bisa sampai 6 ha (dilaporkan dalam Heydon 1994).

Ekologi pencarian makan Pemakan buah/pemakan rumput/tanaman bawah. Kemampuannya memanfaatkan rumput dan tanaman bawah untuk makanan dibandingkan $M$. atherodes bisa menjadi keunggulan kompetitifnya di lingkungan yang rusak.

Ekologi perkembangbiakan Masa kehamilan $=220$ hari (dilaporkan dalam Geist 1998).

Degradasi dan hilangnya habitat Tidak ada informasi.

Hubungan antar spesies Kurang umum dibanding M. atherodes di hutan dataran rendah (Heydon 1994). Lebih dominan dibandingkan dengan M. atherodes di hutan pegunungan dan perbukitan yang luas (Payne et al. 1985).

Status konservasi Tidak terdaftar dalam IUCN (2002). Tidak terdaftar dalam CITES (ARCBD 2002). Dilindungi di Indonesia (PHPA 1996b).

\section{Rusa Sambar Cervus unicolor}

Taksonomi Ada Sekitar 11 spesies dalam genus (Pitra et al. 2004), dan 3 subspesies dalam spesies (Corbet \& Hill 1992).

Penyebaran global India dan Nepal ke Cina bagian selatan (Yunnan, Sichuan, Guangdong), Lao, Thai, Myanmar, Kambodia dan Vietnam, Semenanjung Malaya dan sejumlah pulau di sekitarnya, Sri Lanka, Hainan, Sumatera, dan Borneo (Corbet $\&$ Hill 1992).

Status populasi dan kepadatannya di Borneo Tersebar luas di Borneo, meskipun dilaporkan menurun kondisinya di seluruh pulau (Meijaard per. obs.). Tidak ada nilai estimasi kepadatan populasinya untuk Borneo. Di India tropis bagian selatan, 3,64 \pm 
0,63 individu $/ \mathrm{km}^{2}$ (Jathanna et al. 2003). Di Thailand kepadatannya antara 1,0 dan 5,4 individu $/ \mathrm{km}^{2}$, dengan kepadatan yang lebih rendah di musim kering dibandingkan dengan musim hujan (Srikosamatara 1993). Di Sumatera bagian selatan antara 0,5 dan 2 individu/ $\mathrm{km}^{2}$ (O’Brien et al. 2003). Dengan mempertimbangkan kondisi daya dukung Borneo yang rendah (Meijaard 2003), kepadatan Rusa Sambar di Borneo diperkirakan lebih rendah dibandingkan pendugaan tersebut, yaitu lebih kecil dari 1 individu/ $\mathrm{km}^{2}$. Mencapai ketinggian $3.350 \mathrm{~m}$ dpl di Gunung Kinabalu.

Keberadaan di pulau kecil di Asia Tenggara Balembangan, Banggi, Bangka, Bedung, Bruit, Iyan, Jolo, Klum, Labuan, Lingung, Malawali, Moro Kecil, Padang, Palawan, Phangan, Tao, Tawitawi, dan Perhentian Barat $(n=18)$ (Meijaard 2003b).

Umur Genus/spesies 6.0 Jt/3.0 Jt.

Habitat Hidup di hutan Dipterokarpa dataran rendah dan hutan pegunungan bawah, juga di hutan rawa. Memasuki kebun dan perkebunan untuk makan (Payne et al. 1985). Juga terlihat di padang alang-alang (Imperata cylindrica) dan tidak pernah jauh dari sumber air (van Bemmel 1949-1950).

Aktivitas Aktif di malam hari, juga subuh (sebelum matahari terbit) dan menjelang petang (Yasuma \& Andau 2000).

Pergerakan dan migrasi Banks (1931) menyatakan bahwa Rusa Sambar bisa menjelajah dalam jarak yang cukup jauh, dan hanya jantan yang bersifat teritorial pada waktu-waktu tertentu dalam setahun. Tidak data ada tersedia tentang wilayah jelajah Rusa Sambar di daerah tropis.

Ekologi pencarian makan Makanannya terdiri dari rumput-rumputan, herba, berlukar, daun muda dan tumbuhan berkayu, serta buah-buahan yang jatuh ((Payne et al. 1985).

Ekologi perkembangbiakan Sody (1941) mencatat kelahiran Rusa Sambar pada bulan Mei dan Juni (Kotabumi, Sumatera), Oktober, November (Palembang, Sibolga, keduanya di Sumatera), dan sebagian besar antara bulan Mei dan September di Borneo. Sumber lain dalam van Bemmel (1949-1950) mengungkapkan bahwa sebagian besar kelahiran terjadi antara bulan Maret dan Juli, yaitu masa transisi dari musim kering ke musim hujan (Whitten et al. 1987). Birahi terjadi pada bulan Agustus (van Bemmel 1949-1950. Banks 1931). Umumnya hanya satu anak untuk setiap kelahiran.

Degradasi dan hilangnya habitat Hutan tebang pilih atau daerah bekas ladang di hutan terlihat meningkatkan kepadatan populasi spesies ini (Stuebing 1994).

Hubungan antar spesies Tidak ada informasi

Status konservasi Tidak terdaftar dalam IUCN (2002). Dilindungi di Indonesia (Noerdjito \& Maryanto 2001).

\section{Babi Berjenggot Sus barbatus}

Taksonomi Ada sekitar 10 spesies yang telah dideskripsikan dalam genus ini. Ada 2 subspesies yang dikenal (catatan bahwa subspesies Palawan tidak lagi dianggap berhubungan dekat dengan S. barbatus, Lucchini et al. in press).

Penyebaran global Semenanjung Malaysia, Sumatera, Borneo, di Palawan dan pulau-pulau yang berdekatan di Filipina; Di Malaysia terbatas pada sebagian kecil 
penyebaran historisnya. Masih tersebar luas namun menurun di Borneo (Caldecott et al. 1993).

Status populasi dan kepadatannya di Borneo Tersebar luas dan umum ditemukan di sebagian besar daerah hutan Borneo, meskipun populasinya menurun dengan cepat di daerah yang diburu secara berlebihan (Bennett et al. 1996, 1999).

Keberadaan di pulau kecil di Asia Tenggara Balabak, Balembangan, Banggi, Bangka, Batam, Bintan, Bruit, Burung, Durian, Galang, Jambongan, Juanta, Kundur, Malawali, Mapor, Molleangen, Panebangan, Pelapis, Sugi, dan Tebing Tinggi ( $\mathrm{n}=$ 20) (Meijaard 2003b).

Umur Genus/spesies 7.0 Jt/3.0 Jt.

Habitat Dapat ditemukan di seluruh habitat hutan dan jenis vegetasi di Kalimantan Barat. Babi Berjenggot Sumatera hidup di dataran rendah dan pegunungan. Banyak memanfaatkan komunitas pinggir sungai (MacKinnon et al. 1996). Di Sumatera, spesies ini lebih merupakan satwa hutan primer dibandingkan dengan Babi Celeng (Sus scrofa) yang menggunakan hutan sekunder dan hutan rusak (Meijaard 2000). Babi Celeng (Sus scrofa) sangat jarang ditemukan di alam Borneo dan mungkin sebagian terdiri dari populasi jenis feral; Hutan rawa gambut, rawa air tawar dan hutan pegunungan menyediakan sumber buah-buahan secara terus menerus di saat reproduksi tumbuhan (dan buah) secara massal tidak terjadi (Curran komunikasi pribadi).

Aktivitas Diurnal.

Pergerakan dan migrasi Pergerakan dalam skala besar biasanya terjadi saat hutan mengalami periode produksi buah yang bersamaan musimnya (Curran komunikasi pribadi). Spesies ini terutama berkolerasi dengan illipe nuts Shorea spp., dikenal sebagai tengkawang (Caldecott 1988). Bermigrasi secara massal dan tidak teratur (MacKinnon et al. 1996). Migrasi musiman dalam skala besar (ribuan ekor babi berpindah mencakup daerah yang luas) setelah musim buah pohon-pohon sumber makanan yang disukai (MacKinnon et al. 1996). Ada dua migrasi tahunan yang agak tetap (Pfeffer \& Caldecott dalam Meijaard 2000). Pergerakan harian bisa dilakukan di antara tempat pencarian makan dan beristirahat (Meijaard et al. 2000).

Ekologi pencarian makan Biji yang berminyak dari keluarga Fagaceae dan Dipterocarpaceae dianggap penting (Caldecott dalam Meijaard 2000, Curran komunikasi pribadi); terutama pohon spesies Castanopsis spp., Lithocarpus spp. dan Quercus spp. merupakan makanan yang paling disukai (Curran komunikasi pribadi). Satwa ini memakan akar, jamur, invertebrata dalam tanah dan kayu membusuk, vertebrata kecil, telur kura-kura, dan bangkai (Meijaard 2000). Tidak memakan Neesia spp., Bombacceae dan Ternstroemia magnifica (Curran komunikasi pribadi).

Ekologi perkembangbiakan Umur pertama kali hamil 10 - 20 bulan (Caldecott et al. 1993); masa kehamilan - 90 hingga 120 hari (Caldecott et al. 1993). Berkembang biak hanya pada periode ENSO/reproduksi tumbuhan massal dalam hutan (Curran komunikasi pribadi). Masa birahi bersamaan dengan musim berbunga dalam hutan dengan waktu yang terpusat dalam transisi antara pembentukan bunga akhir dan awal buah (Meijaard 2000). Jumlah anak bervariasi, tergantung pada massa badan 3-12 (Caldecott et al. 1993); jumlah anak saat melahirkan 6-8 (Curran komunikasi pribadi). Status nutrisi tertentu bisa diperoleh betina sebelum mereka 
siap (bereproduksi). Nilai indeks kegemukan betina hamil adalah 1,5 (Caldecott et al. 1993). Bersarang terutama pada hutan rawa air tawar dan hutan rawa gambut meskipun ditemukan sarang pada tumbuhan bawah di sejumlah habitat termasuk hutan bekas tebangan dan potongan belian/hutan sekunder (Curran komunikasi pribadi). Menyukai rotan dan rumput-rumputan (pakis Dicranopteris, dsb.) untuk membangun sarangnya. Atau pada puncak perbukitan dengan palem Sagu dan tegakan kayu keras yang berdekatan (R. Puri komunikasi pribadi).

Degradasi dan hilangnya habitat Tidak ada data.

Hubungan antar spesies Terpengaruh secara langsung oleh pengembangan lahan bagi pohon Dipterokarpa yang bertajuk dan ratusan spesies dari sejumlah famili tumbuhan lainnya (Curran et al. 1999, Curran \& Leighton 2000, Curran \& Webb 2000). Babi Berjenggot bisa berperan penting dalam penyebaran spesies tumbuhan Rafflesia spp. dengan mengambil biji tumbuhan tersebut dengan kukunya (MacKinnon et al. 1996). Diduga membantu penyebaran biji durian (Durio spp.) dengan memakan buah yang jatuh dan menyebarkan biji yang tidak tercerna ke seluruh hutan dalam fesesnya (Meijaard 2000) meskipun berdasarkan kajian sistem pencernaannya (Setyawati pers.comm) hal ini tidak dimungkinkan. Hampir sepenuhnya pemangsa biji (Curran komunikasi pribadi, Curran et al. 1999). Babi berjenggot beradaptasi terhadap hutan Dipterokarpa yang tidak terlalu produktif dan habitat 'nontepi'. Sementara Babi Celeng (S.Scrofa) beradaptasi terhadap habitat tepi yang lebih produktif. Di hutan yang rusak di Malaya dan Sumatera, bisa jadi Babi Celeng menggantikan Babi Berjenggot (Caldecott dalam Meijaard 2000).

Status konservasi Tidak terdaftar dalam IUCN (2002). Tidak terdaftar dalam CITES (ARCBD 2002). Tidak dilindungi di Indonesia (PHPA 1996b).

\section{Beruang Madu Ursus (Helarctos) malayanus}

Taksonomi Banyak pendapat yang berbeda mengenai status genus Helarctos, apakah akan dimasukkan ke dalam genus Ursus bersama beruang lain, sehingga genus Ursus akan terdiri dari 4 spesies. Saat ini, Beruang Madu terdaftar secara resmi oleh Kelompok Ahli Beruang, Komisi Kelangsungan Hidup Spesies IUCN (IUCN Species Survival Commission, the Bear Specialist Group), dan oleh CITES sebagai Helarctos malayanus. Penelitian belum lama ini mengenai ragam ukuran tengkorak di antara spesimen Beruang Madu mengungkapkan bahwa ras Borneo dari Beruang Madu mungkin merupakan subspesies tersendiri, yaitu Ursus malayanus euryspilus (Meijaard in press). Dalam hal ini populasi beruang madu yang lain adalah $U$. m. malayanus.

Penyebaran global Mulai dari perbukitan di India bagian timur laut, Sungai Brahmaputra bagian selatan (Choudhury 1997), Yunnan (Yi-Ching 1983), melalui Myanmar, Thailand, Laos, Vietnam, Kambodia, dan Semenanjung Malaysia, hingga pulau-pulau Sumatera dan Borneo (Santiapillai \& Santiapillai 1996, Servheen 1999). Populasinya cenderung berada di daerah kantung-kantung hutan berukuran kecil hingga sedang di wilayah penyebaran aslinya. Populasinya mungkin lebih besar di daerah Kambodia dan Myanmar, dan yang terbesar adalah di Borneo dan Sumatera.

Status populasi dan kepadatannya di Borneo Mungkin satu beruang $/ 4 \mathrm{~km}^{2} \mathrm{di}$ Sabah (Davies \& Payne 1982) dan 1,13-1,57 beruang/ $\mathrm{km}^{2}$ di Taman Nasional Taman 
Negara, Semenanjung Malaysia (Kawanishi 2002). Karena keterbatasan metodologi termasuk kesulitan mengenali individu beruang melalui foto perangkap kamera, petak sampel kecil, jumlah sampel yang kecil dan kelemahan lain yang diakui oleh penulis aslinya, kami tidak bisa mengandalkan pernyataan Kawanishi. Wilayah jelajah spesies ini di Sabah beragam antara 6,2- 20,6 km² dengan rata-rata $14,8 \mathrm{~km}^{2}$ (Wong 2002) dan $12-15 \mathrm{~km}^{2}$ di Kalimantan Timur bagian utara dan Sumatera bagian utara (Augeri 2002). Wilayah jelajah betina di Sungai Wain, Kalimantan Timur adalah sekitar 4-5 $\mathrm{km}^{2}$ (Fredriksson \& Wich in prep.). Tumpang tindih wilayah jelajah di Sabah beragam dari $0,54 \mathrm{~km}^{2}$ hingga $3,45 \mathrm{~km}^{2}$ (Wong 2002). Beruang Madu biasanya menyendiri, tetapi betinanya sering diamati bersama anak-anaknya, saudaranya, dan kadangkadang dalam kelompok yang terdiri dari sejumlah individu dan berkumpul pada lokasi dengan sumber makanan yang melimpah (Fredriksson pengamatan pribadi, L. Nyagang komunikasi pribadi).

Keberadaan di pulau kecil di Asia Tenggara Bangka, Bengkalis, Padang, dan Rupat $(\mathrm{n}=4)$ (Meijaard 2003b).

Umur Genus/spesies 4,0 Jt/2,7 Jt.

Habitat Konsentrasi kegiatan Beruang Madu terlihat di hutan Dipterokarpa dataran rendah dan perbukitan (Augeri 2002, Davies \& Payne 1982, Fredriksson \& Wich in prep.). Kisaran ketinggian dari 0 - $2.700 \mathrm{~m}$ (Augeri 2004a, b, Payne et al. 1985, R. Steinmetz komunikasi pribadi). Jarang memasuki hutan yang baru terbakar atau daerah bekas tebangan (Fredriksson \& Wich in prep., Augeri 2002).

Aktivitas Terutama diurnal di Sungai Wain, Kalimantan Timur (Fredriksson \& Wich in prep.), di Lembah Danum, Sabah (Wong 2002), dan di Semenanjung Malaysia (Kawanishi 2002). Pola aktivitas diurnal dan nokturnal diamati Kayan Mentarang, Bulungan, dan ekosistem Leuser (Augeri 2002, 2003). Kegiatan nokturnal diamati di daerah yang 'terganggu' seperti di sekitar perkebunan kelapa sawit (Nomura 2003) dan di beberapa lokasi di Sumatera diamati dengan berbagai kegiatan manusia (Griffiths \& van Schaik 1993).

Pergerakan dan migrasi Wilayah jelajah harian di Sungai Wain $8 \mathrm{~km}$ (dengan pola "zigzag") (Fredriksson \& Wich in prep.). Jarak garis lurus antara koordinat telemetri dari $141 \mathrm{~m}$ hingga $5.660 \mathrm{~m}$ (Wong 2002). Jarak garis lurus betina dan anaknya $11 \mathrm{~km}$ antara stasiun jerat kamera di Taman Nasional Gunung Leuser (Augeri in prep.). Beruang Madu mungkin tidak bermigrasi, namun bisa mengubah wilayah jelajahnya musiman dan tahunan tergantung pada ketersediaan makanan. Seperti pada masa berbuah lokal dan musiman atau episode reproduksi yang bersamaan di Borneo atau saat berpindah ke sumber makanan alternatif selama masa ketersediaan buah rendah (Augeri 2004a). Wilayah jelajah beruang betina sering tumpang tindih dengan induknya sementara jantannya menyebar ke wilayah jelajah yang baru, meskipun wilayah jelajah kedua gender dapat bertumpang tindih dengan beruang yang lain (Augeri in prep.).

Ekologi pencarian makan Pemakan segala (omnivora). Makanannya termasuk rayap, semut, kumbang, larva cacing tanah, sarang lebah (madu), satwa kecil, buahbuahan, jamur, tumbuhan berair, bunga (Lekagul \& McNeely 1977, Payne et al. 1985, Wong et al. 2002, Augeri 2002, 2003, Fredriksson \& Wich in prep.). Selain itu, spesies ini memakan ujung tanaman kelapa yang lembut (Meijaard 1999b), 
buah kelapa sawit (Nomura 2003), dan bagian yang lembut dari spesies Pandanus spp. (Fredriksson unpubl.). Memakan setidaknya 113 jenis buah yang ada di lokasi penelitian di Sungai Wain, yaitu buah dari famili Moraceae, Burseraceae, dan Myrtaceae yang umum ditemukan dalam makanannya di lokasi dataran rendah di Kalimantan Timur (Fredriksson \& Wich in prep.). Beruang Madu di Sungai Wain ditemukan makan dalam jumlah yang sangat banyak selama episode reproduksi spesies durian Durio spp., spesies nangka Artocarpus spp., dan Dacryodes spp. Spesies beringin (Ficus spp.) paling sering ditemukan dalam makanannya selama periode di antara dua periode puncak reproduksi/berbuah. Pohon buah yang dimakan beruang ini di Taman Nasional Kayan Mentarang yaitu dari faimli Dipterocarpaceae, Euphorbiaceae, Fagaceae, Lauraceae, Moraceae, Myrtaceae, dan Sapindaceae memiliki dbh rata-rata 44,82 $\mathrm{cm}$. Pola makan serupa diamati di MRF dengan dbh pohon $56,4 \mathrm{~cm}$ (Augeri in prep.). Ukuran dbh pohon yang dimanfaatkan Beruang Madu di Kayan Mentarang dan Malinau berkisar antara 7,96 - 416,36 cm. Buah-buahan dari famili Fagacea yang terdapat pada elevasi yang lebih tinggi lebih sering ditemukan dalam makanannya (Davies \& Payne 1982, Fredriksson \& Wich in prep., Augeri 2003), namun spesies ini diamati pula di ketinggian kurang dari $400 \mathrm{~m}$ dpl (Augeri 2002, 2003). Di lokasi penelitian Sungai Wain, sekitar 48 spesies rayap ditemukan dalam makanan Beruang Madu, selain sekitar 60 spesies semut (Fredriksson \& Wich in prep.) Wong (2002) menemukan sejumlah sumber makanan vertebrata dari 56 kotoran Beruang Madu. Makanan ini mencakup sisa Baning Coklat (Manouria emys), burung dan telur, reptil, ikan, dan sejumlah vertebrata kecil. Hanya 5 dari 1257 kotoran $(<0,5 \%)$ yang dikumpulkan oleh Fredriksson dan Wich (in prep.) di Kalimantan Timur tahun 1997 hingga 2002 berisi sisa potongan rambut dan tulang. Serupa dengan hal itu, data awal menunjukkan bahwa kurang dari 1\% kotoran yang diteliti oleh Augeri (in prep.) di Sumatera bagian utara dan Kalimantan Timur antara tahun 2000 -2003 mengandung sisa vertebrata.

Ekologi perkembangbiakan Betina bersama anak yang kecil diamati ada sepanjang tahun di Kalimantan. Hal ini menunjukkan bahwa reproduksinya tidak bergantung musim (Fredriksson \& Wich in prep.). Di kebun binatang, kelahiran dapat terjadi setiap saat dalam setahun (Nowak 1991). Masa kehamilan rata-rata antara 92 - 107 hari dilaporkan dari berbagai kebun binatang (Dathe 1970). Tiga kehamilan dilaporkan dari Kebun Binatang Fort Worth, selama 174, 228, dan 240 hari, karena keterlambatan perkawinan (McKuster 1974, diacu dalam Nowak 1991), yang umum terjadi pada spesies beruang yang lain. Umur kedewasaan seksual: birahi diamati terjadi pada umur 3 tahun, tetapi pertama kali melahirkan terjadi pada umur 5 tahun (C. Fredericks komunikasi pribadi, L. Kolter komunikasi pribadi). Jarak antar kelahiran: ada satu laporan tentang dua kelahiran dari satu betina dalam satu tahun (contoh kebun binatang) dan mampu untuk cepat hamil kembali saat betina ini kehilangan anaknya (Dathe 1970). Induk biasanya menunggu hingga anak disapih dan cukup besar sebelum bunting kembali. Umumnya satu anak, meskipun kadangkadang diamati pula ada dua anak (Fredriksson pengamatan pribadi, L. Kolter komunikasi pribadi, Nowak 1999). Saat lahir, berat rata-rata anak sebesar 325 gram (Nowak 1991). Penduduk setempat melaporkan bahwa Beruang Madu melahirkan anaknya di batang kayu berongga atau rongga alami lainnya yang aman pada dasar 
pohon yang besar. Anak yang baru lahir ditemukan dalam batang kayu di Sungai Wain setelah induknya lari karena adanya gangguan manusia (Fredriksson unpubl.).

Degradasi dan hilangnya habitat Ancaman utama di Sumatera dan Kalimantan adalah hilangnya habitat (Augeri 2001, Santiapillai \& Santiapillai 1996, Servheen 1999), yang menyebabkan terbatasnya pergerakan dan berubahnya perilaku pencarian makannya, penurunan akses kepada habitat dan makanan utamanya, serta populasinya terpecah-pecah (Augeri 2003). Beruang Madu juga diburu di seluruh wilayah jelajahnya untuk dimakan, diambil bagian-bagian badannya, dan untuk obatobatan serta kosmetika. Beruang muda diambil dari induknya untuk diperdagangkan atau dijual sebagai hewan peliharaan. Perdagangan Beruang Madu masih rendah di Indonesia, meskipun kondisi ini bisa berubah dengan cepat dalam waktu dekat saat beruang di alam menjadi langka (Meijaard 1999a, 2001a, Servheen 1999).

Hubungan antar spesies Burung yang hidup di tanah tertentu kadang-kadang mengikuti Beruang Madu saat mencari rayap (Fredriksson pengamatan pribadi). Selain manusia, sedikit saja pemangsa Beruang Madu. Seekor Ular Sanca mematikan dan memakan seekor Beruang Madu dewasa di Sungai Wain, Kalimantan Timur (Fredriksson unpubl.), namun frekuensi seperti kejadian itu belum pasti. Selama penelitian harimau di Taman Negara, Semenanjung Malaysia, Kawanishi (2002) menemukan satu kerangka Beruang Madu yang mungkin dibunuh oleh harimau dan kotoran harimau yang mengandung sisa tubuh Beruang Madu. Namun sekali lagi, frekuensi interaksi seperti ini tidak diketahui. Setidaknya harimau dan macan dianggap antagonistik saat bertemu dengan Beruang Madu (Augeri 2001). Beruang Madu merupakan agen penyebar biji yang penting (Augeri 2002, Fredriksson unpubl., McConkey \& Galleti 1999, Wong 2002), terutama pohon berbiji besar (Durian (Durio spp.) Nangka (Artocarpus integer), Dacryodes rugosa) (Fredriksson \& Wich in prep.). Beruang Madu juga aktif dalam mengatur populasi serangga, seperti memangsa koloni rayap dan semut (Augeri 2002, 2003, Fredriksson pengamatan pribadi). Sebagai contoh, di Sungai Wain, ada sekitar 300 sarang yang aktif/ha dari satu spesies rayap sementara rata-rata 300 sarang/ha digali dan dirusak oleh beruang (Fredriksson unpubl.). Sebagai pesaing yang tidak langsung dan agonistik, Beruang Madu juga dapat mempengaruhi distribusi dan/atau kegiatan pencarian makan sejumlah spesies pesaing seperti Trenggiling Peusing (Manis javanica), dengan mempengaruhi ketersediaan dan penyebaran sarang rayap yang hidup (Augeri 2003).

Status konservasi Dilindungi di Indonesia sejak 1973. Terdaftar pada Appendix I CITES sejak 1979. Dianggap Rentan (Vulnerable) oleh IUCN Red List of Threatened Animals (IUCN 2003) dan yang paling kini adalah mandat IUCN Bear Specialist Group (Garshelis \& McLellan 2004). 


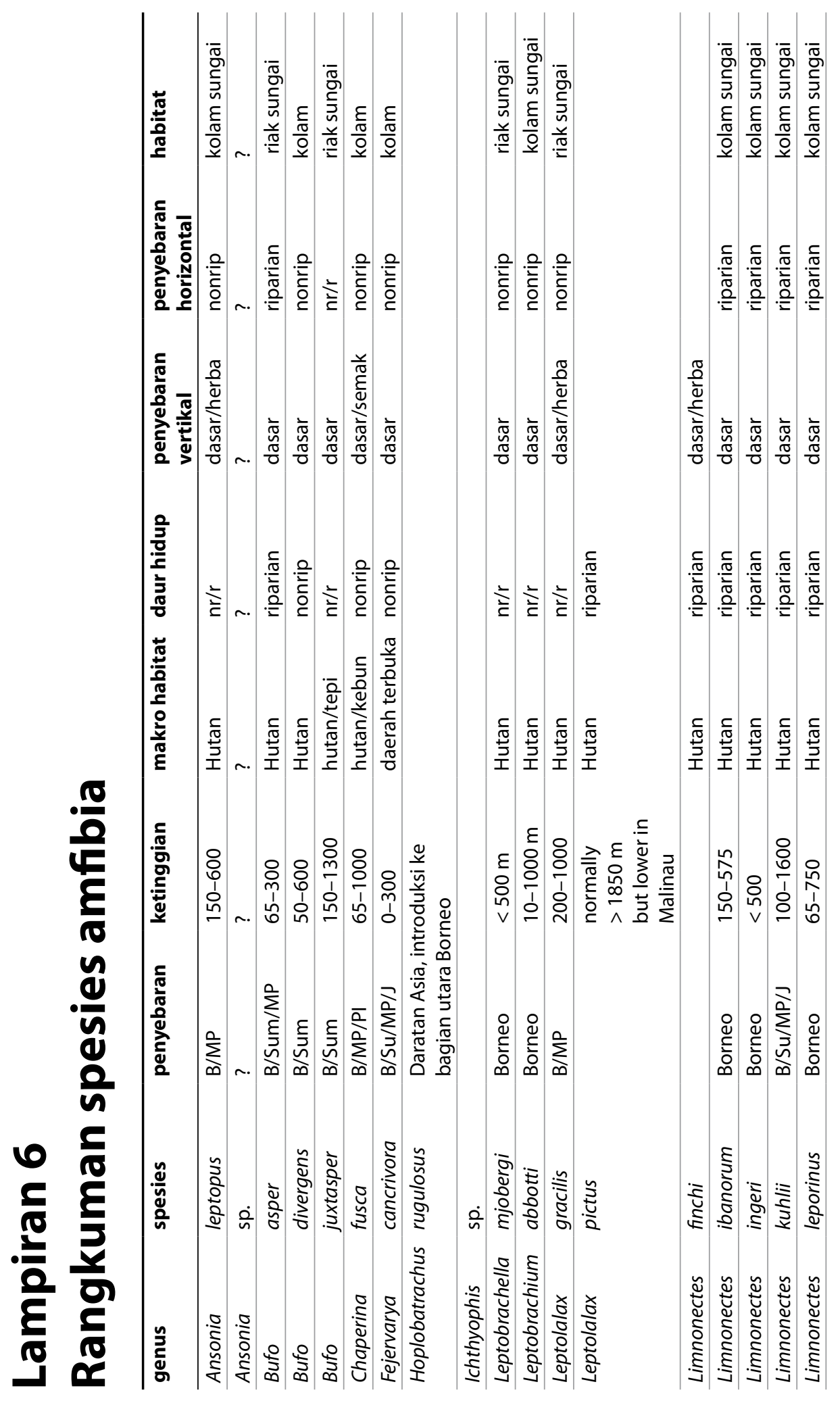




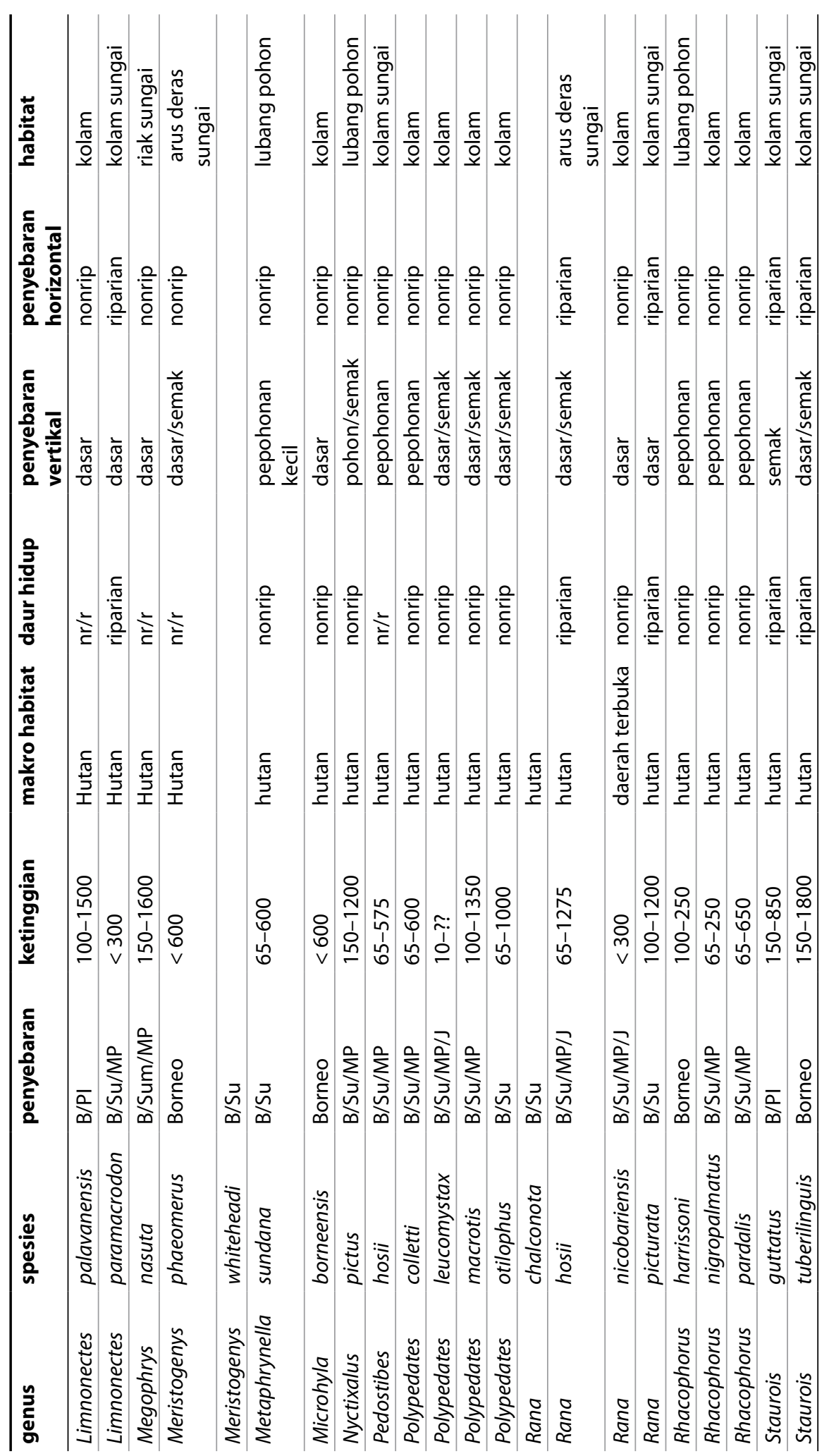




\section{Lampiran 7}

\section{Rangkuman spesies reptil}

\begin{tabular}{|c|c|c|c|c|}
\hline Spesies & Habitat makro & Makanan & $\begin{array}{l}\text { Distribusi } \\
\text { vertikal }\end{array}$ & $\begin{array}{l}\text { Pemanfaatan } \\
\text { oleh penduduk }\end{array}$ \\
\hline $\begin{array}{l}\text { Acrochordus } \\
\text { javanicus }\end{array}$ & Akuatik (Perairan) & ikan & akuatik & tidak dimakan \\
\hline Ahaetulla prasina & $\begin{array}{l}\text { hutan dataran } \\
\text { rendah dan hutan } \\
\text { pegunungan } \\
\text { primer }\end{array}$ & $\begin{array}{l}\text { kadal, katak } \\
\text { pohon }\end{array}$ & $\begin{array}{l}\text { arboreal, tingkat } \\
\text { bawah }\end{array}$ & \\
\hline $\begin{array}{l}\text { Amyda } \\
\text { cartilaginea }\end{array}$ & akuatik (Perairan) & ikan & akuatik & $\begin{array}{l}\text { diburu untuk } \\
\text { makanan dan } \\
\text { perdagangan } \\
\text { satwa hidup }\end{array}$ \\
\hline Boiga cynodon & $\begin{array}{l}\text { hutan dataran } \\
\text { rendah }\end{array}$ & $\begin{array}{l}\text { burung dan telur } \\
\text { burung }\end{array}$ & arboreal & \\
\hline $\begin{array}{l}\text { Boiga } \\
\text { dendrophila }\end{array}$ & dekat sungai & mamalia, burung & arboreal & $\begin{array}{l}\text { diambil untuk } \\
\text { diperdagangkan }\end{array}$ \\
\hline Boiga jaspidea & $\begin{array}{l}\text { biasanya arboreal, } \\
\text { di tingkat bawah }\end{array}$ & kadal, katak & $\begin{array}{l}\text { arboreal, tingkat } \\
\text { bawah }\end{array}$ & \\
\hline Boiga nigriceps & $\begin{array}{l}\text { cabang di atas } \\
\text { sungai }\end{array}$ & $\begin{array}{l}\text { burung kecil, } \\
\text { kadal, kadang } \\
\text { tikus kecil }\end{array}$ & arboreal & $\begin{array}{l}\text { diambil untuk } \\
\text { diperdagangkan }\end{array}$ \\
\hline $\begin{array}{l}\text { Bronchocela } \\
\text { cristatella }\end{array}$ & $\begin{array}{l}\text { hutan dataran } \\
\text { rendah dan } \\
\text { pegunungan, dan } \\
\text { lahan kebun }\end{array}$ & serangga kecil & $\begin{array}{l}\text { arboreal, tingkat } \\
\text { bawah }\end{array}$ & \\
\hline $\begin{array}{l}\text { Bungarus } \\
\text { flaviceps }\end{array}$ & $\begin{array}{l}\text { hutan hujan } \\
\text { primer dan } \\
\text { sekunder }\end{array}$ & mamalia kecil & terestrial & $\begin{array}{l}\text { dimakan dan } \\
\text { diburu untuk } \\
\text { kulitnya }\end{array}$ \\
\hline Calamaria bicolor & Daun yang luruh & $\begin{array}{l}\text { cacing tanah } \\
\text { atau rayap }\end{array}$ & semi-fossorial & \\
\hline
\end{tabular}




\begin{tabular}{|c|c|c|c|c|}
\hline Spesies & Habitat makro & Makanan & $\begin{array}{l}\text { Distribusi } \\
\text { vertikal }\end{array}$ & $\begin{array}{l}\text { Pemanfaatan } \\
\text { oleh penduduk }\end{array}$ \\
\hline Calamaria sp. 1 & Daun yang luruh & $\begin{array}{l}\text { cacing tanah } \\
\text { atau rayap }\end{array}$ & semi-fossorial & \\
\hline $\begin{array}{l}\text { Chrysopelea } \\
\text { paradisii }\end{array}$ & hutan primer & $\begin{array}{l}\text { kadal kecil, } \\
\text { kadang-kadang } \\
\text { katak }\end{array}$ & arboreal & \\
\hline $\begin{array}{l}\text { Cosymbotus } \\
\text { platyurus }\end{array}$ & $\begin{array}{l}\text { dekat } \\
\text { pemukiman }\end{array}$ & serangga & & \\
\hline $\begin{array}{l}\text { Crocodylus } \\
\text { porosus }\end{array}$ & Akuatik (Perairan) & $\begin{array}{l}\text { mamalia kecil, } \\
\text { ikan, reptil }\end{array}$ & dekat sungai & $\begin{array}{l}\text { diburu untuk } \\
\text { kulit dan } \\
\text { makanan }\end{array}$ \\
\hline Cyclemys dentata & $\begin{array}{l}\text { sungai dangkal } \\
\text { berbatu di hutan }\end{array}$ & tumbuhan, buah & semi-akuatik & dimakan \\
\hline $\begin{array}{l}\text { Cylindrophis } \\
\text { ruffus }\end{array}$ & Riparian & ular & fossorial & \\
\hline $\begin{array}{l}\text { Cyrtodactylus } \\
\text { malayanus }\end{array}$ & $\begin{array}{l}\text { kebanyakan di } \\
\text { daerah berhutan, } \\
\text { dekat tanggul } \\
\text { sungai }\end{array}$ & serangga & $\begin{array}{l}\text { arboreal, tingkat } \\
\text { bawah }\end{array}$ & \\
\hline $\begin{array}{l}\text { Dendrelaphis } \\
\text { caudolineatus }\end{array}$ & $\begin{array}{l}\text { dari hutan primer } \\
\text { hingga daerah } \\
\text { yang rusak }\end{array}$ & kadal, katak & $\begin{array}{l}\text { arboreal, tetapi } \\
\text { bergerak di atas } \\
\text { tanah }\end{array}$ & \\
\hline $\begin{array}{l}\text { Dendrelaphis } \\
\text { formosus }\end{array}$ & $\begin{array}{l}\text { umum di vegetasi } \\
\text { di tanggul sungai }\end{array}$ & kadal kecil, katak & $\begin{array}{l}\text { arboreal, tetapi } \\
\text { bergerak di atas } \\
\text { tanah }\end{array}$ & \\
\hline Draco cornutus & $\begin{array}{l}\text { dekat } \\
\text { pemukiman }\end{array}$ & semut, rayap & arboreal & \\
\hline $\begin{array}{l}\text { Elaphe } \\
\text { flavolineata }\end{array}$ & $\begin{array}{l}\text { dari hutan primer } \\
\text { hingga daerah } \\
\text { yang terganggu }\end{array}$ & $\begin{array}{l}\text { mamalia kecil, } \\
\text { burung, katak, } \\
\text { kadal }\end{array}$ & terestrial & \\
\hline Enhydris doriae & $\begin{array}{l}\text { berlimpah di } \\
\text { sawah atau kolam }\end{array}$ & ikan & akuatik & \\
\hline Gekko smithi & $\begin{array}{l}\text { batang pohon } \\
\text { yang besar di } \\
\text { hutan primer dan } \\
\text { sekunder }\end{array}$ & serangga & arboreal & \\
\hline $\begin{array}{l}\text { Gonocephalus } \\
\text { grandis }\end{array}$ & $\begin{array}{l}\text { hutan tepi sungai, } \\
\text { hutan sekunder, } \\
\text { dekat sungai }\end{array}$ & serangga & arboreal & \\
\hline $\begin{array}{l}\text { Gonyosoma } \\
\text { oxycephalum }\end{array}$ & biasanya arboreal & $\begin{array}{l}\text { katak, kadal, } \\
\text { mungkin juga } \\
\text { pengerat kecil } \\
\text { burung }\end{array}$ & $\begin{array}{l}\text { arboreal, } \\
\text { terestrial }\end{array}$ & \\
\hline $\begin{array}{l}\text { Heosemys } \\
\text { spinosa }\end{array}$ & $\begin{array}{l}\text { Akuatik, semi- } \\
\text { akuatik, juga di } \\
\text { pedalaman hutan }\end{array}$ & buah busuk & terrestrial & \\
\hline
\end{tabular}




\begin{tabular}{|c|c|c|c|c|}
\hline Spesies & Habitat makro & Makanan & $\begin{array}{l}\text { Distribusi } \\
\text { vertikal }\end{array}$ & $\begin{array}{l}\text { Pemanfaatan } \\
\text { oleh penduduk }\end{array}$ \\
\hline $\begin{array}{l}\text { Lepturophis } \\
\text { albofuscus }\end{array}$ & $\begin{array}{l}\text { biasanya hutan } \\
\text { dataran rendah }\end{array}$ & $\begin{array}{l}\text { amfibia kecil dan } \\
\text { kadal }\end{array}$ & terrestrial & \\
\hline $\begin{array}{l}\text { Lipinia } \\
\text { quadrivittata }\end{array}$ & $\begin{array}{l}\text { biasanya dalam } \\
\text { pepohonan } \\
\text { yang besar di } \\
\text { hutan primer dan } \\
\text { sekunder, sering } \\
\text { di daerah yang } \\
\text { sedikit terbuka, } \\
\text { dataran rendah }\end{array}$ & serangga kecil & arboreal & \\
\hline Mabuya rudis & $\begin{array}{l}\text { umum di daerah } \\
\text { rusak }\end{array}$ & serangga & & dimakan di lokasi \\
\hline Manouria emys & $\begin{array}{l}\text { biasanya di hutan } \\
\text { perbukitan }\end{array}$ & $\begin{array}{l}\text { tumbuhan, } \\
\text { jamur, buah }\end{array}$ & terestrial & \\
\hline $\begin{array}{l}\text { Maticora } \\
\text { bivirgata }\end{array}$ & $\begin{array}{l}\text { galian dalam } \\
\text { tanah dan humus }\end{array}$ & reptil kecil & semi-fossorial & \\
\hline $\begin{array}{l}\text { Maticora } \\
\text { intestinalis }\end{array}$ & $\begin{array}{l}\text { hutan dataran } \\
\text { rendah dan } \\
\text { perbukitan } \\
\text { hingga } \\
\text { pemukiman }\end{array}$ & cacing, rayap & fossorial & $\begin{array}{l}\text { dimakan untuk } \\
\text { obat }\end{array}$ \\
\hline Naja sumatrana & $\begin{array}{l}\text { hutan hingga } \\
\text { daerah terbuka }\end{array}$ & mamalia kecil & terestrial & \\
\hline $\begin{array}{l}\text { Notochelys } \\
\text { platynota }\end{array}$ & hutan perbukitan & $\begin{array}{l}\text { buah buahan, } \\
\text { daun }\end{array}$ & terestrial & $\begin{array}{l}\text { sering diburu } \\
\text { untuk makanan }\end{array}$ \\
\hline Oligodon sp. 1 & daun luruh & reptil telur & terestrial & \\
\hline Oligodon sp. 2 & $?$ & $?$ & $?$ & \\
\hline $\begin{array}{l}\text { Oligodon } \\
\text { purpurascens }\end{array}$ & $\begin{array}{l}\text { dataran rendah } \\
\text { tidak selalu di } \\
\text { daerah berhutan }\end{array}$ & $\begin{array}{l}\text { kebanyakan } \\
\text { makan kadal } \\
\text { telur }\end{array}$ & $\begin{array}{l}\text { terestrial, } \\
\text { mungkin } \\
\text { semifossorial }\end{array}$ & \\
\hline $\begin{array}{l}\text { Ophiophagus } \\
\text { hannah }\end{array}$ & $\begin{array}{l}\text { hutan hujan } \\
\text { primer, } \\
\text { kadangkala di } \\
\text { daerah terbuka }\end{array}$ & Ular & terestrial & $\begin{array}{l}\text { dimakan, bisa } \\
\text { digunakan untuk } \\
\text { racun }\end{array}$ \\
\hline Orlitia borneensis & $\begin{array}{l}\text { dataran rendah, } \\
\text { sungai besar, } \\
\text { estuaria }\end{array}$ & $\begin{array}{l}\text { daun, buah, biji } \\
\text { berukuran besar }\end{array}$ & semi-akuatik & $\begin{array}{l}\text { Ditangkap untuk } \\
\text { diperdagangkan }\end{array}$ \\
\hline $\begin{array}{l}\text { Pelochelys } \\
\text { cantorii }\end{array}$ & $\begin{array}{l}\text { dataran rendah } \\
\text { dan pesisir, } \\
\text { sungai besar, } \\
\text { estuaria }\end{array}$ & Ikan & akuatik & $\begin{array}{l}\text { dieksploitasi } \\
\text { untuk makanan }\end{array}$ \\
\hline
\end{tabular}




\begin{tabular}{|c|c|c|c|c|}
\hline Spesies & Habitat makro & Makanan & $\begin{array}{l}\text { Distribusi } \\
\text { vertikal }\end{array}$ & $\begin{array}{l}\text { Pemanfaatan } \\
\text { oleh penduduk }\end{array}$ \\
\hline $\begin{array}{l}\text { Psammodynastes } \\
\text { pulverulentus }\end{array}$ & $\begin{array}{l}\text { daun luruh, hutan } \\
\text { tingkat bawah }\end{array}$ & $\begin{array}{l}\text { kadal kecil, } \\
\text { jarang katak }\end{array}$ & tingkat bawah & \\
\hline $\begin{array}{l}\text { Pseudorhabdion } \\
\text { cf. sarawakensis }\end{array}$ & daun luruh & $\begin{array}{l}\text { cacing kecil, } \\
\text { serangga }\end{array}$ & terestrial & \\
\hline $\begin{array}{l}\text { Pseudorhabdion } \\
\text { collaris }\end{array}$ & $\begin{array}{l}\text { hutan tropis } \\
\text { dataran rendah }\end{array}$ & Cacing tanah & semi-fossorial & \\
\hline Ptyas fuscus & $\begin{array}{l}\text { semak, hutan, } \\
\text { juga daerah } \\
\text { terbuka }\end{array}$ & $\begin{array}{l}\text { tikus, burung, } \\
\text { katak, ular kecil }\end{array}$ & terestrial & \\
\hline Python curtus & $\begin{array}{l}\text { langka di hutan, } \\
\text { berlimpah di } \\
\text { perkebunan }\end{array}$ & mamalia kecil & semi-fossorial & $\begin{array}{l}\text { dimakan secara } \\
\text { lokal }\end{array}$ \\
\hline Python reticulatus & $\begin{array}{l}\text { sering terlihat di } \\
\text { tanggul sungai }\end{array}$ & $\begin{array}{l}\text { amfibia, reptil, } \\
\text { burung, mamalia } \\
\text { besar dan kecil }\end{array}$ & arboreal & $\begin{array}{l}\text { dimakan } \\
\text { secara lokal } \\
\text { dan digunakan } \\
\text { untuk tujuan } \\
\text { pengamatan }\end{array}$ \\
\hline $\begin{array}{l}\text { Ramphotyphlops } \\
\text { braminus }\end{array}$ & daun luruh & Cacing & fossorial & \\
\hline $\begin{array}{l}\text { Sphenomorphus } \\
\text { sabanus }\end{array}$ & $\begin{array}{l}\text { terutama hutan } \\
\text { hujan oerimer } \\
\text { pada ketinggian } \\
\text { medium }\end{array}$ & $?$ & $\begin{array}{l}\text { terestrial pada } \\
\text { dasar hutan }\end{array}$ & \\
\hline $\begin{array}{l}\text { Takydromus } \\
\text { sexlineatus }\end{array}$ & $\begin{array}{l}\text { daerah terbuka } \\
\text { seperti padang } \\
\text { rumput }\end{array}$ & serangga kecil & & \\
\hline $\begin{array}{l}\text { Trimeresurus } \\
\text { albolabris }\end{array}$ & semak, hutan & $\begin{array}{l}\text { pengerat kecil } \\
\text { burung, kadang } \\
\text { kadal kecil }\end{array}$ & $\begin{array}{l}\text { biasanya } \\
\text { arboreal, tingkat } \\
\text { bawah }\end{array}$ & \\
\hline $\begin{array}{l}\text { Tropidolaemus } \\
\text { wagleri }\end{array}$ & semak, hutan & $\begin{array}{l}\text { burung, } \\
\text { pengerat } \\
\text { arboreal }\end{array}$ & $\begin{array}{l}\text { arboreal, tingkat } \\
\text { bawah }\end{array}$ & $\begin{array}{l}\text { dimakan, bisa } \\
\text { untuk anak } \\
\text { panah }\end{array}$ \\
\hline $\begin{array}{l}\text { Tropidophorus } \\
\text { brookei }\end{array}$ & $\begin{array}{l}\text { kolam dan } \\
\text { tanggul sungai }\end{array}$ & serangga & & \\
\hline Varanus rudicollis & $\begin{array}{l}\text { sering jauh dari } \\
\text { sungai, hutan } \\
\text { dataran rendah } \\
\text { dan perbukitan } \\
\text { primer }\end{array}$ & $\begin{array}{l}\text { burung, mamalia } \\
\text { kecil, amfibia, } \\
\text { reptil }\end{array}$ & $\begin{array}{l}\text { biasanya } \\
\text { arboreal }\end{array}$ & $\begin{array}{l}\text { kadang diburu } \\
\text { untuk makanan }\end{array}$ \\
\hline Varanus salvator & dekat sungai & $\begin{array}{l}\text { burung, mamalia } \\
\text { kecil, amfibia, } \\
\text { reptil }\end{array}$ & & $\begin{array}{l}\text { diburu untuk } \\
\text { makanannya }\end{array}$ \\
\hline
\end{tabular}




\section{Lampiran 8}

\section{Laporan spesies ikan dari MRF}

Daftar spesies dari Rachmatika et al. 2005.

\begin{tabular}{ll}
\hline Nama lokal & Nama ilmiah \\
\hline Sidat Kalimantan (Ind.) Telakai & Anguilla malgumora \\
\hline Sidat (Ind.) Telakai & Anguilla nebulosa \\
\hline Merap, Salap Putih (Kenyah), Alap (Punan) & Barbodes cf. balleroides \\
\hline Hala (Merap, Salap Putih (Kenyah), Alap (Punan) & Barbodes sp. \\
\hline Madang (Kenyah) & Betta unimaculata \\
\hline Lele (Ind.) Tun (Merap), Kati (Kenyah), Utet (Punan) & Claris anfractus \\
\hline Turui (Merap), Turing (Kenyah), Turing (Punan) & Cyclocheilichthys armatus \\
\hline Turui (Merap), Turing (Kenyah), Turing (Punan) & Cyclocheilichthys repasson \\
\hline Tunjungan(Ind.) Paha (Merap), Lemak, Tulem (Kenyah), & Garra borneensis \\
Ruam (Punan) & \\
\hline Kat (Merap), Leket (Kenyah), Leket (Punan) & Gastromyzon lepidogaster \\
\hline Kat (Merap), Leket (Kenyah), Leket (Punan) & Gastromyzon sp. \\
\hline Kuyung (Merap), Kuyut, Kiung (Kenyah), Kuyun (Punan) & Glyptothorax platypogonoides \\
\hline Lungau (Merap), Buleng (Kenyah), Sunau (Punan) & Hampala macrolepidota \\
\hline Kat Blow (Merap), Leket Bulo (Kenyah), Rungan (Punan) & Homaloptera stephensoni \\
\hline Hanyan (Merap), Sayen (Kenyah), Anyen (Punan) & Leptobarbus melanotaenia \\
\hline Paha (Merap), Pasa (Kenyah), Pa/Neha (Punan) & Lobocheilos cf. bo \\
\hline Lucau (Merap, Kenyah, Punan) & Leiocassis spp. \\
\hline Lan Kuai (Merap), Telan Kuai (Kenyah), La Kuai (Punan) & Mastacembelus unicolor \\
\hline
\end{tabular}




\begin{tabular}{|c|c|}
\hline Nama lokal & Nama ilmiah \\
\hline Lan Kuai (Merap), Telan Kuai (Kenyah), La Kuai (Punan) & Mastacembelus cf. maculates \\
\hline Tikien (Merap), Teliken, Bala (Kenyah), Cike (Punan) & Hemibagrus cf. nemurus \\
\hline Tikien (Merap), Teliken, Bala (Kenyah), Cike (Punan) & Hemibagrus baramensis \\
\hline Kat Blow (Merap), Leket Bulo (Kenyah), Leket (Punan) & Neogastromyzon nieuwenhuisi \\
\hline Lelapeh (Merap), Lepeh (Kenyah), Cipih (Punan) & Nematabramis everetti \\
\hline Tao (Merap), Lanya (Kenyah) & Nemacheilus saravacensis \\
\hline Tao (Merap), Lanya (Kenyah) & Nemacheilus spiniferus \\
\hline Tao (Merap), Lanya (Kenyah) & Nemacheilus selangoricus \\
\hline Lao (Merap), Lao (Kenyah), Tulako (Punan) & Ompok cf. bimaculatus \\
\hline Gurami (Ind.) Kaloi (Merap), Kaloh (Kenyah), Kaluh (Punan) & Osphronemus septemfasciatus \\
\hline Pao (Merap), Lemak (Kenyah), Pa (Punan) & Osteochilus waandersii \\
\hline $\begin{array}{l}\text { Kuanmie (Merap), Betutu Banga (Kenyah), Betutung } \\
\text { (Punan) }\end{array}$ & Puntius binotatus \\
\hline Lungo (Merap), Betutung (Kenyah), Betutung (Punan) & Puntius sealei \\
\hline Hala (Merap), Kuamenyi (Kenyah), Bunau (Punan) & Puntius spp. \\
\hline Lelempau (Merap), Lepeh (Kenyah), Bacan Empu (Punan) & Parachela ingerkongi \\
\hline Kat Blow (Merap), Leket Bulo (Kenyah), Rungan (Punan) & Protomyzon griswoldi \\
\hline Kat (Merap), Leket (Punan) & Porhomatoptera microstoma \\
\hline $\begin{array}{l}\text { Lalau (Merap), Lalang (Kenyah), Lalape (Punan), Lunjar } \\
\text { Pareh (Jawa), Wader padi (Jawa) }\end{array}$ & Rasbora argyrotaenia \\
\hline Lalau (Merap), Lalang (Kenyah), Lalape (Punan) & Rasbora elegans \\
\hline Betelah (Merap), Beteloh (Kenyah), Beteluh (Punan) & Rasbora caudimaculata \\
\hline $\begin{array}{l}\text { Wader Padi (Jawa), Hanyan (Merap), Beteloh (Kenyah), } \\
\text { Beteluh (Punan) }\end{array}$ & Rasbora lateristriata \\
\hline Bacan Karok (Punan) Gurami (Ind.) & Trichgaster trichopterus \\
\hline $\begin{array}{l}\text { Perian (Merap), Padak (Kenyah), Tengah (Punan), } \\
\text { Sengkareng (Jawa) }\end{array}$ & Tor tambra \\
\hline $\begin{array}{l}\text { Sengkarenga (Jawa), Perian (Merap), Padak (Kenyah), } \\
\text { Tengah (Punan) }\end{array}$ & Tor tambroides \\
\hline
\end{tabular}




\section{Lampiran 9 \\ Pasal-pasal yang berkaitan dengan UU No. 5 tahun 1990}

\section{BAB 5}

\section{Pasal 21}

(1) Setiap orang dilarang untuk:

a. mengambil, menebang, memiliki, merusak, memusnahkan, memelihara, mengangkut, dan memperniagakan tumbuhan yang dilindungi atau bagianbagiannya dalam keadaan hidup atau mati;

b. mengeluarkan tumbuhan yang dilindungi atau bagian-bagiannya dalam keadaan hidup atau mati dari suatu tempat di Indonesia ke tempat lain di dalam atau di luar Indonesia.

(2) Setiap orang dilarang untuk:

a. menangkap, melukai, membunuh, menyimpan, memiliki, memelihara, mengangkut, dan memperniagakan satwa yang dilindungi dalam keadaan hidup;

b. menyimpan, memiliki, memelihara, mengangkut, dan memperniagakan satwa yang dilindungi dalam keadaan mati;

c. mengeluarkan satwa yang dilindungi dari suatu tempat di Indonesia ke tempat lain di dalam atau di luar Indonesia;

d. memperniagakan, menyimpan atau memiliki kulit, tubuh, atau bagian-bagian lain satwa yang dilindungi atau barang-barang yang dibuat dari bagian-bagian tersebut atau mengeluarkannya dari suatu tempat di Indonesia ke tempat lain di dalam atau di luar Indonesia;

e. mengambil, merusak, memusnahkan, memperniagakan, menyimpan atau memiliki telur dan atau sarang satwa yang dilindungi. 
Pasal 22

(1) Pengecualian dari larangan sebagaimana dimaksud dalam Pasal 21 hanya dapat dilakukan untuk keperluan penelitian, ilmu pengetahuan, dan atau penyelamatan jenis tumbuhan dan satwa yang bersangkutan.

(2) Termasuk dalam penyelamatan sebagaimana dimaksud dalam ayat (1) adalah pemberian atau penukaran jenis tumbuhan dan satwa kepada pihak lain di luar negeri dengan izin Pemerintah.

(3) Pengecualian dari larangan menangkap, melukai, dan membunuh satwa yang dilindungi dapat pula dilakukan dalam hal oleh karena suatu sebab satwa yang dilindungi membahayakan kehidupan manusia.

(4) Ketentuan lebih lanjut sebagaimana dimaksud dalam ayat (1), ayat (2), dan ayat (3) diatur dengan Peraturan Pemerintah. 


\title{
Lampiran 10
}

\section{Pasal-pasal yang berkaitan dengan UU No. 41 tahun 1999 tentang Kehutanan}

\author{
Bagian Keempat \\ Rehabilitasi dan Reklamasi Hutan
}

Pasal 40

Rehabilitasi hutan dan lahan dimaksudkan untuk memulihkan, mempertahankan, dan meningkatkan fungsi hutan dan lahan sehingga daya dukung, produktivitas, dan peranannya dalam mendukung sistem penyangga kehidupan tetap terjaga.

\section{Pasal 41}

(1) Rehabilitasi hutan dan lahan diselenggarakan melalui kegiatan:
a. reboisasi,
b. penghijauan,
c. pemeliharaan,
d. pengayaan tanaman, atau
e. penerapan teknik konservasi tanah secara vegetatif dan sipil teknis, pada lahan kritis dan tidak produktif.

(2) Kegiatan rehabilitasi sebagaimana dimaksud pada ayat (1) dilakukan di semua hutan dan kawasan hutan kecuali cagar alam dan zona inti taman nasional.

\section{Pasal 42}

(1) Rehabilitasi hutan dan lahan dilaksanakan berdasarkan kondisi spesifik biofisik.

(2) Penyelenggaraan rehabilitasi hutan dan lahan diutamakan pelaksanaannya melalui pendekatan partisipatif dalam rangka mengembangkan potensi dan memberdayakan masyarakat.

(3) Ketentuan lebih lanjut sebagaimana dimaksud pada ayat (1) dan ayat (2) diatur dengan Peraturan Pemerintah. 


\section{Pasal 43}

(1) Setiap orang yang memiliki, mengelola, dan atau memanfaatkan hutan yang kritis atau tidak produktif, wajib melaksanakan rehabilitasi hutan untuk tujuan perlindungan dan konservasi.

(2) Dalam pelaksanaan rehabilitasi sebagaimana dimaksud pada ayat (1), setiap orang dapat meminta pendampingan, pelayanan dan dukungan kepada lembaga swadaya masyarakat, pihak lain atau pemerintah.

\section{Pasal 44}

(1) Reklamasi hutan sebagaimana dimaksud dalam Pasal 21 huruf c, meliputi usaha untuk memperbaiki atau memulihkan kembali lahan dan vegetasi hutan yang rusak agar dapat berfungsi secara optimal sesuai dengan peruntukannya.

(2) Kegiatan reklamasi sebagaimana dimaksud pada ayat (1) meliputi inventarisasi lokasi, penetapan lokasi, perencanaan, dan pelaksanaan reklamasi.

(3) Ketentuan lebih lanjut sebagaimana dimaksud pada ayat (1) dan ayat (2) diatur dengan Peraturan Pemerintah.

\section{Pasal 45}

(1) Penggunaan kawasan hutan sebagaimana dimaksud dalam Pasal 38 ayat (1) yang mengakibatkan kerusakan hutan, wajib dilakukan reklamasi dan atau rehabilitasi sesuai dengan pola yang ditetapkan pemerintah.

(2) Reklamasi pada kawasan hutan bekas areal pertambangan, wajib dilaksanakan oleh pemegang izin pertambangan sesuai dengan tahapan kegiatan pertambangan.

(3) Pihak-pihak yang menggunakan kawasan hutan untuk kepentingan di luar kegiatan kehutanan yang mengakibatkan perubahan permukaan dan penutupan tanah, wajib membayar dana jaminan reklamasi dan rehabilitasi.

(4) Ketentuan lebih lanjut sebagaimana dimaksud pada ayat (1), ayat (2), dan ayat (3) diatur dengan Peraturan Pemerintah.

\section{Bagian Kelima Perlindungan Hutan dan Konservasi Alam}

\section{Pasal 46}

Penyelenggaraan perlindungan hutan dan konservasi alam bertujuan menjaga hutan, kawasan hutan dan lingkungannya, agar fungsi lindung, fungsi konservasi, dan fungsi produksi, tercapai secara optimal dan lestari.

\section{Pasal 47}

Perlindungan hutan dan kawasan hutan merupakan usaha untuk:

a. mencegah dan membatasi kerusakan hutan, kawasan hutan, dan hasil hutan yang disebabkan oleh perbuatan manusia, ternak, kebakaran, daya-daya alam, hama, serta penyakit; dan 
b. mempertahankan dan menjaga hak-hak negara, masyarakat, dan perorangan atas hutan, kawasan hutan, hasil hutan, investasi serta perangkat yang berhubungan dengan pengelolaan hutan.

\section{Pasal 48}

(1) Pemerintah mengatur perlindungan hutan, baik di dalam maupun di luar kawasan hutan.

(2) Perlindungan hutan pada hutan negara dilaksanakan oleh pemerintah.

(3) Pemegang izin usaha pemanfaatan hutan sebagaimana dimaksud dalam Pasal 27 dan Pasal 29, serta pihak-pihak yang menerima wewenang pengelolaan hutan sebagaimana dimaksud dalam Pasal 34, diwajibkan melindungi hutan dalam areal kerjanya.

(4) Perlindungan hutan pada hutan hak dilakukan oleh pemegang haknya.

(5) Untuk menjamin pelaksanaan perlindungan hutan yang sebaik-baiknya, masyarakat diikutsertakan dalam upaya perlindungan hutan.

(6) Ketentuan lebih lanjut sebagaimana dimaksud pada ayat (1), ayat (2), ayat (3), ayat (4), dan ayat (5) diatur dengan Peraturan Pemerintah.

\section{Pasal 49}

Pemegang hak atau izin bertanggung jawab atas terjadinya kebakaran hutan di areal kerjanya.

\section{Pasal 50}

(1) Setiap orang dilarang merusak prasarana dan sarana perlindungan hutan.

(2) Setiap orang yang diberikan izin usaha pemanfaatan kawasan, izin usaha pemanfaatan jasa lingkungan, izin usaha pemanfaatan hasil hutan kayu dan bukan kayu, serta izin pemungutan hasil hutan kayu dan bukan kayu, dilarang melakukan kegiatan yang menimbulkan kerusakan hutan.

(3) Setiap orang dilarang:

a. mengerjakan dan atau menggunakan dan atau menduduki kawasan hutan secara tidak sah;

b. merambah kawasan hutan;

c. melakukan penebangan pohon dalam kawasan hutan dengan radius atau jarak sampai dengan:

1. 500 (lima ratus) meter dari tepi waduk atau danau;

2. 200 (dua ratus) meter dari tepi mata air dan kiri kanan sungai di daerah rawa;

3. 100 (seratus) meter dari kiri kanan tepi sungai;

4. 50 (lima puluh) meter dari kiri kanan tepi anak sungai;

5. 2 (dua) kali kedalaman jurang dari tepi jurang;

6. 130 (seratus tiga puluh) kali selisih pasang tertinggi dan pasang terendah dari tepi pantai.

d. membakar hutan;

e. menebang pohon atau memanen atau memungut hasil hutan di dalam hutan tanpa memiliki hak atau izin dari pejabat yang berwenang; 
f. menerima, membeli atau menjual, menerima tukar, menerima titipan, menyimpan, atau memiliki hasil hutan yang diketahui atau patut diduga berasal dari kawasan hutan yang diambil atau dipungut secara tidak sah;

g. melakukan kegiatan penyelidikan umum atau eksplorasi atau eksploitasi bahan tambang di dalam kawasan hutan, tanpa izin Menteri;

h. mengangkut, menguasai, atau memiliki hasil hutan yang tidak dilengkapi bersama-sama dengan surat keterangan sahnya hasil hutan;

i. menggembalakan ternak di dalam kawasan hutan yang tidak ditunjuk secara khusus untuk maksud tersebut oleh pejabat yang berwenang;

j. membawa alat-alat berat dan atau alat-alat lainnya yang lazim atau patut diduga akan digunakan untuk mengangkut hasil hutan di dalam kawasan hutan, tanpa izin pejabat yang berwenang;

k. membawa alat-alat yang lazim digunakan untuk menebang, memotong, atau membelah pohon di dalam kawasan hutan tanpa izin pejabat yang berwenang;

1. membuang benda-benda yang dapat menyebabkan kebakaran dan kerusakan serta membahayakan keberadaan atau kelangsungan fungsi hutan ke dalam kawasan hutan; dan

m. mengeluarkan, membawa, dan mengangkut tumbuh-tumbuhan dan satwa liar yang tidak dilindungi Undang-undang yang berasal dari kawasan hutan tanpa izin dari pejabat yang berwenang.

(4) Ketentuan tentang mengeluarkan, membawa, dan atau mengangkut tumbuhan dan atau satwa yang dilindungi, diatur sesuai dengan peraturan perundangundangan yang berlaku.

\section{Pasal 51}

(1) Untuk menjamin terselenggaranya perlindungan hutan, maka kepada pejabat kehutanan tertentu sesuai dengan sifat pekerjaannya diberikan wewenang kepolisian khusus.

(2) Pejabat yang diberi wewenang kepolisian khusus sebagaimana dimaksud pada ayat (1) berwenang untuk:

a. mengadakan patroli/perondaan di dalam kawasan hutan atau wilayah hukumnya;

b. memeriksa surat-surat atau dokumen yang berkaitan dengan pengangkutan hasil hutan di dalam kawasan hutan atau wilayah hukumnya;

c. menerima laporan tentang telah terjadinya tindak pidana yang menyangkut hutan, kawasan hutan, dan hasil hutan;

d. mencari keterangan dan barang bukti terjadinya tindak pidana yang menyangkut hutan, kawasan hutan, dan hasil hutan;

e. dalam hal tertangkap tangan, wajib menangkap tersangka untuk diserahkan kepada yang berwenang; dan

f. membuat laporan dan menandatangani laporan tentang terjadinya tindak pidana yang menyangkut hutan, kawasan hutan, dan hasil hutan. 


\section{Lampiran 11}

\section{Sistem Silvikultur Tebang Pilih Tanam Indonesia (TPTI)}

\section{Pendahuluan}

Sistem Silvikultur Tebang Pilih Tanam Indonesia (TPTI) adalah sistem silvikultur yang meliputi cara penebangan dengan batas diameter dan permudaan hutan. Pertama kali dikenal dengan nama Tebang Pilih Indonesia (TPI) pada tahun 1972. Sistem silvikultur ini dipandang yang paling tepat, dan sesuai dari segi ekonomi, ekologi, dan teknologi untuk digunakan pada hutan tropika basah, atau hutan hujan tropis di Indonesia. Hutan alam produksi di Indonesia, baik tetap maupun terbatas, pada umumnya didominasi oleh pohon-pohon yang termasuk famili Dipterocarpaceae, di samping terdapat jenis-jenis pohon komersial lainnya. Beberapa jenis pohon lainnya, kadang-kadang mendominasi hutan tropika basah yang tumbuh pada tapak (site) tertentu. Misalnya pohon ramin pada hutan rawa gambut, pohon agathis (damar) pada hutan yang tanahnya berpasir, pohon eboni (kayu hutan) pada daerah berbatu dan agak kering, pohon ekaliptus pada daerah beriklim kering, pohon bakau di hutan payau (mangrove), pohon pelawan di hutan kerangas, dan sebagainya.

Sistem Silvikultur Tebang Pilih termasuk di antara sistem-sistem silvikultur yang paling sulit pelaksanaannya. Apalagi pada hutan campuran dan berbagai umur, seperti hutan tropika basah di Indonesia. Oleh karena itu, kesiapan rimbawan dan petugas lapangan hutan sangat menentukan keberhasilan pelaksanaan sistem silvikultur TPTI. Meskipun demikian, karena areal bekas tebangan (logged over area) tebangpilih hanya terganggu dan terbuka sedikit dibandingkan pada sistem tebang habis, maka sistem tersebut lebih aman bagi perlindungan dan kelestarian ekosistem hutan tropika basah. 


\section{Sistem Silvikultur Tebang Pilih Tanam Indonesia (TPTI)}

Sistem silvikultur adalah rangkaian kegiatan berencana mengenai pengelolaan hutan, yang meliputi penebangan, peremajaan, dan pemeliharaan tegakan hutan, guna menjamin kelestarian produksi kayu atau hasil hutan lainnya. Sedangkan TPTI adalah sistem silvikultur yang meliputi cara penebangan dengan batas diameter dan permudaan hutan.

Sistem TPTI ditentukan berdasarkan pada risalah hutan, dan memperhatikan asas kelestarian hutan yang mencakup kelangsungan produksi, penyelamatan tanah dan air, perlindungan alam, dan mempertimbangkan pula kepada teknik silvikultur yang harus sesuai dengan kondisi lingkungan, keadaan lapangan, komposisi dari struktur hutan, sifat tumbuh jenis-jenis pohon, serta pertimbangan pengusahaan hutan yang menguntungkan.

Tujuan sistem TPTI adalah untuk mengatur pemanfaatan hutan alam produksi serta meningkatkan nilai hutan, baik kualitas maupun kuantitas pada area bekas tebangan, untuk rotasi tebangan berikutnya, agar terbentuk tegakan hutan campuran yang diharapkan dapat berfungsi sebagai penghasil kayu penghara industri secara lestari.

Untuk mencapai tujuan ini maka tindakan-tindakan silvikultur dalam hal permudaan hutannya diarahkan kepada:

- Pengaturan komposisi jenis pohon di dalam hutan, yang diharapkan dapat lebih menguntungkan, baik ditinjau dari segi ekologi dan ekonomi. 2.

Pengaturan struktur/kerapatan tegakan yang optimal di dalam hutan, yang diharapkan dapat memberikan peningkatan potensi produksi kayu bulat dari keadaan sebelumnya.

- Terjaminnya fungsi hutan dalam rangka pengawetan tanah dan air.

- Terjaminnya fungsi perlindungan hutan.

Sistem Tebang Pilih memang lebih sulit dari pada sistem-sistem silvikultur lainnya, dan memerlukan kecakapan profesional rimbawan. Berbeda dari TPI sebelumnya, dalam TPTI sekarang, pada setiap HPH harus dibentuk bagian Pembinaan Hutan, yang terlepas dari Bagian Eksploitasi atau Pembalakan (logging). Di samping dicukupi sarana dan prasarananya, bagian tersebut harus dipimpin dan diisi dengan tenagatenaga berpendidikan kehutanan. Yaitu rimbawan yang mengerti ilmu dan praktek silvikultur, di samping tersedianya anggaran operasional yang memadai.

Semua kegiatan dan tata waktu dalam TPTI hendaknya dipahami dan dilaksanakan. Pembangunan petak-petak demonstrasi TPTI dan petak-petak Tegakan Benih (Seed stand), dan persemaian-persemaian yang tersebar di areal bekas tebangan (logged over area), akan sangat menunjang keberhasilan sistem silvikultur TPTI. Dengan demikian, setiap petugas Pembinaan Hutan di HPH akan mudah untuk mengacu kepada keadaan yang diinginkan menurut petunjuk teknis TPTI. 


\section{Rangkaian kegiatan}

Untuk mencapai sasaran yang diharapkan dalam pelaksanaan TPTI, maka ditetapkan tahapan pelaksanaan TPTI dan Tata Waktu pelaksanaannya sebagai berikut:

\begin{tabular}{rll}
\hline No. & Tahapan Kegiatan TPTI & Waktu Pelaksanaan (dalam tahun) \\
\hline 1. & Penataan Areal Kerja & $\mathrm{Et}-3$ \\
\hline 2. & Inventarisasi Tegakan Sebelum Penebangan & $\mathrm{Et}-2$ \\
\hline 3. & Pembukaan Wilayah Hutan & $\mathrm{Et}-1$ \\
\hline 4. & Penebangan & $\mathrm{Et}$ \\
\hline 5. & Pembebasan & $\mathrm{Et}+1$ \\
\hline 6. & Inventarisasi Tegakan Tinggal & $\mathrm{Et}+1$ \\
\hline 7. & Pengadaan Bibit & $\mathrm{Et}+2$ \\
\hline 8. & Penanaman/Pengayaan & $\mathrm{Et}+2$ \\
\hline 9. & Pemeliharaan Tahap Pertama & $\mathrm{Et}+3$ \\
\hline 10. & Pemeliharaan Lanjutan & $\mathrm{Et}+4$ \\
& a. Pembebasan & $\mathrm{Et}+9$ \\
& b. Penjarangan & $\mathrm{Et}+14$ \\
\hline 11. & Perlindungan dan Penelitian & $\mathrm{Et}+19$ \\
\hline
\end{tabular}

Keterangan: Et adalah simbol tahun penebangan.

\section{Ketentuan umum}

1. Pelaksanaan sistem silvikultur TPTI dalam pengusahaan hutan, dimaksud; untuk mengatur kegiatan penebangan dan pembinaan hutan alam; produksi, yang mempunyai jumlah pohon inti minimal 25 pohon per hektar. ' Pohon inti yang ditunjuk, diutamakan terdiri dari pohon komersial yang ; sama dengan pohon yang ditebang, dan berdiameter minimal $20 \mathrm{~cm}$. Seandainya jumlahnya masih kurang dari 25 pohon per-hektar, dapat ditambah dari jenis kayu lain.

2. Etat tebangan tahunan (Jatah Penebangan Tahunan) disesuaikan dengan rotasi tebang dan volume cadangan tegakan (standing stock) kayu perdagangan yang bersangkutan.

3. Pemegang Hak Pengusahaan Hutan perlu menyiapkan:

a. Unit organisasi pembinaan hutan yang terpisah dari organisasi pembalakan (logging)

b. Tenaga teknis kehutanan dan tenaga terampil di bidang kehutanan dalam jumlah yang cukup

c. Anggaran biaya yang memadai untuk kegiatan pembinaan hutan.

4. Pada suatu unit kesatuan pengusahaan hutan alam produksi, yang' mempunyai komposisi jenis dan struktur tegakan yang khusus, dapat diadakan penyesuaian sistem silvikultur TPTI sebagai berikut:

a. Pada Hutan Payau, pedoman sistem silvikultur yang dipergunakan tetap berdasarkan pada Keputusan Direktur Jenderal kehutanan No. 60/Kpts/DJ/1 /1978.

b. Pada Hutan Rawa dengan komposisi hutan terdiri dari jenis komersial khusus, misalnya jenis ramin, perupuk, dan jenis komersial lainnya dan pemegang 
HPH tidak sanggup/sulit melaksanakan kegiatan penanaman/pengayaan, maka hanya diijinkan menebang pohon sebanyak-banyaknya $2 / 3$ dari jumlah pohon, sesuai dengan komposisi jenisnya.

c. Pada kondisi hutan tawa yang tidak ditemukan pohon berdiameter $50 \mathrm{~cm}$ ke atas, dalam jumlah yang cukup, misalnya pada hutan ramin campuran, maka khusus untuk jenis ramin dapat dilakukan penurunan batas diameter pohon yang boleh ditebang menjadi $35 \mathrm{~cm}$; dengan jumlah pohon inti paling sedikit 25 pohon per hektar, berdiameter $15 \mathrm{~cm}$ ke atas. Sedangkan rotasi tebang ditetapkan 25 tahun. Pengaturan pohon yang dapat ditebang mengikuti ketentuan pada butir (b) tersebut.

d. Pada kondisi hutan dengan jumlah pohon muda yang berdiameter 20 - 49 $\mathrm{cm}$, yang dapat ditunjuk sebagai pohon inti kurang dari 25 pohon per-hektar, maka kekurangannya harus ditambah dengan pohon jenis komersil lain, yang berdiameter di atas $50 \mathrm{~cm}$, dan berfungsi pula sebagai pohon induk. Batas diameter batang yang boleh ditebang adalah $50 \mathrm{~cm}$, dengan jumlah pohon inti paling sedikit 25 pohon per hektar, sedangkan rotasi tebang ditetapkan 35 tahun.

e. Pada kondisi hutan yang terdiri dari jenis-jenis komersial, yang memiliki pertumbuhan yang lambat dan sulit ditemukan pohon-pohon yang berdiameter $50 \mathrm{~cm}$ ke atas, seperti pada hutan eboni campuran, maka khusus untuk jenis eboni dapat dilakukan penurunan batas diameter pohon yang boleh ditebang menjadi $35 \mathrm{~cm}$, dengan jumlah pohon inti paling sedikit 25 pohon per hektar, berdiameter $15 \mathrm{~cm}$ ke atas. Sedangkan rotasi tebang ditetapkan 45 tahun. 


\section{Lampiran 12}

\section{Peraturan yang terkait dalam pemanenan jenis satwa yang tidak dilindungi di Indonesia - tahun 2004}

Pasal-pasal dari Undang-undang dan Peraturan di bawah ini:

Peraturan Pemerintah Nomor 8 Tahun 1999 tentang Pemanfaatan Jenis Tumbuhan dan Satwa Liar

SK Menteri Kehutanan RI Nomor 447/Kpts-II/2003

Surat Keputusan Ditjen PHKA Nomor 158/KPTS/DJ-IV/2003 
MENTERI KEHUTANAN REPUBLIK INDONESIA

KEPUTUSAN MENTERI KEHUTANAN Nomor 447/Kpts-11/2003

TENTANG

TATA USAHA PENGAMBILAN ATAU PENANGKAPAN DAN PEREDARAN TUMBUHAN DAN SATWA LIAR

\author{
Bagian Kedua \\ Spesimen Tumbuhan dan Satwa Liar Hasil Pengambilan \\ atau Penangkapan dari Habitat Alam
}

Paragraf 1
Penetapan kuota

Pasal 6

(1) Kuota pengambilan atau penangkapan spesimen tumbuhan dan satwa liar dari habitat alam merupakan batasan jenis dan jumlah spesimen tumbuhan dan satwa liar yang dapat diambil atau ditangkap dari habitat alam.

(2) Kuota sebagaimana dimaksud dalam ayat (1) ditetapkan oleh Direktur Jenderal dengan memperhatikan rekomendasi dari Otoritas Keilmuan untuk setiap kurun waktu 1 (satu) tahun takwim, mulai tanggal 1 Januari sampai dengan 31 Desember.

\title{
Pasal 7
}

(1) Kuota sebagaimana dimaksud dalam Pasal 6 ayat (1) berisi nama jenis, ukuran maksimum atau minimum dan satuan serta wilayah pengambilan atau penangkapan pada tingkat provinsi atau wilayah kerja Balai.

(2) Kuota sebagaimana dimaksud dalam ayat (1) diperuntukkan bagi kepentingan pemanfaatan di dalam negeri dan ke luar negeri (ekspor).

(3) Kuota sebagaimana dimaksud dalam ayat (1) ditetapkan untuk spesimen tumbuhan dan satwa liar yang termasuk maupun tidak termasuk dalam daftar Appendiks CITES baik jenis yang dilindungi maupun tidak dilindungi undang-undang.

\section{Pasal 8}

(1) Rekomendasi sebagaimana dimaksud dalam Pasal 6 ayat (2) didasarkan pada data dan informasi ilmiah hasil inventarisasi monitoring populasi. 
(2) Dalam hal data dan informasi sebagaimana dimaksud dalam ayat (1) tidak tersedia, maka data dapat diperoleh atas dasar:

a. Kondisi habitat dan populasi jenis yang ditetapkan;

b. Informasi ilmiah dan teknis lain tentang populasi dan habitat atau jenis yang ditetapkan;

c. Realisasi pengambilan dan penangkapan tumbuhan dan satwa liar dari kuota tahun-tahun sebelumnya;

d. Kearifan tradisional.

\section{Pasal 9}

(1) Inventarisasi dan atau monitoring populasi tumbuhan dan satwa liar sebagaimana dimaksud dalam Pasal 8 ayat (1) dapat dilaksanakan oleh Otoritas Keilmuan, Balai, Dinas lingkup Propinsi atau Kabupaten/Kota yang salah satu tugas pokoknya adalah konservasi tumbuhan dan satwa liar, perguruan tinggi atau organisasi nonpemerintah.

(2) Inventarisasi dan atau monitoring populasi sebagaimana dimaksud dalam ayat (1) harus dilaksanakan berdasarkan metode standar yang ditetapkan atau dikembangkan oleh Otoritas Keilmuan.

(3) Hasil inventarisasi dan atau monitoring populasi sebagaimana dimaksud dalam ayat (1) dapat diserahkan langsung kepada Otoritas Keilmuan atau melalui Direktur Jenderal atau Kepala Balai.

(4) Dalam hal hasil inventarisasi dan atau monitoring sebagaimana dimaksud dalam ayat (1) diserahkan melalui Balai, maka Balai menyampaikan hasil inventarisasi monitoring populasi dimaksud serta data dan informasi lain kepada Otoritas Keilmuan melalui Direktur Jenderal sebagai salah satu bahan pertimbangan dalam penetapan rekomendasi kuota.

\section{Pasal 11}

(1) Dalam hal populasi suatu jenis yang tidak dilindungi dan tidak termasuk dalam Appendiks CITES melimpah, maka Otoritas Keilmuan dapat memberikan rekomendasi berupa penetapan batasan-batasan spesimen yang boleh diambil atau ditangkap dan tidak perlu menetapkan batasan jumlahnya.

(2) Batasan-batasan sebagaimana dimaksud dalam ayat (1) diantaranya berupa ukuran panjang, berat maksimal dan atau minimal, kelas umur, jenis kelamin, wilayah pengambilan atau penangkapan, dan waktu pengambilan atau penangkapan. 


\section{Pasal 12}

(1) Direktur Jenderal menelaah rekomendasi Otoritas Keilmuan dan selanjutnya menetapkan kuota pengambilan dan penangkapan spesimen tumbuhan dan satwa liar dari habitat alam.

(2) Atas dasar pertimbangan teknis pengelolaan, Direktur Jenderal dapat menetapkan kuota lebih kecil dari yang direkomendasikan oleh Otoritas Keilmuan.

(3) Peninjauan kembali kuota yang telah ditetapkan dapat dilakukan pada tahun berjalan, dengan tetap berdasar pada rekomendasi Otoritas Keilmuan.

\section{Paragraf 2}

\section{Pembagian kuota dan penetapan lokasi}

\section{Pasal 13}

(2) Berdasarkan kuota sebagaimana dimaksud dalam ayat (1), Kepala Balai menetapkan lokasi pengambilan atau penangkapan.

(3) Kuota yang telah ditetapkan sebagaimana dimaksud Pasal 12 ayat (1) dan lokasi sebagaimana dimaksud dalam ayat (2) merupakan dasar penerbitan izin pengambilan atau penangkapan spesimen tumbuhan dan satwa liar oleh Kepala Balai.

(4) Kepala Balai atau Kepala Dinas dilarang menerbitkan izin pengambilan dan penangkapan sebagaimana dimaksud dalam ayat (3) tanpa didasari oleh kuota yang ditetapkan oleh Direktur Jenderal.

\section{Pasal 15}

(1) Dalam penetapan lokasi pengambilan atau penangkapan spesimen tumbuhan dan satwa liar sebagaimana dimaksud dalam Pasal 13 ayat (2), Kepala Balai memperhatikan status kawasan. kelimpahan populasi, kondisi habitat, rencana penggunaan lahan, dan aspek-aspek sosial budaya masyarakat setempat.

(2) Lokasi sebagaimana dimaksud dalam ayat (1) sedikitnya memuat nama tempat atau nama desa, nama kecamatan, nama kabupaten dan atau koordinat peta atau koordinat geografis.

(3) Penetapan lokasi sebagaimana dimaksud dalam ayat (2) di atas, dibuat dalam bentuk peta lokasi pengambilan dan penangkapan dengan skala paling kecil 1:250.000 yang selalu dimutakhirkan secara periodik minimal 2 (dua) tahun sekali. 


\section{Pasal 16}

(1) Dalam izin pengambilan atau penangkapan sebagaimana dimaksud dalam Pasal 13 ayat (3) untuk menjamin kelestarian populasi, Kepala Balai perlu melakukan rotasi lokasi pengambilan atau penangkapan di dalam wilayah pengambilan atau penangkapan.

(2) Jangka waktu rotasi ditentukan berdasarkan kondisi populasi, habitat dan sifat-sifat biologis serta perilaku jenis yang ditetapkan.

\section{BAB III \\ PEMANFAATAN SPESIMEN TUMBUHAN DAN SATWA LIAR}

\section{Bagian Kesatu \\ Umum}

\section{Pasal 24}

(1) Pemanfaatan spesimen tumbuhan dan satwa liar dapat dibedakan menjadi

a. Pemanfaatan non-komersial untuk tujuan pengkajian, penelitian dan pengembangan, peragaan non-komersial, pertukaran, perburuan dan pemeliharaan untuk kesenangan;

b. Pemanfaatan komersial untuk tujuan penangkaran, perdagangan, peragaan komersial dan budidaya tanaman obat.

(2) Pemanfaatan non-komersial sebagaimana dimaksud dalam ayat (1) huruf a, dapat dilakukan oleh:
a. perorangan;
b. koperasi;
c. Lembaga Konservasi;
d. Lembaga Penelitian;
e. Perguruan Tinggi, atau
f. Lembaga Swadaya Masyarakat (Organisasi Non-Pemerintah) yang bergerak dalam bidang konservasi sumberdaya alam hayati.

\section{Pasal 26}

(1) Pengambilan atau penangkapan sebagaimana dimaksud dalam Pasal 25 ayat (2) wajib diliput dengan izin.

(2) Peredaran komersial sebagaimana dimaksud dalam Pasal 25 ayat (3) huruf b dan huruf d, hanya dapat diizinkan bagi Pengedar Dalam Negeri atau Pengedar Luar Negeri yang terdaftar dan diakui. 
(3) Khusus bagi pengambilan atau penangkapan komersial sebagaimana dimaksud dalam Pasal 25 ayat (2) huruf b, izin diberikan kepada Pengedar Dalam Negeri sebagaimana dimaksud dalam ayat (2) atau kepada pengumpul tumbuhan dan satwa liar.

\section{Bagian Kedua \\ Izin Pengambilan atau Penangkapan \\ Paragraf 1 \\ Umum}

Pasal 27

(1) Pengambilan atau penangkapan spesimen jenis tumbuhan dan satwa liar harus sesuai dengan izin pengambilan atau penangkapan yang meliputi lokasi pengambilan atau penangkapan, serta dilakukan oleh perorangan atau kelompok Keilmuan bahwa pengambilan atau penangkapan yang dimohonkan tidak akan merusak populasi di habitat alam;

(2) Pengambilan atau penangkapan spesimen jenis tumbuhan dan satwa liar sebagaimana dimaksud dalam ayat (1) dilakukan dengan memperhatikan kelestarian dan tidak menyebabkan kematian atau luka pada spesimen tumbuhan atau satwa liar yang ditangkap.

\section{BAB VI \\ PENEGAKAN HUKUM DAN SANKSI \\ Bagian Kesatu \\ Penunjukan Penegak Hukum}

Pasal 109

(1) Direktur Jenderal dapat membentuk Gugus Tugas yang anggotanya terdiri dari Penyidik Pegawai Negeri Sipil Pusat dan Unit Pelaksana Teknis lingkup Direktorat Jenderal.

(2) Gugus Tugas sebagaimana dimaksud dalam ayat (1) bertugas untuk melakukan penyelidikan dan penyidikan dan menindaklanjuti proses hukum terhadap kasus-kasus pelanggaran peraturan perundang-undangan yang berkaitan dengan tumbuhan dan satwa liar yang mempunyai skala nasional (lintas provinsi) dan internasional. 


\section{Pasal 110}

(1) Kepala Balai yang lingkup wilayah tugasnya meliputi pelabuhan-pelabuhan ekspor atau impor wajib berkoordinasi dengan petugas Bea dan Cukai dan petugas Karantina Hewan, Karantina Tumbuhan maupun Karantina lkan;

(2) Dalam pelaksanaan sebagaimana dimaksud dalam ayat (1) Kepala Balai dapat mengembangkan sistem kerja sama formal dalam bentuk nota kerjasama (Memorandum of Understanding).

\section{Bagian Kedua \\ Penyitaan}

\section{Pasal 111}

Spesimen tumbuhan dan satwa liar yang terkait dengan pelanggaran terhadap Pasal 26 ayat (1), Pasal 27 ayat (1), Pasal 57, Pasal 59, Pasal 61, dan Pasal 63, disita untuk negara sesuai Pasal 64 ayat (1) dan ayat (2) Peraturan Pemerintah Nomor 8 tahun 1999.

\section{Bagian Ketiga \\ Sanksi}

\section{Pasal 112}

(1) Barang siapa melakukan pelanggaran sebagaimana diatur dalam Keputusan ini dikenakan sanksi sesuai dengan Peraturan Pemerintah Nomor 8 Tahun 1999 tentang Pemanfaatan Jenis Tumbuhan dan Satwa liar.

(2) Pengenaan hukuman denda administrasi dan hukuman pembekuan atau pencabutan izin dilakukan oleh pemberi izin serta uang hasil denda administrasi disetor ke Kas Negara.

(3) Pembekuan atau pencabutan izin sebagaimana dimaksud dalam ayat (2) dilakukan setelah diberikan peringatan 3 (tiga) kali berturut-turut dengan tenggang masing-masing 30 (tiga puluh) hari kalender. 


\section{PERATURAN PEMERINTAH REPUBLIK INDONESIA NOMOR 8 TAHUN 1999}

\section{TENTANG \\ PEMANFAATAN JENIS TUMBUHAN DAN SATWA LIAR}

\section{BAB XII \\ S A N K S I}

\section{Pasal 50}

(3) Barang siapa mengambil tumbuhan liar dan atau satwa liar dari habitat alam tanpa izin atau dengan tidak memenuhi ketentuan sebagaimana dimaksud dalam Pasal 4 ayat (3), Pasal 8 ayat (2), Pasal 29 dan Pasal 39 ayat (2) dengan serta merta dapat dihukum denda administrasi sebanyak-banyaknya Rp. 40.000.000,00 (empat puluh juta rupiah) dan atau dihukum tidak diperbolehkan melakukan kegiatan pemanfaatan tumbuhan dan satwa liar. 


\section{Indeks}

A

Accipiter trivirgatus, 13, 197

Aceros comatus, 64

Aceros corrugatus, 64, 196, 242

Aceros undulatus, 196

Aceros waldeni, 66

Achatina fulica, 54, 55

Acrochordus javanicus, 314

Actenoides concretus, 236

Aegithina tiphia, 228

Aethopyga siparaja, 14

Agathis borneensis, 222

Aglaia spp., 64, 178, 196, 248

Ahaetulla prasina, 314

Albizia falcataria, 93

Alcedo atthis, 13

Alcedo euryzona, 13, 160, 191, 198, 236

Alcippe brunneicauda, 237

Alophoixus phaeocephalus, 259, 261

Amazona vittata, 217

Amyda cartilaginea, 191, 192, 198, 208, 239, 314

Anguilla malgumora, 123, 124, 318

Anguilla nebulosa, 318

Anguilla spp., 124

Annona muricata, 94

Annona spp., 300

Anorrhinus galeritus, 14, 65, 66, 242,
Ansonia albomaculata, 113

Ansonia leptopus, 312

Ansonia longidigita, 117

Ansonia sp., 312

Ansonia spinulifer, 117

Anthracoceros albirostris, 64, 196

Anthracoceros malayanus, 14, 62, 64, 65,

159, 190, 196, 237, 242, 247

Anthreptes malacensis, 14

Anthreptes rhodolaema, 14, 238

Anthreptes singalensis, 14

Apis dorsata, 242

Apis spp., 184

Aquilaria, 10

Arachnothera affinis, 14

Arachnothera chrysogenys, 14

Arachnothera flavigaster, 14

Arachnothera longirostra, 14

Arachnothera robusta, 14

Arctictis binturong, 99, 100, 242, 292

Arctogalidia trivirgata, 99, 100, 137,

139, 144, 298

Argusianus argus, 13, 62, 72, 74, 190,

197, 236, 241, 255

Artocarpus integer, 311

Artocarpus spp., 87, 178, 185, 310

Aviceda jerdoni, 13 


\section{B}

Baccaurea spp., 176, 178

Bactris spp., 95

Balionycteris maculata, 96

Barbodes balleroides, 123, 318

Barbodes spp., 231, 232, 318

Batrachostomus spp., 150

Berenicornis comatus, 14, 65, 244

Betta unimaculata, 124, 318

Blythipicus pyrrhotis, 261, 262

Blythipicus rubiginosus, 68, 70, 72, 257, 259, 261

Boiga cynodon, 314

Boiga dendrophila, 314

Boiga jaspidea, 314

Boiga nigriceps, 314

Bombax ceiba, 297

Bos gaurus, 57

Bos javanicus, 46, 48, 57, 105, 108, 191, 226, 238

Bronchocela cristatella, 314

Buceros rhinoceros, 14, 65, 159, 190, 196, 237, 241, 248, 249

Buceros vigil, 241

Bufo asper, 312

Bufo divergens, 113, 117, 312

Bufo juxtasper, 117, 312

Bufo typhonia, 116

Bungarus flaviceps, 314

\section{C}

Cacatua sulphurea, 54

Calamaria bicolor, 314

Calamaria sp., 315

Callosciurus caniceps, 89, 285

Callosciurus nigrovittatus, 89

Callosciurus notatus, 80, 88, 89, 139, 284

Callosciurus prevostii, 88, 89, 91, 139, 285

Calophyllum spp., 148

Calyptomena hosii, 237

Calyptomena viridis, 62, 76, 237

Campnosperma spp., 148

Camponotus gigas, 255
Canarium spp., 94

Carica papaya, 94

Caryota spp., 95

Casnierodius albus, 13

Castanopsis spp., 148, 307

Catopuma badia, 138, 159, 229

Ceiba pentandra, 34

Celeus brachyurus, 69, 259, 263

Cervus unicolor, 29, 46, 105, 106, 139, 159, 192, 193, 209, 212, 226, 229, 241, 305

Ceyx erithacus, 13

Chaperina fusca, 117, 312

Chironax melanocephalus, 96

Chloropsis cochinchinensis, 228

Chrotogale owstoni, 293

Chrysalidocarpus spp., 95

Chrysopelea paradisii, 315

Ciconia stormi, 191, 208, 236

Claris anfractus, 318

Clerodendrum infortunatum, 54

Clidemia hirta, 54

Cocos nucifera, 185

Coffea canephora, 6

Collocalia fuciphaga, 241

Collocalia spp., 5, 185

Connarus spp., 297, 300

Copsychus malabaricus, 241

Coracina fimbriata, 228

Cosymbotus platyurus, 315

Cotylelobium spp., 171

Crematogaster spp., 264

Crocodylus porosus, 119, 120, 231, 315

Crocodylus siamensis, 120

Cuculus vagans, 237

Culicapa ceylonensis, 63

Cyclemys dentata, 241, 315

Cyclocheilichthys armatus, 123, 124, 318

Cyclocheilichthys repasson, 123, 124, 318

Cylindrophis ruffus, 315

Cynocephalus variegatus, 151

Cynogale bennettii, 99, 100, 159, 171, 191

Cynometra cauliflora, 95

Cynopterus brachyotis, 95, 96 
Cynopterus horsfieldii, 95

Cynopterus spp., 94

Cyornis spp., 63, 78

Cyornis turcosus, 78, 238

Cyrtodactylus malayanus, 315

D

Dacryodes rugosa, 311

Dacryodes spp., 310

Dendrelaphis caudolineatus, 315

Dendrelaphis formosus, 315

Dendrocopus canicapillus, 69, 264

Dialium indum, 171

Dialium spp., 148

Dicerorhinus sumatrensis, 46, 47, 48

Dicranopteris spp., 308

Dicrurus paradiseus, 257, 259, 266, 267, 268

Dimocarpus spp., 176

Dinopium rafflesii, 68, 70, 159, 257, 259, 266

Diplogale hosei, 293

Dipterocarpus confertus, 289

Dipterocarpus spp., 171, 199, 231

Dogania subplana, 242

Draco cornutus, 315

Dracontomelon dao, 178

Dracontomelon spp., 176

Draco spp., 144

Dryobalanops spp., 171

Dryocopus javensis, 67, 68, 69, 72, 262

Ducula pickeringii, 160

Durio oxleyanus, 178

Durio spp., 6, 95, 108, 148, 185, 308, 310, 311

Durio zibethinus, 178

Dyera spp., 149

Dysoxylum spp., 178

\section{$\mathbf{E}$}

Echinosorex gymnurus, 92

Egretta garzetta, 13

Egretta intermedia, 13

Eichornia crassipes, 53

Elaeocarpus sphaericus, 94
Elaphe flavolineata, 315

Elephas maximus, 48

Enhydris doriae, 315

Enicurus ruficapillus, 237

Eonycteris spelea, 95

Eucaplyptus deglupta, 93

Eugeissona utilis, 50

Eugenia spp., 95

Eupatorium odoratum, 54

Eupatorium spp., 53

Eupetes macrocerus, 77

Eurylaimus ochromalus, 237

Eusideroxylon zwageri, 34, 37, 184, 222

F

Fejervarya cancrivora, 118, 312

Ficedula spp., 63, 78

Ficus auranticacea, 247

Ficus drupacea, 198

Ficus spp., 36, 64, 95, 105, 176, 178, 191, 199, 222, 231, 250, 280, 293, 297, 300, 310

\section{$\mathbf{G}$}

Gallus gallus, 75

Gallus spp., 242

Garcinia spp., 176

Garra borneensis, 122, 123, 125, 318

Gastromyzon lepidogaster, 123, 318

Gastromyzon spp., 122, 123, 124, 318

Gekko smithi, 315

Geochelone emys, 119

Glyptothorax platypogonoides, 123, 125 , 318

Gmelina arborea, 93

Gonocephalus grandis, 315

Gonyosoma oxycephalum, 315

Gracula religiosa, 53, 160, 241

Grewia latifolia, 289

H

Haemaphysalis asiaticus, 301

Halcyon pileata, 14

Haliastur indus, 13, 242

Hampala macrolepidota, 123, 124, 318 
Harpactes diardii, 13, 63, 76, 237, 268

Harpactes duvaucelii, 13, 76, 237, 259, 266, 271

Harpactes kasumba, 13, 76, 237, 269

Harpactes oreskios, 13, 76, 270

Harpactes orrhophaeus, 272

Harpactes reinwardtii, 75

Harpactes spp., 63

Helarctos malayanus, 308

Hemibagrus baramensis, 123, 319

Hemibagrus nemurus, 123, 124, 319

Hemicircus concretus, 68, 70, 72, 257 ,

259, 267

Hemigalus derbyanus, 99, 100, 137.

139, 293

Hemipus hirundinaceus, 228

Heosemys spinosa, 315

Hieraaetus kienerii, 13

Hipposideros ridleyi, 97

Hipposideros spp., 150

Homaloptera spp., 125

Homaloptera stephensoni, 123, 318

Hopea spp., 66, 171, 251

Hoplobatrachus rugulosus, 54, 55, 118, 312

Huia cavitympanum, 117

Hylobates lar, 83

Hylobates muelleri, 84, 85, 139, 142,

159, 194, 238, 242, 279

Hylobates spp., 229

Hypogranmia hypogranmmici, 14

Hypothymis azurea, 78, 267

Hystrix brachyura, 192, 209, 241

Ichthyophaga humilis, 13, 236

Ichthyophis sp., 312

Ictinaetus malayensis, 13

Imperata arundinacea, 54

Imperata cylindrica, 9, 54, 306

Instia spp., 285

Irena puella, 76, 160

J

Jasminium spp., 54
$\mathbf{K}$

Kalophrynus heterochirus, 117

Kalophrynus pleurostigma, 117

Kenopia striata, 63, 77, 237

Kerivoula papillosa, 97

Knema spp., 252

Koompassia spp., 184, 285

Koordersiondendron spp., 176

$\mathbf{L}$

Lacedo pulchella, 14, 160

Lansium domesticum, 95

Lantana camara, 54

Lariscus hosei, 89, 139, 159, 287

Lariscus insignis, 36, 88, 90, 139, 159, 286

Leiocassis spp., 123, 318

Lenothrix canus, 80, 92

Leopoldamys sabanus, 80, 91

Leptobarbus melanotaenia, 123, 124, 125,318

Leptobarbus spp., 232

Leptobrachella baluensis, 117

Leptobrachella mjobergi, 113, 312

Leptobrachella sp., 117

Leptobrachium abbotti, 113, 117, 312

Leptobrachium montanum, 116, 117

Leptolalax dringi, 117

Leptolalax gracilis, 312

Leptolalax pictus, 312

Lepturophis albofuscus, 316

Leucaena spp., 54

Limnonectes finchi, 117, 312

Limnonectes ibanorum, 115, 118, 312

Limnonectes ingeri, 118, 312

Limnonectes kublii, 117, 118, 312

Limnonectes leporinus, 115, 116, 117, 118,312

Limnonectes palavanensis, 313

Limnonectes paramacrodon, 313

Limnonectes spp., 115

Lipinia quadrivittata, 316

Lithocarpus spp., 148, 307

Livistona spp., 95

Lobiophasis bulweri, 13, 72, 74, 145,

191, 197, 236, 254 
Lobiophasis spp., 28

Lobocheilos bo, 122, 123, 125, 318

Lonchura spp., 226

Lophura erythrophthalma, 62, 72, 74, 190, 197, 208, 236, 251, 252

Lophura ignita, 72, 73, 74, 137, 197 , 242, 252, 253

Lophura leucomelana lathami, 75

Lophura spp., 145

Loriculus galgulus, 52, 53, 242

Lutra spp., 238

\section{M}

Mabuya rudis, 316

Macaca fascicularis, 82, 84, 86, 139, 190, 194, 238, 242, 276, 279

Macaca nemestrina, 83, 84, 86, 133 ,

134, 139, 191, 194, 208, 238, 278

Macaca spp., 226

Macaranga spp., 34, 71, 267

Macroglossus minimus, 95

Macrognathus spp., 124

Macronous gularis, 257, 259

Macronous ptilosus, 237

Macronous spp., 77

Madhuca spp., 148

Malacopteron affine, 237

Malacopteron cinereum, 77, 259, 268

Malacopteron magnum, 237

Malacopteron spp., 77, 160, 228

Mangifera indica, 94

Mangifera spp., 178, 185

Manilkara achras, 95

Manis javanica, 190, 195, 238, 241, 311

Manouria emys, 191, 192, 198, 208, 231, 238, 310, 316

Mastacembelus maculates, 319

Mastacembelus spp., 124

Mastacembelus unicolor, 123, 318

Maticora bivirgata, 316

Maticora intestinalis, 316

Maxomys rajah, 92, 294

Maxomys surifer, 80, 92

Maxomys whiteheadi, 92
Megaderma spasma, 97

Megalaima chrysopogon, 257

Megalaima henricii, 237

Megalaima mystacophanos, 238

Megalaima rafflesii, 238

Megophrys nasuta, 114, 117, 313

Meiglyptes tristis, 68, 70, 71, 257, 265, 266

Meiglyptes tukki, 70, 159, 238, 257, 259, 261, 263, 264, 267

Melastoma spp., 54

Melia azedarach, 94

Meliosma sumatrana, 178

Meristogenys orphnocnemis, 117

Meristogenys phaeomerus, 313

Meristogenys spp., 113

Meristogenys whiteheadi, 313

Metaphrynella sundana, 117, 313

Microhierax fringillarius, 13

Microhyla berdmorei, 117

Microhyla borneensis, 114, 117, 313

Microhyla petrigena, 117

Microhyla spp., 113

Microros spp., 176

Mikania micantha, 54

Mikania scandens, 54

Mulleripicus pulverulentus, 67, 68, 69,

71, 72, 198, 258

Muntiacus atherodes, 105, 106, 139, 158, 304, 305

Muntiacus muntjak, 105, 106, 139, 209, 241, 304, 305

Muntiacus spp., 57, 226

Musa spp., 94

Mustela nudipes, 241

Myotis spp., 96

Myristica spp., 64, 196

\section{$\mathbf{N}$}

Naja sumatrana, 316

Napothera spp., 63

Nasalis larvatus, 191, 194, 238, 278

Nectarinia sperata, 14

Neesia spp., 307

Nemacheilus saravacensis, 123, 124, 319 
Nemacheilus selangoricus, 123, 124, 319

Nemacheilus spiniferus, 124, 319

Nematabramis everetti, 123, 124, 319

Neofelis nebulosa, 7, 38, 98, 151, 159, 190, 194, 229, 238, 242

Neogastromyzon nieuwenhuisi, 123, 319

Neogastromyzon spp., 124

Nepenthes gracilis, 175

Nephelium spp., 176, 178

Niviventer cremoriventer, 92

Notochelys platynota, 191, 198, 208, 239, 316

Nycteris tragata, 97

Nycticebus coucang, 139, 191, 194, 238, 242, 274

Nyctixalus pictus, 117, 313

$\mathbf{0}$

Occidozyga baluensis, 117

Occidozyga laevis, 117

Octomeles sumatrana, 105

Oligodon purpurascens, 316

Oligodon sp., 316

Ompok bimaculatus, 123, 319

Ophiophagus hannah, 242, 316

Oriolus xanthonotus, 238

Orlitia borneensis, 191, 208, 231, 239, 316

Osphronemus septemfasciatus, 319

Osteochilus chinni, 122

Osteochilus spp., 125

Osteochilus waandersii, 123, 319

Otus rufescens, 150

$\mathbf{P}$

Paguma larvata, 99, 100, 294

Palamneus sulpides, 300

Palaquium spp., 148

Pandanus spp., 310

Pangasius spp., 125, 199, 232

Panthera pardus, 38, 151

Panthera tigris, 38, 151, 195

Parachela ingerkongi, 123, 319

Paradoxurus hermaphroditus, 99, 100, 139, 242, 296
Pardofelis marmorata, 98, 138, 229, 238, 242

Parhomaloptera spp., 125

Parkia javanica, 178

Parkia speciosa, 95, 178, 250

Passiflora foetida, 297

Passiflora spp., 54

Payena spp., 148

Pedostibes hosii, 117, 313

Pelargopsis capensis, 14

Pelochelys cantorii, 191, 192, 208, 239, 316

Penelopides exarhatus, 63

Pericrocotus spp., 228

Pernis ptilorhynchus, 13

Petaurista elegans, 288

Petaurista petaurista, 91, 287

Phaenicophaeus chlorophaeus, 257, 259, 263, 266

Phaenicophaeus curvirostris, 257

Philautus hosii, 112, 117

Philautus spp., 112

Philentoma pyrhopterum, 267

Philentoma velatum, 238

Picumnus innominatus, 68

Picus chlorophus, 256

Picus mentalis, 68, 69, 70, 72, 76, 257, 258, 260, 261, 263, 264

Picus miniaceus, 70, 72, 257, 259, 260

Picus puniceus, 68, 70, 72, 137, 256, 259, 260, 264

Piper aduncum, 95

Pipistrellus spp., 96

Pithecellobium spp., 178

Pitta caerulea, 14, 238

Pitta granatina, 14, 238

Polyalthia spp., 297

Polypedates colletti, 116, 117, 313

Polypedates leucomystax, 117, 313

Polypedates macrotis, 116, 117, 118, 313

Polypedates otilophus, 117, 313

Polyplectron bicalcaratum, 75

Polyplectron schleiermacheri, 72, 73, 74

Pomacea canaliculatus, 54

Pometia spp., 148 
Pongo pygmaeus, 48, 82, 83, 159, 215, 229

Porhomatoptera microstoma, 319

Pouteria spp., 148

Presbytis femoralis, 83

Presbytis frontata, 158

Presbytis hosei, 29, 84, 85, 87, 139, 158, 190, 194, 209, 238, 241, 281, 282

Presbytis rubicunda, 84, 85, 87, 139,

148, 194, 238, 282, 283, 284

Presbytis spp., 81, 158, 230

Prionailurus bengalensis, 29, 57, 98

Prionodon linsang, 99, 100, 101

Protomyzon griswoldi, 319

Protomyzon spp., 125

Psammodynastes pulverulentus, 317

Pseudorhabdion collaris, 317

Pseudorhabdion sarawakensis, 317

Psidium guajava, 94

Psidium spp., 54

Pteropus spp., 94

Pteropus vampyrus, 96, 242

Ptilocichla leucogrammica, 77, 191, 208, 236

Ptyas fuscus, 317

Puntius binotatus, 123, 124, 319

Puntius sealei, 123, 124, 319

Puntius spp., 123, 124, 319

Pycnonotus cyaniventris, 76

Pycnonotus erythropthalmos, 76

Pycnonotus eutilotus, 76

Pycnonotus melanoleucos, 76, 237

Pycnonotus squamatus, 76, 237

Pycnonotus zeylanicus, 53, 76, 189, 190 ,

197, 208, 236, 241

Python curtus, 317

Python reticulatus, 241, 317

Python spp., 231

Q

Quercus spp., 148, 307

\section{$\mathbf{R}$}

Raflesia spp., 108, 308

Ramphotyphlops braminus, 317
Rana catesbeiana, 55, 118

Rana chalconota, 113, 117, 313

Rana hosii, 313

Rana nicobariensis, 116, 117, 118, 313

Rana palavanensis, 117

Rana picturata, 117, 313

Rana signata, 116, 117

Rasbora argyrotaenia, 123, 319

Rasbora caudimaculata, 123, 124, 319

Rasbora elegans, 123, 124, 319

Rasbora lateristriata, 123, 319

Rattus tiomanicus, 80, 91, 242

Ratufa affinis, 29, 88, 89, 139, 144,

149, 159, 286, 289

Ratufa bicolor, 88, 89

Reinwardtipicus validus, 67, 68, 70, 72, 259, 262, 266

Rhacophorus dulitensis, 116, 117

Rhacophorus gauni, 117

Rhacophorus harrissoni, 313

Rhacophorus nigropalmatus, 116, 117 , 313

Rhacophorus pardalis, 113, 116, 117, 313

Rhacophorus spp., 118

Rheithrosciurus macrotis, 88

Rhinolophus sedulus, 97

Rhinolophus spp., 150

Rhinomyias spp., 77

Rhinomyias umbratilis, 63

Rhinoplax vigil, 14, 64, 65, 66, 148,

159, 196, 236, 250

Rhinosciurus laticaudatus, 88, 89, 137,

139, 159, 292

Rhipidura javanica, 14

Rhipidura perlata, 63, 257, 266, 268

Rhyticeros cassidix, 63

Rhyticeros corrugatus, 64

Rhyticeros everetti, 64

Rhyticeros undulatus, 14, 65, 245

Rollulus rouloul, 191, 208, 236

Russula sp., 105

$\mathbf{S}$

Saccharum spontaneum, 54 
Salivinia spp., 54

Santiria laevigata, 249

Santiria oblongifolia, 178

Sasia abnormis, 67, 68, 69, 147, 259, 261, 262, 267

Scotophilus spp., 96

Sechium edule, 95

Setornis criniger, 257

Shorea beccarianna, 289

Shorea pinanga, 148

Shorea robusta, 67

Shorea spp., 41, 66, 251, 307

Shorea xanthophylla, 249, 283

Sphaeropieus spp., 300

Sphenomorphus sabanus, 317

Spilornis cheela, 13

Spilornis kinabaluensis, 191, 197, 208, 236

Spizaetus alboniger, 13

Spizaetus barteli, 78

Spizaetus cirrhatus, 13

Spizaetus spp., 78

Spizella passerina, 78

Stachyris erythroptera, 257

Stachyris maculata, 237, 257, 267

Stachyris nigricollis, 237, 257

Stachyris spp., 228

Staurois guttatus, 313

Staurois latopalmatus, 117

Staurois natator, 117

Staurois tuberilinguis, 313

Sterculia parvifolis, 249

Sterna albifrons, 13

Sterna hirundo, 13

Sundasciurus hippurus, 88, 89, 91, 139, 159, 290

Sundasciurus jentinki, 292

Sundasciurus lowii, 87, 88, 90, 139, 290

Sundasciurus tenuis, 88, 90, 139, 291

Sus barbatus, 6, 29, 54, 55, 105, 106, $107,139,158,192,193,215,223$, 226, 229, 241, 306

Sus scrofa, 54, 55, 307
$\mathbf{T}$

Takydromus sexlineatus, 317

Taphozous spp., 96

Tarsius bancanus, 86, 137, 139, 238, 275, 276

Ternstroemia magnifica, 307

Terpsiphone paradisi, 267

Tetramarista glabra, 178

Theobroma cacao, 93

Tomistoma schlegelii, 119

Tor spp., 122, 125, 199, 231, 232

Tor tambra, 123, 160, 241, 319

Tor tambroides, 319

Trachypithecus cristatus, 83

Tragulus javanicus, 36, 105, 106, 107, 209, 301, 303

Tragulus kanchil, 105, 106, 139, 301

Tragulus napu, 105, 106, 139, 209, 241, 301, 302, 303

Tragulus spp., 29, 56, 138, 153, 158, 192, 209

Trema, 178

Trema orientalis, 34

Trema spp., 37

Treron capellei, 160, 191, 198, 208, 236

Treron curvirostra, 242

Treron fulvicollis, 160

Trichastoma rostratum, 77, 237

Trichgaster trichopterus, 319

Trichoglossus haematodus, 54

Trichys fasciculata, 242

Trimeresurus albolabris, 317

Tropidolaemus wagleri, 317

Tropidophorus brookei, 317

Tupaia glis, 80, 92

Tupaia gracilis, 93

Tupaia longipes, 93, 94

Tupaia minor, 93

Tupaia tana, 92, 93

$\mathbf{U}$

Urostigma spp., 250

Ursus malayanus, 7, 29, 56, 101, 139,

$151,158,175,190,195,215,226$, 229, 238, 241, 308 
346 | Indeks

V

Vallaris solanacea, 297

Varanus heteropholis, 119

Varanus rudicollis, 119, 242, 317

Varanus salvator, 119, 317

Varanus spp., 119

Vatica spp., 41, 171

Viverra tangalunga, 29, 99, 100, 137,

139, 144, 299 


\section{Literatur}

Abdulhadi, R., E. Mirmanto, dan K. Kartawinata. 1987. A lowland dipterocarp forest in Sekundur, North Sumatra, Indonesia: five years after mechanized logging. Pages 255-273 in A.J.G.H. Kostermans, editor. Proceedings of the third round table conference on dipterocarps, UNESCO/ ROSTSEA. Jakarta, Indonesia.

Abdulhadi, R., K. Kartawinata, dan S. Sukardjo. 1981. Effects on mechanized logging in the lowland dipterocarp forest at Lempake, East Kalimantan. Malaysian Forester 44:407-418.

Adjers, G., K. Nuryanto, dan J. Kuusipalo. 1996. Rehabilitation of degraded dipterocarp forests: results from South Kalimantan, Indonesia. Pages 316-334 in S. Appanah dan K.C. Khoo, editors. Proceedings fifth round table conference on dipterocarps. 7-10 November 1994. Chiang Mai, Thailand. FRIM, Kepong, Malaysia.

Ahmad, A. H. 1994. The Ecology of Mousedeer (Tragulus species) in a Bornean rain forest, Sabah, Malaysia. MSc thesis. University of Aberdeen, Aberdeen, UK.

Ahmad, N. 2001. Frugivores and fruit production in primary and logged tropical rainforests. PhD dissertation. Faculty of Science and Technology. Universitas Kebangsaan Malaysia, Bangi, Malaysia.

Ahmad, N., M. N. Hasan, dan A. L. Mohamad. in press. Diversity and density of primates in primary and logged lowland tropical rain forest at Danum Valley, Sabah, Borneo. Biodiversity and Conservation.

Aldrich-Blake, F. P. G. 1980. Long-tailed macaques. Pages 147-165 in D. J. Chivers, editor. Malayan Forest Primates: ten years' study in tropical rain forest. Plenum Press, New York, USA.

Alexander, I., N. Ahmad, dan L. S. See. 1992. The role of mycorrhiza in the regeneration of some Malaysian forest trees. Philosophical Transactions of the Royal Society of London. Series B, Biological Sciences 335:379-388.

Ali, S. 1953. The birds of Travancore and Cochin. Oxford University Press, Bombay, India.

Anderson, A. J. U. 1979. Subsistence of the Penan in the Mulu area of Sarawak. Sarawak Gazette 105:204-216.

Anggraini, K., M. Kinnaird, dan T. O’Brien. 2000. The effects of fruit availability and habitat disturbance on an assemblage of Sumatran hornbills. Bird Conservation International 10:189-202.

Anonymous. 1981. Pangolin skins for cowboy boots. Oryx 16:138.

Appanah, S. 1998. Management of natural forests. Pages 133-149 in S. Appanah, dan J. M. Turnbull, editors. A review of dipterocarps, taxonomy, ecology and silviculture. CIFOR, Bogor, Indonesia.

Appanah, S. dan A. M. Mohd-rasol. 1990. Smaller trees can fruit in logged dipterocarp forests. Journal of Tropical Forest Science 3:80-87.

Appanah, S. dan J. M. Turnbull, editors. 1998. A review of dipterocarps. Taxonomy, ecology and silviculture. CIFOR, Bogor, Indonesia. 
Applegate, G., F. E. Putz, L. K. Snook. 2004. Who pays for and who benefits from improved timber harvesting practices in the tropics?: lessons learned and information gaps. CIFOR, Bogor, Indonesia.

Applegate, G., K. Kartawinata, Machfudh, dan A. Klassen. 2001. Reduced impact logging guidelines for Indonesia. CIFOR, Bogor, Indonesia.

ARCBD. 2002. Biodiversity information sharing service (BISS). ASEAN Regional Centre for Biodiversity Conservation. http://www.arcbc.org.ph/data_bases.htm.

Asquith, N. M., S. J. Wright, dan M. J. Clauss. 1997. Does mammal community composition control recruitment in neotropical forests? Evidence from Panama. Ecology 78:941-946.

Augeri, D. 2004a. Effects of disturbance on Malayan Sun Bear habitat use. Presented paper at the International Conference on Conservation Science, Cambridge, UK.

Augeri, D. 2004b. Disturbance effects on sun bears and their primary competitors in Indonesia. Invited paper. Presented at the Conservation Biology Seminar Series. Department of Zoology, University of Cambridge, UK.

Augeri, D. M. 1994. Assessment of Trans Canada Highway perturbation on Black Bear population, guild and community structures in Banff National Park. Unpublished report and proposal for Parks Canada.

Augeri, D. M. 1995. Natural and anthropogenic disturbance effects on edge character and diversity. MSc Thesis. Department of Forest Sciences \& Program for Ecological Studies, Colorado State University, USA.

Augeri, D. M. 2001. Potential disturbance effects on Malayan Sun Bear (Helarctos malayanus). Ecology, landscape use and conservation in Indonesia and Malaysia. Unpublished report. University of Cambridge, Cambridge, UK.

Augeri, D. M. 2002. Effects on Sun Bear (Helarctos malayanus) habitat selection, ecology and landscape use. Paper presented at the International Bear Association Annual Meeting 2002, Steinkjer, Norway.

Augeri, D. M. 2003. Conservation of the Malayan Sun Bear (Helarctos malayanus) in Indonesia: Mitigating potential bear/human conflicts and disturbance effects on Sun Bear ecology and landscape use. Unpublished report for the Indonesian Institute of Sciences.

Austin, S. C. dan M. E. Tewes. 1999. Observation of viverrid, mustelid and herpestid species in Khao Yai NP, Thailand. Small Carnivore Conservation no. 21:13-15.

Auzel, P. dan D. S. Wilkie. 2000. Wildlife use in northern Congo: hunting in a commercial logging concession. Pages 413-426 in J. G. Robinson, dan E. L. Bennett, editors. Hunting for sustainability in tropical forests. Columbia University Press, New York, USA.

Azlan, J. M. 2003. The diversity and conservation of mustelids, viverrids and herpestids in a disturbed forest in Peninsular Malaysia. Small Carnivore Conservation 29:8-9.

Backer, C. A. dan R. C. Bakhuizen-van den Brink Jr. 1963-1968. Flora of Java. Vol. 1-3. WoltersNoordhoff, Groningen, the Netherlands.

Bakshi, B. K., Y. N. Puri, dan S. Singh. 1967. Natural decay resistance of Indian timbers. II Decay resistance of sal (Shorea robusta Gaertn.) and teak (Tectona grandis L.f.). Indian Forester 93: 305328.

Bakuneeta, C., K. Johnson, R. Plumptre, dan V. Reynolds. 1995. Human uses of tree species whose seeds are dispersed by chimpanzees in the Budongo forest. African Journal of Ecology 33:276-278.

Banks, E. 1931. A popular account of the mammals of Borneo. Journal of the Malayan Branch of the Asiatic Society 9:137.

Banks, E. 1937. The distribution of Bornean birds. Sarawak Museum Journal 4:453-496.

Banks, E. 1949. Bornean mammals. The Kuching Press, Kuching, Sarawak.

Barber, C. V. dan J. Schweithelm 2000. Trial by fire. Forest fires and forestry policy in Indonesia’s era of crisis and reform. World Resources Institute (WRI), Forest Frontiers Initiative. In collaboration with WWF-Indonesia and Telapak Indonesia Foundation, Washington D.C, USA.

Barrett, E. B. M. 1984. The ecology of some nocturnal arboreal mammals in the rain forest of Peninsular Malaysia. PhD dissertation. University of Cambridge, UK.

Barrette, C. 1977. Some aspects of the behaviour of muntjacs in Wilpattu National Park. Mammalia 41:1-34

Bartels, M. dan H. Bartels. 1937. Uit het leven der Neushoornvogels (I, II, III) (from the Life of Hornbills). Tropische Natuur 26:117-127, 140-147, 166-172. 
Basuki, I. dan D. Sheil. 2005. Local perspectives of forest landscapes: A preliminary evaluation of land and soils, and their importance in Malinau, East Kalimantan, Indonesia. CIFOR, Bogor, Indonesia.

Baur, K. S. dan M. Hadley. 1990. Reproductive ecology of tropical forest plants. Man and the Biosphere series. UNESCO, Paris, France.

Bearder, S. K. 1987. Lorises, bushbabies, and tarsiers: diverse societies in solitary foragers. Pages 11-24 in B. B. Smuts, D. L. Cheney, S. R.M., R. W. Wrangham, dan T. T. Struhsaker, editors. Primate Societies. Univ. of Chicago Press, Chicago, USA.

Becker, P. dan M. Wong. 1985. Seed dispersal, seed predation, and juvenile mortality of Aglaia sp. (Meliaceae) in lowland dipterocarp rainforest. Biotropica 17:230-237.

Becker, P., M. Leighton, dan J. Payne. 1985. Why tropical squirrels carry seeds out of source crowns. Journal of Tropical Ecology 1:183-186.

Beebe, W. 1918-1922. A monograph of the pheasants. Witherby, London, UK.

Beier, P. dan R. F. Noss. 1998. Do habitat corridors provide connectivity? Conservation Biology 12:1241-1252.

Belovsky, G. E. 1987. Extinction models and mammalian persistence. Pages 35-57 in M. E. Soulé, editor. Viable populations for conservation. Cambridge University Press, Cambridge, UK.

Bennett, E. L. 2002. Is there a link between wild meat and food security. Conservation Biology 16:590592.

Bennett, E. L. dan A. G. Davies. 1994. The ecology of Asian colobines. Pages 129-171 in A. G. Davies, dan J. F. Oates, editors. Colobine monkeys: their ecology, behaviour and evolution. Cambridge University Press, Cambridge, UK.

Bennett, E. L., A. J. Nyaoi, dan J. Sompud. 1997. Hornbills Buceros spp. and culture in northern Borneo: Can they continue to coexist? Biological Conservation 82:41-46.

Bennett, E. L., A. J. Nyaoi, dan J. Sompud. 1999. Saving Borneo's bacon: The sustainability of hunting in Sarawak and Sabah. Pages 305-324 in J. G. Robinson, dan E. L. Bennett, editors. Hunting for sustainability in tropical forests. Columbia University Press, New York, USA.

Bennett, E. L., E. J. Milner-Gulland, M. Bakarr, H. E. Eves, J. G. Robinson, dan D. S. Wilkie. 2002. Hunting the world's wildlife to extinction. Oryx 36:328-329.

Bennett, E. L. dan J. G. Robinson. 2000. Hunting of wildlife in tropical forests. Implications for biodiversity and forest peoples. The World Bank, Washington, D.C., USA.

Bennett, E. L. dan M. T. Gumal. 2001. The inter-relationships of commercial logging, hunting and wildlife in Sarawak, and recommendations for forest management. Pages 359-374 in R. A. Fimbel, A. Grajal, dan J. G. Robinson, editors. The cutting edge: conserving wildlife in logged tropical Forest. Columbia University Press, New York, USA.

Bennett, E. L., M. T. Gumal, J. G. Robinson, dan A. Rabinowitz. 1996. A masterplan for wildlife in Sarawak. Wildlife Conservation Society and Sarawak Forest Department, Kuching, Malaysia.

Bennett, E. L. dan Z. Dahaban. 1995. Wildlife responses to disturbances in Sarawak and their implications for forest management. Pages 66-86 in R. B. Primack, dan T. E. Lovejoy, editors. Ecology, conservation and management of South-East Asian rainforests. Yale University Press, New Haven, USA \& London, UK.

Berenstain, L. 1986. Responses of long-tailed macaques to drought and fire in eastern Borneo: a preliminary report. Biotropica 18:257-262.

Bernard, H. 2004. Effects of selective logging on microhabitat-use patterns of non-volant small mammals in a Bornean tropical lowland mixed-dipterocarp forest. Nature and Human Activities 8:1-11.

Bertault J. dan K. Kadir. 1998. Silvicultural research in a lowland mixed dipterocarp forest of East Kalimantan: the contribution of STREK project. CIRAD Forêt, FORDA dan P.T. INHUTANI I. Bogor Indonesia.

Bertault, J-G. dan P. Sist. 1995. The effects of logging in natural forests. Bois et Forêts des Tropiques 245:5-20.

Bertault, J-G. dan P. Sist. 1997. An experimental comparison of different harvesting intensities with reduced impact and conventional logging in East Kalimantan. Forest Ecology and Management 94:209-218.

Biedermann, R. 2003. Body size and area-incidence relationships: is there a general pattern? Global Ecology \& Biogeography 12:381-387.

Bierregaard, R. O. J. dan P. C. Stouffer. 1997. Understory birds and dynamic habitat mosaics in 
Amazonian rainforests. Pages 138-155. Tropical forest remnants: ecology, management, and conservation of fragmented communities. University of Chicago Press, Chicago, USA.

Bierregaard, R. O. J., T. E. Lovejoy, V. Kapos, A. A. dos Santos, dan R. W. Hutchings. 1992. The biological dynamics of tropical rainforest fragments. Bioscience 42:859-866.

Bierregaard, R. O., C. Gascon, T. E. Lovejoy, dan R. Mesquita 2001. Lessons from Amazonia; the ecology and conservation of a fragmented forest. Yale University Press, New Haven, USA.

Bird, M. in prep. A savanna corridor in Sundaland. Quaternary Science Reviews.

BirdLife International 2001. Threatened birds of Asia: the BirdLife International Red Data Book. BirdLife International, Cambridge, UK.

Blundell, A. G. 1996. A preliminary checklist of mammals at Cabang Panti research station, Gunung Palung National Park, West Kalimantan. Tropical Biodiversity 3:251-259.

Boer, C. 1998. Zur Bedeutung von Baumsturzlücken für die Verteilung und Abundanz von Vogelarten des Unterholzes in Primär- und Sekundärregenwäldern Ostkalimantans. PhD dissertation. JuliusMaximilian-Universität, Würzburg, Germany.

Brandani, A., G. S. Hartshorn, dan G. H. Orians. 1988. Internal heterogeneity of gaps and species richness in Costa Rican tropical wet forest. Journal of Tropical Ecology 4:99-119.

Brandon-Jones, D. 1996. The zoogeography of sexual dichromatism in the Bornean grizzled sureli, Presbytis comata (Desmarest, 1822). Sarawak Museum Journal V:177-200.

Bratawinata, A. A. 1994. The influence of the Indonesian Selective Cutting and Replanting system on the structure composition species of the Lowland Dipterocarp forest. Paper presented on the fifth round table conference on dipterocarps, 7-10 November 1994.

Brearley, F. Q., M. C. Press, dan J. D. Scholes. 2003. Nutrients obtained from leaf litter can improve the growth of dipterocarp seedlings. New Phytologist 160:101-110.

Brokaw, N. 1987. Gap phase regeneration of three pioneer tree species in a tropical forest. Journal of Ecology 75:9-20.

Brook, B. W., N. S. Sodhi, dan P. K. L. Ng. 2003. Catastrophic extinctions follow deforestation in Singapore. Nature 424:420-423.

Brookfield, H. 1997. Landscape history. Land degradation in the Indonesian region. Pages 27-60 in P. Boomgaard, F. Colombijn, dan D. Henley, editors. Paper Landscapes. Explorations in the environmental history of Indonesia. KITLV Press, Leiden, The Netherlands.

Brown, B. N. 1976. Phytophthora cinnamomi associated with patch death in tropical rain forests in Queensland. APPS-Newsletter 5:1-4.

Brown, J. H., O. J. Reichman, dan D. W. Davidson. 1976. Granivory in desert ecosystems. Annual Review of Ecology and Systematics 10:201-227.

Brown, J. H., T. G. Whitham, K. M. Ernest, dan C. A. Gehring. 2001. Complex species interactions and the dynamics of ecological systems: long-term experiments. Science 293:643-650.

Brown, N. D. dan S. Jennings. 1998. Gap-size niche differentiation by tropical rainforest trees: a testable hypothesis or a broken-down bandwagon? Pages 79-94 in D. M. Newbery, H. H. T. Prins, dan N. D. Brown, editors. Dynamics of tropical communities. The 37th symposium of the British Ecological Society, Cambridge University 1996. Blackwell Science, Oxford, UK.

Bruenig, E. 1996. Conservation management of tropical rainforest: an integrated approach to sustainability. CAB International, Wallingford, UK.

Buckle, A. P., T. H. Chia, M. G. P. Fenn, dan M. Visvalingam. 1997. Ranging behaviour and habitat utilisation of the malayan wood rat (Rattus tiomanicus) in an oil palm plantation in johore, malaysia. Crop Protection 16:467-473.

Buechner, H. K. dan H. C. Dawkins. 1961. Vegetation change induced by elephants and fire in Murchison Falls National Park, Uganda. Ecology 42:752-766.

Burgess, P. F. 1971. Effects of logging on hill dipterocarp forest. Malayan Nature Journal 24:231-237.

Burghouts, T., G. Ernsting, G. Korthals, dan T. de Vries. 1992. Litterfall, leaf litter, decomposition and litter invertebrates in primary and selectively logged dipterocarp forest in Sabah, Malaysia. Philosophical Transactions of the Royal Society of London. Series B, Biological Sciences 335:407416.

Butler, J. R. A., J. T. du Toit, dan J. Bingham. 2004. Free-ranging domestic dogs (Canis familiaris) as predators and prey in rural Zimbabwe: threats of competition and disease to large wild carnivores. Biological Conservation 115:369-378.

Caldecott, J. 1988. Hunting and wildlife management in Sarawak. IUCN, Gland, Switzerland. 
Caldecott, J. O. 1986. An ecological and behavioral study of Pig-tailed Macaques. Karger, Basel, Switzerland.

Caldecott, J. O., R. A. Blouch, dan A. A. MacDonald. 1993. The bearded pig (Sus barbatus). Pages 136145 in W. L. R. Oliver, editor. Pigs, peccaries, and hippos. Status survey and conservation action plan. IUCN/SSC Pigs and Peccaries Specialist group and IUCN/SSC Hippos Specialist Group, Gland, Switzerland.

Campbell, D. G. 1991. Gap formation in tropical forest canopy by elephants, Oveng, Gabon, Central Africa. Biotropica 23:195-196.

Cannon, C. H., D. R. Peart, M. Leighton, dan K. Kartawinata. 1994. The structure of lowland rainforest after selective logging in West Kalimantan, Indonesia. Forest Ecology and Management 67:49-68.

Caribbean National Forest. 1997. Final environmental impacts statement for the revised land and resource management plan, Appendix F. Puerto Rican Parrot Management Situation. USDA Forest Service, Southern Region, USA.

Carter, S. 1985. Comparison of bird numbers in primary and selectively felled tropical rain forests in Brunei. Brunei Museum Journal 6:125-130.

Cebrián, J. D. dan C. M. Duarte. 1994. The dependence of herbivory on growth rate in natural plant communities. Functional Ecology 8:518-525.

Chang, M. S., J. Hii, P. Buttner, dan F. Mansoor. 1997. Changes in abundance and behaviour of vector mosquitoes induced by land use during the development of an oil palm plantation in sarawak. Transactions of the Royal Society of Tropical Medicine \& Hygiene 91:382-386.

Chapman, C. A. dan J. E. Lambert. 2000. Habitat alteration and the conservation of African primates: Case study of Kibale National Park, Uganda. American Journal of Primatology 50:169-185.

Chasen, F. N. 1940. A handlist of Malaysian mammals. A systematic list of the mammals of the Malay Peninsula, Sumatra, Borneo and Java, including the adjacent small islands, Singapore. Bulletin of the Raffles Museum, Singapore, Strait Settlements No. 15.

Chen, J., J. F. Franklin, dan T. A. Spies. 1992. Vegetation responses to edge environments in old-growth Douglas-fir forests. Ecological Applications 2:387-396.

Chin, C. 2001. Pig in the pot: Comments on Sus barbatus in the hunting lifestyle of the Penan in Sarawak (Borneo). Asian Wild Pig News 1:10-12.

Chivers, D. J. 1992. Socio-ecology and conservation of gibbons in Southeast Asia with special reference to Borneo. Pages 230-244 in G. Ismail, M. Mohammed, dan S. Omar, editors. Forest biology and conservation in Borneo. Center for Borneo Studies Publication No. 2. Yayasan Sabah, Kota Kinabalu, Malaysia.

Choudhury, A. 1997. The status of bears in Assam, India. International Bear News 6:16.

Chuen, W. W., D. Eaton, dan D. Y. M. 1998. Estimation of petai consumption in the Klang Valley in Peninsular Malaysia. Pages 212-226 in S. S. Lee, Y. M. Dan, I. Gauld, dan J. Bishop, editors. Conservation, management and development of forest resources. Proceedings of the MalaysiaUnited Kingdom Programme Workshop 21-24 October 1996. Forest Research Institute Malaysia.

Chunkao, K. 1978. The effects of logging on soil erosion. Pages 65-72 in R. S. Suparto, I. Soerianegara, Z. Hamzah, H. J. Haeruman, S. Hadi, S. Manan, H. Basjarudin, dan W. Sukotjo, editors. Proceeding of the symposium on the long-term effects of logging in Southeast Asia. BIOTROP, Bogor, Indonesia.

CIFOR. 2004. Workshop to develop a regional applied research program in the Congo Basin (ITTC Decision 10(XXXII)): pilot study on the social, environmental and economic sustainability of industrial concessions in the Congo Basin, main report, part D. International Tropical Timber Organization, Tokyo, Japan.

Civeyrel, L. dan D. Simberloff. 1996. A tale of two snails: is the cure worse than the disease? Biodiversity and Conservation 5:1231-1252.

Clarke, A. L. dan T. Pacin. 2002. Domestic cat "colonies" in natural areas: A growing exotic species threat. Natural Areas Journal 22:154-159.

Clayton, L. dan E. J. Milner-Gulland. 2000. The trade in wildlife in North Sulawesi, Indonesia. Pages 473-496 in J. G. Robinson, dan E. L. Bennett, editors. Hunting for sustainability in tropical forests. Columbia University Press, New York, USA.

Clearwater, M.J., T. Nifinluri, dan P.R. van Gardingen. 1999. Growth response of wild Shorea seedling to high light intensity. Pages 55-64 in P. Sist, C. Sabogal, dan Y. Byron, editors. Management of 
secondary and logged-over forests in Indonesia: Selected proceedings of an International workshop, 17-19 November 1997, CIFOR, CIRAD dan USAID.

Cleary, D. F. R. 2004. Assessing the use of butterflies as indicators of logging in Borneo at three taxonomic levels. Journal of Economic Entomology 97:429-435.

Clevenger, A. P., B. Chruszcz, dan K. Gunson. 2001. Drainage culverts as habitat linkages and factors affecting passage by mammals. Journal of Applied Ecology 38:1340-1349

Clevenger, A. P., B. Chruszczc, dan K. E. Gunson. 2003. Spatial patterns and factors influencing small vertebrate fauna road-kill aggregations. Biological Conservation 109:15-26.

Cochrane, M. A., A. Alencar, M. D. Schulze, C. M. Souza, D. C. Nepstad, P. Lefebvre, dan E. A. Davidson. 1999. Positive feedbacks in the fire dynamic of closed canopy tropical forests. Science 284:1834-1836.

Cochrane, M. dan M. Schulze. 1999. Fire as a recurrent event of the eastern Amazon: effects on forest structure, biomass, species composition. Biotropica 31:2-16.

Colchester, M. 2000. High conservation value forests, note A. Proposed elements of a new forest policy. 3 rd input to the safeguards and definitions focus group of the technical advisory group. Forest Peoples Programme, The World Bank, Washington, USA.

Coleman, D. C. dan D. A. J. Crossley. 2003. Fundamental soil ecology. Academic Press, New York, USA and London, UK.

Coley, P. D. 1987. Interspecific variation in plant anti-herbivore properties: the role of habitat quality and rate of disturbance. New Phytologist 109 supplement:251-263.

Coley, P. D., J. P. Bryant, dan F. S. Chapin. 1985. Resource availability and plant antiherbivore defense. Science 230:895-899.

Colfer, C. J. P. dan I. A. P. Resosudarmo. 2002. Which way forward? People, forests and policymaking in Indonesia. Resources for the Future, Washington D.C., USA.

Collar, N. J., M. J. Crosby, dan A. J. Stattersfield. 1994. Birds to watch 2: The world list of threatened birds. BirdLife Conservation Series 4. BirdLife International, Cambridge, UK.

Colón, C. P. 1999. Ecology of the Malay Civet (Viverra tangalunga) in a logged and unlogged forest in Sabah, East Malaysia. PhD dissertation. Fordham University, New York, USA.

Corbet, G. B. dan J. E. Hill. 1992. The mammals of the Indomalayan region: A systematic review. Oxford University Press, Oxford, UK.

Corlett, R. T. 1988. Frugivory and seed dispersal by vertebrates in the Oriental (Indomalayan) Region. Biological Review 73:413-448.

Corlett, R. T. dan I. M. Turner. 1997. Long-term survival in tropical forest remnants in Singapore and Hong Kong. Pages 333-345 in W. F. Laurance, dan R. O. Bierregaard, editors. Tropical forest remnants: ecology, management and conservation of fragmented communities. Chicago University Press, Chicago, USA.

Crome, F. H. J., M. R. Thomas, dan L. A. Moore. 1996. A novel bayesian approach to assessing impacts of rain forest logging. Ecological Applications 6:1104-1123.

Crompton, R. H. dan P. M. Andau. 1986. Locomotion and habitat utilization in free-ranging Tarsius bancanus: A Preliminary Report. Primates 27:337-355.

Crompton, R. H. dan P. M. Andau. 1987. Ranging, activity rhythms, and sociality in free-ranging Tarsius bancanus: A preliminary report. International Journal of Primatology 8:43-71.

Cronk, Q. C. B. dan J. L. Fuller 1994. Invasive plants: the threat to natural ecosystems worldwide. A WWF Handbook. Chapman and Hall, London, UK.

Crooks, K. R. 2002. Relative sensitivities of mammalian carnivores to habitat fragmentation. Conservation Biology 16:488-502.

Curran, L. M. dan C. O. Webb. 2000. Experimental tests of the spatiotemporal scale of seed predation in mast-fruiting Dipterocarpaceae. Ecological Monographs 70:151-170.

Curran, L. M. dan M. Leighton. 2000. Vertebrate responses to spatiotemporal variation in seed production of mast-fruiting Dipterocarpaceae. Ecological Monographs 70:121-150.

Curran, L. M., I. Caniago, G. D. Paoli, D. Astianti, M. Kusenti, C. E. Nirarita, dan H. Haeruman. 1999. Impact of El Niño and logging on canopy tree recruitment in Borneo. Science 286:21842188.

Curtis, S. E. 1983. Environmental management in animal agriculture. Iowa Stae University Press, Ames, Iowa, USA. 
Dahaban, Z., M. Nordin, dan E. L. Bennett. 1996. Immediate effects on wildlife of selective logging in a hill dipterocarp forest in Sarawak: mammals. Monographiae Biologicae 74:341-346.

Daily, G. C. dan P. R. Ehrlich. 1996. Nocturnality and species survival. Proceedings of the National Academy of Sciences USA 93:11709-11712.

Dale, S. 2001. Necrophilic behaviour, corpses as nuclei of resting flock formation, and road-kills of Sand Martins Riparia riparia. Ardea 89:545-547.

Danielsen, F. dan M. Heegaard. 1994. The impact of logging and forest conversion of lowland forest birds and other wildlife in Seberida, Riau Province, Sumatra. Pages 59-60 in O. W. Sandbukt, editor. Rainforest and Resource Management. Proceedings of NORINDRA Seminar. Indonesian Institute of Sciences, Jakarta, Indonesia.

Danielsen, F. dan M. Heegaard. 1995. The birds of Bukit Tigapuluh, southern Riau, Sumatra. Kukila 7:99-120.

Das, I. 1996. Spatio-temporal resource utilization by a Bornean rainforest herpetofauna: preliminary results. Pages 315-323 in D. S. Edwards, W. E. Booth, dan S. C. Choy, editors. Tropical Forest Research - Current Issues. Proceedings of the conference held in Bandar Seri Begawan, April 1993. Monographiae Biologicae 74. Kluwer Academic Publishers, Dordrecht, the Netherlands.

Das, I. 2002. An introduction to the amphibians and reptiles of tropical Asia. Natural History Publication, Kota Kinabalu, Malaysia.

Daszak, P., A. A. Cunningham, dan A. D. Hyatt. 2001. Anthropogenic environmental change and the emergence of infectious diseases in wildlife. Acta Tropica 78:103-116.

Data Theory Scaling System Group (DTSS). 1999. CATPCA Version 1.0. Faculty of Social and Behavioral Sciences. Leiden University, The Netherlands, Leiden, the Netherlands.

Dathe, H. 1970. A second generation birth of captive sun bears at East Berlin Zoo. International Zoo Yearbook 10:79.

Datta, A. 1998. Hornbill abundance in unlogged forest, selectively logged forest and a forest plantation in Arunachal Pradesh, India. Oryx 32:285-294.

Datta, A. 2000. Pheasant abundance in selectively logged and unlogged forests of western Arunachal Pradesh, northeast India. Journal of the Bombay Natural History Society 97:177-183.

David, P. dan G. Vogel 1996. The snakes of Sumatra: An annotated checklist \& key with natural history notes. Edition Chimaira, Frankfurt am Main, Germany.

Davies, A. G. 1984. An ecological study of the red leaf monkey (Presbytis rubicunda) in dipterocarp forest of northern Borneo. PhD dissertation. University of Cambridge, Cambridge, UK.

Davies, A. G. 1987. Adult male replacement and group formation in Presbytis rubicunda. Folia Primatologica 49:111-114.

Davies, A. G. 1991. Seed-eating by red leaf monkeys (Presbytis rubicunda) in dipterocarp forest of northern Borneo. International Journal of Primatology 12:119-144.

Davies, A. G., E. L. Bennett, dan P. G. Waterman. 1988. Food selection by two southeast Asian colobines (Presbytis rubicunda and Presbytis melalophus) in relation to plant chemistry. Biological Journal of the Linnean Society 34:33-56.

Davies, G. dan J. Payne. 1982. A faunal survey of Sabah. IUCN/WWF Project No. 1692. World Wildlife Fund Malaysia, Kuala Lumpur, Malaysia.

Davies, G., M. Heydon, N. Leader-Williams, J. MacKinnon, dan H. Newing. 2001. The effects of logging on tropical forest ungulates in R. A. Fimbel, A. Grajal, dan J. G. Robinson, editors. The cutting edge: Conserving wildlife in logged tropical forest. Columbia University Press, New York, USA.

Davis, A. J. 2000. Does reduced-impact logging help preserve biodiversity in tropical rainforests? A case study from Borneo using dung beetles (Coleoptera: Scarabaeoidea) as indicators. Environmental Entomology 29:467-475.

Davis, D. D. 1962. Mammals of the lowland rainforests of North Borneo. Bulletin of the National Museum of Singapore 31:1-129.

Davison, G. W. H. 1980. Territorial fighting by lesser mouse-deer. Malayan Nature Journal 34:1-6.

Davison, G. W. H. 1981a. Diet and dispersion of the Great Argus Argusianus argus. Ibis 123:485-494.

Davison, G. W. H. 1981b. Habitat requirements and the food supply of the Crested Fireback. World Pheasant Association 6:40-52.

Davison, G. W. H. dan K. Scriven. 1987. Recent pheasant surveys in peninsular Malaysia. Pages 90-101 in C. Savage, and M. W. Ridley, editors. Proceedings of the 2nd International Symposium on the 
Pheasants in Asia. World Pheasant Association, Exning, Suffolk, UK.

De la Cruz, M. dan R. Dirzo. 1987. A survey of the standing levels of herbivory in seedlings from a Mexican rain forest. Biotropica 19:98-106.

del Hoyo, J., A. Elliott, dan J. Sargatal. 1997. Handbook of the birds of the world. Volume 4: sandgrouse to cuckoos. Lynx Edicions, Barcelona, Spain.

Delvingt, W. 1997. La chasse villageoise. Rapport du programme ECOFAC. Groupement AGRECO G.E.I.E - BDPA - SCETAGRI - SECA - CIRAD-Forêt. Brussels, Belgium.

Dennis, R. A. 1999. A review of fire projects in Indonesia 1982 - 1998. Page 112. CIFOR, Bogor, Indonesia.

Dennis, R. A., J. Mayer, G. B. Applegate, U. Chokkalingam, C. J. P. Colfer, I. Kurniawan, H. Lachowski, P. Maus, R. P. Permana, Y. Ruchiat, F. Stolle, S. Suyanto, dan T. P. Tomich. in prep. Fire, people and pixels: linking social science and remote sensing to understand underlying causes and impacts of fires in Indonesia. Human Ecology.

Dennis, R., E. Meijaard, G. Applegate, R. Nasi, dan P. Moore. 2001. Impact of human-caused fires on biodiversity and ecosystem functioning, and their causes in tropical, temperate and boreal forest biomes. CBD Technical Series No. 5. Convention on Biological Diversity, Montreal, Canada.

Denslow, J. S. 1987. Tropical rainforest gaps and tree species diversity. Annual Review of Ecology and Systematics 18:431-451.

Denslow, J. S. 2003. Weeds in paradise: thoughts on the invasibility of tropical islands. Annals of the Missouri Botanical Garden 90:119-127.

Denslow, J. S., A. E. Gomez Dias, dan T. A. Spies. 1990. Seed rain to tree fall gaps in a neotropical rainforest. Canadian Journal of Forest Research 20:642-648.

DFID. 1999. Indonesia. Towards sustainable forest management. Final report of the senior management advisory team and the provincial level forest management project. Vol. 2. DFID and Ministry of Forestry, Indonesia, Jakarta, Indonesia.

Diamond, J. M. 1984. 'Normal' extinctions of isolated populations. Pages 191-246 in M. H. Nitecki, editor. Extinctions. Chicago University Press, Chicago, USA.

Djamaludin. 1991. The implementation of Indonesian Selective Cutting and Replanting (TPTI) silviculture system for timber improvement in the logged-over areas. In I. Soerianegara, S.S. Tjitrosomo, R.C. Umaly, and I. Umboh, editors. Proceedings of the fourth round table conference on dipterocarps, Bogor, Indonesia. 12-15 December 1989. BIOTROP Special Publication 41:95-110.

Douglas, I., T. Greer, K. Bidin, dan M. Spilsbury. 1993. Impacts of rainforest logging on river systems and communities in Malaysia and Kalimantan. Global Ecology and Biogeography Letters 3:245252.

Douglas, I., T. Spencer, T. Greer, K. Bidin, dan W. Sinun. 1992. The impact of selective commercial logging on stream hydrology, chemistry and sediment loads in the Ulu Segama Rain Forest, Sabah, Malaysia. Philosophical Transaction of the Royal Society of London. Series B. Biological Sciences 235:397-406.

Down to Earth. 2002. Forest, People and Rights. Page 172. International Campaign for Ecological Justice in Indonesia, London.

Duckworth, J. W. 1997a. Mammals in Similajau National Park, Sarawak, in 1995. The Sarawak Museum Journal 51:171-192.

Duckworth, J. W. 1997b. Small carnivores in Laos: a status review with notes on ecology, behaviour and conservation. Small Carnivore Conservation 16:1-21.

Dudgeon, D. 2000. Riverine biodiversity in Asia: a challenge for conservation biology. Hydrobiologia 418:1-13.

Duff, A. B., R. A. Hall, dan C. W. Marsh. 1984. A survey of wildlife in and around commercial tree plantations in Sabah. The Malaysian Forester 47:197-213.

Duncan, R. P., T. M. Blackburn, dan T. H. Worthy. 2002. Prehistoric bird extinctions and human hunting. Proceedings of the Royal Society of London - Series B: Biological Sciences 269:517521.

Dunn, R. R. 2004. Managing the tropical landscape: a comparison of the effects of logging and forest conversion to agriculture on ants, birds, and lepidoptera. Forest Ecology and Management 191:215-225.

Dwiprabowo, H., S. Grulois, P. Sist, dan K. Kartawinata. 2002. Cost-benefit analysis of reduced-impact logging in a lowland Dipterocarp forest in Malinau, East Kalimantan. Pages 39-55. ITTO project 
PD 12/97 Rev.1 (F): forest, science and sustainability: the Bulungan model forest: Technical report phase 1, 1997-2001. CIFOR dan ITTO, Bogor, Indonesia.

Dwiyahreni, A. A. 2003. The effects of forest fire on the squirrel and tree shrew community dynamic in southern Sumatra. In Abstract Booklet 3rd International Colloquium in the ecology of tree squirrels. 7th European squirrel workshop. Ford Castle, Northumberland, UK. 26th-30th May 2003.

Dykstra, D. dan R. Heinrich 1996. FAO model code of forest harvesting. FAO, Rome.

Eames, J. C., A. N. Kuznetsov, G. Fredriksson, dan B. Jarvis. 2001. A preliminary biological assessment of PT Daisy, Berau District, East Kalimantan, Indonesia. Saigon: Tropical Forest Trust, Saigon, Vietnam.

Edwards, P. J. 1989. Insect herbivory and plant defence theory. Pages 275-297 in P. J. Grubb, dan J. B. Whittaker, editors. Towards a more exact ecology. Blackwell Scientific Publications, Oxford, UK.

Effendi, E., B. Shantiko, dan V. M. Dewi. 2002. Peranan ekologis Taman Nasional Kayan Mentarang terhadap perekonomian masyarakat dan fiskal kabupaten di sekitar kawasan. Tempayan 21:8-10.

Eggleton, P., R. Homathevi, D. Jeeva, D. T. Jones, R. G. Davies, dan M. Maryati. 1997. The species richness and composition of termites (Isoptera) in primary and regenerating lowland dipterocarp forest in Sabah, East Malaysia. Ecotropica 3:119-128.

Elias. 1998. Wood harvesting damages, regeneration and growth in the residual stand of dipterocarp forests. In G.L. Enriquez, U.R. Wasrin, dan D. Murdiarso, editors. Tropical Forest Dynamics, BIOTROP Special Publication 60:107-117.

Elias, G. Applegate, K. Kartawinata, Machfudh, dan A. Klassen. 2001. Reduced impact logging guidelines for Indonesia. CIFOR, Bogor, Indonesia.

Elouard, C. 1998. Pests and diseases of Dipterocarpaceae. Pages 115-131 in S. Appanah dan J.M. Turnbull, editors. A review of dipterocarps: taxonomy, ecology, and silviculture. CIFOR, Bogor, Indonesia.

Emmons, L. H. 1980. Ecology and resource partitioning among nine species of African rain forest squirrels. Ecological Monographs 50:31-54.

Emmons, L. H. 2000. Tupai. A field study of Bornean treeshrews. University of California Press, Berkeley, Los Angeles, London, UK.

Emmons, L. H, dan A. H. Gentry. 1983. Tropical forest structure and the distribution of gliding and prehensile tailed vertebrates. American Naturalist 121:513-524.

Enters, T., P. Durst, G. Applegate, P. C. S. Kho, dan G. Man. 2002. Applying reduced impact logging to advance sustainable forest management. FAO Regional Office for Asia and the Pacific. Bangkok, Thailand.

Epp, G. A. 1987. The seed bank of Eupatorium odoratum along a successional gradient in a tropical rain forest in Ghana. Journal of Tropical Ecology 3:139-149.

Eve, R. dan A. M. Guigue. 1989. Survey of the Mahakam River delta, East Kalimantan with special reference to its waterbirds. Publication No. 45. Asian Wetland Bureau, Kuala Lumpur, Malaysia.

Ewer, R. F. 1973. The carnivores. Cornell University Press, Ithica, USA.

Fa, J. E., S. F. Ryan, dan D. J. Bell. 2004. Hunting vulnerability, ecological characteristics and harvest rates of bushmeat species in afrotropical forests. Biological Conservation 121:167-176.

Fagan, W. F., E. Meir, J. Prendergast, A. Folarin, dan P. Karieva. 2001. Characterizing population vulnerability for 758 species. Ecology Letters 4:132-138.

FAO. 1981. National conservation plan for Indonesia. Vol. V. Kalimantan. Field report of UNDP/FAO National Parks Development Project INS/78/081. Food and Agricultural Organization of the United Nations, Bogor, Indonesia.

Feder, M. E. dan W. W. Burggren. 1992. Environmental physiology of the amphibians. University of Chicago Press, Chicago, USA.

Feuilletau-de Bruyn, W. K. H. 1933. Bijdrage tot de kennis van de afdeeling Hoeloe Soengei (Z. en O.afdeeling Borneo). Koloniale Studiën 171: 53-93 dan 183-211.

Fimbel, R. A., A. Grajal, dan J. G. Robinson. 2001. Logging and wildlife in the tropics. Pages 667-695 in R. A. Fimbel, A. Grajal, dan J. G. Robinson, editors. The cutting edge: conserving wildlife in logged tropical forest. Columbia University Press, New York, USA.

Fimbel, R. A., E. L. Bennett, R. Z. Donovan, P. C. Frumhoff, A. Grajal, R. E. Gullison, D. J. Mason, F. E. Putz, J. G. Robinson, dan D. I. Rumiz. 1998. The potential for sustainable forest management 
to conserve wildlife within tropical forest landscapes. Issues and Policy Paper no. 4., Bronx, New York. Wildlife Conservation Society, New York, USA.

Fisher, D. O. dan I. P. F. Owens. 2004. The comparative method in conservation biology. Trends in Ecology \& Evolution 19:391-398.

Fisher, D. O., S. P. Blomberg, dan I. P. F. Owens. 2003. Extrinsic versus intrinsic factors in the decline and extinction of Australian marsupials. Proceedings of the Royal Society of London - Series B: Biological Sciences 270:1801-1808.

Fleming, T. E. 1987. Patterns of tropical vertebrate frugivore diversity. Annual Review of Ecology and Systematics 18:91-109.

Fleming, T. E. 1993. Plant-visiting bats. American Scientist 81:460-468.

Fogden, M. P. L. 1974. A preliminary field study of the western tarsier, Tarsius bancanus Horsfield. Page 151-165 in R. D. Martin, G. A. Doyle, dan A. C. Walker, editors. prosimian biology. University of Pittsburgh Press, Pittsburgh, USA.

Foreman, D. dan B. Haywood. 1989. Ecodefense: A field guide to monkey wrenching. Second Edition. Ned Ludd Books, Tuscon, AZ, USA.

Forman, R. T. T. dan L. E. Alexander. 1998. Roads and their major ecological effects. Annual Review of Ecology \& Systematics 29:207-231.

Forman, R. T. T. dan P. N. Moore. 1992. Theoretical fFoundations for understanding boundaries in landscape mosaics in A. J. Hansen, dan F. di Castri, editors. Landscape boundaries, Consequences for biotic diversity and ecological flows. Springer-Verlag, New York, USA.

Francis, G. 2003. Indonesian conservationists object to border road. Borneo Bulletin (Brunei), November 11,2003 issue.

Fredericksen, N. J. dan T. S. Fredericksen. 2002. Terrestrial wildlife responses to logging and fire in a Bolivian tropical humid forest. Biodiversity and Conservation 11:27-38.

Fredericksen, N. J. dan T. S. Fredericksen. 2004. Impacts of selective logging on amphibians in a Bolivian tropical humid forest. Forest Ecology and Management 191:275-282.

Fredericksen, T. S. dan F. E. Putz. 2003. Silvicultural intensification for tropical forest conservation. Biodiversity and Conservation 12:1445-1453.

Fredriksson, G. 2001. Effects of forest fires on Sun Bear conservation in East Kalimantan (Indonesian Borneo). Presented poster at the Thirteenth International Conference on Bear Research and Management, Jackson, Wyoming, USA.

Fredriksson, G. in press. Human-sun bear conflicts in East Kalimantan, Indonesian Borneo. Ursus.

Fredriksson, G. M. dan V. Nijman. 2004. Habitat use and conservation status of two elusive ground brids (Carpococcyx radiatus and Polyplectron scheiermacheri) in the Sungai Wain Protection Forest, East Kalimantan, Indonesian Borneo. Oryx 38:297-303.

Fredriksson, G. dan S. A. Wich. in prep. Frugivory in sun bears (Helarctos malayanus) linked to El Niñorelated fluctuations in fruit availability in East Kalimantan, Indonesia.

Frith, C. B. dan V. E. Douglas. 1978. Notes on ten Asian hornbill species (Aves: Bucerotidae); with particular reference to growth and behaviour. Natural History Bulletin of the Siam Society 27:3582.

Frumhoff, P. C. 1995. Conserving wildlife in tropical forests managed for timber - to provide a more viable complement to protected areas. BioScience 45:456-464.

Fujita, M. S. dan M. D. Tuttle. 1991. Flying foxes (Chiroptera: Pteropodidae): Threatened animals of key ecological and economic importance. Conservation Biology 5:455-463.

Fuller, D. O., T. C. Jessup, dan A. Salim. 2003. Loss of forest cover in Kalimantan, Indonesia, since the 1997-1998 El Niño. Conservation Biology 18:249-254.

Galetti, M. dan K. McConkey. 1998. Black hornbill Anthracoceros malayanus following gibbons in central Borneo. Ibis 140:686-687.

Garshelis, D. dan B. McLellan. 2004. Bear specialist group quadrennial report. International Bear News 13:10-11.

Gartlan, J. S., D. B. McKey, P. G. Waterman, C. N. Mbi. dan T. T. Struhsaker. 1980. A comparative study of the phytochemistry of two African rain forests. Biochemical Systematics and Ecology 8:401-422.

Gascon, C., G. B. Williamson, dan G. A. B. da Fonseca. 2000. Receding forest edges and vanishing reserves. Science 288:1356-1358. 
Gaston, K. J. dan T. M. Blackburn. 1997. Evolutionary age and risk of extinction in the global avifauna. Evolutionary Ecology 11:557-565.

Gaston, K. J., T. M. Blackburn, J. J. D. Greenwood, R. D. Gregory, R. M. Quinn, dan J. H. Lawton. 2000. Abundance-occupancy relationships. Journal of Applied Ecology 37:39-59.

Gautier-Hion, A. 1984. Seed dispersal by African forest cercopithecines. La Terre et la Vie: Revue d'Ecologie Appliquee 39:159-166.

Gautier-Hion, A., J.-M. Duplantier, R. Quris, F. Feer, C. Sourd, J.-P. Decoux, G. Dubost, L. Emmons, C. Erard, P. Hecketweiler, A. Moungazi, C. Roussilhon, dan J.-M. Thiollay. 1985. Fruit characteristics as a basis of fruit choice and seed dispersal in a tropical forest vertebrate community. Oecologia 65:324-337.

Geist, V. 1998. Deer of the world. Their evolution, behaviour, and ecology. Stackpole Books, Mechanicsburg, USA.

Ghazoul, J. dan J. Hill. 2001. The impacts of selective logging on tropical forest invertebrates. Pages 261-288 in R. Fimbel, A. Grajal, dan J. G. Robinson, editors. The cutting edge: conserving wildlife in logged tropical forest. Columbia University Press, New York, USA.

Ghazoul, J., K. A. Liston, dan T. J. B. Boyle. 1998. Disturbance-induced, density dependent seed selection in Shorea siamensis (Dipterocarpaceae), a tropical forest tree. Journal of Ecology 86:462473.

Gilbert, K. A. 1994. Endoparasitic infection in Red Howling Monkeys (Aloutta seniculus) in the Central Amazonian Basin: A cost of socialitity? Unpublished PhD Dissertation. Rutgers University, New Brunswick, N.J, USA.

Gilbert, K. A. dan E. Z. F. Setz. 2001. Primates in a fragmented landscape: Six species in Central Amazonia. Pages 262-270 in R. O. Bierregaard, G. Gaascon, T. E. Lovejoy, dan R. Mesquita, editors. Lessons from the Amazon. Yale University Press, New Haven, CT, USA.

Gintings, A. 1969. The influence of selective felling on the regeneration of Dipterocarpaceae forests in Eastern Sumatra. (In Indonesian) Sarjana Thesis. Fakultas Kehutanan IPB. Bogor, Indonesia.

Gönner, C. 1997. Description of the middle Mahakam area. Unpublished report.

Goosem, M. 1997. Internal fragmentation: Effects of roads, highways, and powerline clearings on movements and mortality of rainforest vertebrates. Pages 241-255 in W. F. Laurance, dan R. O. J. Bierregaard, editors. Tropical forest remnants: ecology, management, and conservation of fragmented communities. University of Chicago Press, Chicago, USA.

Goosem, S. dan N. I. J. Tucker. 1995. Repairing the rainforest. Theory and practice of rainforest reestablishment in North Queensland's wet tropics. Wet Tropics Management Authority, Cairns, Australia.

Gordon, W. F., S. B. Vinson, L. E. Newstrom, J. F. Barthell, W. A. Haber, dan J. K. Frankie. 1990. Plant phenology, pollination ecology, pollinator behaviour and conservation of pollinators in Neotropical dry forest. Pages 37-48 in K. S. Bawa, dan M. Hadley, editors. Reproductive ecology of tropical forest plants. MAB series 7. UNESCO, Paris, France.

Gosz, J. R. 1991. Fundamental ecological characteristics of landscape boundaries in M. N. Holland, P. G. Riser, dan R. J. Nemine, editors. Ecotones: the role of landscape boundaries in the management and restoration of changing environments. Chapman and Hall, New York, USA.

Gould, K. dan M. Andau. 1989. Selection and rejection of five species of Dipterocarp fruits by wild and captive primates, squirrels and hornbills. Malayan Nature Journal 42:245-249.

Grassman, L. I. J. 1998. Movements and fruit selection of two Paradoxurinae species in a dry evergreen forest in southern Thailand. Small Carnivore Conservation no. 19:25-29.

Griffiths, M. dan C. P. van Schaik. 1993. The impact of human traffic on the abundance and activity periods of Sumatran rain forest wildlife. Conservation Biology 7:623-626.

Grove, S. J. 2001. Extent and composition of dead wood in Australian lowland tropical rainforest with different management histories. Forest Ecology and Management 154:35-53.

Grove, S. J. 2002a. The influence of forest management history on the integrity of the saproxylic beetle fauna in an Australian lowland tropical rainforest. Biological Conservation 104:149-171.

Grove, S. J. 2002b. Saproxylic insect ecology and the sustainable management of forests. Annual Review of Ecology and Systematics 33:1-23.

Groves, C. P. 1998. Systematics of tarsiers and lorises. Primates 39:13-27.

Groves, C. P. 2001. Primate Taxonomy. Smithsonian Institution Press, Washington DC, USA.

Groves, C. P. dan P. Grubb. 1982. The species of muntjac (genus Muntiacus) in Borneo: Unrecognised 
sympatry in tropical deer. Zoologische Mededelingen 56:203-215.

Guevara, S. S. 1986. Plant species availability and regeneration in Mexican tropical rain forest. Acta Universitatis Upsaliensis, Comprehensive Summaries of Uppsala Dissertations for the Faculty of Science 48.

Gullison, R. E. 2003. Does forest certification conserve biodiversity? Oryx 37:153-165.

Gumal, M. T. 2004. Diurnal home range and roosting trees of a maternity colony of Pteropus vampyrus natunae (Chiroptera: Pteropodidae) in Sedilu, Sarawak. Journal of Tropical Ecology 20:247-258.

Hadidan, J. dan I. S. Bernstein. 1979. Female reproductive cycles and birth data from an Old World monkey colony. Primates 20:429-442.

Hadiprakarsa, Y. dan M. Kinnaird. 2001. Foraging characteristics of an assemblage of four Sumatran hornbill species. The Third International Hornbill Workshop on the Ecology of Hornbills with Emphasis on Reproduction and Population, 9-18 May 2001, Phuket and Narathiwat, Thailand.

Hadiprakarsa, Y., M. F. Kinnaird, dan T. G. O’Brien. in press. Foraging characteristics for an assemblage of four Sumatran hornbill species. Bird Conservation International.

Harcourt, A. H. dan M. W. Schwartz. 2001. Primate evolution: A biology of Holocene extinction and survival on the Southeast Asian Sunda Shelf islands. American Journal of Physical Anthropology 114:4-17.

Harcourt, A. H., S. A. Coppeto, dan S. A. Parks. 2002. Rarity, specialization and extinction in primates. Journal of Biogeography 29:445-456.

Harrington, G. N., A. N. D. Freeman, dan F. H. J. Crome. 2001. The effects of fragmentation of an Australian tropical rain forest on populations and assemblages of small mammals. Journal of Tropical Ecology 17:225-240.

Harris, L. D. 1984. The fragmented forest. University of Chicago Press, Chicago, USA \& London, UK.

Harris, L. D. dan G. Silva-Lopez. 1992. Forest fragmentation and the conservation of biological diversity. Pages 197-237 in P. L. Fiedler, dan S. K. Jain, editors. Conservation Biology. Chapman and Hall, London, UK.

Harrison, J. L. 1962a. Natural food of some Malayan mammals. Bulletin of the National Museum of Singapore 30:5-18.

Harrison, J. L. 1962b. The distribution and feeding habits among mammals in tropical rainforest. Journal of Animal Ecology 31:53-64.

Harrison, J. L. 1968. The effect of forest clearance on small mammals. Pages 153-158. Conservation in tropical South East Asia. Proceedings of the Conference on Conservation of Nature and Natural Resources in Tropical South East Asia. Bangkok, Thailand. November 29 - December 4, 1965. IUCN Publication New Series No. 10. IUCN, Morges, Switzerland.

Harrison, J. L. 1969. The abundance and population density of mammals in Malayan lowland forests. Malayan Nature Journal 34:174-178.

Harrison, R. D. 2001. Drought and the consequences of El Niño in Borneo: a case study of figs. Population Ecology 43:63-75.

Harrison, S. dan E. Bruna. 1999. Habitat fragmentation and large-scale conservation: What do we know for sure? Ecography 22:225-232.

Hartyono 1992. Perikanan dan aspek budayanya pada masyarakat Dayak di sekitar kawasan cagar alam Kayan Mentarang. Paper presented at Borneo Research Council 2nd biannual International Conference, 13-17 July 1992, Kota Kinabalu, Malaysia.

Harvey, P. H., R. D. Martin, dan T. H. Clutton-Brock. 1987. Life histories in comparative perspective. Pages 181-196 in B. B. Smuts, D. L. Cheney, S. R.M., R. W. Wrangham, dan T. T. Struhsaker, editors. Primate Societies. University of Chicago Press, Chicago, USA.

Hassanin, A. dan A. Ropiquet. 2004. Molecular phylogeny of the trive Bovini (Bovidae, Bovinae) and the taxonomic status of the Kouprey, Bos sauveli Urban 1937. Molecular Phylogenetics \& Evolution 33:896-907.

Hawthorne, W. D. 1993. Forest regeneration after logging: findings of a study in the Bia South Game Production Reserve, Ghana. ODA Forestry Series. Natural Resources Institute, Chatham, UK.

Hawthorne, W. D. 1994. Fire damage and forest regeneration in Ghana. ODA Forestry Series. Natural Resources Institute, Chatham, UK.

Hawthorne, W. D. dan M. P. E. Parren. 2000. How important are forest elephants to the survival of woody plant species in upper Guinean forests? Journal of Tropical Ecology 16:133-150. 
Hawthorne, W. D., V. K. Agyeman, M. Abu Juam, dan E. G. Foli. 1998. Taking stock: An annotated bibliography of logging damage and recovery in tropical forests, and the results of new research in Ghana. Projet Report. Oxford Forestry Institute, Oxford, UK.

Hayes, J. P. dan R. J. Steidl. 1997. Statistical power analysis and amphibian population trends. Conservation Biology 11:273-275.

Hayssen, V., A. van Tienhoven, dan A. van Tienhoven. 1993. Asdell's patterns of mammalian reproduction: a compendium of species-specific data. Comstock Publishing Associates, Ithaca, USA \& London, UK.

Heaney, L. R. 1978. Island area and body size of insular mammals: Evidence from the tri-colored squirrel (Callosciurus prevosti) of Southeast Asia. Evolution 32:29-44.

Heaney, L. R. 1986. Biogeography of mammals in SE Asia: estimates of rates of colonization, extinction and speciation. Biological Journal of the Linnean Society 28:127-165.

Hedges, S. dan A. A. Dwiyahreni. 2002. Reduced impact logging study, Bulungan Research Forest, East Kalimantan, Indonesia. Mammal and hornbill survey. September-October 1998. Preliminary report. CIFOR dan WCS, Bogor, Indonesia.

Hedges, S. dan E. Meijaard. 1999. Reconnaissance survey for banteng (Bos javanicus) and banteng survey methods training project, Kayan-Mentarang National Park, East Kalimantan, Indonesia. Unpublished report. WWF-Indonesia dan CIFOR, Bogor, Indonesia.

Hedges, S., M. J. Tyson, A. F. Sitompul, M. F. Kinnaird, D. Gunaryadi, dan A. Baco. in prep. Distribution, status, and conservation needs of Asian elephants (Elephas maximus) in Lampung Province, Sumatra, Indonesia. Biological Conservation.

Hels, T. dan E. Buchwald. 2001. The effect of road kills on amphibian populations. Biological Conservation 99:331-340.

Hernowo, J. B. 1989. Studi pendahuluan habitat dan arena tari burung Kuwau (Argusianus argus) di hutan lindung Bukit Soeharto, Kalimantan Timur. Media Konservasi 2:55-63.

Heydon, M. J. 1994. The ecology and management of rain forest ungulates in Sabah, Malaysia: implications of forest disturbance. Final report to ODA/NERC project F3CR26/G1/05. Institute of Tropical Biology, University of Aberdeen, Aberdeen, UK.

Heydon, M. J. dan P. Bulloh. 1996. The impact of selective logging on sympatric civet species in Borneo. Oryx 30:31-36.

Heydon, M. J. dan P. Bulloh. 1997. Mousedeer densities in a tropical rainforest: the impact of selective logging. Journal of Applied Ecology 34:484-496.

Hietz-Seifert, U., P. Hietz, dan S. Guevara. 1996. Epiphyte vegetation and diversity on remnant trees after forest clearance in southern Veracruz, Mexico. Biological Conservation 72:103-111.

Hill, J. K., K. C. Hamer, M. M. Dawood, J. Tangah, dan V. K. Chey. 2003. Rainfall but not selective logging affect changes in abundance of tropical forest butterfly in Sabah, Borneo. Journal of Tropical Ecology 19:35-42.

Hill, W. C. O. 1955. Primates: Comparative anatomy and taxonomy. II. Haplorhini: Tarsioidea. Edinburgh University Press, Edinburgh, UK.

Hilton-Taylor, C. 2000. 2000 IUCN Red List of Threatened Species. IUCN, Gland, Switzerland and Cambridge, UK.

Hobson, K. A. dan M. A. Villard. 1998. Forest fragmentation affects the behavioral response of american redstarts to the threat of cowbird parasitism. Condor 100:389-394.

Hodgkison, R. 2001. Ecology of the spotted-winged fruit bat (Balionycteris maculata, Thomas) in a lowland Malaysian dipterocarp forest. Unpublished Ph.D. thesis. University of Aberdeen, Aberdeen, UK.

Hoffman, H. 2003. "Callosciurus prevostii" (On-line), Animal Diversity Web. Accessed September 14, 2004 at http://animaldiversity.ummz.umich.edu/site/accounts/information/Callosciurus_ prevostii.html.

Hoffmann, A. A., A. Hinrichs, dan F. Siegert. 1999. Fire damage in East Kalimantan in 1997/98 related to land use and vegetation classes: Satellite radar inventory results and proposal for further actions. IFFM-SFMP Report No.1a. MOFEC, GTZ and KfW, Samarinda, East Kalimantan, Indonesia.

Hogberg, P. dan J. Wester. 1998. Root biomass and symbioses in Acacia mangium replacing tropical forest after logging. Forest Ecology and Management 102:333-338.

Holdsworth, A. R. dan C. Uhl. 1997. Fire in Amazonian selectively logged rain forest and the potential for fire reduction. Ecological Applications 7:713-725. 
Holmes, D. 2000. Deforestation in Indonesia. A review of the situation in 1999. World Bank, Jakarta, Indonesia.

Holmes, D. A. 1989. A status report on Indonesian galliforms. Kukila 4:133-143.

Holmes, D. A. 1997. Kalimantan Bird Report. Kukila 9:141-169.

Holmes, D. A. dan K. Burton. 1987. Recent notes on the avifauna of Kalimantan. Kukila 3:2-32.

Hone, J. 2002. Feral pigs in Namadgi National Park, Australia: dynamics, impacts and management. Biological Conservation 105:231-242.

Hoogerwerf, A. 1970. Udjung Kulon. The land of the last Javan rhinoceros. E.J. Brill, Leiden, The Netherlands.

Howe, H. F. dan L. C. Westley 1988. Ecological relationships of plants and animals. Oxford University Press, Oxford, UK.

Howell, D. 2003. The effects of human activity on primates and other large mammals in East Kalimantan, Indonesia. MSc Thesis. Central Washington University, USA.

Howlett, B.E. dan D.W. Davidson. 1996. Diprterocarp seed and seedling performance in secondary logged forests dominated by Macaranga spp. Pages 256-266 in S. Appanah dan K.C. Khoo, editors. Proceedings fifth round table conference on Dipterocarps, Chiang Mai, Thailand. 7-10 November 1994. FRIM, Kepong, Malaysia.

Hubbell, S. P., R. B. Foster, S. T. O’Brien, K. E. Harms, R. Condit, B. Wechsler, S. J. Wright, dan S. Loo de Lao. 1999. Light-gap disturbances, recruitment limitation, and tree diversity in a neotropical forest. Science 283:554-557.

Hunter, M. L. J. 1990. Wildlife, forests and forestry: Principles of managing forests for biological diversity. Prentice Hall, Englewood Cliffs, New Jersey, USA.

Hurlbert, S. H. 1984. Pseudoreplication and the design of ecological field experiments. Ecological Monographs 54:187-211.

Hussin, Bin. M. Z. 1994. Ecological effects of selective logging in lowland dipterocarp forest on avifauna, with special reference to frugivorous birds. MSc thesis. Universiti Kebangsaan, Kuala Lumpur, Malaysia.

Hussin, Bin. M. Z. 1996. Can our logged forest fully regenerate naturally? Paper presented at the National Symposium of Natural Resources Science and Technology. Kota Kinabalu, Sabah. November 2223, 1996.

Hussin, Bin. M. Z. dan C. M. Francis. 2001. The effects of logging on birds in tropical forests of IndoAustralia. Pages 167-192 in R. A. Fimbel, A. Grahal, dan J. G. Robinson, editors. The cutting edge: Conserving wildlife in logged tropical forests. Columbia University Press, USA.

Hutchings, T. R., A. J. Moffat, dan C. J. French. 2002. Soil compaction under timber harvesting machinery: a preliminary report on the role of brash mats in its prevention. Soil Use and Management 18:34-38.

Hutson, A. M., S. P. Mickleburg, dan P. A. Racey 2001. Microchiropteran bats. Global status and conservation action plan. IUCN/SSC Chiroptera Specialist Group, Gland, Switzerland and Cambridge, UK.

Inger, R. F. 1969. Organization of communities of frogs along small rainforest streams in Sarawak. Journal of Animal Ecology 38:123-148.

Inger, R. F. 1980a. Densities of floor dwelling frogs and lizards in lowland forests of Southeast Asia and Central America. American Naturalist 115:761-770.

Inger, R. F. 1980b. Relative abundances of frogs and lizards in forests of Southeast Asia. Biotropica 12:14-22.

Inger, R. F. 1983. Larvae of Southeast Asia species of Leptobrachium and Leptobrachella (Anura: Pelobatidae). Pages 13-32 in A. G. Rhodin, dan K. Miyata, editors. Advances in herpetology and evolutionary biology. Museum of Comparative Zoology, Cambridge, MA, USA.

Inger, R. F. 1985. Tadpoles of the forested regions of Borneo. Fieldiana Zoology 26:1-89.

Inger, R. F. 1986. Diets of tadpoles living in a Bornean rain forest. Alytes (Paris) 5:153-164.

Inger, R. F. dan F. L. Tan 1996. The natural history of amphibians and reptiles in Sabah. Natural History Publication, Kotakinabalu, Malaysia.

Inger, R. F. dan H. H. K. Voris. 1993. A comparison of amphibian communities through time and from place to place in Bornean forests. Journal of Tropical Ecology 9:409-433.

Inger, R. F., H. K. Voris, dan K. J. Frogner. 1986. Organization of a community of tadpoles in rain forest streams in Borneo. Journal of Tropical Ecology 2:193-205. 
Inger, R. F. dan K. V. Voris. 2001. The biogeographical relations of the frogs and snakes of Sundaland. Journal of Biogeography 28:863-891.

Innes, J. L. 1993. Forest health: Its assessment and status. CABInternational, UK.

Interagency Ecosystem Management Task Force. 1995. The ecosystem approach: Healthy ecosystems and sustainable economies. Volume I-Overview. Office of Environmental Policy, Washington, DC, USA.

Iskandar, D. T. 1998. The amphibians of Java and Bali. Research and Development Centre for BiologyLIPI, Jakarta, Indonesia.

Iskandar, D. T. 1999a. Amphibian declines monitoring in the Leuser Management Unit, Aceh, North Sumatra, Indonesia. Froglog 34:2.

Iskandar, D. T. 1999b. Training on "monitoring methods in amphibians and reptiles fauna" at Soraya and Gunung Air Station, Leuser National Park. Unpublished report. Institute of Technology, Bandung, Indonesia.

Iskandar, D. T. 2004. The amphibians and reptiles of Malinau region, Bulungan research forest, East Kalimantan: Annotated checklist with some notes on ecological preferences of the species and local utilization. CIFOR. Http://www.cifor.org/mla/_ref/publication/amphibian.htm.

Iskandar, D. T. dan D. Y. Setyanto. 1999. Environmental impact assessment in four logged forest conditions in South Kalimantan. Presented at Asia Pacific Congress on the Biology of the Environment. Singapore, 21-24 November 1999.

Iskandar, D. T. dan E. Colijn. 2000. Checklist of Southeast Asian and New Guinean Herpetofauna I. Amphibians. Treubia 31:1-134.

Iskandar, D. T. dan E. Colijn. 2002. Checklist of Southeast Asian \& New Guinean Reptiles I. Snakes. Biodiversity Conservation Project, Jakarta, Indonesia.

Islam, K. R., M. R. Ahmed, M. K. Bhuiyan, dan A. Badruddin. 2001. Deforestation effects on vegetative regeneration and soil quality in tropical semi-evergreen degraded and protected forests of Bangladesh. Land Degradation and Development 12:45-56.

Istiadi, Y., D. Priatna, dan N. Panekanan. 1994. Inventarisasasidan analisis populasi jenis-jenis mamalia dan burung di pegunungan Müller, Kalimantan Barat--Kalimantan Timur (Ekspedisi KapuasMahakam, 1994). Unpublished report. KOMPAS-GRAMEDIA, Jakarta, Indonesia.

IUCN. 2002. 2002 IUCN Red List of Threatened Species. www.redlist.org. Downloaded on 10 October 2002.

IUCN. 2003. 2003 IUCN Red List of Threatened Species. www.redlist.org. Downloaded on 5 August 2004.

IUCN-WWF. 2004. Changing realities. Ecosytem approaches and sustainable forest management. www. iucn.org/themes/fcp/publications/arborvitae/avnewsletter.

Iwata, T., M. Inoue, S. Nakano, H. Miyasaka, A. Doi, dan A. P. Covich. 2003. Shrimp abundance and habitat relationships in tropical rain-forest streams, Sarawak, Borneo. Journal of Tropical Ecology 19:387-395.

Izard, M. K., P. C. Wright, dan E. L. Simons. 1985. Gestation length in Tarsius bancanus. American Journal of Primatology 9:327-331.

Jackson, H. D. 2002. A review of Afrotropical nightjar mortality, mainly road kills. Ostrich 73:147-161.

Janzen, D. H. 1974. Tropical blackwater rivers, animals, and mast fruiting by the dipterocarpaceae. Biotropica 6:69-103.

Janzen, D. H. 1979. New horizons in the biology of plant defenses. Pages 331-350 in G. A. Rosenthal, dan D. H. Janzen, editors. Herbivores: Their interaction with secondary plant metabolites. Academic Press, London, UK.

Janzen, D. H. 1983. No park is an island: increase in interference from outside as park size decreases. Oikos 41:402-410.

Jarvie, J. M. Hiller, dan A. Salim. 2002. HCVF Guidelines for Forest Managers in Indonesia. The Nature Conservancy and The United States Forest Service, USA.

Jathanna, D., K. U. Karanth, dan A. J. T. Johnsingh. 2003. Estimation of large herbivore densities in the tropical forests of southern India using distance sampling. Journal of Zoology 261:285-290.

Jeanes, K. dan E. Meijaard. 2000. Danau Sentarum's wildlife. Part 1. Biodiversity value and global importance of Danau Sentarum's wildlife. Borneo Research Bulletin 31:150-229.

Jeanmart, P. 1998. Tentative d'élaboration d'un plan de gestion de la chasse villageoise dans la reserve du Dja. Programme ECOFAC- Composante Cameroun. Groupement AGRECO G.E.I.E - BDPA- 
SCETAGRI-SECA -CIRAD-Forêt (Centre de Coopération Internationale pour la Recherche en Développement), Brussels, Belgium.

Jennings, S. B., N. D. Brown, D. H. Boshier, T. C. Whitmore, dan J. D. A. Lopes. 2001. Ecology provides a pragmatic solution to the maintenance of genetic diversity in sustainably managed tropical rain forests. Forest Ecology and Management 154:1-10.

Jennings, S., R. Nussbaum, dan T. Sysnnott. 2002. A Toolkit for identifying and managing High Conservation Value Forests: Review Draft 1. Prepared by ProForest. Oxford. UK

Jepson, P., F. Momberg, dan H. van Noord. 2002. A review of efficacy of the protected area system of East Kalimantan Province. Natural Areas Journal 22:28-42.

Jepson, P., J. K. Jarvie, K. MacKinnon, dan K. A. Monk. 2001. The end for Indonesia’s lowland forests? Science 292:859-861.

Johns, A. D. 1982. Observations on nesting behaviour in rhinoceros hornbill, Buceros rhinoceros. Malayan Nature Journal 35:173-177.

Johns, A. D. 1983. Ecological effects of selective logging in a West Malaysian rain forest. PhD dissertation. University of Cambridge, Cambridge, UK.

Johns, A. D. 1986a. Effects of selective logging on the behavioral ecology of west Malaysian Primates. Ecology 67:684-694.

Johns, A. D. 1986b. Effects of selective logging on the ecological organization of a Peninsular Malaysian rainforest avifauna. Forktail 1:65-79.

Johns, A. D. 1987. The use of primary and selectively logged rainforest by Malaysian hornbills (Bucerotidae) and implications for their conservation. Biological Conservation 40:179-190.

Johns, A. D. 1988. Effects of 'selective' timber extraction on rainforest structure and composition and some consequences for frugivores and foliovores. Biotropica 20:31-37.

Johns, A. D. 1989a. Recovery of a peninsular Malaysian avifauna following selective timber logging: the first twelve years. Forktail 4:89-105.

Johns, A. D. 1989b. Timber, the environment and wildlife in Malaysian rain forests. Final report to Institute of South-east Asian Biology. University of Aberdeen, Aberdeen, UK.

Johns, A. D. 1992. Species conservation in managed forests. Pages 15-53 in T. C. Whitmore, dan A. J. Sayer, editors. Tropical deforestation and species extinction. Chapman and Hall, London, U.K.

Johns, A. D. 1996. Bird population persistence in Sabahan logging concessions. Biological Conservation 75:3-10.

Johns, A. D. dan J. P. Skorupa. 1987. Responses of rainforest primates to habitat disturbance: a review. International Journal of Primatology 8:157-191.

Johns, A. G. 1997. Timber production and biodiversity conservation in tropical rainforests. Cambridge University Press, Cambridge, UK.

Johns, A.G. dan Johns, B.G. 1995. Tropical forest primates and logging: long-term coexistence? Oryx 29:205-211.

Johns, J. S., P. Barreto, dan C. Uhl. 1996. Logging damage during planned and unplanned logging operations in the eastern Amazon. Forest Ecology and Management 89:59-77.

Johnsgard, P. A. 1999. The pheasants of the world: biology \& natural history. $2^{\text {nd }}$ ed. Smithsonian Institute Press, Washington, D.C., USA.

Johnsgard, P. A. 2000. Trogons and quetzals of the world. Smithsonian Institution Press, Washington, D.C., USA.

Johnson, C. N., S. Delean, dan A. Balmford. 2002. Phylogeny and the selectivity of extinction in Australian marsupials. Animal Conservation 5:135-142.

Jones, D. T., F. X. Susilo, D. E. Bignell, S. Hardiwinoto, A. N. Gillison, dan P. Eggleton. 2003. Termite assemblage collapse along a land-use intensification gradient in lowland central Sumatra, Indonesia. Journal of Applied Ecology 40:380-391.

Jonsson, A. dan B. Ebenman. 2001. Are certain life histories particularly prone to local extinction? Journal of Theoretical Biology 209:455-463.

Jordano, P. 1983. Fig-seed predation and dispersal by birds. Biotropica 15:138-141.

Joshi, A. R., J. L. D. Smith, dan F. J. Cuthbert. 1995. Influence of food distribution and predation pressure on spacing behavior in palm civets. Journal of Mammalogy 76:1205-1212.

Jules, E. S. dan P. Shahani. 2003. A broader ecological context to habitat fragmentation: Why matrix habitat is more important than we thought. Journal of Vegetation Science 14:459-464. 
Jullien, M. dan J. Clobert. 2000. The survival value of flocking in neotropical birds: Reality or fiction? Ecology 81:3416-3430.

Kammesheidt, L., A. A. Dagang, W. Schwarzwäller dan H-J. Weidelt. 2003. Growth patterns of dipterocarps in treated and untreated plots Forest Ecology and Management 174:437-445.

Kapos, V. 1989. Effects of isolation on the water status of forest patches in the Brazilian Amazon. Journal of Tropical Ecology 5:173-186.

Karr, J. R. 1977. Ecological correlates of rarity in a tropical forest bird community. Auk 94:240-247.

Karr, J. R. dan K. E. Freemark. 1983. Habitat selection and environmental gradients - dynamics in the stable tropics. Ecology 64:1481-1494.

Kartawinata, K. 1981. The environmental consequences of tree removal from the forest in Indonesia. In V.J. Sutlive et al. editors. Where have all the flowers gone: Deforestation in the third World. Studies in Third World Societies 13:191-214.

Kartawinata, K. dan A. P. Vayda. 1984. Forest conversion in East Kalimantan, Indonesia: the activities and impact of timber companies, shifting cultivators, migrant pepper-farmers, and others. Pages 98-126 in F. di Castri, F.W.G. Baker, dan M. Hadley, editors. Ecology in practice, Part I: Ecosystem Management, Ticooly, Dublin and UNESCO, Paris.

Kartawinata, K., T. C. Jessup, dan A. P. Vayda. 1989. Exploitation in Southeast Asia. Pages 591-610 in H. Lieth, dan M. J. A. Werger, editors. Tropical Rain Forest Ecosystems: Biogeographical and Ecological Studies, Elsevier, Amsterdam, the Netherlands.

Kartawinata, K. S. Riswan, A.N. Gintings dan T. Puspitojati. 2001. An overview of post extraction secondary forest in Indonesia. Journal of Tropisal Forest Science 15: 621-638.

Kaskija, L. 1995. The Punan Malinau: The persistence of an unstable culture. MSc thesis. Department of Anthropology, University of Uppsala, Uppsala, Sweden.

Kauffmann, J. B. dan C. Uhl. 1990. Interactions of anthropogenic activities, fire and rain forests in the Amazon Basin. Pages 117-134 in J. G. Goldammer, editor. Fire in the tropical biota: Ecosystem processes and global challenges. Springer-Verlag, Berlin, Germany.

Kawanishi, K. 2002. Population status of tigers (Panthera tigris) in a primary rainforest of Peninsular Malaysia. PhD dissertation. University of Florida, USA.

Keßler, P. J. A., dan K. Sidiyasa 1994. Trees of the Balikpapan-Samarinda area, East Kalimantan. A manual to 280 selected species. Tropenbos Series 7. The Tropenbos Foundation, Wageningen, the Netherlands.

Kemp, A. 1995. Bird families of the world. The hornbills: Bucerotiformes. Oxford University Press, Oxford, UK.

Kemp, A. C. dan M. I. Kemp. 1975. Report on a study of hornbills in Sarawak, with comments on their conservation. World Wildlife Fund Report 2/74. WWF Malaysia, Kuala Lumpur, Malaysia.

Kemper, C. dan D. T. Bell. 1985. Small mammals and habitat structure in lowland rainforest of Peninsular Malaysia. Journal of Tropical Ecology 1:5-22.

Keogh, J. S., D. G. Barker, dan R. Shine. 2001. Heavily exploited but poorly known: Systematics and biogeography of commercially harvested pythons (Python curtus group) in Southeast Asia. Biological Journal of the Linnean Society 73:113-129.

Kerr, W. E., V. A. Nascimento, dan G.A. Carvalho. 1994. Ha salvacao para os meliponineos? (Is there salvation for meliponine bees?) Pages 60-65. Anais do 1 deg encontro sobro abelhas, de Ribeirao Preto, 2-4 June 1994, USP-Campus de Ribeirao Preto, Brazil.

Kigomo, B. N., S. R. Woodell, dan P. S. Savill. 1994. Phenological patterns and some aspects of the reproductive biology of Brachylaea huillensis O. Hoffm. African Journal of Ecology 94:296-307.

Kimball, R. T., E. L. Braun, J. D. Ligon, V. Lucchini, dan E. Randi. 2001. A molecular phylogeny of the peacock-pheasants (Galliformes: Polyplectron spp.) indicates loss and reduction of ornamental traits and display behaviours. Biological Journal of the Linnean Society 73:187-198.

Kingston, T. 2004. Malaysian bat conservation. Expedition briefing. http://www.earthwatch.org/ expeditions/kingston/kingston_04.pdf. Downloaded on 10 March 2004.

Kingston, T., C. M. Francis, Z. Akbar, dan T. H. Kunz. 2003. Species richness in an insectivorous bat assemblage from Malaysia. Journal of Tropical Ecology 19:67-79.

Kingston, T., G. Jones, A. Zubaid, dan T. H. Kunz. 1999. Echolocation signal design in Kerivoulinae an Murininae (Chiroptera: Vespertilionidae) from Malaysia. Journal of Zoology 249:359-374.

Kinnaird, M. F. 1998. Evidence for effective seed dispersal by the Sulawesi Red-knobbed Hornbill, Aceros cassidix. Biotropica 30:55-55. 
Kinnaird, M. F., E. W. Sanderson, T. G. O’Brien, H. T. Wibisono, dan G. Woolmer. 2003. Deforestation trends in a tropical landscape and implications for endangered large mammals. Conservation Biology 17:245-257.

Kinnaird, M. F. dan T. G. O’Brien. 1998. Ecological effects of wildfire on lowland rainforest in Sumatra. Conservation Biology 12:954-956.

Kinnaird, M. F., T. G. O’Brien, dan S. Suryadi. 1996. Population fluctuation in Sulawesi red-knobbed hornbills: tracking figs in space and time. Auk 113:431-440.

Kinnaird, M. F., T. G. O’Brien, dan S. Suryadi. 1999. Importance of figs to Sulawesi's imperiled wildlife. Tropical Biodiversity 6:5-18.

Klaus, G., C. Klaus-Hugi, dan B. Schmid. 1998. Geophagy by large mammals at natural licks in the rain forest of the Dzanga National Park, Central African Republic. Journal of Tropical Ecology 14:829-839.

Klein, A. M., I. Steffan-Dewenter, dan T. Tscharntke. 2003. Pollination of Coffea canephora in relation to local and regional agroforestry management. Journal of Applied Ecology 40:837-845.

Kleine, M. dan Heuveldop, J. 1993. A management planning concept for sustained yield of tropical forests in Sabah, Malaysia. Forest Ecology and Management 61: 277-297.

Knapen, H. 1997. Epidemics, droughts, and other uncertainties on Southeast Borneo during the eighteenth and nineteenth centuries. Pages 121-152 in P. Boomgaard, F. Colombijn, and D. Henley, editors. Paper Landscapes. Explorations in the environmental history of Indonesia. KITLV Press, Leiden, the Netherlands.

Kofron, C. P. dan A. Chapman. 1995. Deforestation and bird species composition in Liberia, West Africa. Tropical Zoology 8:239-256.

Kottelat, M., A. J. Whitten, S. N. Kartikasari, dan S. Wirjoatmodjo. 1993. Freshwater fishes of western Indonesia and Sulawesi. Periplus Editions, Hong Kong.

Kunin, W. E. 1998. Extrapolating species abundance across spatial scale. Science 281:1513-1515

Kunz, T. H. dan E. D. Pierson. 1994. Bats of the world: an introduction. Pages 1-46 in R. W. Nowak, editor. Walker's bats of the world. John Hopkins University Press, Baltimore, USA.

Kurek, E. 2002. Microbial mobilization of metal from mineral under aerobic consition. Pages 190225 in P. M. Huang, J. M. Bollag, dan N. Sevesi, editors. Interaction between soil particles and microorganism. Impact on the terrestrial ecosystem. Vol. 8. IUSS-UISS-IBU. John Wiley and Sons Ltd., Chichester, UK.

Kuusipalo, J., Y. Jafarsidik, G. Adjers, dan K. Tuomela. 1996. Population dynamics of tree seedlings in a mixed dipterocarp rain-forest before and after logging and crown liberation. Forest Ecology and Management 81:85-94.

Lagendijk, J. P. 2000. Differences in foraging behaviour of woodpeckers between pristine and disturbed lowland rainforest in West-Kalimantan, Indonesia. Unpublished report. Department of Biology and Zoological Museum, University of Amsterdam, Amsterdam, The Netherlands.

Laidlaw, R. K. 2000. Effects of habitat disturbance and protected areas on mammals in peninsular Malaysia. Conservation Biology 14:1639-1648.

Laman, T. G. 1995a. The ecology of strangler fig seedling establishment. Selbyana 16:223-229.

Laman, T. G. 1995b. Ficus stupenda germination and seedling establishment in a Bornean rain forest canopy. Ecology 76:2617-2626.

Laman, T. G. 1996a. Ficus seed shadows in a Bornean rain forest. Oecologia 107:347-355.

Laman, T. G. 1996b. Specialization for canopy position by hemiepiphytic Ficus in a Bornean rain forest canopy. Journal of Tropical Ecology 12:789-803.

Laman, T. G., J. C. Gaither, dan D. E. Lukas. 1996. Rain forest bird diversity in Gunung Palung National Park, West Kalimantan, Indonesia. Tropical Biodiversity 3:281-296.

Lambert, F. R. 1989a. Daily ranging behaviour of three tropical frugivores. Forktail 4:107-116.

Lambert, F. R. 1989b. Fig eating birds in a Malaysian lowland rainforest. Journal of Tropical Ecology 5:401-412.

Lambert, F. R. 1989c. Fig-eating and seed dispersal by pigeons in a Malaysian lowland forest. Ibis 131:512-527.

Lambert, F. R. 1989d. Pigeons as seed predators and dispersers of figs in a Malaysian lowland forest. Ibis 131:521-530.

Lambert, F. R. 1990a. Avifaunal changes following selective logging of a north Bornean rain forest. Unpublished report. University of Aberdeen, Institute of Tropical Biology, Aberdeen, UK. 
Lambert, F. R. 1990b. Some notes on fig-eating by arboreal mammals in Malaysia. Primates 31:453-458.

Lambert, F. R. 1991. The conservation of fig-eating birds in Malaysia. Biological Conservation 58:3140.

Lambert, F. R. 1992. The consequences of selective logging for Bornean lowland forest birds. Philosophical Transactions of the Royal Society, London, UK. B 335:443-457.

Lambert, F. R. dan J. R. Howes. 1994. Ranging, breeding behaviour and food of the Asian brown tortoise Manouria emys in Borneo. Malayan Nature Journal 48:125-131.

Lambert, F. R. dan N. J. Collar. 2002. The future for Sundaic lowland forest birds: long-term effects of commercial logging and fragmentation. Forktail 18:127-146.

Lammertink, M. 1999. Responses of woodpeckers to forest disturbance after selective logging in Kalimantan-preliminary data. MOFEC/Tropenbos/ NWO workshop "The balance between biodiversity conservation and sustainable forest use of tropical rain forest, Balikpapan, Indonesia. Unpublished report. MOFEC/Tropenbos/NWO, Balikpapan, Indonesia.

Lammertink, M. 2004. A multiple-site comparison of woodpecker communities in Bornean lowland and hill forests: effects of logging and conservation implications. Conservation Biology 18.

Lang, D. dan D. Hubble. 2003. The impacts of conventional logging on Bufo asper, Rana leporine, Rana kublii \& Rana picturata in dipterocarp forest, East Kalimantan. Student project completion report for CIFOR. Unpublished report. CIFOR, Bogor, Indonesia.

Langham, N. 1983. Distribution and ecology of small mammals in three rain forest localities of peninsular Malaysia with particular reference to Kedah Peak. Biotropica 15:199-206.

Laurance, W. F. 1990. Comparative responses of five arboreal marsupials to tropical forest fragmentation. Journal of Mammalogy 71:641-653.

Laurance, W. F. 1991. Ecological correlates of extinction proneness in Australian tropical rain forest mammals. Conservation Biology 5:79-89.

Laurance, W. F. 1997. Responses of mammals to rainforest fragmentation in tropical queensland-a review and synthesis. Wildlife Research 24:603-612.

Laurance, W. F. 1999. Ecology and management of fragmented tropical landscapes. Biological Conservation 91:101-107.

Laurance, W. F. 2000. Do edge effects occur over large spatial scales? Trends in Ecology and Evolution 15:134-135.

Laurance, W. F. 2001. Fragmentation and plant communities: Synthesis and implications for landscape management. Pages 158-168 in R. O. Bierregaard, C. Gascon, T. E. Lovejoy, dan R. Mesquita, editors. Lessons from Amazonia; the ecology and conservation of a fragmented forest. Yale University Press, New Haven, USA.

Laurance, W. F. dan R. O. Bierregaard 1997. Tropical forest remnants-ecology management and conservation of fragmented communities. University of Chicago Press, Chicago, USA and London, UK.

Laurance, W. F. dan S. G. W. Laurance. 1996. Responses of five arboreal marsupials to recent selective logging in tropical australia. Biotropica 28:310-322.

Laurance, W. F., L. V. Ferreira, J. M. Rankin-de Mérona, dan S. G. W. Laurance. 1998. Rain forest fragmentation and the dynamics of Amazonian tree communities. Ecology 79:2032-2040.

Laurance, W. F., R. O. J. Bierregaard, C. Gascon, R. K. Didham, A. P. Smith, A. J. Lynam, V. M. Viana, T. E. Lovejoy, K. E. Sieving, J. W. J. Sites, M. Andersen, M. D. Tocher, E. A. Kramer, C. Restrepo, dan C. Moritz. 1997. Tropical forest fragmentation: Synthesis of a diverse and dynamic discipline. Pages 515-525 in W. F. Laurance, dan R. O. J. Bierregaard, editors. Tropical forest remnants: ecology, management, and conservation of fragmented communities. University of Chicago Press, Chicago, USA.

Lawton, R. M. 1955. The relationship between crown form and sex in Chlorophora excelsa. Empire Forestry Journal 34:192-193.

Lee, R. L. 2000. Impact of subsistence hunting in North Sulawesi, Indonesia and conservation options. Pages 455-472 in J. G. Robinson, dan E. L. Bennett, editors. Hunting for sustainability in tropical forests. Columbia University Press, New York, USA.

Leighton, D. R. 1987. Gibbons: territoriality and monogamy. Pages 35-145 in B. B. Smuts, D. Cheney, R. Seyfarth, R. Wrangham, dan T. Struhsaker, editors. Primate societies. University of Chicago Press, Chicago, USA.

Leighton, M. 1982. Fruit resources and patterns of feeding, spacing, and grouping among sympatric Bornean hornbills (Bucerotidae). PhD dissertation. University of California, Davis, USA. 
Leighton, M. 1984. The El Niño Southern Oscillation Event in Southeast Asia: Effects of drought and fire in tropical forest in eastern Borneo. Page 32. WWF-US, Washington D.C, USA.

Leighton, M. 1986. Hornbill social dispersion: variations on a monogamous theme. Pages 108-130 in D. I. Rubenstein, dan R. W. Wrangham, editors. Ecological aspects of social evolution. Birds and mammals. Princeton University Press, Princeton, USA.

Leighton, M. 2004. TNC East Kalimantan program review 2004: Draft report on ecological aspects. The Nature Conservancy, Samarinda, Kalimatan, Indonesia.

Leighton, M. dan D. R. Leighton. 1983. Vertebrates responses to fruiting seasonality within a Bornean rain forest. Pages 181-196 in S. L. Sutton, T. C. Whitmore, dan A. C. Chadwick, editors. Tropical rain forest: Ecology and management. Blackwell Scientific Publications, Oxford, UK.

Leighton, M. dan N. Wirawan. 1986. Catastrophic drought and fire in Borneo tropical rain forest associated with the 1982-1983 El Niño southern oscillation event. Pages 75-101 in G. T. Prance, editor. Tropical rain forest and world atmosphere. Westview Press, Boulder, Colorado, USA.

Lekagul, B. dan J. A. McNeely. 1977. Mammals of Thailand. Kurusapha Ladproa Press, Bangkok, Thailand.

Lennertz, R. dan K. F. Panzer. 1983. Preliminary assessment of the drought and forest fire damage in Kalimantan Timur. Report of the Fact-Finding Mission. Transmigration Area Development Project PN 76.2010.7. DFS German Forestry Service Ltd. for GTZ, Germany.

Lim, B. L. dan I. Das 1999. The turtles of Borneo. Natural History Publication, Kotakinabalu, Malaysia.

Lindenmayer, D. B. dan R. J. Hobbs. 2004. Fauna conservation in Australian plantation forests-a review. Biological Conservation 119:151-168.

Linkie, M., D. J. Martyr, J. Holden, A. Yanuar, A. T. Hartana, J. Sugardjito, dan N. Leader-Williams. 2003. Habitat destruction and poaching threaten the Sumatran tiger in Kerinci Seblat National Park, Sumatra. Oryx 37:41-48.

Linkie, M. dan L. Sadikin. 2003. The bearded pig in Kerinci Seblat National Park, Sumatra. Asian Wild Pig News 3:3-9.

Loehle, C. 1988. Tree life history strategies: the role of defences. Canadian Journal of Forest Research 18:209-222.

Loiselle, B. A., E. Ribbens, dan O. Vargas. 1996. Spatial and temporal variation of seed rain in a tropical lowland wet forest. Biotropica 28:82-95.

Lovejoy, T. E., B. O. J. Bierregaard, A. B. Rylands, J. R. Malcolm, C. E. Quintela, L. H. Harper, K. S. Brown, A. H. Powell, G. V. N. Powell, H. O. R. Schubart, dan M. B. Hays. 1986. Edge and other effects of isolation on Amazon forest fragments. Pages 257-285 in M. E. Soulé, editor. Conservation biology; the science of scarcity and diversity. Sinauer Associates, Inc., Sunderland, MA, USA.

Lu, X.-M., Y.-X. Wang, dan Y.-P. Zhang. 2001. Divergence and phylogeny of mitochondrial cytochrome b gene from species in Nycticebus. Zoological Research 22:93-98.

Lucas, P. W. dan R. T. Corlett. 1998. Relationship between diet of Macaca fascicularis and forest phenology. Folia Primatologia 57:201-215.

Lucchini, V., E. Meijaard, C. H. Diong, C. P. Groves, dan E. Randi. in press. New phylogenetic perspectives among South-East Asian wild pig species based on mtDNA sequences and morphometric data. Journal of Zoology.

Ludwig, D., M. Mangel, dan B. Haddad. 2001. Ecology, conservation, and public policy. Annual Review of Ecology and Systematics 32:481-517.

Lynch, O. J. dan E. Harwell 2002. Whose natural resources? Whose common good? Towards a paradigm of environmental justice and the national interest in Indonesia. CIEL (Center for International Environmental Law), Washington D.C., USA.

MacDonald, D. W. dan M. J. Wise. 1979. Notes on the behavior of the Malay civet Viverra tangalunga Gray. Sarawak Museum Journal 48:295-299.

Mackie, C. 1984. The lessons behind East Kalimantan's forest fires. Borneo Research Bulletin 16:63-74.

MacKinnon, J. 1977. A comparative ecology of Asian apes. Primates 18:747-772.

MacKinnon, J. K. 2002. Invasive alien species in Southeast Asia. ASEAN Review of Biodiversity and Environmental Conservation 2:9-11.

MacKinnon, J. dan K. MacKinnon. 1980. Niche differentiation in a primate community. Pages 167190 in D. J. Chivers, editor. Malayan forest primates: ten years study in tropical rain forests. 
Plenum Press, New York, USA.

MacKinnon, J. K. dan K. Phillipps. 1993. A field guide to the birds of Borneo, Sumatra, Java, and Bali. Oxford University Press, Oxford, UK.

MacKinnon, K. S. 1978. Stratification and feeding differences among Malayan squirrels. Malayan Nature Journal 330:593-608.

MacKinnon, K. S. 1986. Conservation status of Indonesian primates. Primate Eye 29:30-35.

MacKinnon, K., G. Hatta, H. Halim, dan A. Mangalik. 1996. The ecology of Kalimantan. Periplus Editions, Singapore.

Madge, S. G. 1969. Notes on the breeding of the Bushy-crested Hornbill Anorrhinus galeritus. Malayan Nature Journal 23:1-6.

Malcolm, J. R. dan J. C. Ray. 2000. Influence of timber extraction routes on Central African smallmammal communities, forest structure, and tree diversity. Conservation Biology 14:16231638.

Malingreau, J. P., G. Stephens, dan L. Fellows. 1985. Remote sensing of forest fires: Kalimantan and North Borneo in 1982-83. Ambio 14:314-321.

Mangel, M., L. M. Talbot, G. K. Meffe, M. T. Agardy, D. L. Alverson, J. Barlow, D. B. Botkin, G. Budowski, T. Clark, J. Cooke, R. H. Crozier, P. K. Dayton, D. L. Elder, C. W. Fowler, S. Funtowicz, J. Giske, R. J. Hofman, S. J. Holt, S. R. Kellert, L. A. Kimball, D. Ludwig, K. Magnusson, B. S. Malayang, C. Mann, E. A. Norse, dan et al. 1996. Principles for the conservation of wild living resources. Ecological Applications 6:338-362.

Marcot, B. G., R. E. Gullison, dan J. R. Barborak. 2001. The effects of logging on tropical forest ungulates in R. A. Fimbel, A. Grajal, dan J. G. Robinson, editors. The cutting edge. Columbia University Press, New York, USA.

Marks, S. A. 2001. Back to the future: Some unintended consequences of Zambia's Community-Based Wildlife Program (ADMADE). Africa Today 48:121-141.

Marsden, S. J. 1998. Changes in bird abundance following selective logging on Seram, Indonesia. Conservation Biology 12:605-611.

Marsh, C. W., A. D. Johns, dan J. M. Ayres. 1987. Effects of habitat disturbance on rain forest primates. Pages 83-107 in C. W. Marsh, dan R. A. Mittermeier, editors. Primate conservation in the tropical rain forest. Alan R. Liss, Inc., New York, USA.

Marsh, C. W. dan W. L. Wilson. 1981. A survey of primates in peninsular Malaysian forests. Universiti Kebangsaan Malaysia, Kuala Lumpur, Malaysia dan University of Cambridge, UK.

Martin-Smith, K. M. 1998a. Relationships between fishes and habitat in rainforest streams in Sabah, Malaysia. Journal of Fish Biology 52:458-482.

Martin-Smith, K. M. 1998b. Temporal variation in fish communities from the upper Segama Roiver, Sabah, Malaysian Borneo. Polskie Archiwum Hydrobiologii 45:185-200.

Martin-Smith, K. M. 1998c. Effects of disturbance caused by selective timber extraction on fish communities in Sabah, Malaysia. Environmental Biology of Fishes 53:155-167.

Maryanto, I., Maharadatunkamsi, dan A. Suyanto. 2002. Morphological variation and status of the Plantain Squirrel Callosciurus notatus (Boddaert, 1785) in Indonesia. Treubia 32:39-61.

Mason, D. J. dan F. E. Putz. 2001. Reducing the impacts of tropical forestry on wildlife. Pages 473-509 in R. Fimbel, A. Grajal, dan J. G. Robinson, editors. The cutting edge: Conserving wildlife in logged tropical forest. Columbia University Press, New York, USA.

Mason, D. J. dan J. Thiollay. 2001a. The effects of logging on tropical forest ungulates in R. A. Fimbel, A. Grajal, dan J. G. Robinson, editors. The cutting edge: Conserving wildlife in logged tropical forest. Columbia University Press, New York, USA.

Mason, D. J. dan J. Thiollay. 2001b. Tropical forestry and the conservation of neotropical birds. Pages 167-191 in R. Fimbel, A. Grajal, dan J. G. Robinson, editors. The cutting edge: conserving wildlife in logged tropical forest. Columbia University Press, New York, USA.

Mathews, A. dan A. Matthews. 2002. Distribution, population density, and status of sympatric cercopithecids in the Campo-Ma'an area, Southwestern Cameroon. Primates 43:155-168.

Matsubayashi, H., E. Bosi, dan S. Kohshima. 2003. Activity and habitat use of lesser mouse-deer (Tragulus javanicus). Journal of Mammalogy 84:234-242.

Matsui, M. 1979. Amphibians from Sabah. Systematic and natural history notes. Contributions from the Biological Laboratory Kyoto University 25:303-346. 
Mattson, D. J., S. Herrero, R. G. Wright, dan C. M. Pease. 1996. Designing and managing protected areas for Grizzly Bears: How much is enough? in R. G. Wright, editor. National parks and protected areas: Their role in environmental protection. Blackwell Science, Cambridge, MA, USA.

May, R. M. 1988. How many species are there on earth? Science 241:1441-1449.

May, S. A. dan T. W. Norton. 1996. Influence of fragmentation and disturbance on the potential impact of feral predators on native fauna in australian forest ecosystems. Wildlife Research 23:387-400.

McClure, H. E. 1966. Flowering, fruiting, and animals in the canopy of a tropical rain forest. The Malaysian Forester 29:182-203.

McClure, H. E. 1968. Some problems concerning endangered birds in south-eastern Asia. IUCN Publications (New Series) 10:307-311.

McConkey, K. dan M. Galetti. 1999. Seed dispersal by the sun bear Helarctos malayanus in Central Borneo. Journal of Tropical Ecology 15:237-241.

McDonald, W. dan C. C. St Clair. 2004. Elements that promote highway crossing structure use by small mammals in Banff National Park. Journal of Applied Ecology 41:82-93.

McGowan, P. J. K. dan P. J. Garson. 1995. Pheasants status survey and conservation action plan 19951999. IUCN, Gland, Switzerland.

Mckenney, D. W. dan D. B. Lindenmayer. 1994. An economic assessment of a nest-box strategy for the conservation of an endangered species. Canadian Journal of Forest Research-Journal Canadien de la Recherche Forestiere 24:2012-2019.

McKinney, M. L. dan J. L. Lockwood. 1999. Biotic homogenization: a few winners replacing many losers in the next mass extinction. Trends in Ecology \& Evolution 14:450-453.

McNally, L. C. dan S. S. Schneider. 1996. Spatial distribution and nesting biology of colonies of the African honey bee Apis mellifera scutellata (Hymenoptera: Apidae) in Botswana, Africa. Environmental Entomology 25:643-652.

Medway (Lord). 1969. The wild mammals of Malaya and offshore islands including Singapore. Oxford University Press, London, UK.

Medway (Lord). 1978. The wild mammals of Malaya (Peninsular Malaysia) and Singapore. Oxford University Press, Kuala Lumpur, Malaysia.

Medway (Lord) dan D. R. Wells 1976. The birds of the Malay Peninsula, Vol 5. Conclusions and survey of every species. Wihterby \& Penerbit University Malaya, London, UK.

Meijaard, E. 1999a. Human-imposed threats to sun bears in Borneo. Ursus 11:185 - 192.

Meijaard, E. 1999b. Ursus malayanus, the neglected Malayan sun bear. Nederlandsche Commissie voor International Natuurbescherming, Leiden, The Netherlands.

Meijaard, E. 2000. Bearded pig (Sus barbatus). Ecology, conservation status, and research methodology. Background document for the electronic conference on bearded pig research, and recommendations for a collaborative research programme. Unpublished report. WWF-Indonesia, CIFOR, dan Ecosense Consultants, Bogor, Indonesia.

Meijaard, E. 2001a. Conservation and trade of sun bears in Kalimantan. Pages 26-37 in D. Williamson, editor. Proceedings of the 3rd International Symposium on the Trade in Bear Parts, 26-28 October 1999, Seoul, South Korea.

Meijaard, E. 2001b. Recommendations regarding the use of tree spiking as a legal tool to combat illegal logging in Indonesia. Unpublished report for Directorate General of Nature Conservation. Ministry of Forestry, Indonesia. Australian National University, Canberra, Australia.

Meijaard, E. 2003a. Forest, pigs and people. A plan for the sustainable management of Bearded Pig populations in and around the Kayan Mentarang National Park, East Kalimantan, Indonesia. Unpublished report for WWF-Indonesia. WWF-Indonesia, Jakarta, Indonesia.

Meijaard, E. 2003b. Mammals of South-East Asian islands and their Late Pleistocene environments. Journal of Biogeography 30:1245-1257.

Meijaard, E. 2003c. Solving mammalian riddles. A reconstruction of the Tertiary and Quaternary distribution of mammals and their palaeoenvironments in island South-East Asia. Unpublished $\mathrm{PhD}$ thesis. Department of Anthropology and Archaeology. Australian National University, Canberra, Australia.

Meijaard, E. 2004. A craniometric analysis of the leopard, Panthera pardus, specifically regarding the taxonomic status and biogeographic history of the Javan leopard. Journal of Mammalogy 85: 302-210.

Meijaard, E. in press. Craniometric differences among Malayan sun bears (Ursus malayanus); evolutionary and taxonomic implications. Raffles Bulletin of Zoology December 2004. 
Meijaard, E. dan C. P. Groves. 2004. A taxonomic revision of the Tragulus mouse-deer (Artiodactyla). Zoological Journal of the Linnean Society 140: 63-102.

Meijaard, E. dan D. Sheil. in prep. Why did the chicken cross the road?-and other unanswered mysteries from Borneo.

Meijaard, E. dan V. Nijman. 2000. Distribution and conservation of the proboscis monkey (Nasalis larvatus) in Kalimantan, Indonesia. Biological Conservation 92:15 - 24.

Meijaard, E. dan V. Nijman. 2003. Primate hotspots on Borneo: predictive value for general biodiversity and the effects of taxonomy. Conservation Biology 17:725-732.

Meijaard, E. R. Nasi, D. Sheil, dan A. Grafen. in prep. Predicting the sensitivity of Bornean mammals to selective logging.

Merrill, T., D. J. Mattson, R. G. Wright, dan H. B. Quigley. 1999. Defining landscapes suitable for restoration of Grizzly Bears, Ursus arctos, in Idaho. Biological Conservation 87:231-248.

Mills, J. dan C. Servheen. 1994. The Asian trade in bears and bear parts: Impacts and conservation recommendations. International Conference on Bear Research and Management 9:161-167.

Milner-Gulland, E. J. dan H. R. Akçakaya. 2001. Sustainability indices for exploited populations. Trends in Ecology \& Evolution 16:686-692.

Ministry of Forestry. 1990. Act of the Republic of Indonesia No. 5 of 1990 concerning conservation of living resources and their ecosystems. Ministry of Forestry of the Republic of Indonesia.

Ministry of Forestry. 1992. Daftar binatang dan tumbuhan yang dilingdungi di Indonesia (list of the protected plants and animals in Indonesia). Unpublished report. Balai Konservasi Sumber Daya Alam I, Kantor Wilayah Propinsi Sumatera Utara, Departmen Kehutanan, Medan, Indonesia.

Mitani, J. C. 1992. Singing behavior of male gibbons: field observations and experiments. Pages 199210 in T. Nishida, W. C. McGrew, P. Marler, M. Pickford, dan F. B. M. de Waal, editors. Topics in Primatology: Human Origins. Vol 1. University of Tokyo Press, Tokyo, Japan.

Mitchell, A. H. 1994. Ecology of Hose's Langur, Prebytis hosei, in mixed logged and unlogged dipterocarp forest in north Borneo. Yale University.

Mitchell, R. M. 1979. The sciurid rodents (Rodentia: Sciuridae) of Nepal. Journal of Asian Ecology $1: 21-28$.

Mittermeier, R. A. dan C. G. Mittermeier 1998. Megadiversity: Earth's biologically wealthiest nations. CEMEX.

Miura, S. dan A. H. Idris. 1999. Present status and group size of the mouse-deer on Pulau Tioman, Malaysia. Malayan Nature Journal 53:335-339.

Mjöberg, E. P. 1929. Durch die Insel der Kopfäger. Brockhaus, Leipzig, Germany.

Molengraaff, G. A. F. dan M. Weber. 1920. Het verband tusschen den plistoceenen ijstijd en het ontstaan der Soenda-zee en de invloed daarvan op de verspreiding der koraalriffen en op de fauna. Verslagen der Afdeeling Natuurkunde 28:497-544.

Moll, E. dan D. Sharma 2000. The turtles of Peninsular Malaysia. Natural History Publications, Kota Kinabalu, Malaysia.

Morley, R. J. 2000. Origin and evolution of tropical rain forests. John Wiley \& Sons, Ltd, Chichester, UK.

Moyersoen, B., A. H. Fitter, dan I. J. Alexander. 1998. Spatial distribution of ectomycorrhizas and arbuscular mycorrhizas in Korup National Park rain forest, Cameroon, in relation to edaphic parameters. New Phytologist 139:311-320.

Murniati, D. P. Garrity, dan A. N. Gintings. 2001. The contribution of agroforestry systems to reducing farmers' dependence on the resources of adjacent national parks: a case study from Sumatra, Indonesia. Agroforestry Systems 52:171-184.

Muul, I. dan L. B. Liat. 1978. Comparative morphology, food habits, and ecology of some Malaysian arboreal rodents. Pages 361-370 in G. G. Montgomery, editor. The ecology of arboreal folivores. Smithsonian Institution Press, Washington, D.C., USA.

Muziol, C., C. T. Yuan, dan G. B. Keong. 2000. Reconciling logging and the conservation of biodiversity: Recommendations for a large timber concession in Terengganu, Peninsular Malaysia. Pages 270-277 in M. S. Bista, R. B. Joshi, S. M. Amatya, A. V. Parajuli, M. K. Adhikari, H. K. Saiju, R. Thakur, K. Suzuki, dan K. Ishii, editors. Proceedings of the 8th international workshop of Bio-Refor, Kathmandu, Nepal, November 28 - December 2, 1999. BIO-REFOR, Nepal.

Myers, N. 1985. The primary source. W.W. Norton dan Co, New York, USA.

Nasi, R. dan E. Forni. 2003. La gestion durable des forêts. Le Flamboyant 56:39-40. 
Nasi, R., R. Dennis, E. Meijaard, G. Applegate, dan P. Moore. 2002. Forest fire and biological diversity. Unasylva 53:36-40.

Nason, J. D. dan J. L. Hamrick. 1997. Reproductive and genetic consequences of forest fragmentation: two case studies of neotropical canopy trees. Journal of Heredity 88:264-276.

Ndan, I. 2003. Studi perbandingan teknik perburuan tradisional babi hutan (Sus barbatus Muller, 1896) antara suku dayak Kenyah dan suku Punan di kabupaten Malinau. MSc Thesis. Universitas Mulawarman, Samarinda, Indonesia.

Nederlandsch-Indische Vereeniging tot Natuurbescherming. 1939. Natuur in Zuid- en Oost- Borneo. Fauna, flora en natuurbescherming in de Zuider- en Ooster-Afdeeling van Borneo. Pages 334411 in Nederlandsch-Indische Vereeniging tot Natuurbescherming, editor. 3 Jaren Indisch natuur leven. Opstellen over landschappen, dieren en planten, tevens elfde verslag (1936-1938), Batavia, Indonesia.

Nepstad, D. C., A. G. Moreira, dan A. A. Alencar. 1999a. Flames in the rain forest: origins, impacts and alternatives to Amazonian fires. Page 161. Pilot Program to Conserve the Brazilian Rain Forest, Brasilia, Brazil.

Nepstad, D. C., A. Verissimo, A. Alencar, C. Nobre, E. Lima, P. Lefebvre, P. Schlesinger, C. Potter, P. Mountinho, E. Mendoza, M. A. Cochrane, dan V. Brooks. 1999b. Large-scale impoverishment of Amazonian forests by logging and fire. Nature 398:505-508.

Nettelbeck, A. R. 1997. Sightings of Binturongs in the Khao Yai National Park, Thailand. Small Carnivore Conservation 16:22-24.

Nettelbeck, A. R. 1998. Encounters between lar gibbons (Hylobates lar) and binturongs (Arctictis binturong). Folia Primatologica 69:392-396.

Newmark, W. D. 1991. Tropical forest fragmentation and the local extinction of understorey birds in the Eastern Usambara Mountains, Tanzania. Conservation Biology 5:67-78.

$\mathrm{Ng}$, F. S. P. 1980. Legumes in forestry. Pages 449-456. Proceedings of the symposium on legumes in the tropics. Faculty Agricultural University Pertanian Malaysia.

Ng, F. S. P. 1986. Tropical sapwood trees. Naturalia Monspeliensia. Colloque International sur l'Arbre:61-97.

Ngabo, C. K. M. dan C. Dranzoa. 2001. Bird communities in gaps of Budongo Forest Reserve, Uganda. Ostrich Supplement 15:38-43.

Nicholson, D. I. 1979. The effects of logging and treatment on the mixed dipterocarp forests of southeast Asia. Report FAO MISC/79/8, FAO, Rome, Italy.

Niemitz, C. 1984. Biology of Tarsiers. Gustav Fischer, Stuttgart, Germany.

Nieuwenhuis, A. W. 1907. Quer durch Borneo. Ergebnisse seiner Reisen in den Jahren 1894, 1896-97 und 1898-1900. E.J. Brill, Leiden, The Netherlands.

Nijman, V. 1997. Preliminary survey on colobine monkeys and other primates, in north-east Kalimantan, Indonesia. Unpublished report. University of Amsterdam, Amsterdam, the Netherlands.

Nijman, V. 1998. Habitat preference of great argus pheasant (Argusianus argus) in Kayan-Mentarang National Park, East Kalimantan, Indonesia. Journal für Ornithologie 139:313-323.

Nijman, V. in press. Effects of habitat disturbance and hunting on densities and biomass of the endemic Hose's leaf monkey Prebytis hosei (Thomas 1989) (Mammalia: Primates: Cercopithecidae) in east Borneo. Contributions to Zoology 74.

Nijman, V. dan S. van Balen. 2003. Wandering stars: age-related habitat use and dispersal of Javan Hawk-eagles (Spizaetus bartelsi). Journal of Ornithology 144:451-458.

NIVN (Nederlandsch-Indische Vereeniging tot Natuurbescherming). 1939. Natuur in Zuid- en OostBorneo. Fauna, flora en natuurbescherming in de Zuider- en Ooster-Afdeeling van Borneo. Pages 334-411 in NIVN, editor. 3 Jaren Indisch natuur leven. Opstellen over landschappen, dieren en planten, tevens elfde verslag (1936-1938), Batavia, Indonesia.

Noerdjito, M. dan I. Maryanto. 2001. Jenis-jenis hayati yang dilindungi perundang-undangan Indonesia. Balitbang Zoologi (Museum Zoologicum Bogoriense), Puslitbang-LIPI, dan The Nature Conservancy, Cibinong, Indonesia.

Nomura, F. 2003. Seasonal trends of habitat usage in two ursine species, a destructive beast Ursus arctos yesoensis and an agricutural pest Helarctos malayanus. $\mathrm{PhD}$ thesis. Graduate School of Environmental Earth Science, Division of Bioscience, Laboratory of Environmental Medicine and Informatics. University of Hokkaido, Hokkaido, Japan. 
Norberg, U. M. dan J. M. V. Rayner. 1987. Ecological morphology and flight in bats: wing adaptations, flight performance, foraging strategy and echolocation. Philosophical Transactions of the Royal Society of London - Series B: Biological Sciences 316:335-427.

Nordin, M. dan M. Z. Hussin. 1996. Some effects of logging in mixed lowland dipterocarp forests on birds. CAP-SAM National Conference 5-9 January 1996.

Nowak, R. M. 1991. Walker's Mammals of the World, 5th edition, Vol. II. Johns Hopkins University Press, Baltimore, USA.

Nowak, R. M. 1999. Walker's mammals of the world, 6th edition. Johns Hopkins University Press, Baltimore, USA.

Nowell, K. dan P. Jackson, editors. 1996. Wild cats. Status survey and conservation action plan. IUCN/ SSC Cat Specialist Group, Gland, Switzerland.

Nussbaum, R., J. Anderson, dan T. Spencer 1995. Factors limiting the growth of indigenous tree seedlings planted on degraded rainforest soils in Sabah, Malaysia. Forest Ecology and Management 74:149-159.

Nykvist, N. 1998. Logging can cause a serious lack of calcium in tropical rainforest ecosytems: an example from Sabah, Malaysia. Pages 87-91 in A. Schulte, dan D. Ruhiyat, editors. Soils of tropical forest ecosystems: Characteristics, ecology and management. Springer-Verlag, Berlin, Germany.

Nykvist, N., H. Grip, B. Liang Sim, A. Malmer, dan F. Khiong Wong. 1994. Nutrient losses in forest plantations in Sabah, Malaysia. Ambio 23:210-215.

O'Brien, T. G. 1997. Behavourial ecology of the North Sulawesi Taractic Hornbill Penelopides exarhatus during the breeding season. Ibis 119:97-101.

O’Brien, T. G., editor. 1998. Bulungan Biodiversity Survey: Preliminary Results. Unpublished report to CIFOR and Wildlife Conservation Society. Wildlife Conservation Society - Indonesia, Bogor, Indonesia.

O’Brien, T. G., M. F. Kinnaird, E. S. Dierenfeld, N. L. Conklin-Brittain, R. W. Wrangham, dan S. C. Silver. 1998a. What's so special about figs? Nature 392:668.

O’Brien, T. G., M. F. Kinnaird, dan H. T. Wibisono. 2003. Crouching tigers, hidden prey: Sumatran tiger and prey populations in a tropical forest landscape. Animal Conservation 6:131-139.

O’Brien, T. G., M. F. Kinnaird, P. Jepson, dan I. Setiawan. 1998b. Effect of forest size and structure on the distribution of Sumba Wreathed Hornbills, Aceros everetti. Pages 209-218 in P. Poonswad, editor. Proceedings of the Second Asian Hornbill Workshop, Bangkok. BRTP, Bangkok, Thailand.

O’Brien, T. G., N. Laksmi Winarni, F. Mindasari Saanin, M. F. Kinnaird, dan P. Jepson. 1998c. Distribution and conservation status of Bornean peacock-pheasant Polyplectron schleiermacheri in central Kalimantan, Indonesia. Bird Conservation International 8:373-385.

O'Brien, T. G. dan R. A. Fimbel. 1999. Faunal surveys in unlogged forest of the INHUTANI II Malinau Timber Concession. Unpublished Report to CIFOR and Wildlife Conservation Society. Wildlife Conservation Society - Indonesia, Bogor, Indonesia.

O'Brien, T. G. dan R. Fimbel, editors. 2002. Faunal survey in unlogged forest of the INHUTANI II, Malinau Timber Concession. Unpublished report. Wildlife Conservation Society (WCS) dan CIFOR, Bogor, Indonesia.

Ochoa, J. 1997. Sensibilidades potenciales de una comunidad de mamiferos en un bosque productor de maderas de la Guayana Venezolana. Interciencia 22:1-15.

Ochoa, J. 2000. Effects of logging on small-mammal diversity in the lowland forests of the Venezuelan Guyana region. Biotropica 32:146-164.

Oi, T. 1990. Population organization of wild pig-tailed macaques (Macaca nemestrina nemestrina) in West Sumatra. Primates 31:15-31.

Oka, T., E. Iskandar, dan D. I. Ghozali. 2000. Effects of forest fragmentation on the behavior of gibbons. Pages 229-239 in E. Guhardja, M. Fatawi, M. Sutisna, T. Mori, dan S. Ohta, editors. Rainforest ecosystems of East Kalimantan: El Niño, drought, fire and human impacts. SpringerVerlag, Tokyo, Japan.

Oksanen, L. 2001. Logic of experiments in ecology: is pseudoreplication a pseudoissue? Oikos 94:27-38.

Ouellet, M., J. Bonin, J. Rodrigue, J.-L. DesGranges, dan S. Lair. 1997. Hindlimb deformities in freeliving anurans from agricultural habitats. Journal of Wildlife Diseases 33:95-104.

Overgaard, H. J., B. Ekbom, W. Suwonkerd, dan M. Takagi. 2003. Effect of landscape structure on anopheline mosquito density and diversity in northern Thailand: Implications for malaria transmission and control. Landscape Ecology 18:605-619. 
Owens, I. P. F. dan P. M. Bennett. 2000. Ecological basis of extinction risk in birds: habitat loss versus human persecution and introduced predators. Proceedings of the National Academy of Sciences of the United States of America 97:12144-12148.

Owiunji, I. 2000. Changes in avian communities of Budongo Forest Reserve after 70 years of selective logging. Ostrich 71:216-219.

Parren, M. E. 1991. Forest elephant (Loxodonta africana cyclotis Matschie) messenger-boy or bulldozer? The possible impact on the vegetation, with special reference to 41 tree species of Ghana. Department of Forestry, Wageningen Agricultural University, The Netherlands.

Payne, J. 1979. Synecology of Malayan tree squirrels with special reference to the genus Ratufa. PhD dissertation. University of Cambridge, UK.

Payne, J. 1990. Rarity and extinctions of large mammals in Malaysian rainforests. Pages 310-320 in Y. S. Kheong, dan L. S. Win, editors. In harmony with nature, Kuala Lumpur, Malaysia.

Payne, J. 1995. Links between vertebrates and the conservation of Southeast Asian rainforests. Pages 54-65 in R. B. Primack, dan T. E. Lovejoy, editors. Ecology, conservation and management of Southeast Asian rainforests. Yale University Press, New Haven, USA \& London, UK.

Payne, J., C. M. Francis, dan K. Phillipps. 1985. A field guide to the mammals of Borneo. The Sabah Society, Kota Kinabalu.

Pearson, D. L. 1975. A preliminary survey of the birds of the Kutai Reserve, Kalimantan Timur, Indonesia. Treubia 28:157-162.

Pelissier, R., J. P. Pascal, F. Houllier, dan H. Laborde. 1998. Impact of selective logging on the dynamics of a low elevation dense moist evergreen forest in the Western Ghats (South India). Forest Ecology and Management 105:107-109.

Peluso, N. L. 1993. Coercing conservation. The politics of state resource control in R. D. Lipschutz, dan K. Conca, editors. The state and social power in global environmental politics. Columbia University Press, New York, USA.

Peres, C. A. 2001. Synergistic effects of subsistence hunting and habitat fragmentation on Amazonian forest vertebrates. Conservation Biology 15:1490-1505.

Peters, H. A. 2001. Clidemia hirta invasion at the Pasoh Forest Reserve: An unexpected plant invasion in an undisturbed tropical forest. Biotropica 33:60-68.

Pfeffer, P. 1960. Étude d'une collection d'oiseaux de Bornéo. L'Oiseau et la Revue Française d'Ornithologie 30:191-218 dan 31:199-129.

PHPA. 1996a. List of protected faunas: Burung/Aves. Directorate General Forest Protection and Nature Conservation, Ministry of Forestry. http://www2.bonet.co.id/dephut/burung1.htm. Accessed in March 2002.

PHPA. 1996b. List of protected faunas: Mamalia. Directorate General Forest Protection and Nature Conservation, Ministry of Forestry. http://www2.bonet.co.id/dephut/malia.htm. Accessed in March 2002.

Pinard, M. A. dan F. E. Putz. 1996. Retaining forest biomass by reducing logging damage. Biotropica 28:278-295.

Pinard, M. A., M. G. Barker, dan J. Tay. 2000. Soil disturbance and post-logging forest recovery on bulldozer paths in Sabah, Malaysia. Forest Ecology and Management 130:213-225.

Pinard, M., B. Howlett, dan D. D. 1996. Site conditions limit pioneer tree recruitment after logging of dipterocarp forests in Sabah, Malaysia. Biotropica 28:2-12.

Pitra, C., J. Fickel, E. Meijaard, dan C. P. Groves. 2004. Evolution and phylogeny of Old World deer. Molecular Phylogenetics \& Evolution 33:880-895.

Plumptre, A. dan A. Johns. 2001. The effects of logging on tropical forest ungulates in R. Fimbel, A. Grajal, dan J. G. Robinson, editors. The cutting edge: conserving wildlife in logged tropical forest. Columbia University Press, New York, USA.

Poonswad, P. dan A. Tsuji. 1994. Ranges of males of the great hornbill Buceros bicornis, brown hornbill, Ptiloaemus, and wreathed hornbill Rhyticeros undulatus in Kha Yai National Park, Thailand. Ibis 136:79-86.

Poonswad, P., A. Tsuji, dan C. Ngarmpongsai. 1983. A study of the breeding biology of hornbills (Bucerotidae) in Thailand. Pages 239-265. Proceedings of a Delacour/International Foundation for the Conservation of Birds Symposium on Breeding Birds in Captivity. International Foundation for the Conservation of Bird, Los Angeles, USA.

Poonswad, P., A. Tsuji, dan C. Ngarmpongsai. 1988. A comparative ecological study of four sympatric 
hornbills (Family Bucerotidae) in Thailand. Proceedings of the International Ornithological Congress 19:2781-2791.

Poonswad, P., C. Sukkasem, S. Phataramat, S. Hayeemuida, K. Plongmai, P. Chuailua, Preeda Thiensongrusame, dan N. Jirawatkavi, 2004. Comparison of cavity modification and community involvement as strategies for hornbill conservation in Thailand. Biological Conservation 122:385393.

Poore, D., P. Burgess, J. Palmer, S. Reitbergen, dan T. Syncott 1989. No timber without trees: sustainability in the tropical forest. Earthscan Publications, London, UK.

Pottie, S. A. 1996. Studies of the ecology and behaviour of insectivorous bat species in Singapore. Unpublished Masters Thesis. National University of Singapore, Singapore.

Prawiraatmadja, D. R. 1970. The influence of several mechanical logging methods on the natural regeneration of tropical rain forest in East Kalimantan. (In Indonesian). Sarjana Thesis. Fakultas Kehutanan IPB, Bogor, Indonesia.

Pringle, C. M. dan J. P. Benstead. 2001. The effects of logging on tropical river ecosystems. Pages 305325 in R. F. Fimbel, A. Grajal, dan Robinson.J.G., editors. The cutting edge: Conserving wildlife in logged tropical forest. Columbia University Press, New York, USA.

Puri, R. K. 1997. Hunting knowledge of the Penan Benalui of East Kalimantan, Indonesia. Department of Anthropology. University of Hawaii, USA.

Puri, R. K. 1998. Assessment of the biodiversity of the Bulungan Research Forest: ethnoecology of the Punan Tubu. Unpublished report. Wildlife Conservation Society (WCS)/CIFOR, Bogor, Indonesia.

Puri, R. K. 2001. Bulungan ethnobiology handbook. A field manual for biological and social science research on the knowledge and use of plants and animals among 18 indigenous groups in northern East Kalimantan. CIFOR, Bogor, Indonesia.

Purvis, A., J. L. Gittleman, G. Cowlishaw, dan G. M. Mace. 2000. Predicting extinction risk in declining species. Proceedings of the Royal Society of London - Series B: Biological Sciences 267:19471952.

Putz, F. E. 1984. The natural history of lianas on Barro Colorado Island, Panama. Ecology 65:17131724.

Putz F. E., D. P. Dykstra, dan R. Heinrich. 2000. Why poor logging practices persist in the tropics. Conservation Biology 14: 951-956.

Putz F. E., G. Blate, K. H. Redford, R. Fimbel, dan J. G. Robinson. 2001a. Tropical forest management and conservation of biodiversity: an overview. Conservation Biology 15: 7-20.

Putz, F. E. dan H. A. Mooney (eds.) 1991. The biology of vines. Cambridge University Press, Cambridge, UK

Putz, F. E., L. K. Sirot dan M. A. Pinard. 2001b. Tropical forest management and wildlife. Silvicultural effects on forest structure, fruit production, and locomotion of arboreal animals. Pages 11-34 in R. A. Fimbel, A. Grajal, dan J. G. Robinson, editors. The cutting edge: Conserving wildlife in logged tropical forest. Columbia University Press, New York, USA.

Rabinowitz, A. 1990. Notes on the behavior and movements of leopard cats, Felis bengalensis, in a dry tropical forest mosaic in Thailand. Biotropica 22:379-403.

Rabinowitz, A. R. 1991. Behaviour and movements of sympatric civet species in Huai Kha Khaeng Wildlife Sanctuary, Thailand. Journal of Zoology 223:281-298.

Rabinowitz, A., P. Andau, dan P. P. K. Chai. 1987. The clouded leopard in Malaysian Borneo. Oryx 21:107-111.

Rachmatika, I., R. Nasi, D. Sheil, dan M. Wan. 2005. Fish fauna in Bulungan Research Forest (BRF) Malinau, East Kalimantan. CIFOR, Bogor, Indonesia.

Randi, E., V. Lucchini, A. Hennache, R. T. Kimball, E. L. Braun, dan J. D. Ligon. 2001. Evolution of the mitochondrial DNA control region and cytochrome $b$ genes and the inference of phylogenetic relationships in the avian genus Lophura (Galliformes). Molecular Phylogenetics and Evolution 19:187-201.

Rankin-De Merona, J. M. dan R. W. Hutchings. 2001. Deforestation effects at the edge of an Amazonian forest fragment: Tree mortality, damage, and recruitment. Pages 107-120 in R. O. Bierregaard, Gascion, C., Lovejoy, T.E. dan R. Mesquita, editor. Lessons from Amazonia; the acology and conservation of a fragmented forest. Yale University Press, New Haven, USA. 
Reagan, D. P. dan R. B. Waide 1996. The food web of a tropical rain forest. University of Chicago Press, Chicago.

Redford, K. H. 1992. The empty forest. BioScience 42:412-422.

Redford, K. H. dan P. Feinsinger. 2001. The half-empty forest: sustainable use and the ecology of interactions in J. D. Reynolds, G. M. Mace, K. H. Redford, dan J. G. Robinson, editors. Conservation of exploited species. Cambridge University Press, Cambridge, UK.

Rejmanek, M. 1999. Invasive plant species and invasible ecosystems. Pages 79-102 in O. T. Sandlund, editor. Invasive species and biodiversity management. Kluwer Academic Publishers, Dordrecht, the Netherlands.

Republic of Indonesia. 1999. The law of the Republic of Indonesia number 41 year 1999 on forestry (Unofficial translation by Icel). http://www2. bonet.co.id/dephut/41-99-1.htm.

Reuters. 2003. Tiger parts found in record Australian seizure. http://news.findlaw.com/science/s/ 20031002/australiawildlifedc.html. Accessed on 7 October 2003.

Richards, P. W. 1996. The tropical rain forest. Second edition. Cambridge University Press, Cambridge, UK.

Riitters, K. H., R. V. O’Neill, dan K. B. Jones. 1997. Assessing habitat suitability at multiple scales: a landscape-level approach. Biological Conservation 81:191-202.

Rijksen, H. D. 1978. A fieldstudy on Sumatran orang utans (Pongo pygmaeus abelii Lesson 1827). Ecology, behaviour and conservation. Nature Conservation Department. Agricultural University Wageningen, Wageningen, The Netherlands.

Rijksen, H. D. dan E. Meijaard. 1999. Our vanishing relative. The status of wild orang-utans at the close of the twentieth century. Kluwer Academic Publishers, Dordrecht, The Netherlands.

Riswan, S. dan K. Kartawinata. 1991. Regeneration in a lowland dipterocarp forest in East Kalimantan, Indonesia. Pages 295-301 in: A. Gomez-Pompa, T.C. Whitmore, dan M. Hadley, editors. Rain forest regeneration and management. UNESCO, Paris, France.

Robertson, J. M. Y. dan C. P. van Schaik. 2001. Causal factors underlying the dramatic decline of the Sumatran orang-utan. Oryx 35:26-38.

Robinson, H. C. dan F. N. Chasen. 1936. The birds of the Malay Peninsula. Vol. III. Sporting birds: Birds of the shore and estuaries. Witherby, London, UK.

Robinson, J. G. dan E. L. Bennett. 2000. Carrying capacity limits to sustainable hunting in tropical forests. Pages 13-30 in J. G. Robinson, dan E. L. Bennett, editors. Hunting for sustainability in tropical forests. Columbia University Press, New York, USA.

Robinson, J. G. dan E. L. Bennett. 2002. Will alleviating poverty solve the bushmeat crisis? Oryx 36:332.

Robinson, J. G., K. H. Redford, dan E. L. Bennett. 1999. Wildlife harvest in logged tropical forests. Science 284:595-596.

Robinson, M. H. 1969. The defensive behavior of some orthopteroid insects from Panama. Transactions of the Royal Entomological Socierty of London 121:281-303.

Robson, C. 2000. A field guide to the birds of South-East Asia. New Holland Publishers, London, Cape Town, Sydney, Auckland.

Rodman, P. S. 1978. Diets, densities, and distributions of Bornean primates. Pages 465-478 in G. G. Montgomery, editor. The ecology of arboreal foliovores. Smithsonian Institution Press, Washington, D.C., USA.

Rodman, P. S. 1991. Structural differentiation of microhabitats on sympatric Macaca fascicularis and $M$. nemestrina in East Kalimantan, Indonesia. International Journal of Primatology 12:357-375.

Roonwal, M. L. dan S. M. Mohnot. 1977. Primates of South Asia: Ecology, sociology, and behavior. Harvard University Press, Cambridge, UK.

Rosenbaum, B. 2001. Biodiversity review of the vertebrate fauna at Bulungan research forest, East Kalimantan (and recommendations for research). Unpublished report for CIFOR and WCS, Indonesia.

Ross, C. 1992. Life history patterns and ecology of macaque species. Primates 33:207-215.

Round, P. D. dan W. Y. Brockelman 1998. Bird communities of disturbed lowland forest habitats in southern Thailand. Natural History Bulletin of the Siam Society 46: 171-196.

Rousseau, J. 1990. Central Borneo: Ethnic identity and social life in a stratified society. Clarendon Press, Oxford, UK.

Rowe, N. 1996. The pictorial guide to living primates. Pogonias Press, New York, USA. 
Ruedi, M. dan L. Fumagalli. 1996. Genetic structure of gymnures (genus Hylomys) on continental islands of SE Asia: historical effects of fragmentation. Journal of Zoological Systematics and Evolutionary Research 34:153-162.

Ruslim, Y., A. Hinrichs, B. Sulistioadi, dan PT Limbang Ganeca. 2000. Study on implementation of reduced impact logging. Ministry of Forestry and Estate Crops in Cooperation with Deutsche Gesellschaft für Technische Zusammenarbeit, Samarinda, East Kalimantan, Indonesia.

Saiful, A. A., A. H. Idris, Y. N. Rashid, N. Tamura, dan F. Hayashi. 2001. Home range size of sympatric squirrel species inhabiting a lowland dipterocarp forest in Malaysia. Biotropica 33:346-351.

Saiful, A. A. dan M. Nordin. 2004. Diversity and density of diurnal squirrels in a primary hill dipterocarp forest, Malaysia. Journal of Tropical Ecology 20:45-49.

Sanchez-De Leon, Y., X. Zou, S. Borges, dan H. Ruan. 2003. Recovery of native earthworms in abandoned tropical pastures. Conservation Biology 17:999-1006.

Sanft, K. 1960. Bucerotidae (Aves/Upupae). Das Tierreich 76:1-176.

Santiapillai, A. dan C. Santiapillai. 1996. The status, distribution and conservation of the Malayan sun bear (Helarctos malayanus) in Indonesia. Tigerpaper 23:11-16.

Santiapillai, C. dan H. Supraham. 1985. On the status of the Leopard Cat (Felis bengalensis) in Sumatra. Tigerpaper 12:8-13.

Sastrawinata, H. A. dan R. Effendy. 1991. The influences of several liberation treatment on the natural regeneration of dipterocarps in logged-over forest in Kintap, South Kalimantan. In I. Soerianegara, S. S. Tjitrosomo, R. C. Umaly, dan I. Umboh, editors. Proceedings of the fourth round table conference on dipterocarps, Bogor, Indonesia. 12-15 December 1989. BIOTROP Special Publication 41:395-405.

Saunders, D. A., R. J. Hobbs, dan C. R. Margules. 1991. Biological consequences of ecosystem fragmentation: A review. Conservation Biology 5:18-32.

Scatena, F. N. 2001. Ecological rhythms and the management of humid tropical forests. Examples from the Caribbean national Forest, Puerto Rico. Forest Ecology and Management 154:453-464.

Schnitzer, S. A. dan F. Bongers. 2002. The ecology of lianas and their role in forests. Trends in Ecology and Evolution 17:223-230.

Schreiber, A., R. Wirth, M. Riffel, dan H. van Rompaey. 1989. Weasels, civets, mongooses, and their relatives. An Action Plan for the conservation of mustelids and viverrids. IUCN, Gland, Switzerland.

Schupp, E. W. 1990. Annual variation in seedfall, post-dispersal predation and recruitment of a neotropical tree. Ecology 71:504-515.

Schwaner, C. A. L. M. 1853-1854. Borneo. Beschrijving van het stroomgebied van den Barito en reizen lands eenige voorname rivieren van het Zuid-Oostelijke gedeelte van dat eiland. $1^{\text {st }}$ volume. P.N. van Kampen, Amsterdam, the Netherlands.

Scott, N. J. J. 1976. The abundance and diversity of the herpetofaunas of tropical forest litter. Biotropica 8:41-58.

Sellato, B. 1997. Agricultural practices, social organization, settlement patterns, and ethnogenetic processes in East Kalimantan. Pages 27-57 in K. W. Sörensen, dan B. Morris, editors. Peoples and plants of Kayan Mentarang. WWF, London, UK.

Sellato, B. 2001. Forest, resources and people in Bulungan. Elements for a history of settlement, trade, and social dynamics in Borneo, 1880-2000. CIFOR, Bogor, Indonesia.

Servheen, C. 1999. Sun bear conservation action plan. Pages 219-224 in C. Servheen, S. Herrero, dan B. Peyton, editors. Bears. Status survey and conservation action plan. International Union for Conservation of Nature and Natural Resources, Gland, Switzerland and Cambridge, UK.

Servheen, C., S. Herrero, dan B. Peyton, editors. 1999. Bears: status survey and conservation action plan. IUCN, Gland, Switzerland.

Setyarso, A. 1991. Assessment of stand structure and growth after an intensive logging on dipterocarp forest. In I. Soerianegara, S.S. Tjitrosomo, R.C. Umaly, dan I. Umboh, editors. Proceedings of the fourth round table conference on dipterocarps, Bogor, Indonesia. 12-15 December 1989. BIOTROP Special Publication 41:191-200.

Setyawati, T. 1999. Impact of logging on faunal diversity in Wanariset Sangai, Central Kalimantan. Unpublished report. CIFOR, Bogor, Indonesia.

Sheil, D. 1994. Naturalised and invasive plant species in the evergreen forests of the East Usambara Mountains Tanzania. African Journal of Ecology 32:66-71. 
Sheil, D. 1998. A half century of permanent plot observation in Budongo Forest, Uganda: histories, highlights and hypotheses. Pages 399-428 in F. Dallmeier, dan J. A. Comiskey, editors. Forest biodiversity research, monitoring and modelling: Conceptual background and Old World case studies. Proceedings from the 1995 Smithsonian MAB Washington Symposium. MAB, UNESCO, Paris, France.

Sheil, D. 2001a. Chapter 5. Biodiversity research in Malinau. CIFOR Technical Report. CIFOR, Bogor, Indonesia.

Sheil, D. 2001b. Conservation and biodiversity monitoring in the tropics: Realities, priorities, and distractions. Conservation Biology 15:1179-1182.

Sheil, D. dan D. Burslem. 2003. Disturbing hypotheses in tropical forests. Trends in Ecology \& Evolution 18:18-26.

Sheil, D. dan M. van Heist. 2000. Ecology for tropical forest management. International Forestry Review 2:261-270.

Sheil, D., J. A. Sayer, dan T. O'Brien. 1999. Tree diversity and conservation in logged rainforest. Science 284:1587.

Sheil, D., N. Liswanti, I. Basuki, M. Wan, M. van Heist, I. Samsoedin, K. Kartawinata, Rukmiyati, dan M. Agung. 2003a. Prioritas lokal dan keanekaragaman hayati dalam lansekap hutan: apa yang penting menurut masyarakat? Jurnal Hutan Indonesia (Indonesia Forest Journal).

Sheil, D., N. Liswanti, M. van Heist, I. Basuki, Syaefuddin, I. Samsoedin, Rukmiyati, dan M. Agung. 2003b. Local priorities and biodiversity in tropical forest landscapes: asking people what matters. Tropical Forest Update 13: http:// www.itto.or.jp/newsletter/Newsletter.html.

Sheil, D., R. K. Puri, I. Basuki, M. van Heist, M. Wan, N. Liswanti, Rukmiyati, M. A. Sardjono, I. Samsoedin, K. Sidiyasa, Chrisandini, E. Permana, E. M. Angi, F. Gatzweiler, B. Johnson dan A. Wijaya. 2003c. Exploring biological diversity, environment and local people's perspectives in forest landscapes. CIFOR with ITTO, Bogor, Indonesia.

Sheil, D., R. Nasi, dan B. Johnson. 2004. Ecological criteria and indicators for tropical forestlandscapes: Challenges in the search for progress. Ecology and Society 9:article 7. http://www. eologyandsociety.org/vol9/iss1/art7.

Shekelle, M. in press. Distribution of tarsier acoustic forms, North and Central Sulawesi: With notes on the primary taxonomy of Sulawesi's tarsiers in S. Gursky, P. C. Wright, dan E. L. Simons, editors. The Tarsiiformes: Origins, Taxonomy, Behavior and Conservation. Rutgers University Press, USA.

Short, L. L. 1978. Sympatry in woodpeckers of lowland Malaysian forest. Biotropica 10:122-133.

Short, L. L. 1982. Woodpeckers of the world. Monograph Series Delaware Museum of Natural History 4:1-676.

Sibley, C. dan B. Monroe. 1990. Distribution and taxonomy of birds of the world. Yale University Press, New Haven, USA.

Siegel, S. dan N. J. J. Castellan. 1988. Nonparametric systems for the behavioral sciences. 2nd edition. McGraw-Hill Book Company, New York, USA.

Siegert, F. dan A. A. Hoffmann. 2000. The 1998 forest fires in East Kalimantan (Indonesia): A quantitative evaluation using high resolution, multitemporal ERS-2 SAR images and NOAA-AVHRR hotspot data. Remote Sensing of Environment 72:64-77.

Siegert, F., G. Ruecker, A. Hinrichs, dan A. A. Hoffmann. 2001. Increased damage from fires in logged forests during droughts caused by El Niño. Nature 414:437-440.

Silva, J. N. M., J. O. P. de Carvalho, J. d. C. A. Lopes, R. P. d. K. Oliveira, dan L. C. de Oliveira. 1996. Growth and yield studies in the Tapajos region, Central Brazilian Amazon. Commonwealth Forestry Review 75:325-329 dan 350-352.

Simons, H. 1987. Gunung Niut Nature Reserve. Proposed Management Plan. Page $42+$ appendices. WWF Indonesia, Jakarta, Indonesia.

Sist, N. dan N. Brown. 2004. Silvicultural intensification for tropical forest conservation: a response to Frederickson and Putz. Biodiversity and Conservation 13:2381-2385.

Sist, P. 2001. Why RIL won't work by minimum-diameter cutting alone. ITTO Newsletter 11.

Sist, P., C. Sabogal, dan Y. Byron. 1999. Management of secondary and logged-over forests in Indonesia: Selected proceedings of an international workshop, 17-19 November 1997 CIFOR, Bogor, Indonesia. 
Sist, P., D. Sheil, K. Kartawinata, dan H. Priyadi. 2003b. Reduced-impact logging in Indonesian Borneo: some results confirming the need for new silvicultural prescriptions. Forest Ecology and Management 179:415-427.

Sist, P., D. P. Dykstra, dan R. Fimbel. 1998a. Reduced impact logging guidelines for lowland and hill dipterocarp forest in Indonesia. CIFOR, Bogor, Indonesia.

Sist, P. dan N. Nguyen-Thé. 2002. Logging damage and the subsequent dynamics of a dipterocarp forest in East Kalimantan (1990-1996). Forest Ecology and Management 165: 85-103.

Sist, P., R. Fimbel, D. Sheil, R. Nasi, dan M.-H. Chevallier. 2003a. Towards sustainable management of mixed dipterocarp forests of South East Asia: Moving beyond minimum diameter cutting limits. Environmental Conservation 30:364-374.

Sist, P., T. Nolan, J. G. Bertault, dan D. Dykstra. 1998b. Harvesting intensity versus sustainability in indonesia. Forest Ecology and Management 108:251-260.

Sitompul, A. F., M. F. Kinnaird, dan T. G. O’Brien. In press. Size matters: the effects of forest fragmentation and resource availability on a large frugivore, the endemic Sumba Island hornbill. Bird Conservation International.

Slade, N. A., R. Gomulkiewicz, dan H. M. Alexander. 1998. Alternatives to Robinson and Redford's method for assessing overharvest from incomplete demographic data. Conservation Biology 12:148-155.

Slik, J. W. F. 2004. El Niño droughts and their effects on tree species composition and diversity in tropical rain forests. Oecologia 141:114-120.

Smit-van Dort, M. 1989. Skin, skull and skeleton characters of mouse deer (Mammalia, tragulidae), with keys to the species. Bulletin Zoologisch Museum 12:89-95.

Smythies, B. E. 1957. An annotated checklist of the birds of Borneo. Sarawak Museum Journal 7:1296.

Smythies, B. E. 1981. The birds of Borneo (3th ed.). The Sabah Society and the Malayan Nature Society, Kuala Lumpur, Malaysia.

Smythies, B. E. 1986. The birds of Borneo (revised ed.). Nimrod Press Ltd \& Silvio Mattacchione \& Co., Liss, Hampshire \& Pickering, Ontario, Canada.

Snyder, N. F. R., J. W. Wiley, dan C. B. Kepler 1987. The parrots of Luquillo: natural history and conservation of the Puerto Rican Parrot. Western Foundation of Vertebrate Zoology, Los Angles, CA, USA.

Sodhi, N. S. dan L. H. Liow. 2000. Improving conservation biology research in Southeast Asia. Conservation Biology 14:1211.

Sody, H. J. V. 1941. Tweede bijdrage over de voortplantingstijden der Indische zoogdieren. NederlandschIndische Jager 11:198-201.

Soehartono, T. dan A. Mardiastuti. 2001. Kutai National Park: Where to go. Tropical Biodiversity 7:83101.

Soulé, M. E., D. T. Bolger, A. C. Alberts, J. Wright, M. Sorice, dan S. Hill. 1988. Reconstructed dynamics of rapid extinctions of chaparral-requiring birds in urban habitat islands. Conservation Biology 2:75-92.

Sözer, R., A. M. Rachmat, dan Artinsyah. 1997. The status of the Bornean Peacock Pheasant Polyplectron schleiermacheri in Kalimantan, Indonesia. Preliminary results of the Kalimantan Pheasant Project 1995-1998. Pages 116-129 in N. Sugiri, D. M. Prawiradilaga, K. G. Wiryawan, dan A. S. Adhikerana, editors. Prosiding Seminar Nasional Pelestarian Burung dan Ekosistemnya. Institut Pertanian Bogor, Bogor, Indonesia.

Sözer, R., I. Setiawan, A. P. Setiadi, A. M. Rachmat, dan A. Adut. 1999. Survey of the Bornean Peacock Pheasant Polyplectron schleiermacheri and assessment of status, threats, and distribution of other Galliformes in West, Central, and East Kalimantan, Indonesia. Kalimantan Pheasant Project, Sukabumi, Indonesia.

Srikosamatara, S. 1993. Density and biomass of large herbivores and other mammals in a dry tropical forest, western Thailand. Journal of Tropical Ecology 9:33-43.

Stacy, E. A., J. L. Hamrick, J. D. Nason, S. P. Hubbell, R. B. Foster, dan R. Condit. 1996. Pollen dispersal in low-density populations of three neotropical tree species. The American Naturalist 148:275-298.

Stanford, C. B. dan H. T. Bunn 2001. Meat-eating and human evolution. Oxford University Press, Oxford, UK. 
Start, A. N. 1974. The feeding biology in relation to food sources of nectarivorous bats (Chiroptera: Macroglossinae) in Malaysia. Unpublished Ph.D. thesis. University of Aberdeen, Aberdeen, UK.

Start, A. N. dan A. G. Marshall. 1976. Nectarivorous bats as pollinators of trees in West Malaysia in J. Burley, dan B. T. Styles, editors. Tropical trees: variation breeding and conservation. Academic Press, London, UK.

Steidl, R. J., J. P. Hayes, dan E. Schauber. 1997. Statistical power analysis in wildlife research. Journal of Wildlife Management 61:270-279.

Stephens, D. W. dan J. R. Krebs 1986. Foraging theory. Princeton University Press, Princeton, NJ.

Sterck, E. H. M. 1995. Females, foods and fights. A socioecological comparison of the sympatric Thomas Langur and Long-tailed Macaque. PhD dissertation. Utrecht University, Utrecht, the Netherlands.

Stoms, D. M. 1994. Scale dependence of species richness maps. Professional Geographer 46: 346-358

Stork, N. E., T. J. B. Boyle, V. Dale, H. Eeley, B. Finegan, M. Lawes, N. Manokaran, R. Prabhu, dan J. Soberon. 1997. Criteria and indicators for assessing the sustainability of forest management: conservation of biodiversity. CIFOR Working Paper Number 17. URL: http://www.cifor.cgiar. org/docs/_ref/publications/workingpapers.htm. CIFOR, Bogor, Indonesia.

Stouffer, P. C. dan R. O. J. Bierregaard. 1995. Use of Amazonian forest fragments by understory insectivorous birds. Ecology 76:2429-2445.

Struhsaker, T. T. 2001. Unsustainable hunting in tropical forests. Trends in Ecology and Evolution 6:163-164.

Stuart, S. N., J. S. Chanson, N. A. Cox, B. E. Young, A. S. L. Rodrigues, D. L. Fischman, dan R. W. Waller. Published online 14 October 2004. Status and trends of amphibians declines and extinctions worldwide (in Science Express Reports).

Stuebing, R. 1994. Wildlife abundance, diversity and management. Unpublished technical report, ITTO Model Forest Management Area, Sarawak. Project ITTO PD 105/90 Rev. 1(F). ITTO Unit, Sarawak Forest Department, Kuching, Malaysia.

Stuebing, R. B. dan J. Gasis. 1989. A survey of small mammals within a tree plantation in Malaysia. Journal of Tropical Ecology 5:203-214.

Stuebing, R. B. dan R. F. Inger 1999. The snakes of Borneo. Natural History Publication, Kota Kinabalu, Malaysia.

Styring, A. R. 2002a. Effects of selective logging on a guild of 13 syntopic woodpecker species in a Malaysian forest reserve. Pages 165-171 in P. Pechacek, dan W. d'Oleire-Oltmanns, editors. International Woodpecker Symposium 23-25 March 2001 in Berchtesgarden, Germany. Forschungsbericht 48. Nationalparkverwaltung, Berchtesgaden, Germany.

Styring, A. R. 2002b. Local, regional and global patterns of woodpecker (Picidae) diversity: ecological explanations and practical applications. PhD dissertation. Louisiana State University, Baton Rouge, USA.

Styring, A. R. dan K. Ickes. 2001a. Woodpecker abundance in a logged (40 years ago) vs. unlogged lowland dipterocarp forest in Peninsular Malaysia. Journal of Tropical Ecology 17:261-268.

Styring, A. R. dan K. Ickes. 2001b. Woodpecker participation in mixed species flocks in peninsular Malaysia. Wilson Bulletin 113:342-345.

Styring, A. R. dan M. Z. Hussin. 2004a. Effects of logging on woodpeckers in a Malaysian rainforest: the relationship betwen resource availability and woodpecker abundance. Journal of Tropical Ecology 20:495-504.

Styring, A. R. dan M. Z. Hussin. 2004b. Foraging ecology of woodpeckers in lowland Malaysian rain forests. Journal of Tropical Ecology 20:487-494.

Sudarmaji, T. 1999. Impact of logging and forest fires on soil erosion in tropical humid forest, East Kalimantan. Paper presented at the International Workshop on the Rehabilitation of Degraded Tropical Forest Ecosystems, CIFOR, Bogor, Indonesia. 2-4 November 1999.

Sulastri, I. Rachmatika, dan D. I. Hartoto. 1985. Pola makan dan reproduksi ikan Tor spp. sebagai dasar budidayanya. Berita Biologi 3:84-90.

Sumitro, A. 1991. The cutting of climax trees of dipterocarps stand under intensive management. In I. Soerianegara, S.S. Tjitrosomo, R.C. Umaly dan I. Umboh, editors. Proceedings of the fourth round table conference on dipterocarps, Bogor, Indonesia. 12-15 December 1989. BIOTROP Special Publication 41:201-212. 
Supriatna, J., B. O. Manullang, dan E. Soekara. 1986. Group composition, home range, and diet of the maroon leaf monkey (Presbytis rubicunda) at Tanjung Puting Reserve, Central Kalimantan. Primates 27:185-190.

Supriyatno, N. dan G. Becker. 1999. Secondary logging in natural forests in Central Kalimantan: operational design, production and damage assessment. Pages 65-70 in P. Sist, C. Sabogal, and Y. Byron, editors. Management of secondary and logged-over forests in Indonesia: Selected proceedings of an International workshop, 17-19 November 1997, CIFOR, CIRAD dan USAID, CIFOR, Bogor Indonesia.

Sutisna, M. 1996. The importance of selective tending to improve productivity of I logged-over dipterocarp forest in Indonesia. Pages 279-287 in S. Appanah, dan K.C. Khoo, editors. Proceedings fifth round table conference on dipterocarps, Chiang Mai, Thailand. 7-10 November 1994, Forest Research Institute Malaysia, Kepong. Malaysia.

Sutisna, M. 1998. Growth of a tropical lowland forest in East Kalimantan. In G.L. Enriquez, U.R. Wasrin, dan D. Murdiarso, editors. Tropical Forest Dynamics, BIOTROP Special Publication 60:81-91.

Suzuki, A. 1991. Forest fire effects on the population of primates in Kutai National Park. East Kalimantan, Indonesia. Pages 51-54 in A. Ehara dan T. Kimura, editors. Primatology today. Elsevier Science Publishers, Amsterdam, the Netherlands.

Swaine, M. D. dan J. B. Hall. 1983. Early succession on cleared forest land in Ghana. Journal of Ecology 71:601-627.

Swihart, R. K., T. M. Gehring, M. B. Kolozsvary, dan T. E. Nupp. 2003. Responses of 'resistant' vertebrates to habitat loss and fragmentation: the importance of niche breadth and range boundaries. Diversity and Distributions 9:1-18.

Syakirah, S., A. Zubaid, C. Prentice, A. Lopez, M. R. Azmin, dan A. Mohd-Yusof. 2000. A smallmammal survey at Tasek Bera, Pahang, Malaysia’s first Ramsar site. Malayan Nature Journal 54:3141.

Szaro R. C., J. A. Sayer, D. Sheil, L. K. Snook, dan A. Gillison. 1999. Biodiversity conservation in production forests. IUFRO-SPDC and CIFOR Discussion Paper commissioned by GEF. IUFRO, Vienna, Austria.

Tamura, N. 1995. Space use by sympatric tree squirrels in Malaysian tropical forests. Tropics 4:337343.

Tan, E. S. P. 1979. Some aspects of the biology of Malaysian riverine cyprinids. Aquaculture 3:281289.

Tay, J. 1999. Economic assessment of reduced impact logging techniques in Sabah, Malaysia. PhD dissertation. University of Wales, Bangor, UK.

Taylor, B. D. dan R. L. Goldingay. 2004. Wildlife road-kills on three major roads in north-eastern New South Wales. Wildlife Research 31:83-91.

Teo, D. H. L., H. T. W. Tan, R. T. Corlett, C. M. Wong, dan S. K. Y. Lum. 2003. Continental rain forest fragments in Singapore resist invasion by exotic plants. Journal of Biogeography 30:305-310.

Terborgh, J. 1983. Five New World primates: A study in comparative ecology. Princeton University Press, Princeton, N.J., USA.

Terborgh, J. 1992. Maintenance of diversity in tropical forests. Biotropica 24: 283-292.

Thiensongrusamee, P., P. Poonswaad, dan S. Hayeemuida. 2001. Characteristics of Helmeted Hornbill nests in Thailand. The Third International hornbill workshop on the ecology of hornbills with emphasis on reproduction and population, 9-18 May 2001, Phuket and Narathiwat, Thailand. Abstracts of paper presentations.

Thiollay, J. M. 1992. Influence of selective logging on bird species diversity in a Guianan rain forest. Conservation Biology 6:47-63.

Thiollay, J. M. 1995. The role of traditional agroforests in the conservation of rain forest bird diversity in Sumatra. Conservation Biology 9:335-353.

Thiollay, J. M. 1998. Distribution patterns and insular biogeography of south asian raptor communities. Journal of Biogeography 25:57-72.

Thiollay, J. M. 1999. Responses of an avian community to rain forest degradation. Biodiversity and Conservation 8:513-534.

Thomas, S. C. 1996. Relative size at onset of maturity in rain forest trees: a comparative analysis of 37 Malaysian species. Oikos 76:145-154. 
Tinal, U. dan J. Palinewen. 1978. Mechanical logging damage after selective cutting in the lowland Dipterocarp forest at Beloro, East Kalimantan. In: Proceeding of the symposium on long term effect of logging in Southeast Asia. BIOTROP Special Publication 3:91-96.

Townsend, W. R. 2000. The sustainability of subsistence hunting by the Sirionó Indians of Bolivia. Pages 267-281 in J. G. Robinson, dan E. L. Bennett, editors. Hunting for sustainability in tropical forests. Columbia University Press, New York, USA.

Trockenbrodt, M., Z. Imiyabir, dan J. Josue. 2002. Hollow logs and logging residues from Deramakot Forest Reserve, Sabah, Malaysia. Forest Ecology and Management 165:141-150.

Tsuji, A., P. Poonswaad, dan N. Jirawatkavi. 1987. Application of radio-tracking to study hornbills (Bucerotidae) in Thailand. Pages 316-351. Proceedings 1987 Jean Delacour/FCB Symposium on Breeding Birds in Captivity. International Foundation for the Conservation of Birds, North Hollywood, CA, USA.

Tuomela, K., K. Jussi, L. Vesa, K. Nuryanto, A.P.S. Sagala, dan G. Adjers. 1996. Growth of dipterocarp seedling in artificial gaps: an experiment in logged-over rainforest in South Kalimantan, Indonesia. Forest Ecology and Management 81:95-100.

Turner, I. M. 1996. Species loss in fragments of tropical rainforests: a review of evidence. Journal of Applied Ecology 33:200-209.

Turner, I. M., K. S. Chua, J. S. Y. Ong, B. C. Soong, dan H. T. W. Tan. 1996. A century of plant species loss from an isolated fragment of lowland tropical rain forest. Conservation Biology 10:12291244.

Twedt, D. J., R. R. Wilson, J. L. Henne-Kerr, dan R. B. Hamilton. 2001. Nest survival of forest birds in the Mississippi Alluvial Valley. Journal of Wildlife Management 65:450-460.

Uluk, A., M. Sudana, dan L. Wollenberg. 2001. Ketergantungan masyarakat Dayak terhadap hutan di sekitar Taman Nasional Kayan Mentarang. Unpublished report. CIFOR, Bogor, Indonesia.

Umapathy, G. dan A. Kumar. 2000. The occurrence of arboreal mammals in the rain forest fragments in the Anamalai Hills, south India. Biological Conservation 92:311-319.

Ungar, P. S. 1995. Fruit preferences of four sympatric primate species at Ketambe, Northern Sumatra, Indonesia. International Journal of Primatology 16:221-245.

Utzurrum, R. C. B. 1995. Feeding ecology of Philippine fruit bats: patterns of resrouce use and seed disperseal. Symposium of the Zoological Society of London 67:63-77.

Utzurrum, R. C. B. dan P. D. Heideman. 1991. Differential ingestion of viable vs non viable Ficus seeds by fruit bats. Biotropica 23:311-322.

van Balen, B. 1999a. The birds of Kayan Mentarang National Park, Unpublished report. WWFIndonesia, Jakarta, Indonesia.

van Balen, B. 1999b. Differential extinction patterns in Javan forest birds. Pages 37-57. Birds of fragmented islands: Persistence in the forests of Java and Bali. PhD dissertation. Wageningen University and Research Centre, Wageningen, the Netherlands.

van Balen, B. 1999c. Synthesis: survival on overpopulated islands. Pages 131-146. Birds of fragmented islands: Persistence in the forests of Java and Bali. PhD dissertation. Wageningen University and Research Centre, Wageningen, the Netherlands.

van Balen, B. dan D. Holmes. 1993. Status and conservation of pheasants in the Greater and Lesser Sundas. Pages 40-49 in D. Jenkins, editor. Phesants in Asia 1992. World Pheasant Association, Reading, UK.

van Bemmel, A. C. V. 1949-1950. Revision of the rusine deer in the Indo-Australian archipelago. Treubia 20:191 - 262.

van der Hoeven, C. A., H. H. de Iongh, V. Nijman, dan B. van Balen. 2000. Biodiversity in disturbed ecosystems. A literature review of the use of faunal indicators for the assessment and monitoring of the levels of human disturbance in Bornean tropical lowland forests. Tropenbos Documents no. 16. NWO and the Tropenbos Foundation, Wageningen, The Netherlands.

van der Pijl, I. 1935. Zaadverspreiding door vleermuizen. De Tropische Natuur 24:131-138.

van Dijk, P. P., B. L. Stuart, dan A. G. J. Rhodin. 2000. Asian turtle trade: Proceedings of the Workshop on Conservation and Trade of Freshwater Turtles and Tortoises in Asia. Chelonian Research Monographs 2:1-164.

van Gardingen, P. R., M. J. Clearwater, T. Nifinluri, R. Effendi, P. A. Ruswantoro, K. Ingleby dan R. C. Munro. 1998. Impacts of logging on the regeneration of lowland dipterocarps forest in Indonesia. Commonwealth Forestry Review 77:71-82. 
van Gardingen, P. R., M. J. McLeish, P. D. Phillips, D. Fadilah, G. Tyrie, dan I. Yasman. 2003. Financial and ecological analysis of management options for logged-over Dipterocarp forests in Indonesian Borneo. Forest Ecology and Management 183:1-29.

van Heist, M. dan E. Wollenberg. 2000. Action research on negotiating conflict and community empowerment in forest areas: Participatory mapping of the villages along the Malinau River, East Kalimantan. Preliminary report to ITTO. CIFOR, Bogor, Indonesia.

van Horn, R. N. dan G. G. Eaton. 1979. Reproductive physiology and behavior in prosimians. Pages 79-122 in G. A. Doyle, dan R. D. Martin, editors. The Study of Prosimian Behavior. Academic Press, New York, USA.

van Marle, J. G. dan K. H. Voous. 1988. The birds of Sumatra. An annotated check-list. British Ornithologist Union Checklist No. 10.

van Nieuwstadt, M. G. L., D. Sheil, dan K. Kartawinata. 2001. The ecological consequences of logging in the burned forests of East Kalimantan, Indonesia. Conservation Biology 15:1183-1186.

van Nieuwstadt, M. G. L., K. Kartawinata, dan D. Sheil. 2002. Konsekuensi ekologis pembalakan dalam kawasan hutan yang terbakar di Kalimantan Timur. Jurnal Hutan Indonesia (Indonesia Forest Journal). August 2002:1-4.

van Noordwijk, M. A., C. K. Hemelrijk, L. Herremans, dan E. H. M. Sterck. 1993. Spatial position and behavioral sex differences in juvenile long-tailed macaques. Pages 77-85 in M. E. Pereira, dan L. A. Fairbanks, editors. Juvenile Primates: Life history, development, and behavior. Oxford University Press, New York, USA.

van Putten, G. 2000. An ethological definition of animal welfare with special emphasis on pig behaviour in M. Hovi, dan R. G. Trujillo, editors. Diversity of livestock systems and definition of animal welfare. Proceedings of the Second NAHWOA Workshop, Cordoba, 8-11 January 2000. Spain.

van Schaik, C. P., P. S. Assink, dan N. Salafsky. 1992. Territorial behavior in Southeast Asian langurs: resource defense or mate defense? American Journal of Primatology 26:233-242.

van Strien, N. J. 2001. Indoaustralian mammals. A taxonomic and faunistic reference and atlas. ETI, Amsterdam, The Netherlands.

Vasconcelos, H. L., J. M. S. Vilhena, dan G. J. A. Caliri. 2000. Responses of ants to selective logging of a central Amazonian forest. Journal of Applied Ecology 37:508-514.

Vidal, E., J. Johns, J. J. Gerwing, P. Barreto, dan C. Uhl. 1997. Vine management for reduced-impact logging in eastern amazonia. Forest Ecology and Management 98:105-114.

Vidal, J. 2003. Forced from rich forests into squalor. Tribal people are paying a high price for parks created to protect Africa's wilderness. The Guardian Weekly 2-8 October 2003: 26.

Vitt, L. J. dan J. P. Caldwell. 1994. Resource utilization and guild structure of small vertebrates in the Amazon forest leaf litter. Journal of Zoology 234:463-476.

Vitt, L. J. dan J. P. Caldwell. 2001. The effects of logging on tropical forest ungulates in R. A. Fimbel, A. Grajal, dan J. G. Robinson, editors. The cutting edge: conserving wildlife in logged tropical forest. Columbia University Press, New York, USA.

Wadley, R. L., C. J. P. Colfer, dan I. G. Hood. 1997. Hunting primates and managing forests - the case of Iban forest farmers in Indonesian Borneo. Human Ecology 25:243-271.

Waits, L. P. 1996. A comprehensive molecular study of the evolution and genetic variation of bears. $\mathrm{PhD}$ thesis. University of Utah, Salt Lake City.

Waits, L. P., J. Sullivan, S. J. O’Brien, dan R. H. Ward. 1999. Rapid radiation events in the family Ursidae indicated by likelihood phylogenetic estimation from multiple fragments of mtDNA. Molecular Phylogenetics and Evolution 13:82-92.

Walsh, P. D., K. A. Abernethy, M. Bermejo, R. Beyersk, P. De Wachter, M. E. Akou, B. Huljbregis, D. I. Mambounga, A. K. Toham, A. M. Kilbourn, S. A. Lahm, S. Latour, F. Maisels, C. Mbina, Y. Mihindou, S. N. Obiang, E. N. Effa, M. P. Starkey, P. Telfer, M. Thibault, C. E. G. Tutin, L. J. T. White, dan D. S. Wilkie. 2003. Catastrophic ape decline in western equatorial Africa. Nature 422:611-614.

Walston, J. L. dan J. W. Duckworth. 2003. The first record of small-toothed palm civet Arctogalidia trivirgata from Cambodia, with notes on surveying the species. Small Carnivore Conservation 28:12-13.

Walter, O. 2000. A study of hunting and trade of freshwater turtles and tortoises (Order Chelonia) at Danau Sentarum. Borneo Research Bulletin 31:323-335.

Waterman, P. G. 1983. Distribution of secondary metabolites in rain forest plants; towards an 
understanding of cause and effect. Pages 167-179 in S. L. Sutton, Whitmore, T.C. and Chadwick, A.C., editor. Tropical rain forest ecology and management. Special Publication number 20 of the British Ecological Society. Blackwell Scientific Publications, Oxford, UK.

Waterman, P. G., J. A. M. Ross, E. L. Bennett, dan A. G. Davies. 1988. A comparison of the floristics and leaf chemistry of the tree flora in two Malaysian rainforests and the influence of leaf chemistry on populations of Colobine monkeys in the Old World. Biological Journal of the Linnean Society 34:1-32.

WCS. 1998. Malaysian state of Sarawak bans commercial hunting of wildlife. WCS press release 28 May 1998. http://www.mered.org.uk/saraweb/issues/WCS\%20on\%20trade\%20ban.htm. Accessed on 9 March 2004.

Webb, C. O. dan D. R. Peart. 2001. High seed dispersal rates in faunally intact rainforests: theoretical and concervation implications. Ecology Letters 4: 491-499.

Webb, E. L. 1997. Canopy removal and residual stand damage during controlled selective logging in lowland swamp forest of Costa Rica. Forest Ecology and Management 95:117-129.

Wells, D. R. 1974. Bird report: 1970 and 1971. Malayan Nature Journal 27:30-49.

Wells, D. R. 1998. The birds of the Thai-Malaysian Peninsula. Academic Press, London, UK.

Wells, D. R. 1999. The birds of the Thai-Malay Peninsula. Academic Press, London, UK.

Wells, K. L. 2002. Diversity, dynamics and spacing patterns of a small mammal community in a primary rainforest in Sabah; comparing an arboreal and terrestrial habitat. MSc thesis. Lehrstuhl für Tierökologie und Tropenbiologie der Bayerischen Julius-Maximilians-Universität in Würzburg, Würzburg, Germany.

Wetterer, J. K., P. D. Walsh, dan L. J. T. White. 1999. Wasmannia auropunctata (Roger) (Hymenoptera: Formicidae), a destructive tramp-ant, in wildlife refuges of Gabon. African Entomology 7:292-294.

Wharton, C. H. 1966. Man, fire and wild cattle in north Cambodia. Pages 23-65. 5th Annual Tall Timbers Fire Ecology Conference, Tallahassee, Florida, USA.

Wharton, C. H. 1968. Man, fire and wild cattle in Southeast Asia. Pages 107-167. Proceedings of the 8th Annual Tall Timbers Fire Ecology Conference. Tallahassee, Florida, USA.

White, L. J. T. 1994. The effects of commercial mechanized selective logging on a transect in lowland rainforest in the Lope Reserve, Gabon. Journal of Tropical Ecology 10:313-322.

Whitman, A. A., J. M. Hagan, dan N. V. L. Brokaw. 1998. Effects of selection logging on birds in Northern Belize. Biotropica 30:449-457.

Whitmore, T. C. 1984. Tropical rain forests of the Far East. Oxford University Press, Oxford, U.K.

Whitmore, T. C. 1990a. Tropical rain forest dynamics and its implications for management. Pages 67-89 in A. Gomez-Pompa, T. C. Whitmore, dan M. Hadley, editors. Rain forest regeneration and management. Man and the Biosphere Series, Volume 6. Parthenon Publishing Group, Paris, France.

Whitmore, T. C. 1990b. An introduction to tropical rainforests. Clarendon Press, Oxford, UK.

Whitmore, T. C. 1997. Tropical forest disturbance, disappearance, and species loss in W. F. Laurance, dan R. O. Bierregaard, editors. Tropical Forest Remnants: Ecology, Management, and Conservation of Fragmented Communities. University of Chicago Press, Chicago, USA.

Whitmore, T. C. 1998. An introduction to tropical rain forests. Second Edition. Oxford University Press, New York, USA.

Whitmore, T. C. dan J. A. Sayer 1992. Tropical deforestation and species extinction. Chapman and Hall, London, UK.

Whitmore, T. C. dan N. D. Brown. 1996. Dipterocarp seedling growth in rain forest canopy gaps during six and a half years. Philosophical Transactions of the Royal Society of London - Series B: Biological Sciences 351:1195-1203.

Whitney, K. D. dan T. B. Smith. 1998. Habitat use and resource tracking by African Ceratogymna hornbills: implications for seed dispersal and forest conservation. Animal Conservation 1:107-117.

Whitney, K. D., M. K. Fogiel, A. M. Lamperti, K. M. Holbrook, D. J. Stauffer, B. D. Hardesty, V. T. Parker, dan T. B. Smith. 1998. Seed dispersal by Ceratogymna hornbills in the Dja Reserve, Cameroon. Journal of Tropical Ecology 14:351-371.

Whitten, A. J., S. J. Damanik, A. Jazanul, dan H. Nazaruddin. 1987. The ecology of Sumatra. Gadjah Mada University Press, Yogyakarta, Indonesia.

Whitten, J. E. J. 1981. Ecological separation of three diurnal squirrels in tropical rainforest on Siberut Island, Indonesia. Journal of Zoology 193:405-420. 
Whitten, J. E. J. dan A. J. Whitten. 1987. Analysis of bark eating in a tropical squirrel. Biotropica 19:107-115.

Whitten, T., R.E. Soeriaatmadja, dan S.A. Afiff, 1996. The ecology of Java and Bali. Periplus Editions, Singapore.

Wich, S. A. dan C. P. Schaik van. 2000. The impact of El Niño on mast fruiting in Sumatra and elsewhere in Malesia. Journal of Tropical Ecology 16:563-577.

Wiens, J. A. 1989. The ecology of bird communities. Cambridge University Press, Cambridge, UK.

Wiens, J. A. 1992. Ecological flows across landscape boundaries; a conceptual overview in A. J. Hansen, dan F. di Castri, editors. Landscape Boundaries: Consequences for Biotic Diversity and Ecological Flows. Springer-Verlag, New York, USA.

Wiens, J. A. 1997. Metapopulation dynamics and landscape ecology in I. A. Hanski, dan M. E. Gilpin, editors. Metapopulation biology: Ecology, genetics, and evolution. Academic Press, San Diego, CA, USA.

Wildlife Conservation Society (WCS) dan Sarawak Forest Department. 1996. A masterplan for wildlife in Sarawak. Sarawak Forest Department, Kuching, Malaysia.

Wilkie, D., E. Shaw, F. Rotberg, G. Morelli, dan P. Auzel. 2000. Roads, development, and conservation in the Congo Basin. Conservation Biology 14:1614-1622.

Wilkie, D. S. dan J. F. Carpenter. 1999. Bushmeat hunting in the Congo Basin: an assessment of impacts and options for mitigation. Biodiversity and Conservation 8:927-955.

Wilkie, D. S., J. G. Sidle, G. C. Boundzanga, P. Auzel, dan S. Blake. 2001. Defaunation, not deforestation: Commercial logging and market hunting in Northern Congo. Pages 375-399 in R. Fimbel, A. Grajal, dan J. G. Robinson, editors. The cutting edge: Conserving wildlife in logged tropical forest. Columbia University Press, New York, USA.

Wilkinson, R., G. Dutson, dan B. Sheldon. 1991. The avifauna of Barito Ulu Central Borneo. ICBP Study Report 48, Cambridge, UK.

Wilson, C. C. dan W. L. Wilson. 1975. The influence of selective logging on primates and some other animals in East Kalimantan. Folia Primatologia 23:245-274.

Wilson, W. L. dan A. D. Johns. 1982. Diversity and abundance of selected animal species in undisturbed forest, selectively logged forest and plantations in East Kalimantan, Indonesia. Biological Conservation 24:205-218.

Winarni, N. 2002. Abundance and distribution of great argus Argusianus argus. Tragopan:15.

Winkler, H., D. A. Christie, dan D. Nurney 1995. Woodpeckers: a guide to the woodpeckers, piculets and wrynecks of the world. Pica Press, Mountfield, East Sussex, UK.

Wirawan, A. 1993. The hazard of fire. Pages 242-260 in H. Brookfield, dan Y. Byron, editors. The search for sustainability. United Nations University Press, New York.

Wirawan, N. 1987. Good forest within the burned forest area in East Kalimantan. Pages 413-425 in A. J. G. H. Kostermans, editor. Third Round Table Conference on Dipterocarps. UNESCO, Jakarta, Indonesia.

Wolfheim, J. H. 1983. Primates of the world: Distribution, abundance, and conservation. University of Washington Press, Seattle, USA.

Wollenberg, E., D. Edmunds, L. Buck, J. Fox, dan S. Brodt, editors. 2001. Social learning in community forests. CIFOR dan the East West Center, Bogor, Indonesia.

Wong, A. in press a. The impact of forestry practices on frog communities in Sabah, Malaysia. PhD Dissertation. Universiti Putra Malaysia, Kota Kinabalu, Malaysia.

Wong, A. in press b. Species diversity and abundance of frogs in different forestry practices In Sabah, Malaysia. In International Conference on Bornean Herpetology 16-17 December 2003. Universiti Malaysia Sabah, Kota Kinabalu, Malaysia.

Wong, M. 1985. Understorey birds as indicators of regeneration in a patch of selectively logged West Malaysian rain forest. Pages 249-263 in A. W. Diamond, dan T. E. Lovejoy, editors. Conservation of Tropical Forest Birds. ICBP Technical Publication No. 4. International Council for Bird Preservation, Cambridge, UK.

Wong, M. 1986. Trophic organization of understorey birds in a Malaysian dipterocarp forest. Auk 103:100-116.

Wong, S. T. 2002. The ecology of Malayan sun bears (Helarctos malayanus) in the lowland tropical rainforest of Sabah, Malaysian Borneo. MSc thesis. University of Montana, USA. 
Wong, S. T., C. Servheen, dan L. Ambu. 2002. Food habits of malayan sun bears in lowland tropical forest of Borneo. Ursus 13:127-136.

Wong, S. T., C. Servheen, dan L. Ambu. 2004. Home range, movement and activity patterns, and bedding sites of Malayan sun bears, Helarctos malayanus in the rainforest of Borneo. Biological Conservation 119:169-181.

Woodruffe, R. dan J. R. Ginsberg. 1998. Edge effects and the extinction of populations inside protected areas. Science 280:2126-2128.

Woodruffe, R. dan J. R. Ginsberg. 2000. Ranging behaviour and vulnerability to extinction in carnivores. Pages $125-140$ in I. M. Gosling, dan W. J. Sutherland, editors. Behaviour and conservation. Cambridge University Press, Cambridge, UK.

Woods, P. 1989. Effects of logging, drought, and fire on structure and composition of tropical forests in Sabah, Malaysia. Biotropica 21:290-298.

Worth, W., C. Sheppard, A. Kemp, S. Ellis, dan U. Seale. 1994. Hornbill conservation and management plan. IUCN/SCC Captive Breeding Specialist Group., Apple Valley. Texas, USA.

Wrangham, R. W., J. L. Gittleman, dan C. A. Chapman. 1983. Constraints on group size in primates and carnivores: population density and day range as assays of exploitation competition. Behavioral ecology and Sociobiology 32:199-209.

Wright, P. C., M. K. Izard, dan E. L. Simons. 1986. Reproductive cycles in Tarsius bancanus. American Journal of Primatology 11:207-215.

Wu, D. L., J. Luo, dan B. J. Fox. 1996. A comparison of ground-dwelling small mammal communities in primary and secondary tropical rainforests in China. Journal of Tropical Ecology 12:215-230.

Wyatt-Smith, J. 1963. Manual of Malayan silviculture for inland forests. Malayan Forest Records No. 23. Forest Research Institute Malaysia, Kuala Lumpur, Malaysia.

Wyatt-Smith, J. 1987. The management of tropical moist forest for the sustained production of timber: some issues. Tropical Forestry Policy Paper 4. IUCN/IIED.

Wyatt-Smith, J. 1995. Manual of Malayan Silviculture for Inland Forests, 2nd Edition. Malayan Forest Record No. 23. FRIM, Kuala Lumpur, Malaysia.

Yasuda, M., N. Ishii, T. Okuda, dan N. Azman Hussein. 2003. Small mammal community: habitat preference and effects after selective logging. Pages 533-546 in T. Okuda, N. Manokaran, Y. Matsumoto, K. Niiyama, S. C. Thomas, and P. S. Ashton, editors. Ecology of a lowland rain forest in southeast Asia. Springer-Verlag, Tokyo, Japan.

Yasuma, S. 1996. An invitation to the mammals of Brunei Darussalam. Part I. Indoor information. Brunei Forest Research After Care Project. Special Publication No. 1. Japan International Cooperation Agency and Forestry Department, Ministry of Industry and Primary Resources, Brunei Darussalam.

Yasuma, S. dan M. Andau. 2000. Mammals of Sabah, part 2. Habitat and ecology. Japan International Cooperation Agency and Sabah Wildlife Department, Kuala Lumpur, Malaysia.

Yatim, S. H. 1993. The status and distribution of pheasants in Peninsular Malaysia. Pages 28-39 in D. Jenkins, editor. Pheasants in Asia 1992. World Pheasant Association, Reading, UK.

Yeager, C. 1996. Feeding ecology of the Long-tailed Macaque (Macaca fascicularis) in Kalimantan Tengah, Indonesia. International Journal of Primatology 17:51-62.

Yeager, C. 1999. Research report Lalut-Birai Field Station 1997-1999. WWF Indonesia, KayanMentarang National Park Project, Jakarta, Indonesia.

Yeom, F. B. C. dan C. Chandrasekharan. 2001. Achieving sustainable forest management in Indonesia. ITTO Newsletter.

Yi-Ching, M. 1983. The status of bears in China. Acta Zoologica Fennica 174:165-166.

Zou, X., C. P. Zucca, R. B. Waide, dan W. H. McDowell. 1995. Long-term influence of deforestation on tree species composition and litter dynamics of a tropical rain forest in Puerto Rico. Forest Ecology and Management 78:147-157.

Zubaid, A. 1993. A comparison of the bat fauna between a primary and fragmented secondary forest in Peninsular Malaysia. Mammalia 57: 201-206.

Zubaid, A. dan M. Khairul Effendi Ariffin. 1997. A comparison of small mammal abundance between a primary and disturbed lowland rain forest in Peninsular Malaysia. Malayan Nature Journal 50:201-206. 
Center for International Forestry Research (CIFOR) adalah lembaga penelitian kehutanan internasional terdepan, yang didirikan pada tahun 1993 sebagai tanggapan atas keprihatinan dunia akan konsekuensi sosial, lingkungan dan ekonomi yang disebabkan oleh kerusakan dan kehilangan hutan. Penelitian CIFOR ditujukan untuk menghasilkan kebijakan dan teknologi untuk pemanfaatan dan pengelolaan hutan yang berkelanjutan, dan untuk meningkatkan kesejahteraan masyarakat di negara-negara berkembang yang bergantung kepada hutan tropis untuk kehidupannya. CIFOR adalah salah satu di antara 15 pusat yang didukung oleh Consultative Group on International Agricultural Research (CGIAR). Berpusat di Bogor, Indonesia, CIFOR mempunyai kantor regional di Brazil, Burkina Faso, Kamerun dan Zimbabwe, dan bekerja di lebih dari 30 negara di seluruh dunia.

\section{Donatur}

CIFOR menerima pendanaan dari pemerintah, organisasi pembangunan internasional, yayasan swasta dan organisasi regional. Pada tahun 2005, CIFOR menerima bantuan keuangan dari Australia, Asian Development Bank (ADB), Belgia, Brazil, Canada, China, Centre de coopération internationale en recherche agronomique pour le développement (CIRAD), Cordaid, Conservation International Foundation (CIF), European Commission, Finland, Food and Agriculture Organization of the United Nations (FAO), Ford Foundation, France, German Agency for Technical Cooperation (GTZ), German Federal Ministry for Economic Cooperation and Development (BMZ), Indonesia, International Development Research Centre (IDRC), International Fund for Agricultural Development (IFAD), International Tropical Timber Organization (ITTO), Israel, Italy, The World Conservation Union (IUCN), Japan, Korea, Netherlands, Norway, Netherlands Development Organization, Overseas Development Institute (ODI), Peruvian Secretariat for International Cooperation (RSCI), Philippines, Spain, Sweden, Swedish University of Agricultural Sciences (SLU), Switzerland, Swiss Agency for the Environment, Forests and Landscape, The Overbrook Foundation, The Nature Conservancy (TNC), Tropical Forest Foundation, Tropenbos International, United States, United Kingdom, United Nations Environment Programme (UNEP), World Bank, World Resources Institute (WRI) dan World Wide Fund for Nature (WWF). 
Hutan hujan tropis merupakan ekosistem daratan yang paling kaya akan keragaman jenisnya di bumi. Namun dengan adanya kegiatan penebangan kayu, pertanian, dan pemanfaatan hutan lainnya, luasan hutan tropis ini berkurang dengan laju sekitar 12 juta hektar (sama dengan luas Yunani) dalam setahunnya.

Sejalan dengan hilangnya hutan, banyak jasa dan fungsi yang disediakan oleh keanekaragamanan hayati yang kaya dari hutan tersebut ikut menghilang. Salah satu upaya untuk mengantisipasi hilangnya fungsi hutan ini adalah dengan menetapkan daerah perlindungan. Namun kawasan perlindungan ini bukanlah suatu "panacea", yang dapat menyelesaikan seluruh masalah yang ditimbulkan oleh hilangnya hutan. Kawasan lindung tersebut tidak dapat melestarikan keutuhan keanekaragaman hayati yang ditemukan di hutan tropis. Pada kenyataannya, nasib dari banyak jenis hewan dan tumbuhan yang ditemukan di kawasan lindung sangat tergantung pada apa yang terjadi di luar kawasan lindung tersebut.

Namun, karena hutan yang tidak dilindungi terus-menerus dieksploitasi dalam bentuk kayu dan non-kayu atau untuk kegiatan pertanian, terjadinya perubahan keberadaan tumbuhan dan hewan di dunia tak dapat dihindarkan lagi. Untungnya, besarnya perubahan tersebut sebagian besar dapat dikendalikan melalui perbaikan praktek-praktek operasional dan pilihan pengelolaan hutan.

Dengan memusatkan perhatian pada hidupan satwa liar di Kabupaten Malinau, Kalimantan Timur, yang merupakan daerah hutan tersisa yang paling kaya di Pulau Borneo, buku ini mengamati bagaimana jenis satwa vertebrata dipengaruhi oleh kegiatan penebangan dan kegiatan lainnya yang berkaitan seperti pembangunan jalan dan perburuan. Sebagai daerah yang masih kaya keanekaragaman hayatinya dengan kondisi semakin meningkatnya ancaman yang timbul dari kegiatan penebangan kayu, Malinau merupakan lokasi yang tepat untuk melakukan penelitian, baik pengamatan pengaruh kegiatan penebangan terhadap keberadaan hidupan liar maupun peluang konservasi yang ada melalui pengelolaan hutan yang lebih baik.

Buku ini memberikan sintesis yang terbaik mengenai kegiatan penebangan kayu dan hidupan liar di wilayah ini. Sintesis ini diperoleh dari pengalaman dan keahlian para pakar di bidangnya, serta pustaka yang beragam dan luas. Data yang diperoleh kemudian dikembangkan untuk pengembangan analisis yang baru.

Buku ini mengevaluasi aspek-aspek penyebab mengapa jenis-jenis tertentu rentan terhadap kegiatan intervensi. Juga diusulkan upaya perubahan pengelolaan yang dapat menguntungkan keberadaan hidupan liar yang untuk selanjutnya dapat memperbaiki nilai konservasi hutan bekas tebangan. Buku ini juga memberikan rekomendasi pengelolaan secara rinci serta daftar jenis satwa yang memiliki nilai tinggi bagi kepentingan masyarakat setempat dan dilindungi Undang-undang di Indonesia, atau jenis yang terancam kepunahan secara global.

Panduan baru dalam rangka perbaikan pengelolaan hutan produksi di daerah tropis Asia yang disajikan dalam buku ini merupakan suatu langkah besar. Selain itu buku ini juga mengidentifikasi adanya celah pengetahuan dan informasi penting yang belum digali dan bagaimana celah pengetahuan ini dikedepankan dalam penelitian selanjutnya.
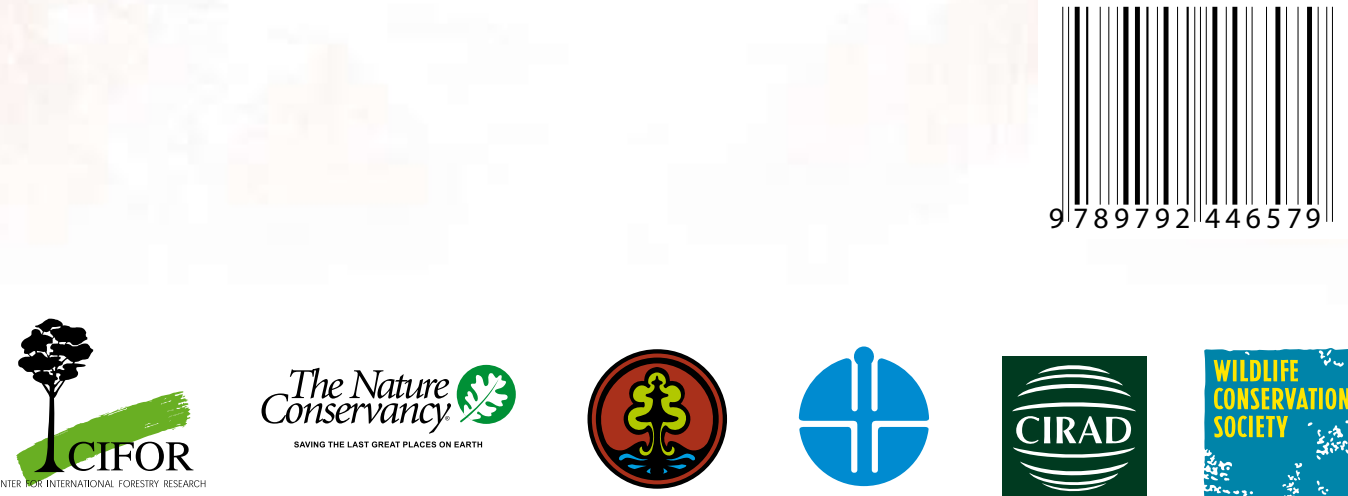

Lembaga

IImu Pengetahuan
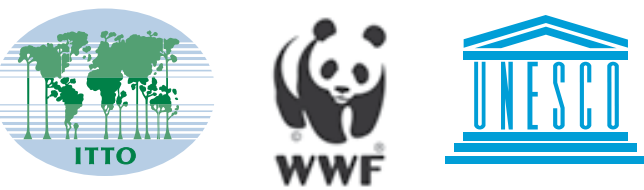

Indonesia

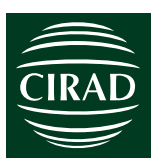

WILDLIFE
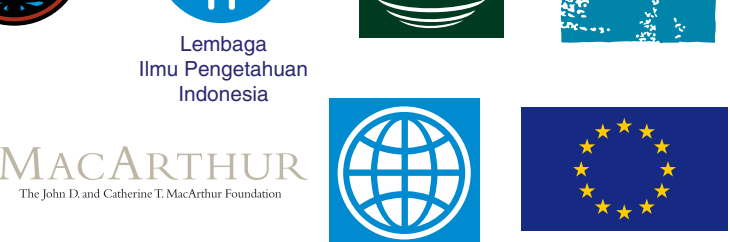